

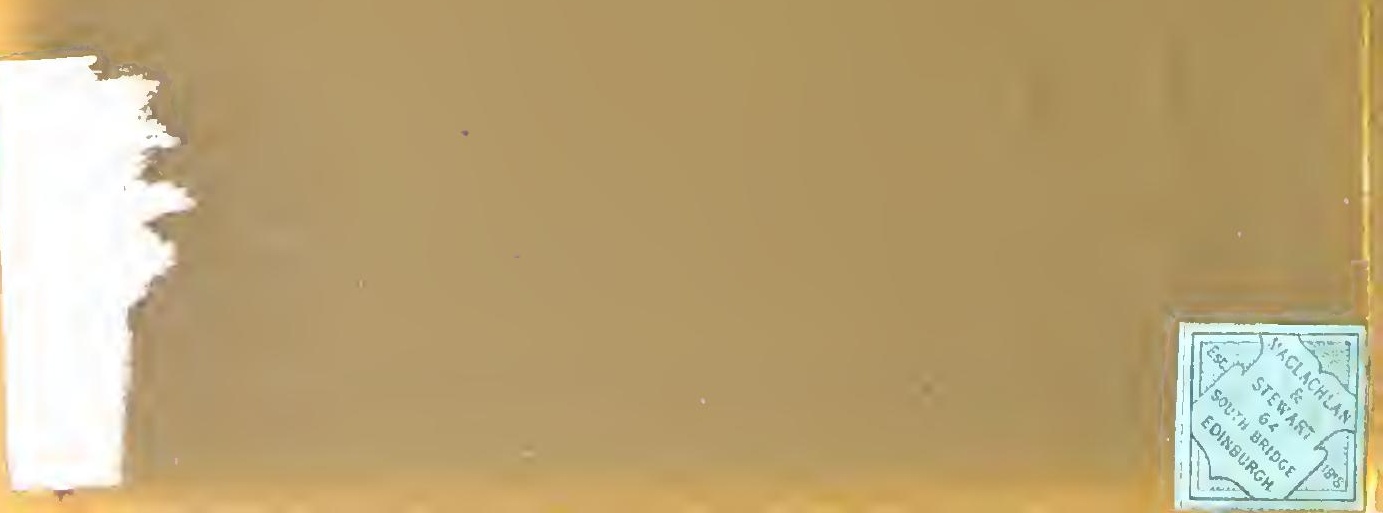




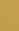


$14 /-$

Ca 8.14

$R 31813$ 
INSECTIVOROUS PLANTS. 



\section{INSECTTVOROUS PLANTS.}

"By CHARLES DARWIN, M.A., F.R.S., ETC.

WITH ILLUSTRATIONS.

LON DON :

JOHN MURRAY, ALBEMARLE STREET. 1875 . 
BY THE SAME AUTHOR.

ON 'THE ORIGIN OF SPECIES BY MEANS OF NATURAL SELECJION; or, "lihe Preservation of Favoured Races in the STrudgige for LIFE. Sixth Edition. Sixteenth Thousand.

MIURRAT.

'THE DESCENT OF MAN, AND SELEOTION IN RELATION TO SEX. Second Edition, revised and augmented. Tenth Thousand. MIdrray.

ON THE VARIOUS CONTKIVANCES BY WHIOH BRITISH AND FOREIGN ORCHIDS ARE FERTILISED BY INSECTS; and on the GOOD ETFeCTs of Crossing. With numerous Woodcuts. Murrar.

A NATURALIST'S VOYAGE ROUND THE WORLD; or, A Journal of Restakches into the Natdral History and Geglogi of the CounTrirs visited during the voyage of H.M.S. 'Beagle,' under the command of Captain FitzRoy, R.N. Twelfth Thousand. MURRAX.

THE EXPRESSION OF THE EMOTIUNS IN MAN AND ANIMALS. Witl Photographic and other Hlustrations. Ninth Thousand.

Murray.

ON THE STRUCTURE AND DISTRIBUTION OF CORAL REEFS. Second Edition. SMITH, ELDER, \& Cu.

GEOLOGICAL OBSERVATIONS ON VOLCANIO ISLANDS. SAT'H, ELDER, \& Co.

GEOLOGICAL OBSERVATIONS ON SOUTH AMERICA. SHith, ELder, \& Co.

A MONOGRAPH OF THE CIRRIPEDIA. With numerous Illustrations. 2 vols. 8 vo. HАIDWICKE.

\section{PREPARING FOR EARLY PUBLICATION.}

I'HE MOVEMENTS AND HABITS OF CLIMBING PLANTS. Second Edition, revised. With lllustrations.

ALSO,

'PHE VARIATION OF ANIMALS AND PLAN'IS' UNDER DOMESTICATION. Second Edition, revised. With lllustrations. Murax.

FACTS AND ARGUMENTS FOR DARWIN. By Frirz MÜulel. 'Trunslated by W. S. Dallas, F.L.S. With lllustrations. Fost \&vo. 6s. Murrar. 


\section{CONTENTS.}

\section{CHAPTER I.}

Drosera rotundifolia, or the Common Sun-dew.

Number of insects captured-Description of the leaves and their appendages or tentacles - Preliminary sketch of the action of the various parts, and of the manner in which insects are captured - Duration of the inflection of the tentacles - Nature of the secretion - Manner in which insects are carried to the centre of the leaf - Evidence that the glands have the power of absorption - Small size of the roots

\section{CIIAPTER II.}

The Movements of the Tentaches from the Contact of SoLID Bodies.

Inflection of the exterior tentacles owing to the glands of the disc being excited by repeated touches, or hy objects left in contact with them - Difference in the action of bodics yiclding and not yiclding solublc nitrogenous matter - Inflection of the cxterior tentacles dircetly caused by objects left in contact with thcir glands - Periods of commcucing inflcction and of subscquent re-cxpansion - Extreme minutcness of the particles eausing inflection - Action under. water Inflection of the cxterior tentacles when their glands are cxcited hy repeated touches - Falling drops of water do not $\begin{array}{llllllllll}\text { crusc inflection . } & . . & . & . & . & . & . & . & & 19-37\end{array}$ 


\section{CHAP'TER III.}

Aggregation of the Protoplabm within the Cells of thL TENTAOLES.

Nature of the contents of the eclls before aggregation - Various causes which excite aggregation - The process commences within the glands and travcls down the tentacles - Description of the aggregated masses and of their spontaneous movements - Currents of protoplasm along the walls of the cells - Action of carbonate of ammonia - The granules in the protoplasm which flows along the walls coalcsce with the central masses - Minuteness of the quantity of carbonate of ammonia causing aggregation-Action of other salts of ammonia - Of other substances, organic fluids, \&c.-Of water - Of heat - Redissolution of the aggregated masses Proximate causes of the aggregation of the protoplasm Summary and concluding remarks - Supplementary observations on aggregation in the roots of plants .. Pages 38-65

\section{CHAPTER IV.}

The Effeots of Heat on the Leaves.

Nature of the experiments - Effects of boiling water - Warm water causes rapid inflection - Water at a higher temperature docs not cause immediate inflection, but does not kill the lcaves, as shown by thcir subsequent re-expansion and by the aggregation of the protoplasm $-\mathrm{A}$ still higher temperature kills the leaves and coagulatcs the albuminous $\begin{array}{llllllll}\text { contents of the glands .. } & . & . . & . . & . . & \text {. } & \text {.. } & 66-75\end{array}$

\section{CHAPTER V.}

The Etfects ol Non-nitrogenous and Nitrogenous Organio Fluido on the Leaves.

Non-nitrogenous fluids - Solutions of gum arabic - Sugar Starch-Diluted alcohol-Olive oil-Infusion and decoction of tea-Nitrogcnous fluids - Milk-Urine-Liquid albumen - Infusion of raw meat - Impure mucus - Saliva - Solution of isinglass - Difference in the action of these two sets of fluids - Decoction of green peas - Decoction and infusion of cabbage - Decoction of grass leares $\quad 76-8 t$ 


\section{CHAPTER VI.}

The Digestive Power of the Segretion of Drosera.

'The secretion rendered acick by the direct and indirect excitement of the glands - Nature of the acid - Digestible substances - Albumen, its digcstion arrested by alkalies, recommences by the addition of an acid - Meat - Fibrin Syntonin - Areolar tissue - Cartilage - Fibro-cartilage Bone-Enamel and dentine - Phosphate of lime - Fibrous basis of bone - Gelatine - Chondrin - Milk, casein and cheese - Gluten - Legumin - Pollen - Globulin - Mrmatin -Indigestible substances - Epidermic productions - Fibroelnstic tissue - Mucin - Pepsin - Urea - Chitine - Cellulose - Gun-cotton-Chlorophyll - Fat and oil - Starch - Action of the secretion on living seeds - Summary and concluding remarks

\section{CHAPTER VII.}

The Effects of Salts of Ammonia.

Manner of performing the experiments - Action of distilled watcr in comparison with the solutions - Carbonate of ammonia, absorhed by the roots - The vaponr absorbed by the glands - Drops on the disc - Mimnte drops applied to separnte glands - Leaves immersed in weak solutionsMinuteness of the doses which induce aggregation of the protoplasm - Nitrate of ammonia, analogous experiments with - Phosplate of ammonia, analogous experiments with - Other salts of ammonia - Summary and concluding remarks on the action of salts of ammonia .. .. $\quad$ 136-173

\section{CHAPTER VIII.}

'Time Effects of vanious other Satits, and Acids, on the LFAVES.

Salts of sorlium, potassium, and otlıer alkaline, cartliy, and motallic salts - Summary on the: action of these saltsVarions acils - Summary on their action .. $\quad . . \quad$ 174-198 


\section{CHAPTER IX.}

The Effects of certain Alkaloid Poisons, other SUdBTANCES AND VAPOURs.

Stryehnine, salts of - Quinine, sulphate of, does not soon arrest the movement of the protoplasm-Other salts of quinine - Digitaline - Nieotine - Atropine - Veratrine Colehieine - Theine - Curare - Morphia - Hyoseyamus Poison of the eobra, apparently aeeelerates the morements of the protoplasm-Camphor, a porwerful stimulant, its vapour nareotie - Certain essential oils exeite movement Glyeerine - Water and eertain solutions retard or prevent the subsequent aetion of phosphate of ammonia-Alcohol innoeuons, its vapour nareotie and poisonous-Chloroform, sulphurie and nitrie ether, their stimulant, poisonous, and nareotie" power - Carbonie aeid nareotie, not quiekly poisonous - Coneluding remarks $\quad$.. $\quad$.. $\quad$.. Pages 199-228

\section{CHAPTER $\mathrm{X}$.}

ON the Sensitiveness of the Leaves, and on the Lines of Transmission of the Motor Impolsh.

Glands and summits of the tentaeles alone sensitive-Transmission of the motor impulse down the pedieels of the tentaeles, and aeross the blade of the leaf - Aggregation of the protoplasm, a reflex aetion-First diseharge of the motor impulse sudden - Direetion of the movements of the tentaeles - Motor impulse transmitted through the eellutar tissue - Mechanism of the movements - Nature of the motor impulse - Re-expansion of the tentreles .. 229-261

\section{CHAPTER XI.}

RecaptTulation of the Chicf OBshirvations on Drosera ROTUNDIFOLIA. 


\section{CHAPTER XII.}

ON THE STRUCTURE AND MoveMeNTS OF SOME OTHER

SPECIES OF DROSERA.

Drosera anglica-Drosera intermedia-Drosera capensis-Drosera sputhulata-Drosera filiformis-Drosera binata-Concluding remarks ..

\section{CHAPTER XIII.}

\section{DionæA MUSCIPULA.}

Structure of the leaves - Scnsitiveness of the filaments - Rapid movement of the lobcs caused by irritation of the filamentsGlands, their power of sccretion-Slow movement caused by the absorption of animal matter-Evidence of absorption from the aggregated condition of the glands - Digestive power of the secretion - Action of chloroform, ether, and hydrocyanic acid-The manner in which insects are captured - Usc of the marginal spikes - Kinds of insects captured The transmission of the motor impulse and mechanism of the movements - Re-expansion of the lobcs .. 286-320

\section{CIIAPTER XIV.}

\section{Aldrovanda vesicolosa.}

Captures crustaccans - Structure of the leaves in comparison with those of Dionrea - Absorption by the glands, by the quadrifid processes, and points on the infolded margins Aldrovunda vesiculosa, var. australis - Captures prey Absorption of animal mattcr - Aldrowanda vesiculosa, var. verticillata - Concluding rcmarlks .. $\quad . \quad$. . $\quad$. $\quad 321-331$

\section{CHAPTER XV.}

DrosopHYLLUM - RoRIDUla - ByBlis - Glandular HAIRS OF other Plants-Concluding Reuarks on the Droseradede.

Drosophyllum-Structurc of lcaves-Nature of the sccretionManner of catching insects-Power of absorption-Digestion of animal substances-Summary on Drosophyllum-Roridula - Byblis - Glandular hairs of other plants, their power of absorption - Saxifraga - Primula - Pelargonium - EricaMirabilis - Nicotiana - Summary on glandular hairs - Concluding remarks on the Droseraceæ $\quad$.. 


\section{CHAPTER XVI.}

\section{Pinguicula.}

Pinguicula vulgaris - Structure of leaves - Number of inseets and other objeets caught-Movement of the margins of the leaves - Usos of this movement - Seeretion, digestion, and absorption - Aetion of the secretion on various animal and vegetable substanees - The effects of substances not eontaining soluble nitrogenous matter on the glands-Pinguicula grandiflora - Pinguicula lusitanica, catches insects - Movement of the leaves, seeretion and digestion .. Pages 368-394

\section{CHAPTER XVII.}

\section{UTRIOULARIA.}

Utricularia neglecta - Stracture of the bladder-The uses of the several parts - Number of imprisoned animals - Manner of eapture - The bladder's cannot digest animal matter, but absorb the products of its decay-Experiments on the absorption of eertain fluids by the quadrifid processes Absorption by the glands - Summary of the observation on absorption-Development of the bladders - Utricularia vulgaris-Utricularia minor-Utriculuria clandcstina 395-430

\section{CHAPTER XVIII.}

\section{UTRICUlaARIA (continued).}

Utricularia montana-Description of the bladders on the subterranean rhizomes - Prey captured by the bladders of plants under eulture and in a state of nature-Absorption by the quadrifid proeesses and glands - Tubers serving as reservoirs for water - Various other species of Utricularia Polypompholyx - Genlisea, different nature of the trap for eapturing prey - Diversified methods by wlich plants are

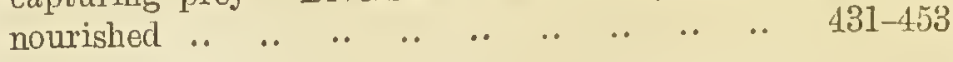

$\begin{array}{llllllllllll}\operatorname{INDEX} & . & . . & . . & . . & . . & . . & . . & . & . . & . . & 455-462\end{array}$ 


\section{INSECTIVOROUS PLANTS.}

\section{CHAPTER I.}

Drosera rotlndifolia, or the common Sun-dew.

Number of insects enptured-Description of the leavos and their appendages or tentaclos - Preliminary sketch of tho action of the various parts, and of the manner in which insects are eaptmied Duration of the inflection of the tentaclos - Nature of the secretion-Manner in which insects are carried to the centre of the leaf - Evidence that the glands have the power of absorptionSmall sizo of the roots.

During the summer of 1860, I was surprised by finding how large a number of insects were eaught by the leaves of the common sun-den (Drosera rotundifolia) on a heath in Sussex. I had heard that insects were thus caught, but knew nothing further on the subjeet.* I

* As Dr. Nitsehle has given ('Bot. Zeitung,' 1860, n. 229) the biblingraphy of Drosera, I need not here go into dctails. Mnst of the notices publisher before 1860 are brief and unimportant. The oldcst paper seems to have been one of the inost valuable, namely, by $\mathrm{Dr}$. lioth, in 1782 . There is also sn interesting thonerh short acerunt of the labitis of Drosera by Wr. Milcle, in thr; 'Bot. Zeitung, $1552,11.540$. In 18555 , in the ${ }^{6} \Lambda 11-$ males dea hic. nat. bot,' tom. iii. ply). 297 and :304, MIT. Cx romland and 'l'reul each published papers, with figures, on the struetule of the leaves; but M. Trécul went st far as to doubt whether they possessed any power of movement. Dr. Nitschlie's papers in the 'Bot. Zcitung' for 1860 and 1861 are by far tho most important ones' which havo been published, loth on the habits and strueture of this plant; and I shall frequently have oceasion to quoto fiom thom. His aliscussions on sevoral prints, for instance on the transnission of an exeitement from our. part of the lont to muother, an'" excellent. On Doc. 11, 1862, Mr.

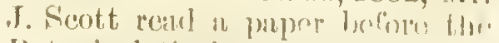

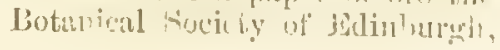


gathered by ehanee a dozen plants, bearing fifty-six fully expanded leaves, and on thirty-one of these dead inseets or remmants of them adhered; and, no doubt, many more would have been eaught afterwards by these same leares, and still more by those as yet not expanded. On one plant all six leaves had eaught their prey; and on several plants very many leaves had eaught more than a single inseet. On one large leaf I found the remains of thirteen distinet insects. Flies (Diptera) are eaptured mueh oftener than other inseets. The largest kind whieh I have seen eaught was a small butterfly (Crnonympha pamphilus); but the Rev. H. M. Wilkinson informs me that he found a large living dragon-fly with its body firmly held by two leaves. As this plant is extremely common in some distriets, the number of insects thus annually slaughtered must be prodigious. Many plants cause the death of inseets, for instanee the sticky buds of the horse-chestnut (AEsculus hippocastanum), without thereby reeeiving, as far as we ean pereeive, any adrantage; but it was soon evident that Drosera was

whieh was published in the Gardener's Chroniele,' 1863, p. 30. Mr. Scott shows that gentle irritation of the hairs, as well as inseets plaeed on the dise of the leaf, rause the hairs to bend inwaris. Mr. A. W. Bennett also gave another interesting aeenunt of the movements of the leaves befole the British Association for 1873. In this same year Dr. Warming pnblished an cssily, in which he deseribes the strueture of the so-ealled hairs, entitled, "Sur la Diffírenee entre les 'Trichomes," ¿e., extraeted fiom tho proceedings of the Sne. I'Hist. Nat. de Copenhague. I shall also liave oeension hercafter to refur to a paper by Mrs. Treat, of New Jersey, on some Ameriean speeies of Drosera. Dr. Burdon Sanderson delivered a leeture on Dionera, before the lioyal Institution (pnblished in ' Nature,' Jnme 14, 1s74), in whieh a short aeeonnt of my ohscrvations on the power of true digestion pussessed by Droserit and loiunaca first appeared. Prof. Asit Gray has done good serviee ly ealling attention to Drosera, aind to other plants having similar labits, in 'T'he Nation' (1874, lp). g(6) and 232 ), and in otlee publicitions. Dr. Honlier, nlso, in his important address on ('armirolous l'lunts (Brit. Assoc, Belfist, 1874), has given a history of the subjeet. 
Chis. I,

excellontly adapted for the speeial purpose of catehing insects, so that the subjeet seemed well worthy of inrestigation.

The results have proved highly remarkable; the more important ones being-firstly, the extraordinary

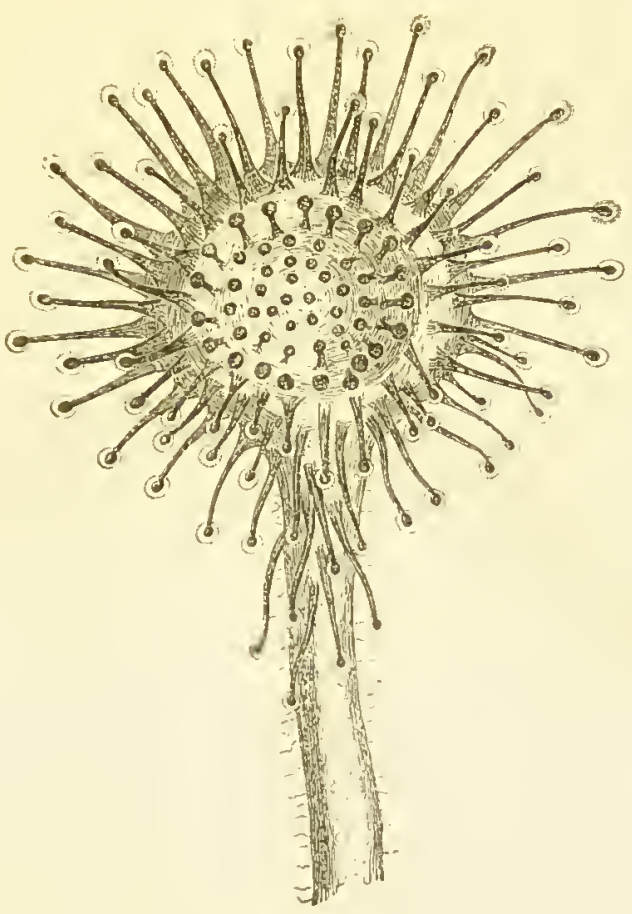

FIG, 1.*

(Drosera rolundifolin.)

Leaf viewed from above; enlarged four times.

sensitiveness of the glands to slight pressure and to minute doses of certain nitrogenous fluids, as shown by the movements of the so-ealled hairs or tentacles;

* The rlrawings of Drosera and Dinn:ea. griven in this work, were made for me by my son George lnarwin: thense of Alilrovinda, and of the sreveral species of Utri- cularia, by my son Erancis. 'They have been excellently reproduced on wood by Mr. Conpere, 18s Strand. 
secondly, the power possessed by the leaves of rendering soluble or digesting nitrogenous substanees, and of afterwards absorbing them; thirdly, the changes whieh take plaee within the cells of the tentaeles, when the glands are exeited in various ways.

It is neeessary, in the first plaee, to deseribe briefly the plant. It bears from two or three to five or six leaves, generally extended more or less horizontally, but sometimes standing vertieally upwards. The shape and general appearanee of a leaf is shown, as seen from above, in fig. 1, and as seen laterally, in fig. 2. The leaves are eommonly a little broader than long,

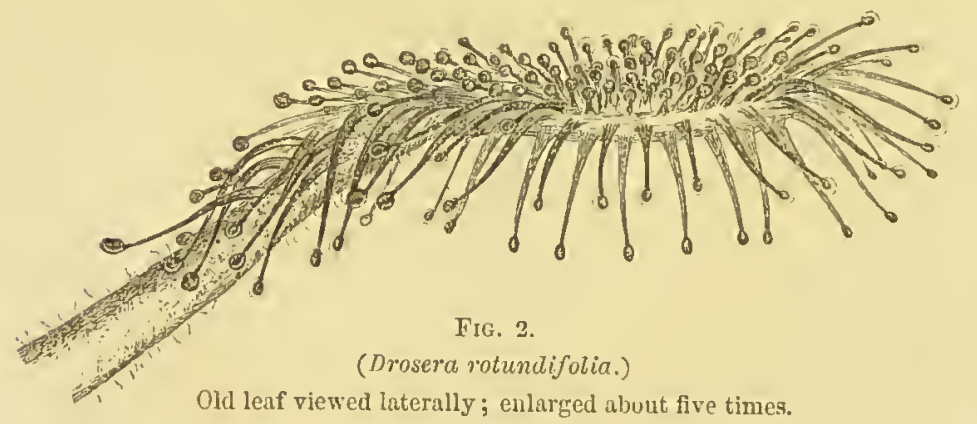

but this was not the ease in the one here figured. The whole upper surfaee is eovered with gland-bearing filaments, or tentaeles, as I shall eall them, from their manner of aeting. The glands were eounted on thirtyone leaves, but many of these were of unusually large size, and the average number was 192; the greatest number being 260, and the least 130 . 'The glands are eaeh surrounded by large drops of extremely viseid seeretion, whieh, glittering in the sun, have given rise to the plant's poetieal name of the sun-dew.

The tentacles on the ecntral part of the lcaf or disc are short and stand upright, and their pedicels nere green. Towards the margin they become longer and longer and more inclined 
outwards, with their pedicels of a purple eolour. Those on the extreme margin project in the same plane with the leaf, or more eommonly (see fig. 2) are eonsiderably reflexcd. A few tcntacles spring from the base of the footstalk or petiole, and thesc are the longest of all, being sometimes nearly $\frac{1}{4}$ of an ineh in length. On a leaf bearing altogether 252 tentaeles, the short ones on the dise, having grcen pedieels, were in number to the longer submarginal and marginal tentaeles, having purple pedieels, as nine to sixteen.

A tentacle eonsists of a thin, straight, hair-like pedieel, earrying a gland on the summit. The pedicel is somewhat flattened, and is formed of several rows of clongated eells, filled with purple fluid or granular matter.* There is, however, a narrow zone close beneath the glands of the longer tentaeles, and a broader zone near their bases, of a green tint. Spiral vessels, aceompanied by simple vaseular tissue, braneh off from the vaseular. bundles in the blade of the leaf, and run up all the tentaeles into the glands.

Several eminent physiologists have diseussed the homological nature of these appendages or tentacles, that is, whethcr they ought to be eonsidercd as hairs (triehomes) or prolongations of the leaf. Nitsehke has shown that they include all the elements proper to the blade of a leaf; and the faet of their ineluding vaseular tissue was formerly thought to prove that they were prolongations of the leaf, but it is now known that vessels sometimes enter true hairs. $\dagger$ The power of movement whieh they posscss is a strong argument against their being viewed as hairs. The eonelusion whieh seems to me the most probable will be given in Chap. XV., namely that thcy existed primordially as glandular hairs, or mere epidermie formations, and that their upper part should still be so eonsidered; but that their lower

* Accorling to Nitschke ('Bot. Zoitung,' 1861, p. 22t) the purple fluid results from the metanorphosis of chlorophyll. Mr. Sinrby rxamined the colouring matter with the spectroscope, and informs me that it consists of tho commonest species of erythrophyll, " which is olten met witl in leaves with low vitality, and in parts, like the petioles, which carry on lcaf-functions in a very imperfect manner. All that cain be said, therefore, is that the hairs (or tentacles) are coloured like parts of a lcaf which do not fulfil their proper office."

+ Dr. Nitschlio has diseussed this subject in 'Bot. Zeitmug,' 1S61, p. 241, Sc. See also Di. Warming ('Sur la Diflérence cutre les 'Jrichomes,' \&e., 1873), who gives references to various publications. Seo also Gíroulaud and 'J'réeul, 'Annal. des Sic. nat. brob,' (1tle series), tom, iii. 1855, 1'l'. 297 and 303. 
part, which alone is capable of movement, consists of a prolongation of the leaf; the spiral vesscls heing extended from this to the uppermost part. We shall hereaftcr sec that the terminal tentacles of the divided leaves of Roridula are still in an intermediatc condition.

The glands, with the exeeption of those borne by the cxtreme

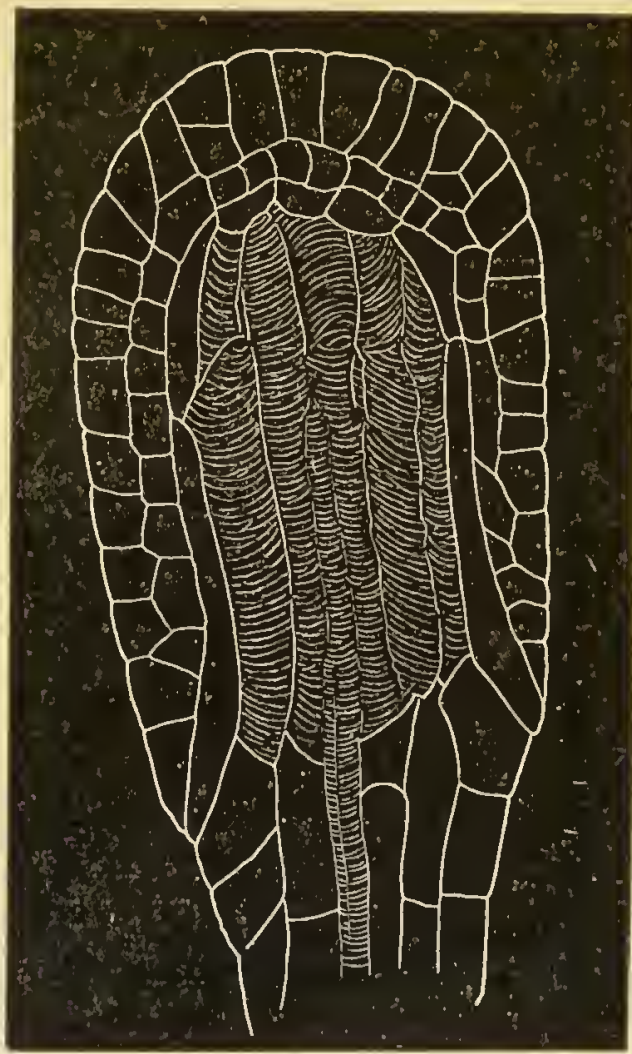

Fig, 3.

(Drosera rotundifolia.)

I.ongritudinal section of a gland; greatly magnilied. From Dr. Warming.

marginal tentaeles, are oval. and of nearly uniform size, viz. about $\frac{t}{500}$ of an inch in length. Their strueture is remarkable, and their functions eomplex, for they sccrete, absorb, and are ncted on by various stimulants. They consist of an outer layer. of small polygonal eells, containing purple granular matter or fluid, and with the walls thicker than those of the pedicels. 
Within this layer of eells there is an inner one of differently shaped ones, likewise filled with purple fluid, but of a slightly different tint, and differently affected by ehloride of gold. These two layers are sometimes well seen when a gland has been erushed or boiled in caustie potash. Aceording to Dr. Warming; there is still another layer of mueh more elongated eells, as shown in the aeeompanying section (fig. 3) copied from his work; but these eells were not seen by Nitsehke, nor by me. In the centre there is a group of elongated, eylindrieal eells of unequal lengths, bluntly pointed at their upper ends, truneated or rounded at their lower ends, elosely pressed together, and remarkable from being surrounded by a spiral line, whieh can be separated as a distinet fibre.

These latter eells are filled with limpid fluid, whieh after long immersion in aleohol deposits much brown matter. I presume that they are aetually conneeted with the spiral vessels whieh run up the tentaeles, for on several occasions the latter were seen to divicle into two or three excessively thin branches, which eould be traeed elose up to the spiriferous eells. Their development has been deseribed by Dr. Warming. Cells of the same kind have been observed in other plants, as I hear from Dr. Hooker, and were seen by me in the margins of the leares of Pinguieula. Whaterer their function may be, they are not necessary for the seeretion of the digestive fluid, or for absorption, or for the eommunication of a motor impulse to other parts of the leaf, as we may infer from the strueturc of the glands in some other genera of the Droseracer.

The extreme marginal tentaeles differ slightly from the others. Their bases are broader, and besides their own vessels, they receive a fine braneh from those which enter the tentacles on eaeh side. Their glands are much elongated, and lie embedded on the upper surfaee of the pedieel, instead of standing at the apex. In other respeets they do not differ essentially from the oval ones, and in one speeimen I found evcry possible transition betwcen the two states. In another speeimen there were no long-headed glands. These marginal tentaeles losc their irritability earlier than the other's; and when a stimulus is applied to the centre of the leaf, they are exeited into aetion after the others. When eut-off leaves are immersed in water, they alone often beeome inflected.

The purple fluid or granular malter whieh fills the colls of the glands differs to a ecrtain extent from that within tho eells of the pedieels. For when a leaf is placed in lot water or in eertain acids, tho glands bceome quite white and opaque, whercas 
the eclls of the pedicels are rendered of a bright red, with the exception of those close beneath the glands. These lattcr cclls lose their pale red tiut; and the green matter which they, as wcll as the basal cells, contain, becomes of a brighter green. The petioles bear many multicellular hairs, some of which near the blade are surmounted, according to Nitschke, by a few rounded cells, which appcar to be rudimentary glands. Both surfaces of the leaf, the pedicels of the tentacles, espccially the lower sides of the outer ones, and the petioles, are studded with minute papillæe (hairs or trichomes), having a conical basis, and bcaring on their summits two, and occasionally three or even four, rounded cells, containing much protoplasm. These papillae are generally colourless, but sometimes include a little purple fluid. 'They vary in devclopment, and graduate, as Nitschke* statcs, and as I repeatedly observed, into the long multicellular hairs. 'Ihe latter, as well as the papilla, are probably rudiments of formerly existing tentacles.

I may here add, in order not to recur to the papillæe, that they do not secretc, but are easily permeated by various fluids: thus whon living or dead learcs are immersed in a solution of one part of chloride of gold, or of nitrate of silver, to 437 of water, thcy are quickly blackcned, and the discoloration soon spreads to the surrounding tissue. The long multicellular hairs are not so quickly affected. After a leaf had becn left in a weak infusion of raw meat for 10 hours, the cclls of the papilla had cridently absorbed animal matter, for instead of limpid fluid they now contained small aggregated masses of protoplasm, which slowly and incessantly changed their forms. A similar result followed from an immersion of only 15 minutes in a solution of one part of carbonate of ammonia to 218 of water, and the adjoining cells of the tentacles, on which the papillio wcre seated, now likewise contained aggregated masses of protoplasm. We may therefore conclude that when a leaf has closcly clasped a captured insect in the manner immediately to be described, the papillæ, which project from the upper surface of the leaf and of the tentacles, probably absorb some of the animal matter dissolved in the scerction; - but this cannot be the case with the papilli on the backs of the lcaves or on the petioles.

* Nitsehke has elaborately described and figuror these papillie, 'Bot. Zeitung,' 1861, pp. 234, 253', 254. 
Preliminary Shetch of the Action of the several Parts, and of the Manner in which Insects are Captured.

If a small organic or inorganic object be placed on the glands in the centre of a lcaf, these transmit a motor impulse to the marginal tentacles. The ncarer ones are first affecter and slowly bend towards the centre, and then those farther off, until at last all become eloscly inflcetcd over the object. This takes plaee in from one hour to four or five or more hours. The difference in the time required depends on many eircumstanees; namcly on the size of the objeet and on its nature, that is, whether it eontains soluble matter of the proper kind; on the vigour and age of the leaf; whether it has lately bcen in action; and, aecording to Nitschle, ${ }^{*}$ on the temperature of the day, as likewise seemed to me to be the case. A living inscet is a morc effieient object than a clead öne, as in struggling it presses against the glauds of many tentaeles. An insect, such as a fly, with thin integuments, through which animal matter in solution ean readily pass into the surrounding dense secretion, is more efficient in eausing prolonged inflection than an insect with a thiek coat, sueh as a beetle. The inflcetion of the tentacles takes place indiffcrently in the light and darkness; and the plant is not subject to any nocturnal movement of so-called sleep.

If the glands on the disc are repcatedly touched or brushed, althongh no object is left on them, the marginal tentaeles eurve inwards. So again, if drops of various fluids, for instance of saliva or of a solution of any salt of ammonia, are placed on the central glands, the same result quickly follows, somctimes in under half an hour.

* 'Bot. Zeitung,' 1860, p. 216. 
The tentacles in the aet of inflection sweep through a wide space; thus a marginal tentaele, extended in the same plane with the blade, moves through an angle of $180^{\circ}$; and I have seen the much reflected tentacles of a leaf which stood upright move through an angle of not less than $270^{\circ}$. The bending part is almost confined to a short space near the base; but a rather larger portion of the elongated exterior tentacles

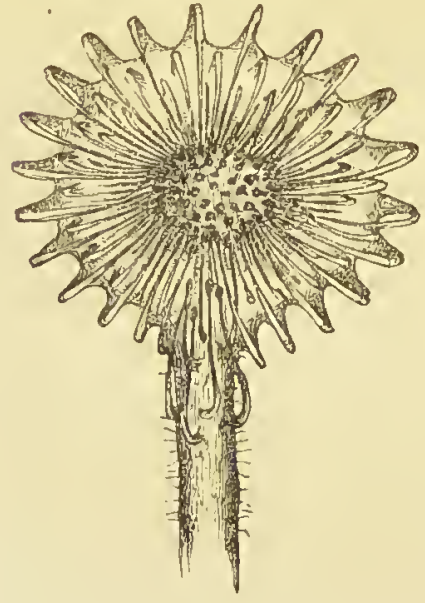

Fig. 4 .

(Drosera rotundifolia.)

Leaf (enlarged) with all the tentrcles closely inflected, from immersion in a solution of phosphate of ammonla (one part to 87,500 of water).

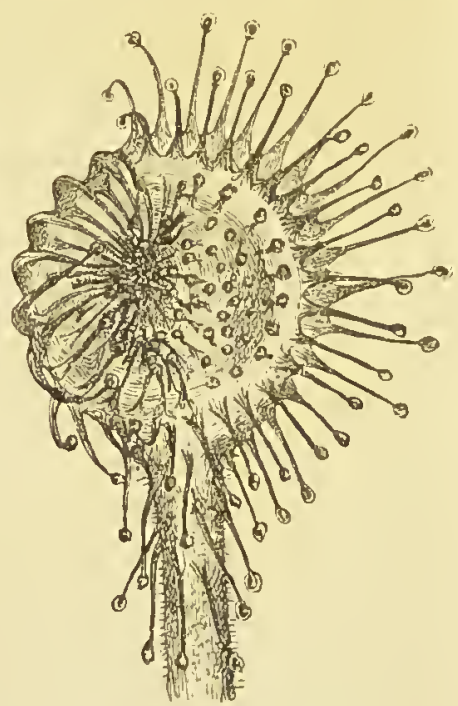

Fio. 5 .

(Drosera rotundifolia.)

Leaf (enlarged) with the tentacles on one side inflected over a bit of meat placed on the disc.

beeomes slightly incurved; the distal half in all cases remaining straight. The short tentaeles in the centre of the disc when directly excited, do not become inflected; but they are eapable of inflection if exeited by a motor impulse received from other glands at a distance. Thus, if a leaf is immersed in an infusion of raw meat, or in a weak solution of ammonia (if the 
solution is at all strong, the leaf is paralysed), all the exterior tentaeles bend inwards (see fig. 4), exeepting those near the eentre, whieh remain upright; but these bend towards any exeiting objeet plaeed on one side of the dise, as shown in fig. 5. The glands in fig. 4 may be seen to form a dark ring round the eentre; and this follows from the exterior tentaeles inereasing in length in due proportion, as they stand nearer to the eireumferenee.

The kind of infleetion whieh the tentaeles undergo is best shown when the gland of one of the long exterior

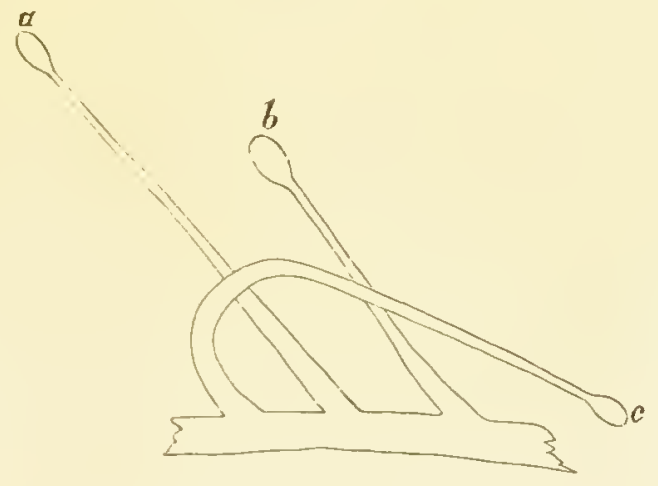

FIi. 6.

(Drosera rotundifolia.)

Diagram showing one of the exterior tentacles closely inflected; the two adjoining ones in their ordinary position.

tentaeles is in any way exeited; for the surrounding ones remain unaffeeted. In the neeompanying outline (fig. 6) we see one tentacle, on which a partiele of meat had been placed, thus bent towards the eentre of the leaf, with two others retaining their original position. $\Lambda$ gland may be excited by being simply touched three or four times, or by prolonged eontaet with organie or inorganie objeets, and various fluids. I have distinctly seen, through a lens, a tentaele beginning to bend in ten seeonds, after an objeet had been 
plaeed on its gland; and I have often seen strongly pronouneed inflection in under one minute. It is surprising how minute a particle of any substanee, such as a bit of thread or hair or splinter of glass, if placed in aetual contact with the surfaee of a gland, suffices to cause the tentacle to bend. If the object, which has been carried by this movement to the centre, be not very small, or if it contains soluble nitrogenous matter, it aets on the central glands; and these transmit a motor impulse to the exterior tentacles, causing them to bend inwards.

Not only the tentacles, but the blade of the leaf often, but by no means always, becomes much incurved, when any strongly exciting substance or fluid is placed on the disc. Drops of milk and of a solution of nitrate of ammonia or soda are particularly apt to produce this effect. The blade is thus converted into a little eup. The manner in which it bends varies greatly. Sometimes the apex alone, sometimes one side, and sometimes both sides, become incurved. For instance, I placed bits of hard-boiled egg on three leaves; one had the apex bent towards the base; the seeond had both distal margins much ineurved, so that it became almost triangular in outline, and this perhaps is the commonest case; whilst the third blade was not at all affected, though the tentacles were as elosely inflected as in the two previous cases. The whole blade also generally rises or bends upwards, and thus forms a smaller angle with the footstalk than it did before. This appears at first sight a distinct kind of morement, but it results from the incurvation of that part of the margin which is attached to the footstalk, causing the blade, as a whole, to curve or move upwards.

The length of time during which the tentacles as 
well as the blade remain infleeted over an objeet placerl on the disc, depents on various ciremmstanees; namely on the vigomr and agc of the leaf, and, aeeording to. 1)r. Nitschke, on the temperature, for during eold weather when the lcaves are inaetive, they re-expand at an earlier perior than when the weather is warm. But the nature of the object is by far the most important eircunstance; I have repeatedly found that the-tentaeles romain clasped for a mueh longer average time over objects whieh yield soluble nitrogenous mattcr than over those, whether organic or inorganic, whieh yield no such matter. After a period varying from one to seven days, the tentacles and blade reexpand, and are then ready to aet again. I have seen the same leaf infleeted three successive times over insects plaeed on the disc; and it would probably have acted a greater number of times.

The seeretion from the glands is extremely viscid, so that it can be drawn out into long threads. It appears eolourless, but stains little balls of paper pale pink. An object of any kind plaeed on a gland always canses it, as I believe, to secrete more freely; but the mere presence of the object renders this diffieult to ascertain. In some eases, however, the effeet was strongly marked, as when partieles of sugar were adderl; but the result in this ease is probably due merely to exosmose. Particles of carbonate and phosphate of ammonia and of some other salts, for instance sulphate of zine, likewisc increase the secretion. Immersion in a solution of one part of ehloride of gold, or of some othcr salts, to 437 of water, exeites the glands to largely increased secuetion; on the other hand, tartrate of antimony produees no such effect. Inmersion in many acids (of the strength of one part to 4,37 of water) likewise causes a wonderful amount of 
secretion, so that when the leaves are lifted out, long ropes of extremcly viscid fluid hang from them. Some acids, on the other hand, do not act in this manner. Increased sccretion is not necessarily dependent on the inflection of the tentacle, for particles of sugar and of sulphate of zinc cause no morcment.

It is a much more remarkable fact that when an object, such as a bit of meat or an insect, is placed on the disc of a leaf, as soon as the surrounding tentacles become considerably inflected, their glands pour forth an increased amount of secretion. I ascertained this by sclecting lcaves with equal-sized drops on the two sides, and by placing bits of meat on one side of the disc; and as soon as the tentacles on this side became much inflected, but bcfore the glands touched the meat, the drops of secretion became larger. This was repeatedly obscrved, but a record was kept of only thirteen cases, in nine of which increased secretion was plainly observed; the four failures being due either to the leaves being rather torpid, or to the bits of meat being too small to cause much inflection. We must therefore conclude that the central glands, when strongly excited, transmit some influence to the glands of the circumferential tentacles, causing them to secrete more copiously.

It is a still more important fact (as we shall see more fully when we treat of the digestive power of the secretion) that when the tentacles become inflected, owing to the central glands having been stimulated mechanically, or by contact with animal matter, the secretion not only increases in quantity, but changes its nature and becomes acid; and this occurs before the glands have touched the object on the centre of the leaf. This acid is of a different nature from that contained in the tissue of the leaves. As long as the 
tentacles remain closely inflected, the glands continue to secrete, and the secretion is acid; so that, if neutralised by earbonate of soda, it again becomes acid after a few hours. I have observed the samc leaf with the tentaeles closely inflected over rather indigestible substances, sueh as chemically preparced cascin, pouring forth aeid seeretion for cight sueeessivc days, and over bits of bone for ten successive days.

The secretion seems to possess, like the gastrie juice of the higher animals, some antiscptic powcr. During very warm weather I placed elosc together two equalsized bits of raw mcat, one on a leaf of the Drosera, and the other surrounded by wet moss. 'They were thus left for 48 hrs., and then examined. The bit on the moss swarmed with infusoria, and was so mueh deeayed that the transverse stria on the muscular fibres could no longer be clcarly distinguished; whilst the bit on the leaf, which was bathed by thc sccretion, was free from infusoria, and its strix were perfectly distinet in the eentral and undissolved portion. In like manner small eubes of albumen and cheese placed on wet moss bccame threadcd with filaments of mould, and had their surfaees slightly discoloured and disintcgrated; whilst those on the leaves of Droscra remaincd clean, the albumen being rhanged into transparent fluid.

As soon as tentacles, which have rcmaincd closely inflected during screral days over an object, begin to re-expand, their glands secrete loss freely, or coase to secrete, and are left dry. In this state they arc coverer with a film of whitish, semi-fibrous matter, which was hold in solution by the secretion. The drying of the glands during the act of re-cxpansion is of some little service to the plant; for I have often obscrved that objects adhering to the leaves 
eould then be blown away by a breath of air; the leaves being thus left unencumbered and free for future action. Nevertheless, it often happens that all the glands do not beeome eompletely dry; and in this case delieate objeets, sueh as fragile inseets, are sometimes torn by the re-expansion of the tentaeles into fragments, which remain seattered all ovcr the leaf. After the re-expansion is eomplete, the glands quickly begin to re-seerete, and as soon as full-sized drops are formed, the tentacles are ready to elasp a new objcet.

When an inseet alights on the eentral dise, it is instantly entangled by the viscid seeretion, and the surrounding tentaeles after a time begin to bend, and ultimately elasp it on all sides. Inseets are generally killed, aeeording to Dr. Nitsehke, in about a quarter of an hour, owing to their trachere being elosed by the seeretion. If an inseet adheres to only a few of the glands of the exterior tentaeles, these soon beeome infleeted and earry their prey to the tentreles next sneeeeding them inwards; these then bond inwards, and so onwards, until the inseet is ultimately earried by a eurious sort of rolling movement to the eentre of the leaf. Then, after an interval, the tentaeles on all sides beeome inflected and bathe their prey with their seeretion, in the same manner as if the insect had first alighted ou the central disc. It is surprising how minute an insect suffices to canse this aetion: for instanee, I have seen one of the smallest speeies of gnats (Culex), whieh had just settled with its exeessively delicate feet on the glands of the ontermost tentaeles, and these were already beginning to eurve inwards, thongh not a single gland had as yet touehed the body of the insect. Had I not interfererl, this minnte ginat would 
assuredly have been carried to the centre of the leaf and been securely clasped on all sides. We shall hereafter see what excessively small doses of certain organic fluids and saline solutions cause strongly marked inflection.

Whether insects alight on the leaves by mere chance, as a resting-place, or are attracted by the odour of the secretion, I know not. I suspect from the number of insects ciught by the English species of Drosera, and from what I have observed with some exotic species kept in my greenhouse, that the odour is attractive. In this latter case the leaves may be compared with a baited trap; in the former case with a trap laid in a run frequented by game, but without any bait.

That the glands possess the power of absorption, is shown by their almost instantaneously becoming darkcoloured when given a minute quantity of carbonate of ammonia ; the change of colour being ehiefly or exclusively due to the rapid aggregation of their contents. When certain other fluids are added, they become palecoloured. Their power of absorption is, however, best shown by the widely different results which follow, from placing drops of various nitrogenous and nonnitrogenous fluirls of the same density on the glands of the disc, or on a single marginal gland; and likewise by the very different lengths of time during which the tentacles remain inflected over objects, which yield or do not yield soluble nitrogenous matter This same conclusion might indeed have been inferred from the structure and movements of the leaves, which are so admirably ardapted for capturing insects.

The absorption of animal matter from captured insects explains how Drosera can flourish in extremely poor peaty soil,-in some cases where nothing brit 
sphagnum moss grows, and mosses depend altogrether on the atmosphere for their nourishment. Although the leaves at a basty glance do not appear green, owing to the purple colour of the tentacles, yet the upper and lower surfaces of the blade, the pedicels of the.central tentacles, and the petioles contain chlorophyll, so that, no doubt, the plant obtains and assimilates carbonic acid from the air. Nevertheless, considering the nature of the soil where it grows, the supply of nitrogen would be extremely limited, or quite deficient, unless the plant had the power of obtaining this important element from captured insects. We can thus understand how it is that the roots are so poorly developed. These usually consist of only two or three slightly divided branches, from half to one inch in length, furnished with absorbent hairs. It appears, therefore, that the roots serve only to imbibe water; though, no doubt, they would absorb nutritious matter if present in the soil; for as we shall hereafter see, they absorb a weak solution of carbonate of ammonia. A plant of Drosera, with the edges of its leaves curled inwards, so as to form a temporary stomach, with the glands of the closely inflected tentacles pouring forth their acid secretion, which dissolves animal matter, afterwards to be absorbed, may be said to feed like an animal. But, differently from an animal, it drinks by means of its roots; and it must drink largely, so as to retain many drops of viscid fluid round the glands, sometimes as many as 260, exposed during the whole day to a glaring sun. 


\section{CHAPTER II.}

The Monements of the Tentacles from the Contact of Solid Bonies.

Inflection of the extcrior tentaeles owing to the glands of the dise being exeited by repeated touches, or by objeets left in contact with them-Difference in the action of bodies yielding and not yielding soluble nitrogenous matter-Inflection of the cxterior tentacles directly caused by objects left in contact with their glands - Periorls of commencing inflection and of subsequent reexpansion - Extreme minutencss of the particlcs causing inflection - Aetion under water - Inflection of the exterior tentacles when their glands are excited by repeated touches-Falling drops of water do not eause inflection.

I WILL give in this and the following chapters some of the many experiments made, which best illustrate the manner and rate of movement of the tentaeles, when exeited in various ways. The glands alone in all ordinary eases are suseeptible to exeitement. When exeited, they do not themselves move or ehange form, but transmit a motor impulse to the bending part of their own and adjoining tentaeles, and are thus earried towards the eentre of the leaf. Strietly speaking, the glands ought to be ealled irritable, as the term sensitive generally implies eonseiousness; but no one supposes that the Sensitive-plant is eonseious, and as I have found the term eonvenient, I shall use it without seruple. I will eommenee with the movements of the exterior tentaeles, when indireetly exeited by stimulants applied to the glands of the short tentaeles on the disc. The exterior tentacles may be said in this ease to be indirectly excited, beeause their own glands are not directly acterl on. The stimulus proeeeding from the glands of the dise arts on the bending part of the 
exterior tentacles, near their bases, and does not (as will hercaftcr be proved) first travel up the pedicels to the glands, to be then reflected back to the bending place. Nevertheless, some influence does travel up to the glands, causing them to sccrete more copiously, and the secretion to become acid. This lattcr fact is, I bclieve, quite new in the physiology of plants; it has indeed only recently been established that in the animal kingdom an influence can be transmitted along the nerves to glands, modifying their power of secretion, independently of the state of the bloodvessels.

The Inflection of the Exterior Tentacles from the Glands of the Disc being excited by Repeated Touches, or by Objects left in Contact with them.

The central glands of a leaf were irritated with a small stiff camel-hair brush, and in $70 \mathrm{~m}$. (minutes) sevcral of the outer tentacles were inflected; in 5 hrs. (hours) all the sub-marginal tentacles were inflected; next morning after an interval of about 22 hrs. they were fully re-expanded. In all the following cases the period is reckoned from the timc of first irritation. Another leaf treated in the same manner had a few tentacles inflected in $20 \mathrm{~m}$.; in $4 \mathrm{hr}$. all the submarginal and some of the extreme marginal tentacles, as well as the edge of the leaf itself, were inflected; in 17 lurs. they had recovered their proper, expanded position. I then put a dead fly in the centre of the last-mentioned leaf, and ncxt morning it was closely clasped; five days afterwards the leaf re-expanded, and the tentacles, with their glands surrounded by secretion, were ready to act again.

Particles of meat, dead flies, bits of paper, wood, dried moss, sponge, cinders, glass, fec., were repcatedly 
placed on leayes, and these objects were well embraced in various periods from $1 \mathrm{hr}$. to as long as $24 \mathrm{hrs}$, and set free again, with the leaf fully re-expanded, in from one or two, to scren or even ten days, according to the nature of the object. On a leaf which had naturally caught two flies, and thercforc had already closed and reopened cither once or more probably twice, I put a fresh fly : in 7 hrs. it was moderately, and in 21 hrs. thoroughly well, clasped, with the edges of the lcaf inflected. In two days and a half the leaf had nearly re-expanded; as the exciting object was an insect, this unusually short period of iuflection was, no doubt, due to the leaf having reccntly been in action. Allowing this same leaf to rest for only a single day, I put on another fly, and it again closed, but now very slowly; neverthcless, in lcss than two days it succeeded in thoroughly clasping the fly.

When a small object is placed on the glands of the disc, on one side of a leaf, as near as possible to its circumference, the tentacles on this side arc first affected, those on the opposite side much later, or, as often occurred, not at all. This was repeatedly proved by trials with bits of meat; but I will here give only the case of a minute fly, naturally caught and still alive, which I found adhering by its delicate fect to the glands on the extreme left side of the central disc. The marginal tentacles on this side closed inwards and killed the fly, and after a time the edge of the leaf on this side also became inflected, and thus remained for several days, whilst neither the tentacles nor the edge on the opposite side were in the least affected.

If young and active leaves are selceted, inorganic particles not larger than the head of a small pin, placed on the central glands, sometinnes eause the 
outer tentacles to bend inwards. But this follows much more surely and quickly, if the object contains nitrogenous matter which can be dissolved by the secretion. On one occasion I observed the following unusual circumstance. Small bits of raw meat (which acts morc energetically than any other substance), of paper, dried moss, and of the quill of a pen were placed on several leaves, and they were all embraced equally well in about $2 \mathrm{hrs}$. On other occasions the above-named substances, or more commonly particles of glass, coal-cinder (taken from the fire), stone, gold-leaf, dricd grass, cork, blotting-paper, cotton-wool, and hair rolled up into little balls, were uscd, and these substances, though they were sometimes wcll embraced, often caused no movement whatevcr in the outcr tentacles, or an extremely slight and slow movement. Yet these same leaves were proved to be in an active condition, as they were excitcd to move by substances yielding soluble nitrogenous matter, such as bits of raw or roast meat, the yolk or white of boiled eggs, fragments of insects of all orders, spiders, \&c. I will give only two instances. Minute flies were placed on the discs of several leaves, and on others balls of paper, bits of moss and quill of about the same size as the flies, and the latter were well embraced in a few hours; whereas after 25 hrs. only a very few tentacles were inflected over the other objects. The bits of paper, moss, and quill were then remored from these leaves, and bits of raw meat placed on them; and now all the tentacles were soon encrgetically inflected.

Again, particles of coal-cinder (weighing rather more than the flies used in the last experiment) were placed on the centres of three leaves: after an interval of $19 \mathrm{hrs}$. one of the particles was tolcrably well embraced; 
a seeond by a rery few tentaeles; and a third by none. I then removed the partieles from the two latter leaves, aud put on them reeently killed flies. These were fairly well embraeed in $7 \frac{1}{2}$ hrs. and thoroughly after $20 \frac{1}{2}$ hrs.; the tentacles resnaining infleeted for many subsequent days. On the other hand, the one leaf whieh had in the course of 19 hrs. embraced the bit of cinder moderately well, and to which no fly was given, after an additional 33 hrs. (i. e. in 52 hrs. from the time when the einder was put on) was eompletely re-expanded and ready to aet again.

From these and numerous other experiments not worth giving, it is eertain that inorganie substanees, or such organie substauces as are not attaeked by the seeretion, act much less quiekly and effieiently than organic substanees yielding soluble matter which is absorbed. Moreover, I have met with very few exeeptions to the rule, and these exceptions apparently depended on the leaf having been too reeently in action, that the tentacles remain elasped for a much longer time over organie bodies of the nature just specified than over those which are not acted on by the seeretion, or over inorganie objeets.*

* Owing to tho extrandinary belief held by M. Ziegler ("Comptes rendus,' May 1872, p. 122), that albuninous substanees, if held for a moment between tho fingers, acquire the property of making the tentacles of Drosera enntract, whereas, if not thus held, they have no such power, I tried some experiments with great care, but the results alid not confirm this belief. Jed-hot einders wore taken nut of the fire, and lits of glass, cotton-thread, blotting paper and thin slices of cork were inmersed in boiling water; and particles were then placed (every instrument with which they were tomehed having been previnusly immersed in boiling water) on the glands of several leaves, and they acted in exactly the sume manner as other particles, which had been purposely handlerl for some time. Bits of a hoilud egg, cut with a knife which had been washed in boiling water, also neted like any other animnl substance. I breathed ou sono lenves for above a minute, and repoated the act two or throe timos, with uny lnouth close to 
The Inflection of the Exterior Tentacles as directly caused by Objects left in Contact with their Glands.

I made a vast number of trials by placing, by means of a fine needle moistened with distilled water, and with the aid of a lens, particles of various substances on the viscid secretion surrounding the glands of the outcr tentacles. I experimented on both the oval and long-headed glands. When a particle is thus placed on a single gland, the movement of the tentacle is particularly well seen in contrast with the stationary condition of the surrounding tentacles. (See previous fig. 6.) In four cases small particles of raw meat caused the tentacles to be greatly inflected in between 5 and $6 \mathrm{~m}$. Another tentacle similarly treated, and observed with special carc, distinctly, though slightly, changed its position in $10 \mathrm{~s}$. (seconds); and this is the quickest movement seen by me. In $2 \mathrm{~m}$. $30 \mathrm{~s}$. it had moved through an angle of about $45^{\circ}$. The movement as seen through a lens resembled that of the hand of a large clock. In $5 \mathrm{~m}$. it had moved through $90^{\circ}$, and when I looked again after $10 \mathrm{~m}$., the particle had reached the centre of the leaf; so that the whole novement was completed in less

them, but this produced no effect. I may here add, as showing that the leaves are not acted on by the odour of nitrogenous substances, that picces of raw meat stur.k on ncedles were fixed as close as possible, without actual contact, to several leaves, but produced no effect whatever. On the other hand, as we shall hereatter see, the vapours of certain volatilo substances and fluids, such as of carbonato of ammonia, chloroform, certain esscutiul oils, Sc., cause inflection. Mr. Zicgler makcs still mole extraordinary statcments with respect to the power of animal snbstances, which have becn left close to, but not in contact with, sulpliate of quinine. The action of salts of quiuine will be described in a future chapter. Since the appenrance of the paper aboro referred to, MI. Ziegler his published a book on the same subject, entitled, 'Atonicite et 'soicité,' 1874. 
than $17 \mathrm{~m} .30 \mathrm{~s}$. In the course of some hours this minute bit of meat, from having been brought into eontaet with some of the glands of the eentral dise, acted eentrifugally on the outer tentacles, which all became elosely inflected. Fragments of flies were placed on the glands of four of the outer tentacles, extended in the same plane with that of the blade, and three of these fragments were carried in $35 \mathrm{~m}$. through an angle of $180^{\circ}$ to the centre. The fragment on the fourth tentaele was very minute, and it was not earried to the eentre until 3 hrs. had elapsed. In three other cases minute flies or portions of larger ones were carried to the eentre in $1 \mathrm{hr}$. $30 \mathrm{~s}$. In these seven cases, the fragments or small flies, whieh had been carried by a single tentaele to the central glands, were well embraeed by the other tentacles after an interval of from 4 to 10 hrs.

I also placed in the manner just described six small balls of writing-paper (rolled up by the aid of pineers, so that they were not tomehed by my fingers) on the glands of six exterior tentacles on distinet leaves; three of these were earried to the eentre in about $1 \mathrm{hr}$., and the other three in rather more than $4 \mathrm{hrs}$.; but after $24 \mathrm{hus}$. only two of the six balls were well embraeed by the other tentacles. It is possible that the secretion may have dissolved a trace of glue or animalised matter from the balls of paper. Four particles of coal-cinder were then placed on the glands of four exterior tentacles; one of these reached the eentre in 3 hrs. $40 \mathrm{~m}$.; the second in 9 hrs.; the third within 24 hrs., but had moved only part of the way in 9 luss.; whilst the fourth moved only a very short distance in 24 hrs., and never: moved any farther. Of the above three bits of einder which were ultimately carried to the centre, one alone was well embraced by 
many of the other tentaeles. We here see clearly that sueh bodies as partieles of cinder or little balls of paper, after being carried by the tentaeles to the eentral glands, aet very differently from fragments of flies, in eausing the movement of the surrounding tentaeles.

I made, without earefully reeording the times of movement, many similar trials with other substanees, sueh as splinters of white and blue glass, partieles of eork, minute bits of gold-leaf, \&e.; and the proportional number of eases varied mueh in whieh the tentaeles reaehed the eentre, or moved only slightly, or not at all. One evening, partieles of glass and eork, rather larger than those usually employed, were placed on about a dozen glands, and next morning, after 13 hrs., every single tentacle had earried its little load to the eentre; but the unusually large size of the partieles will aeeount for this result. In another ease $\frac{6}{7}$ of the partieles of einder, glass, and thread, placed on separate glands, were earried towards, or aetually to, the centre; in another ease $\frac{7}{9}$, in another $\frac{7}{12}$, and in the last case only $\frac{7}{96}$ were thus earried inwards, the small proportion being here due, at least in part, to the leaves being rather old and inaetive. Oeeasionally a gland, with its light load, eould be seen through a strong lens to move an extremely short distanee and then stop; this was espeeially apt to oeeur when exeessively minute partieles, much less than thosc of whieh the measurements will be immediately given, were plaeed on glands; so that we here have nearly the limit of any action.

I was so mueh surprised at the smallness of the partieles whieh eaused the tcntaeles to become greatly infleeted that it seemed worth while carefully to ascertain how minute a partiele would plainly aet. 
Aceordingly measured lengths of a narrow strip of blotting paper, of fine eotton-thread, and of a woman's hair, were carefully weighed for me by Mr. Trenham Reeks, in an exeellent balanee, in the laboratory in Jermyn Street. Short bits of the paper, thread, and hair were then eut off and measured by a mierometer, so that their weights eould be easily ealculated. The bits were placed on the viseid seeretion surrounding the glands of the exterior tentacles, with the precautions already stated, and I am certain that the gland itself was never touched; nor indeed would a single toueh have produced any effeet. A bit of the blotting-paper, weighing $\frac{1}{465}$ of a grain, was placed so as to rest on three glands together, and all three tentaeles slowly eurved inwards; each gland, therefore, supposing the weight to be distributed equally, eould have been pressed on by only $\frac{1}{1395}$ of a grain, or 0464 of a milligramme. Five nearly equal bits of eotton-thread were tried, and all aeted. 'The shortest of these was $\frac{1}{50}$ of an inch in length, and weighed $\frac{1}{8197}$ of a grain. The tentaele in this ease was considerably inflected in 1. hr. $30 \mathrm{~m}$., and the bit of thread was carried to the eentre of the leaf in $1 \mathrm{hr} .40 \mathrm{~m}$. A gain, two particles of the thinner end of a woman's hair, one of these being $\frac{18}{1000}$ of an inch in length, and weighing $\frac{1}{35 \frac{1}{10}}$ of a grain, the other $\frac{19}{\operatorname{Tog} \pi}$ of an inch in length, and weighing of eourse a little more, were plaeed on two glands on opposite sides of the same leaf, and these two tentacles were inflected halfway towards the eentre in $1 \mathrm{hr}, 10 \mathrm{~m}$.; all the many other tentacles round the same leaf remaining motionless. The appearanee of this one lenf showed in an unequivoeal manner that these minute particles suffieed to eause the tentreles to bend. Altogether, ten sueh particles of hair were placed on ten glands on several leaves, and seven of them eaused 
the tentacles to move in a conspicuous manner. The smallest particle which was tried, and which acted plainly, was only $\frac{8}{100}$ of an inch ('203 millimetre) in length, and weighed the $\frac{1}{78 \frac{1}{7+0}}$ of a grain, or 000822 milligramme. In these sevcral cascs, not only was the inflection of the tentacles couspicuous, but the purple fluid within their cells became aggregated into little masses of protoplasm, in the manner to be described in the next chapter; and the aggregation was so plain that I could, by this clue alone, have readily picked out. under the microscope all the tentacles which had carried their light loads towards the centre, from the hundreds of other tentaeles on the same lcaves which had not thus acted.

My surprise was greatly excited, not only 'by the minuteness of the particles which caused movement, but how they could possibly act on the glands; for it must be remembered that they wcrc laid with the greatest eare on the eonvex surface of the secretion. At first I thought-but, as I now know, erroneouslythat particles of such low spccific gravity as those of cork, thread, and paper, would never come into contact with the surfaces of the glands. The particles eannot act simply by their weight being added to that of the sccretion, for small drops of water, many times heavier than the particles, were repeatedly added, and never produced any effeet. Nor does the disturbance of the seeretion produce any effeet, for long threads were drawn out by a needle, and affixed to some adjoining object, and thus left for hours; but the tentacles remained motionless.

I also carefully removed the secretion from four glands with a sharply pointed piece of blotting-paper, so that they were exposed for a time naked to the air, but this eaused no movement; yet these glands were 
in an efficient state, for after 24 hrs. had èlapscd, they were tried with bits of meat, and all became quiekly inflected. It then oeenrred to me that partieles floating on the seeretion would east shadows on the glands, which might be sensitive to the intereeption of the light. Although this seemed highly improbable, as minute and thin splinters of eolourless glass acted powerfully, nevertheless, after it was dark, I put on, by the aid of a single tallow candle, as quiekly as possible, partieles of eork and glass on the glands of a dozen tentacles, as well as some of meat on other glands, and eovered them 11 so that not a ray of light could enter ; but by the next morning, after an interval of 13 hrs., all the partieles were carried to the centres of the leaves.

These negative results led me to try many more experiments, by placing particles on the surfaec of the drops of seeretion, observing, as carefully as I eould, whether they penetrated it and touehed the surfaee of the glands. The seeretion, from its weight, generally forms a thiekcr layer on the under than on the upper sides of the glands, whatever may be the position of the tentaeles. Minute bits of dry cork, thread, blotting paper, and eoal einders were tried, such as those previously employed; and I now obscrved that they absorbed much more of the secretion, in the course of in few minutes, than I should have thought possible; and as they had been laid on the upper surface of the seeretion, where it is thinnest, they were often drawn down, after a time, into contact with at least some one point of the gland. With respect to the minute splinters of glass and particles of hair, I observed that the secretion slowly spread itself a little over their surfices, by which means they were likewise drawn downwards or sideways, and thus one end, or some minute 
prominenee, often eame to touch, sooner or later, the gland.

In the foregoing and following cases, it is probable that the vibrations, to which the furniture in every room is continually liable, aids in bringing the particles into contact with the glands. But as it was sometimes diffieult, owing to the refraction of the secretion, to feel sure whether the particles were in contact, I tried the following experiment. Unusually minute particles of glass, hair, and cork, were gently placed on the drops round several glands, and very few of the tentacles moved. Those which were not affected were left for about half an hour, and the particles were then disturbed or tilted up several times with a fine needle under the microscope, the glands not being touched. And now in the course of a fer minutes almost all the hitherto motionless tentacles began to move; and this, no doubt, was eaused by one end or some prominence of the particles having come into contact with the surface of the glands. But as the partieles were unusually minute, the movement was small.

Lastly, some dark blue glass pounded into fine splinters was used, in order that the points of the particles might be better distinguished when immersed in the seeretion; and thirteen such particles were placed in contaet with the depending and therefore thicker part of the drops round so many glands. Five of the tentacles began moving after an interval of a few minutes, and in these cases I clearly saw that the particles touched the lower surface of the gland. A sixth tentacle moved after $1 \mathrm{hr}$. $45 \mathrm{~m}$., and the particle was now in contact with the gland, whieh was not the ease at first. So it was with the seventh tentacle, but its movement did not begin $u$ til 3 lirs. $45 \mathrm{~m}$. had 
elapsed. The remaining six tentacles never moved as long as they were observed; and the particles apparently never eame into eontaet with the surfaces of the glands.

From these experiments we learn that particles not eontaining soluble matter, when plaeed on glands, often eause the tentacles to begin bending in the course of from one to five minutes; and that in such cases the partieles have been from the first in eontact with the surfaees of the glands. When the tentacles do not begin moving for a much longer time, namely, from half an hour to three or four hours, the partieles have been slowly brought into eontaet with the glands, either by the secretion being absorbed by the partieles or by its gradual spreading over them, together with its consequent quieker evaporation. When the tentaeles do not move at all, the particles have never come into eontact with the glands, or in some cases the tentaeles may not have been in an active condition. In order to excite movement, it is indispensable that the particles should aetually rest on the glands; for a touch onee, twice, or even thrice repeated by any hard body is not sufficient to excite movement.

Another experiment, showing that extremely minute particles aet on the glands when immersed in water, may here be given. A grain of sulphate of quinine was added to an ounee of water, which was not afterwards filtered; and on placing three leaves in ninety minims of this fluid, I was mueh surprised to find that all three leaves were greatly inflected in $15 \mathrm{~m}$.; for I knew from previous trials that the solution does not act so quickly as this. It immediately oceur'ed to me that the particles of the undissolved salt, which were so light as to float about, might lave come 
into contact with the glands, and caused this rapid movement. Accordingly I added to some distilled water a pinch of a quite innocent substance, namely, precipitated carbonate of lime, which consists of all impalpable powder; I shook the mixture, and thus got a fluid like thin milk. Two leaves were immersed in it, and in $6 \mathrm{~m}$. almost every tentacle was much inflected. I placed one of these leaves minder the microscope, and saw innumerable atoms of lime adhering to the external surface of the secretion. Some, however, had pcnetrated it, and wcre lying on the surfaces of the glands; and no doubt it was these particles which caused the tentacles to bend. When a leaf is inmersed in water, the secretion instantly swells much; and I presume that it is ruptured here and there, so that little eddies of water rush in. If so, we can understand how the atoms of chalk, which rested on the surfaces of the glands, had penetrated the secretion. Anyone who has rubbed precipitated chalk between his fingers will have perceived how excessively fine the powder is. No doubt there must be a limit, beyond which a particle would be too small to act on a gland; but what this limit is, I know not. I have often scen fibres and dust, which had fallen from the air, on the glands of plants kept in my room, and these nerer induced any movement; but then such particles lay on the surface of the secretion and never reached the gland itsclf.

Finally, it is an cxtraordinary fact that a little bit of soft thread, $\frac{1}{50}$ of an inch in length and weighing $\frac{1}{8 \frac{1}{1} 9}$ of a grain, or of a luuman hair, $\frac{8}{10 \pi}-\overline{0}$ of an inch in length and weighing only $-\frac{1}{8} \frac{1}{50}$ of a grain (.000822 milligramme), or particles of precipitated chalk, after resting for a short time on a gland, should induce some change in its cells, exciting them 
to transmit a motor impulse throughout the whole length of the pedicel, cousisting of about twenty cells, to near its base, causing this part to bend, and the tentacle to sweep through an angle of above $180^{\circ}$. 'That the contents of the cells of the glands, and afterwards those of the perlicels, are affected in a plainly visible manner by the pressure of minute particles, we shall have abundant evidence when we treat of the aggregation of protoplasm. But the casc is much more remarkable than as yet stated; for the particles are supported by the viscid and dense secretion; nevertheless, even smaller ones than those of which the measurements have been given, when brought by an insensibly slow movement, through the means above specified, into contact with the surface of a gland, act on it, and the tentacle bends. The pressure exerted by the particle of hair, weighing only $\frac{1}{78+50}$ of a grain and supported by a dense fluid, must have been inconceivably slight. We may conjecture that it could hardly have equalled the millionth of a grain; and we shall hereafter see that far less than the millionth of a grain of phosphate of ammonia in solution, when absorbed by a gland, acts on it and induces movement. A bit of hair, 50 of an inch in length, and therefore much larger than those used in the above expcriments, was not perceived when placed on my tongue; and it is extremely doubtful whether any nerve in the human body, even if in an inflamed condition, would be in any way affected by such a particle supported in a dense fluid, and slowly brought into contact with the nerve. Yet the cells of the glands of Drosera are thus excited to transmit a motor impulse to a distant point, inducing movement. It appcars to me that hirdly any nore remarkable fact than this has been observed in the vegetable kingdom. 


\section{The Inflection of the Exterior Tentacles, when their. Glands} are excited by Repeated Touches.

We have already seen that, if the central glands are excited by being gently brushed, they transmit a motor impulse to the exterior tentacles, causing them to bend; and we have now to consider the effects which follow from the glands of the exterior tentacles being themselves tonched. On several occasions, a large number of glands were touehed only once with a needle or fine brush, hard enough to bend the whole flexible tentacle; and though this must have caused a thousandfold greater pressure than the weight of the above described particles, not a tentacle moved. On another oceasion forty-five glands on eleven leaves were touched once, twice, or even thrice, with a needle or stiff bristle. This was done as quickly as possible, but with foree sufficient to bend the tentacles; yet only six of them became infleeted,- three plainly, and three in a slight degree. In order to ascertain whether these tentacles which were not affected were in an efficient state, bits of meat were plaeed on ten of them, and they all soon beeame greatly incurved. On the other hand, when a large number of glands were struck four, five, or six times with the same force as before, a needle or sharp splinter of glass being used, a much larger proportion of tentacles became inflected; but the result was so uneertain as to seem caprieious. For instance, I struck in the above manner three glands, which happened to be extremely sensitive, and all three were infiected almost as quickly as if bits of meat had been placed on them. On another occasion I gave a single for- 
cible touch to a considerable number of glands, and not one moved; but these same glands, after an interval of some hours, bcing touched four or five tims: with a needle, several of the tentacles soon becams. inflected.

The fact of a single touch or cven "of two or thres touches not causing inflection must be of some service to the plant; as during stormy weather, the glands cammot fail to be occasionally touched by the tall blades of grass, or by other plants growing near ; and it would be a great evil if the tentacles were thims brought into action, for the act of re-expansion takes a considerable time, and until the tentacles are reexpanded they cannot catch prey. On the other hand, extreme sensitivencss to slight pressure is of the highest service to the plant; for, as we have seen. if the delicate fect of a minute struggling insect press: ever so lightly on the surfaces of two or three ghands. the tentacles bearing these glands soon curl inwark and carry the insect with them to the centre, causing. after a time, all the circumferential tentacles to embrace it. Nevertheless, the movements of the plant are not perfectly adapted to its requirements: for if a bit of dry moss, peat, or other rubbish, is blown on to the disc, as often happens, the tentareles rlasp it in a useless manner. They soon, however. discover their mistake and relcasc such immutritions oljjerts.

It is also a remarkable fact, that drops of water filling from a height, whether under the form of natural or artificial rain, do not cause the tentacles to more: yet the drops must strike the glands with consid(unhl. force, more especially after the secretion has beon all washer away by houvy rain; and this often ocours. 
though the secretion is so viseid that it can be removed with diffieulty merely by waving the leaves in water. If the falling drops of water are small, they adhere to the secretion, the weight of which must be inereased in a much greater degree, as before remarked, than by the addition of minute partieles of solid matter; yet the drops never eause the tentaeles to beeome infleeted. It would obviously have been a great evil to the plant (as in the ease of oecasional touehes) if the tentacles were excited to bend by every shower of rain; but this evil has been avoided by the glands either having become through habit insensible to the blows and prolonged pressure of drops of water, or to their having been originally rendered sensitive solely to the contact of solid bodies. We shall hereafter see that the filaments on the leaves of Dionæa are likewise insensible to the impaet of fluids, though exquisitely sensitive to momentary touehes from any solid body.

When the pedicel of a tentaele is eut off by a sharp pair of seissors quite close beneath the gland, the tentacle generally beeomes infleeted. I tried this experiment repeatedly, as I was mueh surprised at the fact, for all other parts of the pedieels are insensible to any stimulus. These headless tentacles after a time re-expand; but I shall return to this subjeet. On the other hand, I oeeasionally sneeeeded in erushing a gland between a pair of pineers, but this eaused no infleetion. In this latter ease the tentreles seem paralysed, as likewise follows from the action of too strong solutions of eertain salts, and by too great heat, whilst weaker solutions of the same salts and a more gentle heat eause movement. We shall also see in future chapters that various other fluids, some 
Chap. II.

vapours, and oxygen (after the plant has been for some time excluded from its action), all induce inflection, and this likewise results from an induced galvanic current.*

* My son Franeis, guided by the observations of Dr. Burdon Sanderson on Dionzea, finds that if two needles are inserted into the blade of a leaf of Drosera, the tentacles do not move; but that if sinuilar needles in eonnection with the seeondary coil of a Du Bois induetive apparatus are inserted, the tentaeles eurve in wards in the eourse of a few minutes. My son hopes soon to pululish an account of his observations. 


\section{CHAPTER III.}

Algregation of the Protoplasm mithin the Cells of the TENTACLES.

Nature of the contents of the cclls beforc aggregation-Various causes which cxcite aggregation-The process commences within the glands and travels down the tentacles - Description of the agrgregated masses and of their spontancous movements-Currents of protoplasm along the walls of the cells-Action of carbonate of ammonia-The granules in the protoplasm which flows along the walls coalesce with the central masses-Minuteness of the quantity of carbonato of ammonia causing aggregation-Action of other salts of ammonia - Of othcr substances, organic fluids, de.-Of water-Of heat-Redissolntion of the aggregated masses -Proximate causes of the aggregation of the protoplasm summary and concluding remarks-Supplementary obscrvations on aggregation in the roots of plants.

I WIL here interrupt my account of the morements of the leaves, and describe the phenomenon of aggregition, to which subject I have already allinded. If the tentacles of a young, yet fully matured leaf, that has never been excited or become inflected, be examined, the cells forming the pedicels are seen to be filled with homogeneous, purple fluid. 'The walls are lined by a layer of colourless, circulating protoplasm; but this ean be seen with much greater distinctness atter the process of aggregation has been partly offected than before. The purple fluid which exudes from a crushed tentacle is somewhat coherent, and foes not mingle with the surrounding water; it contains much flocerlent or granular matter. But this matter may have been geneiated by the cells having been erushed; some degree of aggregation haviug hecn thus almost instantly eaused. 
If a tcntacle is examincd some hours after the gland has bcen excited by repcated touches, or by an inorganic or organic particle placed on it, or by the absorption of certain fluids, it presents a wholly changed appcarance. The cclls, instead of being filled with homogeneons purple fluid, now contain variously shaped masses of purple matter, suspended in a colourless or almost colourless fluicl. The change is so conspicuous that it is visible through a weak lens, and even sometimcs by the naked eye; the tentacles now have a mottled appearance, so that one thus affected can bc picked out with ease from all the others. The same result follows if the glands on the disc are irritated in any manner, so that the extcrior tentacles bccome inflected; for their contents will then be found in an aggregated condition, although their glands have not as yet touched any object. But, aggregation may occur indcpendently of inflcction, as we shall presently sec. By whatever cause the process may have becn excited, it commences within the glands, and then travels down the tentacles. It can be observed much morc distinctly in the upper cells of the pedicels than within the glinds, as these are somewhat opaque. Shortly aftcr the tentacles have re-expanded, the little masses of protoplasm arc all redissolved, and the purple fluid within the cclls becomes as homogeneous and transparent as it was at first. The process of redissolution travels upwards from the bases of the tentacles to the glands, and therefore in a reversed dircction to that of aggreration. T'cntacles in an aggregated condition were shown to Prof. Huxlcy, Dr. Hookcr, and Dr. Burdou Sanderson, who observed the changes under the microscope, and werc much struck with the wholc phenomenon. 
The little masses of aggregated matter arc of the most divcrsified shapes, often spherical or oval, sometimes much elongated, or quite irregular with threador necklace-like or club-formed projcctions. They consist of thick, apparently viscid matter, which in the exterior tentacles is of a purplish, and in the short discal tentacles of a greenish, colour. These little masses incessantly change their forms and positions, being never at rest. A single mass will often scparatc into two, which afterwards reunite. Their movements are rather slow, and resemble those of Amoebæ or of the white corpuscles of the blood. We

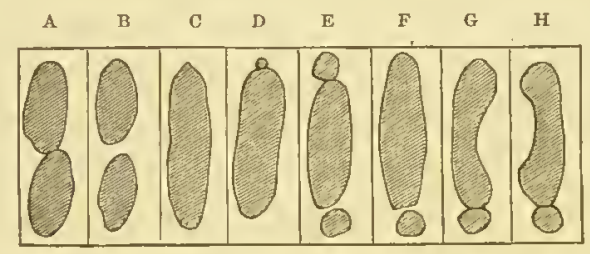

FIG. 7 .

(Drosera rotundifolia.)

Diagram of the same cell of a tentacle, showing the various forms successively assumed by the aggregated masses of protoplasm.

may, therefore, conclude that thcy consist of protoplasm. If their shapes are sketched at intervals of a few minutcs, they arc invariably scen to have undergone grcat changes of form; and the same cell has bcen obscrved for sevcral hours. Eight rude, though accurate sketches of the same cell, madc at intervals of between $2 \mathrm{~m}$. or $3 \mathrm{~m}$., are here given (fig. 7), and illustrate some of the simpler and commonest changes. The cell $A$, when first sketched, included two oval masses of purple protoplasm touching each other. These bccame scparate, as shown at $B$, and then reunited, as at C. After the next interval a very common appearance was presented- 
I), namely, the formation of an extremely minute sphere at one end of an elongated mass. This rapidly increased in size, as shown in $\mathrm{E}$, and was then reabsorbed, as at F, by whieh time another sphere had been formed at the opposite. end.

The cell above figured was from a tentacle of a dark red leaf, whieh had eaught a small moth, and was examined under water. As I at first thought that the morements of the masses might be due to the absorption of water, I placed a fly on a leaf, and when after 18 hrs. all the tentacles were well inflected, these were examined without being immersed in water. The eell

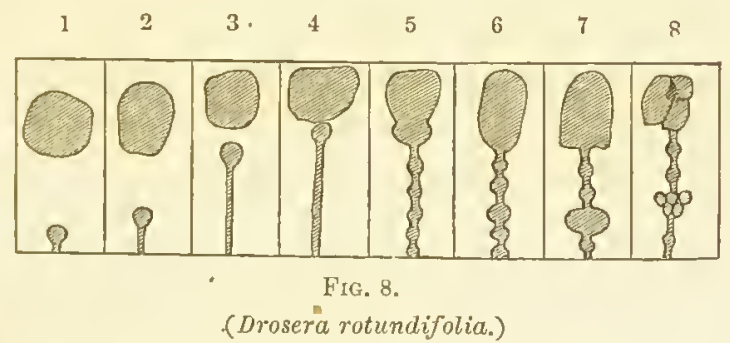

Diagram of the same cell of a tentacle, showing the various forms successively assumed by the aggregated masses of protoplasm.

here represented (fig. 8) was from this leaf, being sketehed eight times in the course of $15 \mathrm{~m}$. These sketehes exhibit some of the more remarkable ehanges whieh the protoplasm undergoes. At first, there was at the base of the eell 1, a little mass on a short footstalk, and a larger mass near the upper end, and these seemed quite separate. Nevertheless, they may have been connected by a fine and invisible thread of protoplasm, for on two other oeeasions, whilst one mass was rapidly increasing, and another in the same cell rapidly decreasing, I was able by varying the light and using a high power, to detect a conneeting thread of extreme tenuity, whieh evidently served as 
the channel of communication between the two. On the other hand, such connecting threads are sometimes seen to break, and their extremitics then quickly become club-headed. The other skctches in fig. 8 show the forms successively assumed.

Shortly aftcr the purple fluid within the cells has become aggregated, the little masses float about in a colourless or almost colourless fluid; and the layer of white granular protoplasm which flows along the walls can now be secn much more distinctly. The strcam flows at an irregular rate, up one wall and down the opposite one, gcnerally at a slower rate across the narrow ends of the elongated cells, and so round and round. But the current sometimes ceases. The movement is often in waves, and their crests sometimes stretch almost across the whole width of the cell, and then sink down again. Small spheres of protoplasm, apparently quite free, are often driven by the current round the cells; and filaments attached to the central masses are swayed to and fro, as if struggling to cscapc. Altogether, one of these cells with the ever changing central masses, and with the layer of protoplasm flowing round the walls, presents a wonderful scene of vital activity.

Many observations were mado on the eontents of the eells whilst undergoing the proeess of aggregation, but I shall detail only a few eases under different heads. A small portion of a leaf was eut off, plaeed under a high power, and the glands very gently pressed under a eompressor. In $15 \mathrm{~m}$. I distinetly saw extremely minute spheres of protoplasm aggregating themselves in the purple fluid; these rapidly inereased in size, both within the eells of the glands and of the upper ends of the pedieels. Partieles of glass, eork, and einders wore also plaeed on the glands of many tentreles; in $1 \mathrm{hr}$. several of them were infleeted, but after $1 \mathrm{hr} .35 \mathrm{~m}$. there was no nggregation. Other tentaeles with these partieles were examined after $S$ lixs., and 
now all thcir cells had undergone aggregation; so had the cells of the exterior tentacles which had become inflected through the irritation transmitted from the glands of the dise, on which the transported particles rested. This was likervise the case with the short tentacles round the margins of the disc, which had not as yet become inflected. This latter fact shows that the process of aggregation is independent of the inflection of the tentacles, of which indeed we have othcr and abundant evidence. Again, the cxterior tentacles on three leaves were carefully examined, and found to contain only homogeneous purple fluid; little bits of thread were then placed on the glands of three of them, and after $22 \mathrm{hrs}$. the purple fluid in their cells almost down to their bases was aggregated into innumerable, spherical, elongated, or filamentous masses of protoplasm. The bits of thread had been carried some time previously to the central dise, and this had caused all the other tentacles to become somewhat inflected; and their cells had likewise undergone aggregation, which however, it should be observed, had not as yet extended down to their bases, but was confined to the cells close beneath the glands.

Not only do repeated touches on the glands* and the contact of minute particles cause aggregation, but if glands, without being themselves injured, are cut off from the summits of the pedicels, this induces a moderate amount of aggregation in the headless tentacles, after they have become inflected. On the other hand, if glands are suddenly crushed between pincers, as was tried in six cases, the tentacles seem paralysed by so great a shock, for they neither become inflected nor exhibit any signs of aggregation.

Carbonate of Ammonia.-Of all the causes inducing aggregation, that which, as far as I have seen, acts the quickest, and is the most powerful, is a solution of carbonate of ammonia. Whatever its strength may be, the glands are always affected first, and soon become quite opaque, so as to appear black. For instance, I placed a leaf in a few drops of a strong solution, namely, of one part to 146 of water (or 3 grs. to $1 \mathrm{oz}$.), and observed it under a high power. All the glands began to

* Judging from an aceount of MI. Heekul's obscrvations, whieh I have only just secn quoterl in the 'Girduner's Chronielo' (Oet. $10,1874)$, he appears to havo observed $a$ similar phenomenon in tho stamens of Berberis, after thoy havo been exeited by a toweh and have moved; for ho says, "the eontents of cael indiviclual eell aro colleeted together in the centro of the cavity." 
darken in $10 \mathrm{~s}$. (seconds); and in $13 \mathrm{~s}$. were conspicuously darker. In $1 \mathrm{~m}$. extremely small spherical masses of protoplasm could be seen arising in the cclls of the pediccls close beneath the glands, as well as in the cushions on which the longheadcd marginal glands rest. In several cascs the process travelled down the pedicels for a length twice or thricc as great as that of the glands, in about $10 \mathrm{~m}$. It was intercsting to obscrve the process momentarily arrested at each transverse partition between two cells, and then to see the transparent contents of the cell next below almost flashing into a cloudy mass. In the lower part of the pedicels, the action proceeded slower, so that it took about $20 \mathrm{~m}$. before the cells halfway down the long marginal and submarginal tentacles became aggregated.

We may infer that the carbonate of ammonia is absorbed by the glands, not only from its action heing so rapid, but from its effect bcing somewhat different from that of other salts. As the glands, when excited, secrete an acid belonging to the acetic series, the carbonate is probably at once converted into a salt of this series; and wc shall presently sec that the acetate of ammonia causes aggregation almost or quite as energetically as does the carbonate. If a few drops of a solution of one part of the carbonate to 437 of water (or $1 \mathrm{gr}$. to $1 \mathrm{oz}$.) be added to the purple fluid which cxudes from crushed tentacles, or to paper stained by bcing rubbed with them, the fluid and the paper are changed into a pale dirty green. Neverthcless, some purple colour could still be detectcd after $1 \mathrm{hr} .30 \mathrm{~m}$. within the glands of a leaf lcft in a solution of twice the above strength (viz. 2 grs, to 1 oz.); and after 24 hrs. the cells of the pedicels close bencath the glands still contained spheres of protoplasm of a fine purple tint. These facts show that the ammonia had not entered as a carbonate, for othcrwisc the colour rould have been discharged. I have, however, somctimes obscrved, especially with the long-headed tentacles on the margins of very palc leaves immersed in a solution, that the glands as well as the upper cells of the pedicels were discoloured; and in these cascs I presume that the unchanged carbonate had been absorbed. The appearance above described, of the aggregating process being arrested for a short time at each transverse partition, impresses the mind with the idea of matter passing downwards from cell to cell. But as the cclls one beneath the other undergo aggregation when inorganic and insoluble particles are placed on the glands, the process must be, at least in thesc cascs, one of molccular change, transmitted from the glands, 
independently of the absorption of any matter. So it may possibly be in the case of the carbonatc of ammonia. As, however, the aggregation causcd by this salt travcls down the tentacles at a quicker rate than when insoluble particles arc placed on the glands, it is probablc that ammonia in some form is absorbed not only by the glands, but passes down the tentacles.

Having examined a leaf in wator, and found the contents of the cells homogeneous, I placed it in a few drops of a solution of one part of the carbonate to 437 of watcr, and attcnded to the cclls immediately beneath the glands, but did not use a very high power. No aggregation was visible in $3 \mathrm{~m}$; ; but aftcr $15 \mathrm{~m}$. small spheres of protoplasm were formed, more especially beneath the long-headed 'marginal glands; the process, however, in this case took place with unusual slowness. In $25 \mathrm{~m}$. conspicuous spherical masses wcre prescnt in the cells of the pedicels for a length about equal to that of the glands; and in $3 \mathrm{hrs}$. to that of a third or half of the whole tentaclc.

If tentacles with cells containing only very pale pink fluid, and apparently but little protoplasm, are placed in a few drops of a weak solution of one part of the carbonate to 4375 of water ( $1 \mathrm{gr}$. to $10 \mathrm{oz}$.), and the highly transparent cells beneath the glands are carefully observed under a high power, these may be seen first to become slightly cloudy from the formation of numberless, only just perccptible, granules, which rapidly grow larger either from coalescence or from attracting more protoplasm from the surrounding fluid. On one occasion I chose a singularly palc leaf, and gavc it, whilst under the microscope, a single drop of a stronger solution of one part to 437 of water; in this case the contents of the cells did not become cloudy, but after $10 \mathrm{~m}$. minute irregular granules of protoplasm could be detectcd, which soon incrcased into irrcgular masses and globules of a grecnish or vcry pale purple tint; but these never formed perfect sphcres, though incessantly changing their shapes and positions.

With moderately red leaves the first effect of a solution of the carbonate generally is the formation of two or thrce, or of several, cxtremely minute purple sphcres which rapidly incrcasc in size. To givo an idea of the rate at which such spheres increase in size, I may mention that a rather palc purplc leaf placed under a slip of glass was given a drop of a solution of onc part to 292 of watcr, and in $13 \mathrm{~m}$. a few minuto spheres of protoplasm werc formed; one of these, after 2 hrs. $30 \mathrm{~m}$." was about two-thirds of the diameter of the cell. After 4 hrs. $25 \mathrm{~m}$. 
it nearly equalled the eell in diameter; and a seeond sphere about half as large as the first, together with a few other minute ones, were formed. After 6 hrs. the fluid in which these spheres floated was almost eolourless. After 8 hrs. 35 m. (always reckoning from the time when the solution was first added) four new minute spheres had appeared. Next morning, after 22 hr's., there were, besides the two large spheres, seven smaller ones, floating in absolutely colourless fluid, in whieh some floeeulent greenish matter was suspended.

At the eommencement of the process of aggregation, more espeeially in dark red leaves, the contents of the cells often present a different appearance, as if the layer of protoplasm (primordial utricle) which lines the cells had separated itself and shrunk from the walls; an irregularly shaped purple bag being thus formed. Other fluids, besides a solution of the carbonate, for instanee an infusion of raw meat, produce this same effect. But the appearance of the primordial utricle shrinking from the Walls is certainly false ; for before giving the solution, I saw on several occasions that the walls were lined with colourless flowing protoplasm, and after the bag-like masses were formed, the protoplasm was still flowing along the walls in a eonspicuous mamer, even more so than before. It appeared jndeed as if the stream of protoplasm was strengthened by the action of the earbonate, but it was impossible to ascertain whether this was really the case. The bag-like masses, when once formed, soon begin to glide slowly round the cells, sometimes sending out projeetions which separate into little spheres; other spheres appear in the fluid surrounding the bags, and these travel much more quickly. That the small spheres are separate is often shown by sometimes one and then another travelling in advanee, and sometimes they revolve round each other. I have occasionally seen spheres of this kind proceeding up and down the same side of a cell, instead of round it. The bag-like masses after a time generally divide into two rounded or oval masses, and these undergo the changes shown in figs. 7 and 8. At other times spheres appear within the bags; and these coalesee and separate in an endless eycle of ehange.

After leaves have been left for several hour's in a solution of the carbonate, and complete aggregation has been effeeted, the

* With other plants I have often seen what appear's to be a true shrinking of the primordial utricle from the walls of the cells, caused by a solntion of carlonate of ammonia, as likewise follows from mechauical injuries. 
stream of protoplasm on the walls of the cells ceases to be visible; I observed this fact repeatedly, but will give only one instancc. A pale purple lcaf was placed in a few drops of a solution of one part to 292 of water, and in 2 hrs. some fine purple spheres were formed in the upper cells of the pedicels, the stream of protoplasm round their walls being still quite distinct; but after an additional 4 hrs., during which time many more spheres were formed, the strcam was no longer distinguishable on the most careful examination; and this no doubt was due to the contained granules having become united with the spheres, so that nothing was left by which the movement of the limpid protoplasm could be perceived. But minute free spheres still travelled up and down the cells, showing that there was still a current. So it was next morning, after 22 hrs., by which time some new minute spheres had been formed; these oscillated from side to side and changed their positions, proving that the current had not ceased, though no stream of protoplasm was visible. On another oceasion, however, a stream was seen flowing round the cell-walls of a vigorous, dark-coloured leaf, after it had been left for $24 \mathrm{hrs}$. in a rather stronger solution, namely, of one part of the carbonate to 218 of water. This Jeaf, therefore, was not much or at all iujured by an immersion for this length of time in the above solution of two grains to the ounce; and on being afterwards left for $24 \mathrm{hrs}$. in water, the aggregated masses in many of the cclls wcre redissolved, in the same manner as occurs with leaves in a state of nature when they re-expand after having caught insects.

In a lcaf which had been left for 22 hrs. in a solution of one part of the carbonate to 292 of water, some spheres of protoplasm (formed by the self-division of a bag-like mass) were gently pressed beneath a covering glass, and then cxamined under a high power. They werc now distinctly divided by well-defined radiating fissures, or were brokcn up into separate fragments with sharp edges; and they were solid to the centre. In the larger broken spheres the central part was more opaque, darker-coloured, and less brittle than the exterior; the latter alone being in some cases penetrated by the fissures. In many of the spheres the line of separation between the outer and inner parts was tolerably well defined. Tho outer parts were of exactly the same very pale purplc tint, as that of the last formed smaller spheres; and these latter did not include any darker central eore.

From these several facts we may conclude that when vigorous dark-coloured leaves are subjected to the action of carbonate of 
ammonia, the fluid within the cells of the tentacles often aggregates exteriorly into cohercnt viscid matter, forming a kind of bag. Small spheres sometimes appear within this bag, and the whole generally soon divides into two or more spheres, which repcatedly coalesce and redivide. After a longer or shorter time the granules in the colourless layer of protoplasm, which flows round the walls, are drawn to and unite with the larger spheres, or form small independent sphercs; these latter being of a much paler colour, and more brittlc than the first aggregated masses. After the granules of protoplasm have bcen thus attracted, the layer of flowing protoplasm can no longer be distinguished, though a current of limpid fluid still flows round the walls.

If a leaf is immersed in a very strong, almost concentrated, solution of carbonate of ammonia, the glands are instantly blackened, and they secrete copiously; but no movcment of the tentacles ensues. Two leaves thus treated became after $1 \mathrm{hr}$. flaccid, and seemed killed; all the cells in their tentacles contained spheres of protoplasm, but these were small and discoloured. Two other leaves were placed in a solution not quitc so strong, and therc was well-marked aggregation in $30 \mathrm{~m}$. After $24 \mathrm{hr}$. the sphcrical or more commonly oblong masses of protoplasm becamc opaque and granular, instead of heing as usual translucent; and in the lower cells there were only innumerable minute spherical granules. It was evident that the strength of the solution had interfered with the completion of the process, as we shall see likewise follows from too great heat.

All the foregoing observations relate to the exterior tentacles, which are of a purple colour; but the green pedicels of the short central tentacles are acted on by the carbonate, and by an infusion of raw mcat, in exactly the samc manner, with the sole difference that the aggregated masses ac of a grecnish colour; so that the process is in mo way dependent on the colour of the fluid within the cclls.

Finally, the most remarkable fact with respect to this salt is the extraordinary small amount which suffices to cause aggregation. Full details will be given in the seventh chapter, and here it will be enough to say that with a sensitive leaf the absorption by a gland of $\frac{1}{134.00}$ of a grain ( $(000482 \mathrm{mgr}$.) is enough to cause in the course of one hour well-marked aggregation in the cclls immediately bencath the gland.

The liffects of certain other Salts and Eluids. - Two lcaves were placed in a solution of onc part of acetate of ammonia to about 
146 of water, and were aeted on quite as encrgotieally, but perhaps not quite so quiekly, as by the earbonate. After $10 \mathrm{~m}$. the glands were blaek, and in the eells beneath them there were traees of aggregation, which after $15 \mathrm{~m}$. was well marked, extending down the tentaeles for a length equal to that of the glands. After 2 hrs. the eontents of almost all the eells in all the tentaeles were broken up into masses of protoplasm. A leaf was immersed in a solution of one part of oxalate of ammonia to 146 of water; and after $24 \mathrm{~m}$. some, but not a eonspienous, ehange eould be seen within the eells beneath the glands. After $47 \mathrm{~m}$. plenty of spherieal masses of protoplasm were formed, and these extended down the tentaeles for about the length of the glands. This salt, therefore, does not aet so quickly as the earbonate. With respeet to the eitrate of ammonia, a leaf was plaeed in a little solution of the above strength, and there was not even a traee of aggregation in the eells beneath the glands, until $56 \mathrm{~m}$. had elapsed; but it was well marked after 2 hrs. $20 \mathrm{~m}$. On another oeeasion a leaf was plaeed in a stronger solution, of one part of the eitrate to 109 of water ( 4 grs. to 1 oz.), and at the same time another leaf in a solution of the earbonate of the same strength. The glands of the latter were blaekened in less than $2 \mathrm{~m}$., and after $1 \mathrm{hr} .45 \mathrm{~m}$. the aggregated masses, which were spherieal and very dark-eoloured, extended down all the tentaeles, for between half and two-thirds of their lengths; whereas in the leaf immersed in the eitrate the glands, after $30 \mathrm{~m}$., were of a dark red, and the agrregated masses in the eells beneath them pink and elongated. After $1 \mathrm{hr} .45 \mathrm{~m}$. these masses extended down for only about one-fiftl or one-fourth of the length of the tentaeles.

'Two leaves were plaeed, eaeh in ten minims of a solution of one part of nitrate of ammonia to 5250 of water ( $1 \mathrm{gr}$. to $12 \mathrm{oz}$.), so that each leaf reeeived $\frac{1}{576}$ of a grain ( $1124 \mathrm{mgr}$.). This quantity eaused all the tentaeles to be infleeted, but after 21 hrs. there was only a traee of aggregation. One of these same leaves was then plaeed in a weak solution of the earbonate, and after $1 \mathrm{hr} .45 \mathrm{~m}$. the tentaeles for half thoir longths showed an astonisling degree of aggregation. Two other leaves were then plaeed in a much stronger solution of onc part of the nitrate to 146 of water (" gris. to $10 \%$ ); in one of these there was no marked ehango after 3 hrs.; but in the other thero was a trace of aggrugation after $52 \mathrm{~m}$., and this was plainly marked after 1 hr. $22 \mathrm{~m}$., but even after. 2 hrs. $12 \mathrm{~m}$. there was eertainly not rnore aggregation than would have fol- 
lowed from an immersion of trom $5 \mathrm{~m}$. to $10 \mathrm{~m}$. in an cqually strong solution of the carbonatc.

Lastly, a leaf was placed in thirty minims of a solution of one part of phosphate of ammonia to 43,750 of water ( $1 \mathrm{gr}$. to $100 \mathrm{oz}$.), so that it received $\frac{1}{1600}$ of a grain ( $04079 \mathrm{mgr}$.); this soon caused the tentacles to be strongly inflected; and atter $24 \mathrm{hrs}$. the contents of the cells were aggregated into oval and irregularly globular masses, with a conspicuous current of protoplasm flowing round the walls. But after so long an interval aggregation would have ensued, whaterer had caused inflection.

Only a few other salts, besides those of ammonia, were tried in relation to the process of aggregation. A leaf was placed in a solution of one part of chloride of sodium to 218 of water, and after $1 \mathrm{hr}$. the eontents of the cells wore aggregated into small, irregularly globular, brownish masses; these after 2 hrs. were almost disintegrated and pulpy. It was evident that the protoplasm had been injuriously affected; and soon afterwards some of the cells appeared quite cmpty. 'l'hese effects differ altogether from those produeed by the several salts of ammonia, as well as by various organic fluids, and by inorgamic particles placed on the glands. A solution of the same strength of carbonate of soda and earbonate of potash acted in nearly the same manner as the chloride; and here again, after 2 hrs. $30 \mathrm{~m}$., the outer cells of some of the glands had emptied themselves of their brown pulpy eontents. We shall see in the eighth chapter that solutions of several salts of soda of half the above strength cause infleetion, but do not injure the leaves. Weak solutions of sulphate of quinine, of nicotine, ermphor, poison of the eobra, \&c., soon induce well-marked aggregation; whereas certain other substances (for instance, a solution of eurare) have no such tendency.

Many acids, though much diluted, are poisonous; and though, as will be shown in the eighth chapter, they cause the tentacles to bend, they do not excite true aggregation. Thus leares were placed in a solution of one part of benzoic acid to 437 of water; and in $15 \mathrm{~m}$. the purple fluid within the cells had shrunk it little from the walls, yet when carefully examined atter 1 hr. $20 \mathrm{~m}$., there was no true aggregation; and after 24 hrs. the leaf was evidently dead. Other leaves in iodic acid, diluted to the same degree, showed after 2 lirs. $15 \mathrm{~m}$. the same shrunlien appearance of the purple fluid within the cells; and these, nfter 6 lirs. $15 \mathrm{~m}$., were seen under a high power to be filled with execssively minute splieres of dull reddish protoplasm, 
which by the next morning, after 24 hrs, had almost disappeared, the leat being evidently dead. Nor was there any true aggregation in lenves immersed in propionic acid of the same strength; but in this case the protoplasm was collected in irregular masses towards the basos of the lower cclls of the tentaclos.

A filtered infusion of raw meat induces strong aggregation, but not very quickly. In one leaf thus immersed there was a little aggregation after $1 \mathrm{hr} .20 \mathrm{~m}$., and in another after $1 \mathrm{hr}$. $50 \mathrm{~m}$. With other leaves a considerably longer time was required: for instance, one immersed for 5 hrs. shorved no ageregation, but was plainly acted on in $5 \mathrm{~m}$., when placed in a few drops of a solution of one part of carbonatc of ammonia to 146 of water. Some leaves were left in the infusion for $24 \mathrm{hrs}$, and theso became aggrcgated to a wonderful degrce, so that the inflected tentacles presented to the naked eye a plainly mottled appearance. The little masses of purple protoplasm were, generally oval or beaded, and not nearly so often spherical as in the case of leaves subjected to carbonate of ammonia. They underwent mcessant changes of form; and the current ot colourless protoplasm round the walls was conspicuously plain after an immersion of 25 hrs. Raw meat is too powerful a stimulant, and even small bits generally injure, and sometimes kill, the leaves to which they are given: the aggregated masses of protoplasm become dingy or almost colourless, and present an musual granular appearance, as is likewise the case with leaves which have been immersed in a very strong solution of carbonate of ammonia. A leaf placed in milk had the contents of its cells somewhat aggregated in $1 \mathrm{~lm}$. Two other leaves, one immersed in human saliva for 2 hrs. $30 \mathrm{~m}$., and anothur in uuboiled white of egg for $1 \mathrm{hr} .80 \mathrm{~m}$., wcre not acted on in this mauncr; though they undoubtedly would have been so, had more timo been allowed. These same two leaves, on being afterwards placed in a solntion of earbonate of ammonia ( $3 \mathrm{grs}$. to $1 \mathrm{oz}$.$) , had their cclls aggregated, the one in 10 \mathrm{~m}$. and tlle other in $5 \mathrm{~m}$.

Several leaves were left for 4 hrs. $30 \mathrm{~m}$. in a solution of one part of white sugar to 146 of water, and no aggregation ensued; on being placed in a solution of this same strength of carbonate of ammonia, they were acted on in $5 \mathrm{~m}$.; as was likewisc a leaf which had bcen left for $1 \mathrm{hr}, 45 \mathrm{~m}$. in a moderately thick solution of gum arabie. Sovoral other leaves were immersed for some hours in densor solutions of sugar, gum, and starch, and they had the contents of their colls grcatly aggregated. This 
effect may be attributed to cxosmose; for the lenres in the syrup became quite flaccid, and those in the gum and starch somewhat flaccid, with their tentacles twisted about in the most irregular manner, the longer ones like corkscrews. Wc shall hereafter see that solutions of these substances, when placed on the discs of leaves, do not incite inflection. Particles of soft sugar were added to the secrction round several glands and wcre soon dissolved, causing a great increase of the secretion, no doubt by cxosmọe; and after 24 hrs. the cells showed a certain amount of aggregation, though the tentacles werc not inflccted. Glycerine causes in a few minutes well-pronounced aggregation, commcncing as ustal within the glands and then travelling down the tentacles; and this I presume may be attributed to the strong attraction of this substance for water. Immersion for several hour's in water causes some degrce of aggregation. Twenty leaves were first carefully examined, and re-examined after having been left immersed in distilled water for various periods, with the following results. It is rare to find even a trace of aggregation until 4 or 5 and generally not until screral more hours have elapsed. When however a leaf becomes quickly inflected in water, as somctimes happens, especially during very warm weather, aggregation may occur in little orcr 1 hr. In all cases leaves left in water for more than 24 hrs. have their glands blackened, which shows that their contents are aggregated; and in the spccimens which wcre carefully examined, there was fairly well-marked aggregation in the upper cells of the pediccls. These trials were made with cut-off leares, and it occurred to me that this circumstance might influence the rcsult, as the footstalks would not perhaps absorb water quickly enough to supply the glands as they contimued to secrete. But this view was provel erroneous, for a plant with uninjured roots, bearing four leaves, was submerged in distilled water for 47 hrs., and the glands were blackened, thongh the tentacles were very littlc inflected. In one of these leares thcre was only a slight degree of aggregation in the tentaclcs; in the secoud rather morc, the purple contents of the cclls being a little separated from the walls; in the third and fourth, whicl were pale leaves, the aggregation in the upper parts of the pedicels was well marked. In thesc leaves the little masses of protoplasm, many of which were oval, slowly changed their forms and positions; so tliat a submergence for $4.7 \mathrm{hr}$. liad not lilled the protoplasm. In a previous trial with a submerged plant, the tentacles werc not in the lcast inflected. 
Heat induces aggregation. A leaf, with the cells of the tentacles containing only homogeneous fluid, was waved about for $1 \mathrm{~m}$. in water at $130^{\circ} \mathrm{Fahr}$. (54.4 Cent.), and was then examined under the microscope as quickly as possible, that is in $2 \mathrm{~m}$. or $3 \mathrm{~m}$; and by this timc the contents of the cells had undergone some degrce of aggregation. A second leaf was waved for $2 \mathrm{~m}$. in watc1 at $125^{\circ}$ ( $51^{\circ} .6 \mathrm{Ccnt}$.) and quickly examined as before; the tcntacles werc well inflected; the purple fluid in all the cells had shrunk a little from the walls, and contained many oval and clongated masses of protoplasm, with a few minute spheres. A third leaf was left in water at 12.5, until it cooled, and when cxamined after $1 \mathrm{hr} .45 \mathrm{~m}$., the inflected tentacles showed some aggregation, which became atter 3 hrs. more strongly marked, but did not subscquently increase. Lastly, a leaf was waved for $1 \mathrm{~m}$. in water at $120^{2}$ ( 480.8 Ccnt.) and then left for $1 \mathrm{hr} .26 \mathrm{~m}$. in cold water; the tentacles were but little inflected, and there was only herc and there a trace of aggregation. In all thesc and other trials with warm water the protoplasm showed much less tendency to agrgregate into sphcrical masses than when excited by carbonate of ammonia.

Rierlissolution of the Aggregated Masses of Protoplasm.-As soon as tentacles which have clasped an inscet or any inorganic object, or have been in any way excited, have fully re-cxpanded, the aggregated masses of protoplasm are redissolved and disappear; the cells being now refillcel with homogeneous purplc fluid as thcy were before the tentacles were inflceted. The process of redissolution in all cases commences at the bases of the tentacles, and proccerls up tlem towards the glands. In old lcaves, however, especially in thoso which have been several times in action, the protoplasm in the uppermost cclls of the pedicels remains in a pcrmanently morc or less aggregated condition. In order to obscrve the process of redissolution, the following olsservations werc made : a leaf was left for 24 hrs. in a little solution of one part of carbonate of ammonia to 218 of water, and the protoplasm was as usual aggregated into numberless purple sphercs, which wcre incossantly changing their forms. The leaf was then washed and placed in distilled water, and after 3 lirs. $15 \mathrm{~m}$. some fow of the spheres begnn to show by their less clearly defined edges sigus of redissolution. After 9 lirs. many of them liad become elongated, and tho surrounding fluid in the cells was slightly more coloured, showing plainly that redissolution had commenced. After 24 hr's., though many cells still contained spheres, here and there one 
eould be seen filled with purple fluid, without a vestige of aggregated protoplasm; the wholo having been redissolved. A leaf with aggregated masses, eaused by its haring been waved for $2 \mathrm{~m}$. in water at the temperature of $125^{\circ}$ Fahr., was left in cold water, and after 11 hr's. the protoplasm showed traces of ineipient redissolution. When again examined three days after its immersion in the warm water, there was a eonspicuous differenee, though the protoplasm was still somewhat aggregated. Another leaf, with the eontents of all the eells strongly aggregated from the aetion of a weak solution of phosphate of ammonia, was left for between three and four days in a mixture (known to be innoenous) of one draehm of aleohol to eight draehms of water, and when re-examined every traee of aggregation had clisappeared, the eells being now filled with homogeneous fluid.

We have seen that leaves immersed for some hours in dense solutions of sugar, gum, and stareh, have the eontents of their cells greatly aggregated, and are rendered more or less flaeeid, witl the tentaeles irregularly eontorted. These leaves, after heing left for four days in distilled water, beeame less flaeeid, with their tentreles partially re-expanded, and the aggregated masses of protoplasm were partially redissolved. A leaf with its tentraeles elosely elasped orer a fly, and with the eontents of the eells strongly aggregated, was plaeed in a little sherry wine; after 2 hrs. several of the tentaeles had reexpanded, and the others eould by a mere touch be pushed baek into their properly expanded positions, and now all traees of aggregation had disappeared, the eells being filled with perfeetly homogeneous pink fluid. The redissolution in these eases may, I presume, be attributed to endosmose.

\section{On the Proximate Causes of the Process of Aggregation.}

As most of the stimulants which canse the inflection of the tentaeles likewise induee aggregation in the contents of their cells, this latter process might be thought to be the direet result of inflection; but this is not the case. If leaves are placed in lather strong solutions of earbonate of ammonia, for instance of three or four, and even sometimes of only two grains to the ounee of water (i.e. one part to 109 , or 146 , or 
218. of water), the tentacles are paralysed, and do not become inflected, yet they soon exhibit strongly marked aggregation. Moreover, the short central tentacles of a leaf which has been immersed in a weak solution of any salt of ammonia, or in any nitrogenous organic fluid, do not become in the least inflected; nevertheless they exhibit all the phenomena of agregation. On the other hand, several acids cause strongly prononnced inflection, but no iggregation.

It is an important fact that when an organic or inorganic object is placed on the glands of the disc, and the exterior tentacles are thus caused to bend inwards, not only is the secretion from the glands of the latter increased in quantity and rendered acid, but the contents of the cells of their porlicels become aggregated. The process always commences in the glands, although these have not as yet touched any object. Some force or influence must, therefore, be transmitter from the central glands to the exterior tentacles, first to near their bases causing this part to bend, and next to the glands causing them to secrete more copionsly. After a short time the glands, thus indirectly exciterl, transmit or reflect some influence down their own perlicels, inducing aggregation in cell beneath cell to their bases.

It seems at first sight a probable view that aggrogation is duc to the glands being cxeited to secrete more copionsly, so that sufficient fluil is not left in their colls, and in the cells of the pedicels, to hold the protoplasm in solution. In favour of this view is the fact that ageregation follows the inflection of the tontacles, and during the movement the glands generally, or, as I bclieve, always, secrete more copiously than they rlid before. I gain, during the rempansion 
of the tentacles, the glands secrete less freely, or quite cease to secrete, and the aggregated masses of protoplasm are then redissolved. Moreover, when leaves are immersed in dense vegetable solutions, or in glycerine, the fluid within the gland-cells passes outwards, and there is aggregation; and when the leares are afterwards immersed in water, or in an imnocuous fluid of less specific gravity than water, the protoplasm is redissolved, and this, no doubt, is due to cndosmose.

Opposed to this view, that aggregation is caused by the outward passage of fluid from the cells, are the following facts. 'There seems no close relation betwcen the degree of increased secretion and that of aggregation. Thus a particle of sugar added to the secretion round a gland causes a much greater increase of secretion, and much less aggregation, than does a particle of carbonate of ammonia given in the same manner. It does not appear probable that pure water would cause much exosmose, and yet aggregation often follows from an immersion in water of between 16 hrs. and 24 hrs., and always after from 24 hrs. to 48 hrs. Still less probable is it that water at a temperature of from $125^{\circ}$ to $130^{\circ} \mathrm{Fahr}$. $\left(51^{\circ} \cdot 6\right.$ to $54^{\circ} \cdot 4$ Cent.) should cause fluid to pass, not only from the glands, but from all the cells of the tentacles down to their bases, so quickly that aggregation is induced within $2 \mathrm{~m}$. or $3 \mathrm{~m}$. Another strong argumcut against this view is, that, after complete aggregation, the spheres and oval masses of protoplasm flont about in an abundant supply of thin colomrless fluirl; so that at least the latter stages of the process canmot be due to the want of fluid to hold the protoplasm in solution. There is still stronger evidence that aggregation is independent of secretion; for the papillo, described in the first chapter, with which the 
leaves are studded are not glandular, and do not secrete, yet they rapilly absorb carbonate of ammonia or an infusion of raw meat, and their contents then quickly undergo aggregation, which afterwards spreads into the cells of the surrounding tissues. We shall hereafter see that the purple fluid within the sensitive filaments of Dionæa, which do not secrete, likewise undergoes aggregation from the action of a weak solution of carbonate of ammonia.

The process of aggregation is a vital one; by which I mean that the contents of the cells must be alive and uninjured to be thus affeeted, and they must be in an oxygenated condition for the transmission of the process at the proper rate. Some tentacles in a drop of water were strongly pressed beneath a slip of glass; many of the cells were ruptured, and pulpy matter of a purple colour, with granules of all sizes and shapes, exuded, but hardly any of the cells were completely emptied. I then added a minute drop of a solution of one part of carbonate of ammonia to 109 of water, and after $1 \mathrm{hr}$. examined the specimens. Here and there a few cells, both in the glands and in the pedicels, had escaped being ruptured, and their contents were well aggregated into sphercs which were constantly changing their forms and positions, and a current could still be seen flowing along the walls; so that the protoplasm was alive. On the other hand, the exurled matter, which was now almost colourless instead of being purple, did not exhibit a trace of aggregation. Nor was there a trace in the many cells which were ruptured, but which had not been completely emptien of their contents. Though I looked carefully, no signs of a current could be secn within these ruptured cells. They had evidently been killed by the pressure; and the matter which they 
still contained did not undergo aggregation any more than that which had exuded. In these specimens, as I may add, the individuality of the life of each cell was well illustrated.

A full aecount will be given in the next chapter of the effects of heat on the leaves, and I need here only. state that leaves immersed for a short time in water at a temperature of $120^{\circ} \mathrm{Fahr}$. ( $48^{\circ} \cdot 8$ Cent.), which, as we have seen, does not immediately induce aggregation, were then placed in a few drops of a strong solution of one part of carbonate of ammonia to 109 of water, and became finely aggregated. On the other hand, leaves, after an immersion in water at $150^{\circ}\left(65^{\circ} \cdot \bar{b}\right.$ Cent.), on being placed in the same strong solution. did not undergo aggregation, the cells becoming filled with brownish, pulpy, or muddy matter. Tith leares subjeeted to temperatures between these two extremes of $120^{\circ}$ and $150^{\circ}$ Fahr. ( $48^{\circ} .8$ and $65^{\circ} .5$ Cent.), there were gradations in the eompleteness of the process: the former temperature not preventing aggregation from the subsequent action of carbonate of ammonia. the latter quite stopping it. Thus, leaves immersed in water, heated to $130^{\circ}\left(54^{\circ} .4\right.$ Cent.), and then in the solution, formed perfectly defined spheres, but these were decidedly smaller than in ordinary eases. With other leaves heated to $140^{\circ}$ ( $60^{\circ}$ Cent.), the spheres were extremely small, yet woll defined, but many of the cells contained, in addition, some brownish pulpy matter. In two cases of leaves heated to $145^{\circ}\left(62^{\circ} \cdot T\right.$ Cent.), a few tentacles conld be found with some of their cells containing a few minute spheres; whilst the other cells and other whole tentacles included only the brownish, disintegrater or pulpy matter.

The fluid within the cells of the tentacles must be in an oxygenated condition, in orler that the forec or 
influence which induces aggregation should be transmitted at the proper rate from cell to cell. A plant, with its roots in water, was left for $45 \mathrm{~m}$. in a ressel containing $122 \mathrm{oz}$ of carbonic acid. A leaf from this plant, and, for comparison, one from a fresh plant, were both immersed for $1 \mathrm{hr}$. in a rather strong solution of carbonate of ammonia. They were then compared, and certainly there was much less aggregation in the leaf which had been subjccted to the carbonic acid than in the other. Another plant was cxposed in the same ressel for 2 his. to carbonic acid, and one of its leaves was then placed in a solution of one part of the carbonate to 437 of water; the glands werc instantly blackened, showing that they har absorbed, and that their contents were aggregated; but in the cells close bencath the glands there was no aggregation even after an interval of 3 hrs. After 4 hrs. $15 \mathrm{~m}$. a few minute spheres of protoplasm were formerl in these cells, but even after 5 hrs. $30 \mathrm{~m}$. the aggregation did not extend down the pedicels for a length equal to that of the glands. After numberless trials with fresh leaves immersed in a solution of this strength, I have never secn the aggregating action transmitted at nearly so slow a rate. Another plant was left for 2 hrs. in carbonic acid, but was then exposed for $20 \mathrm{~m}$. to the open air, during which time the leares, being of a red colour, would have absorbed some oxygen. One of them, as well ns a fresh leaf for comparison, were now immersed in the same solution as before. The former were looked at repeatedly, and after an interval of $65 \mathrm{~m}$. a few spheres of protoplasm were first olsserved in the cells close beneath the glands, but only in two or threc of the longer tentarles. After 3 hrs. the aggregation had travelled down the pedicels of a few of the tentacles 
for a length equal to that of the glands. On the other hand, in the fresh leaf similarly treated, aggregation was plain in many of the tentaeles after $15 \mathrm{~m}$; after $65 \mathrm{~m}$. it had extended down the pedieels for four, five, or more times the lengths of the glands; and after $3 \mathrm{hrs}$. the eells of all the tentaeles were affeeted for one-third or one-half of their entire lengths. Henee there ean be no doubt that the exposure of leaves to earbonie aeid either stops for a time the proeess of aggregation, or eheeks the transmission of the proper influenee when the glands are subsequently exeited by earbonate of ammonia; and this substanee aets more promptly and energetically than any other. It is known that the protoplasm of plants exhibits its spontaneous movements only as long as it is in an oxygenated eondition; and so it is with the white eorpuseles of the blood, only as long as they receive oxygen from the red eorpuseles; ; but the eases above given are somewhat different, as they relate to the delay in the generation or aggregation of the masses of protoplasm by the exelusion of oxygen.

Summary and Conctuding Remartis. - The proeess of aggregation is independent of the infleetion of the tentacles and of inereased seeretion from the glands. It eommenees within the glands, whether these have been directly exeited, or indireetly by a stimulus received from other glands. In both eases the process is transmitted from eell to cell down the whole length of the tentacles, being arrested for a short time at each transverse partition. With pale-eoloured leaves the first change which is pereeptible, but ouly

* With respect to plants, Sichs, 'T'ruité de Bot.,' Brd erlit., 187t, p. Stit. On blood corpuscles, see
- Quarterly Jomrnal of Microseopical Science, April 1874, P $18)^{\prime \prime}$ 
under a high power, is the appearance of the finest grannles in the fluid within the eells, making it slightly cloudy. These granules soon aggregate into small globular masses. I have seen a cloud of this kind appear in $10 \mathrm{~s}$. after a drop of a solution of earbonate of ammonia had been given to a gland. With clark red leaves the first visible ehange often is the conversion of the outer layer of the fluid within the cells into bag-like masses. The agoregated masses, however they may have been developed, ineessantly ehange their forms and positions. They are not filled with fluid, but are solid to their centres. Ultimately the eolourless granules in the protoplasm which flows round the walls eoalesee with the eentral spheres or masses; but there is still a current of limpid fluid flowing within the eells. As soon as the tentacles fully re-expand, the aggregated masses are redissolved, and the cells beeome filled with homogeneous purple fluid, as they were at first. The process of redissolution eommences at the bases of the tentaeles, thenee proceeding upwards to the glands; and, therefore, in a reversed direetion to that of aggregation.

Aggregation is excited by the most diversified causes,- - by the glands being several times touched,by the pressure of particles of any kind, and as these are supported by the dense seeretion, they ean hardly press on the glands with the weight of a millionth of a grain, *- by the tentaeles being cut off close beneath

Aecorling to Hofmeister (as quoted by Sachs, "Traité de Bot.' $1871,1.958)$, very slicrlit pressurc on the eell-membrane arrests immedistely the movenonts of the protoplasin, and oven rloter. mines its separation from the walls. But the proeess of aggre- gation is a different phenomenon, as it relates to the contents of the eclls, and only secondarily to the layer of protoplasin which flows along the walls; though no loult the effeets of pressure or of $n$ toueh on the outsirle must bo transwitted through this layer. 
the glaurls,-by the glands absorbing various fluids or matter dissolved out of certain bodies, - by exosmose, and by a certain degree of heat. On the other hand, a temperature of about $150^{\circ}$ Fahr. (65.5 Cent.) does not excite aggregation; nor does the sudden crushing of a gland. If a cell is ruptured, neither the exuded matter nor that which still remains within the cell undergoes aggregation when carbonate of ammonia is alded. I very strong solution of this salt and rather large bits of raw meat prevent the aggregated masses being well developed. From these facts we may conclude that the protoplasmic fluid within a cell does not become aggregated unless it be in a living state, and only imperfectly if the cell has been injured. We have also seen that the fluid must be in an oxygenated state, in order that the process of aggregation should travel from cell to cell at the proper rate.

Various nitrogenous organic fluids and salts of ammonia induce aggregation, but in different degrees and at very different rates. Carbonate of ammonia is the most powerful of all known substanees; the absorption of $\frac{1}{13+70}$ of a grain $(\cdot 000482 \mathrm{mg}$.) by a gland suffices to cause all the cells of the same tentacle to beeome aggregated. 'The first effect of the carbonate and of certain other salts of ammonia, as well as of some other fluids, is the darkening or blackening of the glands. This follows even from long immersion in cold distilled water. It apparently depends in chief part on the strong aggregation of their cellcontents, which thus become opaque, and lo not reflect light. Some other fluids render the glands of a brighter red; whilst eertain acids, though nutch diluted, the poison of the cobra-suake, fe., make the glands perfectly white and opaque; and this seems to depend on the coagrulation of their contents without 
any ageregation. Nevertheless, beforc being thus affected, they are able, at least in some cases, to excite aggregation in their own tentacles.

That the central glands, if irritated, send centrifugally some influence to the cxtcrior glands, causing them to send back a ecntripetal influenee indueing agreregation, is perhaps the most interesting fact given in this chaptcr. But the wholc process of aggregation is in itself a striking phenomenon. Whenever the periphcral extrcmity of a nerve is tonehed or presserl, and a sensation is felt, it is believer that an invisible moleenlar ehange is sent from onc end of the nerve to the other; but when a gland of Drosera is repeatedly touched or gently pressed, we can actually see a molccular change proceeding from the gland rlown the tentacle; though this change is probably of a very different nature from that in a ncrve. Finally, as so many and such widely different causes excite aggregation, it would appear that the living mattes within the gland-cells is in so unstable a condition that almost any disturbance suffiees to ehange its molecular nature, as in the case of certain ehemical compounds. And this change in the glands, whether excited directly, or indircetly by a stimulus reeeived from other gliunds, is transmitted from eell to cell, causing gramules of protoplasin cither to be aetually cenerated in the previously limpid fluid or to coalesce and thus to become visible.

\section{Supplementary Observations on the Process of Aggre- gution in the Roots of Plants.}

It will hereafter be secn that a weak solution of the carbonate of ammonia induecs agregrogation in the cells of the roots of Jrosera; and this lod me to make a few trials on the roots of other plants. I dug up in the latter part of Oetober the first weed which I met with, viz. Euphorlice peplus, being care- 
ful not to injure the roots; these were washed and placed in a little solution of one part of carbonate of ammonia to 146 of water. In less than one minute I saw a cloud travelling trom cell to cell up the roots, with wonderful rapidity. After from $8 \mathrm{~m}$. to $9 \mathrm{~m}$, the fine granules, which caused this cloudy appearance, became aggregated towards the extremities of the roots into quadrangular masses of brown matter; and some of these soon changed their forms and became spherical. Some of the cells, however, remained unaffected. I reperted the experiment with another plant of the same species, but before I could get the specimen into focus under the microscope, clouds of granules and quadrangular masses of reddish and brown watter were formed, and had run far up all the roots. A fresh root was now left for $18 \mathrm{hrs}$. in a drachm of a solution of une part of the carbonate to 437 of water, so that it received $\frac{1}{8}$ of a grain, or $2.024 \mathrm{mg}$. When examined, the cells of all the roots throughout their whole length contained aggregated masses of reddish and brown matter. Before making these experiments, several roots were closely examined, and not a trace of the cloudy appearance or of the granular masses could be seen in any of them. Roots were also immersed for $35 \mathrm{~m}$. in a solution of one part of carbonate of potash to 218 of water; but this salt produced no effect.

I may here add that thin slices of the stem of the Euphorbia were placed in the same solution, and the cells which were green instantly became cloudy, whilst others which were before colourless were clouded with brown, owing to the formation of numerous granules of this tint. I have also seen with various kinds of leaves, left for some time in a solution of carbonate of ammonia, that the grains of chlorophyll ran together and partially coalesced; and this seems to be a torm of aggregation.

Plants of duck-weed (Lemna) were left for between $30 \mathrm{~m}$. and $45 \mathrm{~m}$. in a solution of one part of this same salt to 146 of water, and three of their roots were then examined. In two of them, all the cells which had previonsly contained only limpid fluid now included little green spheres. After from $1 \frac{1}{2}$ lur. to 2 hrs. similar spheres appeared in the cclls on the borders of the leaves; but whether the ammonia had travelled up the roots or had been directly absorbed by the lcaves, I cammot say. As one species, Lemna arrhiza, produces no roots, tho latter alternative is perhaps the most probable. After about $2 \frac{1}{2}$ hrs. some of the littlo green spheres in the roots were broken up into small granules which exhibited Brownian movements. Some duckweed was also left for $1 \mathrm{hr} .30 \mathrm{~m}$. in a solution of one part of 
carbonate of potash to 218 of water, and no decided changc could be perceived in the cells of the roots; but when these same roots were placed for $25 \mathrm{~m}$. in a solution of carbonate of ammonia of the same strength, little grcen spheres were formed.

A green marine alga was left for some time in this samc solution, but was very doubtfully affected. On the other hand, a red marine alga, with finely pinnated fronds, was strongly affected. The contents of the cells aggregated themsclves into broken rings, still of a red colour, which very slowly and slightly changed their shapes, and the central spaces within these rings became cloudy with red granular matter. The facts herc given (whether they are new, I know not) indicate that interesting results would pcrhaps be gained by observing the action of various saline solutions and other fluids on the loots of plants. 


\section{CHAPTER IV.}

The Efrects of Heat on tme Leaves.

Nature of the experiments - Effects of boiling water - Warm water causes rapid inflection - Watcr at a higher temperature docs not causc inmediate inflection, but does not kill the leaves, as shown by their subsequent re-cxpansion and by the aggregation of the protoplasin-A still higher temperature kills the leaves and coagulates the albuminous contents of the glands.

In my observations on Drosera rotundifolia, the leaves seemed to be more quiekly inflected over animal substanees, and to remain inflected for a longer period during very warm than during eold weather. I wished, therefore, to aseertain whether heat alone would induce infleetion, and what temperature was the most effieient. Another interesting point presented itself, namely, at what degree life was extinguished; for Drosera offers unusual faeilities in this respeet, not in the loss of the power of infleetion, but in that of subsequent re-expansion, and more espeeially in the failure of the protoplasm to beeome aggregated, when the leaves after being heated are immersed in a solution of earbonate of ammonia.*

* When my experiments on the effects of heat wero wadc, I was not aware that the subject had becu carcfully investigated by sevcral obscrvers. For instance, Sachs is convinced ('T'ruité de Botanique,' 187t, pp. 772, 85t) thit tho most different kinds of plants all perish if kept for $10 \mathrm{~m}$. in water at $45^{\circ}$ to $46^{\circ}$ Cent., or $113^{\circ}$ to $115^{\circ} \mathrm{Fuhr}$; and he eon- cludes that the protoplasm within their cells always coagulates, if in a damp condition, at a temperaturo of between $50^{\circ}$ and $60^{\circ}$ Cent. or $122^{\circ}$ to $140^{\circ}$ Falir. MIsx Scluntze and Kílhne (as quoted by Dr. Bastiun in "Contemp. liovicw, 1874, p. 528) "found that the protnplasin of plantcells, with which they experimented, was nlways killed and 
MIy experiments were tried in the following manner. Leaves werc cut off, and this does not in the lcast intcrfere with thcir powcrs; for instance, thrce cut-off lcaves, with bits of meat placed on them, were kcpt in a damp atmosphcre, and after 23 hrs. closely embraced the meat both with thcir tentacles and blades; and the protoplasm within thcir cells was well aggregated. Three ounces of doubly distillcd water was heatcd in a porcelain vessel, with a delicatc thermometer having a long bulb obliquely suspended in it. The water was gradually raised to the required temperature by a spirit-lamp mored about under the vessel; and in all cases the leaves were continually waved for some minutes close to the bulb. They were then placed in cold watcr, or in a solution of carbonate of ammonia. In othcr cases they wcre left in the watcr, which had bcen raised to a certain temperature, until it cooled. Again in other cases the leaves were suddenly plunged into water of a certain temperature, and kept therc for a specified time. Considering that the tentacles are extremely dclicate, and that their coats are very thin, it scems scarcely possible that the fluid contents of their cells should not have been heated to within a degree or two of the tempcraturc of the surrounding water. Any further precautions would, I think, have been superfluous, as the leaves from age or constitutional causes differ slightly in their sensitiveness to heat.

It will be convenient first briefly to describe the effccts of immersion for thirty scconds in boiling water. The leaves arc rendered flaccid, with thcir tentacles bowed backwards, which, as we shall see in a future chapter, is probably duc to their. outcr surfaces retaining their elasticity for a longer period than their inner surfaces retain the powcr of contraction. The purple fluid within the cclls of the pedicels is rendcrcd finely granular, but there is no true aggregation; nor does this follow

altered by a very brief exposure to a temperature of $118 \frac{1}{2}^{\circ}$ Falir. as a maximum." As my results are dedueed from speeial plicnomena, namely, the subsequent aggregation of the protoplasm and tho re-cxpansion of the tentacles, they socm to me wortl giving. We shall find that Drosera resists heat somewhat butter than most other plants. That there should bo consider- able differenees in this respect is not smrprising, considering that somo low vegetable organisms grow in hot springs - eases of which havo been collected by Prof. Wyman (" Ameriean Journal of Seienee,' vol. xliv. 1867). 'Thus, 1)r. Hooker found Confervo in water at $168^{\circ}$ Fulir.; Humboldt, at $185^{\circ}$ Fuhr.; and Descloizcanx, at $208^{\circ}$ Fahr. 
when the leaves are subsequently plaeed in a solution of earbonate of ammonia. But the most remarkable ehange is that the glands beeome opaque and uniformly white; and this may be attributed to the eoagulation of their albuminous eontents.

My first and preliminary experiment eonsisted in putting seven leaves in the same vessel of water, and warming it slowly up to the temperature of $110^{\circ}$ Fahr. ( $43^{\circ} .3$ Cent.); a leaf being taken out as soon as the temperature rose to $80^{\circ}\left(26^{\circ} \cdot 6\right.$ Cent.), another at $85^{\circ}$, another at $90^{\circ}$, and so on. Eaeh leaf, when taken ont, was plaeed in water at the temperature of my room, and the tentaeles of all soon beerme slightly, though irregularly, inflected. They were now removed from the eold water and kept in damp air, with bits of meat plaeed on their dises. The leaf whieh had been exposed to the temperature of $110^{\circ}$ beeame in $15 \mathrm{~m}$. greatly infleeted; and in 2 hrs. every single tentaele elosely embraeed the meat. So it was, but after rather longer intervals, with the six other leaves. It appears, therefore, that the warm bath had inereased their sensitiveness when exeited by moat.

I next observed the degree of infleetion whieh leaves underwent within stated periods, whilst still immersed in warm water, kept as nearly as possible at the same temperature; but I will here and elsewhere give only a few of the many trinls made. A leaf was left for $10 \mathrm{~m}$. in water at $100^{\circ}$ ( $37^{\circ} .7 \mathrm{Cent}$ ), but $\mathrm{no}$ infleetion oceurred. A seeond leaf, however, treated in the same manner, had a ferv of its exterior tentaeles very slightly infleeted in $6 \mathrm{~m}$., and several irregularly but not elosely infleeted in $10 \mathrm{~m}$. A third leaf, kept in water at $105^{\circ}$ to $106^{\circ}$ $\left(40^{\circ} .5\right.$ to $41^{\circ} 1$ Cent.), was very moderately infleeted in $6 \mathrm{~m}$. A fourth leaf, in water at $110^{\circ}\left(43^{\circ} \cdot 3\right.$ Cent.), was somewhat infleeted in $4 \mathrm{~m}$., and eonsiderably so in from $6 \mathrm{~m}$. to $7 \mathrm{~m}$.

Three leaves were plaeed in water whieh was heated rather quiekly, and by the time the temperature rose to $115^{\circ}-116^{\circ}$ $\left(46^{\circ} \cdot 1\right.$ to $46^{\circ} .06$ Cent.), all three were infleeted. I then removed the lamp, and in a few minutes every single tentaele was elosely infleeted. The protoplasm witlin the eells was not killed, for it was seen to be in distinet movement; and the leaves, having been left in eold water for 20 luss., re-expanded. Another leaf was immersed in water at $100^{\circ}$ ( $37^{\circ} .7$ Cent.), whieh was raised to $120^{\circ}$ ( $48^{\circ} .8$ Cent.); and all the tentreles, exeept the extreme marginal ones, soon beeame elosely infleeted. The leaf was now placed in eold water, and in $7 \mathrm{hrs}$. $30 \mathrm{~m}$. it had partly, and in $10 \mathrm{hrs.} \mathrm{fully,} \mathrm{re-exprnded.} \mathrm{On} \mathrm{the} \mathrm{follow-}$ ing morning it was immersed in a weak solution of carbonate of 
ammonia, and the glands quickly became black, with strongly marked aggregation in the tcntacles, showing that the protoplasm was alive, and that the glands had not lost their power of absorption. Another leaf was placed in water at $110^{\circ}\left(43^{\circ} \cdot 3\right.$ Cent.) which was raised to $120^{\circ}\left(48^{\circ} .8\right.$ Cent.); and every tentacle, excepting one, was quickly and closely inflected. This leaf was now immersed in a few drops of a strong solution of carbonate of ammonia (one part to 109 of water); in $10 \mathrm{~m}$. all the glands became intenscly black, and in $2 \mathrm{hr}$. the protoplasm in the cells of the pedicels was well aggregatcd. Another leaf was suddenly plunged, and as usual waved about, in water at $120^{\circ}$, and the tentacles became inflected in from $2 \mathrm{~m}$. to $3 \mathrm{~m}$., but only so as to stand at right angles to the disc. The leaf was now placed in the same solution (viz. one part of carbonate of ammonia to 109 of water, or 4 grs. to 1 oz., which I will for the future designate as the strong solution), and when I looked at it again after the interval of an hour, the glands were blackened, and there was well-marked aggregation. After an additional interval of $4 \mathrm{hrs}$. the tentacles had become much more inflected. It deserves notice that a solution as strong as this never causes inflection in ordinary cases. Lastly a leaf was suddenly placed in water at $125^{\circ}\left(51^{\circ} \cdot 6\right.$ Cent.), and was left in it until the water cooled; the tentaclcs were rendcred of a bright red and soon became inflected. The contents of the cells underwent some degrce of aggregation, which in the course of three hours increased; but the masses of protoplasm did not become spherical, as almost always occurs with leaves immersed in a solution of carbonatc of ammonia.

We learn from these cases that a temperature of from $120^{\circ}$ to $125^{\circ}\left(48^{\circ} .8\right.$ to $51^{\circ} .6$ Cent.) excites the tentacles into quick movement, but does not kill the leaves, as shown either by their subsequent re-expansion or by the aggregation of the protoplasm. We shall now see that a temperature of $130^{\circ}\left(54^{\circ} \cdot 4\right.$ Cent.) is too high to cause immediate inflection, yet does not kill the leaves.

Experiment 1.-A lcaf was plunged, and as in all cases waved alout for a few minutes, in watcr at $130^{\circ}$ (54 $4^{\circ} 4$ Cent.), lout there was no trace of inflcetion; it was then placed in cold water, and after an interval of $15 \mathrm{~m}$. very slow movement was 
distinctly seen in a small mass of protoplasm in one of the cells of a tentacle.* After a ferw hours all the tentacles and the blade became inflected.

Experiment 2.-Another leaf was plunged into water at $130^{\circ}$ to $131^{\circ}$, and as beforc there was no inflection. After being kept in cold water for an hour, it was placed in the strong solution of ammonia, and in the course of $55 \mathrm{~m}$. the tentacles were considerably inflected. The glands, which before had been renclered of a brighter red, were now blackened. The protoplasm in the cells of the tentacles was distinctly aggregated; but the spheres were much smaller than those usually generated in unheated leaves when subjected to carbonate of ammonia. After an additional 2 hrs. all the tentacles, excepting six or seven, were closely inflected.

Experiment 3.-A similar experiment to the last, with exactly the same results.

Experiment 4.-A fine leaf was placed in water at $100^{\circ}\left(37^{\circ} \cdot 7\right.$ Cent.), which was then raised to $145^{\circ}\left(62^{\circ} \cdot 7\right.$ Cent.). Soon after immersion, there was, as might have been cxpected, strong inflection. The leaf was now removed and left in cold water; but from having been exposed to so high a temperature, it never re-expanded.

Experiment 5.-Leaf immersed at $130^{\circ}\left(54^{\circ} 4\right.$ Cent.), and the water raised to $145^{\circ}\left(62^{\circ} \cdot 7\right.$ Cent.), there was no immediate inflection; it was then placed in cold water, and after $1 \mathrm{hr} .20 \mathrm{~m}$. some of the tentacles on one side became inflected. This leaf was now placed in the strong solution, and in $40 \mathrm{~m}$. all the submarginal tentacles were well inflected, and the glands blackened. After an additional interval of $2 \mathrm{hrs.} 45 \mathrm{~m}$. all the tentacles, except eight or ten, were closely inflected, with their cells exhibiting a slight degree of aggregation; but the spheres of protoplasm wcre very small, and the cells of the exterior tentacles contained some pulpy or disintegrated brownish matter.

Experiments 6 and 7.-Two lcaves were plunged in water at $135^{\circ}\left(57^{\circ} \cdot 2\right.$ Cent.) which was raised to $145^{\circ}\left(62^{\circ} \cdot 7\right.$ Cent.); ncither became inflected. One of these, however, after having becn left for $31 \mathrm{~m}$. in cold water, exhibited some slight inflction, which increased after an additional interval of 1 hr. $45 \mathrm{~m}$., until

* Sachs states ("Traité de Botanique,' 1874, p. S.5.5) that the movements of tho protoplasm in the hairs of a Cucurbita ccased after they were exposed for $1 \mathrm{~m}$. in water to a temperature of $47^{\circ}$ to $1 S^{\circ}$ Cent., or $117^{\circ}$ to $119^{\circ}$ Falli. 
all the tentraeles, except sixteen or seventeen, were more or less infleeted; but the leaf was so mueh injured that it never reexpanded. The other leaf, after having been left for half an hour in eold water, was put into the strong solution, but no infleetion ensued; the glands, however, were blaekened, and in some eells there was a little aggregation, the spheres of protoplasm being extremely small; in other eells, espeeially in the exterior tentacles, there was mueh greenish-brown pulpy matter.

Experiment 8.-A leaf was plunged and waved about for a few minutes in water at $140^{\circ}\left(60^{\circ}\right.$ Cent.), and was then left for half an hour in eold water, but there was no infleetion. It was now plaeed in the strong solution, and after 2 hrs. $30 \mathrm{~m}$. the inner submarginal tentaeles were well infleeted, with their glands blaekened, and some imperfeet aggregation in the eells of the pedieels. Three or four of the glands were spotted with the white poreelain-like strueture, like that produeed by boiling water. I have seen this result in no other instance after an immersion of only a few minutes in water at so low a temperature as $140^{\circ}$, and in ouly one leaf out of four, after a similar immersion at a temperature of $145^{\circ} \mathrm{Fahr}$. On the other hand, with two leaves, one placed in water at $145^{\circ}$ ( $62^{\circ} .7$ Cent.), and the other in water at $140^{\circ}\left(60^{\circ}\right.$ Cent.), both being left therein until the water eooled, the glands of both beeame white and poreelain-like. So that the duration of the immersion is an important element in the result.

E.cperiment 9.-A leaf was plaeed in water at $140^{\circ}\left(60^{\circ}\right.$ Cent.), which was raised to $150^{\circ}$ ( $65^{\circ} .5$ Cent.); there was no infleetion; on the eontrary, the outer tentaeles were somewhat bowed baekwards. The glands beeame like porcelain, but some of them were a little mottled with purple. The bases of the glands were often more affeeted than their summits. This leaf having been left in the strong solution did not undergo any infleetion or aggregation.

Experiment 10 . - A leaf was plunged in water at $150^{\circ}$ to $150 \frac{1}{2}^{\circ}$ ( $65^{\circ} .5$ Cent.); it beeame somewhat flaeeid, with the outer tentaeles slightly reflexed, and the inner ones a little bent inwards, but only towards their tips; and this latter faet shows that the movement was not one of true infleetion, as the basal part alone normally bends. The tentaeles twere as usual rendered of a very bright red, with the glands almost white like poreolain, yet tinged with pink. The leaf having been plaeed in tho strong solution, the eell-eontents of the tentaeles beeame of a muddy brown, with no traee of aggregation. 
Experiment 11.-A lcaf was immersed in water at $145^{\circ}\left(62^{\circ} \cdot 7\right.$ Cent.), which was raised to $156^{\circ}\left(68^{\circ} .8\right.$ Cent.). The tentacles became bright red and somewhat reflexed, with almost all the glands like porcelain; those on the disc being still pinkish, those near the margin quite white. The leaf being placed as usual first in cold water and then in the strong solution, the cells in the tentacles became of a muddy greenish brown, with the protoplasm not aggregated. Nevertheless, four of the glands escaped being rendered like porcelain, and the pedicels of these glands were spirally curled, like a French horn, towards their upper ends; but this can by no means be considered as a case of true inflection. The protoplasm within the cells of the twisted portions was aggregated into distinct though excessively minute purple spheres. This case shows clearly that the protoplasm, after having been exposed to a high temperature for a few minutes, is capable of aggregation when afterwards subjected to the action of carbonate of ammonia, unless the heat has been sufficient to cause coagulation.

Concluding Remarks.-As the hair-like tentacles are extremely thin and have delicate walls, and as the leaves were waved about for some minutes close to the bulb of the thermometer, it seems scarcely possible that they should not have been raised very nearly to the temperature which the instrument indieated. From the eleven last observations we see that a temperature of $130^{\circ}\left(54^{\circ} \cdot 4\right.$ Cent.) never causes the immediate infleetion of the tentaeles, though a temperature from $120^{\circ}$ to $125^{\circ}\left(48^{\circ} .8\right.$ to $51^{\circ} \cdot 6$ Cent.) quickly produees this effect. But the leaves are paralysed only for a time by a temperature of $130^{\circ}$, as afterwards, whether left in simple water or in a solution of carbonate of ammonia, they become inflected and their protoplasm undergoes aggregation. This great difference in the effects of a higher and lower temperature may be compared with that from immersion in strong and weak solutions of the salts of ammonia; for the former do not excite movement, whereas the latter aet energetieally. A temporary suspension of the 
power of movement due to heat is ealled by Saehs* heat-rigidity; and this in the case of the sensitiveplant (Mimosa) is indueed by its exposure for a few minutes to humid air, raised to $120^{\circ}-122^{\circ}$ Fahr., or $49^{\circ}$ to $50^{\circ}$ Cent. It deserves notiee that the leaves of Drosera, after being immersed in water at $130^{\circ}$ Fahr., are excited into movement by a solution of the earbonate so strong that it would paralyse ordinary leaves and eause no infleetion.

The exposure of the leaves for a few minutes even to a temperature of $145^{\circ}$ Fahr. $\left(62^{\circ} \cdot 7\right.$ Cent.) does not always kill them; as when afterwards left in eold water, or in a strong solution of carbonate of ammonia, they generally, though not always, become infleeter, and the protoplasm within their cells undergoes aggregation, though the spheres thus formed are extremely small, with many of the eells partly filled with brownish muddy matter. In two instances, when leaves were immersed in water, at a lower temperature than $130^{\circ}\left(54^{\circ} .4\right.$ Cent.), which was then raised to $145^{\circ}$ $\left(62^{\circ} \cdot 7\right.$ Cent.), they beeame during the earlier period of immersion inflected, but on being afterwards left in eold water were ineapable of re-expansion. Exposure for a few minutes to a temperature of $145^{\circ}$ sometimes eauses some few of the more sensitive glands to be speckled with the poreelain-like appearanee; and on one oceasion this occurred at a temperature of $140^{\circ}\left(60^{\circ}\right.$ Cent.). On another oecasion, when a leaf was plaeed in water at this temperature of only $140^{\circ}$, and left therein till the water eooled, every gland became like porcelain. Exposure for a few minutes to a temperature of $150^{\circ}\left(65^{\circ} .5\right.$ Cent.) generally produees this effect, yet many glands retain a

* 'Traité do Bot.' 1874, p. 1031. 
pinkish eolour, and many present a speekled appearance. This high temperature never causes true inflection; on the eontrary, the tentaeles eommonly become reflexed, though to a less degree than when immersed in boiling water; and this apparently is due to their passive power of elastieity. After exposure to a temperature of $150^{\circ} \mathrm{Fahr}$., the protoplasm, if subsequently subjected to earbonate of ammonia, instead of undergoing aggregation, is converted into disintegrated or pulpy diseoloured matter. In short, the leaves are generally killed by this degree of heat; but owing to differenees of age or eonstitution, they vary somewhat in this respect. In one anomalous ense, four out of the many glands on a leaf, whieh had been immersed in water raised to $156^{\circ}\left(68^{\circ} \cdot 8\right.$ Cent.), eseaped being rendered poreellanous; * and the protoplasm in the eells elose beneath these glands underwent some slight, though imperfeet, degree of aggregation.

Finally, it is a remarkable fact that the leaves of Drosera rotundifotia, which flourishes on bleak upland moors throughout Great Britain, and exists (Hooker) within the Aretic Cirele, should be able to withstand for even a short time immersion in water heated to a temperature of $145^{\circ} \cdot \uparrow$

It may be worth adding that immersion in cold

* As the opreity and poreelainlike appearanee of the glands is probably due to the eoagulation of the albunen, I may add, on the authority of Dr. Burdon Sanderson, that albumen coagulates at about $155^{\circ}$, but, in presenee of aeids, the temperature of eagulation is lowor. The leaves of Drosera eontain an acid, and perhaps a differenee in the amount eontained may aeeount for the slight differenees in the results above recorded.

+ It appears that eold-blooded animals are, as might liave been expeeted, far more sensitive to an incrense of temperature thin is Droscra. Thus, as I henr from Dr. Burdon Sindersous, a frog begins to be distressed in water at a temperature of only $S 5^{\circ}$ Filhr. At $95^{\circ}$ the museles beeomo rigid, and the animal dies in a stiffened eondition. 
water does not cause any inflection : I suddenly placed four leaves, taken from plants which had been kept for several days at a high temperature, generally about $75^{\circ}$ Fahr. (23\% 9 Cent.), in water at $45^{\circ}$ ( $7^{\circ} .2$ Cent.), but they were hardly at all affected; not so much as some other leaves from the same plants, which were at the same time immersed in water at $75^{\circ}$; for these became in a slight degree inflected. 


\section{CHAPTER V.}

The Effects of Non-Nitrogenoes and Nitrogenots Organic Fluids ON THE LEAVES.

Non-nitrogenous fluids - Solutions of gum arabic - Sugar - Starch -Diluted alcohol - Olive oil - Infusion and decoction of tea Nitrogenous fluids - Milk - Urinc-Liquid albumen-Infusion of raw meat - Impure mueus - Saliva - Solution of isinglass Difference in the action of these two sets of fluids - Decoction of green peas-Decoction and infusion of cabbagc-Decoction of grass lcaves.

WhEN, in 1860 , I first observed Drosera, and was led to bclieve that the leaves absorbed nutritious matter from the insects which they captured, it seemed to me a good plan to makc some preliminary trials with a few common fluids, containing and not containing nitrogenous matter; and the results are worth giving.

In all the following eases a drop was allowed to fall from the same pointed instrument on the centre of the leaf; and by repeated trials one of these drops was aseertained to be on an average very nearly half a minim, or $\frac{1}{960}$ of a fluid ounce, or $0295 \mathrm{ml}$. But these measurcments obviously do not pretend to any strict aceuracy; moreover, the drops of the viscid fluids were plainly larger than those of water. Only onc leaf on the same plant was tricd, and the plants were colleeted from two distant localities. The experiments were made during August and Scptember. In judging of the effects, one caution is nccessary: if a drop of any adhesive fluid is placed on an old or feeble leaf, the glands of whieh have ceased to seerete copiously, the drop sometimes dries up, especially if the plant 
is kept in a room, and some of the eentral and submarginal tentaeles are thus drawn together, giving to them the false appearanee of having become inflected. This sometimes oecurs with water, as it is rendered adhesive by mingling with the viseid secretion. Hence the only safe criterion, and to this alone I have trusted, is the bending inwards of the exterior tentacles, whieh have not been touched by the fluid, or at most only at their bases. In this case the movement is wholly due to the eentral glands having been stimulated by the fluid, and transmitting a motor impulse to the exterior tentaeles. The blade of the leaf likewise often curves inwards, in the same manner as when an inseet or bit of meat is plaeed on the dise. This latter movement is never eaused, as far as I have seen, by the mere drying up of an adhesive fluid and the eonsequent drawing together of the tentacles.

First for the non-nitrogenous fluids. As a preliminary trial, drops of distilled water were placed on between thirty and forty leaves, and no effect whatever was produced; nevertheless, in some other and rare cases, a few tentaeles became for a short time infleeted; but this may have been caused by the glands having been accidentally tonched in getting the leaves into a proper position. That water should produee no effeet might have been antieipated, as otherwise the leaves would have been excited into movement by every shower of rain.

Gum arubic.-Solutions of four degrees of strength were made; one of six grains to the ounce of water (one part to 73); a second rather stronger, yet very thin; a third moderately thiek, and a fourth so thick that it would only just drop from a pointed instrument. These were tried on fourteen leaves; the drops heing left on the dises from 24 hr's. to 44 lurs.; generally about 
30 hrs. Inflection was never thus causcd. It is necessary to try pure gum arabic, for a friend tried a solution bought ready prepared, and this eansed the tentaeles to bend; but lie aftcrwards asecrtained that it contained much animal matter, probably glue.

Sugar.-Drops of a solution of white sugar of three strengths (the weakest eontaining one part of sugar to 73 of watcr) wcre left on fourtcen leaves from $32 \mathrm{hr}$. to $48 \mathrm{hrs}$; ; but no effect was produced.

Starch.-A mixture about as thiek as ercam was dropped on six leaves and left on them for 30 hrs., no effeet being produced. I am surprised at this fact, as I believe that the stareh of eommerce generally eontains a traee of gluten, and this nitrogenous substance eauses inflcetion, as we shall see in the next ehapter.

Alcohol, Diluted.-One part of alcohol was added to seven of water, and the ustual drops were plaecd on the discs of three lcaves. No infleetion ensued in the eourse of $48 \mathrm{hrs}$. To aseertain whether thesc leaves had been at all injured, bits of meat werc placed on them, and after 24 hrs. they were closely infleeted. I also put drops of sherry-wine on three other leaves; no infleetion was eaused, though two of them secmed somewhat injured. We shall hereafter see that cut-off lcaves immersed in diluted alcohol of the above strength do not beeome inflected.

Olive Oil.-Drops werc placed on the dises of eleven leaves, and no effeet was produeed in from $24 \mathrm{hrs}$. to $48 \mathrm{hrs}$. Four of these leaves were then tested by bits of meat on their dises, and three of them werc found after 24 hrs. with all their tentaeles and blades elosely infleeted, whilst the fourth had only a few tcntacles inflceted. It will, however, be shown in a future place, that cut-off lcaves immersed in olive oil are powerfully affcetcd.

Infusirm and Decoction of Tea.-Drops of a strong infusion and decoetion, as well as of a rather weak decoetion, of tea were placed on ten learcs, nonc of whieh bccame inflected. I aftcrwards tested three of them by adding bits of meat to the drops whieh still remained on their dises, and when I examined them after 24 hrs. they were closely inflceted. The ehcmieal prineiple of tea, mamely theine, was subsequently tried and produced no cffect. The albuminous mattcr which the leares must originally have contained, no doubt, had becn rendered insoluble by theil' having becn completcly dried.

Wo thus see that, excluding the experiments with water, sixty-onc leaves were trich with drops of the 
above-named non-nitrogenous fluids; and the tentaeles were not in a single ease infleeted.

With respeet to nitrogenous fluids, the first which eame to hand were tried. The experiments were made at the same time and in exnetly the same manner as the foregoing. As it was immediately evident that these fluids produeed a great effeet, I neglected in most eases to record how soon the tentreles became infleeted. But this alwrys oecurred in less than 24 hrs. ; whilst the drops of non-nitrogenous fluids whieh produeed no effeet were observed in every ease during a eonsiderably longer period.

Milk.-Drops were placed on sixteen leaves, and the tentaeles of all, as well as the blades of several, soon beeame greatly infleeted. The periods were recorded in only thrce eases, namely, with leaves on which unusually small drops had been plaeed. Their tentreles were somewhat infleeted in $45 \mathrm{~m}$.; and after 7 hrs. $45 \mathrm{~m}$. the blades of two were so mueh eurved inwards that they formed little eups enelosing the drops. These leaves re-expanded on the third day. On another oeeasion the blade of a leaf was much inflected in 5 hrs. after a clrop of milk had been placed on it.

Human Urine.-Drops were placed on twelve leaves, and the tentreles of all, with a single cxeeption, beeame greatly infleeted. Owing, I presume, to differenees in the chemical nature of the urine on different oeeasions, the time required for the movcments of the tentacles varied mueh, but was always effected in under $24 \mathrm{hrs}$. In two instanees I recorded that all the extcrior tentreles were eompletcly infleeted in $17 \mathrm{hr}$.s., but not the blade of the leaf. In anothcr case the edges of a leaf, after $25 \mathrm{hr}$. $30 \mathrm{~m}$., heeame so strongly inflected that it was converted into a eup. The power of urino does not lie in the urea, which, as we shall hereafter see, is inoperative.

Albumen (fresh from a hen's egg), plaeed on seven leaves, eaused the tentaeles of six of them to be well infleeted. In one case the edge of the leaf itself beeame much enrled in after $20 \mathrm{hrs}$. The one leaf which was unaffeeted remained so for 26 his., and was then treated with a drop of milk, and this eaused the tentreles to bend inwards in 12 hrs.

Cold Filtered Infusion of Raw Meat.-This was tried only on a singlo leaf, which had most of its outer tentaeles and the blado inflected in 19 hrs. During subsequent years, I repentedly used this infusion to test lcaves which had heen experimented 
on with other substances, and it was found to act most cnergetically, but as no exact account of these trials was kept, they are not here introduced.

Mucus.-Thick and thin mucus from the bronchial tubes, placed on three leaves, caused inflection. A leaf with thin mucus had its marginal tentacles and blade somewhat curved inward in 5 hrs. $30 \mathrm{~m}$., and greatly so in $20 \mathrm{hrs}$. The action of this fluid no doubt is due either to the saliva or to some albuminous matter* mingled with it, and not, as we shall see in the ncxt chapter, to mucin or the chemical principle of mucus.

Saliva.-Human saliva, when evaporated, yieldst from 1.14 to 1.19 per cent. of residue; and this yields 0.25 per cent. of ashes, so that the proportion of nitrogenous mattcr which saliva contains must be small. Nevertheless, drops placed on the discs of eight leaves acted on them all. In onc case all the exterior tentacles, excepting nine, were inflected in $19 \mathrm{hrs.} 30 \mathrm{~m}$. ; in another case a few became so in 2 hrs., and after 7 hrs. $30 \mathrm{~m}$. all those situated near where the drop lay, as well as the blade, were acted on. Since making these trials, I have many scores of times just touched glands with the handle of my scalpel wetted with saliva, to asccrtain whether a leaf was in an active condition; for this was shown in the course of a few minutes by the bending inwards of the tentacles. The edible nest of the Chinese swallow is formed of mattcr secreted by the salivary glands; two grrins wcre added to one ounce of distilled water (one part to 218), which was boiled for several minutes, but did not dissolve the whole. The usual-sized drops were placed on three leares, and these in $1 \mathrm{hr}$. $30 \mathrm{~m}$. were wcll, and in $2 \mathrm{hrs}$. $15 \mathrm{~m}$. closely, inflected.

Isinglass.-Drops of a solution about as thick as mill, and of a still thicker solution, were placed on eight leaves, and the tentacles of all becrme inflected. In one case the exterior tentacles were well curved in after 6 hrs. $30 \mathrm{~m}$, and the blade of the leaf to a partial extent after $24 \mathrm{hrs}$. As saliva acted so efficicntly, and yet contains so small a proportion of nitrogenous matter, I tried how small a quantity of isinglass would act. One part was dissolved in 218 parts of distilled water, and drops were placed on four leaves. After 5 lirs. two of these were considerably and two moderately inflected; aftcr 22 hrs. the former were greatly and the latter much more inflected. In the course of 48 hrs.

* Mucus from the air-passages is said in Marshall, 'Ontlines of P'hysiology;' vol. ii. 1867 , p. 36t, to contain some albumen. † Ni iiller's 'Elements of Physiology'; Fing. Trans. vol. i. p. 514. 
from the time when the drops wcre placed on the leaves, all tour had almost re-expanded. They were then given little bits of meat, and these acted more powerfully than the solution. One part of isinglass was next dissolved in 437 of water; the fluid thus formed was so thin that it eould not be distinguished from pure water. The usual-sized drops werc plaeed on seven leaves, caeh of whieh thus reeeived $\frac{1}{960}$ of a grain (.0295 mg.). Three of them were observed for 41 hrs., but were in no way affected; the fourth and fifth had two or threc of their exterior tentaeles infleeted after 18 hrs.; the sixth had a few more; and the seventh had in addition tle edge of the lcaf just perceptibly eurved inwards. The tentaeles of the four latter leaves began to re-expand after an additional interval of only 8 hrs. Henee the $\frac{1}{960}$ of a grain of isinglass is sufficient to affect very slightly the more sensitive or active leaves. On ane of the leaves, whieh had not been aeted on by the weak solution, and on another, whieh had only two of its tentacles inflected, drops of the solution as thiek as milk were plaeed; and next morning, after an interval of $16 \mathrm{hrs}$, both were found with all their telltaeles strongly infleeted.

Altogether I experimented om sixty-four leaves with the above nitrogenous fluids, the five leaves tried only with the extremely weak solution of isinglass not being ineluded, nor the numerous trials subsequently made, of whieh no exaet aeeount was kept. Of these sixty-four leaves, sixty-three had their. tentaeles and often their blades well infleeted. 'T'be one which failed was probably too old and torpil. But to obtain so large a proportion of suecessful cises, eare must be taken to select young and aetise leaves. Leaves in this eordition were chosen with equal enre for the sixty-one trials with non-nitrogenous fluids (water not included); and we have seen that not one of these was in the least affeeted, We may therefore safely eonelude that in the sixty-four experiments with nitrogenous fluids the inflection of the exterior tentacles was due to the absorption of 
C'hap. V.

nitrogenous matter by the glands of the tentacles on the dise.

Some of the leaves whieh were not affeeted by the non-nitrogenous fluids were, as above stated, immediately afterwards tested with bits of meat, and were this proved to be in an aetive eondition. But in addition to these trials, twenty-three of the leaves, with drops of gum, syrup, or stareh, still lying on their dises, whieh had produeed no effeet in the eourse of between 24 hrs. and 48 hrs., were then tested with drops of milk, urine, or albumen. Of the twenty-three leaves thus treated, seventeen had their tentaeles, and in some eases their blades, well infleeted; but their powers were somewhat impaired, for the rate of movement was deeidedly slower than when fresh leares were treated with these same nitrogenous fluids. This impairment, as well as the insensibility of six of the leaves, may be attributed to injury from exosmose, caused by the density of the fluids plaeed on their dises.

The results of a few other experiments with nitrogenous fluids may be here eonveniently given. Deeoetions of some vegetables, known to be rieh in nitrogen, were made, and these aeted like animal fluids. Thus, a few green peas were boiled for some time in distilled water, and the moderately thiek deeoetion thus made was allowed to settle. Drops of the superineumbent fluid were plaeed on four leaves, and when these were looked at after 16 hrs., the tentreles and blades of all were found strongly infleeted. I infer from a remark by Gerhardt* that legumin is present in peas "in oombination with an alkali, forming an ineoagulable solution," and this would mingle with boiling water. I may mention, in relation to tine above and following experiments, that aeeording to Sehifft certrin forms of albumen

* Watts' 'Dict. of Chomistry' vol. iii. p. 568 .

t'Leçons sur la Phys. de lat
Digestion,' tom. i. p. 379 ; tom. ii. pp. 154, 166, on legumin. 
exist which are not coagulated by boiling water, but are converted into soluble peptones.

On three occasions chopped cabbagc-leaves * were boiled in distilled water for $1 \mathrm{hr}$. or for $1_{4}^{1} \mathrm{hr}$; and by decanting the decoction after it had been allowed to rest, a pale dirty green fluid was obtained. The usual-sized drops were placed on thirteen leaves. Their tentacles and blades were inflected after 4 hrs. to a quite extraordinary degrec. Next day the protoplasm within the cells of the tentacles was found aggregated in the most strongly marked manner. I also touched the viscid secretion round the glands of several tentacles with minute drops of the decoction on the head of a small pin, and they became well inflected in a few minutes. The fluid proving so powerful, one part was diluted with three of water, and drops were placed on the dises of five leaves; and these ncxt morning were so much acted on that their blades were completely doubled over. We thus see that a decoction of cabbage-learcs is ncarly or quite as potent as an infusion of raw mcat.

About the same quantity of chopped cabbage-leaves and of distilled water, as in the last experiment, were kept in a vessel for $20 \mathrm{hrs}$. in a hot closet, but not heated to near the boilingpoint. Drops of this infusion were placed on four leaves. Onc of these, after 23 hrs., was much inflected; a second slightly; a third had only the submarginal tentacles inflected; and the fourth was not at all affected. The power of this infusion is therefore very much less than that of the decoction; and it is clear that the immersion of cabbage-leaves for an lour in watcr at the boiling tempcrature is much more efficient in extracting matter which excitcs Droscra than immersion during many hours in warm water. Perhaps the contents of the cells are protected (as Schiff remarks with respect to legumin) by the walls being formed of cellulose, and that until thesc are ruptured by boiling-water, but little of the contained albuminous matter is dissolved. We know from the strong odour of cooked cabbage-leaves that boiling watcr produces some chemical change in them, and that they are thus rendered far more digestible and nutritious to man. It is therefore an interesting

* The leaves of young plants, before the heart is formed, such as were used by me, contain $2 \cdot 1$ per cent. of albuminous matter, and the outer leaves of mature plants 1 ' 6 per cent. Watts' 'Dict. of Chemistry, vol. i. p. 653. 
faet that water at this temperature extraets matter from them whieh excites Drosera to an extraordinary degree.

Grasses eontain far less nitrogenous matter than do peas or cabbages, The leaves and stalks of three common kinds were ehopped and boiled for some time in distilled water. Drops of this decoction (after having stood for $24 \mathrm{hrs}$.) were placed on six lenves, and acted in a rather peculiar manner, of which other instances will be given in the seventh ehapter on the salts of ammonia. After 2 hrs. $30 \mathrm{~m}$. four of the leaves had their blades greatly inflected, but not their exterior tentaeles; and so it was with all six leaves after 24 hrs. Two days afterwards the blades, as well as the few submarginal tentacles which had becn infleeted, all re-expanded; and much of the fluid on their dises was by this time absorbed. It appears that the decoetion strongly exeites the glands on the disc, causing the blade to be quickly and greatly inflected; but that the stimulus, differently from what oeeurs in ordinary cases, does not spread, or only in a feeble degree, to the exterior tentacles.

I may here add that one part of the extract of belladonna (procured from a druggist) was dissolved in 437 of water, and drops were placed on six leaves. Next day all six were somewhat inflected, and after $48 \mathrm{hrs}$. were eompletely re-expanded. It was not the included atropine which produced this effect, for I subsequently ascertained that it is quite powerless. I also procured some extract of hyoscyamus from three shops, and made infusions of the same strength as before. Of these three infusions, only one aeted on some of the leares, which were tried. Though druggists believe that all the albumen is precipitated in the preparation of these drugs, I cannot doubt that some is oeeasionally retained; and a trace would be sufficient to exeite the more sensitive leares of Drosera. 


\section{CHAPTER VI.}

The Digestive Power of the Secretion of Drosera.

The secretion rendered acid by the dircet and indirect excitement of the glands - Nature of the acid -- Digestible substances - Albumen, its digestion arrested by alkalies, rccommences by the addition of an acid - Meat - Fibrin - Syntonin - Areolar tissue Cartilage - Fibro-cartilage - Bone-Enamel and dentine - Phosphate of lime-Fibrous basis of bone-Gelatine-ChondrinMilk, caseiu and cheese - Gluten - Legumin - Pollen - Globulin - Hrmatin - Indigestible substances - Epidermic productions Fibro-elastic tissue - Mucin - Pepsin - Urea - Chitine - Cellulose - Gun-cotton - Chlorophyll - Fat and oil - Stareh - Action of the secretion on living seeds - Summary and concluding remarks.

As we have seen that nitrogenous fluids aet very differently on the leaves of Drosera from non-nitrogenous fluids, and as the leaves remain clasped for a much longer time over various organic bodies than over inorganic bodies, such as bits of glass, einder, wood, \&c., it becomes an interesting inquiry, whether they can only absorb matter already in solution, or render it soluble, - that is, have the power of digestion. We shall immediately see that they certainly have this power, and that they act on albuminous compounds in exactly the same manner as does the gastric juice of mammals; the digested matter being afterwards absorbed. This fact, which will be clearly proved, is a wonderful one in the physiology of plants. I must here state that I have been aided throughout all my later experiments by many valuable suggestions and assistance given me with the greatest kindness by Dr. Burdon Sanderson. 
It may be well to premise for the sake of any reader who knows nothing about the digestion of albuminous compounds by animals that this is effected by means of a ferment, pepsin, together with weak hydrochloric acid, though almost any acid will serve. Yet neither pepsin nor an acid by itself has any such power.* We have seen that when the glands of the disc are excited by the contact of any object, especially of one containing nitrogenous matter, the outer tentacles and often the blade become inflected; the leaf being thus converted into a temporary cup or stomach. At the same time the discal glands secrete more copionsly, and the secretion becomes acid. Moreover, they transmit some influence to the glands of the exterior tentacles, causing them to pour forth a more copious secretion, which also becomes acid or more acid than it was before.

As this result is an important one, I will give the evidence. The secretion of many glands on thirty leaves, which had not been in any way excited, was tested with litmus paper ; and the secretion of twentytwo of these leaves did not in the least affect the colour, whereas that of eight caused an exceedingly feeble and sometimes doubtful tinge of red. Two other old leaves, however, which appeared to have been inflected several times, acted much more decidedly on the paper. Particles of clean glass were then placed on five of the leaves, cubes of albumen on six, and bits of raw meat on three, on none of which was the secretion at this time in the least acid. After an interval of $24 \mathrm{hrs}$, when almost all the tentacles on

* It appears, however, neeording to Sehiff, and contrary to the opinion of some pliysiologists, that weak hydrochlorio dissolves, though slowly, a very minute qunntity of conmulated albumen. Sehiff, 'Plyys. de la Digestion,' tom. ii. $1 \$ 67$, p. 25. 
these fourteen leaves had become more or less inflected, I again tested the seeretion, seleeting glands which had not as yet reached the eentre or toucherl any object, and it was now plainly acid. The degree of aeidity of the seeretion varied somewhat on the glands of the same leaf. On some leaves, a few tentacles did not, from some unknown cause, beeome inHected, as often happens; and in five instances their secretion was found not to be in the least aeid; whilst the secretion of the adjoining and inflccted tentacles on the same lcaf was deeidedly aeid. With leaves exeited by particles of glass plaecd on the central glands, the secretion which eollects on the dise beneath them was much more strongly acid than that poured forth from the exterior tentaeles, whieh werc as yet only moderately infleetcd. When bits of albumen (and this is naturally alkaline), or bits of meat were plaeed on the disc, the secretion eollected beneath them was likewisc strongly acid. As raw meat moistened with water is slightly aeid, I compared its aetion on litmus paper before it was plaecd on the leaves, and afterwards when bathed in the seeretion; and there could not be the least doubt that the latter was vcry mueh more aeid. I have indeer tried hundreds of times the state of the seeretion on the dises of leaves which wcre infleeted over various objects, and never failed to find it acid. We may, therefore, conelude that the sccretion from inexcited leaves, though extremely viseid, is not acid or only slightly so, but that it beeomes aeid, or mueh more strongly so, after the tentacies have begun to bend over any inorganie or organie objeet; and still more strongly acid after the tentaeles have remained for some time closely clasped over any objeet.

I may here remind the reader that the secretion 
ippears to be to a certain extent antiseptic, as it checks the appearance of mould and infusoria, thus preventing for a time the discoloration and decay of such substances as the white of an egg, cheese, \&c. It therefore acts like the gastric juice of the higher animals, which is known to arrest putrefaction by destroying the microzymes.

As I was anxious to learn what acid the secretion eontained, 445 leaves werc washed in distilled water, given me by Prof. Frankland; but the seeretion is so viscid that it is seareely possible to serape or wash off the whole. The eonditions were also unfavourable, as it was late in the year and the leaves were sinall. Prof. Frankland with great kindness undertook to test the fluid thus eolleeted. The leaves were exeited by clean particles of glass plaeed on them $24 \mathrm{hrs}$. previously. No doubt mueh more aeid would have been seercted had the leares becn excited by animal matter, but this would have rendercd the analysis more diffieult. Prof. Frankland informs me that the fluid eontained no traee of hydroehlorie, sulphurie, tartaric, oxalie, or formic aeids. This having been aseertained, the remainder of the fluid was evaporated nearly to droness, and acidified with sulphurie acid; it then evolved rolatile acid rapour, whieh was eondensed and digested with earbonate of silver. "The weight of the silver salt thus prodneed was only - $37 \mathrm{gr}$., mueh too small a quantity for the aceurate determination of the molceular weight of the aeid. The number obtained, however, eorresponded nearly with that of propionie acid; and I believe that this, or a mixture of acctie and butyrie aeids, were present in the liquid. The aeid doubtless belongs to the acetie or fatty series."

Prof. Frankland, as wcll as his assistant, olserved (and this is an important faet) that the fluid, "when aciditied with sulphuric acid, emitted a powerful odnur like that of pepsin." The leaves from whieh the sceretion had been mashed wcrc also sent to Prof. Frankland; they werc maeerated for some hour's, then acidified with sulphurie-acid and distilled, but no acid passed over'. 'Thcrefore thc aeid whieh fresh leaves eontain, as shown by their diseolonring litmus paper whell crushed, must be of a different mature from that present in the secretion. Nor was any odour of pepsin emitted by them. 
Although it has long been known that pepsin with acetic aeid has the power of digesting albuminous eompounds, it appeared advisable to asecrtain whether acctic acid could be replaced, without the loss of digestive power, by the allied asids which are believed to occur in the seerction 'of Drosera, namely, propionic, butyric, or valcrianic. Dr. Burdon Sandcrsoll was so kind as to make for me the following experiments, the results of which are valuable, independently of the present inquiry. Prof. Frankland supplied the acids.

"1. The purpose of the following cxperiments was to determine the digestive activity of liquids containing pepsin, when acidulated with certain volatile acids belonging to tho acetic series, in comparison with liquids acidulated with hydroehloric acid, in proportion similar to that in whieh it exists in gastric juiee.

" 2 . It has been determined empirically that the best results are obtained in artificial digestion when a liquid containing two per thousand of hydrochloric acid gas by weight is used. This corresponds to about 6.25 eubic centimetres per litre of ordinary strong hydrochloric aeid. The quantities of propionic, butyrie, and valerianic aeids respeetively which are required to neutralise as much base as 6.25 cubic ecntimetres of $\mathrm{HCl}$, are in grammes 4.04 of propionie aeid, 4.82 of butyrie aeid, and 5.68 of valerianie acid. It was therefore judged expedicnt, in comparing the digestive powers of tlese acids with that of hydroehlorie acid, to use them in these proportions.

" 3 . Five hundred eubs cent. of a liquid containing about 8 eub. eent. of a glycerine extraet of the mucous membrane of the stomach of a dog killed during digestion having been prepared, 10 cub. cent. of it were evaporated and dried at $110^{\circ}$. This quantity yiclded 0.0031 of residuc.

"4. Of this liquid four quantities were taken which were screrally acidulated with hydrochloric, propionie, butyrie, and valerianic acids, in the proportions abovo indicatcd. Eacl liquid was then placed in a tube, which was allowed to float in a water bath, containing a thcrmometer which indicated a temperature of $38^{\circ}$ to $40^{\circ}$ Cent. Into each, a quantity of unboilcd fibrin was introduced, and tho whole allowed to stand for four hours, the tempcraturo being maintained duriug the whole time, and caro being taken that cach containcd thronghout an excess of fibrin. "At tho end of the period each liquid was filtered. Of tho filtrate, whieh of courso contained as much of the fibrin as had becn digested during the four hours, 
$10 \mathrm{cub}$, cent. were measured out and evaporated, and dried at $110^{\circ}$ as hefore. The residues were respectivcly-

"In the liquid containing hydrochloric acid 0.4079

$\begin{array}{llll}\prime & , & \text { propionic acid } & 0 \cdot 0601 \\ \prime & \Rightarrow & \text { butyric acid } & 0 \cdot 1468 \\ , & \quad & \text { valerianic acid } & 0 \cdot 1254\end{array}$

"Hence, deducting from each of thesc the above-mentioned residue, left when the digestive liquid itself was evaporated, viz. 0.0031, we have,

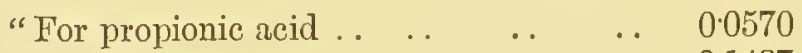

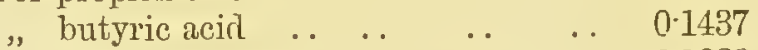

$$
\begin{aligned}
& \text { „ valerianic acid.. . . } \quad . . \quad \ldots \quad \text {. } 0.1223
\end{aligned}
$$

as compared with 0.4048 for hydrochloric acid; these several numbers cxpressing the quantities of fibrin by weight digested in prescnec of equivalent quantitics of the respective acids under identical conditions.

"The results of the experiment may be stated thus:-If 100 represent the digestive power of a liquid containing pepsin with the usual proportion of hydrochloric acid, $14 \cdot 0,35 \cdot 4$, and $30 \cdot 2$, will represent respectively the digestive powers of the three acids under investigation.

"5. In a second experiment in which the procedure was in every respect the same, excepting that all the tubes werc plunged into the same water-bath, and the residues dried at $115^{\circ} \mathrm{C}$, the results were as follows :-

"Quantity of fibrin dissolved in four hours by $10 \mathrm{cub}$. cent. of the liquid-

$$
\begin{array}{lllll}
\text { “Propionic acid } & . . & . . & . . & 0.0563 \\
\text { Butyric acid } & . & . . & . . & 0.0835 \\
\text { Valerianic acid } & . & . . & . . & 0.0615
\end{array}
$$

"The quantity digested by a similar liquid containing hydrochloric acid was 0.3376 . Hence, taking this as 100 , the following numbers represent the relative quantitics digested by the other acids :

$$
\begin{array}{ccccc}
\text { "Propionic acid } & . . & . . & . . & 16 \cdot 5 \\
\text { Butyric acid } & . . & . . & . & 21.7 \\
\text { Valerianic acid } & . . & . . & . . & 16 \cdot 1
\end{array}
$$

"6. A third experiment of the same kind gave: 
"Quantity of fibrin digested in four hours by 10 cub. cent. of the liquid:

$\begin{array}{lllll}\text { " Hydrochloric acid } & \text {.. } & \text {.. } & 0 \cdot 2915 \\ \text { Propionic acid } & \text {.. } & \text {. } & \text {. } & 0 \cdot 1490 \\ \text { Butyric acid } & \text {.. } & \text {. } & \text {. } & 0 \cdot 1044 \\ \text { Valerianic acid } & \text {.. } & \text {.. } & \text {.. } & 0 \cdot 0520\end{array}$

"Comparing, as before, the thrce last numbers with the first taken as 100, the digestive power of propionic acid is represented by 16.8 ; that of butyric acid by 35.8 ; and that of valerianic by $17 \cdot 8$.

"The mean of thesc threc scts of observations (hydrochloric acid bcing taken as 100) gives for

$\begin{array}{lllll}\text { "Propionic acid } & . & . & \ldots & 15.8 \\ \text { Butyric acid } & . & . & . & 32.0 \\ \text { Valerianic acid } & . . & . . & . . & 21 \cdot 4\end{array}$

"7. A further experiment was made to ascertain whether the digestive activity of butyric acid (which was selected as being. apparently the most efficacious) was relatively greater at ordinary temperatures than at the temperaturc of the body. It was found that whereas $10 \mathrm{cub}$. cent. of a liquid containing the ordinary proportion of hydrochloric acid digcsted $0 \cdot 1311$ grammc, a similar liquid prepared with butyric acid digcsted 0.0455 gramme of fibrin.

"Hencc, taking the quantities digested with hydrochloric acid at the temperaturc of the body as 100, wc have the digestive power of hydrochloric acid at the temperature of $16^{\circ}$ to $18^{\circ}$ Cent. represented by 44.9 ; that of butyric acid at the same temperature bcing $15 \cdot 6$."

We here sce that at the lower of these two temperatures, hydrochloric acid with pepsin digests, within the same time, rather less than half the quantity of fibrin compared with what it digests at the higher temperaturo; and tho power of butyric acid is reduced in the same proportion under similar conditions and temperatures. We have also scen that butyric acid, which is mucl morc efficacious than propionic or valerianic acids, digests with popsin at the higher temperature less than a thire of the fibrin which is digested at the samo temperature by hydrochloric acid. 
I will now give in detail my experiments on the digestive power of the secretion of Drosera, dividing the substanees tried into two series, namely those whieh are digested more or less eompletely, and those which are not digested. We shall presently see that all these substances are aeted on by the gastrie juiee of the higher animals in the same manner. I beg leave to eall attention to the experiments under the head albumen, showing that the secretion loses its power when neutralised by an alkali, and reeovers it when an aeid is added.

Substances which are completely or partially digested by the Secretion of Drosera.

Albumen.-After having tried various substanees, Dr. Burdon Sanderson suggested to me the use of cubes of eoagulated albumen or hard-boiled egg. I may premise that five cubes of the same size as those used in the following experiments were placed for the sake of eomparison at the same time on wet moss elose to the plants of Drosera. The weather was hot, and after four days some of the eubes were diseoloured and mouldy, with their angles a little rounded; but they were not surrounded by a zone of transparent fluid as in the case of those undergoing digestion. Other eubes retained their angles and white colour. After eight days all were somewhat reduced in size, diseolonred, with their angles mueh rounded. Nevertheless in four out of the five speeimens, the central parts were still white and opaque. So that their state differed widely, as we shall see, from that of the cubes subjected to the action of the seeretion.

Experiment 1. - Rather large eubes of albumen were first tried; the tentacles were well inflected in 24 hrs.; after an 
additional day the angles of the cubes were dissolved and rounded;* but the cubes were too large, so that the leaves were injured, and after seven days onc died and the others were dying. Albumen which has been kept for four or five days, and which, it may be presumed, has begun to decay slightly, scems to act more quickly than freshly boiled eggs. As the latter were generally used, I often moistened them with a little saliva, to make the tcntacles close more quickly.

Experiment 2.-A cube of $\frac{1}{10}$ of an inch (i.e. with each side $\frac{1}{10}$ of an inch, or $2.54 \mathrm{~mm}$., in length) was placed on a lcaf, and after $50 \mathrm{hrs}$. it was converted into a sphere about $\frac{3}{4.0}$ of an inch (1.905 $\mathrm{mm}$.) in diameter, surrounded by perfectly transparcnt fluid. After ten days the leaf re-expanded, but therc was still left on the dise a minute bit of albumen now rendered trinsparent. More albumen had been given to this leaf than could be dissolved or digested.

Experiment 3.-Two cubes of albumen of $\frac{1}{20}$ of an inch (1.27 mm.) were placcd on two leaves. After $46 \mathrm{hrs}$. crery atom of one was dissolved, and most of the liquefied matter was absorbed, the fluid which remained being in this, as in all other cases, very acid and viscid. The othcr cube was acted on at a rather slower rate.

Experiment 4.-Two cubes of albumen of the same size as the last were placed on two leaves, and were convertcd in 50 hrs. into two large drops of transparent fluid; but when these were removed from beneath the inflectcd tentacles, and viewed by reflected light under the microscupc, finc strcaks of white opaque matter could be secn in the onc, and traces of similar streaks in the other. 'I'he drops wcre replaced on the leaves, which re-expanded after 10 days; and now nothing was left except a very Jittle transparent acid fluid.

Lxperiment 5.-This experiment was slightly varied, so that the albumen might be more quickly cxposed to the action of the secretion. Two cubcs, cacli of about $\frac{1}{1.0}$ of an inch ( $635 \mathrm{~mm}$.), were placed on the same leaf, and two similar cubes on another

* In all my numerous cxperiments on the digestion of cubes of albumen, the angles and edges were invariably first rounded. Now, Schiff' states ('Lecons pliys. de la Digestion,' vol. ii. [s(j7, 1. 149) that this is charue- teristic of the digestion of albumen by the gastric juice of animals. On the other hand, he remarks, "les rissolutions, on chimic, ont licu sur toute la sur. finee les eorps an contact avec l'agent clissolvant." 
leaf. These were examined after $21 \mathrm{hrs} .30 \mathrm{~m}$., and all four were found rounded. After 46 hrs. the two cubes on the one leaf were completely liquefied, the fluid being perfectly trans. parent; on the other leaf some opaque white streaks could still be seen in the midst of the fluid. After $72 \mathrm{hrs}$. these streaks disappeared, but there was still a little viscid fluid left on the disc; whereas it was almost all absorbed on the first leaf. Both leaves were now beginning to re-expand.

'The best and almost sole test of the presence of some fcrmcnt analogous to pepsin in the secretion appeared to be to neutralise the acid of the secretion with an alkali, and to obscrve whether the process of digestion ceased; and then to add a little acid and obscrve whether the process recommenced. This was donc, and, as we shall sce, with success, but it was necessary first to try two control cxpcriments; namely, whether the addition of minute drops of watcr of the same size as those of the dissolved alkalies to be used would stop the process of digestion; and, secondly, whether minutc drops of weak hydrochloric acid, of the some strength and size as those to be used, would injure the leaves. The two following experiments were therefore tried:-

Experiment 6.-Small cubes of albumen were put on three leaves, and minute drops of distilled water on the head of a pin were added two or three times daily. These did not in the least delay the proeess; for, after 48 hrs., the cubes were completely dissolved on all three leaves. On the third day the leares began to re-expand, and on the fourth day all the fluid was absorbed.

Experiment 7.- Small cubes of albumen were put on two leaves, and minute drops of hydroehloric aeid, of the strength of one part to 4.37 of water, were added two or three times. This did not in the least delny, but seemed rather to hasten, the process of digestion; for every trace of the albumen disappenred in 24 hrs. $30 \mathrm{~m}$. After three days the leaves partially reexpanded, and by this time almost all the riscid fluid on their dises was absorbed. It is almost superfluous to state that 
cubes of albumen of the srime size as those above used, left for seven days in a little hydrochloric acid of the above strength, retained all their angles as perfect as ever.

Experiment 8.-Cubes of albumen (of $\frac{1}{20}$ of an inch, or 2.54 $\mathrm{mm}$.) were placed on five leaves, and minute drops of a solution of one part of carbonate of soda to 437 of water were added at intervals to three of them, and drops of carbonate of potash of the same strength to the other two. The drops were given on the head of a rather large pin, and I ascertained that each was cqual to about $\frac{1}{10}$ of a minim (.0059 ml.), so that each contained only $\frac{1}{4800}$ of a grain ( $0135 \mathrm{mg}$.) of the alkali. This was not sufficient, for after 46 hrs. all five cubes werc dissolved.

Experiment 9.-The last experiment was repeated on four leaves, with this difference, that drops of the same solution of carbonate of soda were added rather oftener, as often as the secretion became acid, so that it was much more effectually neutralised. And now after 21 hrs. the angles of three of the cubes were not in the least rounded, those of the fourth being so in a very slight degree. Drops of cxtrcmely weak hydrochloric acid (viz. one part to 847 of water) were then added, just enough to neutralise the alliali which was still present; and now digestion immediately recommenced, so that after 23 hrs. $30 \mathrm{~m}$. three of the cubes wcre completely dissulved, whilst the fourth was converted into a minute sphere, surrounded by transparent fluid; and this sphere next day disappeared.

Experiment 10.-Stronger solutions of carbonate of soda and of potash were next uscd, viz. one part to 109 of water; and as the same-sized drops were given as before, each drop containcd $\frac{1}{1200}$ of a grain ( $0539 \mathrm{mg}$.) of either salt. Two cubes of albumen (each about $\frac{1}{40}$ of an inch, or $635 \mathrm{~mm}$.) were placed on the same leaf, and two on another. Each leaf received, as soon as the sccretion becarne slightly acid (and this occurred four times within 24 lırs.), drops either of the soda or potash, and the acid was thus effcctually ncutralised. The experiment now succeeded perfectly, for after $22 \mathrm{hr}$. the angles of the eubes werc as sharp as they were at first, and we know from experiment 5 that such small cubcs would have been completely rounded within this time by the secretion in its natural state. Some of the fluid was now rumoved with blotting-paper from the dises of the leaves, and minute drops of hydrochloric acid of the strength of one part to 200 of water was added. Acid of this greater strength was uscd as the solutions of the allalics were stronger. The 
process of digestion now eommenced, so that within $48 \mathrm{hrs.}$ from the time when the aeid was given the four eubes were not only eompletely dissolved, but mueh of the liquefied albumen was absorbed.

Experiment 11.- Two cubes of albumen ( $\frac{1}{40}$ of an ineh, or $.635 \mathrm{~mm}$.) were plaeed on two leaves, and were treated with alkalies as in the last experiment, and with the same result; for after 22 hrs. they had their angles perfectly sharp, showing that the digestive proeess had been eompletely arrested. I then wished to aseertain what would be the effeet of using stronger hydroehlorie acid; so I added minute drops of the strength of 1 per eent. This proved rather too strong, for after $48 \mathrm{hrs}$. from the time when the aeid was added one cube was still almost perfeet, and the other only very slightly rounded, and both were stained slightly pink. This latter faet shows that the leaves were injured,* for during the normal proeess of digestion the albumen is not thus coloured, and we ean thus uuderstand why the eubes were not dissolved.

From these experiments we clearly see that the secretion has the power of dissolving albumen, and we further see that if an alkali is added, the process of digestion is stopped, but immediately recommences as soon as the alkali is neutralised by weak hydrochloric acid. Even if I had tried no other experiments than these, they would have almost sufficed to prove that the glands of Drosera secrete some ferment analogous to pepsin, which in presence of an acid gives to the secretion its power of dissolving albuminous compounds.

Splinters of clean glass were seattered on a large number of leaves, and these became moderately inflected. They were eut off and divided into three lots; two of them, after being left for some time in a little distilled water, were strained, and some dis-

* Sachs remarks ("l'raité de Bot.' 1874, p. 774), that cells which arc killed by freezing, by ton great heat, or by eliemical ngents, nllow all their colouring matter to escape into the surrounding water. 
coloured, viseid, slightly acid fluid was thus obtained. The third lot was well soaked in a few drops of glycerine, which is well known to dissolve pepsin. Cubes of albumen ( $\frac{1}{20}$ of an inch) werc now placed in the three fluids in watch-glasses, some of which were kcpt for several days at about $90^{\circ}$ Fahr. $\left(32^{\circ} \cdot 2\right.$ Cent.), and others at the temperature of $\mathrm{my}$ room; but none of the cubes were dissolved, the angles remaining as sharp as ever. This fact probably indicates that the ferment is not secreted until the glands are excited by the absorption of a minute quantity of already soluble animal matter,-a conclusion which is supported by what we shall hereafter see with respect to Dionæa. Dr. Hooker likewise found that, although the fluid within the pitchers of $\mathrm{Ne}$ penthes possesses extraordinary power of digestion, yet when removed from the pitchers before they have been excited and placed in a vessel, it has no such power, although it is already acic; and we can account for this fact only on the supposition that the proper ferment is not secreted until some exciting matter is absorbed.

On threc other occasions eight leaves werc strongly excited with albumen moistened with saliva; they were then cut off, and allowed to soak for several hours or for a whole day in a few drops of glycerine. Some of this extract was added to a little hydrochloric acid of various strengths (generally one to 400 of water), and minutc cubes of albumen were placed in the mixturc.* In two of these trials the cubes were not in the lcast acted on; but in the third

* As a control experiment bits of albumen were placed in the same glycerine with hydrochloric acid of the same strength; and the albumen, as might have been expected, was not in the lesst aflected after two days. 
the expcriment was successful. For in a vessel containing two eubes, both werc reduced in size in 3 hrs.; and after $24 \mathrm{hrs}$. mere streaks of undissolved albumen were left. In a second vessel, containing two minute ragged bits of albumen, both were likewise reduced in size in 3 hrs., and after 24 hrs. completely disappearerl. I then added a little weak liydrochloric acid to both vessels, and placed fresh cubes of albumen in them; but these were not acted on. This latter fact is intelligible according to the high authority of Schiff,* who has demonstrated, as he belicves, in opposition to the view held by some physiologists, that a certain small amount of pepsin is destroyed during the act of digestion. So that if my solution contained, as is probable, an extremely small amount of the ferment, this would have been consumed by the dissolution of the cubes of albumen first given; none being left when the hydrochloric acid was added. The destruction of the ferment during the process of digestion, or its absorption after the albumen had been converted into a peptone, will also account for only one out of the three latter scts of experiments having been successful.

Digestion of Roast Meat.-Cubes of about $\frac{1}{20}$ of an inch $(1.27 \mathrm{~mm}$.) of moderately roasted meat were placed on five leaves which became in 12 hrs. closely inflected. After 48 hrs. I gently opened one leaf, and the meat now consisted of a minute central sphere, partially digested and surrounded by a thick envelope of transparent viscid fluid. The whole, without being much disturbed, was removed and placed nuder the microscope. In the central part the transverse strix on the muscular fibres were quite distinct; and it was

* 'Leçons physs. do la Digestion,' 1867, tom. ii. jup. 11t-126. 
interesting to observe how gradually they disappeared, when the same fibre was traced into the surrounding fluid. They disappeared by the strix being replaced by transverse lines formed of excessively minute dark points, which towards the exterior could be seen only under a very high power; and ultimatcly these points were lost. When I made these observations, I had not read Schiff's account* of the digestion of meat by gastric juice, and I did not understand the meaning of the dark points. But this is explained in the following statement, and we further see how closely similar is the process of digestion by gastric juice and by the secretion of Drosera.

"On a dit que le suc gastrique faisait perdre à la fibre museulaire ses stries transversales. Ainsi énoneée, eetto proposition pourrait donner lieu à une équivoque, ear ee qui se perd, ee n'est que l'aspect extérieur de la striature et non les éléments anatomiques qui la eomposent. On sait que les stries qui donnent un ispeet si earaetéristique à la fibre museulaire, sont le résultat de la juxtaposition et du parallélisme des eorpuseules élémentaires, plaeés, à distanees égales, dans l'intérieur des fibrilles eonliguës. Or, dès que le tissu eonneetif qui relie entre elles les fibrilles élémentaires vient à se gonfler et à se dissoudre, et que les fibrilles elles-mêmes se dissoeient, ee parallélisme est détruit et avee lui l'nspeet, le phénomène optique des stries. Si, après la désagrégation des fibres, on examine au mieroscope les fibrilles élémentaires, on distingue eneore très-nettement à leur intérieur les eorpuseules, et on eontinue à les voir, de plus en plus pâles, jusqu'au moment nù les fibrilles elles-mêmes se liquéfient et disparaissent dans le sue gastrique. Ce qui eonstitue la striature, à proprement parler, n'est done pas détruit, avant la liquéefaetion de la fibre eharnue elle-même."

In the viscid fluid surromnding the central sphere of undigested meat there were globules of fat and little bits of fibro-elastic tissuc; neither of which were in

* 'T،econs phys. de la Digestion,' tom. ii. p. 1.t5. 
the least digested. There were also little free parallelograms of yellowish, highly translueent matter. Sehiff, in speaking of the digestion of meat by gastrie juiee, alludes to sueh parallelograms, and says :-

"Le gonflement par lequel commence la digestion de la viande, résulte de l'action du suc gastrique acide sur le tissu connectif qui se dissout d'abord, et qui, par sa liquéfaction, désagrége les fibrilles. Celles-ci se dissolvent ensuite en grande partic, mais, avant de passer à l'état liquide, elles tendent à se briser en petits fragments transversaux. Les 'sarcous elements' de Bowman, qui ne sont autre chose que les produits de cette division transversale des fibrilles élémentaires, peuvent être préparés et isolés à l'aide du suc gastrique, pourvu qu'on n'attend pas jusqu'à la liquéfaction complète du muscle."

After an interval of $72 \mathrm{hrs}$, from the time when the five eubes were plaeed on the leaves, I opened the four remaining ones. On two nothing eould be seen but little masses of transparent viseid fluid; but when these were examined under a high power, fat-globules, bits of fibro-elastic tissue, and some few parallelograms of sareous matter, eould be distinguished, but not a vestige of transverse striæ. On the other two leaves there were minute spheres of only partially digested meat in the centre of mueh transparent fluid.

Fibrin.-Bits of fibrin were left in water during four days, whilst the following experiments were tried, but they were not in the least aeted on. The fibrin whieh I first used was not pmre, and included dark particles: it had either not been well prepared or had subsequently undergone some ehange. Thin portions, about $\frac{1}{1}$ of an ineh square, were plaeed on several leaves, and though the fibrin was soon liquefied, the whole was never dissolved. Smaller partieles were then placed on four leaves, and minute 
drops of hydrochloric acid (one part to 437 of water) were added; this seemed to hasten the process of digestion, for on one leaf all was liquefied and absorbed after 20 hrs.; but on the three other leaves some undissolved residue was left after $48 \mathrm{hrs}$. It is remarkable that in all the above and following experiments, as well as when much larger bits of fibrin were used, the leaves were very little excited; and it was sometimes necessary to add a little saliva to induce complete inflection. The leaves, moreover, began to re-expand after only 48 hrs., whereas they would have remained inflected for a much longer time had insects, meat, cartilage, albumen, \&c., been placed on them.

I then tried some pure white fibrin, sent me by Dr. Burdon Sanderson.

Experiment 1.-Two particles, barely $\frac{1}{20}$ of an inch (1.27 mm.) square, were placed on opposite sides of the same leaf. One of these did not excite the surrounding tentacles, and the gland on which it rested soon dried. The other particle caused a few of the short adjoining tentacles to bc inflected, the more distant ones not being affected. After 24 hrs. both were almost, and after 72 hrs. completely, dissolved.

Experiment 2.-The same experiment with the same result, only one of the two bits of fibrin exciting the short surrounding tentacles. This bit was so slowly acted on that after a day I pushed it on to some fresh glands. In three days from the time when it was first placed on the leaf it was completely dissolved.

Experiment 3.-Bits of fibrin of about the samo sizc as beforo were placed on the discs of two leavcs; these caused vcry little inflection in 23 hrs., but after 48 hrs. both werc well clasped by the surrounding short tentacles, and after an additional 24 hrs. werc completcly dissolved. On tho disc of onc of these leaves much clear acid fluid was lcft.

Experiment 4.-Similar bits of fibrin wero placed on tho discs of two lcaves; as after 2 hrs. tho glands scemed rather dry, they wero freely moistcned with saliva; this soon cansed strong inflection both of the tentacles and blades, with copious 
seeretion from the glands. In $18 \mathrm{hrs}$. the fibrin was completely liquefied, but undigested atoms still floated in the liquid; these, however, disappenred in under two additional days.

From these experiments it is elear that the secretion eompletely dissolves pure fibrin. The rate of dissolution is rather slow; but this depends merely on this substanee not exeiting the leaves suffieiently, so that only the immediately adjoining tentaeles are inflected, and the supply of seeretion is small.

Syntonin.-This substanee, extraeted from musele, was kindly prepared for me by Dr. Moore. Very differently from fibrin, it aets quiekly and energetieally. Small portions placed on the dises of three leaves caused their tentaeles and blades to be strongly infleeted within 8 hrs.; but no further observations were made. It is probably due to the presence of this substanee that raw meat is too powerful a stimulant, often injuring or even killing the leaves.

Areolar Tissue.-Small portions of this tissue from a sheep were placed on the discs of three leaves; these beeame moderately well infleeted in 24 hrs., but began to re-expand after 48 hrs., and were fully re-expanded in 72 his., always reekoning from the time when the bits were first given. This substanee, therefore, like fibrin, exeites the leaves for only a short time. The residue left on the leaves, after they were fully reexpanded, was examined under a high porrer and found much altered, but, owing to the presence of a quantity of elastie tissue, whieh is never acted on, could hardly be sajd to be in a liquefied eondition.

Some areolar tissue free from elastie tissue was next proeured from the viseeral envity of a toad, and moderately sized, as well as very small, bits were placed on five lenves. After 24 hrs. two of the bits 
were completely liquefied; two others were rendered transparent, but not quite liquefied; whilst the fifth was but little affeeted. Several glands on the three latter leaves were now moistened with a little saliva, whieh soon caused mueh infleetion and secretion, with the result that in the eourse of 12 additional hrs. one leaf alone showed a remnant of undigested tissue. On the dises of the four other leaves (to one of which a rather large bit had been given) nothing was left exeept some transparent viseid fluid. I may add that some of this tissue included points of blaek pigment, and these were not at all affeeted. As a control experiment, small portions of this tissue were left in water and on wet moss for the same length of time, and remained white and opaque. From these faets it is elear that areolar tissue is easily and quiekly digested by the seeretion; but that it does not greatly excite the leaves.

Cartilage.-Three eubes ( $\frac{1}{20}$ of an ineh or $1.27 \mathrm{~mm}$.) of white, translucent, extremely tough eartilage were eut from the end of a slightly roasted leg-bone of a sheep. These were plaeed on three leaves, borne by poor, small plants in my greenhouse during November; and it seemed in the highest degree improbable that so hard a substance would be digested under sueh unfavourable eireumstances. Nevertheless, after 48 hrs., the eubes were largely dissolved and eonverted into minute spheres, surrounded by transparent, very aeid fluid. Two of these spheres were eompletely softened to their centres; whilst the third still contained a very small irregularly shaped eore of solid cartilage. 'Their surfaees were seen under the mieroscope to be euriously marked by prominent ridges, showing that the eartilage had been uıequally eorroded by the seeretion. I need hardly 
say that cubes of the same eartilage, kept in water for the same length of time, were not in the least affected.

During a more farourable season, moderately sized bits of the skinned ear of a eat, which ineludes cartilage, areolar and elastic tissue, were plaeed on three leaves. Some of the glands were touched with saliva, which caused prompt inflection. Two of the leaves began to re-expand after three days, and the third on the fifth day. The fluid residue left on their discs was now examined, and consisted in one ease of perfectly transparent, viseid matter; in the other two eases, it contained some elastic tissue and apparently remnants of half digested areolar tissue.

Fibro-cartilage (from between the vertebræ of the tail of a sheep). Moderately sized and small bits (the latter about $\frac{1}{20}$ of an inch) were placed on nine leaves. Some of these were well and some very little infleeted. In the latter ease the bits were dragged over the dises, so that they were well bedaubed with the secretion, and many glands thus irritated. All the leares re-expanded after only two days; so that they were but little excited by this substanee. The bits were not liquefied, but were certainly in an altered condition, being swollen, much more transparent, and so tender as to disintegrate very easily. My son Francis prepared some artificial gastrie juice, which was proved efficient by quickly dissolving fibrin, and suspended portions of the fibro-cartilage in it. These swelled and became hyaline, exaetly like those exposed to the secretion of Drosera, but were not dissolved. This result surprised me much, as two physiologists were of opinion that fibro-cartilage would be easily digested by gastric juice. I therefore asked Dr. Klein to examine the specimens; and 
he reports that the two which had becn subjected to artificial gastric juice were "in that state of digestion in which we find conncetive tissuc when treatcd with an acid, viz. swollen, more or less hyaline, the fibrillar bundles haying become homogeneous and lost thcir fibrillar structure." In the specimens which had been left on the leaves of Drosera, until they reexpanded, "parts were altercd, though only slightly so, in the same manncr as those subjected to the gastric juice, as they had become more transparcnt, almost hyaline, with the fibrillation of the bundles indistinct." Fibro-cartilage is therefore acted on in nearly the same manner by gastric juice and by the secretion of Drosera.

Bone. - Small smooth bits of the dried hyoidal bone of a fowl moistencd with saliva were placed on two leaves, and a similarly moistened splinter of an extremely hard, broiled mutton-chop bone on a third leaf. These leaves soon became strongly inflectcd, and remained so for an unusual length of time; namely, one leaf for ten and the other two for nine days. The bits of bonc were surrounded all the time by acid secretion. When examined under a weak power, they were found quite softened, so that they were readily penetrated by a blunt needlc, torn into fibres, or compressed. Dr. Klcin was so kind as to make sections of both bones and examinc them. $\mathrm{Hc}$ informs me that both prescnted the normal appcarance of decalcified bone, with traces of the carthy salts occasionally left. The corpuscles with their processes were very distinct in most parts; but in some parts, especially near the periphery of the hyoidal bone, none could be seen. Other parts again appeared amorphous, with even the longitudinal striation of bone not distinguishable. This amorphous structurc, 
as Dr. Klein thinks, may be the result either of the incipient digestion of the fibrous basis or of all the animal matter having becn removed, the corpuscles being thus rendered invisible. A hard, brittle, yellowish substance occupied the position of the medulla in the fragments of the hyoidal bone.

As the angles and little projections of the fibrous basis were not in the least rounded or corroded, two of the bits were placed on fresh leaves. These by the next morning were closely inflected, and remained so,- - the one for six and the other for seven days,therefore for not so long a time as on the first occasion, but for a much longer time than ever occurs with leaves inflected over inorganic or even over many organic bodies. The secretion during the whole time coloured litmus paper of a bright red; but this may have been due to the presence of the acid superphosphate of lime. When the leaves re-expanded, the angles and projections of the fibrous basis were as sharp as ever. I therefore concluded, falsely as we shall presently see, that the secretion cannot touch the fibrous basis of bone. The more probable explanation is that the acid was all consumed in decomposing the phosphate of lime which still remained; so that none was left in a free state to act in conjunction with the ferment on the fibrous basis.

Enamel and Dentine.-As the secretion decalcified ordinary bone, I determined to try whether it would act on enamel and dentine, but did not expect that it would succeed with so hard a substance as enamel. Dr. Klein gave me some thin transverse slices of the canine tooth of a $\operatorname{dog}$; small angular fragments of which were placed on four lcaves; and these were examined each sincceeding day at the same hour. The results are, I think, worth giving in detail. 
Experiment 1.-May 1st, fragment plaeed on leaf; 3rd, tentaeles but little inflected, so a littlo saliva nas added; 6 th, as the tentaeles were not strongly inflected, the fragment was transferred to another leaf, whieh acted at first slowly, but by the 9th closely embraeed it. On the 11th this seeond leaf - began to re-expand; the fragment was manifestly softened, and Dr. Klein reports, "a great deal of enamel and the greater part of the dentine decaleified."

Experiment 2.-May 1st, fragment placed on leaf; 2nd, tentaeles fairly well infleeted, with much seeretion on the dise, and remained so until the 7 th, when the leaf re-expanded. The fragment was now transferred to a fresh leaf, whieh next day (8th) was infleeted in the strongest manner, and thus remained until the 11 th, when it re-expanded. Dr. Klein reports, "a great deal of enamel and the greater part of the dentine decaleified."

Experiment 3.-May 1st, fragment moistened with saliva and placed on a leaf, whieh remained well infleeted until 5th, when it re-expanded. The enamel was not at all, and the dentine only slightly, softened. The fragment was now transferred to a fresh leaf, whieh next morning (6th) was strongly infleeted, and remained so until the 11th. The enamel and dentine both now somewhat softened; and Dr. Klein reports, "less than half the enamel, but the greater part of the dentine, deealeified."

Experiment 4.-May 1st, a minute and thin bit of dentine, moistened with saliva, was plaeed on a leaf, whieh was soon infleeted, and re-expanded on the 5 th. The dentine had become as flexible as thin paper. It was then transferred to a fresh leaf, whieh next morning (6th) was strongly infleoted, and reopened on the 10th. The deealeified dentine was now so tender that it was torn into shreds merely by the foree of the re-expanding tentacles.

From these experiments it appears that enamel is attacked by the seeretion with more diffieulty than dentine, as might have been expeeted from its extreme hardness; and both with more difficulty than ordinary bone. After the process of dissolution has once eommeneed, it is carried on with greater ense; this may be inferred from the leaves, to which the fragments were transferred, beeoming in all four cases strongly inflected in the eourse of a single day; whereas the first set of leaves acted much, less quiekly and 
energetieally. The angles or projeetions of the fibrous basis of the enamel and dentine (except, perhaps, in No. 4, whieh could not be well observed) were not in the least rounded; and Dr. Klein remarks that their microscopieal structure was not altered. But this eould not have been expeeted, as the deealcifieation was not eomplete in the three speeimens which were earefully examined.

Fibrous Basis of Bone.-I at first coneluded, as already stated, that the seeretion eould not digest this substanee. I therefore asked Dr. Burdon Sanderson to try bone, enamel, and dentine, in artifieial gastrie juice, and he found that they were after a eonsiderable time completely dissolved. Dr. Klein examined some of the small lamellæ, into whieh part of the skull of a eat beeame broken up after about a week's immersion in the fluid, and he found that towards the edges the " matrix appeared rarified, thus producing the appearanee as if the canalieuli of the bone-eorpuseles had beeome larger. Otherwise the eorpuseles and their eanalieuli were very distinet." So that with bone subjected to artifieial gastric juiee eomplete deealeifieation precedes the dissolution of the fibrous basis. Dr. Burdon Sanderson suggested to me that the failure of Drosera to digest the fibrous basis of bone, enamel, and dentine, might be due to the aeid being eonsumed in the decomposition of the earthy salts, so that there was none left for the work of digestion. Aeeordingly, my son thoroughly decaleified the bone of a sheep with weak hydroehlorie aeid; and seven minute fragments of the fibrous basis were placed on so many leaves, four of the fragments being first damped with saliva to aid prompt infleetion. All seven leaves beeame inflected, but only very moderately, in the course of a day. 
They quiekly began to re-expand; five of them on the seeond day, and the other two on the third day. On all seven leaves the fibrous tissue was eonverted into perfeetly transparent, viseid, more or less liquefied little masses. In the middle, however, of one, my son saw under a high power a few corpuseles, with traees of fibrillation in the surrounding transparent matter. From these faets it is elear that the leares are rery little exeited by the fibrous basis of bone, but that the seeretion easily and quiekly liquefies it, if thoroughly deealeified. The glands whieh had remained in eontaet for two or three days with the viseid masses were not diseoloured, and apparently had absorbed little of the liquefied tissue, or had been little affeeted by it.

Phosphate of Lime.-As we have seen that the tentaeles of the first set of leaves remained elasped for nine or ten days over minute fragments of bone, and the tentaeles of the seeond set for six or seven days over the same fragments, I was led to suppose that it was the phosphate of lime, and not any ineluded animal matter, whieh eaused sueh long eontinued infleetion. It is at least eertain from what has just been shown that this eannot have been due to the presenee of the fibrous basis. With enamel and dentine (the former of whieh eontains only 4 per eent. of organie matter) the tentaeles of two sueeessive sets of leaves remained infleeted altogether for eleven days. In order to test my belief in the poteney of phosphate of lime, I proeured some from Prof. Frankland absolutely free of animal matter and of any aeid. A small quantity moistened with water was placed on the dises of two leaves. One of these was only slightly affeeted ; the other remained elosely inflected for ten days, when a few of the tentaeles began to 
re-expand, the rest being mueh injured or killed. I repeated the experiment, but moistened the phosphate with saliva to insure prompt infleetion; one leaf remained infleeted for six days (the little saliva used would not have aeted for nearly so long a time) and then died; the other leaf tried to re-expand on the sixth day, but after nine days failed to do so, and likewise died. Although the quantity of phosphate given to the above four leaves was extremely small, mueh was left in every ease undissolved. A larger quantity wetted with water was next plaeed on the dises of three leaves; and these beeame most strongly infleeted in the eourse of $24 \mathrm{hrs}$. They never reexpanded; on the fourth day they looked siekly, and on the sixth were almost dead. Large drops of not very viseid fluid hung from their edges during the six days. This fluid was tested eaeh day with litmus paper, but never eoloured it; and this eireumstanee I do not understand, as the superphosphate of lime is aeid. I suppose that some superphosphate must have been formed by the aeid of the seeretion aeting on the phosphate, but that it was all absorbed and injured the leaves; the large drops whieh hung from their edges being an abnormal and dropsieal secretion. Anyhow, it is manifest that the phosphate of lime is a most powerful stimulant. Even small doses are more or less poisonous, probably on the same prineiple that raw meat and other nutritious substanees, given in exeess, kill the leares. Henee the eonelusion, that the long continued infleetion of the tentaeles over fragments of bone, enamel, and dentine, is eaused by the presenee of phosphate of lime, and not of any ineluded animal matter, is no doubt eorrect.

Gelatine.-I used pure gelatine in thin sheets given 
me by Prof. Hoffmann. For eomparison, squares of the same size as those placed on the leaves were left elose by on wet moss. These soon swelled, but retained their angles for three days; after five days they formed rounded, softened masses, but even on the eighth day a traee of gelatine eould still be detected. Other squares were immersed in water, and these, though mueh swollen, retained their angles for six days. Squares of $\frac{1}{10}$ of an ineh ( $2.54 \mathrm{~mm}$.), just moistened with water, were plaeed on two leaves; and after two or three days nothing was left on them but some aeid viseid fluid, whieh in this and other eases never showed any tendeney to regelatimise; so that the seeretion must aet on the gelatine differently to what water does, and apparently in the same manner as gastric juiee.* Four squares of the same size as before were then soaked for three days in water, and placed on large leaves; the gelatine was liquefied and rendered acid in two days, but did not exeite much infleetion. The leaves began to re-expand after fonr or five days, much viseid fluid being left on their lises, as if but little had been absorbed. One of these leaves, as soon as it re-expanded, eaught a small fly, and after 24 hrs. was closely infleeted, showing how inuch more potent than gelatine is the animal matter absorbed from an inseet. Some larger pieces of gelatine, soaked for five days in water, were next p]aeed on three leaves, but these rid not beeome mueh inHeeted until the third lay; nor was the gelatine completely liquefied until the fourth day. $O_{n}$ this lay one leaf began to re-expand; the second on the fifth; and third on the sixth. These severul ficts

* Dr. Jauder Brunton, 'Handbonk for the Pliys. Ialioratory,' 187:, pp. 477, 45T; Sichiff', 'Leçons phys, de la Digestion,' 1867, p.
249 . 
prove that gelatine is far from acting energetically on Drosera.

In the last chapter it was shown that a solution of isinglass of commerce, as thick as milk or cream, induces strong inflection. I therefore wished to compare its action with that of pure gelatine. Solutions of one part of both substances to 218 of water were made; and half-minim drops (.0296 ml.) were placed on the discs of eight leaves, so that each received $\frac{1}{480}$ of a grain, or $135 \mathrm{mg}$. The four with the isinglass were much more strongly inflected than the other four. I conclude therefore that isinglass contains some, though perhaps very little, soluble albuminous matter. As soon as these eight leaves reexpanded, they were given bits of roast meat, and in some hours all became greatly inflected; again showing how much more meat excites Drosera than does gelatine or isinglass. This is an interesting fact, as it is well known that gelatine by itself has little power of nourishing animals.*

Chondrin.-This was sent me by Dr. Moore in a gelatinous state. Some was slowly dried, and a small chip was placed on a leaf, and a much larger chip on a second leaf. The first was liquefied in a day; the larger piece was much swollen and softened, but was not completely liquefied until the third day. The undried jelly was next tried, and as a control experiment small cubes were left in water for four days and retained their angles. Cubes of the same size were placed on two leaves, and larger cubes on two other leaves. The tentacles and lamins of the latter were closely inflected after 22 hrs., but those of the

* Dr. Lauder Brunton gives in tho 'Modical Record,' Janunry 1873, p. 36 , wn account of Voit's view of the indirect part which gelatine plays in nutrition. 
two leaves with the smaller cubes only to a moderate degree. The jelly on all four was by this time liquefied, and rendered very acid. The glands were blackened from the aggregation of their protoplasmic contents. In 46 hrs. from the time when the jelly was given, the leares had almost re-expanded, and completely so after 70 hrs.; and now only a little slightly adhesive fluid was left unabsorbed on their discs.

One part of chondrin jelly was dissolved in 218 parts of boiling water, and half-minim drops were given to four leaves; so that each received about $\frac{1}{480}$ of a grain $(\cdot 135 \mathrm{mg}$.) of the jelly.; and, of course, much less of dry chondrin. This acted most powerfully, for after only $3 \mathrm{hrs} .30 \mathrm{~m}$. all four leaves were strongly inflected. Three of them began to reexpand after 24 hrs., and in 48 hrs. were completely open; but the fourth had only partially re-expanded. All the liquefied chondrin was by this time absorbed. Hence a solution of chondrin seems to act far more quickly and energetically than pure gelatine or isinglass; but I am assured by good authorities that it is most difficult, or impossible, to know whether chondrin is pure, and if it contained any albuminous compound, this would have produced the above effects. Nevertheless, I have thought these facts worth giving, as there is so much doubt on the nutritious value of gelatine; and Dr. Lauder Brunton does not kuow of any experiments with respect to animals on the relative value of gelatine and chondrin.

Mitk.-We have seen in the last chapter that milk acts most powerfully on the leaves; but whether this is due to the contained casein or albumen, I know not. Rather large drops of milk excite so much secretion (which is very acid) that it sometimes trickles down 
from the leaves, and this is likewisc charactcristic of chemically prepared cascin. Minute drops of milk, placed on leaves, were coagulated in about ten minutes. Schiff denies* that the coagulation of milk by gastric juice is exclusively due to the acid which is prescnt, but attributes it in part to the pepsin; and it scems doubtful whether with Drosera the coagulation can be wholly due to the acid, as the secretion docs not commonly colour litmus paper until the tcntacles have become well inflected; whercas the coagulation commences, as we have seen, in about ten minutes. Minute drops of skimmed milk were placed on the dises of fivc leaves; and a large proportion of the coagulated matter or eurd was dissolved in 6 hrs. and still more completely in $\delta$ hrs. These leaves re-expanded after two days, and the viscid fluid left on their dises was then carefully scraped off and examined. It seemed at first sight as if all the casein had not been dissolved, for a little matter was left which appeared of a whitish colour by reflected light. But this matter, when examined under a high power, and when compared with a minute drop of skimmed milk coagulated by acetic acid, was secn to consist exclusivcly of oilglobules, more or less aggregated together, with no trace of casein. As I was not familiar with the microscopical appearance of milk, I asked Dr. Lander Brunton to examine the slides, and he tested the globules with ether, and found that they werc dissolved. We may, therefore, conclude that the secretion quickly dissolves casein, in the state in which it exists in milk.

Chemically Prepared Casein.-This substance, which

* ‘Lcçons,' \&ce. tom, ii. p. 151. 
is insoluble in water, is supposed by many chemists to differ from the casein of fresh milk. I procured some, consisting of hard globules, from Messis. Hopkins and Williams, and tried many experiments with it. Small particles and the powder, both in a dry state and moistened with water, caused the leaves on which they were placed to be inflected very slowly, generally not until two days had elapsed. Other particles, wetted with weak hydrochloric acid (one part to 437 of water) acted in a single day, as did some casein freshly prepared for mc by Dr. Moore. The tentacles commonly remained inflected for from seven to nine days; and during the whole of this time the secretion was strongly acid. Even on the eleventh day some secretion left on the disc of a fully reexpanded leaf was strongly acid. The acid secms to be secreted quickly, for in one case the secretion from the discal glands, on which a little powdered casein had been strewed, colourcd litmus paper, before any of the extcrior tentacles were inflected.

Small cubes of hard casein, moistcned with water, were placed on two leaves; after thrce days onc cube had its angles a little rounded, and after seven days both consisted of rounded softencd masses, in the midst of much viscid and acid secretion; but it must not be inferred from this fact that the angles were dissolved, for cubes immersed in watcr were, similarly acted on. After nine days these leaves began to reexpand, but in this and other cases the casein did not appear, as far as could be judged by the cyc, much, if at all, reduced in bulk. According to Hoppe-Seyler and Lubavin* casein consists of an albuminous, with

* Dr. Lauder Brunton, 'Handbook for Phys. Lab.' p. 529. 
a non-albuminous, substance; and the absorption of a very small quantity of the former would excite the leares, and yet not decreasc the casein to a perceptible degrec. Schiff asserts*-and this is an important fact for us - that "la caséine purifiée des chimistes est un corps presque complètement inattaquable par le suc gastrique." So that here we have another point of accordance between the secretion of Drosera and gastric juice, as both act so differently on the fresh casein of milk, and on that prepared by chemists.

A few trials were made with cheese; cubes of $\frac{1}{20}$ of an inch $(1.27 \mathrm{~mm}$.) were placed on four leaves, and these after one or two days became wcll inflected, their glands pouring forth much acid secretion. After five days they began to re-cxpand, but one dicd, and some of the glands on the other leaves were injured. Judging by the eye, the softened and subsided masses of cheese, lcft on the discs, were very little or not at all reduced in bulk. We may, however, infer from the time during which the tentacles remained inflected,--from the changed colour of some of the glands,-and from the injury done to others, that matter had been absorbed from the checse.

Legumin.-I did not procure this substance in a separate state; but there can hardly be a doubt that it would be easily digested, judging from the powerful effect produced by drops of a decoction of green peas, as described in the last chapter. Thin slices of it dried pea, after being soaked in water, wcre placed on two leaves; these became somewhat inflected in the course of a single hour, and most strongly so in 21 hrs. They re-expanded after three or four days.

* 'Leçons,' \&c. tom. ii. p. 153. 
'The sliees were not liquefied, for the walls of the eells, composed of cellulose, are not iu the least acted on by the sccretion.

Pollen.-A little fresh pollen from the eommon pea was plaeed on the discs of five leaves, which soon beeame elosely inflected, and remained so for two or thrce days.

The grains being then removed, and examined under the microscope, wcrc found diseoloured, with the oilglobules remarkably aggregated. Many had their contents much shrunk, and some werc almost empty. In only a few eascs wcre the pollen-tubes emittci. There could be no doubt that the seeretion had penetrated the outer coats of the grains, and had partially digested their contents. So it must be with the gastric juice of the inseets which feed on pollen, without masticating it.* Drosera in a state of nature eannot fail to profit to a certain extcnt by this power of digesting pollen, as innumerable grains from the cariees, grasses, rumices, fir-trees, and othcr windfertiliscd plants, whieh eommonly grow in the same neighbourhood, will be inevitably eaught by the viscid seeretion surrounding the many glands.

Gluten.-This substance is eomposed of two albuminoids, one soluble, the other insoluble in aleohol. $†$ Some was prepared by merely washing whcaten flour in water. A provisional trial was made with rather large picces placed on two lcaves; these, after 21 hrs., were closely inflected, and remained so for four days, when one was killed and the other had its glands extremely blackened, but was not afterwards observed.

* Mr. A. W. Bennett found the undigested enats of tho grains in the intestinal canal of pollencating Diptera; see 'Journal of
Hort. Soc. of London,' vol. iv. 1874, p. 158.

† Watts' 'Diet. of Cliemistry, vol. ii. 1872, p. 873. 
Smaller bits were plaeed on two leaves; these were only slightly infleeted in two days, but afterwards beeame mueh more so. Their seeretion was not so strongly aeid as that of leaves exeited by easein. The bits of gluten, after lying for three days on the leaves, were more transparent than other bits left for the same time in water. After seven days both leaves re-expanded, but the gluten seemed hardly at all redueed in bulk. The glands whieh had been in contaet with it were extremely black. Still smaller bits of half putrid gluten were now tried on two leaves; these were well infleeted in 24 hrs., and thoroughly in four days, the glauds in eontact being mireh blaekened. After five days one leaf began to re-expand, and after eight days both were fully reexpanded, some gluten being still left on their dises. Four little ehips of dried gluten, just dipped in water, were next tried, and these aeted rather differently from fresh gluten. One leaf was almost fully re-expanded in three days, and the other three leares in four days. The ehips were greatly softened, almost liquefied, but not nearly all dissolved. 'The glands whieh had been in eontaet with them, instead of being mueh blaekened, were of a very pale eolour, and many of them were evidently killed.

In not one of these ten eases was the whole of the gluten dissolved, even when very small bits were given. I therefore asked Dr. Burdon Sanderson to try gluten in artifieial digestive fluid of pepsin with hydroehlorie aeid; and this dissolved the whole. 'The gluten, however, was aeted on mueh more slowly than fibrin; the proportion dissolved within four hours being as 40.8 of gluten to 100 of fibriu. Giluten was also tried in two other digestive fluids, in whieh hydrochlorie acid was replaeed by propionie 
and butyric acids, and it was completely dissolved by these fluids at the ordinary temperaturc of a room. Here, then, at last, we have a casc in which it appcars that there exists an essential difference in digestive powcr between the sccretion of Drosera and gastric juice; the difference bcing confincd to the fcrment, for, as we have just secn, pepsin in combination with acids of the acetic scries acts perfectly on gluten. I believe that the explanation lies simply in the fact that gluten is too powerful a stimulant (like raw meat, or phosphate of lime, or cren too large a piecc of albumen), and that it injures or kills the glands before they have had time to pour forth a sufficient supply of the proper secretion. 'That some matter is absorbed from the gluten, we have clear cridence in the length of time during which the tcntacles remain inflccted, and in the greatly changed colour of the glands.

At the suggestion of Dr. Sinderson, some gluten was left for $15 \mathrm{hrs}$. in weak hydrochloric acid (.02 per cent.), in order to remove the starch. It becamc colourless, morc transparent, and swollen. Small portions werc washed and placed on five leaves, which werc soon closely inflected, but to my surprise reexpanded completely in 48 hrs. A merc vestige of gluten was left on two of the leaves, and not a vestige on the other three. The viscid and acid scerction, which remained on the dises of the three latter leaves, was scraped off and examincl by my son under a high power; but nothing conld be seen except a little dirt, and a good many starch grains which had not been dissolved by the hydrochloric acid. Some of the grands were rather pale. Wo thus learn that gluten, treated with weak hydrochloric acid, is not so poycrlul or so cnduring a 
stimnlant as fresh gluten, and does not much injure the glands; and we further learn that it can be digested quickly and completely by the secretion.

Globulin or Crystallin.--This substance was kindly prepared for me from the lens of the eye by Dr. Moorc, and consisted of hard, colourless, transparent fragments. It is said* that globulin ought to "swell up in water and dissolve, for the most part forming a gummy liquid;" but this did not occur with the above fragments, though kept in water for four days. Particles, some moistened with water, others with weak hydrochloric acid, others soaked in water for one or two days, were placed on ninetcen leaves. Most of thcse leaves, espccially those with the long soaked particles, bccame strongly inflected in a few hours. The greatcr number re-expanded after three or four days; but thrce of the leares remained inflected during one, two, or three additional days. Hence some exciting matter must have been absorbed; but the fragments, though perhaps softened in a greatcr degree than those kcpt for the same time in water, retained all their angles as sharp as ever. As globulin is an albuminous substance, I was astonished at this result; and $\mathrm{my}$ object being to compare the action of the sccretion with that of gastric juice, I asked Dr. Burdon Sanderson to try some of the globulin used by me. He reports that "it was subjected to a liquid containing 0.2 per cent. of hydrochloric acid, and about 1 per cent. of glycerine extract of the stomach of a dog. It was then ascertained that this liquid was capable of digesting. $1 \cdot 31$ of its weight of unboiled fibrin in $1 \mathrm{hr}$.; whereas, during the hour, only 0.141 of the above globulin was dissolved. In both cases an cxcess of the substance to be digested was subjected to the liquid." $†$ We thus see that within the same time less than onc-ninth by weight of globulin than of fibrin was dissolved; and bcaring in mind that pepsin with acids of the acctic series has only about one-third of the digestive power of pepsin. with hydrochloric acid, it is not surprising that the fragments of

* Watts' 'Dict. of Chemistry, vol. ii. p. 874 .

+ I may add that Dr. Sanderson prepared some fresh globulin hy Schmidt's method, and of this 0.865 was dissolved within the same time, namoly, one hour'; so that it was far more soluble than that which I nsed, though less soluble than fibrin, of which, as wo havo seen, 1.31 was dissolved. I wish that I had tried on Drosera globulin prepared by this mothod. 
globulin were not eorroded or rounded by the seeretion of Drosera, though some soluble matter was certainly extracted from them and absorberl by the glands.

Ilematin.-Some dark red granules, prepared from bullock's blood, were given me; these were found by Dr. Sanderson to be insoluble in water, acids, and aleohol, so that they were probably hrematin, together with other bodies derived from the blood. Partieles with little drops of water were plaeed on four leaves, three of which wcre pretty elosely infleeted in two days; the fourth only moderately so. On the third day the glands in eontact with the hrmatin were blaekened, and some of the tentreles seemed injured. After five days two leaves died, and the third was dying; the fourth was beginning to reexpand, but many of its glands were blackened and injured. It is therefore clear that matter hal been absorbed which was either actually poisonous or of too stimulating a nature. The partieles were mueh more softened than those kept for the same time in water, but, judging by the eye, very little redueed in bulk. Dr. Sanderson tried this substance with artifieial digestive fluid, in the manner described under globulin, and found that whilst 1.31 of fibrin, only 0.456 of the hæmatin was dissolred in an hour; but the dissolution by the sceretion of even a less amount would aecount for its action on Drosera. T'he residue left by the artificial digestive fluid at first yiclded nothing more to it during scveral sueeeeding days.

\section{Sibstances which are not Digested by the Secretion.}

All the substances hitherto mentioned canse prolonged inflection of the tentacles, and are either completely or at least partially dissolved by the secretion. But there are many other substances, some of them containing nitrogen, which are not in the least acted on by the secretion, and do not induce inflection for a longer time than do inorganic and insoluble objects. These mexciting and indigestible substances are, as far as I have olserved, epidermie productions (such as bits of human nails, balls of hair, the quills of feathers), fibro-elastic tissne, mucin, pepsin, urea, chitine, chlorophyll, cellulose, gun-cottou, fitt, oil, and starch. 
To these may be added dissolved sugar and gum, diluted alcohol, and vegetable infusions not containing albumen, for none of these, as shown in the last chapter, excite inflection. Now, it is a remarkable fact, which affords additional and important evidence, that the ferment of Drosera is closely similar to or identical with pepsin, that none of these same substances are, as far as it is known, digested by the gastric juice of animals, though some of them are acted on by the other secretions of the alimentary canal. Nothing more need be said about some of the above enumerated substances, excepting that they were repeatedly tried on the leaves of Drosera, and were not in the least affected by the secretion. About the others it will be advisable to give my experiments.

Fibro-elastic Tissue.-We have already seen that when little cubes of meat, \&c., were plaeed on leaves, the muscles, areolar tissue, and cartilage were completely dissolved, but the fibroelastie tissue, even the most delieate threads, were left without the least signs of having been attacked. And it is well known that this tissue cannot be digested by the gastric juice of animals.*

Mucin.-As this substance contains about 7 per cent. of nitrogen, I expeeted that it would have exeited the leares greatly and been digested by the seeretion, but in this I was mistalien. From what is stated in chemieal works, it appears extremely doubtful whether mucin can be prepared as a pure prineiple. That which I used (prepared by Dr. Noore) was dry and hard. Particles moistened with water were plaeed on four leaves, but after two days there was only a trace of infleetion in the immediately adjoining tentacles. These leares were then tried with bits of meat, and all four soon beeame strongly infleeted. Some of the dried mucin was then soaked in water for two days, and little cubes of the proper size wcre placed on three leaves. After four days the tcutacles

* See, for instanee, Schiff, 'Phys. de la Digestion' 1S67, tom. ii. p. 38. 
round the margins of the dises were $a$ little inflected, and the secretion collected on the dise was acid, but the exterior tentacles rere not affected. One leaf began to re-expand on the fourth day, and all were fully re-expanded on the sixth. The glands which had been in contact with the mucin were a little darkened. We may therefore conclude that a small amount of some impurity of a moderatcly exciting nature had been absorbed. That the mucin employed by me did contain some soluble matter was proved by Dr. Sanderson, who on subjecting it to artificial gastric juice found that in $1 \mathrm{hr}$. some was dissolved, but only in the proportion of 23 to 100 of fiblin during the same time. The cubes, though perhaps rather softer than those left in water for the same time, retained their angles as sharp as ever. We may therefore infer that the mucin itself was not dissolved or digested. Nor is it digested by the gastric juice of living animals, and according to Schiff* it is a layer of this substance which protects the coats of the stomach from being corroded during digestion.

Pepsin.-My experimeuts are hardly worth giving, as it is scarcely possible to prepare pepsin free from other albuminoids; but I was curious to ascertain, as far as that was possible, whether the ferment of the secretion of Drosera would act on the ferment of the gastric juice of animals. I first used the eummon pepsin sold for medicinal purposes, and afterwards some which was much purer, prepared for me by Dr. Moore. Five leaves to which a considerable quantity of the former was given remained inflected for five days; four of them then died, apparently from too great stimulation. I then tricd Dr. Moore's pepsin, making it into a paste with water, and placing such small particles on the dises of five leaves that all would have been quickly dissolved had it been meat or albumen. The leaves were soon inflected; two of them began to re-expand after only $20 \mathrm{hrs}$., and the other three were almost completcly re-expanded after 44 hrs. Some of the glands which had been in contaet with the particles of pepsin, or with the acid secretion surrounding them, werc singularly pale, whereas others were singularly dark-coloured. Some of the secretion was scraped off and examined mder a high powcr; and it abounded with granules undistingnishable from those of pepsin left in water for the same length of time. Wo may therefore infer, as highly probable (remembering what small quantitios were given), that the ferment of Drosera does not act on or digest

* 'Leģnns phys. de la Digestion,' 1867, tom. ii. p. $30 t$. 
pepsin, but absorbs from it some albuminous impurity which induees infleetion, and whieh in large quantity is lighly injurious. Dr, Lauder Brunton at my request endeavoured to aseertain whether pepsin with hydroehloric aeid would digest pepsin, and as far as he could judge, it had no sueh power. Gastrie juiee, therefore, apparently agrees in this respeet with the seeretion of Drosera.

Urea.-It seemed to me an interesting inquiry whether this refuse of the living body, which eontains mueh nitrogen, would, like so many other animal fluids and substanees, be absorbed by the glands of Drosera and eause infleetion. Halfminim drops of a solution of one part to 437 of water were plaeed on the dises of four leares, eaeh drop eontaining the quantity usually employed by me, namely $\frac{1}{960}$ of a grain, or - $0674 \mathrm{mg}$; ; but the leaves were hardly at all affeeted. They were then tested with bits of meat, and soon beeame elosely infleeted. I repeated the same experiment on four leaves with some fresh urea prepared by Dr. Moore; after two days there was no infleetion; I then gave them another dose, but still there was no infleetion. These leaves were afterwards tested with similarly sized drops of an infusion of law meat, and in $6 \mathrm{hr}$ s, there was eonsiderable inflection, whieh beeame exeessive in 24 hrs. But the urea apparently was not quite pure, for when four leaves were immersed in $2 \mathrm{dr} .(7 \cdot 1 \mathrm{ml}$.) of the solution, so that all the glands, instead of merely those on the dise, were enabled to absorb any small amount of impurity in solution, there was eonsiderable infleetion after 24 hrs., certainly more than would have followed from a similar immersion in pure water. That the urea, which was not perfeetly white, should have eontrined a suffieient quantity of albuminous matter, or of some salt of ammonia, to have eaused the above effeet, is far from surprising, for, as we shall see in tho next ehapter, astonishingly small doses of ammonia are highly effieient. We may therefore eonelude that urea itself is not exeiting or nutritious to Drosera; nor is it modified by the seeretion, so as to be rendered nutritious, for, had this been the ease, all the leaves with drops on their dises assuredly would have been well infleeted. Dr. Lander Brinton informs me that from experiments made at my request at St. Bartholomow's Hospital it appears that urea is not aeted on by artifieial gastrie juieo, that is by pepsin with hydroehlorie aeid.

Chitine.-The ehitinous eoats of inseets uaturally eaptured by the leaves do not appear in the least corroded. Small square piees of tho delieate wing and of the elytron of a Stapliylinus 
were placed on some lcaves, and aftcr thesc had re-cxpanded, the piees were carefully cxamined. Their angles wcre as sharp as ever, and they did not differ in appoarance from the other wing and elytron of the same inscet whieh had becn left in water. The clytron, howevcr, had evidently yiclded some nutritious mattcr, for the leaf remained clasped over it for four days; whereas the leaves with bits of the true wing re-expanded on the second day. Any one who will examine the excrement, of insect-eating animals will sec how powerless their gastric juice is on ehitine.

Cellulose.-I did not obtain this substance in a separate state, but tried angular bits of dry wood, cork, sphagnum moss, linen, and cotton thread. None of these bodies were in the lcast attacked by the sceretion, and they caused only that moderate amount of inflection which is common to all inorganie objects. Gun-cotton, which consists of eellulose, with the hydrogen replaced by nitrogen, was tried with the same result. We have seen that a decoetion of cabbage-leaves exeiles the most powerful inflection. I therefore placed two little square bits of the blade of a cabbage-leaf, and four little cubes cut from the midrib, on six leaves of Drosera. These bccamc well inflected in 12 hrs., and remained so for between two and four days; the bits of cabbage being bathed all the time by acid seeretion. This shows that some cxciting mattcr, to which I shall presently refer, had been absorbed; but the angles of the squares and eubes remained as sharp as ever, proving that the framework of cellulose had not bcen attaeked. Small square bits of spinach-leaves were tried with the same result; the glands pouring forth a modcrate supply of acid secretion, and the tentacles romaining infleted for threc days. We have also seen that the delicatc conts of pollen grains are not dissolved by the secretion. It is well known that the gastrie juice of animals does not attack cellulose.

Chlwrophyll.--This substance was tricd, as it contains nitrogen. Dr. Moore sent me some preserved in aleohol; it was dried, but soon deliqueseerl. Partieles were placed on four leaves; after 3 lirs. the secretion was acid; alter 8 hr's. there was a good deal of inflection, which in 21 hrs. bceame fairly well markcd. After four days two of the leaves began to open, and tho other two were then almost filly re-cxpanded. It is thereforo clcar that this chlorophyll contained matter which excited the leaves to a moderate degree; lut judging ly the eye, little or none was dissolved; so that in a pure state it would not probably have been attacked ly the sccretion. Dr. Sanderson tricd that which I 
uscd, as well as some freshly prepared, with artificial digestive liquid, and found that it was not digested. Dr. Lauder Brunton likewise tried some prepared by the process given in the British Pharmacopoia, and exposed it for five days at the temperature of $37^{\circ}$ Cent. to digestive liquid, but it was not diminished in bulk, though the fluid acquired a slightly brown colour. It was also tried with the glycerine extract of pancreas with a negative result. Nor does chlorophyll seem affected by the intestinal secretions of various animals, judging by the colour of their cxcrement.

It must not be supposed from these facts that the grains of ehlorophyll, as they exist in living plants, eannot be attacked by the secretion; for these grains consist of protoplasm merely eoloured by chlorophyll. My son Franeis placed a thin slice of spinach lcaf, moistened with saliva, on a lcaf of Droscra, and other sliccs on damp cotton-wool, all exposed to the same tcmperature. After 19 hrs. the slice on the leaf of Drosera was bathed in much secretion from the inflected tentacles, and was now examined under the microscope. No perfect grains of chlorophyll could be distinguished; some were shrunken, of a yellowish-grecn colour, and colleeted in the middle of the eells; others were disintegrated and formed a ycllowish mass, likewise in the middle of the eells. On the other hand, in the slices surrounded by damp eotton-wool, the grains of chlorophyll were green and as perfect as ever. My son also placed some slices in artificial gastric juice, and these wcre acted on in nearly the same manner as by the secretion. We have secn that bits of fresh cabbage and spinaeh leaves eause the tentaeles to be inflected and the glands to pour forth mueh acid sccretion; and there can bc little doubt that it is the protoplasm forming the grains of chlorophyll, as well as that lining the walls of the eells, whieh excites the lcaves.

Fut and Oit.-Cubes of almost pure incooked fat, placed on several leaves, did not have their angles in the least rounder. We have also seen that the oil-globules in milk are not digested. Nor does olive oil dropped on the discs of lcaves eause any inflection; but when they are immersed in olive oil, they becomc strongly inflected; but to this subject I slabl have to recur. Oily substances are not digested by the gastric juice of animals.

Starch.-Rather large bits of dry starch caused well-marked inflcction, and the lcaves did not re-expand until the fourth day; but I have no doubt that this was dne to the prolonged irritation of the glands, as the starch continued to absorb the secretion. The particles wcre not in the least reduced in sizc; 
and we know that leaves immersed in an emulsion of starch are not at all affeeted. I need hardly say that starch is not digested by the gastric juice of animals.

\section{Action of the Secretion on Living Seeds.}

The results of some experiments on living seeds, selected by hazard, may here be given, though thoy bear only indirectly on
our prosent subject of digestion.

Seven cabbage seeds of the previous year were plaeed on the same number of leaves. Some of these leaves were moderately, but the greater number only slightly infleeted, and most of them re-expanded on the third day. One, however, remained clasped till the fourth, and another till the fifth day. Those leaves therefore were excited somewhat more by the seeds than by inorganic objects of the same sizo. After they re-expanded, the seeds were plaeed under favourable conditions on damp sand; other seeds of the same lot being tried at the same time in the same manner, and found to germinate well. Of the seven seeds which had been exposed to the secretion, only three gorminated; and one of the throe seedlings soon perished, the tip of its radicle boing from the first decayed, and the edges of its cotyledons of a dark brown colour; so that altogether five out of the seven seeds ultimately perished.

Radish seeds (liaphanus satious) of the provious year wore placed on three leaves, which beenme moderately inflected, and re-expanded on the third or fourth day. Two of tliose seeds wore transferred to damp sand; only one germinated, and that very slowly. This seodling had an extremely short, erooked, diseased, radicle, with no absorbent hairs; and tho cotyledons were oddly mottled with purple, with the edgos blackenod and partly withorod.

Cross seods (Lepidum sativnm) of the previous year were placod oul four leavos; two of these noxt moruing were modelately and two strongly inflocted, and remained so for four, five, and even six days. Soon after these seods wore placed on the lcaves and had becomo damp, they socreted in the usual manner a layer of tenacious mueus; and to aseertain whether it was the absorption of this substanco by tho glands which caused so mueh inflection, two seeds were put into water, and as much of tho mucus as possible sernped off: They wero then plaecd on leaves, which becamo very strongly infleeted in tho ccurse of 3 hrss., and were still closoly inflected on the third day; so that it evidently was not the mucus which cxeitod so 
mueh infleetion; on the contrary, this served to a certain extent as a protection to the seeds. Two of the six seeds germinated whilst still lying on the leaves, bnt the seedlings, when transferred to damp sand, soon died; of the other four seeds, only one germinated.

Two seeds of mustard (Sinapis nigra), two of celery (Apium graveotens)-both of the previous year, two seeds well soaked of caraway (Carum carui), and two of wheat, did not excite the leaves more than inorganic ohjects often do. Five seeds, hardly ripe, of a bnttercup (Ranuncnlus), and two fresh seeds of Anemone nemorosa, induced only a little more effect. On the other hand, four seeds, perhaps not quite ripe, of Carex syluatica eaused the leaves on whieh they were placed to be ver'y strongly inflected; and these only began to reexpand on the third day, one remaining inflected for seven days.

It follows from these few facts that different kinds of seeds exeite the leaves in very different degrees; whether this is solely dne to the natnre of their coats is not clear. In the case of the cress seeds, the partial removal of the layer of mncns hastened the inflection of the tentreles. Whenever the leaves remain inflected during several days over seeds, it is clear that they absorb some matter from them. That the seeretion penetrates their eoats is also evident from the large proportion of cabbage, raddish, and cress seeds whieh were killed, and from several of the seedlings being greatly injured. This injury to the seeds and seedlings may, horvever, be dne solely to the aeid of the secretion, and not to any proeess of digestion; for MIr. Traherne Moggridge has shown that very weak acids of the aeetie series are highly injurious to seeds. It never oeeurred to me to observe whether seeds are often blown on to the viscid lenves of plants growing in a state of nature; bnt this ean hardly fail sometimes to oecur, as we shall hereafter see in the ease of Pingnieula. If so, Drosera will profit to a slight degree by absorbing matter from sneh seeds.

Summary and Concluding Remarles on the Digestive Power of Drosera.

When the glands on the disc are excited either by the absorption of nitrogenous matter or by mechanical irritation, their secretion increases in quantity and becomes acid. They likewise transmit 
some influcnce to the glands of the cxtcrior tentaeles, causing them to secrete more copiously; and their seerction likewise becomcs acid. With animals, reeording to Sehiff, mcehanical irritation exeitcs the glands of the stomach to seeretc an acid, but not pepsin. Now, I have cvery reason to believe (though the faet is not fully cstablished), that although the glands of Droscra arc eontinually sccreting viseid fluid to replaee that lost by evaporation, yet they do not secrete the ferment proper for digestion when meehanically irritated, but only after absorbing eertain matter, probably of a nitrogenous nature. I infer that this is the case, as the secretion from a large number of leaves which had bcen irritated by partieles of glass placed on their discs did not digest albumcn; and more especially from the analogy of Dionra and Nepenthes. In like manner, the glands of the stomaeh of animals seerete pepsin, as Sehiff asserts, only aftcr thcy have absorbed certain soluble substances, which he designates as peptogenes. Thcre is, thercforc, a rcmarkable parallelism between the glands of Drosera and those of the stomach in the sccretion of their proper acid and ferment.

The secretion, as we have secn, completely dissolves albumen, musele, fibrin, areolar tissue, cartilage, the fibrous basis of bone, gelatin, chondrin, cascin in the state in whieh it exists in milk, and gluton which has been subjeeted to weak hydroehloric acid. Syntonin and legumin cxcitc the lcaves so powcrfully an! quickly that there ean hardly be a doubt that both womld be dissolved by the sccretion. The secretion

* 'Phys. de la Digestion,' 1867, tom. ii. pp. 188, 245. 
tailed to digest fresh gluten, apparently from its injuring the glands, though some was absorbed. Raw meat, unless in very small bits, and large pieees of albumen, \&c., likewise injure the leaves, whieh seem to suffer, like animals, from a surfeit. I know not whether the analogy is a real one, but it is worth notiee that a decoetion of eabbage leaves is far more exeiting and probably nutritious to Drosera than an infusion made with tepid water; and boiled eabbages are far more nutritious, at least to man, than the uncooked leaves. The most striking of all the eases, though not really more remarkable than many others, is the digestion of so hard and tough a substance as artilage. 'The dissolution of pure phosphate of lime, of bone, dentine, and espeeially enamel, seems wonlertul; but it depends merely on the long-eontinued secretion of an acid; and this is secreted for a longer time under these cireumstances than under any others. It was interesting to observe that as long as the aeid was consumed in dissolving the phosphate of lime, no true digestion oeeurred; bnt that as soon as the bone was eompletely deealeified, the fibrous basis was attreked and liquefied with the greatest ease. The twelve substanees above enumerated, which are eompletely dissolved by the secretion, are likewise dissolved by the gastrie juiee of the higher animals; and they are acted on in the same manner, as shown by the rounding of the angles of albumen, and more especially by the manner in whieh the transrerse strix of the fibres of muscle disappear.

The seeretion of Drosera and gastrie juiee were both able to dissulve some element or impurity out of the globulin and hamatin employed by me. The seeretion also dissolved something out of chemically 
prepared cascin, whieh is said to cousist of two substanees; and although Sehiff asserts that casciu in this statc is not attacked by gastric juice, he might easily have ovcrlooked a miuute quantity of some albuminous matter, which Drosera would detect and absorb. Again, fibro-cartilage, though not properly dissolved, is aeted on in the same manner, both by the secretion of Drosera and gastrie juice. But this substauce, as well as the so-called hrematiu used by me, ought perhaps to have been classed with indigestible substauccs.

That gastric juice acts by means of its ferment, pepsin, solely in the presenee of an aeid, is well established; and we have execllent evidence that a ferment is present in the sccretion of Drosera, which likewise acts only iu the presence of an aeid; for we have seen that when the seeretion is neutralised by minutc drops of the solution of an alkali, the digestion of albumen is eompletely stopped, and that ou the addition of a minute dose of hydrochloric aeid it immediately recommences.

The nine following substauces, or classes of substances, namely, cpiclermic produetions, fibro-elastic tissue, muciu, pepsin, urea, chitiuc, cellulosc, guncotton, ehlorophyll, starch; fat aud oil, are not aeted on by the secretion of Drosera; nor are thcy, as far as is known, by the gastrie juice of amimals. Some soluble matter, howcrer, was extraeted from the muein, pepsin, and chlorophyll, used by me, both by the secretion and by artifieial gastric juiec.

The several substanees, which are completcly dissolver by the secretion, and which arc afterwards absorbed by the glands, affeet the leaves rather differently. They induee inflection at very differeni 
rates and in very different degrees; and the tentacles remain inflected for very different periods of time. Quick inflection depends partly on the quantity of the substance given, so that many glands are simultaneously affected, partly on the facility with which it is penctrated and liquefied by the secretion, partly on its nature, but chicfly on the presence of cxciting matter already in solution. Thus saliva, or a weak solution of raw mcat, acts much more quickly. than even a strong solution of gelatine. So again leaves which have re-cxpanded, after absorbing drops of a solution of purc gelatinc or isinglass (the latter being the more powerful of the two), if given bits of meat, are inflected much morc cnergetically and quickly than they werc before, notwithstanding that some rest is generally requisite between two acts of inflection. We probably sce the influence of texture in gelatine and globulin when softened by having been soaked in water acting morc quickly than when merely wetted. It may be partly due to changed texture, and partly to changed chemical naturc, that albumen, which has becn kept for some time, and gluten which has bcen subjceted to weak hydrochloric acid, act morc quickly than these substances in their fresh state.

The length of time during which the tentacles remain inflected largely depends on the quantity of the substance given, partly on the facility with which it is penetrated or acted on by the secretion, and partly on its essential nature. The tentacles always remain inflected much longer over large bits or large drops than over small bits or drops. Texture probably plays a part in determining the extraordinary length of time during which the tentacles remain inflected 
over the hard grains of chemically prepared casein. But the tentacles remain inflected for an equally long time over finely powdered, precipitated phosphate of lime; phosphorus in this latter ease evidently being the attraction, and animal matter in the ease of casein. The leaves remain long inflected over insects, bat it is doubtful how far this is due to the protection afforded by their chitinous integuments; for animal matter is soon extracted from insects (probably by exosmose from their bodies into the dense surrounding secretion), as shown by the prompt infleetion of the leaves. We see the influenee of the nature of different substances in bits of meat, albumen, and fresh gluten acting very differently from equal-sized bits of gelatine, areolar tissue, and the fibrous basis of bone. The former eause not only far more prompt and energetic, but more prolonged, inflection than do the latter. Hence we are, I think, justified in believing that gelatine, areolar tissue, and the fibrous basis of bone, would be far less nutritious to. Drosera than such substances as insects, meat, albumen, \&c. This is an interesting conelusion, as it is known that gelatine affords but little nutriment to animals; and so, probably, would areolar tissue and the fibrous basis of bone. The ehondrin which I used aeted more powerfully than gelatine, but then I do not know that it was pure. It is a more remarkable fact that fibrin, which belongs to the great class of Proteids, ${ }^{*}$ ineluding albumen in one of its sub-groups, does not exeite the tentacles in a greater degree, or keep them inflecterl for a longer time, than does gelatine, or

* See the elnssifieation alopted by Dr. Mielnal Foster in Watts' 'Dict. of Chemistry,' Supplement 1872, p. $96 \%$. 
arcolar tissue, or the fibrous basis of bonc. It is not known how long an animal would survive if fed on fibrin alone, but Dr. Sanderson has no doubt longer than on gelatine, and it would be hardly rash to predict, judging from the effects on Drosera, that albumen svould be found morc nutritious than fibrin. Globulin likewise belongs to the Proteids, forming another sub-group, and this substance, though containing some matter which excited Drosera rather strongly, was hardly attacked by the secretion, and was very little or very slowly attacked by gastric juice. How far globulin would be nutritious to animals is not known. We thus see how differently the above specified several digestible substances act on Drosera; and we may infer, as highly probable, that they would in like manner be nutritious in very different degrees both to Drosera and to animals.

The glands of Drosera absorb mattcr from living secds, which are injured or killed by the scerction. They likewise absorb matter from pollen, and from fresh leaves; and this is notoriously the ease with the stomachs of vegetablc-fcerling animals. Drosera is properly an insectivorous plant; but as pollen cannot fail to be often blown on to the glands, as will occasionally the secds and leares of surrounding plants, Drosera is, to a certain cxtent, a regetablefeeder.

Finally, the experiments recorded in this chapter show ns that there is a remarkablc accordance in the power of digestion between the gastric juice of animals with its pepsin and hydrochloric acid and the secretion of Drosera with its ferment and acid belonging to the acetic series. We can, therefore, harlly doubt that the ferment in both cases is closely similar, 
Chap. VI.

if not identically the same. That a plant and an animal should pour forth the same, or nearly the same, complex secretion, adapted for the same purpose if digestion, is a new and wonderful fact in physiology. But I shall have to recur to this subject in the fifteenth chapter, in my concluding remarks on the Droseracer. 


\section{CHAPTER VII.}

\section{The EFfects of Salts of Ammovia.}

Mumner of performing the experiments - Aetion of distilled water in comparison with the solutions - Carbonate of ammonia, absorbed by the roots - The vapour absorbed by the glands - Drops on the dise-Minute drops applied to separate glands - Leaves immersed in weak solutions - Minuteness of the doses which induce aggregation of the protoplasm - Nitrate of ammonia, analogous experiments with - Phosphate of ammonia, analogous experiments with-Other salts of ammonia-Summary and concluding remarks on the aetion of the salts of ammonia.

'T'He chief object in this chapter is to show how powerfully the salts of ammonia act on the leaves of Drosera, and more especially to show what an extraordinarily small quantity suffices to excite inflection. I shall, therefore, be compelled to enter into full details. Doubly distilled water was always used; and for the more delicate experiments, water which had been prepared with the utmost possible care was giren me by Professor Frankland. The graduated measures were tested, and found as accurate as such measures call be. The salts were carefully weighed, and in all the more delicate experiments, by Borda's donble method. But extreme accuracy would have been superfluous, as the leaves differ greatly in irritability, according to age, condition, and constitution. Even the tentacles on the same leaf differ in irritability to a marked degree. My experiments were tried in the following several ways.

Firstly.-Drops which were aseertained by repeated trials to he on an average about half a minim, or the $\frac{1}{860}$ of a fluid ounce $(0296 \mathrm{ml}$ ), were plaeed by the same pointed instrument on the 
discs of the leaves, and the inflection of the cxterior rows of tentaeles obscrved at successive intervals of time. It was first aseertained, from between thirty and forty trials, that distilled water dropped in this mamner produees no effeet, except that sometimes, though rarely, two or three tentacles become inflceted. In faet all the many trials with solutions which were so weak as to produec no effect lead to the same result that water is incfficient.

Secondly. - The head of a small pin, fixed into a handle, was dipped into the solution under trial. The small drop which adhered to it, and which was mueh too small to fall off, was cautiously placed, by the aid of a lens, in contaet with the sccretion surrounding the glands of one, two, threc, or four of the exterior tentacles of the same leaf. Great carc was taken that the glands themselves should not be touched. I had supposed that the drops were of nearly the samc size; but on trial this proved a great mistake. I first measurcd some water, and removed 300 drops, touching the pin's head each time on blottingpaper; and on again measuring the watcr, a drop was found to equal on an average about the $\frac{1}{60}$ of a minim. Some water in a small vessel was weighed (and this is a moro accurate method), and 300 drops removed as before; and on again weighing the water, a drop was found to equal on an average only the $\frac{1}{89}$ of a minim. I repeated the operation, but endeavoured this time, by taking the pin's head out of the water obliquely and rather quickly, to remove as large drops as possiblc; and the result showed that I had succeeded, for each diop on an a reragc equalled $\frac{1}{10^{-4}}$ of a minim. I repeated the operation in cxactly the same manner, and now the drops avcraged $\frac{1}{23.5}$ of a minim. Bearing in mind that on these two latter oeeasions speeial pains were taken to removo as large drops as possible, we may safely conclude that the drops used in my experiments were at least cqual to the $\frac{1}{20}$ of a minim, or $0029 \mathrm{ml}$. One of thesc drops could be applicd to thee or even four glands, and if the tentaeles became infleeted, some of the solution must have been ahsorbed by all; for drops of pure water, applied in the same manncr, never produeed any effect. I was able to hold the drop in steady contaet with the secretion only for ten to fifteen scconds; and this was not time enough for the diffusion of all the salt in solution, as was cvident, from three or four tentacles treated successively with the same drop, often beeoming inflceted. All the matter in solution was even then probably not cxhausted.

Thirdly.-Leaves wcre cut off and immersed in a measured 
quantity of the solution under trial; the same number of leaves being inmersed at the same time, in the same quantity of the distilled water which had been used in making the solution. The leaves in the two lots were compared at short intervals of time, up to $24 \mathrm{hrs}$, and sometimes to 48 hrs. They were immersed by being laid as gently as possible in numbered watch-glasses, and thirty minims $(1.775 \mathrm{ml}$.) of the solution or of water was poured over each.

Some solutions, for instance that of carbonate of ammonia, quickly discolour the glands; and as all on the same leaf were discoloured simultaneously, they must all have absorbed some of the salt within the same short period of time. This was likewise shown by the simultaneous inflection of the several exterior rows of tentacles. If we had no such evidence as this, it might have been supposed that only the glands of the exterior and inflected tentacles had absorbed the salt; or that only those on the dise had absorbed it, and had then transmitted a motor impulse to the exterior tentacles; but in this latter case the exterior tentacles would not have become inflected until some time had elapsed, instead of within half an hour, or even within a few minutes, as usually occurred. All the glands on the same leaf are of nearly the same size, as may best be seen by cutting off a narrow transverse strip, and laying it on its side; hence their absorbing surfaces are nearly equal. The long-headed glands on the extreme margin must be excepted, as they are much longer than the others; but only the upper surface is capable of absorption. Besides the glands, both surfaces of the leaves and the pedicels of the tentacles bear numerous minute papillæ, which absorb carbonate of ammonia, an infusion of raw meat, metallic salts, and probably many other substances, but the absorption of matter by these papille never induces inflection. We must remember that the morement of each separate tentacle depends on its gland being excited, except when a motor impulse is transmitted from the glands of the dise, and then the morement, as just stated docs noi take place until some little time has clapsed. I hare made these remarks because they show us that when a leaf is immersed in a solution, and the tentacles are inflected, we can judge with some accuracy how much of the salt each gland las absorbed. For instance, if a leaf bearing 212 glands be immersed in a measured quantity of a solution, contrining $\frac{1}{10}$ of a grain of a salt, and all the exterior tentacles, cxcept twelve, are inflected, we may feel sure that each of the 200 glands can on an average lave absorbed at most $\frac{1}{2000}$ of a grain of the salt. I say at 
most, for the papille will have absorbed some small amount, and so will perhaps the glands of the twelve excluded tentacles which did not become inflected. The application of this principlc leads to remarkable conclusions with respect to the minuteness of the doses causing inflection.

\section{On the Action of Distilled Water in causing Inflection.}

Although in all the more important experiments the difference between the leaves simultanconsly immersed in water and in the several solutions will be describcd, nevertheless it may be well here to give a summary of the effects of water. The fact, moreovcr, of pure water acting on the glands deserves in itself some notice. Lcavcs to the number of 141 were immersed in water at the same time with thosc in the solutions, and their state recorded at short intervals of time. Thirty-two other leaves were separately obscrved in water, making altogether 173 experiments. Many scorcs of leaves were also immersed in water at other times, but no exact record of the effects produced was kept; yet thesc cursory observations support the conclusions arrived at in this chapter. A few of the long-headed tentacles, namely from one to about six, were commonly inflected within half an hour after immersion; as were occasionally a few, and rarcly a considerable number of the exterior round-headed tentacles. After an immersion of from 5 to $8 \mathrm{hrs}$. the short tentacles surrounding the outer parts of the disc generally become inflected, so that their glands form a small dark ring on the disc; the extcrior tentaclcs not partaking of this movement. Hence, cxcepting in a fow cases hereafter to be specified, wc can judge whether a solution produces any effect only by observing the cxtcrior tentacles within the first 3 or 4 hrs. aftcr immersion.

Now for a summary of the state of the 173 lcaves after an immersion of 3 or 4 hrs. in purc watcr. Onc lcaf had almost all its tentacles inflected; thrco leaves had most of them subinflected; and thirtecn had on an avcrage 36.5 tcntacles inflected. Thus seventcen leaves out of the 173 werc acted on in a marked manner. Eightecn leaves had from scven to nineteen tentacles inflected, the average being $9 \cdot 3$ tentacles for each leaf. Forty-four leaves had from one to six tentacles inflected generally the long-headed oncs. So that altogether of the 173 leaves carefully observed, seventy-nine were affected by the watcr in some degree, though commonly to a very slight degree; and ninety-four wero not affected in the least degrec. 'This 
amount of inflection is utterly insignificant, as we shall hereaftcr see, compared with that eauscd by very weak solutions of several salts of ammonia.

Plants whieh have lived for some time in a rather high temperature are far more sensitive to the aetion of water than those grown out of doors, or reeently brought into a warm greenhouse. Thus in the above screnteen cases, in which the immersed leaves had a considerable number of tentaeles inflected, the plants had been kept.during the winter in a very warm grecnhouse; and they bore in the early spring remarkably fine leaves, of a light red eolour. Had $I$ then known that the sensitiveness of plants was thus inereased, perhaps I should not have used the leaves for my experiments with the very weak solutions of phosphate of ammonia; but my experiments arc not thus vitiated, as I invariably used leaves from the same plants for simultaneous immersion in water. It often happened that some leaves on the same plant, and some tentaeles on the same leaf, were more sensitive than others; but why this should be so, I do not know.

Besides the differences just indicated between the leares im-

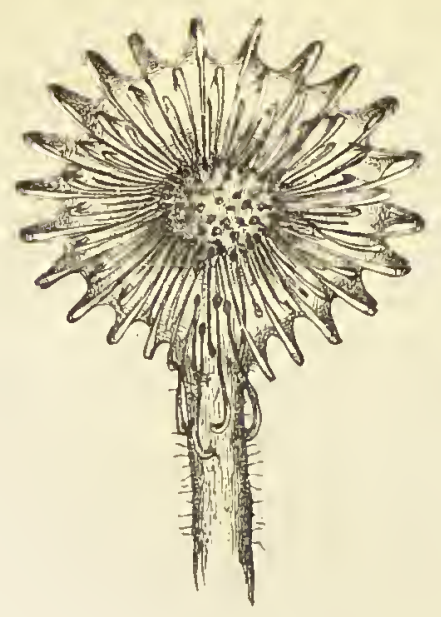

Fig. 9.

(Drosera rotundifolia.)

Leaf (cnlarged) with all the tentacles closely inflected, from immersion in a solution of plosplunte of ammonia (one part to 87,500 of water). mersed in water and in weak solutions of ammonia, the tentacles of the latter are in most eases much more elosely infleeted. The appearanee of a leaf after immersion in a few drops of a solution of one grain of phosphate of ammonia to $200 \mathrm{oz}$. of water (i.e. one part to 87,500 ) is here reproduced: sueh encrgetie infleetion is never eaused by water alone. With leaves in the weak solutions, the blade or lamina often becomes infleeted; and this is so rare a eireumstance with leaves in water that $I$ have scen only two instances; and in both of these the inflection was very fceble. Again, with leaves in the weak solutions, the infleetion of the tentreles and blade often goes on steadily, though slowly, increasing during many hours; and 
this again is so rare a circumstance with leaves in water that I have seen only three instances of any such increase after the first $S$ to 12 hirs.; and in these three instances the two outer rows of tentacles wero not at all affected. Hence there is sometimes a much greatcr difference between the leaves in water and in the weak solutions, after from S hrs. to $24 \mathrm{hrs}$, than there was within the first 3 his. ; though as a general rule it is best to trust to the difference observed within the shorter time.

With respect to the period of the re-expansion of the leaves, when left immersed either, in water or in the weak solutions, nothing could be more variable. In both cases the exterior tentacles not rarely begin to re-expand, after an interval of only from 6 to 8 hrs.; that is just about the time when the short tentacles round the borders of the disc beconie inflectcd. On the other hand, the tentacles sometimes remain inflected for a whole day, or even two days; but as a general rule they remain inflected for a longer period in very weak solutions than in water. In solutions which are not extremely weak, they never re-expand within nearly so short a period as six or eight hours. From these statements it might be thought difficult to distinguish between the effects of water and the weaker solutions; but in truth therc is not the slightest difficulty until excessively weak solutions are tried; and then the distinction, as might be expected, becomes very doubtful, and at last disappears. But as in all, except the simplcst, cases the state of the leaves simultaneously immersed for an equal length of time in water and in the solutions will be described, the reader can judge for himself.

\section{Carbonate of Ammonia.}

This salt, when absorbed by the roots, does not cause the tentacles to be infleeted. A plant was so plaeed in a solution of one part of the carbonate to 146 of water that the young uninjured roots eould be observed. The terminal eells, which were of a pink colour, instantly became colourless, and their limpid contents elouly, like a mezzo-tinto engraving, so that some degree of aggregation was alinost instantly eaused; but no further ehange ensued, and the absorbent hairs were not visibly affected. The tentacles 
did not bend. Two other plants were placed witlı their roots surrounded by damp moss, in half an ounce $(14 \cdot 198 \mathrm{ml}$.) of a solution of one part of the earbonate to 218 of water, and were observed for 24 hrs.; but not a single tentacle was inflected. In order to produce this effect, the carbonate must be absorbed by the glands.

The vapour produces a powerful effect on the glands, and induces inflection. Three plants with their roots in bottles, so that the surrounding air could not have become very humid, were placed under a bell-glass (holding 122 fluid ounces), together with 4 grains of carbonate of ammonia in a watch-glass. After an interval of 6 hrs. $15 \mathrm{~m}$. the leaves appeared unaffected; but next morning, after 20 hrs., the blackened glands were secreting copiously, and most of the tentacles were strongly inflected. These plants soon died. Two other plants were placed under the same bellglass, together with half a grain of the carbonate, the air being rendered as damp as possible; and in 2 hrs. most of the leaves were affected, many of the glands being blackened and the tentacles inflected. But it is a curious fact that some of the closely adjoining tentaeles on the same leaf, both on the disc and round the margins, were much, and some, apparently, not in the least affected. The plants were kept mnder the bell-glass for 24 hrs., but no further change ensued. One healthy leaf was hardly at all affected, though other leaves on the same plant were much aftected. On some leaves all the tentacles on one side, but not those on the opposite side, were inflected. I doubt whether this extremely unequal action can be explained by supposing that the more active glands absorb all the vapour as quickly as it is generated, so that none is left for the others; for we shall meet with 
analogons cases with air thoroughly permeated with the vapours of chloroform and ether.

Minute particles of the carbonate were added to the seeretion surrounding several glands. These instantly became black and secreted eopiously; but, exeept in two instances, when extremely minute partieles were given, there was no inflection. This result is analogous to that which follow's from the immersion of leares in a strong solution of one part of the earbonate to 109 , or 146 , or even 218 of water, for the leaves are then paralysed and no inflection ensues, though the glands are blackened, and the protoplasm in the cells of the tentacles undergoes strong aggregation.

We will now turn to the cffeets of solutions of the earbonate. Half-minims of a solution of one part to 437 of water were plaeed on the dises of twelve leaves; so that eaeh reecived $\frac{1}{960}$ of a grain or $\cdot 0675 \mathrm{mg}$. Ten of these had their exterior tentacles well infleeted; the blades of some being also mueh eurved inwards. In two eases several of the exterior tentaeles were infleeted in $35 \mathrm{~m}$.; but the movement was generally slower. These ten leaves re-expanded in periods varying between $21 \mathrm{hrs}$. and $45 \mathrm{hrs}$, but in one ease not until 67 hrs. had elapsed; so that they re-expanded mueh more quiekly than leaves whieh have
eaught inseets.

The same-sized drops of a solution of one part to 875 of water were plaeed on the dises of eleven leaves; six remained quite unaffeeted, whilst five had from three to six or eight of their exterior tentacles inflected; but this degree of movement ean hardly be considered as trustworthy. Each of these leaves reeeived $\frac{1}{1927}$ of a grain $(\cdot 0337 \mathrm{mg}$.), distributed between the glands of the dise, but this was too small an amount to produee any deeided effect on the exterior tentreles, the glands of whieh had not themselves received any of the salt.

Minute drops on the head of a small pin, of a solution of one part of the earbonate to 218 of water, wore next tried in the manner above deseribed. A drop of this kind equals on an average $\frac{1}{20}$ of a minim, and therefore contains $\frac{x}{400}$ of a grain $(\cdot 013.5 \mathrm{mg}$.) of the earbonate. I touehed with it the viseid secretion round three glands, so that each gland received only 

$\frac{1}{1400}$ of a grain $(\cdot 00445 \mathrm{mg}$.). Neverthcless, in two trials all
the glands were plainly blackened; in one case all three tentacles were well inflected after an interval of 2 hrs. $40 \mathrm{~m}$; and in another case two of the three tcntacles were inflected. I then tried drops of a weaker solution of one part to 292 of watcr on twenty-four glands, always touching the viscid secretion round three glands with the same little drop. Fach gland thus receired only the $\frac{1}{19^{200}}$ of a grain ( $.00337 \mathrm{mg}$.), yet some of them wcre a little darkencd: but in no one instance were any of the tentacles inflected, though they were watched for 12 hrs. When a still weaker solution (viz. one part to 437 of water) was tried on six glands, no effect whatever was perceptible. We thus learn that the $\frac{1}{14.00}$ of a grain ( $00445 \mathrm{mg}$.) of carbonate of ammonia, if absorbed by a gland, suffices to induce inflection in the basal part of the same tentacle; but as already stated, I was able to hold with a steady hand the minutc drops in contact with the secretion only for a few seconds; and if more time had been allowed for diffusion and absorption, a much weaker solution would certainly have acted.

Some experiments were made by immersing cut-off leaves in solutions of different strengths. Thus four leaves were left for about 3 hrs. each in a drachm $(3.549 \mathrm{ml}$.) of a solution of one part of the carbonate to 5250 of water ; two of thesc had almost every tentacle inflected, the third had about half the tentacles and the fourth about one-third inflected; and all the glands were blackened. Another leaf was placed in the same quantity of a solution of one part to 7000 of water, and in $1 \mathrm{hr} .16 \mathrm{~m}$. every single tentacle was well inflected, and all the glands blackened. Six learcs were immersed, each in thirty minims (1.774 ml.) of a solution of one part to 4375 of water, and the glands were all blackened in $31 \mathrm{~m}$. All six lcaves cxhibited some slight inflcction, and one was strongly inflected. Four lcaves wcre then immersed in thirty minims of a solution of one part to 8750 of water, so that each leaf received the $\frac{1}{320}$ of a grain ( $2025 \mathrm{mg}$.). Only one became strongly inflected; but all the glands on all the leaves were of so dark a red after one hour as almost to deserve to be called black, whereas this did not occur with the leaves which were at tho same timo immerscd in water; nor did water produce this cffect on any other occasion in nearly so short a time as an hour. These cases of tho simultancous darkening or blackening of the glands from the action of wcak solutions are important, as they show that all the glands absorbed tho carbonate within the samo time, which fact indeed there was not the least reason to doubt. So again, whencrer all the 
tentacles beeome inflected within the same time, we have evidence, as before remarked, of simultaneous absorption. I did not count the number of glands on these four lcaves; but as they were fine ones, and as we know that the average number of glands on thirty-one leaves was 192, we may safely assume that each bore on an arerage at least 170; and if so, each blaekened gland eould have absorbed only $\frac{1}{54400}$ of a grain ( $00119 \mathrm{mg}$.) of the carbonate.

A large number of trials had been previously made with solutions of one part of the nitrate and phosphate of ammonia to 43750 of water (i.e. one grain to 100 ounees), and these were found highly effieient. Fourteen leaves were therefore placed, eaeh in thirty minims of a solution of one part of the earbonate to the above quantity of water; so that eaeh leaf reeeived $\frac{1}{16 \frac{1}{00}}$ of a grain ( $0405 \mathrm{mg}$.). The glands were not much darkcned. Ten of the leaves were not affeeted, or only very slightly so. Four, however, were strongly affeeted; the first having all the tentaeles, exeept forty, infleeted in $47 \mathrm{~m}$.; in $6 \mathrm{hrs}$. $30 \mathrm{~m}$. all exeept eight; and after 4 hrs. the blade itself. The seeond leaf after $9 \mathrm{~m}$. had all its tentaeles exeept nine infleeted; after 6 hrs. $30 \mathrm{~m}$. these nine were sub-infleeted; the blade having beeome much infleeted in $4 \mathrm{hrs}$. The third lcaf after $1 \mathrm{hr} .6 \mathrm{~m}$. had all but forty tentreles infleeted. The fourth, after $2 \mathrm{hrs} .5 \mathrm{~m}$., had about half its tentaeles and after 4 hrs. all but forty-five infleeted. Leaves which were immersed in water at the same time were not at all affeeted, with the exeeption of one; and this not until $8 \mathrm{hrs}$. had elapsed. Henee there can be no doubt that a highly sensitive leaf, if immersed in a solution, so that all the glands are enabled to absorb, is aeted on by $\frac{1}{1600}$ of a grain of the earbonate. Assuming that the leaf, which was a large one, and which had all its tentaeles exeepting eight infleeted, bore 170 glands, eaeh gland eould have absorbed only $\frac{1}{265000}$ of a grain ( $00024 \mathrm{mg}$.$) ; yet this sufficed to aet on each of the 162$ tentaeles which were infleeted. But as only four out of the above fourteen leaves were plainly affected, this is nearly the minimum dose whieh is effieient.

Aggregation of the Protoplasm from the Action of Curbonate of Ammonia. - I have fully deseribed in the third ehapter the remarkable effeets of moderately strong doses of this salt in eausing the aggregation of the protoplasm within the eells of the glands and tentaeles; and here my olject is merely to show what small doses suffice. A leaf was immersed in twenty minims $(1.183 \mathrm{ml}$.) of a solution of one part to 1750 of water, 
and another leaf in the same quantity of a solution of one part to 3062 ; in the former case aggregation occurred in $4 \mathrm{~m}$., in the latter in $11 \mathrm{~m}$. A leaf was then immersed in twenty minims of a solution of one part to 4375 of water, so that it received $\frac{1}{240}$ of a grain (.27 mg.); in $5 \mathrm{~m}$. there was a slight change of colour in the glands, and in $15 \mathrm{~m}$. small spheres of protoplasm were formed in the cells beneath the glands of all the tentacles. In these cases there could not be a shadow of a doubt about the action of the solution.

A solution was then made of one part to 5250 of water, and I experimented on fourteen leaves, but will give only a few of the cases. Eight young leaves were sclected and cxamined with care, and they showed no trace of aggregation. Four of these were placed in a drachm $(3 \cdot 549 \mathrm{ml}$.) of distilled water; and four in a similar vessel, with a drachm of the solution. After a time the leaves were examined under a high power, being taken alternately from the solution and the water. The first leaf was taken out of the solution after an immersion of 2 hrs. $40 \mathrm{~m}$., and the last leaf out of the water after 3 hrs. $50 \mathrm{~m}$; the examination lasting for $1 \mathrm{hr} .40 \mathrm{~m}$. In the four leaves out of the watcr there was no trace of aggregation except in one specimen, in which a very few, extremely minute spheres of protoplasm were present beneath some of the round glands. All the glands were translucent and red. The four lcaves which had been immersed in the solution, besides being inflected, presented a widely different appearance; for the contents of the cells of every single tentacle on all four leaves were conspicuously aggregated; the spheres and elongated masses of protoplasm in many cases extcnding halfway down the tentacles. All the glands, both those of the central and exterior tentaclcs, were opaque and blackened; and this shows that all had absorbed some of the carbonate. These four lcaves were of very nearly the same size, and the glands were counted on onc and found to bc 167. This heing the case, and the four leaves having becn immersed in a drachm of the solution, each gland could have received on an average only $\frac{1}{64125}$ of a grain (.001009 mg.) of the salt; and this quantity sufficed to induce within a short time conspicuous aggregation in the cells beneath all the glands.

A vigorous but rather small red lcaf was placed in six minims of the same solution (viz. one part to 5250 of watcr), so that it received $\frac{1}{50}$ of a grain ( $.0675 \mathrm{mg}$.). In $40 \mathrm{~m}$. the glands appeared rather darker; and in 1 hr. from four to six splicres of protoplasm were formed in the wells bencath the glands of all the tentrcles. I did not count the tentacles, but we may 
safely assume that there wero at least 140; and if so, eaeh gland eould have received only the $\frac{1}{134400}$ of a grain, or - $00048 \mathrm{mg}$.

A weaker solution was then made of one part to 7000 of water, and four leaves were immersed in it; but I will give only one case. A leaf was placed in ten minims of this solution; after $1 \mathrm{hr} .37 \mathrm{~m}$. the glands beeame somewhat darker, and the eells beneath all of them now eontained many spheres of aggregated protoplasm. This leaf reeeived $\frac{1}{765}$ of a grain, and bore $166^{\circ}$ glands. Eaeh gland eould, therefore, have reeeived only $\frac{1}{12 \frac{1}{7} 45 \mathrm{~S}}$ of a grain ( $.000507 \mathrm{mg}$.) of the earbonate.

Two other experiments are worth giving. A leaf was immersed for 4 hrs. $15 \mathrm{~m}$. in distilled water, and there was no aggregation; it was then plaeed for $1 \mathrm{hr} .15 \mathrm{~m}$. in a little solution of one part tu 5250 of water; and this exeited well-marked aggregation and infleetion. Another leaf, after having been immorsed for 21 hrs. $15 \mathrm{~m}$. in distilled water, had its glands blackened, but there was no aggregation in the eells beneath them; it was then left in six minims of the same solution, and in $1 \mathrm{hr}$. there was much aggregation in many of the tentacles; in 2 hrs. all the tentaeles (146 in number) were affected-the aggregation extending down for a length equal to half or the whole of the glands. It is extremely improbable that these two leaves wonld have undergone aggregation if they had been left for a little longer in the water, namely for $1 \mathrm{hr}$. and $1 \mathrm{hr} .15 \mathrm{~m}$, during which time they were immersed in the solution; for the process of aggregation seems invariably to supervene slowly and very gradually in water.

\section{Summary of the Results with Carbonate of Ammonia.-} The roots absorb the solution, as shown by their changed eolour, and by the aggregation of the eontents of their cells. The vapour is absorbed by the glands; these are blackened, and the tentacles are infleeted. The glands of the disc, when exeited by a half-minim drop (.0296 ml.), eontaining $\frac{1}{100}$ of a grain (.0675 mg.), transmit a motor impulse to the exterior tenticles. causing them to bend inwards. A minute drop, eontaining $\frac{1}{1+400}$ of a grain (.00445 $\mathrm{mg}$.), if held for a few seconds in eontact with a gland, soon eauses the tentacle bearing it to be inflected. If a leaf is left, 
immerser for a few hours in a solution, and a gland absorbs the $\frac{1}{13+100}$ of a grain $(.00048 \mathrm{mg}$.), its colour becomes darker, though not actually black; and the contents of the cells beneath the gland are plainly aggregated. Lastly, under the same circumstances, the absorption by a gland of the $\frac{1}{9800}$ of a grain (.00024 $\mathrm{mg}$.) suffices to excite the tentacle bearing this gland into movement.

\section{Nitrate of Ammonia.}

With the salt I attended only to the inflection of the leaves, for it is far less efficient than the carbonate in causing aggregation, although considerably more potent in causing inflection. I experimented with half-minims (.0296 ml.) on the dises of fiftytwo leaves, but will give only a few cases. A solution of one part to 109 of water was too strong, causing little inflection, and after 24 hrs. killing, or nearly killing, four out of six leaves which were thus tried; each of which received the $\frac{1}{24.0}$ of a grain (or $\cdot 27 \mathrm{mg}$. ). A solution of one part to 218 of water acted most energetically, causing not only the tentacles of all the leaves, but the blades of some, to be strongly inflected. Fourteen leaves were tried with drops of a solution of one part to 875 of water, so that the disc of each received the $\frac{1}{1920}$ of a grain (.0337 mg.). Of these leaves, seven were very strongly acted on, the edges being gencrally inflected; two were moderately acted on; and five not at all. I subsequently tried three of these latter five leaves with urine, saliva, and mucus, but they were only slightly affected; and this proves that they were not in an active condition. I mention this fact to show how necessary it is to experiment on several leaves. Two of the leaves, which were well inflected, re-expanded after 51 hrs.

In the following experiment I happened to select rery sensitive leaves. Half-minims of a solution of one part to 1094 of water (i e. $1 \mathrm{gr}$. to $2 \frac{1}{2} \mathrm{oz}$.) were placed on the discs of nine leaves, so that each received the $\frac{1}{2.00}$ of a grain $(\cdot 027 \mathrm{mg}$.). Three of them had their tentacles strongly inflected and their blades curled inwards; five were slightly and somewhat doubtfully affected, having from three to eight of their exterior tentacles inflected: one leaf was not at all affected, yet was afterwards acted oul by saliva. In six of these eases, a trace of action was perceptible in 
7 hr's., but the full effect was not produced until from 24 hrs. to 30 hi's. had clapsed. Two of the leaves, which were only slightly inflcetcd, re-expanded after an additional interval of $19 \mathrm{hrs}$.

Half-minims of a rather weaker solution, viz. of one part to 1312 of water ( $1 \mathrm{gr}$. to $3 \mathrm{oz}$.) were tried on fourteen leaves; so that each received $\frac{1}{2500}$ of a grain ('0225 mg.), instead of', as in the last experiment, $\frac{1}{2100}$ of a grain. The blade of one was plainly inflected, as were six of the exterior tentacles; the blade of a second was slightly, and two of the exterior tentacles well, inflected, all the other tentacles being curled in at right angles to the disc; three other leaves had from fivc to eight tentacles inflected; five others only two or three, and occasionally, though very rarely, drops of pure water cause this much action; the four remaining leaves were in no way affected, yet three of them, when subsequently tried with urine, became greatly inflected. In most of these cases a slight effect was perceptible in from 6 hrs. to 7 lirs. but the full effect was not produced until from $24 \mathrm{hrs}$. to 30 hr's. had elapsed. It is obvious that we have here reached very nearly the minimum amount, which, distributed between the glands of the disc, acts on the exterior tentacles; these having themselves not received any of the solution.

In the next place, the viscid secretion round three of the exterior glands was touched with the same little drop ( $\frac{1}{20}$ of a minim) of a solution of one part to 437 of water; and after an interval of $2 \mathrm{hrs} .50 \mathrm{~m}$. all three tentacles were well inflected. Each of these glands could have received only the $\frac{1}{2 \mathrm{SBO0}}$ of a grain, or $0022.5 \mathrm{mg}$. A little drop of the same size and strength was also applied to four other glands, and in $1 \mathrm{hr}$. two became inflected, whilst the other two never moved. We here sce, as in the case of the half-minims placed on the discs, that the nitrate of ammonia is more potent in causing inflection than the carbonate; for minute drops of the latter salt of this strength produced no effect. I tried minute drops of a still weaker solution of the nitrate, viz. one part to 875 of water, on twenty-one glands, but no effect whatever was produced, except perhaps in one iustance.

Sixty-three leavos were immersed in solutions of various strengths; other leaves being immersed at the same time in the same pure water used in making the solutions. The results are so romarkable, though less so than with phosphate of ammonia, that I must describe the experiments in detail, but I will give only a few. In speaking of the successive periods when inflection occurred, I always reckon from the time of first immersion. 
Having made some preliminary trials as a guide, five leaves were plaeed in the same little vessel in thirty minims of a solution of one part of the nitrate to 7875 of water ( $1 \mathrm{gr}$. to $18 \mathrm{oz}$.); and this amount of fluid just suffieed to eover them. After 2 hrs. $10 \mathrm{~m}$. three of the leaves were eonsiderably infleeted, and the other two moderately. The glands of all beeame of so dark a red as almost to deserve to be called blaek. After $8 \mathrm{hr}$. four of the leaves had all their tentaeles more or less infleeted; whilst the fifth, whieh I then pereeived to be an old leaf, had only thirty tentaeles infleeted. Next morning, after 23 hrs. $40 \mathrm{~m}$., all the leares were in the same state, exeepting that the old leaf had a few more tentaeles infleeted. Five leares whieh had been plaeed at the same time in water were observed at the same intervals of time; after 2 hrs. $10 \mathrm{~m}$. two of them had four, one had seven, one had ten, of the long-headed marginal tentaeles, and the fifth had four round-headed tentaeles, infleeted. After 8 hrs. there was no ehange in these leaves, and after $24 \mathrm{hrs}$. all the marginal tentaeles had re-expansled; but in one leaf, a dozen, and in a seeond leaf, half a dozen, submarginal tentaeles had beeome infleeted. As the glands of the fire leaves in the solntion were simultaneously darkened, no doubt they had all absorbed a nearly equal amount of the salt: and as $\frac{1}{288}$ of a grain was given to the five leaves together, each got $\frac{T}{14+0}$ of a grain $(.045 \mathrm{mg}$.). I did not eount the tentaeles on these leaves, whieh were moderately fine ones, but as the average number on thirty-one leaves was 192 , it would be safe to assume that eneh bore on an average at least 160. If so, eaeh of the darkened glands eould have reeeived only $\frac{1}{230+00}$ of a grain of the nitrate; and this caused the infleetion of a great majority of the tentaeles.

This plan of immersing several leaves in the same vessel is a bad one, as it is impossible to feel sure that the more vigorous leaves do not rob the weaker ones of their share of the salt. The g]ands, moreover, must often toueh one another or the sides of the ressel, and movement may have been thus exeited; but the corresponding leaves in water, whieh were little infleeted, though rather more so than eommonly oeeurs, were exposed in an almost equal degree to these same sourees of error. I will, therefore, give only one other experiment made in this manner, though many were tried and all eonfirmed the foregoing and following results. Four lenves were placed in forty minims of a solution of one part to 10,500 of water; and assuming that they absorbed equally, eaeh leaf reeeived $\frac{1}{1152}$ of a grain $(.0562 \mathrm{mg}$.). After $1 \mathrm{hr} .20 \mathrm{~m}$. many of the tentaeles on all four leaves were somewhat infleeted. After 
5 hrs. $30 \mathrm{~m}$. two leaves had all their tentacles inflected; a third leaf all except the extreme marginals, which seemed old and torpid; and the fourth a large number. After '21 lirs. every single tentacle, on all four leaves, was closely inflected. Of the four leaves placed at the same time in watcr, one had, after 5 hrs. $45 \mathrm{~m}$., five marginal tentacles inflected; a second, ten; a third, nine marginals and submarginals; and the fourth, trvelve, chiefly submarginals, inflected. After 21 hrs. all these marginal tentacles re-expanded, but a few of the submarginals on two of the leaves remained slightly curved inwards. The eontrast was wonderfully great between these four leaves in water and those in the solution, the latter having every one of their tentacles closely inflected. Making the moderate assumption that each of these leaves bore 160 tentacles, each gland eould have absorbed only $\frac{1}{154320}$ of a grain (.000351 mg.). This experiment was repeated on three leaves with the same relative amount of the solution; and after $6 \mathrm{hrs} .15 \mathrm{~m}$. all the tentacles except nine, on all three leaves taken together, were closely inflected. In this case the tentacles on each leaf were counted, and gave an average of 162 per leaf.

The following experiments were tried during the summer of 1873 , by placing the leaves, each in a separate watch-glass and pouring over it thirty minims $(1.775 \mathrm{ml}$.) of the solution; other leaves being treated in exactly the same manner with the doubly distilled water used in making the solutions. The trials above given were made several years before, and when I read over my notes, I could not believe in the results; so I resolved to begin again with moderately strong solutions. Six leaves were first immersed, each in thirty minims of a solution of one part of the nitrate to 8750 of water $(1 \mathrm{gr}$. to $20 \mathrm{oz}$.), so that each received $\frac{1}{320}$ of a grain $(2025 \mathrm{mg}$.). Before $30 \mathrm{~m}$. had elapsed, four of these leaves were immensely, and two of them moderately, inflected. The glands were rendered of a dark red. The four corresponding leaves in water wcre not at all affected until $6 \mathrm{hrs}$. had elapsed, and then only the short tentacles on the borders of the disc; and their inflection, as previously explained, is never of any significance.

Four leaves were immersed, each in thirty minims of a solution of one part to 17,500 of water ( $1 \mathrm{gr}$. to $40 \mathrm{oz}$.), so that each received $\frac{1}{640}$ of a grain ( $101 \mathrm{mg}$.); and in less than $45 \mathrm{~m}$. three of them had all their tentacles, except from four to ten, inflected; the blade of onc being inflected after 6 hrs., and the blade of a second after 21 hrs. 'The fourth leaf was not at all affected. The glands of none were darkened. Of the corresponding leaves 
in water, only one had any of its exterior tcntacles, namcly five, inflected; after 6 hrs. in one case, and after 21 hrs. in two other cases, the short tentrcles on the bordcrs of the disc formed a ring, in the nstual manner.

Four leaves wcre immcrsed, each in thirty minims of a solution of one part to 43,750 of watcr ( $1 \mathrm{gr}$. to $100 \mathrm{oz}$.), so that each leaf got $\frac{1}{1600}$ of a grain ( $0405 \mathrm{mg}$.). Of these, one was much inflected in $8 \mathrm{~m}$. , and after $2 \mathrm{hrs} .7 \mathrm{~m}$. had all the tentacles, except thirteen, inflected. The second leaf, after $10 \mathrm{~m}$., had all except three inflected. The third and fourth were hardly at all affccted, scarcely more than the corresponding leaves in water. of the latter, only one was affected, this having two tentacles inflected, with those on the outer parts of the disc forming a ring in the usual manner. In the leaf which had all its tentacles except three inflected in $10 \mathrm{~m}$., each gland (assuming that the leaf bore 160 tentacles) could have absorbed only $\frac{1}{251200}$ of a grain, or $000258 \mathrm{mg}$.

Four leaves were separately immersed as before in a solution of one part to 131,250 of water ( $1 \mathrm{gr}$. to $300 \mathrm{oz}$.), so that each received $\frac{1}{4800}$ of a grain, or $0135 \mathrm{mg}$. After $50 \mathrm{~m}$. one leaf had all its tentacles except sixteen, and after 8 hrs. $20 \mathrm{~m}$. all but fourteen, inflected. The second leaf, after $40 \mathrm{~m}$., had all but twenty inflected; and after $8 \mathrm{hrs}, 10 \mathrm{~m}$. began to l'c-expand. The third, in $3 \mathrm{hrs}$. had about half its tentacles inflected, which began to re-expand after 8 hrs. $15 \mathrm{~m}$. The fourth leaf, after 3 hrs. $7 \mathrm{~m}$, had only twenty-nine tentacles more or less inflected. Thus three out of the four leares were strongly acted on. It is clear that very sensitive lcaves had been accidcntally selected. The day moreover was hot. The four corresponding leaves in water were likewise acted on rather morc than is usual; for after 3 hrs. one had nine tcntacles, another four, and another two, and the fourth none, inflected. With respect to the lcaf of which all the tentaclos, except sixteen, were inflected after $50 \mathrm{~m}$, each gland (assuming that the lcaf bore 160 tentacles) could have absorbed only $\frac{\lambda}{60 x^{2}} \overline{00}$ of a grain ( 0000937 $\mathrm{mg}$.), and this appcars to be about the least quantity of the nitrate which suffices to induce the inflection of a single tentacle.

As ncgative results are important in confirming the foregoing positive ones, cight leaves were immersed as beforc, each in thirty minims of a solution of one part to 175,000 of water ( $1 \mathrm{gr}$. to $400 \mathrm{oz}$.$) , so that cach reccived only \frac{1}{3.00}$ of a grain (.0101 mg.). This minute quantity prociuced a slight cffect on only four of the eight lenves. One had fifty-six tentacles inflected after 2 his. $13 \mathrm{~m}$; a sccond, twenty-six inflected, or sub-inflected, after 
3S m.; a third, eighteen inflected, after 1 hr.; and a fourth, ten inflected, after $35 \mathrm{~m}$. The four other leaves werc not in the least affected. Of the eight corresponding leaves in water, one had, after 2 hrs. 10 m., nine tentacles, and four others from one to four long-hcaded tentacles, inflected; the remaining thrce bcing unaffected. Hence, the $\frac{1}{6400}$ of a grain given to a sensitive leaf during warm weather perhaps produces a slight cffect; but we must bear in mind that occasionally watcr causes as great an amount of inflection as occurred in this last experiment.

Summary of the Results with Nitrate of Ammonia.The glands of the dise, when cxcited by a half-minim drop $(.0296 \mathrm{ml}$.$) , containing \frac{1}{9-00}$ of a grain of the nitrate $(.027 \mathrm{mg}$.$) , transmit a motor impulse to the$ exterior tentacles, causing them to bend inwards. A minute drop, containing $\frac{1}{28800}$ of a grain $(\cdot 00225 \mathrm{mg}$.), if held for a few seconds in contact with a gland, causes the tentaclc bearing this gland to be inflected If $a^{\prime}$ lcaf is left immersed for a few hours, and sometimes for only a few minutes, in a solution of such strength that each gland can absorb only the $\frac{1}{691200}$ of a grain ( $\cdot 0000937 \mathrm{mg}$.$) , this small amount is$ enough to excite each tentacle into movement, and it becomes closely inflected.

\section{Phosphate of Ammonia.}

This salt is more powerful than the nitrate, even in a greater degrec than the nitrate is more powerful than the carbonate. This is shown by weaker solutions of the phosphate acting when dropped on the dises, or applied to the glands of the extcrior tentacles, or when leaves are immersed. The difference in the power of these three salts, as tried in three different ways, supports the results prescutly to be 
given, whieh are so surprising that their eredibility requires every kind of support. In 1872 I experimented on twelve immersed leaves, giving each only ten minims of a solution; but this was a bad method, for so small a quantity hardly eovered them. None of these experiments will, therefore, be given, though they indicate that exeessively minute doses are effieient. When I read over my notes, in 1873 , I entirely disbelieved them, and determined to make another set of experiments with serupulous care, on the same plan as those made with the nitrate; namely by plaeing leaves in wateh-glasses, and pouring over each thirty minims of the solution under trial, treating at the same time and in the same manner other leaves with the distilled water used in making the solutions. During 1873, seventy-one leaves were thus tried in solutions of various strengths, and the same number in water. Notwithstanding the care taken and the number of the trials made, when in the following year I looked merely at the results, without reading over my observations, I again thought that there must have been some error, and thirty-five fresh trials were made with the weakest solution; bnt the results were as plainly marked as before. Altogether, 106 earefully selected leaves were tried, both in water and in solutions of the phosphate. Hence, after the most anxious eonsideration, I ean entertain no doubt of the substantial aeeuraey of my results.

Before giving my experiments, it may be well to premise that crystallised phosphate of ammonia, sueh as I used, eontains 35.33 per cent. of water of erystallisation; so that in all the following trials the efficient elements formed only 64.67 per cent. of the salt used.

Extremely minute partieles of the dry phosphate were plaeed 
with the point of a needle on the secrotion surrounding several glands. These poured forth much secretion, were blackened, and ultimately died; but the tentacles moved only slightly. The dose, small as it was, evidently was too great, and the result was the same as with particles of the carbonate of ammonia.

Half-minims of a solution of one part to 437 of water were placed on the clises of three leaves and acted most energetically, eausing the tentacles of one to be inflected in $15 \mathrm{~m}$., and the blades of all three to be much eurved inwards in $2 \mathrm{hrs}$. $15 \mathrm{~m}$. Similar drops of a solution of one part to 1312 of water, ( $1 \mathrm{gr}$, to $3 \mathrm{oz}$.) were then placed on the dises of five leaves, so that each received the $\frac{1}{2880}$ of a grain ( $0225 \mathrm{mg}$.). After $8 \mathrm{hrs}$. the tentacles of four of them were considerably inflected, and after $24 \mathrm{hrs}$. the blades of three. After 48 hrs. all five were almost fully re-expanded. I may mention with respect to one of these leaves, that a drop of water had been left during the previous 24 hrs. on its disc, but produced no effect; and that this was hardly dry when the solution was added.

Similar drops of a solution of one part to 1750 of water ( $1 \mathrm{gr}$. to $4 \mathrm{oz}$.) were next plaeed on the discs of six leaves; so that each reeeived $\frac{1}{38 * 0}$ of a grain ( $0169 \mathrm{mg}$.); after $8 \mathrm{hrs}$, three of them had many tentacles and their blades inflected; two others had only a few tentacles slightly infleeted, and the sixth was not at all affected. After 24 hrs. most of the leaves had a few more tentacles inflected, but one had begun to re-expand. We thus see that with the more sensitive leaves the $\frac{1}{38 \times 0}$ of a grain, absorbed by the central glands, is enough to make many of the exterior tentacles and the blades bend, whereas the $\frac{1}{1920}$ of a grain of the earbonate similarly given produeed no effect; and $\frac{1}{2 \times 50}$ of a grain of the nitrate was only just sufficient to produce a well-marked effect.

A minute drop, about equal to $\frac{1}{20}$ of a minim, of a solution of one part of the phosplate to 875 of water, was applied to the secretion on three glands, each of which thus received only $\frac{1}{57600}$ of a grain ('00112 mg.), and all three tentaeles became inflected. Similar drops of a solution of one part to 1312 of water ( $1 \mathrm{gr}$. to $3 \mathrm{oz}$.) were now tried on three leaves; a drop being applied to four glands on the same leaf. On the first lcaf, three of the tentaeles became slightly infleeted in $6 \mathrm{~m}$, and rc-cxpanded after 8 hrs. $45 \mathrm{~m}$. On the second, two tentacles bccame sub-inflected in $12 \mathrm{~m}$. And on the third all four tentacles wero decidedly infleeted in $12 \mathrm{~m}$.; they remained so for 8 hrs. $30 \mathrm{~m}$., but by the next morning wero fully re-expanded. 
In this latter case each gland could have received only the $\frac{1}{115200}$ (or $\cdot 000563 \mathrm{mg}$.) of a grain. Lastly, similar drops of a solution of one part to 1750 of water ( $1 \mathrm{gr}$. to 4 oz.) were tried on five leaves; a drop being applied to four glands on the same leaf. The tentacles on three of these leaves were not in the least affected; on the fourth leaf, two became inflected; whilst on the fifth, which happened to be a very sensitive one, all four tentacles were plainly inflected in $6 \mathrm{hrs} .15 \mathrm{~m}$.; but only one remained inflected after 24 hrs. I should, however, state that in this case an unusually large drop adhered to the head of the pin. Each of these glands could have received ver'y little more than $\frac{1}{153600}$ of a grain (or 000423); but this small quantity sufficed to cause inflection. We must bcar in mind that these drops were applied to the viscid secretion for only from 10 to 15 seconds, and we have good reason to believe that all the phosphate in the solution would not be diffused and absorbed in this time. We have seen under the same circumstances that the absorption by a gland of $\frac{1}{19200}$ of a grain of the carbonate, and of $\frac{1}{57800}$ of a grain of the nitrate, did not cause the tentacle bearing the gland in question to be inflected; so that here again the phosphate is much more powerful than the other two salts.

We will now turn to the 106 experiments with immersed leaves. Having ascertained by repeated trials that moderately strong solutions were highly efficient, I commenced with sixteen leaves, each placed in thirty minims of a solution of one part to 43,750 of water ( $1 \mathrm{gr}$. to $100 \mathrm{oz}$.) ; so that ench received $\frac{3}{1600}$ of a grain, or $04058 \mathrm{mg}$. Of these leaves, eleven had nearly all or a great number of their tentacles inflected in $1 \mathrm{hr}$., and the twelfth leaf in $3 \mathrm{hrs}$. One of the eleven had every single tentacle closely inflected in $50 \mathrm{~m}$. Two leaves out of the sixteen were only moderately affected, jet more so than any of those simultaneously immersed in water; and the remaining two, which were pale leaves, were hardly at all affected. Of the sixtecn corresponding leaves in water, one had nine tentacles, another sis, and two others two tentacles inflected, in the course of 5 hrs. So that the contrast in appearance between the two lots was extremely great.

Eighteen leaves were immersed, cach in thirty minims of a solution of one part to 87,500 of water ( $1 \mathrm{gr}$. to $200 \mathrm{oz}$.), so that cach received $\frac{7}{3200}$ of a grain $(-0202 \mathrm{mg}$.). Fourteen of these were strongly inflected within 2 hrs., and some of them within $15 \mathrm{~m}$; three out of the eighteen were only slightly affected, having twenty-one, nineteen, and twelve tentacles in- 
fleeted; and one wrs not at all aeted on. By an aceident only fifteon, instead of eighteen, leaves were immersed at the same time in water; these were observed for $24 \mathrm{hrs}$; one had six, another four, and a third two, of their outer tentaeles inflected; the remainder being quite unaffeeted.

The next experiment was tried under very favourable cireumstances, fort he day (July S) was very warm, and I happened to have unusually fine leaves. Five were immersed as before in a solution of one part to 131,250 of water ( $1 \mathrm{gr}$. to $300 \mathrm{oz}$.), so that each reeeived $\frac{1}{4500}$ of a grain, or' $0135 \mathrm{mg}$. After an immersion of $25 \mathrm{~m}$. all five leaves were much infleeted. After $1 \mathrm{hr} .25 \mathrm{~m}$. one leaf had all but eight tentaelos infleeted; the second, all but three; the third, all but five; the fourth, all but twenty-three; the fifth, on the other hand, never had more than twenty-four infleeted. Of the eorresponding five leaves in water, one had seven, a seeond two, a third ten, a fourth one, and a fifth none inflected. Let it be observed what a eontrast is presented between these latter leaves and those in the solution. I counted the glands on the second leaf in the solution, and the number was 217 ; assuming that the threc tentacles whieh did not beeome infleeted absorbed nothing, we find that each of the 214 remaining glands eould have absorbed only $\frac{1}{1027200}$ of a grain, or $0000631 \mathrm{mg}$. The third leaf bore 236 glands, and subtraeting the five which did not beeome infleeted, eaeh of the remaining 231 glands could have absorbed only $\frac{1}{1108500}$ of a grain (or $0000584 \mathrm{mg}$.), and this amount sufficed to eause the tentaeles to bend.

Twelve leaves were tried as before in a solution of one part to 175,000 of water $\left(1 \mathrm{gr}\right.$. to $400 \mathrm{oz}$.), so that each leaf received $\frac{1}{6400}$ of a grain (.0101 mg.). My plants were not at the time in a good state, and many of the leaves were young and pale. Nevertheless, two of them had all their tentacles, exeept three or four, elosely infleeted in under $1 \mathrm{hr}$. Seven were eonsiderably affeeted, some within $1 \mathrm{hr}$., and others not until $3 \mathrm{hrs}$., $4 \mathrm{hrs} .30 \mathrm{~m}$., and $8 \mathrm{hrs}$. had elapsed; and this slow aetion may be attributed to the leaves being young and pale. of these nine leaves, four had their blades well infleeted, and a fifth slightly so. The three remaining leaves were not affeetcd. With respeet to the twelve eorresponding leaves in water, not one had its blade inflected; after from 1 to 2 hrs. ono had thirteen of its outer tentaeles infleeted; a seeond six, and four others either onc or two inflected. After $8 \mathrm{hrs}$. the outer tentaeles did not beeome more inflected; whereas this oeeurred. with the leaves in the solution. I record in my notes that 
after the $S$ hrs. it was impossible to comparc the two lots, and doubt for an instant the power of the solution.

Two of the above lcaves in the solution had all their tentacles, except three and four, inflected within an hour. I counted thcir glands, and, on the same principle as beforc, cach gland on onc leaf could have absorbed only $\frac{1}{116+800}$, and on the othcr lcaf only $\frac{1}{147_{2000}}$, of a grain of the phosphate.

Twenty leaves werc immerscd in the usual manner, each in thirty minims of a solution of one part to 218,750 of water ( $1 \mathrm{gr}$. to 500 oz.). So many leaves werc tried bccause I was then under the false impression that it was incredible that any wcaker solution could produce an effect. Each leaf received $\frac{1}{\text { s000 }}$ of a grain, or $0081 \mathrm{mg}$. The frst cight leaves which I tried both in the solution and in water were either young and palc or too old; and the weather was not hot. They were hardly at all affected; nevertheless, it would be unfair to exclude them. I then waited until I got eight pairs of fine leaves, and the weather was favourable; the temperature of the loom where the leaves were immersed varying from $75^{\circ}$ to $81^{\circ}\left(23^{\circ} \mathrm{S}\right.$ to $27^{\circ .2}$ Cent.). In another trial with four pairs (included in the abore twenty pairs), the temperature in my room was rathcr.low, about $60^{\circ}$ ( $15^{\circ} .5$ Cent.); but the plants had been kept for several days in a very warm greenhouse and thus rendered extremely sensitive. Special precautions were taken for this set of experiments; a chemist weighed for mc a grain in an excellent balance; and fresh water, given me by Professor Frankland, was carefully measured. The leaves were selected from a largc number of plants in the following manner: the four finest were immersed in water, and the next four finest in the solution, and so on till the twenty pairs were complete. The water specimens were thus a little favoured, but they did not undergo more illflection than in the previous cases, comparatircly with those in the solution.

Of the twenty leaves in the solution, eleven bccame inflected within $40 \mathrm{~m}$.; eight of them plainly and three rather doubtfully; but the latter had at lcast twenty of their outer tentacles inflected. Owing to the weakness of the solution, inflection occurred, except in No. 1, much more slowly than in the previous trials. The condition of the elcven lcaves which were considerably inflected will now be given at stated intervals, always leckoning from the time of immersion :-

(1) After only $8 \mathrm{~m}$. a lal'gc number of tentacles inflected, and after $17 \mathrm{~m}$. all but fiftcen; after $2 \mathrm{hrs}$. all but eight in- 
flectcd, or plainly sub-inflectcd. After $4 \mathrm{hr}$. the tentacles began to re-expand, and such prompt re-expansion is unusual; after $7 \mathrm{hrs}, 30 \mathrm{~m}$. they wcre almost fully re-expanded.

(2) After $39 \mathrm{~m}$. a large number of tentacles inflected; after 2 hrs. $18 \mathrm{~m}$. all but twenty-five inflected; after 4 hrs. $17 \mathrm{~m}$. all but sixteen inflected. The leaf remained in this state for many hour's.

(3) After $12 \mathrm{~m}$. a considcrable amount of inflection; after 4 hr's. all the tentacles inflected exccpt those of the two outer rows, and the leaf remained in this state for some time; after $23 \mathrm{hrs}$, began to re-expand.

(4) After $40 \mathrm{~m}$. much inflection; after 4 hrs. $13 \mathrm{~m}$. fully half the tentacles inflected; after $23 \mathrm{hrs}$, still slightly inflected.

(5) After $40 \mathrm{~m}$. much inflection; after $4 \mathrm{hrs} .22 \mathrm{~m}$. fully half the tentacles inflected; after 23 hr's. still slightly inflected.

(6) After $40 \mathrm{~m}$. some inflection; after 2 hrs. $18 \mathrm{~m}$. about twenty-eight outer tentacles inflceted; after 5 hrs. $20 \mathrm{~m}$. about a third of the tentacles inflected; after 8 hrs. much re-expanded.

(7) After $20 \mathrm{~m}$. some inflection; after 2 hrs. a considerable number of tentacles inflected; after 7 hrs. $45 \mathrm{~m}$. began to re-expand.

(8) Aftcr $38 \mathrm{~m}$. twenty-eight tentacles inflected; after 3 hrs. $45 \mathrm{in}$. thirty-three inflected, with most of the submarginal tentacles sub-inflected; continued so for two days, and then partially re-expanded.

(9) After $38 \mathrm{~m}$. forty-two tentaclcs inflected; aftcr $3 \mathrm{hrs}$, $12 \mathrm{~m}$. sixty-six inflected or sub-inflected; after 6 hrs. $40 \mathrm{~m}$. all but twenty-four inflected or sub-inflected; after 9 hr's. $40 \mathrm{~m}$. all but seventeen inflected; after 24 hrs. all but four inflected or sub-inflected, only a few being closely inflected; after $27 \mathrm{hrs}$. $40 \mathrm{~m}$. the blade inflectcd. The leaf remained in this state for' two days, and then began to re-expand.

(10) After $38 \mathrm{~m}$. twenty-one tentacles inflected; after 3 hrs. $12 \mathrm{~m}$. forty-six tentacles inflccted or sub-inflected; after 6 hrs. $40 \mathrm{~m}$. all but sercnteen inflected, though none closcly; aftcr. 24 hrs. cvery tentacle slightly curved inwards; after 27 hrs. $40 \mathrm{~m}$. blade strongly inflected, and so continucd for two days, and then the tentacles and blade very slowly rec-cxpanded.

(11) This fine dark r'cd and rather old leaf, though not very large, bore an cxtraordinary number of tentacles (viz. 252), and hehaved in an anomalous manner. After 6 hrs. $40 \mathrm{~m}$. only the short tentacles round the outcr part of the disc were inflected, forming a ring, as so often occurs in from 8 to $24 \mathrm{hrs}$. witl leaves both in water and the weaker solutions. But after 9 hrs. 
$40 \mathrm{~m}$. all the outer tentacles except twenty-five were infleeted, as was the blade in a strongly marked mamer. After 24 hrs. every tentacle except one was closely infleeted, and the blade was eompletely doubled over. Thus the leaf remained for two days, when it began to re-expand. I may add that the three latter leaves (Nos. 9, 10, and 11) were still somewhat infleeted after three days. The tentacles in but few of these eleven leaves became closely inflected within so short a time as in the previous experiments with stronger solutions.

We will now turn to the twenty corresponding leaves in water. Nine had none of their outer tentacles inflected; nine others had from one to three inflected; and these re-expanded after 8 hrs. The remaining two leaves were moderately affeeted; one having six tentacles infleeted in $34 \mathrm{~m}$. ; the other twenty-three inflected in $2 \mathrm{hrs} .12 \mathrm{~m}$; and both thus remained for 24 hrs. None of these leaves had their blades infleeted. So that the contrast between the twenty leaves in water and the twenty in the solution was very great, both within the first hour and after from 8 to $12 \mathrm{hrs}$. had elapsed.

Of the leaves in the solution, the glands on leaf No. 1, whieh in 2 hrs. had all its tentacles except eight inflected, were counted and found to be 202. Subtracting the eight, each gland could have received only the $\frac{1}{1552000}$ of a grain (.0000 $111 \mathrm{mg}$.) of the phosphate. Leaf No. 9 had 213 tentacles, all of which, with the exception of four, were inflectcd after 24 hrs., but none of them elosely; the blade was also inflected; each gland could liave received only the $\frac{1}{1872000}$ of a grain, or 0000387 mg. Lastly, leaf No. 11, which had after 24 hrs. all its tentaeles, exeept one, elosely infleeted, as well as the blade, bore the unusually large number of 252 tentacles; and on the same principle as before, each gland could have absorbed only the $\overline{200}+\frac{1}{000}$ of a grain, or $0000322 \mathrm{mg}$.

With respect to the following experiments, I must premise that the leaves, both those placed in the solutions and in water, were taken from plants whieh had been kept in a very warm greenhouse during the winter. They were thus rendered extremely sensitive, as was shown by water exciting them mueh more than in the previous experiments. Before giving my observations, it may be well to remind the reader that, judging from thirty-one fine leaves, the average number of tentacles is 192, and that the outer or exterior ones, the morements of whieh are alone significant, are to the short ones on the dise in the proportion of about sixteen to nine. 
Four lenves were immersed as before, each in thirty minims of a solution of one part to 328,125 of water ( $1 \mathrm{gr}$. to $750 \mathrm{oz}$.). Each leaf thus received $\frac{\text { ? }}{12000}$ of a grain ( $0054 \mathrm{mg}$.) of tho salt; and all four were greatly inflected.

(1) After 1 lir. all the outer tentrcles but one inflected, and the blade greatly so ; after 7 hrs. began to re-expand.

(2) After I hr. all the outer tentacles but eight inflected; after 12 hrs, all re-expanded.

(3) After $1 \mathrm{hr}$. much inflection; after 2 hrs. $30 \mathrm{~m}$, all the tentacles but thirty-six inflected; after 6 hrs. all but twenty-two inflected; after $12 \mathrm{hrs}$. partly re-expanded.

(4) After $1 \mathrm{hr}$. all the tentacles but thirty-two inflected; after 2 hrs. $30 \mathrm{~m}$. all but twenty-one inflected; after 6 hrs. almost re-expancled.

Of the four corresponding leaves in water:-

(1) After I hr. forty-five tentacles inflected; but after 7 hrs. so maily had re-expanded that only ten remained much inflected.

(2) After I hr. scren tentacles infleeted; these were almost re-expanded in 6 hrs.

(3) and (4) Not affected, except that, as usual, after 11 hrs. the short tentacles on the border's of the disc formed a ring:

There can, therefore, be no cloubt about the efficiency of the above solution; and it follows as before that each gland of No. I could have absorbed only $\frac{1}{24.12000}$ of a grain (0000268 mg.) and of No. 2 only $\frac{1}{2+\frac{1}{60000}}$ of $\Omega$ grain ( $0000263 \mathrm{mg}$.) of the phosphate.

Seven leaves were inmersed, each in thirty minims of a solution of one part to 437,500 of water ( 1 gr. to 1000 oz.). Eneh leaf thus received $\frac{1}{16000}$ of a grain (.00405 mg.). The day was warm, and the lcaves were very fine, so that all circumstances were favourable.

(1) After $30 \mathrm{~m}$. all the outer tentaeles except five inflected, and most of them closely; after I hr. blade slightly infleeted; after 9 his. $30 \mathrm{~m}$. began to re-expand.

(2) After $33 \mathrm{~m}$. all the outer tentaeles but twenty-five inflected, and blade slightly so; atter $1 \mathrm{hr} .30 \mathrm{~m}$. blade strongly inflected and remained so for 24 hr's.; but some of the tentacles had then r'c-expanded.

(3) After $1 \mathrm{hr}$. all but twelve tentacles inflected; after 2 lurs. $30 \mathrm{~m}$. all but nine inflected; and of tho inflected tentacles all excepting four closely; blade slightly inflected. After 8 hrs. blade quite doubled up, and now all the tentacles excepting 
eight closely inflected. The lcaf remained in this state for two days.

(4) After 2 hrs. $20 \mathrm{~m}$. only fifty-ninc tentacles inflected; but after 5 lurs. all tho tentacles elosely inflected excepting two whieh were not affected, and cleven which were only sub-inflected; aftcr 7 hrs. blade eonsiderably inflected; after 12 hrs. much re-expansion.

(5) After 4 hirs. all the tentacles but fourteen infleeted; after 9 hrs. $30 \mathrm{~m}$. beginning to $\mathrm{l}^{\mathrm{z}} \mathrm{e}$-cxpand.

(6) After 1 hr. thirty-six tentaeles inflected; after 5 hrs. all but fifty-four inflected; after 19 hrs. eonsiderable re-cxpansion.

(7) After $4 \mathrm{hrs} .30 \mathrm{~m}$. only thirty-five tentacles inflected or sub-inflceted, and this small amount of infleetion never increased.

Now for the seven eorresponding lenves in water:-

(1) After 4 hrs. thirty-eight tentaeles inflectcd; but after
7 hrs. these, with the exception of six, re-expanded.

(2) After 4 hrs. $20 \mathrm{~m}$. twenty inflected; these after 9 hrs. partially re-expanded.

(3) After 4 hrs. five infleeted, which bcgan to re-expand after 7 lirs.

(4) After 24 hrs. one infleeted.

(5), (6) and (7) Not at all affeeted, though observed for 24 hrs., excepting the short tentrales on the borders of the dise, whieh as usual formed a ring.

A comparison of the leares in the solution, espeeially of the first five or even six on the list, with those in the water, aftcr $1 \mathrm{hr}$. or after $4 \mathrm{hrs}$, and in a still more marked degree after 7 hrs. or 8 hrs., could not leave the least doubt that the solution had produced a great effect. This was shown not only by the rastly greater number of infleeted tentacles, but by the degree or elosencss of their inflection, and by that of their blades. Yet each gland on leaf No. 1 (whieh bore 255 glands, all of whieh, exeepting five, were inflected in $30 \mathrm{~m}$.) eould not have reecived more than one-four-millionth of a grain ( 0000162 mg.) of the salt. Again, each gland on leaf No. 3 (which bore 233 glands, all of which, exeept nine, were inflected in 2 hr's. $30 \mathrm{~m}$.) could have reccived at most only the $\overline{35 \mathrm{~s} \pm 000}$ of a grain, or $0000181 \mathrm{mg}$.

Four lcaves wcre immcrsed as beforc in a solution of one part to 656,250 of water ( $1 \mathrm{gr}$. to $1500 \mathrm{oz}$.) ; but on this oecasion I happened to selcet lcaves which were very little sensitive, as on other oecusions I chanecd to seleet unusually scnsitire leaves. The lcaves were not more afiected after 12 hrs. than 
the four corresponding ones in water; but after 24 hrs. they were slightly more inflected. Such evidence, however, is not at all trustworthy.

Twelve leaves were immersed, each in thirty minims of a solution of one part to $1,312,500$ of water $(1 \mathrm{gr}$. to $3000 \mathrm{oz}$.) ; so that each leaf received $\frac{1}{48000}$ of arain $(.00135 \mathrm{mg}$.). The leaves werc not in very good condition; four of them were too old and of a dark red colour; four were too pale, yet onc of these latter acted well; the four others, as far as could be told by the eyc, seemed in excellent condition. The result was as follows:-

(1) This was a pale leaf; after $40 \mathrm{~m}$. about thirty-eight tentacles inflected; after $3 \mathrm{hrs} .30 \mathrm{~m}$. the blade and many of the outer tentacles inflected; after 10 hrs. $15 \mathrm{~m}$. all the tentacles but seventeen inflected, and the blade quite doubled up; after $21 \mathrm{hrs}$. all the tentacles but ten more or less inflected. Most of them were closely inflected, but twenty-five were only sub-
inflected.

(2) After $1 \mathrm{hr} .40 \mathrm{~m}$. twenty-five tentacles inflected; after 6 hrs. all but twenty-one inflected; after 10 hrs. all but sixteen more or less inflected; after 24 hrs. re-expanded.

(3) After 1 hr. $40 \mathrm{~m}$. thirty-five inflected; after 6 hrs. " $a$ large number" (to quote my own memorandum) inflected, but from want of time they were not counted; after 24 hrs. re-

(4) After $1 \mathrm{hr} .40 \mathrm{~m}$. about thirty inflected; after $6 \mathrm{hrs}$. " a large number all round the leaf" inflected, but they were not counted; after 10 hrs. began to re-expand.

(5) to (12) These werc not more inflected than leaves often are in water, having respectively $16,8,10,8,4,9,14$, and 0 tentacles inflected. Two of these leaves, however, were remarkable from having their blades slightly inflected after $6 \mathrm{hrs}$.

With respect to the twelve corresponding leavos in water, (1) had, after $1 \mathrm{hr}$. $35 \mathrm{~m}$., fifty tentacles inflected, but after 11 hrs. only twenty-two remaincd so, and these formed a group, with the blade at this point slightly inflocted. It appoared as if this lenf had boen in some manner accidentally excited, for instance by a particle of animal matter which was dissolved by tho wator. (2) After $1 \mathrm{hr} .45 \mathrm{~m}$. thirty-two tentacles inflected, but after 5 hrs. $30 \mathrm{~m}$. only twenty-five inflected, and these after $10 \mathrm{hrs}$. all re-cxpanded; (3) after $1 \mathrm{hr}$. twenty-five inflected, which after 10 hrs. $20 \mathrm{~m}$. were all re-expanded; (4) and (5) aftcr $1 \mathrm{hr} .35 \mathrm{~m}$. six and scven tentacles inflected, which re-expanded aftcr 11 hrs.; (6), (7) and (8) from one to thrco inflected, which 
soon re-expanded; (9), (10), (11) and (12) none infleeted, though observed for twenty-four hours.

Comparing the states of the twelve leaves in water with those in the solution, there eould be no doubt that in the latter a larger number of tentaeles were infleeted, and these to a greater degree; hut the evidenee was by no means so elear as in the former experiments with stronger solutions. It deserves attention that the infleetion of four of the leaves in the solution went on inereasing during the first 6 hrs., and with some of them for a longer time; whereas in the water the infleetion of the three leaves whieh were the most affeeted, as well as of all the others, began to decrease cluring this same interval. It is also remarkable that the blades of three of the leaves in the solution were slightly infleeted, and this is a most rare event with leaves in water, though it oeeurred to a slight extent in one (No. 1), which seemed to have been in some manner reeidentally exeited. All this shows that the solution produeed some effeet, though less and at a mueh slower rate than in the previous eases. The small effeet produeed may, however, be aeeounted for in large part by the majority of the leaves having been in a poor eondition.

Of the leaves in the solution, No. 1 hore 200 glands and reeeived $\frac{1}{4.5000}$ of a grain of the salt. Subtrneting the seventeen tentaeles which were not infleeted, ench gland eould have ahsorbed only the $\frac{1}{875000}$ of a grain (-00000738 $\mathrm{ng}$.). This amount eansed the tentrele bearing ench gland to be greatly infleeted. 'The blade ras also infleeted.

Lastly, eight lenves were immersed, eneh in thirty minims of a solution of one part of the phosphate to $21,875,000$ of water ( $1 \mathrm{gr}$ : to $5000 \mathrm{oz}$.). Eaeh leaf thus reeeived $\frac{1}{50000}$ of a grain of the salt, or $00081 \mathrm{mg}$. I took espeeial pains in seleeting the finest leares from the hot-house for immersion, both in the solution and the water, and almost all proved extremely sensitive. Begiming as before with those in the solution:-

(1) After 2 hrs. $30 \mathrm{~m}$. all the tentaeles but trenty-tro infleeted, but some only sulb-infleeted; the blade much infleeted; after 6 hrs. $30 \mathrm{~m}$. all but thirteen infleeted, with the blade immensely infleeted; and remained so for 48 hr's.

(2) No ehange for the first 12 hrs., but after 24 hrs. all the tentreles infleeted, excepting those of the outermost row, of whiel only cleven were inflested. The infleetion eontinued to inerease, and after $48 \mathrm{hrs}$. all the tentreles except three were infleeted, 
and most of them rather closely, four or five being only subinflected.

(3) No change for the first 12 hrs.; but after 24 hrs. all the tentacles excepting those of the outermost row were sub-inflected, with the blade inflected. After $36 \mathrm{hrs}$. blade strongly inflected, with all the tentacles, except three, inflected or sub-inflected. After 48 hrs. in the same state.

(4) to (S) These leaves, after 2 hrs. $30 \mathrm{~m}$, had respectively $32,17,7,4$, and 0 tentaeles inflected, most of which, after a few hours, re-expanded, with the exception of No.4, which retained its thirty-two tentacles inflected for 48 hrs.

Now for the eight corresponding leaves in water :-

(1) After 2 hrs. $40 \mathrm{~m}$. this had twenty of its outer tentacles inflected, five of which re-expanded after 6 hrs. $30 \mathrm{~m}$. After 10 hrs. $15 \mathrm{~m}$. a most unusual circumstance occurred, namely, the whole blade became slightly bowed towards the footstalk, and so remained for 48 hrs. The exterior tentacles, excepting those of the three or four outermost rows, were now also inflected to an unusual degree.

(2) to (8) These leaves, after 2 hrs. $40 \mathrm{~m}$., had respectively 42, $12,9,8,2,1$, and 0 tentacles inflected, which all re-expanded within 24 hrs., and most of them within a much shorter time.

When the two lots of eight leaves in the solution and in the water were compared after the lapse of 24 hrs., they undoubtedly differed much in apperance. The few tentacles on the leaves in water which were inflected had after this interval reexpanded, with the exception of one leaf; and this presented the very unusual case of the blade being somewhat inflected, though in a degree hardly approaching that of the two leaves in the solution. Of these latter leaves, No. 1 had almost all its tentacles, together with its blade, inflected after an immersion of $2 \mathrm{hrs} .30 \mathrm{~m}$. Leaves No. 2 and 3 were affectcd at a much slower rate; but after from 24 hrs. to 48 hrs. almost all their tentacles were closcly inflected, and the blade of one quite doubled up. We must therefore admit, incredible as the fact may at first appear, that this extremely wcak solution acted on the more sensitive leaves; each of which received only the $\frac{1}{80000}$ of a grain (.00081 ing.) of the phosphate. Now, leaf No. 3 bore 178 tentacles, and subtracting the three which were not inflected, each gland could have absorbed only the $\frac{\overline{1+00000}}{1.000}$ of a grain, or $00000463 \mathrm{mg}$. Leaf No. 1, which was strongly acted on within 2 hrs. $30 \mathrm{~m}$., and had all its onter tentaeles, except thirteen, inflected within $6 \mathrm{hrs}, 30 \mathrm{~m}$, bore 260 tentacles; and on the same principlo as before, eael gland could have 
absorbed only $\frac{7}{1070000}$ of $a$ grain, or $\cdot 00000328 \mathrm{mg}$.; and this exeessively minute amount suffieed to eause all the tentreles bearing these glands to be greatly infleeted. The blade was also infleeted.

Summary of the Results with Phosphate of Ammonia.The glands of the disc, when excited by a half-minim drop (0296 ml.), containing $\frac{1}{38+\pi}$ of a grain (.0169 $\mathrm{mg}$.) of this salt, transmit a motor impulse to the exterior tentacles, causing them to bend inwards. A minute drop, containing $T \frac{1}{5360}$ of a grain (.000423 $\mathrm{mg}$.$) , if held for a few seconds in contact with a$ gland, causes the tentacle bearing this gland to be inflected. If a leaf is left immersed for a few hours, and sometimes for a shorter time, in a solution so weak that each gland can absorb only the $\frac{1}{19 \frac{1}{60000}}$ of a grain $(\cdot 00000328 \mathrm{mg}$.), this is enough to excite the tentacle into movement, so that it becomes closely inflected, as does sometimes the blade. In the general summary to this chapter a few remarks will be added, showing that the efficiency of such extremely minute doses is not so incredible as it must at first appear.

Sulphate of Ammonia.-The few trials made with this and the following five salts of ammonia were undertaken merely to solution of one part of the sulphate of ammonia to 437 of water were plaeed on the dises of seven leaves, so that each reeeived $\frac{1}{960}$ of $\Omega$ grain, or $\cdot 0675 \mathrm{mg}$. After $1 \mathrm{hr}$. the tentaeles of five of them, as well as the blade of one, were strongly infleeted. 'I he leaves were not afterwards olserved.

Citrate of Ammonir.- Half-minims of a solution of one part to 437 of water were plneed on the dises of six lenves. In $1 \mathrm{hr}$. the short outer tentreles round the dises were $\Omega$ little infleeted, with the glands on the dises blaekened. After 3 hrs. $25 \mathrm{~m}$. one leaf had its blade inflected, but none of the exterior tentaeles. All six leavos remained in nearly the same state during the day, the sulmarginal tentacles, however, 
beconing morc inflected. After 23 hrs. thrce of the leaves had their blades somewhat inflected; and the submarginal tentacles of all considerably inflected, but in none wcre the two, three, or four outer rows affected. I have rarcly scen cases like this, except from the action of a dccoction of grass. The glands on the discs of the abovc lcaves, instead of bcing almost black, as after the first hour, wcre now after 23 hrs. very pale. I next tried on four leaves half-minims of a weakcr solution, of one part to 1312 of water ( $1 \mathrm{gr}$. to $3 \mathrm{oz}$.) ; so that each reccived $\frac{2}{2580}$ of a grain $(.0225 \mathrm{mg}$ ). After 2 hrs. $18 \mathrm{~m}$. the glands on the disc were very dark-coloured; after 24 his. two of the leaves were slightly affected; the other two not at all.

Acetute of Ammonia.-Half-minims of a solution of about one part to 109 of water werc placed on the discs of two lcaves, both of which were actcd on in 5 hrs. $30 \mathrm{~m}$, and after 23 hrs. had every single tentaclc closely inflectcd.

Oxalate of Ammonia.-Half-minims of a solution of onc part to 218 of water were placed on two leaves, which, after 7 hrs., became moderately, and after 23 hrs. strongly, inflccted. Two other leaves wcre tried with a wcaker solution of one part to 437 of water; one was strongly inflected in $7 \mathrm{hrs}$; the other not until 30 hrs. had elapsed.

Turtrute of Ammonia.- Half-minims of $\Omega$ solution of one part to 437 of water werc placed on the dises of five leaves. In $31 \mathrm{~m}$. there was a tracc of inflcction in the extcrior tcntacles of some of the leaves, and this bccame more dccided after $1 \mathrm{hr}$. with all the lcaves; but the tentacles wcre never closcly inflected. After 8 hrs. $30 \mathrm{~m}$. they bcgan to re-expand. Next morning, after 23 hrs., all werc fully re-cxpanded, excepting one which was still slightly inflected. The shortness of the period of inflection in this and the following casc is remarkable.

Chloride of Ammonium. - Half-minims of a solution of one part to 437 of water were placed on the discs of six lcaves. A decided degrec of inflection in the outcr and submarginal tentacles was perceptiblc in $25 \mathrm{~m}$.; and this increased during the next thrce or four hours, but never bccame strongly marked. After only $8 \mathrm{hr} s .30 \mathrm{~m}$. the tentacles began to r'c-cxpand, and by the ncxt morning, after 24 hrs., wcre fully recxpanded on four of the lcarcs, but still slightly inflected on two.

\section{General Summary and Conctuding Remarlis on the Salts of Ammonia.-We have now seen that the nime}


salts of ammonia whieh were tried, all cause the inflection of the tentaeles, and often of the blade of the leaf. As far as can be aseertained from the superficial trials with the last six salts, the eitrate is the least powerful, and the phosphate eertainly by far the most. The tartrate and chloride are remarkable from the short duration of their aetion. The relative effieieney of the earbonate, nitrate, and phosphate, is shown in the following table by the smallest amount whieh suffiees to eause the inflection of the tentreles.

\begin{tabular}{|c|c|c|c|}
\hline Solutions, how applied. & $\begin{array}{c}\text { Carbonate of } \\
\text { Ammonia. }\end{array}$ & $\begin{array}{l}\text { Nitrate of } \\
\text { Ammonia. }\end{array}$ & $\begin{array}{l}\text { Pliosphate of } \\
\text { Ammonia. }\end{array}$ \\
\hline $\begin{array}{l}\text { Placed on the glands of } \\
\text { the dise, so as to net } \\
\text { indirectly on the outer } \\
\text { tentacles. }\end{array}$ & $\begin{array}{l}{ }^{\frac{1}{1}} \text { of of a } \\
\text { grain, or } \\
.0675 \mathrm{mg} .\end{array}$ & $\begin{array}{l}\frac{1}{2100} \text { of a } \\
\text { grain, or } \\
027 \mathrm{mg} \text {. }\end{array}$ & $\begin{array}{l}\frac{1}{3870} \text { of a } \\
\text { grain, or } \\
.0169 \mathrm{mg} \text {. }\end{array}$ \\
\hline $\left.\begin{array}{l}\text { Applied for a few se- } \\
\text { conds dircetly to the } \\
\text { gland of an outer } \\
\text { tentacle . . . . }\end{array}\right\}$ & $\begin{array}{l}\frac{1}{\pi+m} \text { of a } \\
\text { grain, or } \\
.00 \pm 45 \mathrm{mg} \text {. }\end{array}$ & $\begin{array}{l}\frac{1}{2880 \pi} \text { of } \mathrm{a} \\
\text { grain, or } \\
.0025 \mathrm{mg} \text {. }\end{array}$ & $\begin{array}{l}\frac{1}{1536 m 0} \text { of a } \\
\text { grain, or } \\
.000+23 \mathrm{mg} \text {. }\end{array}$ \\
\hline $\left.\begin{array}{l}\text { Leaf immersed, with } \\
\text { time allowed for each } \\
\text { gland to absorb all } \\
\text { that it can . . . }\end{array}\right\}$ & $\begin{array}{l}\frac{1}{268800} \text { of } \mathrm{a} \\
\text { grain, or } \\
00024 \mathrm{mg} .\end{array}$ & $\begin{array}{c}\frac{1}{691200} \text { of a } \\
\text { grain, or } \\
.0000937 \mathrm{mg} .\end{array}$ & $\begin{array}{l}\frac{1}{19760000} \text { of a } \\
\text { grain, or } \\
.00000325 \mathrm{mg} \text {. }\end{array}$ \\
\hline $\begin{array}{l}\text { Amount absorbed by a } \\
\text { gland which suffices } \\
\text { to cause the aggre- } \\
\text { gation of the proto- } \\
\text { plasm in the adjoin- } \\
\text { ing cells of the ten- } \\
\text { tacles. }\end{array}$ & $\begin{array}{c}\frac{1}{734 \pi 00} \text { of a } \\
\text { grain, or } \\
.00048 \mathrm{mg} .\end{array}$ & - & \\
\hline
\end{tabular}

From the experiments tried in these three different ways, we see that the carbonate, which eontains 23.7 per eent. of nitrogen, is less efficient than the nitrate, which contains 35 per cent. The phosphate contains less nitrogen than either of these salts, namely, only $21 \cdot 2$ per cent., and yet is far more 
effieient; its power no doubt depending quite as mueh on the pliosphorus as on the nitrogen which it eontains. We may infer that this is the ease, from the energetie manner in which bits of bone and phosphate of lime affect the leaves. The infleetion excited by the other salts of ammonia is probably due solely to their nitrogren,--on the same principle that nitrogenous organic fluids aet powerfully, whilst non-nitrogenous organic fluids are powerless. As sueh minute doses of the salts of ammonia affeet the leaves, we may feel almost sure that Drosera absorbs and profits by the amount, though small, which is present in rain-water, in the same manner as other plants absorb these same salts by their roots.

The smallness of the doses of the nitrate, and more espeeially of the phosphate of ammonia, whieh eause the tentaeles of immersed leaves to be inflected, is perhaps the most remarkable faet reeorded in this volume. When we see that much less than the millionth* of a grain of the phosphate, absorbed by a gland of one of the exterior tentaeles, causes it to bend, it may be thought that the effeets of the solution on the glands of the dise have been overlooked; namely, the transmission of a motor impulse from them to the exterior tentaeles. No doubt the movements of the latter are thus aided; but the aid thus rendered must be insignifieant; for we know that a drop eontaining as much as the $\frac{1}{38}$ of a grain pląeed on the disc is only just able to enuse the onter tentaeles of a highly sensitive leaf to bend. It is eer-

* It is scarcely possible to renliso what a million means. The best illustration which I have met with is that given by Mr. Croll, who says, - Take a narrow strip of paper $83 \mathrm{ft} .4 \mathrm{in}$. in longtl, and streteh it along the wall of a large hall; then matk off at one end the tentli of an inels. 'This tenth will represent a hundrod, and tlue entire strip a million. 
tainly a most surprising fact that the $\frac{1}{195000}$ of a grain, or in round numbers the one-twenty-millionth of a grain (.0000033 mg.), of the phosphate should affect any plant, or indeed any animal; and as this salt contains 35.33 per cent. of water of crystallisation, the efficient elements are reduced to $\frac{1}{30535126}$ of a grain, or in round numbers to one-thirty-millionth of a grain (•00000216 mg.). The solution, moreover, in these experiments was diluted in the proportion of one part of the salt to $2,187,500$ of water, or one grain to $5000 \mathrm{oz}$. The reader will perhaps best realise this degree of dilution by remembering that $5000 \mathrm{oz}$. would more than fill a 31-gallon cask; and that to this large body of water one grain of the salt was arlded ; only half a drachm, or thirty minims, of the solution being poured over a leaf. Yet this amount sufficed to cause the inflection of almost every tentacle, and often of the blade of the leaf.

I am well aware that this statement will at first appear incredible to almost every one. Drosera is far from rivalling the power of the spectroscope, but it can detect, as shown by the movements of its leaves, a very much smaller quantity of the phosphate of ammonia than the most skilful chemist can of any substance.* My results were for a long time incredible

* When my first observations were made on the nitrate of ammonia, fourteen years ago, the powers of the spectroscope had not been discovered; and I felt all the greater interest in the then unrivalled powers of Drosern. Now the spectroscope has altogether beaten Drosera; for according to Bunsen and Kirchloff probably less than one $\frac{1}{20000000}$ of a grain of solium can be thus detecter (see Balfour Stewart,
'Treatise on Heat,' 2nd edit. 1871 , p. 228). With respect to ordinary chemical tests, I gather from Dr. Alfred Taylor's work on 'Poisons' that about $\frac{1}{5000}$ of a grain of arsenic, $\frac{1}{100}$ of $\mathrm{a}$ grain of prussic acil, $\frac{1}{10}$ of iodine, and $\frac{1}{2000}$ of tartarised antimony, can be detected; but the power of detection depends much on the solutions under trial not being extremely weal. 
even to myself, and I anxiously sought for every souree of error. The salt was in some cases weighed for me by a chemist in an excellent balanee; and fresh water was measured many times with eare. The observations were repeated during several years. Two of my sons, who were as ineredulous as myself, eompared sereral lots of leaves simultaneously immersed in the weaker solutions and in water, and declared that there eould be no doubt about the differenee in their appearanee. I hope that some one may hereafter be induced to repeat my experiments; in this ease he should seleet young and vigorous leaves, with the glands surrounded by abundant secretion. The leaves should be earefully cut off and laid gently in watch-glasses, and a measured quantity of the solution and of water poured over eaeh. The water used must be as absolutely pure as it can be made. It is to be especially observed that the experiments with the weaker solutions ought to be triel after several days of very warm weather. Those with the weakest solutions should be made on plants whieh have been kept for a considerable time in a warm greenhouse, or cool hothouse; but this is by no means neeessary for trials with solutions of moderate strength.

I beg the reader to observe that the sensitiveness or irritability of the tentacles was ascertained by three different methods-indireetly by clrops plaeed on the disc, directly by drops applied to the glands of the outer tentacles, and by the immersion of whole leaves; and it was found by these three methods that the nitrate was more powerful than the earbonate, and the phosphate much more powerful than the nitrate; this result boing intelligible from the difference in the amount of nitrogen in the first two salts, and from the presenee of phosphorus in the third. It may aid the 
reader's faith to turn to the experiments with a solution of one grain of the phosphate to $1000 \mathrm{oz}$. of water, and he will there find decisive evidence that the one-four-millionth of a grain is sufficient to cause the inflection of a single tentacle. There is, therefore, nothing very improbable in the fifth of this weight, or the one-twenty-millionth of a grain, acting on the tentacle of a highly sensitive leaf. Again, two of the leaves in the solution of one grain to 3000 oz., and three of the leaves in the solution of one grain to 5000 oz., were affected, not only far more than the leaves tried at the same time in water, but incomparably more than any five leaves which can be picked out of the 173 observed by me at different times in water.

There is nothing remarkable in the mere fact of the one-twenty-millionth of a grain of the phosphate, dissolved in above two-millionth of its weight of water, being absorbed by a gland. All physiologists admit that the roots of plants absorb the salts of ammonia brought to them by the rain; and fourteen gallons of rain-water contain* a grain of ammonia, therefore only a little more than twice as much as in the weakest solution employed by me. The fact which appears truly wonderful is, that the one-twentymillionth of a grain of the phosphate of ammonia (including less than the one-thirty-millionth of efficient matter), when absorbed by a gland, should induce some change in it, which leacls to a motor impulse being transmitted down the whole length of the tentacle, causing the basal part to bend, often through an angle of above 180 degrees.

Astonishing as is this result, there is no soumd reason

* Miller's 'Elements of Chemistry', part ii. p. 107, 3ri edit. $156 t$. 
why we should reject it as incredible. Prof. Donders, of Utrecht, informs me that from experiments formerly made by him aud Dr. De Ruyter, he inferred that less than the one-millionth of a grain of sulphate of atropine, in an extremely diluted state, if applied directly to the iris of a dog; paralyses the muscles of this organl. But, in fact, every time that we perceive an odour, we have evidence that infinitely smaller particles act on our nerres. When a dog stands a quarter of a mile to leeward of a deer or other animal, and perceives its presence, the odorous particles produce some change iu the olfactory nerves; yet these particles must be infinitely smaller* than those of the phosphate of ammonia weighing the one-twenty-millionth of a grain. These nerves then transmit some influence to the brain. of the dog, which leads to action on its part. With Drosera, the really marvellous fact is, that a plant without any specialised nervous system should be affected by such minute particles; but we have no grounds for assuming that other tissues could not be renclered as exquisitely susceptible to impressions from without if this were beneficial to the organism, as is the nervous system of the higher animals.

* My son, Gcorge Darwin, has calculated for me the diameter of a sphere of phosphate of ammonia (spccifie gravity 1.678), weighing the one-twenty-millionth of a grain, and finds it to be $\frac{1}{15}$ of an inch. Now, Dr. Klein informs me that the smallest Microcoeei, which are distinctly discernible uncler a power of 800 dianctersi, are estimated to be from .0002 to -000.5 of a millinetre - that is, from $\frac{1}{30800}$ to $\frac{1}{\sqrt{2} 7500}$ of an inch-in diameter. 'Th(refore, an object from thirty-one to seventy-scren times as large as a sphere of the phosphate of ammonia of the abovo weight ean be seen under a high power; and no one sup?poses that oclorous pirticles, snch as those emitted finm the deer in the above illustration, could be seen under any power of the microseope. 


\section{CHAPTER VIII.}

The Effects of various Salts and Acids on the Ijeates.

Salts of sodium, potassium, and other alkalinc, carthy, and metallic salts - Summary on the action of these salts - Various acids -

Summary on their action.

HAving found that the salts of ammonia were so powerful, I was led to investigate the action of some other salts. It will be convenient, first, to give a list of the substances tried (including forty-nine salts and two metallic acids), divided into two columns, showing those which cause inflection, and those which do not do so, or only doubtfully. My experiments were made by placing half-minim drops on the clises of leaves, or, more commonly, by immersing them in the solutions; and sometimes by both methods. A summary of the results, with some concluding remarks, will then be given. The action of various acids will afterwards be described.

\section{Salts causing Inflection.}

Salts not CAUSing Inflection. (Arranged in Groups according to the Chemical Classification in Watts' 'Dictionary of Chemistry.')

Sodium carbonate, rapid inflection.

Sodium nitrate, rapid inflection.

Sodium sulphate, molcratcly rapid inflection.

Sodium phosphate, very rapid inflection.

Sodium citrate, rapid inflection.

Sodium nxalate, rapid inflection.

Sodium chloride, modcrately rapid inflection.
Potassium carbonatc: slowly poisonous.

Potassium nitrate: somewhat poisonous.

Potassium sulphatc.

Potassium phosphatc.

Potrssium citrate.

Potassium chloride. 
Salts catesing Inflection. Salts not causing INfleotion.

(Arranged in Groups according to the Chcmical Classification in Watts' 'Dictionary of Chemistry.'

Sodium iodide, rather slow inflection.

Sodium bromide, moderately rapid inflection.

Potassium iodicle, a slight and doubtful amount of inflection.

Potassium bromide.

Potassium oxalate, slow and doubtlul inflection.

Lithium nitrate, modcrately rapid inflection.

Cresium chloride, rather slow inflection.

Silver nitrate, rapid inflection: quick poison.

Cadmium chloride, slor inflection. Iercury perchloride, rapid inflection: quick poison.

Calcium acetate.

Calcium nitrate.

Magnesium acetate.

Magnesium nitrate.

Magnesinm ehloride.

Magnesium snlphate.

Barium acetate.

Barinm nitrate.

Strontium acetatc.

Strontium nitrate.

Zinc chloride.

Aluminium chloride, slow and donbtful inflection.

Gold chloride, rapid inflection : quick poison.

Aluminium nitrate, a trace of inHection.

Aluminium and potassium snlphate.

Tin chloricle, slow inflection: poi-

Lead chloride. sonons.

Antimony tartratc, slow inflection: probably poisonous.

Arsenions acid, quick inflection : poisonous. Iron chloride, slow inflection: Manganese chloride.
probably poisonous.

Chromic acid, quick inflection: highly poisonous.

Copper chloride, rather slow inflection: poisonous.

Nickel chloride, rapid inflection : probably poisonous.

Platinum chloride, rapid inflection: poisonous.

Cobalt chloride. 
Eodium, Carbonate of (pure, given.me by Prof. Hoffmann).Half-minims ( $.0296 \mathrm{ml}$.) of a solution of one part to 218 of water (2 grs. to $1 \mathrm{oz}$.) were plaeed on the dises of twelve leaves. Seven of these became well infleeted; three had only two or three of their outer tentacles infleeted, and the remaining two were quite unaffeeted. But the close, though only the $\frac{1}{480}$ of a grain (-135 mg.), was eviclently too strong, for three of the seven well-infleeted leaves were killed. On the other hand, one of the seven, whieh had only a few tentaeles infleeted, reexpanded and seemed quite healthy after 48 hrs. By employing a weaker solution (viz. one part to 437 of water, or $1 \mathrm{gr}$. to $1 \mathrm{oz}$.), doses of $\frac{7}{960}$ of $a$ grain ( $.0675 \mathrm{mg}$.) were given to six leaves. Some of these were affeeted in $37 \mathrm{~m}$.; and in $8 \mathrm{hrs}$. the outer tentreles of all, as well as the blades of two, were eonsiderably infleeted. After $23 \mathrm{hrs} .15 \mathrm{~m}$. the tentaeles had almost re-expanded, but the blades of the two were still just pereeptibly eurved inwards. After 48 hrs. all six leaves were fully re-expanded, and appeared perfeetly healthy.

Three leaves were immersed, each in thirty minims of a solution of one part to 875 of water ( $1 \mathrm{gr}$. to $2 \mathrm{oz}$.), so that eaeh reeeived $\frac{1}{32}$ of a grain (2.02 mg.); after $40 \mathrm{~m}$. the three were mueh affeeted, and after $6 \mathrm{hrs} .45 \mathrm{~m}$. the tentaeles of all and the blacle of one elosely infleeted.

Sulium, Nitrate of (pure).-Half-minims of a solntion of one part to 437 of water, eontaining $\frac{1}{90}$ of a grain (.0675 mg.), were plaeed on the dises of five leaves. After $1 \mathrm{hr} .25 \mathrm{~m}$. the tentreles of mearly all, and the blade of one, were somewhat inflected. The infleetion eontinued to inerease, and in $21 \mathrm{hrs}$. $15 \mathrm{~m}$. the tentreles and the blades of four of them were greatly affeeted, and the blade of the fifth to a slight extent. After an additional 24 hrs. the four leaves still remained elosely infleeted, whilst the fifth was beginming to expand. Four days after the solution had been applied, tro of the leaves had quite, and one had partially, re-expanded; whilst the remaining two remained elosely infleeted and appeared injured.

Three leaves rere immersed, each in thirty minims of a solution of one part to 875 of water; in $1 \mathrm{hr}$. there was great infleetion, and after 8 hrs. $15 \mathrm{~m}$. every tentaele and the blades of all three were most sirongly infleeted.

Sodium, Sulphute of.-Half-minims of a solution of one part to 437 of water were plaeed on the dises of six leaves. After 5 hrs. $30 \mathrm{~m}$. the tentaeles of three of them (with the blade of one) were eonsiderably, and those of the other three slightly, infleeted. After 21 hrs. the infleetion had a little deereased, 
and in $45 \mathrm{hrs}$, the leaves were fully expanded, appearing quite healthy.

Three leavcs were immersed, cach in thirty minims of a solution of one part of the sulphate to 875 of water; after $1 \mathrm{hr}$. $30 \mathrm{~m}$. there was some inflection, which increased so much that in $8 \mathrm{hrs} .10 \mathrm{~m}$. all the tentacles and the blades of all three leaves wcre closely inflected.

Solium, Phosphate of.-Hulf-minims of a solution of one part to 437 of water wcre placed on the dises of six leaves. The solution acted with extraordinary rapidity, for in $8 \mathrm{~m}$. the outer tentacles on several of the leaves were mueh incurved. After 6 hrs. the tentacles of all six leaves, and the blades of two, were closely infleeted. This state of things continued for $24 \mathrm{hrs}$, excepting that the blade of a third leaf beeamc incurved. After 48 hrs. all the leaves re-expanded. It is elear that $\frac{1}{960}$ of a grain of phosphate of soda has great powcr in eausing inflection.

sodium, Citrate of.-Half-minims of a solution of one part to 437 of water wcre placed on the discs of six leaves, but these were not observed until $22 \mathrm{hrs}$. had elapsed. The submarginal tentacles of five of them, and the blades of four, were then found inflected; but the outer rows of tentacles were not affected. One leaf, which appeared older than the othcrs, was very little affected in any way. After $46 \mathrm{hrs}$. four of the leaves were almost re-expanded, including their blades. Three leaves were also immersed, each in thirty minims of a solution of one part of the citrate to 875 of water; they were much acted on in $25 \mathrm{~m}$.; and after $6 \mathrm{hrs} .35 \mathrm{~m}$. almost all the tentacles, inclucling those of the outer rows, were inflected, but not the blades.

Sodium, Oxalate of:-Half-minims of a solution of one part to 437 of water were placed on the discs of sevcn leaves; after 5 hrs. $30 \mathrm{~m}$. the tentacles of all, and the blades of most of them, were much affceted. In $22 \mathrm{hrs}$, besides the inflcction of the tentacles, the blades of all seven leaves were so much doubled over that their tips and bases almost touched. On no other occasion have I seen the blades so strongly affected. Three lcaves were also immersed, each in thirty minims of a solution of one part to 875 of watcr; after $30 \mathrm{~m}$. there was mueh inflection, and after $6 \mathrm{hrs}$. $35 \mathrm{~m}$. the blades of two and the tentreles of all wiere closely inflected.

Sodium, Chloride of (best culinary salt).-Half-minims of a solution of one part to 218 of water werc plaeed on the dises 
of four leaves. Two, apparently, wcre not at all affected in 48 hrs.; the third had its tentacles slightly inflected; whilst the fourth had almost all its tentreles inflected in $24 \mathrm{hrs}$, and these did not begin to re-expand until the fourth day, and were not perfectly expanded on the seventh day. I presume that this leaf was injured by the salt. Half-minims of a weaker solution, of one part to 437 of water, were then dropped on the dises of six leaves, so that each received $\frac{1}{960}$ of a grain. In $1 \mathrm{hr} .33 \mathrm{~m}$. there was slight infleetion; and after $5 \mathrm{hr} .30 \mathrm{~m}$. the tentaeles of all six leaves were considerably, but not elosely, infleeted. After $23 \mathrm{hrs}$. $15 \mathrm{~m}$. all had eompletely re-expanded, and did not appear in the lcast injured.

Three leaves were immersed, eaeh in thirty minims of a solution of one part to 875 of water, so that each received $\frac{r}{32}$ of a grain, or $2.02 \mathrm{mg}$. After $1 \mathrm{hr}$. there was much inflection; after 8 hrs. $30 \mathrm{~m}$. all the tentacles and the blades of all three werc elosely infleeted. Four other leaves werc also immersed in the solution, each receiving the same amount of salt as before, viz. $\frac{1}{32}$ of a grain. They all soon became infleetcd; after $48 \mathrm{hrs}$. they began to re-expand, and appeared quite uninjured, though the solution was suffieiently strong to taste saline.

Sodium, Todide of.-Half-minims of a solution of one part.to 437 of water were plaeed on the dises of six leaves. After 24 hrs. four of them had their blades and many tentacles'infleeted. The other two had only their submarginal tentacles infleeted; the outer ones in most of the leaves being but little affected." After 46 hrs. the leaves had nearly re-expanded. Three leaves. were also immersed, eneh in thirty minims of a solution of one part to 875 of water. After 6 hrs. $30 \mathrm{~m}$. almost all the tentaeles, and the blade of one leaf, wele elosely inflected.

Sodium, Bromide of.--Half-minims of a solution of one part to 437 of watcr were placed on six lcaves. After 7 his, there was some inflection; after $22 \mathrm{hrs}$. three of the lenves had their blades and most of their tentreles infleeted; the fourth lenf was very slightly, and the fifth and sixth hardly at all, affeeted. Thrce leaves were also immersed, each in thirty minims of a solution of one part to 875 of water; after $40 \mathrm{~m}$. there was some inflection; after 4 hrs. the tentreles of all three leaves and the blades of two werc inflected. These leaves were then plaeed in vater, and after 17 hrs. $30 \mathrm{~m}$. two of them werc almost eompletely, and the third partially, re-expanded; so that apparently they were not injured. 
Polassizum, Carbonate of (pure).-Half-minims of a solution - of one part to 437 of water were plaeed on six leaves. No effect was produced in 24 hrs.; but aftcr 48 hrs. some of the leares had their tentacles, and one the blade, considerably inflected. This, however, seemed the result of their being injured; for on the third day after the solution was given, three of the leaves were dead, and one was very unhealthy; the other two were recovering, but with several of their tentacles apparently injured, and these remained permanently inflected. It is evident that the $\frac{1}{960}$ of a grain of this salt acts as a poison. Three leaves were also immersed, each in thirty minims of a solution of one part to 875 of water, though only for 9 hrs, ; and, very differently from what occurs with the salts of soda, no inflection ensued.

Potassium, Nitrate of.-Half-minims of a strong solution, of one part to 109 of water ( $4 \mathrm{grs}$. to $1 \mathrm{oz}$.), were placed on the dises of four leaves; two were much injured, but no inflection ensued. Eight leaves were treated in the same manner, with drops of a weaker solution, of one part to 218 of water. After 50 hrs. there was no inflection, but two of the leaves seemed injured. Five of these leaves were subsequently tested with drops of milk and a solution of gelatinc on their dises, and only one became inflected; so that the solution of the nitrate of the above strength, acting for $50 \mathrm{hrs}$, apparently had injured or paralysed the leaves. Six leaves were then treated in the same manner with a still weaker solution, of one part to 437 of water, and these, after $48 \mathrm{hrs}$, were in no way affected, with the exception of perhaps a single leaf. Three leaves were next immersed for 25 hrs., each in thirty minims of a solution of one part to 875 of water, and this produced no apparent effect. They were then put into a solution of one part of carbonate of ammonia to 218 of watcr; the glands were immediately blackened, and after $1 \mathrm{hr}$. there was some inflection, and the protoplasmic contents of the cells became plainly aggregated. This shows that the leaves had not been much injured by their immersion for 25 hrs. in the nitrate.

Potussium, Sulphate of.-Half-minims of a solution of one part to 437 of water were placed on the discs of six lcaves. After 20 hrs. 30 m. no effect was produced; after an additional 24 hr's. three remained quite unaffeetcd; two scemed injured, and the sixth scemed almost dead with its tentacles inflected. Nevertheless, after two additional days, all six leaves reeovered. The immersion of thrce leaves. for 24 hrs., eaell in thirty minims of 
a solution of one part to 875 of water, produced no apparent effect. They wcre then treated with the same solution of carbonate of ammonia, with the same result as in the case of the nitrate of potash.

Potassium, Phosphate of--Half-minims of a. solution of one part to 437 of water were placed on the discs of six leaves, which were observed during three days ; but no effect was produced. The partial drying up of the fluid on the disc slightly drew together the tentacles on it, as often occurs in experimonts of this kind. The leaves on the third day appeared quite healthy.

Putassium, Citrate of.-Half-minims of a solution of one part to 437 of water, left on the discs of six leaves for three days, and the immersion of three leaves for $9 \mathrm{hrs}$, cach in $30 \mathrm{minims}$ of a solution of one part to 875 of water, did not produce the least effect.

Potassium, Oxalate of.-Half-minims were placcd on different occasions on the discs of serentecn leaves; and the results perplexed.me much, as they still do. Inflection supervened rcry slowly. After 24 hrs. four leaves out of the seventeen were well inflected, together with the blades of two; six were slightly affected, and seven not at all. Thrce leaves of onc lot were obscrved for five clays, and all died; but in another lot of six, all excepting one looked hcalthy after four days. Three leaves wcrc immersed during $9 \mathrm{hrs}$, each in 30 minims of a solution of one part to 875 of water, and were not in the least affected; but they ought. to have been observed for a longer time.

Lotassium, Chloride of. Neither half-minims of a solution of onc part to 437 of water, left on the discs of six leaves for threc days, nor the immersion of three leaves during $25 \mathrm{hrs}$., in 30 minims of a solution of one part to 875 of water, produeed the least effect. The immersed leaves were then treated with carbonate of ammonia, as described under nitrate of potash, and with the same result.

Potrssium, Todide of - - Half-minims of a solution of one part to 437 of water were placer on the discs of scven leaves. In $30 \mathrm{~m}$. one leaf had the blade inflected; after some hours three leaves had most of their submarginal tentacles moderatcly inflected; the remaining threc being very slightly affected. Hardly any of these leaves had thcir outer tentacles inflected. After. 21 hrs. all re-cxpanded, cxcepting two which still had a few submarginal tentacles inflccted. Threc leaves. wcro next 
immersed for $S$ hrs. 40 m., eacl in 30 minims of a solution of one part to 87う of water, and were not in the least affected. I do not know what to conclude from this conflicting evidence; but it is clear that the iodide of potassium does not generally produce any marked effect.

Potassium, Bromide of--Half-minims of a solution of one part to 437 of water were placed on the dises of six leaves; after 22 hrs. one had its blade and many tentacles inflected, but I suspect that an insect might have alighted on it and then escaped; the five other leaves were in no way affected. I tested three of these leaves with bits of meat, and after 24 hrs. they became splendidly inflected. Three leaves were also immersed for 21 lirs. in 30 minims of a solution of one part to 875 of water; but they were not at all affected, excepting that the glands looked rather pale.

Lithium, Acetute of.-Four leaves were immersed together in a vessel containing 120 minims of a solution of one part to 437 of water; so that each received, if the leaves absorbed equally, $\frac{1}{16}$ of a grain. After $2 t$ hrs. there was no inflection. I then added, for the sake of testing the leares, some strong solution (viz. $1 \mathrm{gr}$. to $20 \mathrm{oz}$., or one part to 8750 oi water) of phosphate of ammonia, and all four became in $30 \mathrm{~m}$. closely inflected.

Lithium, Nitrute of.-Four leaves were immersed, as in the last case, in 120 minims of a solution of one part to 437 of water; after 1 h. $30 \mathrm{~m}$. all four were a little, and after 24 hrs. greatly, inflected. I then diluted the solution with some water, but they still remained somewhat inflected on the third day.

Cosium, Chloride of.-Four leaves were immersed, as abore, in 120 minims of a solution of one part to 437 of water. After $1 \mathrm{hr} .5 \mathrm{~m}$. the glands were darkened; after $4 \mathrm{hrs}$. $20 \mathrm{~m}$. there was a trace of inflection; after 6 hrs. $40 \mathrm{~m}$. two leaves were greatly, but not closely, and the other two considerably inflected. After 22 hrs. the inflection was extremely great, and two had their blades inflected. I then transferred the leaves into water, and in 46 hrs. from their first immersion they were almost reexpanded.

Rubirlium, Chloride of.-Four leaves which were immer'sed, as above, in 120 minims of a solution of one part to 437 of water, were not acted on in 22 hrs. I then added some of the strong solution ( $1 \mathrm{gr}$. to $20 \mathrm{oz}$.) of phosphate of ammonia, and in $30 \mathrm{~m}$. all were immensely inflected.

Silver, Nitrate of. - Three leaves were immersed in nincty 
minims of a solution of one part to 437 of water; so that each reeeived, as before, $\frac{1}{16}$ of a grain. After $5 \mathrm{~m}$. slight infleetion, and aftcr $11 \mathrm{~m}$. very strong inflection, the glands beeoming excessively black; after $40 \mathrm{~m}$. all the tentaeles were closely inflected. After 6 hrs. the leaves were taken out of the solutiou, washed, and plaeed in water; but next morning they were evidently dead.

('alcium, Acetute of.-Four leaves were immersed in 120 minims of a solution of one part to 437 of water; after $24 \mathrm{hrs}$. none of the tentaeles were inflected, exeepting a few where the blade joined the petiole; and this may have been caused by the absorption of the salt by the cut-off cnd of the petiole. I then added some of the solution ( 1 gr. to $20 \mathrm{oz}$.) of phospate of ammonia, but this to my surprise exeited only slight inflection, even after 24 hrs. Henee it would appear that the acetate had reindered the leaves torpid.

Culcium, Nitrate of.-Four leaves were immersed in 120 minims of a solution of one part to 437 of water, but were not affeeted in 24 hrs. I then added some of the solution of phosphate of ammonia (1 gr. to $20 \mathrm{oz}$.), but this caused only very slight infleetion after 24 hrs. A fresh leaf was next put into a mixed solution of the above strengths of the nitrate of ealeium and phosphate of ammonia, and it beeame closely infleeted in between $5 \mathrm{~m}$. and $10 \mathrm{~m}$. Half-minims of a solution of one part of the nitrate of ealeium to 218 of water were dropped on the dises of three leaves, but produeed no effect.

Magnesiun, Acetate, Nitrate, and Chloride of.-Four leaves were immersed in 120 minims of solutions, of one part to 437 of water, of eaeh of these three salts ; after 6 hrs. there was no infleetion ; but after 22 lurs. one of the leaves in the acetate was rather more inflected than generally oceur's from an immersion for this length of time in water. Some of the solution ( $1 \mathrm{gr}$. to $20 \mathrm{oz}$.) of phosphate of ammonia was then added to the three solutions. The leaves in the acetate mixed with the phosphate undertrent some infleetion; and this was well pronounced after 24 hrs. Those in the mixed nitrate were deeidedly infleeted in $4 \mathrm{hrs}$ : $30 \mathrm{~m}$., but the clegree of inflection did not afterwards mueh increase; whereas the four leaves in the mixed elloride were greatly inflected in a few minutes, and after 4 hrs. had almost every tentacle closcly infleeted. We thus see that the aeetate and nitrate of magnesium injure the leares, or at least prevent the subsequent aetion of phosphate of ammonia; whereas the chloride has no such tendeney. 
Magnesium, Sulphate of.-Half-minims of a solution of one part to 218 of water were plaeed on tho dises of ten leaves, and produeed no effeet.

Barium, Acetate of.-Four leaves were immersed in 120 minims of a solution ot one part to 437 of water, and after 22 hr's. there was no infleetion, but the glands were blaekened. The leaves were then plaeed in a solution (1 gr. to $20 \mathrm{oz}$.) of phosphate of ammonia, which eaused after 26 hrs. only a little infleetion in two of the leares.

Burium, Nitrute of.-Four leaves were immersed in 120 minims of a solution of one part to 437 of water; and after 22 hr's. there was no more than that slight degree of infleetion, whieh often follows from an immersion of this length in pure water. I then added some of the same solution of phosphate of ammonia, and after $30 \mathrm{~m}$. one leaf was greatly infleeted, two other's moderately, and the fourth not at all. The leaves remained in this state for 24 hr's.

Strontium, Acetate of.-Four leaves, immersed in 120 minims of a solution of one part to 437 of water, were not affeeted in $22 \mathrm{hrs}$. They were then plaeed in some of the same solution of phosphate of ammonia, and in $25 \mathrm{~m}$. two of them were greatly infleeted; after 8 hrs. the third leaf was eonsiderably infleeted, and the fourth exhibited a traee of infleetion. They were in the same state next morning.

Strontium, Nitrate of.-Five leaves were immersed in 120 minims of a solution of one part to 437 of water; after 22 hrs. there was some slight inflection, but not more than sometimes oeeurs with leaves in water. They wero then plaeed in the same solution of phosphate of ammonia; after 8 hrs. three of them were moderately inflected, as were all five after $24 \mathrm{hrs}$.; but not one was elosely infleeted. It appears that the nitrate of strontium renders the leaves half torpid.

Cadmium, Chloride of:-Three lenves were immersed in ninety minims of a solution of one part to 437 of water; after 5 hrs. $20 \mathrm{~m}$. slight inflection oceurred, whieh inereased during the next three hour's. After 24 hrs. all three leaves had their tentaeles well infleeted, and remained so for an additional 24 hrs.; glands not diseoloured.

Mercury, Perchloride of.-Three leaves were immersed in ninety minims of a solution of one part to 437 of water; after $22 \mathrm{~m}$. there was some slight infleetion, whieh in $48 \mathrm{~m}$. beeame well pronouneed; the glands were now blaekened. After 5 hrs. $35 \mathrm{~m}$. all the tentaeles elosely infleeted; after 24 hrs. still 
inflected and diseoloured. The lcaves were then removed and left for two days in watcr; but thcy never rc-cxpanded, being evidently dead.

Zinc, Chloritle of.-Threc lcaves immersed in ninety minims of a solution of one part to 437 of water were not affeeted in 2.5 hrs. $30 \mathrm{~m}$.

Aluminium, Chloride of.-Four leaves were immersed in 120 minims of a solution of one part to 437 of water; after 7 hrs. $45 \mathrm{~m}$. no infleetion; after 24 hr's. one leaf rather closcly, the sccond moderately, the third and fourth hardly at all, inflected. The cridenec is doubtful, but I think some power in slowly eausing infleetion must be attributed to this salt. These lcaves were then plaeed in the solution ( 1 gr. to $20 \mathrm{oz}$.) of phosphate of ammonia, and after $7 \mathrm{hrs} .30 \mathrm{~m}$. the three, whieh had been but little affeeted by the ehloride, beeame rather elosely inflected.

Aluminium, Nitrate of.-Four leaves were immersed in 120 minims of a solution of onc part to 437 of water; after 7 hrs. $45 \mathrm{~m}$. there was only a traee of inflection; after $24 \mathrm{hrs}$. one leaf was moderately inflected. The evidence is here again doubtful, as in the ease of the chloride of aluminium. The lcaves were then transferred to the same solution, as before, of phosphate of ammonia; this produced hardly any effeet in $7 \mathrm{hrs} .30 \mathrm{~m}$. ; but after $25 \mathrm{hrs}$. one lcaf was pretty closely infleeted, the three others very slightly, perhaps not more so than from water.

Aluminium and Potassium, Sulphate of (common alum).-Halfminims of a solution of the usual strength werc placed on the dises of nine leaves, but produeed no effect.

Gold, Chloride of.--Seven lcaves were immersed in so much of a solution of one part to 437 of water that eneh reecived 30 minims, eontaining $\frac{1}{16}$ of a grain, or $4.048 \mathrm{mg}$., of the ehloride. There was some inflection in $8 \mathrm{~m}$., whieh bccame cxtreme in $45 \mathrm{~m}$. In 3 hrs. thic surrounding fluid was eoloured purple, and the glands were blaekened. After 6 hrs. the leaves were transferrcd to water; next morning they were found diseoloured and evidently killed. The seeretion deeomposes the chloride very readily; the glands themselves beeoming coatcd with the thinnest layer of metallie gold, and particles float about on the surface of the surrounding fluid.

Lead, Chloride of - Threc leaves were immersed in nincty minims of a solution of one part to 437 of watcr. Aftcr 23 hrs. there was not a trnee of infleetion; the glands were not b]nekened, and the leaves did not appoar injured. They were then trans- 
ferred to the solution ( $1 \mathrm{gr}$. to $20 \mathrm{oz}$.) of phosphate of ammonia, and after $2 t$ hrs. two of them were somewhat, the third vcry little, inflected; and they thus r'cmaincd for anothcr 24 hrs.

Tin, Chturide of.-Four leaves were immersed in 120 minims of a solution of about one part (all not being dissolved) to 437 of water. After 4 hrs. no effcct; after 6 hrs. $30 \mathrm{~m}$. all four leaves had their submarginal tentacles inflected; after 22 hrs. every single tentacle and the blades were closely inflected. The surrounding fluid was now coloured pink. The leaves were washed and transferred to water, but next morning were evidently dead. This chloride is a deadly poison, but acts slowly.

Antimony, Turtrute of.-Three leaves were immorsed in ninety minims of a solution of one part to 437 of water. After 8 hrs. $30 \mathrm{~m}$. there was slight inflection; after 24 hrs. two of the leaves were closely, and the third modcrately, inflected; glands not much darkened. 'The leaves wcrc washed and placed in water, but they remained in the same statc for 48 additional hours. This salt is probably poisonous, but acts slowly.

Arsenious Acir.-A solution of one part to 437 of water; three leaves were immersed in ninety minims; in $25 \mathrm{~m}$. considerable inflection; in $1 \mathrm{~h}$. great inflection; glands not discoloured. After $6 \mathrm{hrs}$. the leaves were transferred to watcr; next morning they looked fresh, but after four days were pale-coloured, had not re-expanded, and were evidently dead.

Iron, Chloride of.-Thrce lcaves were immersed in ninety minims of a solution of one part to 437 of water; in 8 hrs. no inflection; but after 21 hrs. considerable inflection; glands blackened; fluid coloured yellow, with floating flocculent particles of oxide of iron. The leaves were then placed in water; after 48 hrs. they had re-expanded a very little, but I think were killed; glands excessively black.

Chromic Acid.-Onc part to 437 of water; three laves were immersed in ninety minims; in $30 \mathrm{~m}$. some, and in $1 \mathrm{hr}$. considerable, inflection; after 2 hrs. all the tentacles closcly inflected, with the glands discoloured. Placed in water, next day leares quite discoloured and evidently killed.

Manjariese, Chloride of.-Three leaves immersed in ninety minims of a solution of one part to 437 of water; after 22 lurs. no more inflection than often occur's in water; glands not blackened. The leaves were then placed in the usual solution of phosphate of ammonia, but no inflection was caused even
after 48 hrs.

Copper, Chloride of.-Three leaves immersed in nincty minims 
of a solution of ono part to 437 of water; after 2 hrs. some infleetion; after 3 lirs. $45 \mathrm{~m}$. tentaeles elosely infleeted, with the glands blackened. After 22 lirs. still elosely infleeted, and the leaves flaeeid. Plaeed in pure water, next day evidently dead. A rapid poison.

Nicket, Chloride of. - Three leaves immersed in ninety minims of a solution of one part to 437 of water; in $25 \mathrm{~m}$. eonsiderablo infleetion, and in 3 hrs. all the tentreles elosely infleeted. After 22 hris. still elosely inflected; most of the glands, but not all, blaekened. The leaves were then plaeed in water; after 24 hrs. remained infleeted; were somewhat diseoloured, with the glands and tentaeles dingy red. Probably killed.

Cobalt, Chloride of.-Three leaves immersed in ninety minims of a solution of one part to 437 of water; after 23 hrs. there was not a trace of inflection, and the glands were not more blackened than often oeeurs after an equally long immersion in .water.

Platinum, Chloride of.-Three lenves immersed in ninety minims of a solution of one part to 437 of water ; in $6 \mathrm{~m}$. some infleetion, which beeame immense after $48 \mathrm{~m}$. After 3 hrs. the glands were rather pale. After 24 hrs. all the tentaeles still elosely infleeted; glands colourless; remained in same state for four days; leaves evidently killed.

Concluding Remarlis on the Action of the foregoing Salts.-Of the fifty-one salts and metallic acids which were tried, twenty-five eaused the tentacles to be inflected, and twenty-six had no such effect, two rather doubtful eases oeeurring in each series. In the table at the head of this discussion, the salts are arranged according to their chemical affinities; but their action on Drosera does not seem to be thus governed. The nature of the base is far more important, as far as can be judged from the few experiments here given, than that of the acid; and this is the conclusion at which physiologists have arrived with respect to animals. We see this faet illustrated in all the nine salts of soda causing inflection, and in not being poisonous exeept when given in large doses; whereas seven of 
the corresponding salts of potash do not cause inflection, and some of them arc poisonous. Two of them, however, viz. the oxalate and iodide of potash, slowly induced a slight and rather doubtful amount of inflection. This difference between the two scrics is interesting, as Dr. Burdon Sanderson informs me that sodium salts may be introduced in large doses into the cireulation of mammals without any injurious effects; whilst small doses of potassium salts cause death by suddenly arresting the movements of the heart. An excellent instance of the different action of the two series is presented by the phosphate of soda quickly causing vigorous inflection, whilst phosphate of potash is quitc incfficient. The grcat power of the former is probably duc to the presence of phosphorus, as in the cases of phosphate of lime and of ammonia. Hence we may infer that Drosera cannot obtain phosphorus from the phosphate of potash. This is remarkable, as I hear from Dr. Burdon Sandcrson that phosphate of potash is certainly dceomposed within the bodics of animals. Most of the salts of soda act very rapidly; the iodide aeting slowest. The oxalate, nitratc, and eitrate seem to have a special tendeney to cause the blade of the leaf to be inflccted. The glands of the disc, aftcr absorbing the citrate, transmit hardly any motor impulsc to the outer tentaeles; and in this character the citrate of soda resembles the citratc of ammonia, or a dceoction of grass-leaves; thcse three fluids all acting chicfly on the blade.

It scems opposed to the rule of the preponderant influence of the base that the nitrate of lithium causes modcrately rapid infleetion, whereas the aectatc causes nonc; but this metal is closely allied to sodium 
and potassium,* whieh aet so differently; therefore we might expect that its aetion would be intermediate. We see, also, that exsium eauses infleetion, and rubidium does not; and these two metals are allied to sodium and potassium. Most of the earthy salts are inoperative. Two salts of ealeium, four of magnesium, two of barium, and two of strontium, did not cause any infleetion, and thus follow the rule of the preponderant power of the base. Of three salts of aluminium, one did not aet, a second showed a traee of aetion, and the third aeted slowly and doubtfully, so that their effeets are nearly alike.

of the salts and aeids of ordinary metals, seventeen were tried, and only four, namely those of zine, lead, manganese, and cobalt, failed to eause infleetion. The salts of eadmium, tin, antimony, and iron, aet slowly; and the three latter seem more or less poisonous. The salts of silver, mereury, gold, eopper, niekel, and platinum, ehromie and arsenious acids, eause great infleetion with extreme quickness, and are deadly poisons. It is surprising, judging from animals, that lead and barium should not be poisonous. Most of the poisonous salts make the glands blaek, but ehloride of platinum made them very pale. I shall have oeeasion, in the next chapter, to add a few remarks on the different effects of phosphate of ammonia on leares previously immersed in various solutions.

\section{ACIDS.}

I will first give, as in the case of the salts, a list of the twenty-four aeids whieh were tried, divided into two scries, aceording as they eause or do not eause

* Miller's 'Elements of Chemistry,' 3rd edit. Pp. 337, 448. 
Chap. VIIT.

inflection. After describing the experiments, a few concluding remarks will be added.

AcIds, MCCH DILLTED, WHICH CAUSE INFLECTION.

1. Nitric, strong infleetion; poisonous.

2. Hydrochlorie, modernte and slow inflection; not poisonous.

3. Hydriodic, strong infleetion; poisonous.

4. Iodie, strong infleetion; poisonous.

5. Sulphuric, strong inflection; somewhat poisonous.

6. Phosphoric, strong inflection; poisonous.

7. Borncic, moderate and rather slow inflection; not poisonous.

8. Formic, very slight inflection; not poisonous.

9. Acetic, strong and rapid inflection; poisonous.

10. Propionic, strong but not very rapid inflection; poisonous.

11. Oleic, quick inflection; very poisonous.

12. Carbolic, very slow inflection; poisonous.

13. Iactic, slow and moderate infleetion; poisonous.

14. Oxalic, moderatcly quick inflection; very poisonous.

15. Malic, very slow but eonsiderable inflection; not poisonous.

16. Benzoic, rapid inflcetion; very poisonous.

17. Suceinic, moderately quick inflection; modcrately poisonous.

18. Hippuric, rather slow inflection; poisonous.

19. Hydroeyanic, rather rapid inflection; very poisonous.

\section{ACIDS, DILUTED TO THE SAME DEgReE, WHICH DO NOT CALSE INELEOTION.}

1. Gallic; not poisonous.

2. 'Tannic; not poisonous.

3. Tartarie; not poisonous.

4. Citric; not poisonous.

5. Uric ; (?) not poisonous.

Nitric Acid.-Four leaves wero plaeed, caeh in thirty minims of one part by weight of the aeid to 437 of water, so that each reeeived $\frac{\pi}{10}$ of a grain, or $4.048 \mathrm{mg}$. This strength was ehosen for this and most of the following experiments, as it is the same 
as that of most of the foregoing saline solutions. In $2 \mathrm{hrs} .30 \mathrm{~m}$. some of the leares were considerably, and in 6 hrs. $30 \mathrm{~m}$. all were immensely, inflected, as were their blades. The surrounding fluid was slightly coloured pink, which always shows that the lcaves have becn injured. They were then left in water for three days; but they remained inflected and wcre evidently killed. Most of the glands had beeome colourless. Two leaves were then immersed, each in thirty minims of one part to 1000 of water; in a few hours there was some inflection; and after $2 t$ hrs. both leaves had almost all their tentacles and blades infleeted; they were left in watcr for thrce days, and one partially re-expanded and recovered. Two leaves were ncxt immersed, each in thirty minims of one part to 2000 of watcr ; this produced very little effeet, except that most of the tentacles close to the summit of the petiole were infleeted, as if the aeid had been absorbed by the eut-off end.

Hydrochloric Acid.-One part to 437 of water ; four lcaves were immersed as before, each in thirty minims. After 6 hrs. only one lcaf was eonsiderably infleetcd. After 8 hrs. $15 \mathrm{~m}$. one had its tentacles and blade well inflected; the other three were moderately inflceted, and the blade of one slightly. The surrounding fluid was not coloured at all pink. After $25 \mathrm{hrs}$. three of thesc four leaves began to re-expand, but thcir glands were of a pink instead of a red colour; after two more days they fully re-expanded; but the fourth leaf rcmained infleeted, and secmed much injured or killed, with its glands white. Four leaves wcre then treated, cach with thirty minims of one part to 875 of water; after 21 hrs. they were moderately infleeted; and on being transferred to water, fully re-expanded in two days, and sccmed quite healthy.

Hydriodic Acid.-One to 437 of water; three leaves were immersed as before, each in thirty minims. After $45 \mathrm{~m}$. the glands were diseoloured, and the surrounding fluid beeame pinkish, but there was no inflection. After 5 hrs. all the tentacles were elosely infleeted; and an immense amount of mucus was secreted, so that the fluid could be drawn out into long ropes. The leaves wcre then placed in water, but never rc-expanded, and wcre evidently killed. Four leaves werc next immersed in one part to 875 of water; the aetion was now slower, but after 22 hrs. all four leaves wcre eloscly infleeted, and were affeeted in other respeets as above deseribed. These leaves did not re-expand, though left for four days in water. This acid aets far more porrerfully than hydrochlorie, and is poisonous.

Iodic Acid.-One to 437 of water; three leaves were immersed, 
each in thirty minims; after 3 hrs. strong inflection ; after 4 hrs. glinds dark brown; after $8 \mathrm{hrs} .30 \mathrm{~m}$. elose inflection, and the leaves had become flaccid; surrounding fluid not coloured pink. These leaves were then placed in water, and next day were eviclently dead.

Sulphuric Acil.-One to 437 of water; four leaves were immersed, each in thirty minims; after 4 hrs. great inflection; after 6 hrs. surrounding fluid just tinged pink; they were then placed in water, and after 46 hrs. two of them were still closely inflected, tro beginning to re-expand; many of the glands colourless. This acid is not so poisonous as hydriodie or iodic acids.

Yhosphoric Acid.-Onc to 437 of water; three leaves were immersed together in ninety minims; after $5 \mathrm{hrs} .30 \mathrm{~m}$. some inflection, and some glands colourless; after 8 hrs. all the tentacles closely infleeted, and many glands colourless; surrounding fluid pink. Left in water for two days and a half, remained in the same state and appcared dead.

Boracic Acid.-One to 437 of water; four leaves werc immersed together in 120 minims ; after 6 hrs. very slight inflection; after 8 hrs. $15 \mathrm{~m}$. two were considerably inflected, the other two slightly. After 24 hr's. one leaf was rather closely inflected, the seeond less closely, the third and fourth moderately. The leaves were washed and put into water; after 21 hrs. they were almost fully re-expanded and looked healthy. This aeid agrees closely with hydrochloric acid of the same strength in its power of causing inflection, and in not being poisonous.

Furmic Acid.-Four leaves were immersed together in 120 minims of one part to 437 of water; after $40 \mathrm{~m}$. slight, and after 6 hrs. $30 \mathrm{~m}$. very moderate inflection; after 22 hrs. only a little more inflection than often oecurs in water. Two of the leaves were then washed and placed in a solution (1 gr. to $20 \mathrm{oz}$.) of phosphate of ammonia; after 24 hrs. they were eonsiderably inflccted, with the eontents of their cells aggregated, showing that the phosphate liad acted, though not to the full and
ordinary degree.

Acctic Acid.-Four leaves were immersed together in 120 minims of one part to 437 of water. In $1 \mathrm{hr}, 20 \mathrm{~m}$. the tentacles of all four and the blades of two were greatly inflected. After 8 hrs. the leaves had become flaecid, but still remained closely inflected, the surrounding fluid being coloured pink. Thoy were then washed and placed in water; next morning they were still inflected and of a very dark red colour, but with their glands colourless. After another day they were dingy-coloured, and 
evidently dcad. This acid is far more powerful than formic, and is highly poisonous. Half-minim drops of a stronger mixture (viz. one part by measure to 320 of water) were placed on the dises of five leaves; none of the exterior tentacles, only those on the borders of the disc which actually absorbed the acid, became inflected. Probably the dose was too strong and paralysed the leaves, for drops of a weaker mixture caused much inflection; nevertheless the leaves all died after two clays.

Propionic Acid.-Three leaves were immersed in ninety minims of a mixture of one part to 437 of water; in $1 \mathrm{hr}$. $50 \mathrm{~m}$. there was no inflection; but aftcr 3 hrs. $40 \mathrm{~m}$. one leaf was greatly inflected, and the other two slightly. The inflection continued to increase, so that in $8 \mathrm{hrs}$, all three leaves were closely inflected. Next morning, after $20 \mathrm{hrs}$, most of the glands were very pale, but some few were almost black. No mucus had been secreted, and the surrounding fluid was only just perceptibly tinted of a pale pink. After 46 hrs. the leaves became slightly flaccid and were evidently. killed, as was afterwards proved to be the case by keeping them in water. The protoplasm in the closely inflected tentacles was not in the least aggregated, but towards their bases it was collecterl in little browuish masses at the bottoms of the cells. This protoplasm was dead, for on leaving, the leaf in a solution of carbonate of ammonia, no aggregation ensued. Propionic acid is highly poisonous to Drosera, like its ally acetic acid, but induces inflection at a much slower rate.

Oleic Acid (given me by Prof. Frankland),-Threc leaves were immersed in this acid; some inflection was almost immediately caused, which increased slightly, but then ceased, and the leaves scemed killed. Next morning they were rather shrivelled, and many of the glands had fallen off the tentrcles. Drops of this acid were placed on the dises of four leaves; in $40 \mathrm{~m}$. all the tentacles were greatly inflected, exccpting the extremc marginal ones; and many of these after 3 hrs. became inflected. I ras led to try this acid from supposing that it was present (which does not seem to be tho case)* in olive oil, the action of which is anomalous. Thus drops of this oil placed on the disc do not cause the outer tentacles to be inflected; yet when minute drops were added to the secretion surrounding the glands of the outer teutacles, these were occasionally, but by means always, inflected. Two leaves were also immersed in this oil, -and there

* See articles on Glyeerine and Oleie Acid in Watts' 'Diet. of Chemistry.' 
was no infleetion for about 12 hrs.; but after 23 hrs. almost all the tentaeles were infleeted. Three leaves were likewise immersed in unboiled linseed oil, and soon beeame somewhat, and in 3 hrs. greatly, infleeted. After $1 \mathrm{hr}$. the seeretion round the glands was coloured pink. I infer from this latter faet that the power of linseed oil to cause infleetion eannot be attributed to the albumin which it is said to contain.

Carbolic Acid.-Two leaves were immersed in sisty minims of a solution of $1 \mathrm{gr}$. to 437 of water; in $7 \mathrm{hrs}$. one was slightly, and in 24 hrs. both were elosely, infleeted, with a surprising amount of mueus seereted. These leaves were washed and left for two days in water; they remained infleeted; most of their glands became pale, and they seemed dead. This aeid is poisonous, but does not aet nearly so rapidly or powerfully as might have been expeeted from its known destruetive power on the lowest organisms. Half-minims of the same solution were placed on the dises of three leaves; after $24 \mathrm{hr}$ s. no infleetion of the outer tentaeles ensued, and when bits of meat were given them, they beeame fairly well infleeted. Again half-minims of $a$. stronger solution, of one part to 218 of water, were plaeed on the dises of three leaves; no infleetion of the outer tentaeles ensued; bits of meat were then given as before; one leaf alone becaine well infleeted, the discal glands of the other two appearing mueh injured and dry. We thus see that the glands of the dises, after absorbing this aeid, rarely transmit any motor impulse to the outer tentaeles; though these, when their own glands absorb the acid, are strongly aeted on.

Lactic Acill.-Three leaves were immersed in ninety minims of one part to 437 of water. After $48 \mathrm{~m}$. there was no infleetion, but the surrounding fluid was eoloured jink; after 8 hrs. $30 \mathrm{~m}$. one leaf alone was a little infleeted, and almost all the glands on all three leaves were of a very pale colour. The leaves were then washed and flaeed in a solution ( $1 \mathrm{gr}$. to $20 \mathrm{oz}$.) of phosphate of ammonia; after about $16 \mathrm{hrs}$. there was only a traee of inflection. They were left in the phosphate for 48 hrs., and remained in the same state, with almost all their glands discolowred. The prutoplasm within the eells was not aggregated, except in a very few tentacles, the glands of which were not muel discoloured. I believe, therefore, that almost all the glands and tentaeles had been killed by the aeid so suddenly that hardly any infleetion was eaused. Four leaves were next immersed in 120 minims of a weaker solution, of one part to $87 \mathrm{j}$ of wator; after 2 hrs. $30 \mathrm{mn}$, the surrounding fluid was quite pink; the glands were pale, but 
there was no inflection; after 7 hrs. $30 \mathrm{~m}$. two of the leares showed some inflection, and the glands were almost whitc; after 21 hrs. two of the leaves wcrc considerably inflected, and a third slightly; most of the glands wcre whitc, the others dark red. Aftcr $45 \mathrm{hrs}$. onc lcaf had almost crery tentaclc inflected; a second a large number; the third and fourth very few; almost all the glands wcre whitc, excepting those on the dises of two of the lcaves, and many of these were very dark red. The leaves apperred dead. Hence lactic acid acts in a very peculiar manner, causing inflection at an extraordinarily slow rate, and being highly poisonous. Immersion in even weaker solutions, viz. of one part to 1312 and 1750 of water, apparently killed the leaves (the tentacles after a time being bowed backwards), and rendered the glands white, but caused no inflection.

Gallic, Tunnic, Turtaric, and Citric Acids.-One part to 437 of water. Three or four leaves werc immersed, each in thirty minims of these four solutions, so that each lcaf received $\frac{1}{16}$ of a grain, or $4.048 \mathrm{mg}$. No inflection was caused in $24 \mathrm{hrs}$., and the leaves did not appear at all injured. Those which had been in the tannic and tartaric acids were placed in a solution ( $1 \mathrm{gr}$. to $20 \mathrm{oz}$.) of phosphate of ammonia, but no inflection ensued in $24 \mathrm{hrs}$. On the other hand, the four leaves which had been in the gitric acid, when treated with the plosphate, bccame dccidedly inflected in $50 \mathrm{~m}$. and strongly inflected after $5 \mathrm{hrs}$, and so remained for the next 24 hrs.

Malic Acid.-Three leaves were immersed in ninety minims of a solution of one part to 437 of water; no inflection was caused in $8 \mathrm{hrs} .20 \mathrm{~m}$., but after $24 \mathrm{hrs}$. two of them were considerably, and the third slightly, inflccted-more so than could be accounted for by the action of water. No great amount of mucus was secreted. They were then placed in watcr, and aftcr two days partially re-expanded. Hcnce this acid is not poisonous.

Oxalic Acid.--Three leaves were immersed in ninety minims of a solution of $1 \mathrm{gr}$. to 437 of water; after 2 hrs. $10 \mathrm{~m}$. there was much inflection; glands pale; the surrounding fluid of a dark pink colour; after $8 \mathrm{hrs}$. cxcessive inflection. The leaves rere then placed in water; after about 16 lirs. the tentacles were of a very dark red colour, like those of the leares in acetic acid. Aftcr 24 additional hours, the three leaves were dead and their glands colourless.

Bcnzoic Acid.-Five leaves were immerscd, cach in thirty minims of a solution of $1 \mathrm{gr}$. to 437 of water. 'This solution was so weak that it only just tasted acid, yet, as we shall sce, was highly poisonous to Drosera. After $52 \mathrm{~m}$. the submarginal 
tentacles were somewhat inflected, and all the glands very palecoloured; the surrounding fluid was coloured pink. On one occasion the-fluid becamo pink in the course of only $12 \mathrm{~m}$., and the glands as white as if the leaf had been dipped in boiling water. After 4 hrs. much inflection; but nonc of the tentacles were closely inflected, owing, as I believe, to thcir having been paralysed before they had time to complete their movement. An cxtraordinary quantity of mucus was secreted. Some of the leaves were left in the solution; others, after an immersion of $6 \mathrm{hr}$ s. $30 \mathrm{~m}$., werc placed in watcr. Next morning both lots werc quite dead; the lcaves in the solution being flaccid, those in the water (now coloured ycllow) of a palc brown tint, and their glands white.

Succinic Acid.-Three leaves were immersed in ninety minims of a solution of $1 \mathrm{gr}$. to 437 of water; aftcr $4 \mathrm{hr} s, 15 \mathrm{~m}$. considerable and after $23 \mathrm{hrs}$, great inflection; many of the glands pale; fluid coloured pink. The lcaves werc then washed and placed in water; after two days thcre was some re-cxpansion, but many of the glands were still white. This acid is not nearly so poisonous as oxalic or benzoic.

Uric Acid.-Three leaves werc immersed in 180 minims of a solution of $1 \mathrm{gr}$. to 875 of warm water, but all the acid was not dissolved; so that each received nearly $\frac{1}{16}$ of a grain. After $25 \mathrm{~m}$. there was some slight inflection, but this never increased; after 9 hl's. the glands wcre not discoloured, nor was the solution coloured pink; nevertheless much mucus was secreted. The leaves werc then placed in water, and by next morning fully re-expanded. I doubt whether this acid really causes inflection, for the shight movement which at first occurred may lave becn due to the presence of a trace of albuminous matter. But it produces some effect, as shown by the sccretion of $\mathrm{so}_{0}$ much mucus.

Hippuric Acid.-Four leaves were immersed in 120 minims of a solution of $1 \mathrm{gr}$, to 437 of water. After 2 hrs. the fluid was coloured pink; glands pale, but no inflection. After 6 hrs. some inflection; after 9 lirs. all four leaves greatly inflected; much mucus sccreted; all the glands very pale. The leaves werc then left in water for two days; they remaincd closely inflecter, with their glands colourless, and I do not doubt were killed.

Iydrocyanic Acid.-Fonr leaves were immersed, each in thirty minims of one part to 437 of watcr; in $2 \mathrm{hrs} .45 \mathrm{~m}$. all the tentacles were considcrably inflected, with many of the glands palc; after 3 hrs. $45 \mathrm{~m}$. all strongly inflected, and the surrounding fluid coloured pink; after 6 hrs. all closely inflected. After 
an immersion of 8 hrs. $20 \mathrm{~m}$. the leaves were washed and placed in water; next morning, after about 16 hrs., they were still infleeted and diseoloured; on the succeeding day they were evidently dead. Two leaves were immersed in a stronger mixture, of one part to fifty of water; in $1 \mathrm{hr} .15 \mathrm{~m}$. the glands became as white as poreelain, as if they had been dipped in boiling water; very few of the tentacles were infleeted; but after 4 his. almost all were infleeted. These leaves were then placed in water, and next morning were evidently dead. Half-minim drops of the same strength (viz. one part to fifty of water) were next plaeed on the dises of five leaves; after $21 \mathrm{hrs}$. all the outer tentacles were inflected, and the leaves appeared much injured. I likewise touched the secretion round a large number of glands with minute drops (about $\frac{1}{20}$ of a minim, or $00296 \mathrm{mi}$.) of Seheele's mixture (6 per cent.); the glands first beeame bright red, and after 3 hrs. $15 \mathrm{~m}$. about two-thirds of the tentacles bearing these glands were infleeted, and remained so for the two succeeding days, when they appeared dead.

Conctuding Remarks on the Action of Acids.-It is evident that acids have a strong tendency to cause the inflection of the tentacles; * for out of the twenty-four acids tried, nineteen thus acted, either rapidly and energetically, or slowly and slightly. 'This fact is remarkable, as the juices of many plants contain more acid, judging by the taste, than the solutions employed in my experiments. From the powerful effects of so many acids on Drosera, we are led to infer that those naturally contained in the tissues of this plant, as well as of others, must play some important part in their economy. Of the five cases in which acids did not cause the tentacles to be inflected, one is doubtful; for uric acid did act slightly, and caused a copious secretion of mucus. Mere sourness to the taste is no

* According to M. Fournier (- De la Fécondition dans les I'hanérogames,' $1863, \mathrm{p}, 61$ ) drops ol acetic, hydrocyanic, and sulphoure acid cause the stamens of
Berberis instantly to close; though drops of water have no such power, which latter statement I can confirm. 
criterion of the power of an acicl on Drosera, as citric and tartaric acids are very sour, yet do not excite inflection. It is remarkable how acids differ in their power. Thus, hydrochloric acid acts far less powcritully than hydriodic and many other acids of the same strength, and is not poisonous. This is an interesting fact, as hydrochloric acid plays so important a part in the digestive process of animals. Formic acid induces very slight inflection, and is not poisonons; whereas its ally, acetic acid, acts rapidly and powerfully, and is poisonous. Malic acid acts slightly, whereas citric and tartaric acids produce no effect. Lactic acid is poisonous, and is remarkable from inducing inflection only after a considerable interval of time. Nothing surprised me more than that a solution of benzoic acid, so weak as to be hardly acidulous to the taste, should act with grcat rapidity and be highly poisonous; for I am informed that it produces no marked cffect on the animal cconomy. It may be seen, by looking down the list at the head of this discussion, that most of the acids are poisonous, often highly so. Diluter acids are known to induce negative osmose, * and the poisonous action of so many acids on Drosera is, perhaps, connected with this power, for we have secn that the fluids in which they were immersed often became pink, and the glands pale-coloured or white. Many of the poisonous acids, such as hydriodic, benzoic, hippuric, and carbolic (but I neglected to record all the cases), caused the secretion of an extroordinary amount of mucus, so that long ropes of this matter hung from the leaves when they were lifted out of the solutions. Other acids, such as hydrochloric and malic, have no such ten-

* Miller's 'Elements of Chemistry,' part i. 1867 , p. 87. 
dency; in these two latter eases the surrounding fluid was not eoloured pink, and the leaves were not poisoned. On the other hand, propionie aeid, which is poisonous, does not cause much mucus to be secreted, yet the surrounding fluid beeame slightly pink. Lastly, as in the ease of saline solutions, leaves, after being immersed in certain aeids, were soon aeted on by phosphate of ammonia; on the other hand, they were not thus affeeted after immersion in eertain other acids. To this subject, however, I shall have to reeur. 


\section{CHAPTER IX.}

The Emfects of certain Alkaloid Poisons, other Substamces and VAPOURS.

Strychuine, salts of - Quinine, sulphate of, does not soon arrest the movement of the protoplasm - Other salts of quinine-Digitaline - Nicotine - Atropine-Veratrine-Colchicine-Theine-Curare - Morphia - Hyoscyamus - Poison of the cobra, apparently accelerates the movements of the protoplasm - Camphor, a powerful stimulant, its vapour narcotic - Certain essential oils excite movement - Glycerine - Water and certain solutions retard or prevent the subsequent action of phosphate of ammonia-Alcohol innocuous, its vapour narcotic and poisonous - Chloroform, sulphuric and nitric ether, their stimulant, poisonous, and narcotic powerCarbonic acid narcotic, not quickly poisonous - Concluding remarks.

As in the last chapter, I will first give my experiments, and then a brief summary of the results with some concluding remarks.

Acetate of Strychnine.-Half-minims of a solution of one part to 437 of water were plaeed on the dises of six leaves; so that each received $\frac{1}{0 ! 5}$ of a grain, or $\cdot 0296 \mathrm{mg}$. In $2 \mathrm{hr} s .30 \mathrm{~m}$. the outer tentacles on some of them were inflected, but in an irregular manner, sometimes only on one side of the lcaf. The next morning, after 22 hrs. $30 \mathrm{~m}$, the inflection had not inereased. The glands on the ecntral dise were blaekened, and had eeased seereting. After an additional 24 hrs. all the eentral glands seemed dead, but the inflected tentaeles had re-cxpanded and appeared quite healthy. Hence the poisonous aetion of stryehnine scems eonfined to the glands which have absorbed it; nevertheless, these glands transmit a motor impulso to the exterior tentaeles. Minute drops (about $\frac{1}{20}$ of a minim) of the same solution applied to the glands of the outel tentaeles occasionally eaused them to bend. The poison does not seem to aet quickly, for having applied to several glands similar drops of a rather stronger solution, of onc part to 292 of water, this did not prevent the tentaeles bending, when their glands 
were excited, after an intcrval of a quarter to three quarters of an hour, by being rubbed or given bits of meat. Similar drops of a solution of one part to 218 of water ( 2 grs. to 1 oz.) quickly blackened the glands; some few tentacles thus trcated moved, whilst others did not. The latter, however, on being subsequently moistencd with saliva or given bits of meat, became incurved, though with extreme slowness; and this shows that they had been injured. Stronger solutions (but the strength was not ascertained) sometimes ar'rested all power of movement very quickly; thus bits of meat were placed on the glands of several extcrior tentaclcs, and as soon as they began to move, minute drops of the strong solution were added. They continued for a short time to go on bending, and then snddenly stood still; other tentacles on the same leaves, with ment on thcir glands, but not wetted with the strychnine, continued to bend and soon reached the centre of the leaf.

Cirrate of Strychnine.-Half-minims of a solution of one part to 437 of water were placed on the discs of six leaves; after 24 hrs. the outer tentacles shorved only a tracc of inflection. Bits of meat were then placed on three of these leaves, but in 24 hrs. only slight and irregular inflection occurred, proving that the leaves had bcen greatly injured. Two of the leaves to which meat had not bcen given had their discal glands dry and much injured. Minute drops of a strong solution of one part to 109 of water ( 4 grs. to $1 \mathrm{oz}$.) were added to the sccretion round several glands, but did not produce nearly so plain an cffect as the drops of a much weaker solution of the acetate. Particles of the dry citrate were placed on six glands; two of these moved some way towards the centre, and then stood still, being no doubt killed; three others curved much farther inwards, and were then fixed; one alone reached the ccntre. Five leaves were immersed, each in thirty minims of a solution of one part to 437 of water; so that each reccived $\frac{1}{16}$ of a grain; after about $1 \mathrm{hl}$. some of the outcr tentacles became inflected, and the glands were oddly mottled with black and whitc. These glands, in from $4 \mathrm{hrs}$. to $5 \mathrm{hrs}$., becamo whitish and opaque, and the protoplasm in the cclls of the tentacles was well aggregated. By this time two of the leaves were grcatly inflected, but the three others not much more inflected than they mero before. Nevertheless two fresh leaves, after an immersion rcspectively for $2 \mathrm{hr}$ s. and $4 \mathrm{hr}$ s. in the solution, worc not killed; for on being left for $1 \mathrm{hr}$. $30 \mathrm{~m}$. in a solntion of one part of carbonate of ammonia to 218 of water, their tentacles became more inflected, and there was much aggregation. The glands 
of two other leaves, after an immersion for 2 hrs. in a stronger solution, of one part of the citrate to 218 of water, becaine of an opaque, pale pink colour, which before long disappeared, leaving them white. One of these two leaves had its blade and tentacles greatly inflected; the other hardly at all; but the protoplasm in the cells of both was aggregated down to the bases of the tentacles, with the spherical masses in the cells close beneath the glands blackened. After 24 hrs. one of these leaves was colourless, and evidently dead.

Sulphate of Quinine.-Some of this salt was added to water, which is said to dissolve $\frac{1}{1000}$ part of its weight. Five leaves were immersed, each in thirty minims of this solution, which tasted bitter. In less than $1 \mathrm{hr}$. some of them had a ferv tentacles inflected. In $3 \mathrm{brs}$. most of the glands became whitish, others dark-coloured, and many oddly mottled. After $6 \mathrm{hr}$. two of the leaves had a good many tentacles inflected, but this very moderate degree of inflection never increased. One of the leaves was taken out of the solution after 4 lurs., and placed in water; by the next morning some few of the inflected tentacles had re-expanded, showing that they were not dead; but the glands were still much discoloured. Another leaf not included in the above lot, after an immersion of $3 \mathrm{hrs} .15 \mathrm{~m}$., was carefully examined; the protoplasm in the cells of the outer tentacles, and of the short green ones on the dise, had become strongly aggregated down to their bases; and I distinctly saw that the little masses changed their positions and shapes rather rapidly; some coalescing and again separating. I was surprised at this fact, because quinine is said to arrest all movement in the white corpuscles of the blood; but as, according to Binz, ${ }^{*}$ this is due to their being no longer supplied with oxygen by the red corpuscles, any such arrestment of movement could not be expected in Drosera. That the glands had absorbed some of the salt was evident from their change of colour; but I at first thought that the solution might not have travelled down the cells of the tentreles, where the protoplasm was seen in active movement. This view, however, I lave no doubt, is erroneous, for a leaf which had been immersed for 8 hiss. in the quinine solution was then placed in a little solution of one part of carbonate of ammonia to 218 of water; and in $30 \mathrm{~m}$. the glands and the upper cells of the tentacles became intensely black, with the protoplasm presenting a very unusual appearance; for it

* 'Quartcrly Journal of Microscopical Scicnce,' April 1874, ए. 185. 
had beeome aggregnted into retieulated dingy-eoloured masses, having rounded and angular interspaees. As I have never seen this effeet produeed by the earbonate of ammonia alone, it must be attributed to the previous aetion of the quinine. These retieulated masses were watehed for some time, but did not ehange their forms; so that the protoplasm no doubt had been killed by the eombined aetion of the two salts, though exposed to them for only a short time.

Another leaf, after an immersion for 24 hrs. in the quinine solution, beeame somewhat flaceid, and the protoplasm in all the eells was aggregated. Many of the aggregated masses were diseoloured, and presented a granular appearanee; they were spherieal, or elongated, or still more eommonly eonsisted of little eurved ehains of small globules. None of these masses exhibited the least movement, and no doubt were all dead.

Half-minims of the solution were plaeed on the dises of six leaves; after $23 \mathrm{hrs}$. one had all its tentaeles, two had a few, and the others none infleeted; so that the diseal glands, when irritated by this salt, do not transmit any strong motor impulse to the outer tentaeles. After $48 \mathrm{hrs}$. the glands on the dises of all six leaves were evidently mueh injured or quite killed. It is elear that this salt is highly poisonous.*

Acetate of Quinine.-Four leaves were immersed, eaeh in thirty minims of a solution of one part to 437 of water. The solution was tested with litmus paper, and was not aeid. After only $10 \mathrm{~m}$. all four leaves were greatly, and after $6 \mathrm{hrs}$. immensely, infleeted. They were then left in water for $60 \mathrm{hrs}$., but never re-expanded; the glands were white, and the leaves evidently dead. This salt is far more effieient than the sulphate in eausing infleetion, and, like that salt, is highly poisonous.

Nitrate of Quinine.-Four leaves were immersed, eaeh in thirty minims of a solution of one part to 437 of water. After 6 hrs. there was hardly a traee of infleetion; after $22 \mathrm{hr}$. three of the leaves were moderately, and the fourth slightly infleeted; so that this salt induees, though rather slowly, well-marked infleetion. These leaves, on being left in water for 48 hrs., almost

* Binz fonnd several years ago (as stated in "T'he Journal of Anatomy and Phys.' November 1872, p. 195) that quinia is an energetic poison to low vegetable and animal organisms. Even one part added to 1000 parts of blood arrests the movements of the white eorpuseles, which become "rounded and granular." In the tentacles of Drosern the agrregated masses of protoplasm, which appeared killed by the quinine, likewise presented a granular appenzanee. $\Lambda$ similar appearance is enused by very hot water. 
eompletely re-expanded, but the glands wcre muel discoloured. Henee this salt is not poisonous in any high degrec. The different action of the three foregoing salts of quinine is singular.

Digitaline.-Halif-minims of a solution of one part to 437 of watcr were placed on the discs of five leaves. In 3 hrs. $45 \mathrm{~m}$. some of them had their tentaeles, and one had its blade, moderately inflected. After 8 hrs. three of them werc well inflected; the fourth had only a few tentacles infleeted, and the fifth (an old leaf) was not at all affected. They remained in nearly the same state for two days, but the glands on their discs beeame palc. On the third day the lcaves appcared much injured. Neverthcless, when bits of meat were placed on two of them, the outer tentacles became inflected. A minute drop (about $\frac{1}{20}$ of a minim) of the solution was applied to threc glands, and after 6 hrs. all three tentacles were infleeted, but next day had nearly re-expanded; so that this very small dose of $\frac{1}{28500}$ of a grain ( $.00225 \mathrm{mg}$.) acts on a tentaele, but is not poisonous. It appears from these several facts that digitaline eauses inflection, and poisous the glands which absorb a moderately large amount.

Nicotine.-The secretion round sevcral glands was tonched with a minute drop of the pure fluid, and the glands were instantly blackened; the tentaeles beeoming inflected in a few minutes. Two leaves were immersed in a weak solution of two drops to $1 \mathrm{oz}$, or 437 grains, of watcr. When cxamined after $3 \mathrm{hrs} .20 \mathrm{~m}$., only twenty-one tentaeles on one lcaf were elosely inflected, and six on the other slightly so; but all the glands were blackened, or very dark-eoloured, with the protoplasm in all the cells of all the tentacles much aggregated and dark-colourcd. The leaves were not quitc killed, for on being placed in a little solution of carbonate of ammonia ( 2 grs. to 1 oz.) a few more tentacles beenme infleeted, the remainder not being acter on during the next 24 hrs.

Half-minims of a stronger solution (two dropss to $\frac{1}{2} \mathrm{oz}$. of watcr) werc placed on the discs of six lcaves, and in $30 \mathrm{~m}$. all those tentacles became infleeted; the glands of whieh had actually touched the sulution, as shown by their blackness; but hardly any motor influence was transmitted to the onter tentreles. After 22 hrs. most of the glands on the discs appeared dead; but this could not have been the ease, as when bits of meat were plaeed on threc of them, some few of the outer tentacles were inflected in 24 hrs. Hence nicotine lias $\Omega$ great tendeney to blaeken the glands and to induec aggregation 
of the protoplasm, but, except when pure, has very moderate power of inducing inflection, and still less power of causing a motor influence to be transmitted from the discal glands to the outer tentacles. It is moderately poisonous.

Atropine.-A grain was added to 437 grains of water, but was not all dissolvecl; another grain was added to 437 grains of a mixture of one part of alcohol to seven parts of water; and a third solution was made by adding one part of valerianate of atropine to 437 of water. Half-minims of these three solutions were placed, in each case, on the discs of six leaves; but no effect whaterer was produced, excepting that the glands on the dises to which the valerianate was given were slightly discoloured. The six leares on which drops of the solution of atropine in diluted alcohol had been left for $2 \mathrm{l}$ hrs. were given bits of meat, and all became in 24 hrs. fairly well inflected; so that atropine does not excite morement, and is not poisonous. I also tried in the same manner the alkaloid sold as daturine, which is believed not to differ from atropine, and it produced no effect. Three of the leaves on which drops of this latter solution had been left for $24 \mathrm{hrs}$. were likewise given bits of meat, and they had in the course of 24 hrs. a good many of their submarginal tentacles inflected.

Veratrine, Colchicine, Theine.-Solutions were made of these three alkaloids by adding one part to 437 of water. Half-minims were placed, in each case, on the clises of at least six leaves, but no inflection was cansed, except perhaps a very slight amount by the theine. Half-minims of a strong infusion of tea likewise produced, as formerly stated, no effect. I also tried similar diops of an infusion of one part of the extrnet of colchicum, sold by druggists, to 218 of water: and the leaves were observed for 48 hrs., without any effect being produced. 'The seven leaves on which drops of veratrine had been left for $26 \mathrm{hrs}$. were given bits of meat, and after 21 hrs. were well inflected. These three alkaloids are therefore quite innocuous.

Curare.-One part of this famous poison was added to 218 of water, and three leaves were immersed in ninety minims of the filtered solution. In $3 \mathrm{hrs}$. $30 \mathrm{~m}$. some of the tentacles were a little inflected; as was the blade of one, after 4 hrs. After $7 \mathrm{hrs}$. the glands were wonderfully blackened, showing that matter of some kincl had been absorbed. In 9 lrrs. two of the leaves had most of their tentacles sub-inflected, but the inflection did not increase in the course of 24 lirs. One of these leaves, after being immersed for 9 hrs. in the solution, was placed in watcr, and by next morning had largely re-expanded; 
- the other two, after their immersion for $24 \mathrm{hrs}$., were likewise placed in water, and in 24 hrs. were considerably re-expanded, thougly their glands were as black as ever. Half-minims were placed on the dises of six leares, and no infleetion ensued; but after three days the glands on the cliscs appeared rather dry, yet to my surprise were not blackened. On another occasion drops were placed on the dises of six leaves, and a considerable amount of inflection was soon caused; but as I had not filtered the solution, floating particles may have aeted on the glands. After 21 hrs. bits of meat were placed on the discs of three of these leares, and next day they became strongly inflected. As I at first thought that the poison might not have been dissolved in pure water, one grain was added to 437 grains of a mixture of one part of alcoliol to seven of water, and half-minims were placed on the discs of six leaves. These were not at all affected, and when after a day bits of meat were given them, they were slightly inflected in 5 hrs., and closcly aftcr $24 \mathrm{hrs}$. It follows from these several facts that a solution of curare induces a very moderate degree of inflection, and this may perhaps be due to the presence of a minute quantity of albumen. It certainly is not poisonous. The protoplasm in one of the leaves, which had been immersed for 24 hrs., and which had become slightly inflected, had undergone a very slight amount of aggregationnot more than often ensues from an immersion of this lengtle of time in water.

Acetate of Morphia. - I tried a great number of experiments with this substanee, but with no certain result. A eonsiderable number of lenves were immersed from between 2 hrs. and 6 hrs. jn a solution of one part to 218 of water, and did not become infleeted. Nor were they poisoned; for when they were washed and placed in weak solutions of phosphate and carbonate of ammonia, they soon became strongly inflected, with the protoplasm in the cells wcll aggregated. If, however, whilst the leaves were immersed in the morphia, phospliate of ammonia was added, inflection did not rapidly onsue. Minute drops of the solution werc applied in the usual manner to the secretion round between thirty and forty glands; and when, aftcr an interval of $6 \mathrm{~m}$., bits of meat, a little saliva, or particles of glass, were placed on them, the movement of the tentacles was grcatly retarded. But on other occasions no such retardation occurred. Drops of water similarly applied never have any retarding nower. Minute drops of a solution of sugar of the same strength (one part to 218 of water) sometimes retarded the smbseruent action of ment and of particles of glass, and 
sometimes did not do so. At one time I fclt eonvinccd that morphia aeted as a narcotic on Droscra, but after having found in what a singular manner immcrsion in eertain non-poisonous salts and aeids prevents the subsequent action of phosphate of ammonia, whercas other solutions have no. sueh power, my first conviction seems very doubtful.

Extract of Hyoscyamus.-Sevcral leaves were plaeed, eaeh in thirty minims of an infusion of $3 \mathrm{grs}$. of the extract sold by druggists to $1 \mathrm{oz}$. of water. One of them, after being immorsed for 5 hrs. $15 \mathrm{~m}$., was not inflected, and was then put into a solution ( $1 \mathrm{gr}$. to $1 \mathrm{oz}$.) of carbonate of ammonia; after 2 hrs. $40 \mathrm{~m}$. it was found eonsiderably inflected, and the glands much blackened. Four of the leaves, after bcing immersed for $2 \mathrm{hrs} .14 \mathrm{~m}$., were placed in 120 minims of a solution (1 gr. to $20 \mathrm{oz}$.) of phosphate of ammonia; they had already beeome slightly inflected from the hyoscyamus, probably owing to the presence of some albuminous matter, as formcrly cxplained, but the infleetion immcdiatcly increased, and after $1 \mathrm{hr}$. was strongly pronounced; so that hyoscyamus does not act as a nareotic or poison.

Poison from the Fang of a Living Adder.-Minutc drops were plaeed on the glands of many tentacles; thcse wcre quickly infleeted, just as if saliva had been given them. Next morning, after 17 hrs. $30 \mathrm{~m}$., all werc beginning to re-expand, and they appeared uninjured.

Poison from the Cobra.-Dr. Fayrer, well known from his investigations on the poison of this deadly snakc, was so kind as to give me some in a dried state. It is an albuminous substance, and is believed to replaee the ptyaline of saliva.* A minutc drop (about $\frac{1}{20}$ of a minim) of a solution of onc part to 437 of water was applied to the secretion round four glands; so that each received only about $\frac{1}{38400}$ of a grain (•0016 mg.). The operation was repeated on four other glands; and in $15 \mathrm{~m}$. several of the eight tentacles becamc well inflected, and all of them in $2 \mathrm{hrs}$. Next morning, after $24 \mathrm{hrs}$., they wore still infleeted, and the glands of a very pale pink eolour. After an additional $24 \mathrm{hrs}$. they were ncarly re-expanded, and eompletely so on the succeeding day; but most of the glands remained almost white.

Half-minims of the same solution were plaeed on the dises of three lcaves, so that each received $\frac{7}{060}$ of a grain ( $\left.0675 \mathrm{mg}.\right)$; in

Ur. Fayrer, 'The 'Thanatophidia of India,' 1872, p. 150. 
4 lurs. $15 \mathrm{~m}$, the outer tentacles were much inflected; and after 6 hr's. $30 \mathrm{~m}$. those on two of the leaves wcre closcly inflected and the blade of one; the third lcaf was only moderately affected. The loaves remained in the same statc during the next day, but after 48 hrs. ro-cxpanded.

Three leaves wcre now immcrsed, cach in thirty minims of the solution, so that each received $\frac{1}{16}$ of a grain, or $4.048 \mathrm{mg}$. In $6 \mathrm{~m}$. there was some inflcetion, which stcadily incrcascd, so that after 2 hrs. $30 \mathrm{~m}$. all thrce leaves were closcly inflected; the glands wcre at first somewhat darkened, then rendered pale; and the protoplasm within the cclls of the tentaclcs was partially aggregatcd. The little masses of protoplasm werc examincd aftcr 3 hrs., and again after 7 hrs., and on no other occasion have I scen them undcrgoing such rapid changes of form. After 8 hrs. $30 \mathrm{~m}$. the glands had become quite white; they had not secreted any great quantity of mucus. The lcaves werc now placed in water, and after 40 hrs. re-expanded, showing that they were not much or at all injured. During their immersion in water the protoplasm within the cells of the tentacles was occasionally examined, and always found in strong movement.

Two lcaves were next immersed, each in thirty minims of a much stronger solution, of one part to 109 of water; so that each received $\frac{1}{4}$ of a grain, or $16.2 \mathrm{mg}$. Aftcr $1 \mathrm{hr} .45 \mathrm{~m}$. the submargimal tentacles were strongly inflected, with the glands somewhat pale; after 3 hrs. $30 \mathrm{~m}$. both leaves had all their tentacles closely inflected and the glands white. Hence the weakcr solution, as in so many othcr cases, induced morc rapid inflection than the stronger one; but the glands were sooner rendered whitc by the latter. After an immcrsion of $2 t$ hrs. some of the tentacles werc examined, and the protoplasm, still of a fine purple colour, was found aggregatcd into chains of small globular masses. These changed their shapes with remarkable quickncss. After an immersion of 48 hrs. they wcre again examined, and their movements were so plain that they could casily be seen under a weak powcr. The leaves were now placed in watcr, and after 24 hrs. (i.e. 72 hrs. from their first immersion) the little masses of protoplasm, which had becomo of a dingy purple, were still in strong movement, changing their shapes, coalcscing, and again scparating.

In 8 hrs. after these two leaves had becn placed in watcr (i.e. in 56 hrs. after thcir immcrsion in the solution) thcy bcgan to re-expand, and by the next morning wero more expanded. After an additional day (i.e. on the fourth day alter their immersion in the solution) they wcre largely, but not quite fully 
expanded. The tentacles were now examined, and the aggregated masses were almost wholly redissolved; the cells being filled with homogeneous purple fluid, with the exception here and there of a single globular mass. We thus see low completely the protoplasm had escaped all injury from the poison. As the glands were soon rendered quite white, it occurred to me that their texture might have been modified in such a manner as to prevent the poison passing into the cells beneath, and consequently that the protoplasm within these cells had not been at all affected. Accordingly I placed another leaf, which had been inmersed for 48 hrs. in the poison and afterwards for 24 hrs. in water, in a little solution of one part of carbonate of ammonia to 218 of watcr; in $30 \mathrm{~m}$. the protoplasm in the cells beneatl the glands became darker, and in the course of 24 hr's. the tentacles were filled down to their bases with dark-coloured spherical masses. Hence the glands had not lost their power of absorption, as far as the carbonate of ammonia is concerned.

From these facts it is manifest that the poison of the cobra, though so deadly to animals, is not at all poisonous to Drosera; jet it causes strong and rapid inflection of the tentacles, and soon discharges all colour from the glands. It seems even to act as a stimulant to the protoplasm, for after considerable experience in observing the movements of this substance in Drosera, I have never seen it on any other occasion in so active a state. I was therefore anxious to learn how this poison affected animal protoplasm; and Dr. Fayrer was so kind as to make some observations for me, which he has since published.* Ciliated epithelium from the mouth of a frog was placed in a solution of .03 gramme to 4.6 cubic $\mathrm{cm}$. of water; others being placed at the same time in pure water for comparison. The movements of the cilia in the solntion seemed at first increased, but soon languished, and after between 15 and 20 minntes ceased; whilst those in the water were still acting vigorously. The white corpuscles of the blood of a frog, and the cilin on two infusorial animals, a Paramrcium and Volvox, were similarly affected by the poison. Dr. Fayrer also found that the muscle of a frog lost its irritability after an immersion of $20 \mathrm{~m}$. in the solution, not then responding to a strong electrical current. On the other hand, the movements of the cilia on the mantle of an Unio were not always ar'ested, even when left for a consicier-

* 'Procccdings of Royal Society; Fub. 18, 1875. 
able time in a very strong solution. On tho whole, it seems that the poison of the cobra acts far more injuriously on the protoplasm of the higher animals than on that of Drosera.

There is one other point which may be noticed. I have oceasioually observed that the drops of secretion round the glands were rendered somewhat turbid by certain solutious, and morc especially by some acids, a film being formed on the surfaces of the drops; but I never saw this effect produced in so conspicuous a manner as by the cobra poison. When the stronger solution was employed, the drops appeared in $10 \mathrm{~m}$. like littlc white rounded clouds. After 48 hrs. the secretion was changed into threads and sheets of a membranous substance, including minute grauules of various sizes.

Camphor.-Some seraped camphor was left for a day iu a bottle with distilled water, and then filtered. A solution thus made is said to contain $\frac{1}{1000}$ of its weight of eamphor; it smelt and tasted of this substance. Ten leaves were immersed in this solution; after $15 \mathrm{~m}$. five of them were well inflected, two showing a first trace of movement in $11 \mathrm{~m}$. and $12 \mathrm{~m}$.; the sixth leaf did not begin to move until $15 \mathrm{~m}$. had clapscd, but was fairly well inflected in $17 \mathrm{~m}$. and quite closed in $24 \mathrm{~m}$.; the seventh began to move in $17 \mathrm{~m}$., and was completely shut in $26 \mathrm{~m}$. The eighth, ninth, and tenth leaves were old aud of a very dark red colour, and these were not inflected after an immersion of 24 hrs.; so that in malsing experiments with camphor it is necessary to avoid such leaves. Some of these leaves, on being left in the solution for 4 hrs., became of a rather dingy pink colour, and scereted much mueus; although their tentacles were closely inflectcd, the protoplasm within the cells was not at all aggregated. On another oecasion, however, after a longer immersion of 24 hrs., there was well marked aggregation. A solution madc by adding two drops of camphorated spirits to an ounce of water did not act on one leaf; whereas thirty minims added to an ounce of water aeted on two loavos immersed together.

M. Vogel has shown* that the flowers of various plants do not wither so soon when their stems are placed in a solution of eamphor as when in water; and that if already slightly withered, they recover more quickly. The germination of certain seeds is also aecelerated by the solution. So that camphor acts as a stimulant, and it is the only known stimulant for plants. I

* 'Gardener's Chronicle,' 1874, p. 671. Ncarly similar obscrvations were Inade in 1798 by B. S. Barlon. 
wished, therefore, to aseertain whether camphor would render the leaves of Drosera more sensitive to meehanical irritation than they naturally are. Six leaves were left in distilled water for $5 \mathrm{~m}$. or $6 \mathrm{~m}$., and then gently brushed twiee or thrice, whilst still under water, with a soft camel-hair brush; but no movement ensued. Nine leaves, which had been immersed in the above solution of eamphor for the times stated in the following table, were next brushed only once with the same brush and in the same manner as before; the results are given in the table. My first trials were made by brushing the leaves whilst still immersed in the solution; but it oceurred to me that the viscid seeretion round the glands would thus be removed, and the eamphor might aet more effectually on them. In all the following trials, therefore, eaeh leaf was taken out of the solution, waved for about $15 \mathrm{~s}$. in water, then placed in fresh water and biushed, so that the brushing would not allow the freer aeeess of the camphor; but this treatment made no differenee in the results.

\begin{tabular}{|c|c|c|c|}
\hline 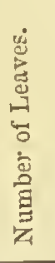 & $\begin{array}{c}\text { Length of } \\
\text { Immersion in } \\
\text { the Solution } \\
\text { of Camphor. }\end{array}$ & $\begin{array}{l}\text { Length of Time between the Act of Brushing } \\
\text { and the Inflection of the Tentacles. }\end{array}$ & $\begin{array}{l}\text { Length of } \\
\text { Time between } \\
\text { the Immersion } \\
\text { of the Leaves in } \\
\text { the Solution } \\
\text { and the First } \\
\text { Sign of the } \\
\text { Inflection of the } \\
\text { Tentacles. }\end{array}$ \\
\hline 1 & $5 \mathrm{~m}$. & $\left\{\begin{array}{r}3 \text { m. eonsiderable infleetion } ; \pm \text { m. all } \\
\text { the tentacles exeept } 3 \text { or } 4 \text { infleeted. }\}\end{array}\right\}$ & $\mathrm{S} \mathrm{m}$. \\
\hline 2 & $5 \mathrm{~m}$. & $6 \mathrm{~m}$. first sign of infleetion. & $11 \mathrm{~m}$. \\
\hline 3 & $5 \mathrm{~m}$. & $\left\{\begin{array}{c}6 \mathrm{~m} .30 \mathrm{~s} . \text { slight inflection; } ; \mathrm{m} .30 \mathrm{~s} . \\
\text { plain infleetion. }\end{array}\right.$ & $11 \mathrm{~m} .30 \mathrm{~s}$ \\
\hline 4 & $4 \mathrm{~m} .30 \mathrm{~s}$ & $\left\{\begin{array}{c}2 \mathrm{~m} .30 \text { s. a traee of inflection; } 3 \mathrm{~m} . \\
\text { plain } ; 4 \mathrm{~m} \text {. strongly marlied. }\end{array}\right\}$ & $7 \mathrm{~m}$ \\
\hline$\tilde{\jmath}$ & $4 \mathrm{~m}$. & $\left\{\begin{array}{c}2 \mathrm{~m} .30 \mathrm{s.} \text { a trace of infleetion; } 3 \mathrm{~m} . \\
\text { plain infleetion. }\end{array}\right.$ & $6 \mathrm{~m} .30 \mathrm{~s}$. \\
\hline 6 & $4 \mathrm{~m}$. & 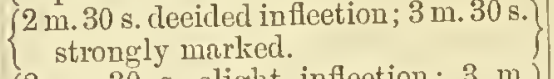 & $6 \mathrm{~m} .30 \mathrm{~s}$. \\
\hline 7 & $4 \mathrm{~m}$. & $\left\{\begin{array}{l}2 \mathrm{~m} .30 \text { s. slight infleetion; } 3 \mathrm{~m} . \\
\text { plain; } 4 \mathrm{~m} \text {. well marked. }\end{array}\right.$ & $6 \mathrm{~m} .30 \mathrm{~s}$. \\
\hline 8 & $3 \mathrm{~m}$. & $\left\{\begin{array}{l}2 \mathrm{~m} \text {. traee of inflection; } 3 \mathrm{~m} \text {. eon- } \\
\text { siderable, } 6 \mathrm{~m} \text {. strong inflection. }\end{array}\right.$ & $5 \mathrm{~m}$. \\
\hline 9 & m. & $\left\{\begin{array}{l}2 \mathrm{~m} \text {. traec of infleetion; } 3 \mathrm{~m} \text {. eon- } \\
\text { siderable, } 6 \mathrm{~m} \text {. strong infleetion. }\end{array}\right.$ & $5 \mathrm{~m}$. \\
\hline
\end{tabular}

Other leaves were left in the solution without being brushed; one of these first showed a trace of inflection after $11 \mathrm{~m}$; a sceond after $12 \mathrm{~m}$; fire were not infleeted until $15 \mathrm{~m}$. had 
clapsed, and two not witil a few minutes later. On the otler lrand, it will be seen in the riglit-hand column of the table that most of the leaves subjected to the solution, and which wcre brushed, becamc inflected in a mueh shorter time. The movement of the tentacles of some of these leaves was so rapid that it eould be plainly seen through a very wcak lens.

Two or three other experiments are worth giving. A large old leaf, after being immersed for $10 \mathrm{~m}$. in the solution, did not appear likely to be soon inflected; so I brushed it, and in $2 \mathrm{~m}$. it began to move, and in $3 \mathrm{~m}$. was completely shut. Another leaf, after an immersion of $15 \mathrm{~m}$., showed no signs of infleetion, so was brushed, and in $4 \mathrm{~m}$. was grandly inflected. A third leaf, after an immersion of $17 \mathrm{~m}$., likewise showed no signs of inflection; it was then brushed, but did not move for $1 \mathrm{hr}$.; so that here was a failure. It was again brushed, and now in $9 \mathrm{~m}$. a few tentacles became infleeted; the failure thereforc was not complete.

We may conclude that a small dose of camplor in solution is a powerful stimulant to Droscra. It not only soon cxcites the tentacles to bend, but apparently renders the glands sensitive to a touch, which by itself does not causc any movement. Or itmay be that a slight mechanical irritation not enough to causc any inflection yet gives some tendency to movement, and thus reinforces the action of the camphor. This latter view would have appeared to me the more probable one, had it not been shown by MI. Vogel that camphor is a stimulant in other ways to various plants and seeds.

Two plants bearing four or five leaves, and with their roots in a little cup of water, were exposed to the vapour of some bits of camphor (about as large as a filbert-nut), under a vessel holding ten fluid ounces. After $10 \mathrm{hr}$. no inflection ensued; but the glands appeared to bc seereting more copiously. The leaves were in a narcotised condition, for on bits of meat being placed on two of them, there was no inflection in 3 hrs, $15 \mathrm{~m}$., and even after 13 hrs. $15 \mathrm{~m}$. only a few of the outcr tcntacles wore slightly inflected; but this degree of movement shows that the lcaves had not been killed by an exposure during 10 hrs. to the vapour of camphor.

Oil of Caravay. - Water is said to dissolve about a thousandth part of its wcight of this oil. A clrop was added to an ounce of water and the bottlc occasionally shaken during a day; but many minute glolules remained undissolved. Fivo leaves werc immersed in tllis mixture; in from $4 \mathrm{~m}$. to $5 \mathrm{~m}$. there was sornc inflection, whieh became moderately pronounced in two w 
three additional minutes, After $14 \mathrm{~m}$. all five leaves were wcll, and some of them closely, inflected. After 6 hrs. the glands were white, and much mucus had been secreted. The leaves were now flaccid, of a peculiar dull-red colour, and evidently dead. One of the leares, after an immersion of $4 \mathrm{~m}$., was brushed, like the leaves in the camphor, but this produced no effect. A plant with its roots in water was exposed under a $10-\mathrm{oz}$. vessel to the vapour of this oil, and in $1 \mathrm{hr} .20 \mathrm{~m}$. one leaf showed a trace of inflection. After 5 hrs. $20 \mathrm{~m}$. the cover was taken off and the leaves examined; one had all its tentacles closely inflected, the second about half in the same state; and the third all subinflected. The plant was left in the open air for $42 \mathrm{hr}$.'s., but not a single tentacle expanded; all the glauds appeared dead, except here and there ono, which was still secreting. It is evident that this oil is highly exciting and poisonous to Drosera.

Oil of Cloves. - A mixture was made in the same manner as in the last case, and three leaves were immersed in it. After $30 \mathrm{~m}$. there was only a trace of inflection which never incrensed. After $1 \mathrm{hr} .30 \mathrm{~m}$. the glands were pale, and after $6 \mathrm{hrs}$. white. No doubt the leaves were much injured or killed.

T'urpentine.-Small drops placed on the dises of some leares killed them, as did likewise drops of creosote. A plant was left for $15 \mathrm{~m}$. under a 12-oz. vessel, with its inner surface wetted with twelve drops of turpentine; but no movement of the tentacles ensued. After 24 hrs. the plant was dead.

Glycerine.-Half-minims were placed on the dises of three leaves: in 2 hrs, some of the outer tentacles were irregularly inflected; and in 19 hrs. the leaves were flaccid and apparently dead; the glands which bad tonched the glycerine were colourless. Minute drops (about $\frac{\pi}{20}$ of a minim) were apphied to the glands of several tentacles, and in a few minutes these mored and soon reached the centre. Similar drops of a mixtme of four dropped drops to $1 \mathrm{oz}$. of water were likewise applied to several glands; but only a few of the tentacles mored, and these very slowly and slightly. Half-minims of this same mixture placed on the discs of some leaves caused, to my surprise, no inflection in the course of 48 hrs. Bits of meat were then given them, and next day they were well inflected; notwithstanding that some of the discal glands had been rendered almost colourless. Two leaves were immersed in the same mixture, but only for 4: hrs.; they were not inflected, and on being afterwards left for 2 hrss. $30 \mathrm{~m}$. in a solution ( $1 \mathrm{gr}$. to $1 \mathrm{oz}$.) of carbounte of ammonia, their glands wore blackened, their tentacles inflected, and the protoplasm within their cells aggregated. It appears 
from these facts that a mixture of four drops of glyccrine to inl ounce of water is uot poisonous, and exeites very little infleetion; but that pure glycerine is poisonous, and if applied in very minute quantities to the glands of the outer tentaeles causes their inflection.

The Liffects of Immersion in Water and in various Solutions on the subsequent Action of Phosphate and Carbonate of Ammonic.We have seen in the third and seventh ehapters that immersion in distillerl water causes after a time some degree of aggregation of the protoplasm, and a moderatc amount of inflcetion, espceially in the case of plants which have been kept at a rather high temperature. Water docs not exeitc a copious secretion of mueus. We have here to consider the effects of immcrision in various funids on the subsequent action of salts of ammonia and other stimulants. Four leaves which had becn left for 24 hrs. in water wcre given bits of meat, but did not clasp them. Ten leaves, after a similar immersion, were left for 24 hrs. in a powerful solution ( $1 \mathrm{gr}$. to $20 \mathrm{oz}$.) of phosphate of ammonia, and only one showed even a trace of inflection. Three of thesc leaves, on being left for an additional day in the solution, still remained quite unaffeeted. When, however, some of these leaves, which had been first immersed in water for 24 hrs., and then in the phosphate for $24 \mathrm{hr}$. were placed in a solution of earbonate of ammonia (one part to 218 of water), the protoplasm in the eclls of the tcntaeles became in a few hour's strongly aggregated, showing that this salt had becn absorbed and taken cffect.

A short immersion in water for $20 \mathrm{~m}$. did not retard the subsecuent action of the phosplate, or of splinter's of glass plaeed on tlie glands; but in two instances an immersion for $50 \mathrm{~m}$. prevented any effect from a solution of eamphor. Scveral lcaves which liad becn left for $20 \mathrm{~m}$. in a solution of one part of white sugar to 218 of water werc placed in the phosphate solution, the action of which was delayed; whercas a.mixed solution of sugar and the phosphate did not in the least interfere with the effeets of the latter. Three lcaves, after bcing immersed for $20 \mathrm{~m}$. in the sugar solution, were placed in a solution of carbonate of ammonia (one part to 218 of water'); in $2 \mathrm{~m}$. ol $3 \mathrm{~m}$. the glands were blackened, and after $7 \mathrm{~m}$. the tentacles were considcrably inflected, so that the solution of sugar, though it delayed the aetion of the phosphate, flid not delay that of the carbonate. Immersion in a similar solution of gum arabic for $20 \mathrm{~m}$. had 110 retarding action on the plosphate. Threo leaves were left for $20 \mathrm{~m}$. in a mixture of one part of alcolol to seven parts of water, 
and then placed in the phosphate solution : in 2 lirs. $15 \mathrm{~m}$. there was a trace of infleetion in one leaf, and in 5 hrs. $30 \mathrm{~m}$. a second was slightly affected; the infleetion subsequently increased, though slowly. Hence diluted alcohol, which, as we shall see, is hardly at all poisonous, plainly retards the subsequent action of the phosphate.

It was shown in the last chapter that leaves whieh did not become inflected by nearly a day's immersion in solutions of various salts and aeids behaved very differently from one another when subsequently placed in the phosphate solution. I here give a table summing up the results.

\begin{tabular}{|c|c|c|}
\hline $\begin{array}{l}\text { Name of the Salts and } \\
\text { Acids in Solution. }\end{array}$ & $\begin{array}{c}\text { Period of } \\
\text { Immersion } \\
\text { of the } \\
\text { Leaves in } \\
\text { Solutious } \\
\text { of one part } \\
\text { to } 437 \text { of } \\
\text { water. }\end{array}$ & $\begin{array}{l}\text { Effects produced on the Leaves by their snbse- } \\
\text { quent Immersion for stated periods in a } \\
\text { Sulution of one part of phosphate of } \\
\text { ammonia to } 8750 \text { of water, or l gr. to } \\
20 \mathrm{oz} \text {. }\end{array}$ \\
\hline Rubidium chloricle . & 22 hrs. & $\begin{array}{l}\text { After } 30 \mathrm{~m} \text {. strong inflection of the } \\
\text { tentaeles. }\end{array}$ \\
\hline Potassium carbonate & $20 \mathrm{~m}$. & $\begin{array}{l}\text { Seareely :ny infleetion until } 5 \text { hrs. } \\
\text { had elapsed. }\end{array}$ \\
\hline Calcium aeetate & 24 hrs. & After 24 hrs. very slight infleetion. \\
\hline Calcium nitrate . & $\begin{array}{l}2 \pm \text { hrs. } \\
22 \text { hrs. }\end{array}$ & $\begin{array}{l}\text { Do. } \\
\text { Some slight inflection, whieh beeame }\end{array}$ \\
\hline & & well pronouneed in 24 hrs. \\
\hline Magnesium nitrate. & 22 his. & $\begin{array}{l}\text { After } 4 \text { hrs. } 30 \mathrm{~m} \text {, a fair amount of } \\
\text { inflection, which nerer increased. }\end{array}$ \\
\hline Mirgnesium ehloride & 22 hrs. & $\begin{array}{l}\text { After a few minutes great inflection ; } \\
\text { after } 4 \text { hrs. all fomr lenves with almost } \\
\text { every teutacle elosely inflected. }\end{array}$ \\
\hline Barium aeetate . & 22 hrs. & $\begin{array}{l}\text { After } 24 \text { hrs. two leaves out of four } \\
\text { slightly infleeted. }\end{array}$ \\
\hline Parinm nitrate & 22 hrs. & $\begin{array}{l}\text { After } 30 \mathrm{~m} \text {. ono leaf grcatly, and two } \\
\text { others moderately, infleeted; they } \\
\text { remained thas for } 2 t \text { lurs. }\end{array}$ \\
\hline Strontium aeetate & 22 lirs. & $\begin{array}{l}\text { After } 25 \mathrm{~m} \text {. two lcaves greatly in- } \\
\text { fleeted; after } 8 \text { hrs. a third leaf } \\
\text { moderately, and the fourth rery } \\
\text { slightly, inflected. All four thus } \\
\text { remained for } 2+\text { lirs. }\end{array}$ \\
\hline Stroutium nitrate & 22 hrs. & $\begin{array}{l}\text { After S lirs. threo leaves out of fire } \\
\text { moderately inflected; after } 2 t \text { hrs. } \\
\text { all fivo in this state; but not ono } \\
\text { elosely infleeted. }\end{array}$ \\
\hline Aluminium chlorite & $2 t$ hrs. & $\begin{array}{l}\text { Three lenves which had either been } \\
\text { slightly or not at all atieeted by tho } \\
\text { chlorido beeame after } 7 \text { hrs. } 30 \mathrm{~m} \text {. } \\
\text { ruther elosely infleeted. }\end{array}$ \\
\hline
\end{tabular}




\begin{tabular}{|c|c|c|}
\hline $\begin{array}{l}\text { Name of the Salts and } \\
\text { Acids in Solution. }\end{array}$ & $\begin{array}{c}\text { Period of } \\
\text { Immersion } \\
\text { of the } \\
\text { Leaves in } \\
\text { Solutions } \\
\text { of one part } \\
\text { to t37 of } \\
\text { water. }\end{array}$ & $\begin{array}{l}\text { Effects Iroduced on the Leaves by their sub- } \\
\text { sequent Immersion for stated periods in a } \\
\text { Solution of one part of phosphate of } \\
\text { ammonla to } 8750 \text { of water, or } 1 \mathrm{gr} \text {. to } \\
20 \mathrm{oz} \text {. }\end{array}$ \\
\hline Aluminium nitrate. & $2+$ hrs. & Aftcr 25 hrs. slight and doubtful effect. \\
\hline Lerid chloride. . & 23 hrs. & $\begin{array}{l}\text { After } 24 \text { hrs. two leaves somewhat } \\
\text { inflected, the third very little; and } \\
\text { thus remained. }\end{array}$ \\
\hline Manganese chloride & 22 hrs. & Aftcr 48 hrs. not the least inflcction. \\
\hline Lactic acid . . & 48 hrs. & $\begin{array}{l}\text { After } 2 \pm \text { hrs. a trace of inflection in } \\
\text { a few tentacles, the glands of } \\
\text { which had not been killed by the } \\
\text { acid. }\end{array}$ \\
\hline Tannic acid . & $24 \mathrm{hrs}$. & After 24 hrs, no inflection. \\
\hline Tartaric acid & $24 \mathrm{hrs}$. & Do. do. \\
\hline Citric acid . . . & $24 \mathrm{hrs}$. & $\begin{array}{l}\text { Aftcr } 50 \mathrm{~m} \text {. tentacles decidedly in- } \\
\text { flected, and after } 5 \mathrm{hrs} \text {. strongly } \\
\text { inflected; so remained for the next } \\
24 \text { hrs. }\end{array}$ \\
\hline Formic acid. . & 22 hrs. & $\begin{array}{l}\text { Not obselved until } 24 \text { hrs. had clapsed; } \\
\text { tentacles considerably inflected, and } \\
\text { protoplasm aggregated. }\end{array}$ \\
\hline
\end{tabular}

In a large majority of these twenty eases, a varying degree of inflection was slowly eaused by the phosphate. In four eases, however, the infleetion was rapid, oceurring in less than half an hour or at most in $50 \mathrm{~m}$. In three cases the phosphate did not produee the least effeet. Now what are we to infer from these faets? We know from ten trials that immersion in distilled water for 24 hrs. prevents the subsequent aetion of the phosphate solution. It would, therefore, appear as if the solutions of ehloride of manganese, tannie and tartaric aeids. whieh are not poisonous, aeted exaetly like water, for the phosphate produeed no effeet on the leaves whieh had been previously immersed in these three solutions. The majority of the other solutions behaved to a eertain extent like water, for the phosphate produced, after a considerable interval of time, only a slight effeet. On the other hand, the leaves which had been immersed in the solutions of the elloride of rubidium and magnesium, of reetate of strontium, nitrate of barium, and eitric acid, wero quiekly aeted on by the phosphate. Now was water absorbed from these five weak solutions, and yet, owing to the presence of the salts, did not prevent the subsequeut aetion of the phosphate? Or 
may we not suppose* that the interstiecs of the walls of the glands were blocked up with the molceules of thcse fire substanccs, so that thcy were rendered impermcable to water; for had water entered, we know from the ten trials that the phosphatc would not afterwards have produeed any effeet? It further appears that the molccules of the carbonate of ammonia can quickly pass into glands whieh, from having been immersed for $20 \mathrm{~m}$. in a weak solntion of sugar, either absorb the phosphate very slowly or are acted on by it very slowly. On the other hand, glands, however thcy may have been treated, seem easily to permit the subsequent entrance of the molecules of earbonate of ammonia. Thus leaves whieh had been immer'sed in a solution (of onc part to 437 of water) of nitiate of potassium for 48 hrs.- of sulphate of potassium for 24 hrs.--and of the ehloride of potassium for 25 hrs. - on being plaeed in a solution of onc part of earbonate of ammonia to 218 of water, had their glands immediately blaekened, and after 1 hr. their tentacles somewhat inflectcd, and the protoplasm aggregated. But it would be an endless task to endeavour to aseertain the wonderfully diversified effects of various solutions on Drosera.

Alcohol (one part to seven of water). - It has already been shown that half-minims of this strength placed on the dises of leaves do not cause any inflection; and that when two days afterwards the lenves werc given bits of meat, they became strongly inflectcd. Four lcaves were immersed in this mixture, and two of them after $30 \mathrm{~m}$. wcrc brushed with a camel-hair brush, like the leaves in the solution of camphor, but this produced no effect.

* See Dr. M. Traube's curious expcriments on the production of artificial cells, and on their permeability to various salts, described in his papcrs: "Experimente zur 'Theorie der" Zcllcnbildung und Endosmosc," Breslart, 1866; and "Experimente zur" physicalischen Erklärung der Bildung der Zellhant, ihres Wachsthums durch Intussusception," Breslau, 1874. These researches perhaps explain my results. Dr. 'Truubo commonly employed as a membrane tho precipitate formed when tannic acid connes into contact with a solution of gelatine.
By allowing a precipitation of sulplate of barium to take place at the same time, the membrane becomes "infiltrated" with this salt; and in consequence of the intercalation of molecules of sulphate of barium among those of the gelatine precipitate, the molecular interstices in the membrane are mado smaller. In this altered eondition, the membrane no longer allows the pissage through it of either sulphate of ammonia or nitrate of barium, thongh it retains its permenbility for water and chloride of ammonit. 
Nor did these four leaves, on being left for $24 \mathrm{hr}$. in the diluted alcohol, undergo any inflection. They were then removed; one being plaeed in an infusion of raw meat, and bits of meat on the dises of the other three, with their stalks in water. Next day one seemed a little injured, whilst two others showed merely a trace of inflection. We must, howercr, bear in mind that immersion for 21 hrs. in water prevents leaves from elasping meat. Hence alcohol of the abore strength is not poisonous, nor does it stimulate the leaves like camphor does.

The vapour of aleohol acts differently. A plant having three good lcaves was left for $25 \mathrm{~m}$. uncler a receiver holding $19 \mathrm{oz}$. with sixty minims of alcohol in a watch-glass. No movement ensued, but some few of the glands were blackened and shrivelled, whilst many became quite pale. These were seattered over all the leaves in the most irregular manner, reminding me of the manner in which the glands were affeeted by the vapour of carbonate of ammonia. Immediately on the removal of the receiver partieles of raw meat were placed on many of the glands, those which retained their proper eolour being chiefly selected. But not a single tentacle was inflected during the next 4 hrs. After the first 2 hrs. the glands on all the tentacles began to dry; and next morning, after 22 hrs., all three leaves appeared almost dead, with their glands dry; the tentaeles on one leaf alone being partially inflected.

A second plant was left for only $5 \mathrm{~m}$. with some alcohol in a watch-glass, under a 12-oz. receiver, and partieles of meat were then placed on the glands of sereral tentacles. After $10 \mathrm{~m}$. some of them began to curve inwards, and after $55 \mathrm{~m}$. nearly all were considerably inflected; but a few did not move. Some anrsthethic effect is lere probable, but by no means certain. A third plant was also left for $5 \mathrm{~m}$. under the same small vessel, with its whole inncr surface wetted with about a dozen drops of aleohol. Particles of meat were now placed on the glands of several tentacles, some of which first begrn to move in $25 \mathrm{~m}$.; after $40 \mathrm{~m}$. most of them were somewhat inflected, and after $1 \mathrm{hr} .10 \mathrm{~m}$. almost all were considerably infleeted. From their slow rate of movement there can be no doubt that the glands of these tentacles had been rendered insensible for a time by exposure during $5 \mathrm{~m}$. to the vapour of alcohol.

Vapour of Chloroform.- The aetion of this vapour on Drosera is very variable, depending, I suppose, on the constitution or age of the plant, or on some unknown condition. It sometimes causes the tentacles to move with extraordinary rapiclity, and sometimes produces no such effect. The glauds are sometimes 
rendered for a time insensible to the action of raw meat, but sometimes arc not thus affected, or in a very slight degree. A plant recovers from a small dose, but is easily killed by a larger one.

A plant was left for $30 \mathrm{~m}$. under a bell-glass holding 19 fluid oz. ( $539.6 \mathrm{ml}$.) with eight drops of ehloroform, and beforc the cover was removed, most of the tentaeles became mueh inflected, though they did not reaeh the centre. After the cover was lemoved, bits of mcat wcre placed on the glands of screral of the somewhat ineurved tentacles; these glands were found mueh blaekened after 6 hrs. $30 \mathrm{~m}$, but no further movement ensued. After 24 his. the leaves appeared almost dead.

A smaller bell-glass, holding 12 fluid oz. ( $340 \cdot 8 \mathrm{ml}$.), was now employed, and a plant was left for $90 \mathrm{~s}$. under it, with only two drops of ehloroform. Immediately on the removal of the glass all the tentaeles eurved inwards so as to stand perpendicularly up; and some of them eould actually be seen moving with extraordinary quiekness by little starts, and therefore in an unnatural manner; but they never reaehcd the centre. After 22 hrs. they fully re-expanded, and on meat being plaeed on their glands, or when roughly touehed by a needle, they promptly beeame inflected; so that these leaves had not been in the least injured.

Another plant was placed under the same small bell-glass with three drops of ehloroform, and beforc two mimutes had elapsed, the tentacles began to curl inwards with rapid littlc jerks. The glass was then removed, and in the course of two or three additional mimntes almost crery tentaele reached the centrc. On several other occasions the vapour did not exeitc any movement of this kind.

There secms also to be great variability in the degreo and manner in whieh ehlorofor'm renders the glands insensible to the subsequent aetion of meat. In the plant last refer'ed to, whieh had been exposed for $2 \mathrm{~m}$. to threo drops of elıloroform, some few tentacles eurved up only to a perpcudieular position, and particles of meat were plaeed on their glands; this eaused them in $5 \mathrm{~m}$. to begin moving, but they moved so slowly that they did not reaeh the centre until $1 \mathrm{hr} .30 \mathrm{~m}$. had elapsed. Another plant was similarly exposed, that is, for $2 \mathrm{~m}$. to three drops of chloroform, and on partieles of mcat being placed on the glands of several tentaeles, which had eurved np into a perpendieular position, onc of these began to bend in $8 \mathrm{~m}$., but afterwards moved vcry slowly; whilst none of the other tentacles 
mored for the noxt $40 \mathrm{~m}$. Nevcrtheless, in $1 \mathrm{hr} .45 \mathrm{~m}$. from the time when the bits of meat had been given, all the tentacles reached the centrc. In this case some slight anresthetic effect apparently had been produced. On the following day the plant had perfectly recovered.

Another plant bearing two leaves was exposed for $2 \mathrm{~m}$. under the 19-oz. vessel to two drops of ehloroform; it was then taken out and cxamined; again exposed for $2 \mathrm{~m}$. to two drops; taken out, and re-exposed for $3 \mathrm{~m}$. to three drops; so that altogether it was exposed alternately to the air and during $7 \mathrm{~m}$. to the vapour of scren drops of chloroform. Bits of meat were now plaeed on thirtcen glands on the two leaves. On one of these lcaves, a single tcntacle first began moving in $40 \mathrm{~m}$., and two others in $54 \mathrm{~m}$. On the second leaf some tentacles first moved in $1 \mathrm{hr} .11 \mathrm{~m}$. Aftcr $2 \mathrm{hr}$. many tentacles on both leaves were inflected; but none had leached the centre within this time. In this case there could not be tho least cloubt that the chloroform had exerted an anæsthetic influence on the leaves.

On the other hand, another plant was exposcd under the same vessel for a much longer time, viz. $20 \mathrm{~m}$., to twicc as much chloroform. Bits of meat were then placed on the glands of many tentacles, and all of them, with a single exception, reached the centre in from $13 \mathrm{~m}$. to $14 \mathrm{~m}$. In this casc, little or no anrsthetic effect had becn produced; and how to reconeile these discordant results, I know not.

Vupour of Sulphuric Ether.-A plant was exposed for $30 \mathrm{~m}$. to thirty minims of this cther in a vessel holding $19 \mathrm{oz}$; and bits of raw meat were afterwards placed on many glands which had hecome pale-coloured: but none of the tentacles moved. After 6 hrs. $30 \mathrm{~m}$. the leaves appcarcd sickly, and the discal glands were almost dry. By the next morning many of the tentaelcs wcre dead, as were all those on which mcat had bcen placed; showing that matter had bcen absorbed from the meat which had increased the evil effects of the vajour. Aftcr four days the plant itsclf died. Another plant was cxposed in the same vessel for $15 \mathrm{~m}$. to forty minims. One young, small, and tender leaf had all its tentacles inflected, and seemed much injured. Bits of raw meat wcre placed on scveral glands on two other and oldcr leaves. 'These glands became dry after' 6 lu's, and secmed injured; the tentacles never moved, cxeepting one which was ultimately a little inflected. The glands of the other tentreles continued to secrete, and appeared uninjured, but the whole plant after three days became very sickly. 
In the two foregoing expcriments the doses were evidently too large and poisonous. With weaker doses, the anæsthetic effect was variable, as in the case of chloroform. A plant was exposed for $5 \mathrm{~m}$. to ten drops under a 12-oz. vessel, and bits of meat were then plaecd on many glands. None of the tentacles thus treated began to move in a decided manner until $40 \mathrm{~m}$. liad elapsed; but then some of them moved very quickly, so that two reached the eentre after an additional interval of only $10 \mathrm{~m}$. In 2 hrs. $12 \mathrm{~m}$. from the time when the meat was given, all the tentacles reached the centre. Another plant, with two leaves, was exposed in the same vessel for $5 \mathrm{~m}$. to a rather larger dose of ether, and bits of meat were placed on several glands. In this case one tentacle on each leaf began to bend in $5 \mathrm{~m}$.; and after $12 \mathrm{~m}$. two tentacles on one leaf, and one on the second leaf, reached the centre. In $30 \mathrm{~m}$. after the meat had becn given, all the tentacles, both those with and without meat, were closely inflceted; so that the ether apparently had stimulated these leaves, causing all the tentacles to bend.

Vapour of Nitric Ether. - This vapour seems more injurious than that of sulphuric ether. A plant was cxposed for $5 \mathrm{~m}$. in a 12oz. vessel to eight drops in a watch-glass, and I distinctly saw a few tentacles eurling inwards before the glass was removed. Immediately afterwards bits of meat wcre placed on three glands, but no movement ensued in the course of $18 \mathrm{~m}$. The same plant was placed again undcr the same vessel for $16 \mathrm{~m}$. with ten drops of the ether. None of the tentacles moved, and next morning those with the meat were still in the same position. After 48 hrs. one leaf secmed healthy, but the others were mueh injured.

Another plant, having two good leaves, was exposed for 6 , 7 . under a 19-oz. vessel to the vapour from ten minims of the ether, and bits of meat were then placed on the glands of many tentaeles on both leaves. After $36 \mathrm{~m}$. several of them on one leaf became infleeted, and after $1 \mathrm{hr}$. almost all the tentaeles, those with and without meat, nearly reached the eentre. On the other leaf the glands began to dry in $1 \mathrm{hr} .40 \mathrm{~m}$., and after several hours not a single tentacle was infleeted; but by the next morning, after 21 hrs., many were inflected, though they scemed much injured. In this and the previous experiment, it is doubtful, owing to the injury which the leaves had suffered, whether any anæsthetic effeet had been prodneed.

A third plant, having two good leaves, was exposed for only $4 \mathrm{~m}$. in the 19-oz. vessel to the vapour from six drops. Bits of meat were then plaeed on tho glands of seven tentreles on tho 
sume leaf. A single tentacle moved after $1 \mathrm{hr}$. $23 \mathrm{~m}$; after 2 hrs. $3 \mathrm{~m}$. several were inflected; and after 3 hrs. $3 \mathrm{~m}$. all the seren tentacles witl meat were well inflected. From the slowness of these movements it is clear that this leaf had been rendered insensible for a time to the action of the meat. A second leaf was rather differently affected; bits of meat were placed on the glands of five tentacles, three of which were slightly inflected in $28 \mathrm{~m}$.; after $1 \mathrm{hr}$. $21 \mathrm{~m}$. one reached the centre, but the other two were still only slightly inflected; after 3 hrs. they were much more inflected; but even after 5 hr's. $16 \mathrm{~m}$. all five had not reached the centre. Although some of the tentacles began to move moderately soon, they afterwards mored with extreme slowness. By next morning, after 20 hrs., most of the tentacles on both leaves were closely inflected, but not quite regularly. After 48 brs. neither leaf appeared injured, though the tentacles were still inflected; after $72 \mathrm{hrs}$. one was almost dead, whilst the other was re-expanding and recovering.

Carbonic Acirl-A plant was placed under a 122-oz. bell-glass filled with this gas and standing over water; but I did not make sufficient allowance for the absorption of the gas by the water, so that towards the latter part of the experiment some air was drawn in. After an exposure of 2 hrs. the plant was removed, and bits of raw meat placed on the glands of three leaves. One of these leaves liung a little down, and was at first partly and soon afterwards completely covered by the water, which rose within the vessel as the gas was absorbed. On this latter leaf the tentacles, to which meat had been given, became well inflected in $2 \mathrm{~m} .30 \mathrm{~s}$, that is, at about the normal rate; so that until I remembered that the leaf had been protected from the gas, and might perhaps have absorbed oxygen from the water which was continually drawn inwards, I falsely concluded that the carbonic acid had produced no effect. On the other two leaves, the tentacles with meat behaved very differently from those on the first leaf; two of them first began to more slightly in $1 \mathrm{hr} .50 \mathrm{~m}$., always reckoning from the time when the meat was placed on the glands-were plainly inflected in 2 hrs. $22 \mathrm{~m}$.- and in 3 hrs $22 \mathrm{~m}$. reached tho centre. Three other tentacles did not begin to move until 2 hrs. $20 \mathrm{~m}$. had elapsed, hut reached the centre at about the same time with the others,
viz. in 3 hrs. $22 \mathrm{~m}$.

This experiment was repeated several times with nearly tho same results, excepting that the interval before the tentacles began to move varied a little. I will give only one other case. 
A plant was exposed in the same vessel to the gas for $45 \mathrm{~m}$., and bits of meat were then plaeed on four glands. But the tentacles did not move for 1 hr. $40 \mathrm{~m}$.; after 2 hrs. $30 \mathrm{~m}$. all four were well infleeted, and after 3 hrs. reached the eentre.

The following singular phenomenon sometimes, but by no means always, oeenrred. A plant was immersed for 2 hrs., and bits of meat were then plaeed on several glands. In the eourse of $13 \mathrm{~m}$. all the submarginal tentaeles on one leaf beeame eonsiderably infleeted; those with the meat not in the least degree more than the others. On a seeond leaf, whieh was rather old, the tentreles with meat, as well as a few others, were moderately infleeted. On a third leaf all the tentaeles were elosely infleeted, though meat had not been plaeed on any of the glands. This movement, I presume, may be attributed to exeitement from the absorption of oxygen. The last-mentioned leaf, to whieh no meat had been given, was fully re-expanded after 24 hrs.; whereas the two other leaves had all their tentaeles elosely infleeted over the bits of meat whieh by this time had been earried to their eentres. Thus these three leaves had perfeetly reeovered from the effeets of the gas in the eourse of $24 \mathrm{hrs}$.

On another oeeasion some fine plants, after having been left for 2 hris. in the gas, were immediately given bits of meat in the usual manner, and on their exposure to the air most of their tentaeles beeame in $12 \mathrm{~m}$. eurved into a vertieal or sub-rertieal position, but in an extremely irregular manner; some only on one side of the leaf and some on the other. They remained in this position for some time; the tentaeles with the bits of meat not having at first moved more quiekly or farther inwards the? the others without meat. But after 2 hrs. $20 \mathrm{~m}$. the former began to move, and steadily went on bending until they reaehed the eentre. Next morning, after 22 hrs., all the tentaeles on these leaves were elosely elasped over the meat whieh had been earried to their eentres; whilst the vertieal and sub-vertieal tentreles on the other leaves to whieh no meat had been given had fully re-expanded. Judging, however, from the subsequent aetion of a weak solution of earbonate of ammonia on one of these latter leaves, it had not perfeetly reeovered its exeitability and power of morement in 22 hrs.; but another leaf, after an additional 24 hrs., had eompletely reeovered, judging from the manner in whieh it elasped a fly plaeed on its dise.

I will give only one other experiment. After the exposure of a plant for 2 his. to the gas, one of its leaves was immersed in a rather strong solution of earbonate of ammonia, together with 
a fresh leaf from another plant. The latter had most of its tentaeles strongly infleeted within $30 \mathrm{~m}$.; whereas the leaf which had been exposed to the earbonic aeid remained for 24 hrs. in the solution withont undergoing any inflcetion, with the exeeption of two tentacles. This leaf had been almost completely paralysed, and was not able to reeover its sensibility whilst still in the solution, which from having been made with distilled water probably eontained little oxygen.

\section{Concluding Remarks on the Effects of the foregoing} Agents.-As the glands, when excited, transmit some influence to the surrounding tentaeles, eausing them to bend and their glands to pour forth an inereased amount of modified seeretion, I was anxious to ascertain whether the leaves ineluded any element having the nature of nerve-tissue, which, though not eontinuous, served as the channel of transmission. This led me to try the several alkaloids and other substanees whieh are known to exert a powerful influenee on the nervous system of animals. I was at first encouraged in my trials by finding that stryehnine, digitaline, and nieotine, whieh all act on the nervous system, were poisonous to Drosera, and caused a eertain amount of infleetion. Hydroeyanic acid, again, which is so deadly a poison to animals, eaused rapid movement of the tentaeles. But as several innoeuous aeids, though much diluted, sueh as benzoic, acetie, \&e., as well as some essential oils, are extremely poisonous to Drosera, and quiekly eause strong inflection, it seems probable that stryehnine, nieotine, digitaline, and hydrocyanie aeid, excite infleetion by acting on elements in no way analogous to the nerve-cells of animals. If elements of this latter nature had been present in the leaves, it might have becn expeeted that morphia, hyoseyamus, atropine, veratrine, colehicine, enrare, and diluted aleohol would have produced some marked effeet; whereas 
these substances are not poisonous and have no power, or only a very slight one, of indueing infleetion. It should, however, be observed that eurare, colchicine, and veratrine are muscle-poisons-that is, act on nerves having some special relation with the muscles, and, therefore, eould not be expected to aet on Drosera. The poison of the cobra is most deadly to animals, by paralysing their nerve-centres, ${ }^{*}$ yet is not in the least so to Drosera, though quickly causing strong inflection.

Notwithstanding the foregoing facts, which show how widely different is the effect of certain substances on the health or life of animals and of Drosera, yet there exists a certain degree of parallelism in the action of certain other substances. We have seen that this holds good in a striking manner with the salts of sodium and potassium. Again, various metallic salts and acids, namely those of silver, mereury, gold, tin, arsenic, chromium, copper, and platina, most or all of whieh are highly poisonous to animals, are equally so to Drosera. But it is a singular fact that the chloricle of lead and two salts of barium were not prisonous to this plant. It is an equally strange fact, that, though acetic and propionic acids are highly poisonous, their ally, formic acid, is not so; and that, whilst eertain vegetable acids, namely oxalie, benzoie, \&c., are poisonous in a high degree, gallic, tannic, tartaric, and malie (all diluted to an equal degree) are not so. Malic aeid induees inflection, whilst the three other just named vegretable aeids have no sueh power. But a pharmaeopoeia would be requisite to describe the diversified effects of rarious substances on Drosera. $\dagger$

* Dr. Fayrer, "The Thauntophidia of Indin,' 1872, p. 4.

+ Secing that nectic, lyydro- cyrnuic, and chromic acids, acetitc of strychnine, and rapour of ether, wre poisonous to Urosern, 
Of the alkaloids and their salts which were tried, several had not the least power of indueing infleetion; others, whieh were eertainly absorbed, as shown by the changed colour of the glands, had but a very moderate power of this kind; others, again, sueh as the acetate of quinine and digitaline, eaused strong inflection.

The several substanees mentioned in this ehapter affect the eolour of the glands very differently. These often beeome dark at first, and then very pale or white, as was eonspieuously the ease with glands subjected to the poison of the eobra and eitrate of strychnine. In other cases they are from the first rendered white, as with leaves placed in hot water and several aeids; and this, I presume, is the result of the eoagulation of the albumen. On the same leaf some glands become white and others dark-eoloured, as ceeurred with leaves in a solution of the sulphate of quinine, and in the vapour of alcohol. Prolonged immersion in nieotine, eurare, and even water, blaekens the glands; and this, I believe, is due to the aggregation of the protoplasm within their eells. Yet eurare caused very little aggregation in the cells of the tentreles, whereas nieotine and sulphate of quinine indueed strongly marked aggregation down their bases. The aggregated masses in leaves which had been immersed for 3 hrs. $15 \mathrm{~m}$. in a saturated solution of sulphate of quinine exhibited ineessant

it is remarkable that Dr. Ransom ('Philosoph. 'Transact.' 1867, p. 480), who used much stronger solutions of these substances than I did, states "that the rliythmic contrnetility of the yolk (of the ova of the pike) is not materially intluereed by any of the poisons used, which did not aet ehemi- cally, with the excoption of ehloroform and carbonic acid." I find it stated by several writers that eurare has no influenco on sareode or protoplasm, and we have seen that, thougli euraro excites some degree of inflection, it causes very littlo aggregation of the protoplasm. 
changes of form, but after 24 hrs. were motionless; the leaf being flaccid and apparently dcad. On the other hand, with leaves subjected for 48 hrs. to a strong solution of the poison of the cobra, the protoplasmic masses werc unusually active, whilst with the higher animals the vibratile cilia and white corpuscles of the blood seem to be quickly paralysed by this substance.

With the salts of alkalics and earths, the nature of the basc, and not that of the acid, determines their physiological action on Droscra, as is likewise the case with animals; but this rule hardly applies to the salts of quinine and strychnine, for the acetate of quinine canses much more inflection than the sulphate, and both are poisonous, whcreas the nitratc of quinine is not poisonous, and induces inflection at a much slower rate than the acctate. The action of the citrate of strychninc is also somewhat different from that of the sulphatc.

Leaves which have been immersed for 24 hrs. in watcr, and for only $20 \mathrm{~m}$. in diluted alcohol, or in a wcak solution of sugar, are afterwards acted on very slowly, or not at all, by the phosphate of ammonia, though they are quickly acted on by the carbonate. Immersion for $20 \mathrm{~m}$. in a solution of gum arabic has no such inhibitory powcr. The solutions of certain salts and acids affect the learcs, with respect to the subscquent action of the phosphate, exactly like water, whilst others allow the phosphate afterwards to act quickly and encrgetically. In this latter case, the interstices of the ccll-walls may have been blocked up by the molecules of the salts first given in solution, so that watcr could not aftcrwards cnter, though the molccules of the phosphate could do so, and those of the carbonate still more easily. 
The aetion of eamphor dissolved in water is remarkable, for it not only soon induees infleetion, but apparently renders the glands extremely sensitive to meehanieal irritation; for if they are brushed with a soft brush, after being immersed in the solution for a short time, the tentaeles begin to bend in about $2 \mathrm{~m}$. It may, however, be that the brushing, though not a suffieient stimulus by itself, tends to exeite movement merely by reinforeing the direct aetion of the eamphor. The vapour of camphor, on the other hand, serves as a nareotie.

Some essential oils, both in solution and in vapour, cause rapid infleetion, others have no sueh power; those which I tried were all poisonous.

Diluted alcohol (one part to seven of water) is not poisonous, does not induee inflection, nor inerease the sensitiveness of the glands to meehanieal irritation. The vapour aets as a nareotic or anæsthetic, and long exposure to it kills the leaves.

The vapours of chloroform, sulphurie and nitric ether, act in a singularly variable manner on different leaves, and on the several tentacles of the same leaf. 'This, I suppose, is owing to differenees in the age or' constitution of the leaves, and to whether eertain tentaeles have lately been in aetion. That these vapours are absorbed by the glands is shown by their ehanged colour; but as other plants not furnisher with glands are affected by these vapours, it is probable that they are likewise absorbed by the stomata of Drosera. They sometimes exeite extraordinarily rapid inflection, but this is not an invariable result. If allowed to aet for even a moderately long time, they kill the leaves; whilst a small dose aeting for only a short time serves as a nareotic or anesthetic. In this ease the tentaeles, whether or not they have 
become inflected, are not excited to further movement by bits of meat placed on the glands, until some considerable time has elapsed. It is generally believed that with animals and plants these vapours act by arresting oxidation.

Exposure to carbonic acid for $2 \mathrm{hrs}$., and in one case for only $45 \mathrm{~m}$., likewise rendered the glands insensible for a time to the powerful stimulus of raw meat. The leaves, however, recovered their full powers, and did not seem in the least injured, on being left in the air for 24 or 48 hrs. We have seen in the third chapter that the process of aggregation in leaves subjected for two hours to this gas and then immersed in a solution of the carbonate of ammonia is much retarded, so that a considerable time elapses before the protoplasm in the lower cells of the tentacles becomes aggregated. In some cases, soon after the leaves were removed from the gas and brought into the air, the tentacles moved spontaneously; this being due, I presume, to the excitement from the access of oxygen. These inflected tentacles, however, could not be excited for some time afterwards to any further movement by their glands being stimulated. With other irritable plants it is known * that the exclusion of oxygen prevents their moving, and arrests the movements of the protoplasm within their cells, but this arrest is a different phenomenon from the retardation of the process of aggregation just allucled to. Whether this latter fact ought to be attributed to the direct action of the carbonic acid, or to the exclusion of oxygen, I know not.

* Sachs, 'Traité de Bot.' 1S74, pp. S46, 1037. 


\section{CHAPTER X.} Os the Sexsitiveness of the Leaves, and on the Lines of
Transmission of the Motor Impulse.

Glands and summits of the tentacles alone sensitive-Transmission of the motor impulse down the pedicels of the tentacles, and across the blade of the leaf - Aggregation of the protoplasm, a reflex action - First discharge of the motor impulse suddenDirection of the movements of the tentacles-Motor impulse transmitted through the cellular tissue - Mechanism of the morements - Nature of the motor impulse-Re-expansion of the tentacles.

IVE have seen in the previous chapters that many widely different stimulants, meehanieal and ehemical, exeite the movement of the tentaeles, as well as of the blade of the leaf; and we must now eonsider, firstly, what are the points whieh are irritable or sensitive, and seeondly how the motor impulse is transmitted from one point to another. The glands are almost exelusively the seat of irritability, yet this irritability must extend for a very short distanee below them; for when they were eut off with a sharp pair of scissors without being themselves tonehed, the tentaeles often beeame infleeted. These headless tentaeles frequently re-expanded; and when afterwards drops of the two most powerful known stimulants were placed on the eut-off ends, no effect was prodneed. Nevertheless these headless tentaeles are eapable of subsequent infleetion if exeited by an impulse sent from the dise. I sueeeeded on several oceasions in crushing glands between fine pineers, but this dicl not excite any movement; nor did raw meat and salts of annmonia, when placed on such erushed glands. 
It is probable that they were killed so instantly that they were not able to transmit any motor impulse; for in six observed cases (in two of which however the gland was quite pinched off) the protoplasm within the eells of the tentacles did not become aggregated; whereas in some adjoining tentaeles, which were infleeted from having been roughly touched by the pincers, it was well aggregated. In like manner the protoplasm does not become aggregated when a leaf is instantly killed by being dipped into boiling water. On the other hand, in several cases in which tentacles became infleeted after their glands had been cut off with sharp scissors, a distinct though moderate degree of aggregation supervened.

The pedicels of the tentaeles were roughly and repeatedly rubbed; raw meat or other exciting substances were placed on them, both on the upper surface near the base and elsewhere, but no distinet movement ensued. Some bits of meat, after being left for a considerable time on the pedicels, were pushed upwards, so as just to touch the glands, and in a minute the tentacles began to bend. I believe that the blade of the leaf is not sensitive to any stimulant. I drove the point of a lancet through the blades of several leaves, and a needle three or four times through nineteen leaves: in the former case no movement ensued; but about a dozen of the leares which were repeatedly pricked had a few tentacles irregularly infleeted. As, however, their backs had to be supported during the operation, some of the outer glands, as well as those on the dise, may hare been touched; and this perhaps suffieed to cause the slight degree of movement observed. Nitsehke* says 
that cutting and pricking the leaf docs not cxcite movement. The petiole of the leaf is quitc inscnsible. The backs of the leaves bcar numcrous minute papille, which do not secrete, but have the powcr of absorption. Thesc papillæe are, I believe, rudiments of formerly existing tentacles together with their glands. Many experiments were made to ascertain whether the backs of the leaves could be irritated in any way, thirty-seven leaves being thus tried. Some were rubbed for a long time with a blunt needle, and drops of milk and other exciting fluids, raw meat, crushed flies, and various substances, placed on others. These substances were apt soon to become dry, showing that no secretion had been excited. Hence I moistened them with saliva, solutions of ammonia, weak hydrochloric acid, and frequently with the secretion from the glands of other leaves. I also kept some leaves, on the backs of which cxciting objects had been placed, under a damp bell-glass; but with all my carc I never saw any truc movement. I was led to make so many trials because, contrary to my previous cxpcricnce, Nitschkc states* that, after affixing objects to the backs of leaves by the aid of the viscid secretion, he repeatedly saw the tentacles (and in one instance the bladc) become rcflcxed. This movement, if a true one, would be most anomalous; for it implies that the tentacles reccive a motor impulse from an unnatural source, and have the power of bending in a direction exactly the reverse of that which is habitual to them; this power not being of the lcast use to the plant, as insects cannot adhere to the smooth backs of the leaves.

I have said that no effect was produced in the above

* 'Bot. Zeitung,' 1860, p. 437. 
cases; but this is not strictly true, for in three instances a little syrup was added to the bits of raw meat on the backs of leaves, in order to keep them damp for a time; and after 36 hrs. there was a trace of reflexion in the tentacles of onc leaf, and certainly in the blade of another. After twelve additional hours, the glands began to dry, and all three leaves seemed much injured. Four lcaves were then placed under a bell-glass, with their footstalks in water, with drops of syrup on their backs, but without any meat. 'Two of these leaves, after a day, had a few tentacles reflexed. The drops had now increased considerably in size, from having imbibed moisture, so as to trickle. down the backs of the tentacles and footstalks. On the second day, one leaf had its blade much reflexed; on the third day the tentacles of two werc much reflexed, as well as the blades of all four to a greater or less degree. The upper side of one leaf, instead of being, as at first, slightly concave, now presented a strong convexity upwards. Even on the fifth day the leaves did not appear dead. Now, as sugar does not in the least excite Drosera, we may safely attribute the reflexion of the blades and tentacles of the above leares to exosmose from the cells which were in contact with the syrup, and their consequent contraction. When drops of syrup are placed on the leaves of plants with their roots still in damp earth, no inflection ensues, for the roots, no doubt, pump up water as quickly as it is lost by exosmosc. But if cut-off leares arc immersed in syrup, or in any dense fluid, the tentacles are greatly, though irregularly, inflected, some of them assuming the shape of corkscrers; and the leaves soon become flaccid. If they are now immersed in a fluid of low specific gravity, the tentacles re-expand. From these 
facts we may conelude that drops of syrup plaeed on the backs of leaves do not aet by exeiting a motor impulse whieh is transmitted to the tentaeles; but that they eause reflexion by indueing exosmose. Dr. Nitschke used the seeretion for stieking inseets to the baeks of the leaves; and I suppose that he used a large quantity, whieh from being dense probably caused exosmose. Perhaps he experimented on eut-off leaves, or on plants with their roots not supplied with enough water.

As far, therefore, as our present knowledge serves, we may eonelude that the glands, together with the immediately underlying eells of the tentaeles, are the exclusive seats of that irritability or sensitiveness with whieh the leaves are endowed. The degree to whieh a gland is excited can be measured only by the number of the surrounding tentacles whieh are infleeted, and by the amount and rate of their movement. Equally vigorous leaves, exposed to the same temperature (and this is an important eondition), are exeited in different degrees under the following cireumstanees. A minute quantity of a weak solution produees no effeet; add more, or give a rather stronger solution, and the tentacles bend. Toueh a gland onee or twiee, and no movement follows; toueh it three or four times, and the tentaele beeomes inflected. But the nature of the substanee whieh is given is a very important element: if equal-sized partieles of glass (which aets only mechnnieally), of gelatine, and raw meat, are plaeed on the dises of several leaves, the meat eauses for more rapid, encrgetie, and wirlely extended movement than the two former sulstanees. The number of glands which are cxeited also makes a great difference in the result: place a bit of meat on one or two of the diseal 
glands, and only a few of the immediately surrounding short tentacles are inflected; place it on several glands, and many more are acted on; place it on thirty or forty, and all the tentacles, including the extreme marginal ones, become closely inflected. We thus see that the impulses proceeding from a number of glands strengthen one another, spread farther, and act on a larger number of tentacles, than the impulse from any single gland.

Transmission of the Motor Impulse.-In every case the impulse from a gland has to travel for at least a short distance to the basal part of the tentacle, the upper part and the gland itself being merely carried by the inflection of the lower part. The impulse is thus always transmitted down nearly the whole length of the pedicel. When the central glands are stimulated, and the extreme marginal tentacles bccome inflected, the impulse is transmitted across half athe diameter of the disc; and when the glands on one side of the disc are stimulated, the impulse is transmitted across nearly the whole width of the disc. A gland transmits its motor impulse far more easily and quickly down its own tentacle to the bending place than across the disc to neighbouring tentacles. Thus a minute dose of a very weak solution of ammonia, if given to one of the glands of the exterior tentacles, causes it to bend and reach the centre; whereas a large drop of the same solution, given to a score of glands on the disc, will not cause through their combined influence the least inflection of the exterior tentacles. Again, when a bit of meat is placed on the gland of an exterior tentacle, I have seen movement in ten seconds, and repeatedly within a minute; but a much larger bit placed on several glands on the dise does not cause 
the exterior tentacles to bend until half an hour or even several hours have elapsed.

The motor impulse spreads gradually on all sides from one or more cxcited glands, so that the tentacles which stand nearest are always first affected. Hence, when the glands in the centre of the disc are excited, the extreme marginal tentacles are the last inflected. But the glands on different parts of the leaf transmit their motor power in a somewhat different manner. If a bit of meat be placed on the long-headed gland of a marginal tentacle, it quickly transmits an impulse to its own bending portion; but never, as far as I have observed, to the adjoining tentacles; for these are not affected until the meat has been carried to the central glands, which then radiate forth their conjoint impulse on all sides. On four occasions leaves were prepared by removing some days previously all the glands-from the centre, so that these could not be excited by the bits of meat brought to them by the inflection of the marginal tentacles; and now these marginal tentacles re-expanded after a time without any other tcntacle being affected. Other leaves werc similarly prepared, and bits of meat were placed on the glands of two tentacles in the third row from the outside, and on the glands of two tentacles in the fifth row. In these four cases the impulse was sent in the first place laterally, that is, in the same concentric row of tentacles, and then towards the centre; but not centrifugally, or towards the cxterior tentacles. In one of these cases only a single tentacle on each side of the onc with meat was affected. In the three other cases, from half a dozen to a dozen tentacles, both laterally and towards the centre, were well inflected or sub-inflected. Lastly, in 
ten other experiments, minute bits of meat were placed on a single gland or on two glands in the centre of the disc. In order that no other glands should touch the meat, through the inflection of the closcly adjoining short tentacles, about half a dozen glands had been previously removed round the selected oncs. On eight of these leaves from sixtecn to twenty-five of the short surrounding tentacles were inflected in the course of one or two days; so that the motor impulse radiating from onc or two of the discal glands is able to produce this much effect. The tentacles which had been removed are included in the above numbers; for, from standing so close, they would ccrtainly have been affected. On the two remaining leaves, almost all the short tentacles on the dise wcre inflected. With a more powerful stimulus than meat, namely a little phosphate of lime moistened with saliva, I have seen the inflection spread still farther from a single gland thus treated; but cven in this case the three or four outer rows of tcntacles wcre not affected. From these cxperiments it appears that the impulse from a single gland on the disc acts on a greater number of tentacles than that from a gland of onc of the exterior elongated tentacles; and this probably follows, at least in part, from the impulse having to travel a very short distance down the pedicels of the central tentacles, so that it is able to spread to a considcrable distance all round.

Whilst examining these leaves, I was struck with the fact that in six, perhaps seven, of them the tentacles were much more inflceted at the distal and proximal ends of the leaf (i.e. towards the apex and base) than on either side; and yet the tentacles on the sides stood as near to the gland where the bit of meat lay as did those at the two ends. It thus appeared as 
if the motor impulsc was transmitted from the centre across the dise more readily in a longitudinal than in a transverse direction; and as this appeared a new and interesting fact in the plyysiology of plants, thirty-five fresh cxperiments were madc to test its truth. Minutc bits of meat were placed on a single gland or on a few glands, on the right or left side of the dises of cighteen leaves; other bits of the same size bcing placed on the distal or proximal ends of seventeen other leaves. Now if the motor impulse were transmitted with cqual force or at an equal rate through the blade in all dircetions, a bit of meat placed at one side or at one end of the dise ought to affect equally all the tentacles situated at an equal distance from it; but this certainly is not the casc. Before giving the gencral results, it may bc well to describe three or four rather unusual cases.

(1) A minute fragment of a fly was placed on onc side of the disc, and after $32 \mathrm{~m}$. seven of the outer tentacles near the fragment were inflected; after $10 \mathrm{hrs}$, several more became so, and after 23 hrs. a still greater number; and now the bladc of the leaf on this side was bent inwards so as to stand up at right angles to the other side. Neither the blade of the lcaf nor a single tentacle on the opposite side was affected; the linc of separation between the two halves extending from the footstalk to the apex. The leaf remained in this state for three days, and on the fourth day began to re-expand; not a single tentacle having been inflected on the opposite side.

(2) I will here give a case not included in the above thirtyfive experiments. A small fly was found adhering by its fect to the left side of the disc. The tentacles on this side soon closed in and killed the fly; and owing probably to its struggle whilst alive, the leaf was so much excited that in about $24 \mathrm{hrs}$. all the tentacles on the opposite side became inflected; but as they tound no prey, for their glands did not reach the fly, they reexpauded in the coursc of 15 hrs, ; the tentacles on the left side remaining clasped for several days.

(3) A bit of meat, rather larger than those commonly used, 
was placed in a medial line at the basal end of the disc, near the footstalk; aftcr 2 hrs. $30 \mathrm{~m}$. some neighbouring tentacles were inflected; after 6 hrs. the tentreles on both sides of the footstalk, and some way up both sides, were moderately inflected; after 8 hrs. the tentacles at the further or distal end were more inflected than those on either side; after 23 hrs. the meat was well clasped by all the tentacles, excepting by the exterior ones on the two sides.

(4) Another bit of meat was placed at the opposite or distal end of another leaf, with exactly the same relative results.

(5) A minute bit of meat was plased on one sicle of the disc; next day the neighbouring short tentacles wcre inflected, as well as in a slight degree three or four on the opposite side near the footstalk. On the second day these latter tentacles showed signs of re-expanding, so I added a fresh bit of meat at nearly the same spot, and aftcr two days some of the short tentacles on the opposite sicle of the disc were inflected. As soon as these began to re-expand, I added another bit of meat, and next day all the tentacles on the opposite side of the disc were inflected towards the meat; whereas we have scen that those on the same side werc affected by the first bit of meat which was given.

Now for the general results. Of the eighteen leares on which bits of meat, were placed on the right or left sides of the disc, eight had a vast number of tentacles inflected on the same side, and in four of them the blade itself on this side was likewise inflected; whereas not a single tentacle nor the blade was affected on the opposite side. These leaves presented a very curious appearance, as if only the inflected side was active, and the other paralysed. In the remaining ten cases, a few tentacles became inflected beyond the medial line, on the side opposite to that where the meat lay; but, in some of these cases, only at the proximal or distal ends of the leares. The inflection on the opposite side always occurred considerably after that on the same side, and in one instance not until the fourth day. We have also seen 
with No. 5 that bits of meat had to be added thriee before all the short tentreles on the opposite side of the dise were infleeted.

The result was widely different when bits of meat were plaeed in a medial line at the distal or proximal ends of the disc. In three of the seventeen experiments thus made, owing either to the state of the leaf or to the smallness of the bit of meat, only the immediately adjoining tentaeles were affeeted; but in the other fourteen eases the tentaeles at the opposite end of the leaf were infleeted, though these were as distant from where the meat lay as were those on one side of the dise from the meat on the opposite side. In some of the present eases the tentaeles on the sides were not at all affected, or in a less degree, or after a longer interval of time, than those at the opposite end. One set of experiments is worth giving in fuller detail. Cubes of meat, not quite so small as those usually employed, were placed on one side of the dises of four leaves, and eubes of the same size at the proximal or distal end of four other leaves. Now, when these two sets of leaves were eompared after an interval of 24 hrs., they presented a striking differenee. Those having the eubes on one side were very slightly affected on the opposite side; whereas those with the eubes at either end had almost every tentacle at the opposite end, even the marginal ones, elosely infleeted. After 48 hrs. the eontrast in the state of the two sets was still great; yet those with the meat on one side now had their diseal and submarginal tentaeles on the opposite side somewhat infleeted, this being due to the large size of the eubes. Finally we may eonclude from these thirty-five experiments, not to mention the six or seven previous ones, that the motor impulse is transmitted from any single gland 
or small group of glands through the blade to the other tentacles more readily and effectually in a longitudinal than in a transverse direction.

As long as the glands remain excited, and this may last for many days, even for eleven, as when in contact with phosphate of lime, they continue to transmit a motor impulse to the basal and bending parts of their own pedicels, for otherwise they would re-expand. 'The great difference in the length of time during which tentacles remain inflected over inorganic objects, and over objects of the same size containing soluble nitrogenous matter, proves the same fact. But the intensity of the impulse transmitted from an excited gland, which has begun to pour forth its acid secretion and is at the same time absorbing, seems to be very small compared with that which it transmits when first excited. Thus, when moderately large bits of meat were placed on one side of the disc, and the discal and submarginal tentacles on the opposite side became inflected, so that their glands at last touched the meat and absorbed matter from it, they did not transmit any motor influence to the exterior rows of tentacles on the same side, for these never became inflected. If, however, meat had been placed on the glands of these same tentacles before they had begun to secrete copiously and to absorb, they undoubtedly would have affected the exterior rows. Nevertheless, when I gave some phosphate of lime, which is a most powerful stimulant, to several submarginal tentacles already considerably inflected, but not yet in contact with some phosphate previously placed on two glands in the centre of the disc, the exterior tentacles on the same side were acted on.

When a gland is first excited, the motor impulse is discharged within a few seconds, as we know from the 
bending of the tentacle; and it appears to be discharged at first with much greatcr force than afterwards. Thus, in the casc above given of a small fly uaturally canght by a few glands on onc sidc of a lcaf, an impulse was slowly transmitted from them across the whole brcadth of the lcaf, causing the opposite tentacles to be temporarily inflected, but the glands which remained in contact with the inscet, though they continued for several days to scnd an impulse down their own pedicels to the bending place, dirl not prevent the tentacles on the oppositc side from quickly re-expanding; so that the motor discharge must at first have been morc powerful than afterwards.

When an object of any kind is placed on the disc, and the surrounding tcntacles arc inflccted, their glands secrete more copiously and the secrction becomes acid, so that some influcnce is sent to them from the discal glands. This change in the nature and amount of the secretion cannot depend on the bending of the tentacles, as the glands of the short central tentacles sccretc acid when an object is placed on them, though they do not themsclves bend. Therefore I inferred that the glands of the disc sent some influence up the surrounding tentacles to their glands, and that these reflected back a motor impulse to their basal parts; but this vicw was soon proved erroncous. It was found by many trials that tentacles with their glands closely cut off by sharp scissors often becomc inflected and again re-expand, still appearing healthy. Onc which was observed continned healthy for ten days after the opcration. I therefore cut the glands off twenty-five tcntacles, at different times and on different leaves, and scventeen of these soon became inflected, and aftcrwards re-expanded. 'The re-cxpansion commenced in about 
8 hrs. or 9 hrs., and was eompleted in from 22 hrs. to $30 \mathrm{hls}$. from the time of infleetion. After an interval of a day or two, raw meat with saliva was plaeed on the dises of these seventeen leaves, and when obserred next day, seven of the headless tentaeles were infleeted orer the meat as elosely as the uninjured ones on the same leaves; and an eighth headless tentaele beeame infleeted after three additional days. The meat was removed from one of these leares, and the surfaee washed with a little stream of water, and after three days the headless tentacle re-expanded for the second time. These tentaeles without glands were, however, in a different state from those provided with glands and which had absorbed matter from the meat, for the protoplasm within the eells of the former had undergone far less aggregation. From these experiments with headless tentaeles it is eertain that the glands do not, as far as the motor impulse is eoneerned, aet in a reflex manner like the nerve-ganglia of animals.

But there is another aetion, namely that of aggregation, which in eertain eases may be ealled reflex, and it is the only known instance in the regetable kingdom. We should bear in mind that the proeess does not depend on the previous bending of the tentaeles, as we elearly see when leaves are immersed in eertain strong solutions. Nor does it depend on inereased seeretion from the glands, and this is shown by several faets, more espeeially by the papilla, which do not seerete, yet undergoing aggregation, if given earbonate of ammonia or an infusion of raw meat. When a gland is direetly stimulated in any way, as by the pressure of a minute partiele of glass, the protoplasm within the cells of the gland first beeomes aggregated, then that in the eells immediately beneath the gland, and so lower and lower down the tentaeles to their bases:- 
that is, if the stimulns has been sufficient and not injurious. Now, when the glands of the disc are excited, the exterior tentacles are affected in exactly the same manner: the aggregation always commences in their glands, though these have not been directly excited, but have only received some influence from the disc, as shown by their increased acid secretion. The protoplasm within the cells immediately beneath the glands are next affected, and so downwards from cell to cell to the bases of the tentacles. This process apparently deserves to be called a reflex action, in the same manner as when a sensory nerve is irritated, and carries an impression to a ganglion which sends back some influence to a muscle or gland, cansing movement or increased secretion; but the action in the two cases is probably of a widely different nature. After the protoplasm in a tentacle has been aggregated, its redissolution always begins in the lower part, and slowly travels up the pedicel to the gland, so that the protoplasm last aggregated is first redissolved. This probably depends merely on the protoplasm being less and less aggregated, lower and lower down in the tentacles, as can be seen plainly when the excitement has been slight. As soon, therefore, as the aggregating action altogether ceases, redissolution naturally commences in the less strongly aggregated matter in the lowest part of the tentacle, and is there first completed.

Direction of the Inflected Tentacles.-When a particle of any kind is placed on the gland of one of the outer tentacles, this invariably moves towards the centre of the leaf; and so it is with all the tentacles of a leaf immersed in any exciting fluid. 'The glands of the cxterior tentacles then form a ring romnd the middle part of the disc, as shown in a previons figure (fig. 4, 
p. 10). The short tentacles within this ring still retain their vertical position, as they likewise do when a large object is placed on their glands, or when an insect is caught by them. In this latter case we can see that the inflection of the short central tentacles would be useless, as their glands are already in contact with their prey.

The result is very different when a single gland on one side of the disc is excited, or a few in a group,

These send an impulse to

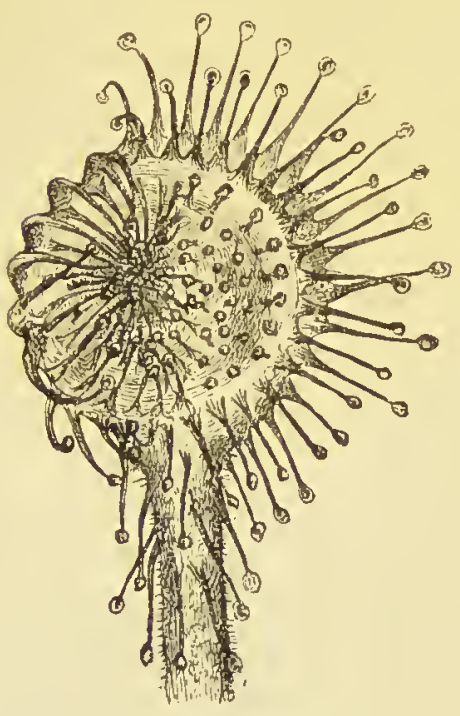

Fig. 10.

(Drosera rotundifolia.)

Leaf (enlarged) with the tentracles infected over a bit of meat placed on one side of the disc. the surrounding tentacles, which do not now bend towards the centre of the leaf, but to the point of excitement. $\mathrm{We}$ owe this capital observation to Nitschke, ${ }^{*}$ and since reading his paper a few years ago, I have repeatedly verified it. If a minute bit of meat be placed by the aid of a needle on a single gland, or on three or four together, halfway between the centre and the circumference of the disc, the directed movement of the surrounding tentacles is well exhibited. An accurate drawing of a leaf with meat in this position is here reproduced (fig. 10), and we see the tentacles, including some of the exterior ones, accurately dirceterl to the point where the meat lay. But a much better

* 'Bot. Zeitung,' 1S60, p. 210. 
plan is to plaee a partiele of the phosphate of lime moistened with saliva on a single gland on one side of the dise of a large leaf, and another partiele on a single gland on the opposite side. In four sueh trials the excitement was not suffieient to affeet the outer tentaeles, but all those near the two points were direeted to them, so that two wheels were formed on the dise of the same leaf; the pedieels of the tentaeles forming the spokes, and the glands united in a mass over the phosphate representing the axles. The preeision with which eaeh tentacle pointed to the partiele was wonderful; so that in some eases I eould deteet no deviation from perfeet aeeuraey. Thus, although the short tentaeles in the middle of the dise do not bend when their glands are exeited in a direet manner, yet if they reeeive a motor impulse from a point on one side, they direet themselves to the point equally well with the tentaeles on the borders of the dise.

In these experiments, some of the short tentaeles on the dise, whieh would have been direeted to the eentre, had the leaf been immersed in an exeiting fluid, were now infleeted in an exaetly opposite direetion, viz. towards the eireumferenee. These tentaeles, therefore, had deviated as mueh as $180^{\circ}$ from the direetion whieh they would have assumed if their own glands had been stimulated, and whieh may be eonsidered as the normal one. Between this, the greatest possible and no deviation from the normal direetion, every degree eould be observed in the tentreles on these several leaves. Notwithstanding the preeision with whieh the tentaeles generally were direeted, those near the eireumferenee of one leaf were not aeeurately directed towards some phosphate of lime at a rather distant point on the opposite side of the dise. It appeared as if the motor 
impulsc in passing trausversely aeross nearly the whole width of the dise had departed somewhat from a true eoursc. This aceords with what we have already seen of the impulsc travelling less readily in a transverse than in a longitudinal direetion. In some other eases, the exterior tentaeles did not seem eapable of such aeeurate movement as the shorter and more eentral ones.

Nothing eould be more striking than the appcaranee of the above four leaves, each with their tentaeles pointing truly to the two little masses of the phosphate on their dises. We might imagine that we were looking at a lowly organised animal seizing prey with its arms. In the ease of Drosera the explanation of this aceurate power of movement, no doubt, lies in the motor impulse radiating in all direetions, and whichever side of a tentacle it first strikes, that sicle eontraets, and the tentacle consequently bends towards the point of exeitement. The pedieels of the tentaeles are flattened, or elliptie in section. Near the bases of the short eentral tentaeles, the flattened or broad faee is formed of about five longitudinal rows of cells; in the outer tentaeles of the dise it eonsists of about six or seven rows; and in the extreme marginal tentaeles of above a dozen rows. As the flattened bases are thus formed of only a few rows of eells, the preeision of the movements of the tentacles is the more remarkable; for when the motor impulse strikes the base of a tentaele in a very oblique direction relatively to its broad face, searccly more than one or two cells towards one end can be affeeted at first, and the contrnetion of these cells must draw the whole tentacle into the proper direction. It is, perhaps, owing to the exterior pedieels being muel flatteued that they do not bend quitc so accurately to the point of excitement as the 
more eentral ones. The properly direeted movement of the tentacles is not an unique ease in the vegetable lingdom, for the tendrils of many plants eurve towards the side whieh is tonched; but the ease of Drosera is far more interesting; as here the tentaeles are not direetly excited, but receive an impulse from a distant point; nevertheless, they bend aeeurately towards this point.

On the Nature of the Tissues through which the Motor Impulse is Transmitted.-It will be neessary first to deseribe briefly the eourse of the main fibrovascular bundles. These are shown in the aeeompanying sketch (fig. 11) of a small leaf. Little vessels from the neighbouring bundles enter all the many tentaeles with whieh the surface is studded; but these are not here represented. The eentral trunk, whieh runs up the footstalk; bifureates near the centre of the leaf, eaeh branch bifureating again and again aecordling to the

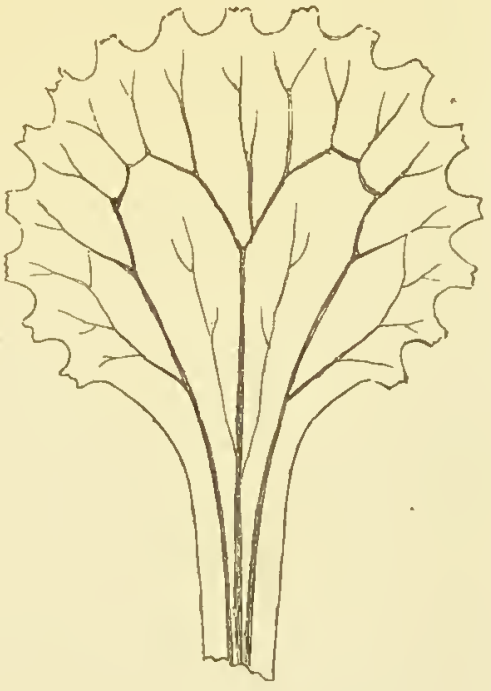

FIG. 11. (Drosera rotundifolia.)

Diagram showing the distribution of the vascular tissue in a small leaf. size of the leaf. This eentral trunk sends off, low down on eaeh side, a delieate braneh, which may be ealled the sublateral braneh. There is also, on each side, a main lateral braneh or bundle, whieh bifurcates in the same manner as the others. Bifureation does not imply that any single vessel divides, but that a bundle 
divides into two. By looking to either side of the leaf, it will be seen that a braneh from the great central bifureation inoseulates with a braneh from the lateral bundle, and that there is a smaller inoseulation between the two ehief branehes of the lateral bundle. The eourse of the vessels is very eomplex at the larger inoseulation; and here vessels, retaining the same diameter, are often formed by the minion of the bluntly pointed ends of two vessels, but whether these points open into eaeh other by their attaehed surfaees, I do not know. By means of the two inoseulations all the ressels on the same side of the leaf are brought into some sort of conneetion. Near the eireumferenee of the larger leaves the bifureating, branehes also eome into elose union, and then separate again, forming a eontinuous zigzag line of vessels round the whole eireumferenee. But the union of the vessels in this zigzag line seems to be mueh less intimate than at the main inoseulation. It should be added that the eourse of the vessels differs somewhat in different leaves, and even on opposite sicles of the same leaf, but the main inoseulation is always present.

Now in my first experiments with bits of meat plaeed on one side of the dise, it so happened that not a single tentaele was infleeted on the opposite side; and when I saw that the vessels on the same side were all eonneeted together by the two inoseulations, whilst not a vessel passed over to the opposite side, it seemed probable that the motor impulse was eondueted exclusively along them.

In order to test this view, I divided transversely with the point of a laneet the eentral trunks of four leaves, just beneath the main bifureation; and two days afterwards placed rather large bits of raw meat 
(a most powerful stimulant) near the eentre of the dise above the ineision-that is, a little towards the apex-with the following results:-

(1) This leaf proved rather torpid: after $4 \mathrm{hrs} .40 \mathrm{~m}$. (in all cases reekoning from the time when the meat was given) the tentacles at the distal end were a little infleeted, but nowhere else; they remained so for three days, and re-expandod on the fourth day. The leaf was then disseeted, and the trunk, as well as the two sublateral branehes, were found divided.

(2) After 4 hrs. $30 \mathrm{~m}$. many of the tentreles at the distal end were well infleeted. Next day the blade and all the tentaeles at this end were strongly infleeted, and were separated by a distinet transverse line from the basal half of the leaf, whieh was not in the least affeeted. On the third day, however, some of the short tentaeles on the dise near the base were very slightly inflceted. The incision was found on disseetion to extend aeross the leaf as in the last ease.

(3) After $4 \mathrm{hrs} .30 \mathrm{~m}$. strong inflection of the tentacles at the distal end, whieh during the next two days never extended in the least to the basal end. The imeision as before.

(4) This leaf was not observed until 15 hrs. had elapsed, and then all the tentaeles, exeept the extreme marginal ones, were found equally well infleeted all round the leaf. On eareful examination the spiral vessels of the eentral trunk were eertainly divided; but the incision on one side had not passed through the fibrous tissue surrounding these vessels, though it had passed through the tissue on the other side.*

The appearanee presented by the leaves (2) and (3) was very curious, and might be aptly eompared with that of a man with his baekbone broken and lower extremities paralysed. Exeepting that the line between the two halves was here transverse instead of longitudinal, these leaves were in the same state as some of those in the former experiments, with bits of meat placed on one side of the dise. The ease of leaf (4)

* M. Ziegler made similar experiments by cutting the spiral ressels of Drosera intermedia
('Comptes rendus,' 1874, p. 1417), but arrived at conclusions widely difierent from mine. 
proves that the spiral vessels of the central trunk may be divided, and yet the motor impulse be transmitted from the distal to the basal end; and this led me at first to suppose that the motor force was sent through the closely surrounding fibrous tissue; and that if one half of this tissue was left undivided, it sufficed for complete transmission. But opposed to this conclusion is the fact that no vessels pass directly from one side of the leaf to the other, and yet, as we have seen, if a rather large bit of meat is placed on one side, the motor impulse is sent, though slowly and imperfectly, in a transverse direction across the whole breadth of the leaf. Nor can this latter fact be accounted for by supposing that the transmission is effected through the two inosculations, or through the circumferential zigzag line of union, for had this been the case, the exterior tentacles on the opposite side of the disc would have been affected before the more central ones, which never occurred. We have also seen that the extreme marginal tentacles appear to have no power to transmit an impulse to the adjoining tentacles; yet the little bundle of vessels which enters each marginal tentacle sends off a minute branch to those on both sides, and this I have not observed in any other tentacles; so that the marginal ones are more closely connected together by spiral vessels than are the others, and yet have much less power of communicating a motor impulse to one another.

But besides these several facts and arguments re, have conclusive evidence that the motor impulse is not sent, at least exclusively, through the spiral vessels, or through the tissue immediately surrounding them. We know that if a bit of meat is placed on a gland (the immediately adjoining ones having been removed) on any part of the clisc, all the short sur- 
rounding tentacles bend almost simultaucously with great preeision towards it. Now there are tentacles on the disc, for instance near the extremities of the sublateral bundles (fig. 11), whieh are supplicd with vessels that do not eome into eontact with the branehes that enter the surrounding tentacles, cxeept by a very long and extremely eircuitous eoursc. Nevertheless, if a bit of meat is placed on the gland of a tentacle of this kind, all the surrounding ones are infleeted towards it with great preeision. It is, of eourse, possible that an impulse might be sent through a long and cireuitous eourse, but it is obviously impossible that the direction of the movement eould be thus eommunieated, so that all the surrounding tentacles should bend preeisely to the point of exeitement. The impulse no doubt is transmitted in straight radiating lines from the exeited gland to the surrounding tentaeles; it eannot, therefore, be sent along the fibrovaseular bundles. The effeet of eutting the eentral vessels, in the above cases, in preventing the transmission of the motor impulse from the distal to the basal end of a leaf, may be attributed to a eonsiderable spaee of the cellular tissue having been divided. We shall hereafter see, when we treat of Dionæa, that this same eonclusion, namely that the motor impulse is not transmitted by the fibro-vascular bundles, is plainly confirmed ; and Professor Cohn has eome to the same eonelusion with respeet to Aldrovanda-both members of the Droseraecie.

As the motor impulse is not transmitted along the vessels, there remains for its passage only the ecllular tissue; and the structure of this tissue explains to a eertain extent how it travels so quiekly down the loug extcrior tentaeles, and much more slowly aeross the blade of the leaf. We shall also see why it erosses 
the blade more quickly in a longitudinal than in a transverse direction; though with time it can pass in any direction. We know that the same stimulus causes movement of the tentacles and aggregation of the protoplasm, and that both influences originate in and proceed from the glands within the same brief space of time. It seems therefore probable that the motor impulse consists of the first commencement of a molccular change in the protoplasm, which, when well developed, is plainly visible, and has been designated aggregation; but to this subject I shall return. We further know that in the transmission of the aggregating process the chief delay is caused by the passage of the transverse cell-walls; for as the aggregation travels down the tentacles, the contents of each successive cell seem almost to flash into a cloudy mass. We may therefore infer that the motor impulse is in like manner dclayed chiefly by passing through the cell-walls.

The greater celerity with which the impulsc is transmitted down the long exterior tentacles than across the disc may be largcly attributed to its being closely confincd within the narrow pedicel, instead of radiating forth on all sides as on the disc. But besides this confinement, the cxterior cells of the tentacles are fully twice as long as those of the disc; so that only half the number of transverse partitions have to be traversed in a given length of a tentacle, compared with an equal space on the disc; and there would be in the same proportion less retardation of the impulse. Morcover, in sections of the exterior tentacles given by Dr. Warming, ${ }^{*}$ the parenchymatous

* 'Videnskabeligo Meddelelser de la Soc. d'Hist. nat. de Copenhague,' Nos. 10-12, 1872, woodcuts iv. and v. 
eells are shown to be still more elongated; and these would form the most direet line of eommunieation from the gland to the bending plaee of the tentacle. If the impulse travels down the exterior eells, it would have to eross from between twenty to thirty transverse partitions; but rather fewer if down the inner parenchymatous tissue. In either ease it is remarkable that the impulse is able to pass through so many partitions down nearly the whole length of the pedieel, and to aet on the bending plaee, in ten seeonds. Why the impulse, after having passed so quickly down one of the extreme marginal tentaeles (about $\frac{1}{2} \overline{0}$ of an ineh in length), should never, as far as I have seen, affect the adjoining tentaeles, I do not understand. It may be in part aeeounted for by mueh energy being expended in the rapidity of the transmission.

Most of the cells of the dise, both the superfieial ones and the larger eells which form the five or six underlying layers, are about four times as long as broad. They are arranged almost longitudinally, radiating from the footstalk. The motor impulse, therefore, when transmitted aeross the disc, has to cross nearly four times as many eell-walls as when transmitted in a longitudinal direction, and would consequently be mueh delayed in the former ease. The eells of the dise converge towards the bases of the tentaeles, and are thus fitted to eonvey the motor impulse to them from all sides. On the whole, the arrangement and shape of the eells, both those of the disc and tentaeles, throw mueh light on the rate and manner of diffusion of the motor impulse. But why the impulse proceeding from the glands of the exterior rows of tentaeles tends to travel laterally and towards the eentre of the leaf, but not eentrifugally, is by no means elear. 
Mechanism of the Movements, and Nature of the Motor Impulse.-Whatever may bc the means of movcment, the exterior tentacles, eonsidering their delicaey, are infleeted with mueh foree. A bristle, held so that a length of 1 ineh projeeted from a handle, yielded when I tried to lift with it an inflected tentaelc, whieh was somewhat thinncr than the bristle. The amount or extcnt, also, of the movement is great. Fully expanded tentaeles in beeoming infleeted sweep through an angle of $180^{\circ}$; and if they are beforehand reflexed, as often occurs, the angle is considerably greater. It is probably the superfieial eells at the bending plaee whieh ehiefly or exelusirely eontraet; for the interior eells have very delicate walls, and are so few in number that they eould hardly eause a tentaele to bend with preeision to a definite point. Though I. carefully looked, I could never detect any wrinkling of the surfaee at the bending place, even in the ease of a tentaele abnormally eurred into a eomplete eirele, under eireumstanees hereafter to be mentioned.

All the eells are not acted on, though the motor impulse passes through them. When the gland of one of the long extcrior tentacles is exeited, the upper cells arc not in the least affeeted; about halfway down there is a slight bending, but the ehief movement is confined to a short space near the base; and no part of the inner tcntacles bends except the basal portion. With respect to the bladc of the leaf, the motor impulsc may be transmitted through many eclls, from the eentre to the eircumference, without their being in the least affeetcd, or thcy may be strongly acted on and the blade greatly inflected. In the latter easc the movement seems to depend partly on the strength of the stimulus, and partly on 
its nature, as when leaves are immersed in eertain Hinicls.

'The power of movement which various plants possess, when irritated, has been attributed by high authorities to the ripid passage of fluid out of eertain eells, whieh, from their previous state of tension, immediately eontraet.* Whether or not this is the primary eause of such morements, fluid must pass out of closed eells when they eontraet or are pressed together in one direetion, unless they at the same time expand in some other direction. For instanee, fluid can be seen to ooze from the surfaee of any young and vigorous shoot if slowly bent into a semi-eirele. $t$ In the ease of Drosera there is eertainly mueh movement of the fluid throughout the tentaeles whilst they are undergoing inflection. Many leaves ean be found in whieh the purple fluid within the eells is of an equally dark tint on the upper and lower sides of the tentacles, extending also downwards on both sides to equally near their bases. If the tentaeles of sueh a leaf are exeited into movement, it will generally be found after some hours that the eells on the eoncave side are much paler than they were before, or are quite eolourless, those on the convex side having beeome mueh darker. In two instances, after particles of hair had been plaeed or glands, and when in the course of $1 \mathrm{hr} .10 \mathrm{~m}$. the tentaeles were incurved halfway towards the eentre of the leaf, this change of colour in the two sides was conspicuously plain. In another case, after a bit of meat had been placerl on a gland, the purple eolour was observed at intervals to be slowly travelling from the upper to the lower part, dowu the eonvex side of

* Sarhs, 'Traité de Bot.' Brrl edit. 1874, p. 10:38. 'This vicw was, I belicve, first sugrgested by
Lamarck.

$\dagger$ Sachs, ibid. p. 219. 
the bending tentacle. But it does not follow from these observations that the cells on the convex side become filled with more fluid during the act of inflection than they contained before; for fluid may all the time be passing into the disc or into the glands which then secrete freely.

The bending of the tentacles, when leaves are immersed in a dense fluid, and their subsequent reexpansion in a less dense fluid, show that the passage of fluid from or into the cells can cause movements like the natural ones. But the inflection thus caused is often irregular; the exterior tentacles being sometimes spirally curved. Other unnatural movements are likewise caused by the application of dense fluids, as in the case of drops of syrup placed on the backs of leaves and tentacles. Such movements may be compared with the contortions which many regetable tissues undergo when subjected to exosmose. It is therefore doubtful whether they throw any light on the natural movements.

If we arlmit that the outward passage of fluid is the cause of the bending of the tentacles, we must suppose that the cells, before the act of inflection, are in a high state of tension, and that they are elastic to an extraordinary degree; for otherwise their contraction could not cause the tentacles often to sweep through an angle of above $180^{\circ}$. Professor Cohn, in his interesting paper* on the movements of the stamens of certain Compositre, states that these organs, when dead, are as elastic as threads of indiarubber, and are then only half as long as they were when alive. He believes that the living protoplasm

* 'Abhand. der Schles. Gesell. für vaterl. Cultur,' 1861, Heft i. An excellent abstract of this paper is given in the "Annals and MTag. of Nat. Hist.' 3rd scries, 1S63, rol. xi. pp. 1SS-197. 
within their cells is ordinarily in a statc of cxpansion, but is paralysed by irritation, or may be said to suffer temporary death; the elasticity of the cell-walls then coming into play, and causing the contraction of the stamens. Now the cells on the uppcr or concave side of the bending part of the tentacles of Droscra do not appear to be in a statc of tension, nor to be highly elastic; for when a leaf is suddenly killed, or dies slowly, it is not the upper but the lower sides of the tentacles which contract from elasticity. We may, thereforc, conclude that thcir movements cannot be accounted for by the inhcrent elasticity of certain cells, opposed as long as they are alive and not irritated by the expanded state of their contents.

A somewhat different view has been advanced by other physiologists - namely that the protoplasm, when irritatcd, contracts like the soft sarcode of the muscles of animals. In Droscra the fluid within the cells of the tcntacles at the bending place appcars under the microscope thin and homogeneous, and after aggregation consists of small, soft masses of matter, undergoing incessant changes of form and floating in almost colourless fluid. These masscs are complctely redissolved when the tcntacles re-expand. Now it seems scarcely possible that such mattcr should have any direct mechanical powcr; but if through somc molecular change it werc to occupy less space than it did before, no doubt the ccll-walls would close up and contract. But in this case it might be cxpected that the walls would exhibit wrinkles, and none could cver be seell. Moreover, the contents of all the cells sccm. to be of exactly the samc nature, both before and aftcr aggregation; and yct only a few of the basal cells contract, the rest of the tentacle remaining straight.

A third view maintained by some physiologists, 
though rejected by most others, is that the whole eell, ineluding the walls, aetively eontracts. If the walls are composed solely of non-nitrogenous eellulose, this view is highly improbable; but it ean hardly be doubted that they must be permeated by proteid matter, at least whilst they are growing. Nor does there seem any inherent improbability in the eell-walls of Drosera contraeting, eonsidering their high state of organisation; as shown in the ease of the glands by their power of absorption and seeretion, and by being exquisitely sensitive so as to be affected by the pressure of the most minute partieles. The eell-walls of the pedieels also allow various impulses to pass through them, indueing movement, inereased seeretion and aggregation. On the whole the belief that the walls of eertain cells eontraet, some of their eontained fluid being at the same time foreed outwards, perhaps aecords best with the observed faets. If this view is rejeeted, the next most probable one is that the fluid contents of the eells shrink, owing to a ehange in their moleenlar state, with the eonsequent elosing in of the walls. Anyhow, the movement ean hardly be attributed to the elastieity of the walls, together with a previous state of tension.

With respeet to the nature of the motor impulse whieh is transmitted from the glands down the pedieels and aeross the dise, it seems not improbable that it is elosely allied to that influenee whieh eauses the protoplasm within the eells of the glands and tentaeles to aggregate. We have seen that both forees originate in and proeeed from the glands within a few seeonds of the same time, and are excitel by the same eauses. The aggregation of the protoplasm lasts almost as long as the tentaeles remaim inflecterl, even thongh this be for more than a week; but the 
protoplasm is redissolved at the bending place shortly before the tentacles re-expand, showing that the cxciting cause of the aggregating process has then quite ceased. Exposure to carbonic acid causes both the latter process and the motor impulse to travel very slowly down the tentacles. We know that the aggregating process is delayed in passing through the cellwalls, and we have good reason to believe that this holds good with the motor impulse; for we can thus understand the different rates of its transmission in a longitudinal and transverse line across the dise. Under a high power the first sign of aggregation is the appearance of a cloud, and soon afterwards of extrcmely fine granules, in the homogeneous purple fluid within the cells; and this apparently is duc to the union of molecules of protoplasm. Now it does not seem an improbable view that the same tendency-namely for the molecules to approach each other-should be communicated to the inner surfaces of the cell-walls which are in contact with the protoplasm; and if so, thcir molecules would approach each other, and the ccll-wall would contract.

To this view it may with truth be objected that when leaves are immersed in various strong solutions, or are subjected to a heat of above $130^{\circ}$ Fahr. (54.4 Cent.), aggregation ensues, but there is no morement. Again, various acids and some other fluids cause rapid movement, but no aggregation, or only of an abnormal nature, or only after a long interval of time; but as most of these fluids are nore or less injurious, they may check or prevent the aggregrating process by injuring or killing the protoplasm. There is another and more important difference in the two processes: when the glands on the dise are excited, they transmit some infuence "1) the surrounding 
tentacles, which aets on the eells at the bending place, but does not induce aggregation until it has reached the glands; these then send baek some other influenee, causing the protoplasm to aggregate, first in the upper and then in the lower cells.

The Re-expansion of the Tentacles. - This movement is always slow and gradual. When the eentre of the leaf is exeited, or a leaf is immersed in a proper solution, all the tentaeles bend directly towards the centre, and afterwards directly baek from it. But when the point of excitement is on one side of the disc, the surrounding tentaeles bend towards it, and therefore obliquely with respect to their normal direction; when they afterwards re-expand, they bend obliquely baek, so as to reeover their original positions. The tentacles farthest from an exeited point, wherever that may be, are the last and the least affected, and probably in eonsequenee of this they are the first to re-expand. The bent portion of a closely inflected tentacle is in a state of active eontraction, as shown by the following experiment. Meat was placed on a leaf, and after the tentacles were elosely inflected and had quite ceased to move, narrow strips of the clise, with a few of the outer tentaeles attached to it, were eut off and laid on one side under the microscope. After sereral failures, I suceeded in eutting off the eonvex surface of the bent portion of a tentaele. Movement immediately recommeneed, and the already greatly bent portion went on bending until it formed a perfect eircle; the straight distal portion of the tentacle passing on one side of the strip. The eonvex surfaee must therefore have previously been in a state of tension, suffieient to counterbalance that of the eoneave surfaee, which, when free, emrled into a complete ring.

The tentaeles of an expanded and unexcited leaf 
are moderately rigid and elastic; if bent by a ncedle, the upper end yiclds more casily than the basal and thicker part, which alone is capable of bccoming inflected. The rigidity of this basal part seems due to the tension of the outcr surface balancing a state of active and persistent contraction of the cells of the inner surface. I bclieve that this is the casc, because, when a leaf is dipped into boiling water, the tentacles suddenly become reflexed, and this apparently indicates that the tension of the outer surface is mechanical, whilst that of the inner surface is vital, and is instantly destroyed by the boiling water. We can thus also understand why the tentacles as they grow old and feeblc slowly become much reflexed. If a leaf with its tentacles closely inflected is dipped into boiling water, these risc up a little, but by no mcans fully re-expand. This may be owing to the heat quickly destroying the tension and elasticity of the cells of the convex surface; but I can hardly believe that their tension, at any one time, would suffice to carry back the tentacles to their original position, oftcn through an angle of above $180^{\circ}$. It is more probable that fluid, which we know travels along the tcntacles during the act of inflection, is slowly reattracted into the cells of the convex surface, their tension being thus gradually and continually increased.

A recapitulation of the chicf facts and discussions in this chapter will be given at the close of the next chapter. 


\section{CHAPTER XI.}

\section{Recaptclation of the Chief Observations on Drosera rotundifulia.}

As summaries have been given to most of the chapters, it will be sufficient here to recapitulate, as briefly as I ean, the chief points. In the first chapter a preliminary sketch was given of the structure of the leaves, and of the manner in which they capture insects. This is effected by drops of extremely viscid fluid surrounding the glands and by the inward movement of the tentacles. As the plants gain most of their nutriment by this means, their roots are very poorly developed; and they often grow in places where hardly any other plant except mosses can exist. The glands have the power of absorption, besides that of seeretion. They are extremely sensitive to various stimulants, namely repeated touches, the pressure of minute partieles, the absorption of animal matter and of various fluids, heat, and galvanic action. A tentacle with a bit of raw meat oul the gland has been seen to begin bending in $10 \mathrm{~s}$, to be strongly incurved in $5 \mathrm{~m}$., and to reach the centre of the leaf in half an hour. The blade of the leaf often becomes so much inflected that it forms a cup, enclosing any object placed on it.

A gland, when excited, not only sends some influence down its own tentacle, eansing it to bend, but likewise to the surrounding tentacles, which become incurved; so that the beuding plaee ean be acted on by an impulse received from opposite directions, 
namely from the gland on the summit of the same tentacle, and from one or more glands of the neighbouring tentacles. Tentaeles, when inflected, re-expand after a time, and during this proeess the glands seerete less eopiously, or beeome dry. As soon as they begin to secrete again, the tentaeles are ready to re-act; and this may be repeated at least three, probably many more times.

It was shown in the seeond ehapter that animal substanees plaeed on the dises eause mueh morc prompt and energetic inflection than do inorganie bodies of the same size, or mere mechanical irritation; but there is a still more marked differcnce in the greater length of time during which the tentaeles rcmain infleeted over bodies yielding soluble and nutritious matter, than over those whieh do not yicld sueh matter. Extremely minute particles of glass, cinders, hair, thread, precipitated ehalk, \&e., when plaeed on the glands of the outer tentaeles, eause them to bend. A partiele, unless it sinks through the secretion and aetually touehes the surfacc of the gland with some one point, does not produee any effeet. A little bit of thin human hair $\frac{A}{10.00}$ of an ineh $(203 \mathrm{~mm}$.) in length, and weighing only $\frac{7}{7} \frac{1}{7}-$ of a grain ( 000822 mg.), though largely supported by the dense seeretion, suffiecs to induce movement. It is not probable that the pressure in this ease eould have amounted to that from the millionth of a grain. Even smaller particles eause a slight movemcnt, as could be seen through a lens. Larger particles than those of whieh the ineasurements have been given cause no sensation when plaeer on the tongue, one of the most sensitive parts of the human body.

Movement ensucs if a gland is momentarily towehed three or four times; but if tonehed only once or twiee, 
though with considerable force and with a hard object, the tentacle does not bend. The plant is thus saved from much useless movement, as during a high wind the glands can hardly escape being occasionally brushed by the leaves of surrounding plants. Though insensible to a single touch, they are exquisitely sensitive, as just stated, to the slightest pressure if prolonged for a few seconds; and this capacity is manifestly of service to the plant in capturing small insects. Even gnats, if they rest on the glands with their delicate feet, are quickly and securely embraced. The glands are insensible to the weight and repeated blows of clrops of heavy rain, and the plants are thus likewise saved from much useless movement.

The description of the morements of the tentacles was interrupted in the third chapter for the sake of describing the process of aggregation. This process always commences in the cells of the glands, the contents of which first become clondy; and this has been observed within $10 \mathrm{~s}$. after a gland has been excited. Granules just resolvable under a very high power soon appear, sometimes within a minute, in the cells beneath the glands; and these then aggregate into minute spheres. The process afterwards travels down the tentacles, being arrested for a short time at each transverse partition. The small spheres coalesce into larger spheres, or into oval, club-headed, threador necklace-like, or otherwise shaped masses of protoplasm, which, suspended in almost colourless fluid, exhibit incessant spontaneous changes of form. These frequently coalesce and again separate. If a gland has been powerfully excited, all the cells down to the base of the tentacle are affected. In cells, especially if filled with dark red fluid, the first step in the 
proeess often is the formation of a dark red, baglike mass of protoplasm, whieh afterwards divides and mudergoes the usual repented changes of form. Before any aggregation has been excited, a sheet of eolourless protoplasm, including granules (the primordial utricle of Mohl), flows round the walls of the cells; and this beeomes more distinet after the eontents have been partially aggregated into spheres or bag-like masses. But after a time the granules are drawn towards the eentral masses and unite with them; and then the eireulating sheet ean no longer be distinguished, but there is still a eurrent of transparent fluid within the eells.

Aggregation is exeited by almost all the stimulants whieh induee movement; sueh as the glands being touehed two or three times, the pressure of minute inorganie partieles, the absorption of various fluids, even long, immersion in distilled water, exosmose, and heat. Of the many stimulants tried, earbonate of ammonia is the most energetie and acts the quiekest:

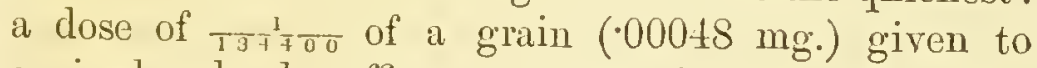
a single gland suffiees to eause in one hour wellmarked aggregation in the upper eells of the tentaele. The proeess goes on only as long as the protoplasm is in a living, vigorous, and oxygenated eondition.

The result is in all respeets exactly the same, whether a gland has been exeited direetly, or has reeeived an influenee from other and distant glauds. But there is one important differenee: when tho eentral glands are irritated, they transmit centrifugally an influenee up the pedieels of the exterior tentacles to their glands; but the aetual proeess of aggregation travels centripetally, from the glands of the exterior tentacles down their pedicels. 'The exciting influence, therefore, which is transmitted from 
one part of the leaf to another must be different from that which actually indnces aggregation. The proeess does not depend on the glands seereting more copiously than they did before; and is independent of the inflection of the tentacles. It continues as long as the tentacles remain inflected, and as soon as these are fully re-expanded, the little masses of protoplasm are all redissolved; the cells becoming filled with homogeneous purple fluid, as they were before the leaf was excited.

As the process of aggregation can be excited by a few touches, or by the pressure of insoluble particles, it is evidently independent of the absorption of any matter, and must be of a molecular nature. Eren when eaused by the absorption of the earbonate or other salt of ammonia, or an infusion of meat, the process seems to be of exaetly the same nature. The protoplasmie fluid must, therefore, be in a singularly unstable condition, to be acted on by such slight and yaried eauses. Physiologists believe that when a nerve is touched, and it transmits an influence to other parts of the nervous system, a molecular change is indueed in it, though not visible to us. Therefore it is a very interesting spectacle to wateh the effects on the eells of a gland, of the pressure of a bit of hair, weighing only $\div \frac{1}{\square} \div 0$ of a grain and largely supported by the dense secretion, for this exeessively slight pressure soon causes a visible change in the protoplasm, whieh change is transmitted down the whole length of the tentacle, giving it at last a mottled appearance, distingmishable even by the naked eye.

In the fourth chapter it was shown that leares placed for a short time in water at a temperature of $110^{\circ}$ Fahr. ( $43^{\circ} \cdot 3$ Cent.) become somewhat inflected; they are thus also rendered more sensitive to the action 
of meat than they were before. If exposed to a temperature of between $115^{\circ}$ and $125^{\circ}\left(46^{\circ} \cdot 1-51^{\circ} \cdot 6\right.$ Cent.), they are quickly infleeted, and their protoplasm undergoes aggregation; when afterwards plaeed in eold water, they re-expand. Exposed to $130^{\circ}\left(54^{\circ} .4\right.$ Cent.), no infleetion immediately oeeurs, but the leaves are only temporarily paralysed, for on being left in eold water, they often beeome infleeted and afterwards re-expand. In one leaf thus treated, I distinetly saw the protoplasm in movement. In other leaves, treated in the same manner, and then immersed in a solution of earbonate of ammonia, strong aggregation ensued. Leaves plaeed in eold water, after an exposure to so high a temperature as $145^{\circ}\left(62^{\circ} .7\right.$ Cent.), sometimes beeome slightly, though slowly, infleeted; and afterwards have the eontents of their cells strongly aggregated by earbonate of ammonia. But the duration of the immersion is an important element, for if left in water at $145^{\circ}$ ( $62^{\circ} .7$ Cent.), or only at $140^{\circ}\left(60^{\circ}\right.$ Cent.), until it beeomes eool, they are killed, and the eontents of the glands are rendered white and opaque. This latter result seems to be due to the eoagulation of the albumen, and was almost always eaused by even a short exposure to $150^{\circ}\left(65^{\circ} .5\right.$ Cent.) ; but different leaves, and even the separate eells in the same tentaele, differ eonsiderably in their power of resisting heat. Unless the heat has been suffieient to eagulate the albumen, earbonate of ammonia subsequently induces aggregation.

In the fifth ehapter, the results of plaeing drops of various nitrogenous and nou-nitrogenous organie fluids on the dises of leaves were given, and it was shown that they detect with almost unerring eertainty the presenee of nitrogen. A deeoction of green peas or of fresh eabbage-leaves acts almost as powerfully as an infusion of raw meat; whereas an infusion of cabbage- 
leaves made by keeping them for a long time in merely warm water is far less efficient. A deeoetion of grass-leaves is less powerful than one of green peas or cabbage-leaves.

These results led me to inquire whether Drosera possessed the power of dissolving solid animal matter. The experiments proving that the leaves are capable of true digestion, and that the glands absorb the digested matter, are given in detail in the sixth ehapter. These are, perhaps, the most interesting of all my observations on Drosera, as no sueh power was before distinetly known to exist in the vegetable kingdom. It is likewise an interesting faet that the glands of the dise, when irritated, should transmit some influenee to the glands of the exterior tentaeles, eausing them to seerete more eopionsly and the seeretion to become aeid, as if they had been direetly exeited by an objeet placed on them. The gastrie juice of animals eontains, as is well known, an aeid and a ferment, both of whieh are indispensable for digestion, and so it is with the seeretion of Drosera. When the stomaeh of an animal is meehanically irritated, it seeretes an acid, and when partieles of glass or other sueh objeets were plaeed on the glands of Drosera, the seeretion, and that of the surrounding and untonched glands, was inereased in quantity and beeame aeid. But, according to Sehiff, the stomaeh of an animal does not seerete its proper ferment, pepsin, until eertain substances, which he calls peptogenes, are absorbed; and it appears from my experiments that some matter must be absorbed by the glands of Drosera before they seerete their proper ferment. That the seeretion does eontain a ferment which aets only in the presenee of an acid on solid animal matter, was clearly proved by adding minute closes of 
an alkali, whieh entirely arrested the proeess of digestion, this immediately reeommeneing as soon as the alkali was neutralised by a little weak hydrochlorie acid. From trials made with a large number of substances, it was found that those whieh the seeretion of Drosera dissolves eompletely, or partially, or not at all, are acted on in exaetly the same manner by gastrie juice. We may, therefore, conelude that the ferment of Drosera is closely analogous to, or identieal with, the pepsin of animals.

The substanees whieh are digested by Drosera act on the leaves very differently. Some eause mueh more energetie and rapid infleetion of the tentacles, and keep them infleeter for a mueh longer time, than do others. We are thus led to believe that the former are more nutritious than the latter, as is known to be the ease with some of these same substanees when given to animals; for instance, meat in eomparison with gelatine. As cartilage is so tough a substanee and is so little acted on by water, its prompt dissolution by the seeretion of Drosera, and subsequent absorption, is, perhaps, one of the most striking eases. But it is not really more remarkable than the digestion of meat, which is dissolved by this seeretion in the same manner and by the same stages as by gastrie juiee. The secretion dissolves bone, and even the enamel of teeth, but this is simply due to the large quantity of acid secreted, owing, apparently, to the desire of the plant for phosphorus. In the ease of bone, the ferment does not eome into play until all the phosphate of lime has been deeomposed and free aeid is present, and then the fibrous basis is quickly dissolved. Lastly, the seeretion attieks and dissolves matter out of living seeds, which it sometimes kills, or injures, as shown by the diseased state 
of the seedlings. It also absorbs matter from pollen, and from fragments of leaves.

The seventh ehapter was devoted to the action of the salts of ammonia. These all cause the tentaeles, and often the blade of the leaf, to be infleeted, and the protoplasm to be aggregated. They aet with very different power; the citrate being the least powerful, and the phosphate, owing, no doubt, to the presenee of phosphorus and nitrogen, by far the most powerful. But the relative effieieney of only three salts of ammonia was earefully determined, namely the earbonate, nitrate, and phosphate. The experiments were made by plaeing half-minims ( $(0296 \mathrm{ml}$.) of solutions of different strengths on the dises of the leaves,- - by applying a minute drop (about the $\frac{1}{20}$ of a minim, or $.00296 \mathrm{ml}$.) for a few seeonds to three or four glands,and by the immersion of whole leaves in a measured quantity. In relation to these experiments it was neeessary first to ascertain the effeets of distilled water, and it was found, as deseribed in detail, that the more sensitive leaves are affeeted by it, but only in a slight degree.

A solution of the carbonate is absorbed by the roots and induces aggregation in their eells, but does not affect the leaves. The vapour is absorbed by the glands, and causes infleetion as well as aggregation. A drop of a solution eontaining $\frac{1}{960}$ of a grain (.0675 mg.) is the least quantity which, when placed on the glands of the disc, exeites the exterior tentaeles to bend inwards. But a minute drop, eontaining $\frac{1}{T-\frac{1}{4}}$ of a grain $(.00445 \mathrm{mg}$.), if applied for a few seeonds to the secretion surrounding a gland, enuses the infleetion of the same tentaele. When a highly sensitive leaf is immersed in a solution, and there is mple time for absorption, the $\frac{1}{16 \frac{1}{8}}$ 
(.0002t mg.) is sufficient to excite a single tentacle into movement.

The nitrate of ammonia induces aggregation of the protoplasm much less quickly than the carbonate, but is more potent in causing inflection. A drop containing $\frac{1}{9}$. of a grain $(.027 \mathrm{mg}$.) placed on the disc acts powerfully on all the exterior tentacles, which have not themselves reccived any of the solution; whereas a drop with $\frac{1}{2800}$ of a grain caused only a few of these tentacles to bend, but affected rather morc plainly the blacle. A minute drop applied as before, and containing $\frac{1}{28800}$ of a grain $(.0025 \mathrm{mg}$.$) , caused the tentacle$ bearing this gland to bend. By the immersion of whole leaves, it was proved that the absorption by a single gland of $\frac{1}{69 \frac{1}{1200}}$ of a grain $(.0000937 \mathrm{mg}$.) was sufficient to set the same tentacle into movement.

The phosphate of ammonia is much more powerful than the nitrate. A drop containing $\frac{1}{38 \div \overline{0}}$ of a grain . (.0169 mg.) placed on the disc of a sensitive leaf canses most of the exterior tentacles to be inflectcd, as well as the blade of the leaf. A minute drop containing $\frac{1}{15 \frac{1}{3} 600}$ of a grain (.000423 mg.), applied for a few seconds to a gland, acts, as shown by the movement of the tentacle. When a leaf is immerser in thirty minims $(1.7748 \mathrm{ml}$.) of a solution of one part by weight of the salt to $21,875,000$ of water, the absorption by a gland of only the $\frac{1}{1, \pi 0000}$ of a grain $(.00000328 \mathrm{mg}$.$) , that is, a little less than the one-$ twenty-millionth of a grain, is sufficient to cause the tentacle bearing this gland to bend to the centre of the leaf. In this expcriment, owing to the prescnce of the water of crystallisation, less than the one-thirtymillionth of a grain of the efficient elements could have been absorber. There is nothing remarkable in such minute qrantities being absorbed by the glands; 
for all physiologists admit that the salts of ammonia, which must be brought in still smaller quantity by a single shower of rain to the roots, are absorbed by them. Nor is it surprising that Drosera should be enabled to profit by the absorption of these salts, for yeast and other low fungoid forms flourish in solutions of ammonia, if the other necessary elements are present. But it is an astonishing fact, on which I will not here aggain enlarge, that so inconceivably minute a quantity as the one-twenty-millionth of a grain of phosphate of ammonia should induce some change in a gland of Drosera, sufficient to eause a motor impulseto be sent down the whole length of the tentacle; this impulse exciting movement often through an angle of above $180^{\circ}$. I know not whether to be most astonished at this fact, or that the pressure of a minute bit of hair, supported by the dense secretion, should quickly eause conspieuous movement. Moreorer, this extreme sensitiveness, exceeding that of the most delicate part of the human body, as well as the power of transmitting various impulses from one part of the leaf to another, have been acquired without the intervention of any nervous system.

As few plants are at present known to possess glands specially adapted for absorption, it seemed worth while to try the effeets on Drosera of rarious other salts, besides those of ammonia, and of various acids. Their aetion, as described in the eighth chapter, does not correspond at all strictly with their ehemieal affinities, as inferred from the elassification commonly followed. The nature of the base is far more influential than that of the acid; and this is known to hold good with animals. For instanee, nine salts of sodium all caused well-marked infleetion, and none of them were poisonous in small doses; whereas seven of the nine corre- 
sponding salts of potassium produced no effect, two causing slight inflection. Small doses, moreover, of some of the latter salts were poisonous. The salts of sodium and potassium, when injected into the veins of animals, likewise differ widely in their action. The so-called earthy salts produce hardly any effect on Drosera. On the other hand, most of the metallic salts cause rapid and strong inflection, and are highly poisonous; but there are some odd exceptions to this rule; thus chloride of lead and zine, as well as two salts of barium, did not cause inflection, and wcre not poisonous.

Most of the acids which were tried, though much diluted (one part to 437 of water), and given in small doses, acted powerfully on Droscra ; nincteen, out of the twenty-four, causing the tentacles to be more or less inflected. Most of them, even the organic acids, are poisonous, often highly so; and this is remarkable, as the juices of so many plants contain acids. Benzoic acid, which is innocuous to animals, seems to be as poisonous to Drosera as hydrocyanic. On the other hand, hydrochloric acid is not poisonous either to animals or to Droseril, and induces only a moderate amornt of inflection. Many acids excite the glands to secrete an cxtraordinary quantity of mucus; and the protoplasm within their cells secms to be often killed, as may be inferred from the surrounding fluid soon becoming pink. It is strange that allied acids act very differently: formic acid induces very slight inflection, and is not poisonous; whereas acetic acid of the same strength acts most powerfully and is poisonous. Lactic acid is also poisonous, but causes inflection only after a considerable lapse of time. Malic acid acts slightly, whereas citric and tartaric acids produce no effect. 
In the ninth chapter the effeets of the absorption of various alkaloids and eertain other substanees were deseribed. Although some of these are poisonous, yet as several, whieh aet powerfully on the nervous system of animals, produee no effeet on Drosera, we may infer that the extreme sensibility of the glands, and their power of transmitting an influenee to other parts of the leaf, eausing movement, or modified seeretion, or aggregation, does not depend on the presence of a cliffused element, allied to nerve-tissue. One of the most remarkable faets is that long immersion in the poison of the eobra-snake does not in the least cheek, but rather stimulates, the spontaneous movements of the protoplasm in the eells of the tentacles. Solutions of various salts and aeids behave very differently in delaying or in quite arresting the subsequent aetion of a solution of phosphate of ammonia. Camphor dissolved in water aets as a stimulant, as do small doses of eertain essential oils, for they eause rapid and strong infleetion. Aleohol is not a stimulant. The rapours of eamphor, aleohol, ehloroform, sulphurie and nitrie ether, are poisonous in moderately large doses, but in small doses serve as nareoties or anæstheties, greatly delaying the subsequent aetion of meat. But some of these vapours also aet as stimulants, exeiting rapid, almost spasmodie movements in the tentaeles. Carbonie aeid is likewise a nareotie, and retards the aggregation of the protoplasm when carbonate of ammonia is subsequently given. The first aeeess of air to plants whieh have been immersed in this gas sometimes aets as a stimulant and incluees movement. But, as before remarked, a speeial pharmacopœia would be neeessary to deseribe the diversified effects of various substances on the leaves of Drosera.

In the tentl ehapter it was shown that the sensitive- 
ness of the leaves appears to be wholly confined to the glands and to the immediately undcrlying cells. It was further shown that the motor impulse and other forces or influences, proceeding from the glands when excited, pass through the cellular tissuc, and not along the fibro-vascular bundles. A gland sends its motor impulse with great rapidity down the pedicel of the same tentacle to the basal part which alone bends. The impulse, then passing onwards, spreads on all sides to the surrounding tentacles, first affecting those which stand nearest and then those farther off. But by bcing thus spread out, and from the cells of the disc not being so much elongatcd as those of the tentacles, it loses force, and here travels much more slowly than down the pedicels. Owing also to the direction and form of the cells, it passes with greater easc and celerity in a longitudinal than in a transverse line across the disc. The impulse proceeding from the glands of the extreme marginal tcntacles docs not seem to have force enough to affect the adjoining tentacles; and this may bc in part due to their length. The impulse from the glands of the next fer inner rows spreads chiefly to the tentacles on cach side and towards the centre of the lcaf; but that proceeding from the glands of the shorter tentacles on the disc radiates almost equally on all sides.

When a gland is strongly cxeited by the quantity or quality of the substance placed on it, the motor impulse travels farther than from one slightly cxcited; and if several glands are simultancously cxeited, the impulses from all unitc and spread still farther. As soon as a gland is excited, it discharges an impulsc which extends to a considcrable distance; but afterwards, whilst the gland is secreting and absorbing, the impulse suffices only to keep the sanc tentacle 
infleeted; though the infleetion may last for many days.

If the bending plaee of a tentaele reeeives an impulse from its own gland, the movement is always towards the centre of the leaf; and so it is with all the tentaeles, when their glands are exeited by immersion in a proper fluid. The short ones in the middle part of the dise must be exeepted, as these do not bend at all when thus exeited. On the other hand, when the motor impulse eomes from one side of the dise, the surrounding tentaeles, ineluding the short ones in the middle of the dise, all bend with preeision towards the point of exeitement, wherever this may be seated.. This is in every way a remarkable phenomenon; for the leaf falsely appears as if endowed with the senses of an animal. It is all the more remarkable, as when the motor impulse strikes the base of a tentaele obliquely with respeet to its flattened surfaee, the eontraetion of the eells must be eonfined to one, two, or a very fer rows at one end. And different sides of the surrounding tentaeles must be aeted on, in order that all should bend with preeision to the point of exeitement.

The motor impulse, as it spreads from one or more glands aeross the dise, enters the bases of the surrounding tentaeles, and immediately aets on the bending plaee. It does not in the first place proeeed up the tentaeles to the glands, exeiting them to reflect baek an impulse to their bases. Nevertheless, some influenee is sent up to the glands, as their seeretion is soon increased and rendered aeid; and then the glands, being thus exeited, send baek some other influenee (not dependent on inereased seeretion, nor on the infleetion of the tentacles), eausing the protoplasm to aggregate in eell beneath eell. This may 
be ealled a reflex aetion, though probably very different from that proeeeding from the nerve-ganglion of an animal; and it is the only known case of reflex aetion in the vegetable kingdom.

About the mechanism of the movements and the nature of the motor impulse we know very little. During the act of infleetion fluid eertainly travels from one part to another of the tentaeles. But the hypothesis which agrees best with the observed facts is that the motor impulse is allied in nature to the aggregating proeess; and that this causes the moleeules of the eell-walls to approaeh each other, in the same manner as do the moleenles of the protoplasm within the cells; so that the eell-walls eontraet. But some strong objeetions may be urged against this view. The re-expansion of the tentaeles is largely due to the elastieity of their outer cells, whieh eomes into play as soon as those on the inner side eease eontracting with prepotent foree; but we have reason to suspect that fluid is eontinually and slowly attracted into the outer eells during the act of re-expansion, thus inereasing their tension.

I have now given a brief recapitulation of the ehief points observed by me, with respeet to the strueture, movements, eonstitution, and habits of Droserc rotundifotia; and we see how little has been made out in eomparison with what remains unexplained and unknown. 


\section{CHAPTER XII.}

Os the Strccture and Movements of some other Species of Drosera.

Drosera anglica-Drosera intermedia-Drosera capensis-Drosera spathulata-Drosera filiformis-Drosera binata-Coneluding remarks.

I EXAMINED six other species of Drosera, some of them inhabitants of distant countries, chiefly for the sake of ascertaining whether they caught insects. This seemed the more necessary as the leaves of some of the species differ to an extraordinary degree in shape from the rounded ones of Drosera rotundifolia. In functional powers, however, they differ very little.

Drosera anylica (Hudson).*-The leaves of this spccies, which was sent to me from Ircland, arc much elongated, and gradually widcn from the footstalk to the bluntly pointed apex. They stand almost erect, and their blades sometimes exceed 1 inch in length, whilst their breadth is only the $\frac{2}{5}$ of an inch. The glands of all the tentacles have the same structure, so that the extrcme marginal oncs do not differ from the others, as in the case of Droseru rotundifoliu. When they are irritated by being roughly touched, or by the pressure of minute inorganic particles, or by coutact with animal matter, or by the absorption of carbonate of ammonia, the tentacles become inflected; the basal portion bcing the chief scat of movement. Cutting or pricking the blade of the leaf did not cxcite any movement. They frequently capture inscets, and the glands of the inflected tentacles pour forth much acid secretion. Bits of roast meat wcre placed on some glands, and the tcutacles hegan to more in $1 \mathrm{~m}$. or

* Mrs. Trent has given an exeellent aeeount in "The American Naturalist,' Deeember 1873, p.705, of Drosera longifolia (whieh is a synonym in part of Drosera anglica), of Drosera rotundifolia aud filiformis. 
$1 \mathrm{~m} .30 \mathrm{s.}$; and in $1 \mathrm{hr} .10 \mathrm{~m}$. reached the centre. Two bits of boiled cork, one of boiled thread, and two of coal-cinders taken from the fire, were placed, by the aid of an instrument whieh had been immersed in boiling water, on five glands; these superfluous precautions having been taken on account of M. Ziegler's statements. One of the particles of cinder caused some inflection in $8 \mathrm{hrs} .45 \mathrm{~m}$., as did after $23 \mathrm{hrs}$. the other particle of cinder, the bit of thread, and both bits of cork. Three glands were touched half a dozen times with a needle; one of the tentaeles became well inflected in $17 \mathrm{~m}$., and re-expanded after $24 \mathrm{hrs.}$; the two other's never moved. The homogeneons fluid within the cells of the tentacles undergoes aggregation after these have bccome infleeted; especially if given a solution of earbonate of ammonia ; and I observed the usual movements in the masses of protoplasm. In one ease, aggregation ensucd in $1 \mathrm{hr} .10 \mathrm{~m}$. after a tentacle had carried a bit of meat to the centre. From these faets it is clear that the tentacles of Drosera anglira bebave like those of Drosera votundifolia.

If an insect is plaeed on the central glands, or has been naturally caught there, the apex of the leaf curls intrards. For instance, dead flies were placed on three learcs ncar their bases, and after $24 \mathrm{hrs}$. the previously straight apices were curled completely over', so as to embrace and eonccal the flies; they had therefore moved through an angle of $180^{\circ}$. After three days the apex of one leaf, together with the tentaelcs, began to re-cxpand. But as far as I have scen-and I made many trials--tho sides of the leaf are never inflected, and this is the onc functional difference between this species and Drosera rolundifolia.

Drosera intermedia (Hayne).-This species is quite as common in some parts of England as Drosera rotundifolia. It differs from Drosera anglica, as far as the leaves are conecrned, only in their smaller size, and in their tips being generally a little reflexed. 'They capture a large number of insects. The tentacles are exeited into movement by all the causes abore spccified; and aggregation ensues, with movement of the protoplasmic masses. I have seen, through a lens, a tentacle beginning to bend in less than a minute after a particle of raw meat had been placed on the gland. The apox of the leaf curls over an exciting object as in the case of Drosera anglica. Acid secretion is copiously poured over captured insects. A leaf whieh had embraeed a fly with all its tentacles re-expanded after nearly three days.

Droserc capensis. - This specios, a native of the Capc of Good Hone, was sent to me by Dr. Hooker. 'The leaves are elongated, slightly eoncave along the middle and taper towards the apex, 
whieh is bluntly pointed and reflexed. They rise from an almost woody axis, and their greatest peeuliarity consists in thcir foliaceous green footstalks, which are almos' as broad and even longer than the gland-bearing bladc. This species, therefore, probably draws more nourishment from the air, and less from eaptured insects, than the other species of the genus. Nerertheless, tho tentacles are erowded together on the disc, and are extremely numerous; those on the margins being much longer than the central ones. All the glands have the same form; their secretion is extremely viseid and acid.

The specimen which I examined had only just reeovered from a weak state of health. This may account for the tentacles moving very slowly when particles of meat werc placed on the glands, and perhaps for my never succecding in causing any morement by repeatedly touching them with a ncedle. But with all the species of the genus this latter stimulus is the least effective of any. Particles of glass, cork, and coal-cinders, were placed on the glands of six tentacles; and one alone moved after an interval of $2 \mathrm{hrs} .30 \mathrm{~m}$. Nevertheless, two glands were extremely sensitive to very small doses of the nitrate of ammonia, namely to about $\frac{1}{20}$ of a minim of a solution (one part to 5250 of water), containing only $\frac{1}{115^{2}} \overline{00}$ of $\Omega$ grain (.000562 mg.) of the salt. Fragments of flies were placed on two lcaves near their tips, which beeame incurved in 15 hrs. A fly was also placed in the middle of the leaf; in a few hours the tentacles on eaeh side embraced it, and in $8 \mathrm{hrs}$. the whole leaf direetly beneath the fly was a little bent transversely. By the next molning, after 23 hrs., the lcaf was curled so completely over that the apex rested on the upper end of the footstalk. In no ease did the sides of the leaves beeome inflected. A crushed fly was placed on the foliaceous footstalk, lut produeed no effect.

Drosera spathulata (sent to me by Dr. Hooker). - I made only a few observations on this Australian species, whieh has long, narrow leaves, gradually widening towardis their tips. The glands of the cxtreme marginal tentacles are elongated and differ from the others, as in the case of Drosera rotundifolia. A fly was placed on a leaf, and in $18 \mathrm{hr}$ s. it was embraeed by the adjoining tentacles. Gum-water dropped on several leares produced no effeet. A fragment of a leaf was immersed in a few drops of a solution of one part of carbonate of ammonia to 146 of water; all the glands rere instantly blackened; the process of aggregntion eould bo seen travelling rapidly down the cells of the tentacles; and the granules of protoplasm soon united into spheres and variously shaped masses, which displayed tho usual more- 
ments. Half a minim of $a$ solution of one part of nitrate of ammonia to 146 of water was next placed on the centre of a leaf ; after 6 hrs. some marginal tentacles on both sides were inflected, and after 9 hrs. they met in the centre. The lateral edges of the leaf also became incurved, so that it formed a half-cylinder; but the apex of the leaf in none of my few trials was inflected. The above close of the nitrate (viz. $\frac{1}{320}$ of a grain, or $\cdot 202 \mathrm{mg}$.) was too powerful, for in the comrse of $23 \mathrm{hrs}$. the leaf died.

Drosera fliformis.-This North American species grows in such abundance in parts of New Jersey as almost to cover the ground. It catches, according to Mrs. Treat,* an extraordinary number of sinall and large insects, -even great flies of the geutus Asilus, moths, and butterfies. The specimen which I examined, sent me by Dr. Hooker, had thrcad-like leaves, from 6 to 12 inches in length, with the upper surface convex and the lower flat and slightly channelled. The whole convex surface, down to the roots-for there is no distinct footstalk - is covered with short gland-bearing tentacles, those on the margins being the longest and reflexed. Bits of ment placed on the glands of some téntacles caused them to be slightly inflected in $20 \mathrm{~m}$; ; but the plant was not in a vigorous state. After 6 lirs. they moved through an angle of $90^{\circ}$, and in $24 \mathrm{hrs}$. reached the centre. The surrounling tentacles by this time began to curve inwards. Ultimately a large drop of extremely viscid, slightly acid secretion was pourcd over the meat from the united glands. Several other glands were touched with a littlc saliva, and the tentacles bccame incurved in under $1 \mathrm{hr}$, and re-expanded after 18 hrs. Particles of glass, cork, cinders, thread, and gold-leaf, were placed on numerous glands on two leaves; in about $1 \mathrm{hr}$. four tentacles became curved, and four others after an additional intcrval of $2 \mathrm{hrs} .30 \mathrm{~m}$. I ncvcr once succeeded in causing any movement by repeatedly tonching the glands with a needle; and Mrs. Trcat madc similar trials for me with no success. Small flies were placed on several leaves ncar their tips, but tlie thread-like blade became only on one occasion very slightly bent, directly beneath the inscet. Perhaps this indicates that the blades of vigorous plants would bend over captured insects, and Dr. Canby informs mo that this is the case; but the movement cannot be strongly pronounced, as it was not observed by Mrs. Treat.

Drosera binuta (or dichotoma). - I am mucl indebted to Lady

* 'American Naturalist,' Dec. 1873, p. 705. 
Dorothy Nevill for a fine plant of this almost gigantic Australian species, whieh differs in some interesting points from those previously described. In this specimen the rush-like footstalks of the leaves were 20 inches in length. The blade bifurcates at its junetion with the footstalk, and twice or thrice afterwards, curling about in an irregular manner. It is nalrow, being only $\frac{3}{20}$ of an inch in breadth. One blade was $7 \frac{1}{2}$ inehes long, so that the entire leaf, including the footstalk, was above 27 inches in length. Both surfaces are slightly hollowed out. The upper surface is eovered with tentacles arranged in alternate rows; those in the middle being short and crowded together, those towards the margins longer, even twice or thrice as long as the blade is broad. The glands of the exterior tentaeles are of a much darker red than those of the central ones. The pedicels of all are green. The apex of the blade is attenuated, and bears very long tentacles. Mr. Copland informs me that the leaves of a plant which he kept for some years were generally covered with captured insects before they withered.

The leaves do not differ in essential points of structure or of funetion from those of the previously deseribed specics. Bits of meat or a little saliva placed on the glands of the exterior tentacles caused well-marked movement in $3 \mathrm{~m}$., and particles of glass aeted in $4 \mathrm{~m}$. The tentaeles with the latter particles re-expanded after 22 hrs. A piece of leaf immersed in a few drops of a solution of one part of carbonate of ammonia to 437 of water had all the glands blackened and all the tentacles infleeted in $5 \mathrm{~m}$. A bit of raw meat, plaeed on several glands in the medial furrow, was well clasped in 2 hrs. $10 \mathrm{~m}$. by the marginal tentaeles on both sides. Bits of roast meat and small flies did not aet quite so quickly; and albumen and fibrin still less quickly. One of the bits of meat excited so mich secretion (which is always acid) that it flowed some way down the medial furrow, causing the inflection of the tentacles on both sides as far as it extended. Particles of glass placed on the glands in the medial furrow did not stimulate them sufficiently for any motor impulse to be sent to the outer tentaeles. In no case was the blade of the leaf, even the attenuated apex, at all infleeted.

On both the upper and lower surfaee of the blado there are numerous minute, almost sessile glands, consisting of four, eight, or twelve eells. On the lower surfaee they are pale purple, on the upper greenish. Nearly similar organs occur on the footstalks, but they aro smaller and often in a shrivelled condition. The minute slands on the blade ean absorb rapidly: thus, a pieee of leaf was immersed in a solution of one part of carbonate 
of ammonia to 218 of water ( $1 \mathrm{gr}$. to $2 \mathrm{oz}$.), and in $5 \mathrm{~m}$. they were all so mueh darkened as to be almost blaek, with their eontents aggregated. They do not, as far as I eould observe, secrete spontaneously; but in between 2 and 3 hrs. after a leaf had been rubbed with a bit of raw meat moistened with saliva, they seemed to be seereting freely; and this eonelusion was afterwards supported by other appearanees. They are, therefore, homologous with the sessile glands hereafter to be described on the leaves of Dionæa and Drosophyllum. In this latter genus they are assoeiated, as in the present ease, with glands which seerete spontaneously, that is, without being exeited.

Drosera binata presents another and more remarkable peeuliarity, namely, the presenee of a few tentaeles on the backs of the leaves, near their margins. These are perfeet in strueture; spiral vessels run up their peclieels; their glands are surrounded by drops of viseid seeretion, and they have the power of absorbing. This latter faet was shown by the glands immediately beeoming blaek, and the protoplasm aggregated, when a leaf was plaeed in a little solution of one part of earbonate of ammonia to 437 of water. These dorsal tentacles are short, not being nearly so long as the marginal ones on the upper surface; some of them are so short as almost to graduate into the minute sessile glands. Their presenee, number', and size, vary on different leaves, and they are arranged rather irregularly. On the back of one leaf I eounted as many as twentyone along one sicle.

These dorsal tentacles differ in one important respeet from those on the upper surfaee, namely, in not possessing any power of movement, in whatever manner they may be stimulated. Thus, portions of four leaves were plaeed at different times in solutions of earbonate of ammonia (one part to 437 or 218 of water), and all the tentaeles on the upper surface soon beenme elosely infleeted; but the dorsal ones did not move, though the leaves were left in the solution for many hours, and though their glands from their blackened eolour had obviously absorbed some of the salt. Rather young leaves should be seleeted for sueh trials, for the dorsal tentaeles, as they grow old and begin to wither, often spontancously ineline towards the middle of the leaf. If these tentreles had possessed the power of movement, they would not have been thus rendered more servieeable to the plant; for they are not long enough to bend round the margin of the leaf so as to reach an inseet eaught on the upper surface, Nor would it have been of any use if these tentaeles eould have 
moved towards the middle of the lower surfaee, for there are no viseid glands there by whieh inseets ean be eaught. Although they have no power of movement, they are probably of some use by absorbing animal matter from any minute inseet which may be eaught by them, and by absorbing ammonia from the rain-water. But their varying presenee and size, and their irregular position, indieate that they are not of mueh serviee, and that they are tending towards abortion. In a future ehapter we shall see that Drosophyllum, with its elongated leaves, probably represents the eondition of an early progenitor of the genus Drosera; and none of the tentaeles of Drosophyllum, neither those on the upper nor lower surfaee of the leaves, are eapable of movement when exeited, though they eapture numerous inseets, which serve as nutriment. Therefore it seems that Iroserce binate has retained remuants of eertain aneestral charaetersnamely a few motionless tentaeles on the baeks of the leares, and fairly well developed sessile glands-whieh have been lost by most or all of the other speeies of the genus.

Concluding Remarks.-From what we have now seen, there can be little doubt that most or probably all the species of Drosera are adapted for catching insects by nearly the same means. Besides the two Australian species above described, it is said* that two other species from this country, namely Drosera pallida and Drosera sulphurea, "close their leaves upon insects with "great rapidity: and the same phenomenon is mani"fested by an Indian species, D. Iunata, and by sereral " of those of the Cape of Good Hope, especially by "D. trinervis." Another Australian species, Droser"a heterophylla (made by Lindley into a distinct genus, Sondera) is remarkable from its peculiarly shaped leaves, but I know nothing of its power of catching insects, for I have seen only dried specimens. The leaves form minute flattened cups, with the footstalks attached not to one margin, but to the bottom. The

* 'Gardener's Chronicle,' 1874, p. 209. 
inner surface and the edges of the cups are studded with tentacles, which include fibro-vaseular bundles, rather different from those secn by me in any other species; for some of the vessels are barred and punctured, instcad of being spiral. The glands scerete copiously, judging from the quantity of dried secretion adhering to them. 


\section{CHAPTER XIII.}

\section{DION ZEA MITSUIPULA.}

Structure of the leaves-Sensitiveness of the filaments - Rapid movement of the lobes eaused by irritation of the filaments Glands, their power of sccretion - Slow movement caused by the absorption of animal matter-Evidenee of absorption from the aggregated eondition of the glands - Digestive power of the secretion - Action of ehloroform, ether, and hydrocyanic aeid - The manner in which inseets are captured-Use of the inarginal spikes-Kinds of inscets captured-The transinission of the motnr impulse and meehanism of the movements - Re-expansion of the lobes.

THIs plant, commonly called Venus' fly-trap, from the rapidity and force of its movements, is one of the most wonderful in the world.* It is a member of the small family of the Droseracer, and is found only in the eastern part of North Carolina, growing in damp situations. The roots are small; those of a moderately fine plant which I examined consisted of two branehes about 1 inch in length, springing from a bulbous enlargement. They probably serve, as in the case of Drosera, solely for the absorption of water; for a gardener, who has been very successful in the eultivation of this plant, grows it, like an epiphytic orchid, in well-drained damp moss without any soil.t The form of the bilobed leaf, with its foliaceous footstalk, is shown in the accompanying drawing (fig. 12).

* Dr. Hooker, in his address to tho British Association at Belfast, 1874 , has given so full an historical aceount of the observatious which havo been published on the habits of this plant, that it would be superfluous on my part to repent them.

† 'Gardenor's Chroniele,' 1sit, p. 164. 
The two lobes stand at rather less than a right angle to each other. Threc minute pointed processes or filaments, placed triangularly, project from the upper surfaces of both; but I have sccn two leaves with four filaments on each side, and another with only two. These filaments are remarkable from their extreme sensitiveness to a touch, as shown not by their own movement, but by that of the lobes. The margins of the leaf are prolonged into sharp rigid projections which I will call spikes, into cach of which a bundle

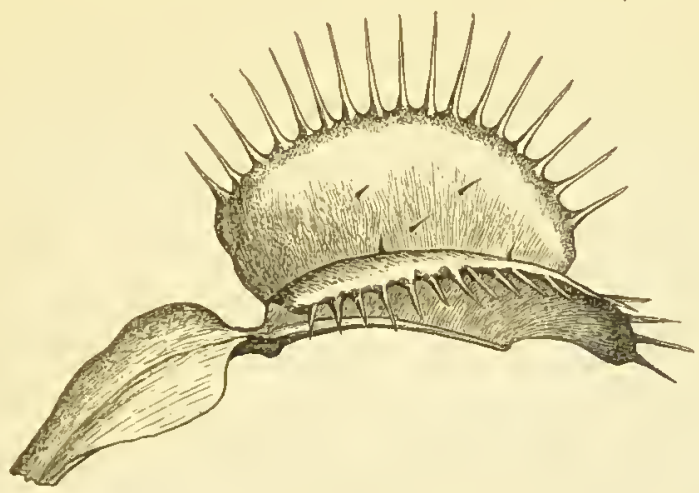

Fig. 12.

(Dionaa muscipula.)

Leaf viewed laterally in its expanded state.

of spiral vessels enters. The spikes stand in such a position that, when the lobes close, they inter-loek like the teeth of a rat-trap. The midrib of the leaf, on the lower side, is strongly developed and prominent.

The upper surface of the lcaf is thickly covered, excepting towards the margins, with minute glands of a reddish or purplish colour, the rest of the leaf bcing green. There are no glands on the spikes, or on the folinecous footstalk. 'The glands are formed of from 
twenty to thirty polygonal eells, filled with purple fluid. Their upper surfaee is eonvex. They stand on very short pedieels, into whieh spiral vessels do not enter, in whieh respeet they differ from the tentaeles of Drosera. They seerete, but only when exeited by the absorption of eertain matters; and they have the power of absorption. Minute projections, formed of eight divergent arms of a reddish-brown or orange colour, and appearing under the mieroseope like elegant little flowers, are seattered in eonsiderable numbers over the foot-stalk, the baeks of the leares, and the spikes, with a few on the upper surfaee of the lobes. These oetofid projeetions are no doubt homologous with the papilla on the leaves of Drosera rotundifolia. There are also a few very minute, simple, pointed hairs, about $\frac{7}{12000}(.0148 \mathrm{~mm}$.) of an ineh in length on the baeks of the leares.

The sensitive filaments are formed of several rows of elongated cells, filled with purplish fluid. They are a little above the $\frac{1}{20}$ of an ineh in length; are thin and delieate, and taper to a point. I examined the bases of several, making seetions of them, but no traee of the entranee of any ressel eould be seen. The apex is sometimes bifid or even trifid, owing to a slight separation between the terminal pointed eells. Towards the base there is eonstrietion, formed of broader eells, beneath whieh there is an artieulation, supported on an enlarged base, eonsisting of differently shaped polygonal cells. As the filaments projeet at right angles to the surfaee of the leaf, they would have been liable to be broken whenever the lobes elosed together, had it not been for the artieulation whieh allors them to bend flat down.

These filaments, from their tips to their bases, are exquisitely sensitive to a momentary toncle. It is scireely 
possible to touch them ever so lightly or quickly with any hard object without causing the lobes to close. A piece of very delicate human hair, $2 \frac{1}{2}$ inches in length, held dangling over a filament, and swayed to and firo so as to touch it, did not excite any movement. But when a rather thick cotton thread of the same length was similarly swayed, the lobes closed. Pinches of fine wheaten flour, dropped from a height, produced no effect. The above-mentioned hair was then fixed into a handle, and cut off so that 1 inch projected; this length being sufficiently rigid to support itself in a nearly horizontal line. The extremity was then brought by a slow movement laterally into contact with the tip of a filament, and the leaf instantly closed. On another occasion two or three touches of the same lind were necessary before any movement ensued. When we consider how flexible a fine hair is, we may form some idea how slight must be the touch given by the extremity of a piece, 1 inch in length, moved slowly.

Although these filaments are so sensitive to a momentary and delicate touch, they are far less sensitive than the glands of Drosera to prolonged pressure. Several times I succeeded in placing on the tip of a filament, by the aid of a needle moved with extreme slowness, bits of rather thick human hair, and these did not excite movement, although they were more than ten times as long as those which caused the tentacles of Drosera to bend; and although in this latter case they were largely supported by the dense secretion. On the other hand, the glands of Drosera may be struck with a needle or any hard object, once, twice, or even thrice, with considerable force, and no movement ensues. 'I'his singular difference in the nature of the sensitiveness of the filaments of Dionsa and of 
the glands of Drosera evidently stands in relation to the habits of the two plants. If a minute inseet alights with its delieate feet on the glands of Drosera, it is eaught by the viseid seeretion, and the slight, though prolonged pressure, gives notiee of the presenee of prey, whieh is seeured by the slow bending of the tentaeles. On the other hand, the sensitive filaments of Dionæa are not viscid, and the capture of insects can be assured only by their sensitiveness to a momentary toueh, followed by the rapid closure of the lobes.

As just stated, the filaments are not glandular, and do not seerete. Nor have they the power of absorption, as may be inferred from drops of a solution of earbonate of ammonia (one part to 146 of water), plaeed on two filaments, not produeing any effeet on the eontents of their eells, nor eausing the lobes to elose. When, however, a small portion of a leaf with an attaehed filament was cut off and immersed in the same solution, the fluid within the basal cells beeame almost instantly aggregated into purplish or eolourless, irregularly shaped masses of matter. The proeess of aggregation gradually travelled up the filaments from eell to cell to their extremities, that is in a reverse course to what oeeurs in the tentaeles of Drosera when their glands have been excited. Several other filaments were eut off elose to their bases, and left for $1 \mathrm{hr}$. $30 \mathrm{~m}$. in a weaker solution of one part of the earbonate to 218 of water, and this caused aggregation in all the eells, commeneing as before at the bases of the filaments.

Long immersion of the filaments in distilled water likewise eauses aggregation. Nor is it rare to find the eontents of a few of the terminal cells in a spontaneonsly aggregated condition. The aggregated 
masses undergo ineessant slow changes of form, uniting and again separating; and some of them apparently revolve round their own axes. A current of eolourless gramular protoplasm eould also be seen travelling round the walls of the cells. This current ceases to be risible as soon as the contents are well aggregated; but it probably still eontinues, though no louger visible, owing to all the granules in the flowing layer having beeome united with the eentral masses. In all these respeets the filaments of Dionæa behave exaetly like the tentacles of Drosera.

Notwithstanding this similarity there is one remarkable differenee. The tcntacles of Drosera, after their glands have been repeatedly touehed, or a partiele of any kind has been placed on them, become infleeted and strongly aggregated. No such effeet is produced by touching the filaments of Dionza; I compared, after an hour or two, some whieh had been touehed and some which had not, and others after twenty-five hours, and there was 110 differenee in the eontents of the cells. The leares were kept open all the time by elips; so that the filaments were not pressed against the opposite lobe.

Drops of water, or a thin broken stream, falling from a height on the filaments, did not eause the blades to elose; though these filaments were afterwards proved to be highly sensitive. No doubt, as in the ease of Drosera, the plant is indifferent to the heaviest shower of rain. Drops of a solution of a half an ounee of sugar to a fluid ounee of water werc repeatedly allowed to fall from a lieight on the filaments, but prodiseed no effect, unless they adhered to them. Again, I blew many times through a fine pointed tube with my utmost force against the filaments without any effeet; such blowing being reeeived 
with as mueh indifferenee as no doubt is a heary gale of wind. We thus see that the sensitiveness of the filaments is of a speeialised nature, being related to a momentary toueh rather than to prolonged pressure; and the toueh must not be from fluids, sueh as air or water, but from some solid objeet.

Although drops of water and of a moderately strong solution of sugar, falling on the filaments, does not exeite them, yet the immersion of a leaf in pure water sometimes eaused the lobes to elose. One leaf was left immersed for $1 \mathrm{hr} .10 \mathrm{~m}$., and three other leaves for some minutes, in water at temperatures varying between $59^{\circ}$ and $65^{\circ}\left(15^{\circ}\right.$ to $18^{\circ} \cdot 3$ Cent.) without any effeet. One, however, of these four leaves, on being gently withdrawn from the water, elosed rather quickly. The three other leaves were proved to be in good eondition, as they elosed when their filaments were touehed. Nevertheless two fresh leaves on being dipped into water at $75^{\circ}$ and $62 \frac{1}{2}^{\circ}\left(23^{\circ} .8\right.$ and $16^{\circ} .9$ Cent.) instantly closed. These were then plaeed with their footstallks in water, and after 23 hrs. partially re-expanded; on touehing their filaments one of them elosed. This latter leaf after an additional 24 hrs. again re-expanded, and now, on the filaments of both leaves being touehed, both elosed. We thus see that a short immersion in water does not at all injure the leaves, but sometimes exeites the lobes to elose. The movement in the above eases was evidently not eaused by the temperature of the water. It has been shown that long immersion eauses the purple fluid within the eells of the sensitive filaments to beeome aggregated; and the tentaeles of Drosera are aeted on in the same mamner by long immersion, often being somewhat infleeted. In both eases the result is probably due to a slight degree of exosmose. 
I am confirmed in this belief by the effects of immersing a leaf of Dionea in a moderately strong solution of sugar; the leaf having been previously left for $1 \mathrm{hr} .10 \mathrm{~m}$. in water without any effect; for now the lobes closed rather quickly, the tips of the marginal spikes crossing in $2 \mathrm{~m} .30$ s., and the leaf being completely shut in $3 \mathrm{~m}$. Three leaves were then immersed in a solution of half an ounce of sugar to a fluid ounce of water, and all threc leaves closed quickly. As I was doubtful whether this was due to the cells on the upper surface of the lobes, or to the sensitive filaments, being acted on by exosmose, one leaf was first tried by pouring a little of the same solution in the furrow between the lobes over the midrib, which is the chief seat of movement. It was left there for some time, but no movement ensued. The whole upper surface of leaf was then painted (except close round the bases of the sensitive filaments, which I could not do without risk of touching them) with the same solution, but no effect was produced. So that the cells on the upper surface are not thus affected. But when, after many trials, I succeeded in getting a drop of the solution to cling to one of the filaments, the leaf quickly closed. Hence we may, I think, conclude that the solution causes fluid to pass out of the delicate cells of the filaments by exosmose; and that this sets up some molecular change in their contents, analogous to that which must be produced by a touch.

The immersion of leaves in a solution of sugar affects them for a much longer time than does an immersion in water, or a touch on the filaments; for in these latter cases the loles begin to re-expand in less than a day. On the other hand, of the three leaves which were immersed for a short time in the solution, and were then washed by means of a syringe inserted 
between the lobes, one re-expanded after tro days; a seeond after seven clays; and the third after nine days. The leaf which closed, owing to a drop of the solution having adhered to one of the filaments, opened after two days.

I was surprised to find on two occasions that the heat from the rays of the sun, eoncentrated by a lens on the bases of several filaments, so that they were scorched and discoloured, did not cause any movement; though the leaves were active, as they closed, though rather slowly, when a filament on the opposite side was touched. On a third trial, a fresh leaf closed after a time, though very slowly; the rate not being increased by one of the filaments, which had not been injured, being touched. After a day these three leaves opened, and were fairly sensitive when the uninjured filaments were touched. The sudden immersion of a leaf into boiling water does not cause it to close. Judging from the analogy of Drosera, the heat in these several cases was too great and too suddenly applied. The surface of the blade is very slightly sensitive; it may be freely and roughly handled, without any movement being eaused. A leaf was scratched rather hard with a needle, but did not close; but when the triangular spaee between the three filaments on another leaf was similarly scratched, the lobes closed. They always closed when the blade or midrib was deeply pricked or eut. Inorganie bodies, even of large size, such as bits of stone, glass, \&e.-or organic bodies not eontaining soluble nitrogenous matter, sueh as bits of wood, eork, moss, - or bodies eontaining soluble nitrogenous matter, if perfectly dry, snch as bits of meat, albumen, gelatine, se., may be long left (and many were tried) on the lobes, and no movement is exeited. The result, however, is widely different, as we 
shall presently see, if nitrogenous organie bodies which are at all dump, are left on the lobes; for these then close by a slow and gradual movement, very different from that caused by touching one of the sensitive filaments. The footstalk is not in the least sensitive; a pin may be driven through it, or it may be cut off, and no movement follows.

The upper surfaee of the lobes, as already stated, is thickly eovered with small purplish, almost sessile glands. These have the power both of secretion and absorption; but unlike those of Drosera, they do not seerete until exeited by the absorption of nitrogenous matter. No other exeitement, as far as I have seen, produees this effect. Objects, such as bits of wood, cork, moss, paper, stone, or glass, may be left for a length of time on the surfaee of a leaf, and it remains quite dry. Nor does it make any differenee if the lobes elose over sueh objeets. For instanee, some little balls of blotting paper were placed on a leaf, and a filament was touehed; and when after $24 \mathrm{hrs}$. the lobes began to re-open, the balls were removed by the aid of thin pineers, and were found perfeetly dry. On the other hand, if a bit of damp meat or a crushed fly is plaeed on the surfaee of an expanded leaf, the glands after a time seerete freely. In one sueh ease there was a little secretion direetly beneath the meat in 4 hrs.; and after an additional 3 hrs. there was a considerable quantity both under and close round it. In another case, after 3 hrs. $40 \mathrm{~m}$., the bit of meat was quite wet. But none of the glands secreted, exeepting those which aetually tonched the meat or the seeretion eontaining dissolved animal matter.

If, however, the lobes are marle to elose over a bit of meat or an insect, the result is different, for the glands over the whole surfaec of the leaf now seerete copiously. 
As in this ease the glands on both sides are pressed against the meat or inseet, the seeretion from the first is twice as great as when a bit of meat is laid on the surface of one lobe; and as the two lobes eome into almost elose eontaet, the seeretion, eontaining dissolved animal matter, spreads by eapillary attraction, eausing fresh glands on both sides to begin seereting in a continually widening eirele. The seeretion is almost eolourless, slightly mueilaginous, and, judging by the manner in which it eoloured litmus paper, more strongly aeid than that of Drosera. It is so eopious that on one oeeasion, when a leaf was eut open, on whieh a small eube of albumen had been plaeed 45 hrs. before, drops rolled off the leaf. On another oeeasion, in whieh a leaf with an enelosed bit of roast meat spontaneously opened after eight days, there was so mueh seeretion in the furrow over the midrib that it triekled down. A large erushed fly (Tipula) was plaeed on a leaf from whieh a small portion at the base of one lobe had previously been eut away, so that an opening was left; and through this, the seeretion eontinued to run down the footstalk during nine days, - that is, for as long a time as it was observed. By foreing up one of the lobes, I was able to see some distanee between them, and all the glands within sight were secreting freely.

We have seen that inorganie and non-nitrogenous objeets plaeed on the leaves do not exeite any movement; but nitrogenous bodies, if in the least degree damp, eause after several hours the lobes to close slowly. Thus bits of quite dry meat and gelatine were plizeed at opposite ends of the sime leaf, and in the eourse of 24 hrs. exeited neither seeretion nor morement. They were then dipped in water, their surfaces dried on blotting paper, and replaeed on the same 
lcaf, the plant being now eovered with a bell-glass. After 24 hrs. the damp meat had cxeited some acid secretion, and the lobes at this end of the leaf were almost shut. At the other end, where the damp gelatine lay, the leaf was still quite open, nor had any secretion becn excitcl; so that, as with Drosera, gelatine is not nearly so exeiting a substanee as meat. The secretion beneath the meat was tested by pushing a strip of litmus paper under it (the filaments not being touched), and this slight stimulus eaused the leaf to shut. On the eleventh day it reopened; but the end where the gelatine lay, cxpanded several hours before the opposite end with the meat.

A second bit of roast meat, whieh appearcd dry, though it had not been purposely dried, was left for 24 hrs. on a leaf, eaused ncither movement nor secretion. The plant in its pot was now covered with a bell-glass, and the meat absorbed some moisture from the air; this suffieed to excite aeid seeretion, and by the next morning the leaf was closely shut. A third bit of meat, dried so as to be quite brittle, was plaeed on a leaf under a bell-glass, and this also became in $24 \mathrm{hrs}$. slightly damp, and excited some aeid seeretion, but no movement.

A rather large pieee of perfeetly dry albumen was left at one end of a leaf for 24 hr's. without any effect. It was then soaked for a few minutes in water, rolled about on blotting paper, and replaeed on the leaf; in 9 hrs. some slightly aeid seeretion was excited, and in $24 \mathrm{hrs}$. this end of the leaf ras partially elosed. The bit of albumen, which was now surrounded by much seeretion, was gently removed, and although no filament was touehed, the lobes closed. In this and the previous case, it appears that the absorption of animal matter by the glands renders 
the surface of the leaf much morc sensitive to a touch than it is in its ordinary state; and this is a curious fact. Two days afterwards the end of the leaf where nothing had been placed began to open, and on the third day was much more open than the opposite end where the albumen had lain.

Lastly, large drops of a solution of one part of carbonate of ammonia to 146 of water were placed on some leaves, but no immediate movement ensued. I did not then know of the slow movement caused by animal matter, otherwise I should have observed the leaves for a longer time, and they would probably have becn found closed, though the solution (judging from Drosera) was, perhaps, too strong.

From the foregoing cases it is certain that bits of meat and albumen, if at all damp, excite not only the glands to secretc, but the lobes to close. This movement is widely different from the rapid closure cansed by one of the filaments being touched. We shall see its importance when we treat of the manner in which insects are captured. There is a great contrast between Drosera and Dionæa in the effects produced by mechanical irritation on the one hand, and the absorption of animal matter on the other. Particles of glass placed on the glands of the extcrior tentacles of Drosera excite movement within nearly the same time, as do particles of meat, the latter being rather the most efficient; but when the glands of the disc have bits of meat given them, thcy transmit a motor impulse to the exterior tentacles much more quickly than do these glands when bearing inorganic particles, or when irritated by repeated tonches. On the other hand, with Dionæa, touching the filaments excites incomparably quicker movement than the absorption of animal matter by the glands. Nevertheless, in 
certain cases, this latter stimulus is the more powerful of the two. On three occasions leaves wcre found which from some cause werc torpid, so that thcir lobes closed only slightly, however mueh their filaments wcre irritated; but on inscrting crushed insccts betwecn the lobes, they beeamc in a day closely shut.

The faets just given plainly show that the glands have the power of absorption, for otherwise it is impossible that the leaves should be so differently affected by non-nitrogenous and nitrogenous bodies, and between these latter in a dry and damp condition. It is surprising how slightly damp a bit of meat or albumen need be in order to excite secretion and afterwards slow movement, and equally surprising how minute a quantity of animal matter, when absorbed, suffices to produce these two effeets. It seems hardly credible, and yet it is eertainly a faet, that a bit of hard-boiled white of egg, first thoroughly dried, then soakcd for some minutes in water and rolled on blotting paper, should yield in a few hours enough animal mattcr to the glands to cause them to seercte, and afterwards the lobes to close. That the glands have the power of absorption is likcwise shown by the very different lengths of time (as we shall presently sec) during which the lobes remain elosed over inscets and other bodics yielding soluble nitrogenous matter, and over sueh as do not yicld any. But there is dircet evidence of absorption in the condition of the glands which have remaincd for some time in contact with animal matter. Thus bits of meat and crushed insects were scveral times placed on glands, and these werc compared after some hours with other glands from distant parts of the same leaf. The latter showed not a trace of aggregation, whereas those which had been in contact with the animal matter were 
well aggregated. Aggregation may be seen to occur very quickly if a piece of a leaf is immersed in a weak solution of earbonate of ammonia. Agrain, small cubes of albumen and gelatine were left for eight days on a leaf, which was then cut open. The whole surface was bathed with acid secretion, and every eell in the many glands which were examined had its contents aggregated in a beautiful manner into clark or pale purple, or colourless globular masses of protoplasm. These underwent incessant slow changes of forms; sometimes separating from one another and then reuniting, exactly as in the cells of Drosera. Boiling water makes the contents of the gland-cells white and opaque, but not so purely white and porcelain-like as in the case of Drosera. How living insects, when naturally caught, excite the glands to secrete so quickly as they do, I know not; but I suppose that the great pressure to which they are subjected forces a little excretion from either extremity of their bodies, and we have seen that an extremely small amount of nitrogenous matter is suffieient to exeite the glands.

Before passing on to the subject of digestion, I may state that I endeavoured to discover, with no suceess, the functions of the minute octofid processes with which the leaves are studded. From faets hereafter to be given in the chapters on Aldrovanda and Utricularia, it seemed probable that they served to absorb deeayed matter left by the captured inseets; but their position on the backs of the leares and on the footstalks rendered this almost impossible. Nevertheless, leaves were immersed in a solution of one part of urea to 437 of water, and after 24 hrs. the orange layer of protoplasm within the arms of these processes did not appear more aggregated than in other speci- 
mens kept in water. I then tried suspending a leaf in a bottle over an excessively putrid infusion of raw meat, to see whether they absorbed the vapour, but their contents were not affected.

Digestive Power of the Secretion.*-When a leaf closes over any object, it may be said to form itself into a temporary stomach; and if the object yields ever so little animal matter, this serves, to use Schiff's expression, as a peptogene, and the glands on the surface pour forth their acid secretion, which acts like the gastric juice of animals. As so many experiments were tried on the digestive power of Drosera, only a few were made with Dionrea, but they were amply sufficient to prove that it digests. This plant, moreover, is not so well fitted as Drosera for observation, as the process goes on within the closed lobes. Insects, even beetles, after being subjected to the secretion for several days, are surprisingly softened, though their chitinous coats are not corroded.

Esperiment 1.-A cube of albumen of $\frac{1}{10}$ of an inch (2.544 $\mathrm{mm}$.) was placed at one end of a leaf, and at the other end an oblong piece of gelatine, $\frac{1}{5}$ of an inch $(5.08 \mathrm{~mm}$.) long, and

* Dr. W. Mr. Canby, of Wilmington, to whom I am mueh indebterl for information regarding Dionsen in its native home, lins published in the 'Gardener's Monthly, Plilarlelphia, August 1868 , some interesting observations. II aseertained that the seeretion digests animal matter, such as the eontents of inseets, bits of meat, \&c.; and that the seeretion is reabsorlued. He was also well awaro that the lobes remain eloserl for a mueh longer time when in enotact with nnimal matter than when made to shut by a mere touch, or over objects not yielding soluble nutriment; and that in these latter enses the glands do not seerete. 'The Riev. Dr. Curtis first observed ('Boston Journal Nat. Hist.' vol. i. p. 123) the seeretion from the glands. I mny here add thnt a gardener, Mr. Knight, is said (Kirby and Speneer's 'Introduetion to Entomology,' 1818, vol. i. p. 295) to have found that a plant of the Jionsen, on the lenves of whieh "he laid fine filaments of raw beef, was mueh more luxuriunt in its growth than others not so treated." 
$\frac{1}{10}$ broad; the leaf was then made to elose. It was eut open after $45^{\circ}$ hrs. The albumen was hard and eompressed, witl its angles only a little rounded; the gelatine was corroded into an oval form; and both were bathed in so mueh aeid secretion that it dropped off the leaf. The digestive proeess apparently is rather slower than in Drosera, and this agrees with the length of time during whieh the leaves remain elosed over digestible objeets.

Experiment 2.-A bit of albumen $\frac{1}{10}$ of an ineh square, but only $\frac{1}{20}$ in thickness, and a piece of gelatine" of the same size as before, were plaeed on a leaf, whieh eight days afterwards was eut open. The surface was bathed with slightly adhesive, very acid seeretion, and the glands were all in an aggregated condition. Not a vestige of the albumen or gelatine was left. Similarly sized pieees were plaeed at the same time on wet moss on the same pot, so that they were subjeeted to nearly similar conditions ; after eight days these were brown, deeayed, and matted with fibres of mould, but had not disappeared.

Experiment 3.-A piece of albumen $\frac{3}{20}$ of an ineh $(3.81 \mathrm{~mm}$.) long, and $\frac{1}{20}$ broad and thiek, and a pieee of gelatine of the same size as before, were placed on another leaf, whieh was eut open after seven days; not a vestige of either substanee was left, and only a moderate amount of seeretion on the surface.

Experiment 4.--Pieces of albumen and gelatine, of the same size as in the last experiment, were placed on a leaf, whieh spontaneously opened after twelve days, and here again not a vestige of either was left, and only a little secretion at one end of the midrib.

Experiment 5.-Pieces of albumen and gelatine of the same. size were plaeed on another leaf, whieh after twelve days was still firmly elosed, but had begun to wither; it was ent open, and eontained notbing except a vestige of brown matter where the albumen had lain.

Experiment 6.-A eube of albumen of $\frac{1}{10}$ of an ineh and a piece of gelatine of the same size as before were plaeed on a leaf, whieh opened spontaneously after thirteen days. The albumen, which was twiee as thiek as in the latter experiments, was too large; for the glands in eontact with it were injured and were dropping off; a film also of albumen of a brown colour, matted with mould, was left. All the gelatine was absorbed, and there was only a little acid seeretion left on the midrilo.

Experiment 7.-A bit of half roasted ment (not measured) and a bit of gelatine were placed on the two ends of a leaf', whiel 
opened spontaneously after eleven days; a vestige of the meat was left, and the surfaec of the leaf was here blackened; tho gelatine had all disappeared.

Experiment 8.-A bit of half roasted meat (not measured) was plaeed on a leaf whieh was foreibly kept open by a elip, so that it was moistened with the seeretion (very aeid) only on its lower surfaee, Nevertheless, after only $22 \frac{1}{2}$ hr's. it was surprisingly softened, when compared with another bit of the same meat which had been kept damp.

Experiment 9.-A eube of $\frac{\lambda}{10}$ of an inch of very eompaet roasted beef was placed on a leaf, whieh opened spontaneously after trvelve days; so mueh feebly aeid secretion was left on the leaf that it triekled off. The meat was eompletely disintegrated, but not all dissolved; there was no mould. The little mass was plaeed under the mieroseope; some of the fibrilla in the middle still exhibited transverse striæ; other's showed not a vestige of strix; and every gradation could be traeed between these two states. Globules, apparently of fat, and some undigested fibro-elastie tissuc remained. The meat was thus in the same state as that formerly described, which was half digested by Drosera. Here, again, as in the case of albumen, the digestive process seems slower than in Drosera. At the opposite end of the same leaf, a firmly eompresscd pellet of bread had been plaeed; this was eompletely disintegrated, I suppose, owing to the digestion of the gluten, but seemed very little reduced in bulk.

Lxperiment 10.-A eube of $\frac{1}{20}$ of an ineh of eheese and another of albumen were plaeed at opposite ends of the same leaf. After nine days the lobes opcned spontaneously a little at the end enclosing the eheese, but hardly any or none was dissolved, though it was softened and surrounded by seeretion. Two days subsequently the end with the albumen also opened spontancously (i.e. eleven days after it was put on), a mere traee in a blackened and dry eondition being left.

Experiment 11.-The same experiment with eheese and albumen repeated on another and rather torpid leaf. The lobes at the end with the eheese, after an interval of six days, opcned spontaneously a littlc; the eubo of checse was much softened, but not dissolved, and but little, if at all, reduced in size. Twelve hours afterwards the end with the albumen opened, which now eonsisted of a large drop of transparent, not acid, viseid fluid.

Experiment 12.-Same experiment as the two last, and hero again the leaf at the end enelosing the eheeso opened before the 
opposite end with the albumen; but no further observations were made.

Experiment 13.-A glohule of chemically prepared easein, about $\frac{1}{10}$ of an inch in diameter, was placed on a leaf, whieh spontaneously opened after eight days. The easein now consisted of a soft stieky mass, very little, if at all, reduced in size, but bathed in aeid seeretion.

These experiments are suffieient to show that the seeretion from the glands of Dionxa dissolves albumen, gelatine, and meat, if too large piees are not given. Globules of fat and fibro-elastie tissue are not digested. The secretion, with its dissolved matter, if not in exeess, is subsequently absorbed. On the other hand, although ehemieally prepared easein and cheese (as in the ease of Drosera) exeite mueh aeid seeretion, owing, I presume, to the absorption of some ineluded albuminous matter, these substances are not digested, and are not appreciably, if at all, reduced in bulk.

Effects of the Vapours rif Chloroform, Sulphuric Ether, and Hydrocyanie Acid.-A plant bearing one leaf was introdueed into a large bottle with a draehm $(3.549 \mathrm{ml}$.) of chloroform, the mouth being imperfectly elosed with eotton-wool. The vapour caused in $1 \mathrm{~m}$. the lobes to begin moving at an imperceptibly slow rate; but in $3 \mathrm{~m}$. the spikes crossed, and the leaf was soon completely shut. The dose, however, was mueh too large, for in between 2 and 3 hrs. the leaf appeared as if burnt, and soon died.

Two leaves were exposed for $30 \mathrm{~m}$. in a 2-oz. vessel to the vapour of 30 minims $(1.774 \mathrm{ml}$.) of sulphurie ether. One leaf closed after a time, as did the other whilst being removed from the vessel without being touched. Both leaves wero grently injured. Another leaf, exposed for $20 \mathrm{~m}$. to 15 minims of ether, elosed its lobes to a eertain extent, and the sensitive filaments were now quite insensible. After 24 hrs. this leaf recovered its sensibility, but was still rather torpid. A leaf exposed in a large bottle for only $3 \mathrm{~m}$. to ten drops was rendered insensible. After $52 \mathrm{~m}$. it recovered its sensibility, and when one of the filaments was touched, the lobes closed. It begrm 
to r'eopen after 20 hrs. Lastly another leaf was exposed for $4 \mathrm{in}$. to only four drops of the ether; it was rendered insensiblc, and did not elose when its filaments were repeatedly touehed, but elosed when the end of the open leaf was ent off". This shows: either that the internal parts had not been rendered insensible, or that an ineision is a more powerful stimulus than repeated touches on the filaments. Whether the larger doses of ehloroform and ether, which eaused the leaves to elose slowly, aeted on the sensitive filaments or on the leaf itself, I do not know.

Cyanicle of potassium, when left in a bottle, generates prussic or hydroeyanie aeid. A leaf was exposed for $1 \mathrm{hr}$. $35 \mathrm{~m}$. to the vapour thus formed; and the glands became within this time so colourlcss and shrunken as to be scarccly visible, and I at first thought that they had all dropped off. The leaf was not rendered insensible; for as soon as one of the filaments was touehed it closed. It had, however, suffered, for it did not reopen until nearly two days had passed, and was not even then in the least sensitive. After an additional day it recovered its powers, and elosed on being touehed and subsequently reopened. Another leaf bohaved in nearly the same manner after a shorter exposure to this vapour.

On the Manner in which Insects are caught.-We will now consider the aetion of the leaves when insects happen to touch one of the sensitive filaments. This often occurred in my greenhouse, but I do not know whether insects arc attracted in any spceial way by the lcaves. They are eaught in large numbers by the plant in its native eountry. As soon as a filament is touched, both lobes close with astonishing quickncss; and as they stand at less than a right angle to each. other, they have a good chance of eatching any intruder. The angle betwecn the blade and footstalk does not change when the lobes close. The chicf seat of movement is near the midrib, but is not confiner to this part; for, as the lobes come together, cach curves inwards across its wholc breadth; the marginal spikes however, not becoming curved. This move- 
ment of the whole lobe was well scen in a lcaf to which a large fly had been given, and from which a large portion had been cut off the end of one lobe; so that the oppositc lobe, mecting with no resistance in this part, went on eurving inwards much beyond the medial linc. The whole of the lobe, from which a portion had bcen cut, was afterwards removed, and the opposite lobe now curled eompletely over, passing through an angle of from $120^{\circ}$ to $130^{\circ}$, so as to oeeupy a position almost at right angles to that which it would have held had the opposite lobe bcen present.

From the curving inwards of the two lobes, as they move towards each other, the straight marginal spikes intercross by their tips at first, and ultimately by their bases. The leaf is then completely shut and encloses a shallow cavity. If it has been made to shut merely by one of the sensitive filaments having been touched, or if it includes an objeet not yielding soluble nitrogenous matter, the two lobes retain their inwardly concave form until they re-expand. The re-expansion under these circumstances-that is when no organic matter is enelosed-was observed in ten cases. In all of these, the leaves re-expanded to about two-thirds of the full cxtent in 24 hrs. from the time of closure. Even the leaf from whieh a portion of one lobe had been eut off opcned to a slight degree within this same time. In one case a lcaf re-expanded to about twothirds of the full extent in 7 hrs., and eompletely in 32 hrs.; but one of its filaments had becu touched mcrely with a hair just enough to canse the leaf to elose. Of these ten leaves only a few rc-expanded eomplctely in less than two days, and two or three required cven a little longer time. Beforc, however, they fully re-expand, they are ready to elose 
instantly if their scusitive filaments arc touched. How many times a leaf is capablc of shutting and opening if no animal matter is left enclosed, I do not know; but one leaf was madc to close four times, reopening afterwards, within six days. On the last occasion it caught a fly, and then remained closed for many days.

This power of rcopening quickly aftcr the filaments have been accidentally touched by blades of grass, or by objects blown on the leaf by the wind, as occasionally happens in its native placc, ${ }^{*}$ must be of some importance to the plant; for as long as a leaf remains closed, it cannot of course capture an insect.

When the filaments are irritatcd and a leaf is made to shut over an inscct, a bit of meat, albumcn, gelatinc, casein, and, no doubt, any other substance containing soluble nitrogenous matter, the lobes, instead of remaining concave, thus including a concavity, slowly press closely together throughout thcir whole breadth. As this takcs place, the margins gradually bccome a littlc evcrted, so that the spikes, which at first intercrossed, at last project in two parallcl rows. The lobes press against each othcr with such forcc that I have seen a cubc of albumen much flattcned, with distinct impressions of the little prominent glands; but this latter circumstance may have becn partly caused by the corroding action of the secretion. So firmly do they become pressed together that, if any large inscct or other object has becn caught, a corresponding projection on the outsidc of the leaf is distinctly visible. When the two lobes arc thus completely shut, they

* According to Dr. Curtis, in 'Boston Journal of Nat. Hist.' vol. i. 1837, p. 123. 
resist being opened, as by a thin wedge driven between them, with astonishing foree, and are generally ruptured rather than yield. If not ruptured, they elose again, as Dr. Canby informs me in a letter, "with quite a loud flap." But if the end of a leaf is held firmly between the thumb and finger, or by a elip, so that the lobes eannot begin to close, they exert, whilst in this position, very little foree.

I thought at first that the gradual pressing together of the lobes was eaused exelusively by eaptured inseets erawling over and repeatedly irritating the sensitive filaments; and this view seemed the more probable when I learnt from Dr. Burdon Sanderson that whenever the filaments of a elosed leaf are iritated, the normal eleetrie emrent is disturbed. Nevertheless, sueh irritation is by no means neeessary, for a dead inseet, or a bit of meat, or of albumen, all aet equally well; proving that in these eases it is the absorption of animal matter whieh exeites the lobes slowly to press elose together. We have seen that the absorption of an extremely small quantity of sueh matter also eauses a fully expanded leaf to elose slowly; and this movement is elearly analogous to the slow pressing together of the eoncave lobes. This latter aetion is of high funetional importanee to the plant, for the glands on both sides are thus brought into eontaet with a eaptured inseet, and eonsequently seerete. The seeretion with animal matter in solution is then drawn by eapillary attraetion over the whole surfaee of the leaf, eausing all the glands to seerete and allowing them to absorb the diffused animal matter. The movement, exeited by the absorption of sueh matter, though slow, suffiees for its final purpose, whilst the movement excited by one of the sensitive filaments being tomehed is rapid, and this is indis- 
peusable for the eapturing of inseets. These two movements, exeited by two sueh widely different means, are thus both well adapted, like all the other functions of the plant, for the purposes which they subserve.

There is another wide differenee in the aetion of leaves whieh enelose objeets, sueh as bits of wood, cork, balls of paper, or whieh have had their filaments merely touehed, and those whieh enelose organie bodies yielding soluble nitrogenous matter. In the former ease the leaves, as we have seen, open in under $2 t \mathrm{hrs}$. and are then ready, even before being fully expanded, to shut again. But if they have elosed over nitrogen-yielding bodies, they remain elosely shut for many days; and after re-expanding are torpid, and never aet again, or only after a eonsiderable interval of time. In four instanees, leaves after eatehing insects never reopened, but began to wither, remaining elosed-in one ease for fifteen days over a fly; in a seeond, for twenty-four days, though the fly was small; in a third for twenty-four days over a woodlouse; and in a fourth, for thirty-five days over a large Tipula. In two other eases leaves remained elosed for at least nine days over flies, and for how many more I do not know. It should, however, be ardided that in two instanees in whieh very small insects had been naturally caught the leaf opened as quickly as if nothing had been eaught; and I suppose that this was due to such small inseets not having been erushed or not having excreted any animal matter, so that the glands were not exeited. Small angular bits of albumen and gelatine were placed at both ends of three leaves, two of which remained closed for thirteen and the other for twelve days. 'Two other lenves remained closed over bits of 
meat for eleven days, a third leaf for eight days, and a fourth (but this had been cracked and injured) for only six days. Bits of cheese, or casein, were placed at one end and albumen at the other end of three leaves; and the cnds with the former opened after six, cight, and nime days, whilst the opposite ends opened a little later. None of the above bits of meat, albumen, \&c., exceeded a cube of $\frac{1}{10}$ of an inch $(2.54 \mathrm{~mm}$. $)$ in size, and were sometimes smaller; yet these small portions sufficed to keep the leaves closed for many days. Dr. Canby informs me that lcaves remain shut for a longer time over inseets than over meat; and from what I have seen, I can well believe that this is the case, espeeially if the insects are Jarge.

In all the above cases, and in many others in which leaves remained closed for a long but unknown period over insects naturally caught, they were more or less torpid when they reopened. Generally they were so torpid during many succeeding days that no excitcment of the filaments eaused the least morement. In one instance, however, on the day after a leaf opened which had clasped a fly, it closed with extreme slowness when one of its filaments was touehed; and although no object was left enelosed, it was so torpid that it did not re-open for the second time until 44 hrs. had elapsed. In a seeond case, a' leaf which had expanded after remaining closed for at least nine days over a fly, when greatly irritated, moved one alone of its two lobes, and retained this unusual position for the next two days. A third case offer's the strongest exception which I have observed; a leaf, after remaining clasped for an mnknown time over a fly, opened, and when one of its filaments was touched, closed, though rather slowly. Dr. Cauby, 
who observed in the United States a large number of plants which, altlıough not in their native site, were probably more vigorous than my plants, informs me that he has "several times known vigorous leaves to devour their prey several times; but ordinarily twiee, or, quite often, once was enough to render them unservieeable." Mrs. Treat, who eultivated many plants in New Jersey, also informs me that "several leaves eaught suceessively three inseets each, but most of them were not able to digest the third fly, but dierl in the attempt. Five leaves, however, digested each three flies, and elosed over the fourth, but died soon after the fourth capture. Many leaves did not digest even one large insect." It thus appears that the power of digestion is somewhat limited, and it is certain that leaves always remain elasped for many days over an insect, and do not recover their power of closing again for many subsequent days. In this respeet Dionæa differs from Drosera, whieh catches and digests many inseets after shorter intervals of time.

We are now prepared to understand the use of the marginal spikes, whieh form so eonspicuous a feature in the appearanee of the plant (fig. 12, p. 287), and which at first seemed to me in my ignoranee useless appendages. From the inward eurvature of the lobes as they approaeh each other, the tips of the marginal spikes first intereross, and ultimately their bases. Until the edges of the lobes come into contaet, elongater spaees between the spikes, varying from the $\frac{1}{15}$ to the $\frac{1}{10}$ of an inch (1.693 to $2.54 \mathrm{~mm}$.) in breadth, aeeording to the size of the leaf, are left open. 'Thus an insect, if its body is not thieker than these measurements, can easily eseape between the erosser spikes, when disturbed by the elosing lobes and in- 
creasing darkness; and one of my sons actually saw a small insect thus escaping. A moderately large insect, on the other hand, if it tries to escape between the bars will surely be pushed back again into its horrid prison with closing walls, for the spikes continue to eross more and more until the edges of the lobes come into contact. A very strong insect, however, would be able to free itself, and Mrs. Treat saw this effected by a rose-chafer (Macrodactylus subspinosus) in the United States. Now it would manifestly be a great disadrantage to the plant to waste many days in remaining clasped over a minute insect, and several additional days or weeks in afterwards recovering its sensibility; inasmuch as a minute insect would afford but little nutriment. It would be far better for the plant to wait for a time until a moderately large insect was captured, and to allow all the little ones to escape; and this adrantage is secured by the slowly intercrossing marginal spikes, which act like the large meshes of a fishing-net, allowing the small and useless fry to escape.

As I was anxious to know whether this view was correct-and as it seems a good illustration of how cautious we ought to be in assuming; as I had done with respect to the marginal spikes, that any fully developed structure is useless-I applied to Dr. Canby. He visited the native site of the plant, early in the season, before the leaves had grown to their full size, and sent me fourteen leaves, containing naturally captured inseets. Four of these had eaught rather small insects, viz. three of them ants, and the fourth * rather small fly, but the other ten had all eanght large insects, namely, five elaters, two ehrysomelas, i cureulio, a thick and broad spider, and a scolopendra. Out of these ten inseets, no less than eight 
werc beetles, * and out of the whole fourtecn there was only one, viz. a dipterous insect, which could readily take flight. Drosera, on the other hand, lives chiefly on insects which are good flycrs, espccially Diptera, caught by the aid of its viscid secretion. But what most concerns us is the size of the ten larger insects. 'Theil average length from head to tail was .256 of an inch, the lobes of the leaves being on an average 53 of an inch in length, so that the insects were very nearly half as long as the leaves within which they wcre enclosed. Only a few of these lcaves, therefore, had wasted their powers by capturing small prey, though it is probable that many small insects had crawled over them and bcen caught, but had then escaped through the bars.

The Transmission of the Motor Impulse, and Means of Movement.-It is sufficient to touch any one of the six filaments to cause both lobes to close, these becoming at the same time incurved throughout their whole breadth. The stimulus must therefore radiate in all directions from any one filament. It must also be transmitted with much rapidity across the lcaf, for in all ordinary cases both lobes close simultaneously, as far as the eye can judge. Most physiologists believe that in irritable plants the excitement is transmitted along, or in close conncetion with, the fibrovaseular bundles. In Dionea, the course of these resscls (composed of spiral and ordinary raseular

* Dr. Canby remarks ('Gardener's Montlily, August 1868), "as a gencral thing beetles and insects of that kind, thonerh always lillerl, secm to loe too liardshelled to scrve as foorl, and after a short time ure lejected." I am surprised at this statement, at lenst with respect to such beetles as elaters, for the five which I examined wero in an extremely fragilo and empty condition, as if all thcir internal parts had been mrtially digested. Mrs. Treat informs me that the plants which she cultivated in Now Jersey chiefly caught Diptera. 
tissue) seems at first sight to favour this belief; for they rum up the midrib in a great bundle, sencling off small bundles almost at right angles on eaeh side. These bifureate oeeasionally as they extend towards the margin, and close to the margin small branches from adjoining vessels unite and enter the marginal spikes. At some of these points of union the ressels form eurious loops, like those deseribed under Drosera. A eontinuous zigzag line of vessels thus runs round the whole eireumferenee of the leaf, and in the midrib all the vessels are in elose eontaet; so that all parts of the leaf seem to be brought into some degree of "eommunieation. Nevertheless, the presenee of ressels is not neeessary for the transmission of the motor impulse, for it is transmitted from the tips of the sensitive filaments (these being about the $\frac{1}{20}$ of an ineh in length), into whieh no vessels enter; and - these eould not have been overlooked, as I made thin vertieal seetions of the leaf at the bases of the filaments.

On several oeeasions, slits about the $\frac{1}{T_{0}}$ of an ineh in length were made with a laneet, elose to the bases of the filaments, parallel to the midrib, and, therefore, direetly aeross the eourse of the ressels. These were made sometimes on the inner and sometimes on the outer sides of the filaments; and after several days, when the leaves had reopened, these filaments were touched roughly (for they were always rendered in some degree torpid by the operation), and the lobes then elosed in the ordinary manner, though slowly, and sometimes not until after a considerable interval of time. These eases show that the motor impulse is not transmitted along the vessels, and they further show that there is no neeessity for a direct line of eommunieation from the filament whieh is 
touched towards the midrib and opposite lobe, or towards the onter parts of the same lobe.

Two slits neir each other, both parallel to the midrib, were next marle in the same manner as before, one on each sicle of the base of a filament, on five distinct leares, so that a little slip bearing a filament was eonineeted with the rest of the leaf only at its two ends. 'These slips were nearly of the same size; one was earefully measured ; it was 12 of an ineh ( $3.048 \mathrm{~mm}$.) in length, and 08 of an ineh $(2.032 \mathrm{~mm}$.) in breadth; and in the middle stood the filament. Only one of these slips withered and perished. After the leaf had recovered from the operation, though the slits were still open, the filaments thus cireumstanced were roughly touehed, and both lobes, or one alone, slowly closed. In two instanees tomehing the filament produced no effeet; but when the point of a needle was driven into the slip at the base of the filament, the lobes slowly closed. Now in these cases the impulse must have proeeeded along the slip in a line parallel to the midrib, and then have radiated forth, either from both ends or from one end alone of the slip, over the whole surface of the two lobes.

dgain, two parallel slits, like the former ones, were made, one on each sicle of the base of a filament, at right angles to the midrib. After the leaves (two in number) had recovered, the filaments were roughly touched, and the lobes slowly elosed; and here the impulse must have travelled for a short distance in a line at right angles to the midrib, and then have radiated forth on all sides over both lobes. 'These several cases prove that the motor impulse travels in all directions through the cellular tissue, independently of the conrse of the vessels.

With Drosera we have seen that the motor impulso 
is transmitted in like manmer in all directions through the cellular tissue; but that its rate is largely governed by the length of the eells and the direetion of their longer axes. Thin seetions of a leaf of Dionaca were made by my son, and the eells, both those of the central and of the more superficial layers, were found mueh elongated, with their longer axes direeted towards the midrib; and it is in this direction that the motor impulse must be sent with great rapidity from one lobe to the other, as both elose simultaneously. The central parenehymatous eells are larger, more loosely attaehed together, and have more delieate walls than the more superfieial eells. A thick mass of eellular tissue forms the upper surface of the midrib over the great eentral bundle of vessels.

When the filaments were roughly touehed, at the bases of whieh slits had been made, either on both sides or on one side, parallel to the midrib or at right angles to it, the two lobes, or only one, mored. In one of these cases, the lobe on the side whieh bore the filament that was touehed moved, but in three other eases the opposite lobe alone moved; so that an injury whieh was suffieient to prevent a lobe moving did not prevent the transmission from it of a stimulus which exeited the opposite lobe to move. We thus also learn that, although normally both lobes more together, eaeh has the power of independent movement. A case, indeed, has already been given of a torpid leaf that had lately re-opened after catching an inseet, of whieh one lobe alone moved when irritated. Moreover, one end of the same lobe ean elose and reexpand, independently of the other end, as was seen in some of the foregoing experiments.

When the lobes, whieh are rather thick, elose, no traee of wrinkling ean be seen on any part of their upper 
surfaces. It appears therefore that the cells must contract. The chief seat of the movement is evidcntly in the thick mass of cclls which overlies the central bundle of vessels in the midrib. To ascertain whether this part contracts, a leaf was fastened on the stage of the microscope in such a manner that the two lobes could not become quite shut, and having made two minute black dots on the midrib, in a transverse line and a little towards one side, they were found by the micrometer to be $\frac{17}{1000}$ of an inch apart. One of the filaments was then touched and the lobes closed; but as they were prevented from meeting, I could still see the two dots, which now were $\frac{1.5}{1000}$ of an inch apart, so that a small portion of the upper surface of the midrib had contracted in a transverse line $\frac{a}{1000}$ of an inch (.0508 mm.).

We know that the lobes, whilst closing, become slightly incurved throughout their whole breadth. This movcment appears to be due to the contraction of the superficial laycrs of cells over the whole upper surface. In order to observe their contraction, a narrow strip was cut out of one lobe at right angles to the midrib, so that the surface of the opposite lobe could be seen in this part when the leaf was shut. After the leaf had recovered from the opcration and had re-expanded, three minute black dots were made on the surface opposite to the slit or window, in a line at right angles to the midrib. The distance betwcen the dots was found to be $\frac{4 n}{1000}$ of an inch, so that the two extreme dots were $\frac{8 n}{1000}$ of an inch apart. One of the filaments was now touched and the leaf closed. On again measuring the distances between the dots, the two next to the midrib were nearer together by $\frac{1+\frac{2}{100}}{1000}$ of an inch, and the two further dots by $\frac{3 \operatorname{tn} 4}{100 \mathrm{U}}$ of an inch, than they were before; so that the two extreme 
dots now stood about $\frac{5}{1000}$ of an inch $(\cdot 127 \mathrm{~mm}$.) nearer together than before. If we suppose the whole upper surfaee of the lobe, whieh was $\frac{4 n n}{1000}$ of an ineh in breadth, to have eontraeted in the same proportion, the total contraetion will have amounted to about T $\frac{25}{000}$ or $\frac{1}{7} \frac{1}{0}$ of an ineh $(635 \mathrm{~mm}$.); but whether this is suffieient to aeeount for the slight inward curvature of the whole lobe, I am unable to say.

Finally, with respeet to the movement of the leaves, the wonderful diseovery made by Dr. Burdon Sanderson* is now universally known; namely that there exists a normal eleetrieal eurrent in the blade and footstalk; and that when the leaves are irritated, the eurrent is disturbed in the same manner as takes plaee during the contraction of the muscle of an animal.

The Re-expansion of the Leaves. - This is effeeted at an insensibly slow rate, whether or not any objeet is enelosed. $\dagger$ One lobe can re-expand by itself, as occurred with the torpid leaf of whieh one lobe alone had elosed. We have also seen in the experiments with cheese and albumen that the trio ends of the same lobe ean re-expand to a certain extent independently of each other. But in all ordinary cases both lobes open at the same time. The re-expansion is not determined by the sensitive filaments; all three filaments on one lobe were eut off close to their bases; and the three

* 'Proe. Royal Soe.' vol. xxi. p. 495 ; and leeture at the Royal Institution, Jume 5, 1874, given in 'Nature,' 1874, pp. 105 and 127.

+ Nuttall, in his 'Gen. Americau Plants,' p. 277 (note), says that, whilst eollecting this plant in its nativo home, "I liad oceasiou to observe that a detaehed leaf would make repeated eftorts towards diselosing itself to the influenee of the sun; these attempts consisted in an undulatory motion of the marginal eilia, necompanied by a partial opening and succecding eollapse of the lamina, whieh it leugth terminated in a eomplete exprusion and in the destrnetion of sensibility." I am indebted to Prof. Oliver for this referenee; but I do not understand what took place. 
leaves thus treated re-expanded,- - one to a partial extent in 24 hrs., - $\rightarrow$ a second to the same extent in 48 hrs., - and the third, whieh had been previously injured, not until the sixth day. These leaves after their re-expansion elosed quiekly when the filaments on the other lobe were irritated. These were then eut off one of the leares, so that none were left. This mutilated leaf, notwithstanding the loss of all its filaments, re-expanded in two days in the usual manner. When the filaments have been exeited by immersion in a solution of sugar, the lobes do not expand so soon as when the filaments have been merely touehed; and this, I presume, is due to their having been strongly affeeted through exosmose, so that they eontinue for some time to transmit a motor impulse to the upper surface of the leaf.

The following facts make me believe that the several layers of eells forming the lower surface of the leaf are always in a state of tension; and that it is owing to this meehanical state, aicled probably by fresh fluid being attracted into the eells, that the lobes begin to separate or expand as soon as the eontraetion of the upper surfaee diminishes. A leaf was eut off and suddenly plunged perpendicularly into boiling water: I expected that the lobes would have elosed, but instead of doing so, they diverged a little. I then took another fine leaf, with the lobes standing at an angle of nearly $80^{\circ}$ to eaeh other ; and on immersing it as before, the angle suddenly increased to $90^{\circ}$. A third leaf was torpid from having reeently re-expanded after having eanght a fly, so that repeated touehes of the filaments eaused not the least movement; nevertheless, when similarly immersed, the lobes separated a little. As these lenves were inserted perpendicularly into the boiling water, both surfaces and the filaments 
must have been equally affeeted; and I ean understand the divergenee of the lobes only by supposing that the cells on the lower side, owing to their state of tension, aeted mechanieally and thus suddenly drew the lobes a little apart, as soon as the eells on the upper surfaee were killed and lost their eontraetile power. We have seen that boiling water in like inanner causes the tentaeles of Drosera to eurve baekwards; and this is an analogous movement to the divergenee of the lobes of Dionxa.

In some eoneluding remarks in the fifteenth ehapter on the Droseraeex, the different kinds of irritability possessed by the several genera, and the different manner in which they capture insects, will be compared. 


\section{CHAPTER XIV.}

\section{Aldrofanda vesiculosa.}

Captures crustaceans - Strueture of the leaves in eomparison with those of Dionan - Absorption by the glands, by the quadrifid processes, and points on the infolded margins - Aldrovanda vcsiculosa, var. australis - Cnptures prey - Absorption of animal matterAlllrovanda vesiculosa, var. verticillata - Coneluding remarks.

This plant may be called a miniature aquatic Dionæa. Stein discovered in 1873 that the bilobed leaves, which are generally found closed in Europe, open under a sufficiently high tcmperature, and, when touched, suddenly close.* They re-cxpand in from 24 to 36 hrs., but only, as it appears, when inorganic objects are enclosed. The leaves sometimes contain bubbles of air, and were formerly supposed to be bladders; hence the specific name of vesiculosa. Stein observed that water-insects were sometimes caught, and Prof. Cohn has recently found within the leaves of naturally growing plants many kinds of crustaceans and larvæ. $t$ Plants which had been kept, in filtered water wcre placed by him in a vessel con-

* Sinco his original publication, Stein has found out that the irritability of the lenves was observerl by De Sassus, as recorded in 'Bull. Bot. Soc. de France, in 1861. Delpino states in a paper published in 1871 ('Nuovo (xiornale Bot. Ital.' vol. iii. p. 174) that "una quantith di chioecioline e di nltri animaleoli nequatici" are enught and suffocated by the lenves. I presumo that chiocciolinc are fresh-water molluses. It would be interesting to know whether their shells are at all eorroded by the acid of the digestive seeretion.

$\dagger$ I am greatly indebtod to this distinguished naturn list for having sent mo a eopy of his memoir on Aldrovanda, belore its publiention in his 'Beitrïgo zur Biologio der Pflanzon,' drittes Helt, 1875 . p. 71 . 
taining mumerous crustaceans of the genus Cypris, and next morning many were found imprisoned and alive, still swimming about within the closed leaves, but doomed to certain death.

Dircctly after reading Prof. Cohn's memoir, I receired through the kindness of Dr. Hooker living plants from Germany. As I can add nothing to Prof. Cohn's excellent description, I will give only two illustrations, one of a whorl of leaves copied from his work, and the other of a leaf pressed flat open, drawn by my son Francis. I will, however, append a few remarks on the differcnces between this plant and Dionæa.

Aldrovanda is destitute of roots and floats freely in the watcr. The leaves are arranged in whorls round the stem. Their broad petioles terminate in from four to six rigid projections, ${ }^{*}$ each tipped with a stiff, short bristle. The bilobed leaf, with the midrib likewise tipped with a bristle, stands in the midst of these projcctions, and 'is cvidently defended by them. The lobes are formed of very delicate tissue, so as to be translucent; they open, according to Cohn, about as much as the two valves of a living musscl-shell, thereforc cren less than the lobes of Dionæa; and this must make the capture of aquatic animals more easy. The outside of the leaves and the petioles are rovered with minute two-armed papillæ, evidently answering to the cight-rayed papillæ of Dionæa.

Each lobe rather cxcecds a semi-circlc in convexity, and consists of two very different concentric portions: the inner and lesser portion, or that next to the midrib,

* There has been mueh discussion by botanists on the homological nature of these projections. Dr. Nitschle ('Bot. 'Keitung,'

$1861,1 \% 146$ ) belieres that they enrespond with the fimbriated seale-like bodies found at the bises of the petioles of Drosern. 
is slightly concave, and is formed, according to Cohn, of three layers of cells. Its upper surface is studded with colourless glands like, but more simple than, those of Dionea; they are supported on distinct footstalks, consisting of two rows of cells. The outer
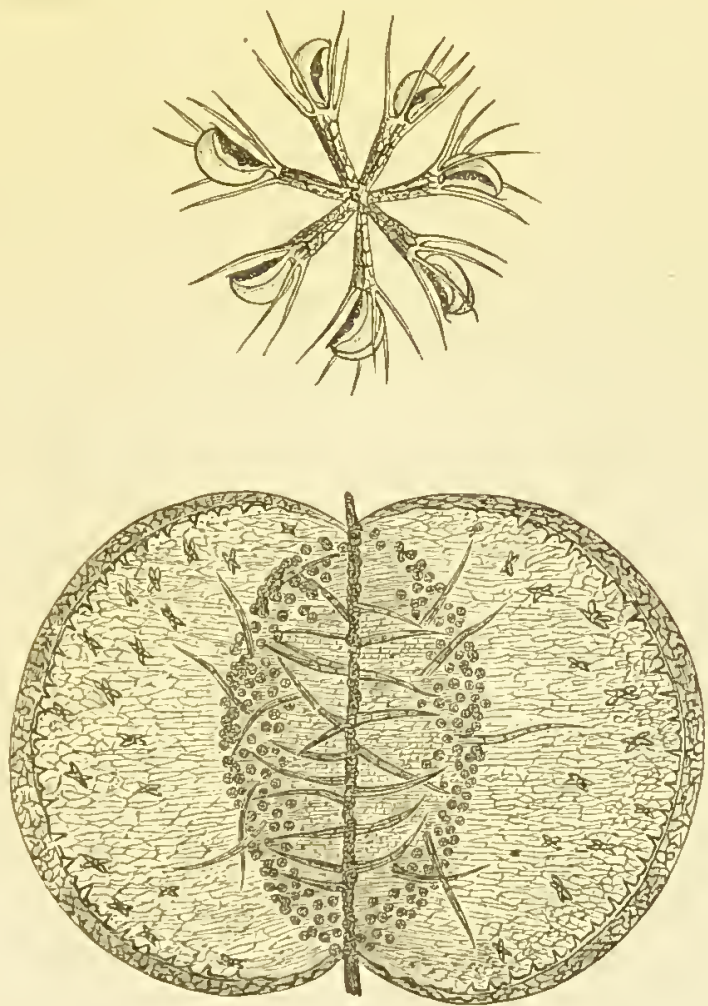

Fig. 13.

(Aldrovanila vesiculosa.)

Upper figure, whorl of lenves (from Prof. Colnn).

Lower figure, leaf pressed flat open and greatly enlarged.

and broarler portion of the lobe is flat and very thin, being formed of only two layers of cells. Its upper surface does not bear any glands, but, in their place, small quadrifid processes, each consisting of four tapering projections, which rise from a common 
prominence. These processes are formed of very delicate membrane lined with a layer of protoplasm; and they sometimes contain aggregated globules' of hyaline matter. Two of the slightly diverging arms are directed towards the circumference, and two towards the midrib, forming together. a sort of Greek cross. Occasionally two of the arms are replaced by one, and then the projection is trifid. We shall see in a future chapter that these projections curiously resemble those found within the bladders of Utricularia, more especially of Utricularia montana, although this genus is not related to Aldrovanda.

A narrow rim of the broad flat exterior part of each lobe is turned inwards, so that, when the lobes are closed, the exterior surfaces of the in-folded portions come into contact. The edge itself bears a row of conical, flattened, transparent points with broad bases, like the prickles on the stem of a bramble or Rubus. As the rim is infolded, these points are directed towards the midrib, and they appear at first as if they were adapted to prevent the escape of prey; but this can hardly be their chief function, for they are composed of very delicate and highly flexible membrane, which can be easily bent or quite doubled back without being cracked. Nevertheless, the infolded rims, together with the points, must somewhat interfere with the retrograde movement of any small creature, as soon as the lobes begin to close. The circumferential part of the leaf of Aldrovanda thus differs greatly from that of Dionea; nor can the points on the rim be considered as homologous with the spikes round the leaves of Dionæa, as these latter are prolongations of the blade, and not mere epidermic productions. They appear also to serve for a widely different purpose. 
On the concave gland-bearing portion of the lobes, and especially on the midrib, there are numerous, long, finely pointed hairs, which, as Prof. Cohn remarks, there can be little doubt are sensitive to a touch, and, when touched, cause the leaf to close. They are formed of two rows of cells, or, aeeording to Cohn, sometimes of four, and do not include any vascular tissue. They differ also from the six sensitive filaments of Dionxa in being colourless, and in having a medial as well as a basal articulation. No doubt it is owing to these two articulations that, notwithstanding their length, they escape being broken when the lobes close.

The plants which I received during the early part of October from Kew never opened their leaves, thongh subjected to a high temperature. After examining the structure of some of them, I experimented on only two, as I hoped that the plants would grow; and I now regret that I did not sacrifice a greater number.

A leaf was cut open along the midrib, and the glands examined under a high power. It was then placed in a few drops of an infusion of raw meat. After $3 \mathrm{hrs} .20 \mathrm{~m}$. there was no change, but when next examined after 23 hrs. $20 \mathrm{~m}$., the outer cells of the glands contained, instead of limpid fluid, spherical masses of a granular substance, showing that matter had been absorbed from the infusion. That these glands secrete a fluid which dissolves or digests animal matter out of the bodies of the creatures which the leaves capture, is also highly probable from the analogy of Dionaca. If we may trust to the same analogy, the concave and inner portions of the two lobes probably close together by a slow movement, as soon as the glands have absorbed a slight amount of 
already soluble animal matter. The ineluded water would thus be pressed out, and the secretion consequently not be too much diluted to act. With respect to the quadrifid proeesses on the onter parts of the lobes, I was not able to deeide whether they had been acted on by the infusion; for the lining of protoplasm was somewhat shrunk before they were immersed. Many of the points on the infolded rims also had their lining of protoplasm similarly shrunk, and contained spherical granules of hyaline matter.

A solution of urea was next employed. This substance was chosen partly because it is absorbed by the quadrifid processes and more especially by the glands of Utricularia-a plant which, as we shall hereafter see, feeds on decayed animal matter. As urea is one of the last products of the chemical changes going on in the living body, it seems fitted to represent the early stages of the decay of the dead body. I was also led to try urea from a curious little fact mentioned by Prof. Cohn, namely that when rather large erustaceans are caught between the elosing lobes, they are pressed so hard whilst making their escape that they often roid their sausage-shaped masses of exerement, which were found within most of the leaves. These masses, no doubt, eontain urea. They would be left either on the broad outer surfaces of the lobes where the quadrifids are situated, or within the closed concavity. In the latter case, water charged with excrementitions and deeaying matter would be slowly foreed outwards, and would bathe the quadrifids, if I am right in believing that the eoneave lobes eontraet after a time like those of Dionæa. Foul water would also be apt to ooze out at all times, espeeially when bubbles of air were generated within the coneavity.

A leaf was cut open and examined, and the outer 
cells of the glands were found to contain only limpid Huid. Some of the quadrifids included a few spherieal granules, but several were transparent and empty, and their positions were marked. This leaf was now immersed in a little solution of one part of urea to 146 of water, or three grains to the ounee. After 3 hrs. $40 \mathrm{~m}$. there was no ehange either in the glands or quadrificls; nor was there any eertain ehange in the glands after 24 hrs.; so that, as far as one trial goes, urea does not aet on them in the same manner as an infusion of raw meat. It was different with the quadrifids; for the lining of protoplasm, instead of presenting a uniform texture, was now slightly shrumk, and exhibited in many places minute, thickened, irregular, Jellowish speeks and ridges, exactly like those which appear within the quadrifids of Utrieularia when treated with this same solution. Moreover, several of the quadrifids, whieh were before empty, now eontained moderately sized or very small, more or less aggregated, globules of yellowish matter, as likewise oecurs under the same cireumstances with Utrieularia. Some of the points on the infolded margius of the lobes were similarly affeeted f for their lining of protoplasm was a little shrunk and ineluded yellowish speeks; and those whieh were before empty now contained small spheres and irregular masses of hyaline matter, more or less aggregated; so that both the points on the margins and the quadrifids had absorbed matter from the solution in the course of $24 \mathrm{hrs}$. ; but to this subjeet I shall recur. In another rather old leaf, to which nothing had been given, but whieh had been kept in foul water, some of the quadrifids eontained aggregated translueent globules. These were not aeted on by a solution of one part of carbonate of ammonia to 218 of water; and this negative result 
agrees with what I have observed under similar cirstances with Utrieularia.

Aldrovanda vesiculosa, var. australis.-Dried leaves of this plant from Queensland in Australia were sent me by Prof. Oliver from the herbarium at Kew. Whether it ought to be eonsidered as a distinet species or a variety, eannot be told until the flowers are examined by a botanist. The projeetions at the upper end of the petiole (from four to six in number) are eonsiderably longer relatively to the blade, and mueh more attenuated than those of the European form. They are thiekly covered for a eonsiderable spaee near their extremities with the upeurved priekles, which are quite absent in the latter form; and they generally bear on their tips two or three straight priekles instead of one. The bilobed leaf appears also to be rather larger and somewhat broader, with the pedieel by whieh it is attaehed to the upper end of the petiole a little longer. The points on the infolded margins likewise differ; they have narrower bases, and are more pointed; long and short points also alternate with much more regularity than in the European form. The glands and sensitive hairs are similar in the two forms. No quadrifid proeesses eould be seen on several of the leaves, but I do not doubt that they were present, though indistinguishable from their delicaey and from having shrivelled; for they were quite distinet on one leaf under eireumstanees presently to be mentioned.

Some of the elosed leaves eontained no prey, but in one there was a rather large beetle, whieh from its flattened tibix I suppose was an aquatie speeies, but was not allied to Colymbetes. All the softer tissues of this beetle were eompletely dissolved, and its chitinous integuments wore as clean as if they had been 
boiled in caustie potash; so that it must have been enelosed for a eonsiderable time. The glands were browner and more opaque than those on other leaves whieh had eanght nothing; and the quadrifid processes, from being partly filled with brown granular matter, eould be plainly distinguished, whieh was not the ease, as already stated, on the other leaves. Some of the points on the infolded margins likewise eontained brownish granular matter. We thus gain additional evidenee that the glands, the quadrifid processes, and the marginal points, all have the power of absorbing. matter, though probably of a different nature.

Within another leaf disintegrated remnants of a rather small animal, not a erustaeean, whieh had simple, strong, opaque mandibles, and a large unartieulated ehitinous coat, were present. Lumps of blaek organie matter, possibly of a vegetable nature, were enelosed in tro other leaves; but in one of these there was also a small worm much decayed. But the nature of partially digested and deeayed bodies, which have been pressed flat, long dried, and then soaked in water, eannot be recognised easily. All the leaves eontained unicellular and other Algæ, still of a greenish eolour, which had evidently lived as intruders, in the same manner as oeeurs, aeeording to Cohn, within the leaves of this plant in Germany.

Aldrovanda vesiculosa, var. verticillata.-Dr. King, Superintendent of the Botanic Gardens, kindly sent me dried speeimens eolleeted near Calcutta. This form was, I believe, eonsidered by Wallich as a distinet speeies, inder the name of verticillata. It resembles the Anstralian form much more nearly than the European; namely in the projections at the upper end of the petiole being mueh attenuated and eovered with 
upeurved priekles; they terminate also in two straight little priekles. The bilobed leaves are, I believe, larger and eertainly broader even than those of the Australian form; so that the greater eonvexity of their margins was eonspieuous. 'The length of an open leaf being taken at 100, the breadth of the Bengal form is nearly 173, of the Australian form 147, and of the German 134. The points on the infolded margins are like those in the Australian form. Of the few leaves whieh were examined, three eontained entomostraean ertustaeeans.

Conctuding Remarks.--The leaves of the three foregoing elosely allied speeies or varieties are manifestly adapted for eatehing living ereatures. With respeet to the funetions of the several parts, there ean be little doubt that the long jointed hairs are sensitive, like those of Dionrea, and that, when touehed, they eause the lobes to elose. That the glands seerete a true digestive fluid and afterwards absorb the digested matter, is highly probable from the analogy of Dionæa,--from the limpid fluid within their eells being aggregated into spherieal masses, after they had absorbed an infusion of raw meat,--from their opaque and granular eondition in the leaf, whieh had enelosed a beetle for a long time,-and from the elean eondition of the integuments of this inseet, as well as of erustaeeans (as deseribed by Cohn), whieh have been long eaptured. Again, from the effeet produeed on the quadrifid proeesses by an immersion for $24 \mathrm{hrs}$. in a solution of urea,-from the presenee of brown granular matter within the quadrifids of the leaf in whieh the beetle had been eaught, - and from the analogy of Utrieularia,-it is probable that these proeesses absorb exerementitious and deenying animal matter. - It is a more eurious faet that the points on 
the infolded margins apparently serve to absorb deeayed animal matter in the same manner as the quadrifids. We ean thus understand the meaning of the infolded margins of the lobes furnished with delieate points direeted inwards, and of the broad, flat, outer portions, bearing quadrifid proeesses; for these surfaees must be liable to be irrigated by foul water flowing from the eoncavity of the leaf when it eontains dead animals. This would follow from various eauses, - from the gradual eontraetion of the eoneavity, - from fluid in exeess being seereted,- - and from the generation of bubbles of air. More observations are requisite on this head; but if this view is eorreet, we have the remarkable ease of different parts of the same leaf serving for very different purposes-one part for true digestion, and another for the absorption of deeayed animal matter. We ean thus also understand how, by the gradual loss of either power, a plant might be gradually adapted for the one funetion to the exelusion of the other; and it will hereafter be shown that two genera, namely Pinguieula and Utrieularia, belonging to the same family, have been adapted for these two different functions. 


\section{CHAPTER XV.}

\section{Drosophyllem - Romidula - Brblis - Glandular Hatrs of other Plants-- Concludikg Remarks on the Droseracez.}

Drosophyllum -- Structure of learcs - Nature of the sccretion - Manner of catching insects -- Power of absorption -Digestion of animal substances - Summary on Drosophyllum - Roridula - Byblis Glandular hairs of other plants, their power of absorption - Saxifraga - Primula - Pclnrgonium - Erica - Mirabilis - Nicotiana - Summary on glandular hairs - Concluding remarks on the Droseracer.

DrosophyluUM LUSITANICUM.--This rare plant has been found only in Portugal, and, as I hear from Dr. Hooker, in Moroeco. I obtained living spceimens through the great kindness of $\mathrm{Mr}$. W. C. Tait, and afterwards from Mr. G. Maw and Dr. Moore. Mr. Tait informs me that it grows plentifully on the sides of dry hills near Oporto, and that vast numbers of flies adhere to the leaves. This latter faet is well known to the villagers, who call the plant the "fly-eatcher," and hang it up in their eottages for this purpose. A plant in my hot-house eaught so many insects during the early part of April, although the weather was cold and insects searce, that it must have been in some manner strongly attractive to them. On four leaves of a young and small plant, 8, 10, 14, and 16 minute inseets, ehiefly Diptern, werc found in the autumn adhcring to them. I negleeted to examine the roots, but I hear from Dr. Hooker that they are very small, as in the case of the previously mentioned nembers of the same family of the Droseracex. 'I'he lcaves arise from an almost woody axis; they 
are linear, much attenuated towards their tips, and several inches in length. The upper surface is concave, the lower convex, with a narrow channel down the middle. Both surfaces, with the exception of the channel, are covered with glands, supported on pediccls and arranged in irregular longitudinal rows. These organs I shall call tentacles, from thcir close resemblance to those of Droscra, though they have no power of movement. Those on the samc leaf differ much in length. The glands also differ in sizc, and are of a bright pink or of a purple colour; their upper surfaces are convex, and the lower flat or even concave, so that they resemble miniature mushrooms in appearance. They are formed of two (as I bclieve) laycrs of delicate angular cells, enclosing eight or ten larger cells with thicker, zigzag walls. Within thesc larger cells there are others marked by spiral lincs, and apparently connceted with the spiral vessels which run up the green multicellular pedicels. The glands sccrete large drops of viscid sccrction. Other glands, having the samc general appearance, are found on the flowcrpeduncles and calyx.

Besides the glands which arc borne on longer or shorter pediccls, there are numerous ones, both on the ujpper and lower surfaces of the lcaves, so small as to be scarccly visible to the naked cyc. They are colourless and almost sessile, eithcr circular or oval in ontline; the latter occurring chicfly

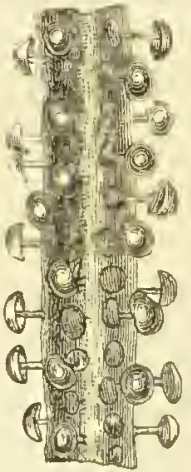

FiG. 14.

(Drosophyllum lusitanicum.)

Purt of leaf, enlargal seven times, showing lower surface. on the backs of the leaves (fig. 14). Intcrnally they have cxactly the same structure as the larger glands which are supported on pedicels; 
and indeed the two sets almost graduate into one another. But the sessile glands differ in one important respeet, for they never seerete spontaneously, as far as I have seen, though I have examined them under a high power on a hot day, whilst the glands on pedieels were seereting eopiously. Nevertheless, if little bits of damp albumen or fibrin are plaeed on these sessile glands, they begin after a time to seerete, in the same mamner as do the glands of Dionzea when similarly treated. When they were merely rubbed with a bit of raw meat, I believe that they likewise seereted. Both the sessile glands and the taller ones on pedieels have the power of rapidly absorbing nitrogenous matter.

The seeretion from the taller glands differs in a remarkable manner from that of Drosera, in being aeid before the glands have been in any way exeited; and judging from the ehanged eolour of litmus paper, more strougly aeid than that of Drosera. This faet was observed repeatedly; on one oeeasion I ehose a young leaf, whieh was not seereting freely, and had never eaught an inseet, yet the seeretion on all the glands eoloured litmus paper of a bright red. From the quiekness with whieh the glands are able to obtain animal matter from sueh substanees as well-washed fibrin and eartilage, I suspeet that a small quantity of the proper ferment must be present in the seeretion before the glands are exeited, so that a little animal matter is quiekly dissolved.

Owing to the nature of the seeretion or to the shape of the glands, the drops are removed from them with singular faeility. It is even somewhat diffieult, by the aid of a finely pointed polished needle, slightly damped with water, to plaee a minute partiele of any kind on one of the drops; for on withdrawing the 
needle, the drop is generally withdrawn; whcreas with Drosera there is no such difficulty, though the drops are occasionally withdrawn. From this peculiarity, when a small insect alights on a leaf of Drosophyllum, the drops adhere to its wings, fect, or body, and are drawn from the gland; the insect then crawls onward and other drops adhere to it; so that at last, bathed by the viscid secretion, it sinks down and dies, resting on the small sessile glands with which the surface of the leaf is thickly covered. In the case of Droscra, an insect sticking to one or more of the exterior glands is carried by their movement to the centre of the leaf; with Drosophyllum, this is effected by the crawling of the insect, as from its wings being clogged by the secretion it cannot fly away.

There is another difference in function between the glands of these two plants: we know that the glands of Drosera secrete more copiously when propcrly excited. But when minute particles of carbonate of ammonia, drops of a solution of this salt or of the nitrate of ammonia, saliva, small insects, bits of raw or roast meat, albumen, fibrin or cartilage, as well as inorganic particles, werc placed on the glands of Drosophyllum, the amount of sccretion never appcared to be in the least increased. As inscets do not commonly adhere to the taller glands, but withdraw the sccretion, we can see that there would be little use in their having acquired the habit of sccreting copiously when stimulated; whereas with Drosera this is of usc, and the habit has been acquired. Neverthcless, the glands of Drosophyllum, without being stimulated, continually secrete, so as to replace the loss by cvaporation. Thus when a plant was placed under a small bellglass with its inner surface and support thoroughly wetted, there was no loss by evaporation, and so much 
secretion was accumulated in the coursc of a day that it ran down the tentacles and covered large spaces of the leaves.

The glands to which the above named nitrogenous substances and liquids were given did not, as just stated, secretc more copiously; on the contrary, they absorbed thcir own drops of secretion with surprising quickness. Bits of damp fibrin werc placed on five glands, and when they were looked at after an interval of $1 \mathrm{hr} .12 \mathrm{~m}$., the fibrin was almost dry, the secretion having been all absorbed. So it was with three cubes of albumen after $1 \mathrm{hr} .19 \mathrm{~m}$., and with four other cubes, though these latter were not looked at until 2 hrs. $15 \mathrm{~m}$. had elapsed. The same result followed in between $1 \mathrm{hr} .15 \mathrm{~m}$. and $1 \mathrm{hr} .30 \mathrm{~m}$. when particles both of cartilagc and meat were placed on several glands. Lastly, a minute drop (about $\frac{1}{20}$ of a minim) of a solution of one part of nitrate of ammonia to 146 of water was distributed betwcen the secretion surrounding three glands, so that the amount of fluid surrounding each was slightly increased; yet when looked at after 2 hrs., all three were dry. On the other hand, seven particles of glass and three of coalcinders, of ncarly the same size as those of the above named organic substances, were placed on ten glands; some of them bcing observed for 18 hrs., and others for two or threc days; but there was not the least sign of the secretion being absorbed. Hence, in the former cases, the absorption of the secretion must have been duc to the presence of some nitrogenous matter, which was cither already soluble or was rendered so by the sccrction. As the fibrin was pure, and had becn well washed in distilled water after bcing kept in glyccrinc, and as the cartilage had been soaked in watcr, I suspect that these substances must 
have been slightly aeted on and rendered solnble within the above stated short periods.

The glands have not only the power of rapid absorption, but likewise of secreting again quiekly; and this latter habit has perhaps been gained, inasmuch as insects, if they touch the glands, generally withdraw the drops of secretion, which have to be restored. The exact period of re-secretion was recorded in only a few eases. The glands on whieh bits of meat were plaeed, and whieh were nearly dry after about $1 \mathrm{hr}$. $30 \mathrm{~m}$., when looked at after 22 additional hours, were found seereting; so it was after 24 hrs. with one gland on whieh a bit of albumen had bejen plaeed. The three glands to which a minute drop of a solution of nitrate of ammonia was distributed, and whieh beeame dry after 2 hrs., were beginning to re-secrete after only 12 additional hours.

Tentacles Incapable of Movement.-Many of the tall tentacles, with insects adhering to them, were carefully observed; and fragments of inseets, bits of raw meat, albumen, \&c., drops of a solution of two salts of ammonia and of saliva, were placed on the glands of many tentacles; but not a trace of movement could ever be detected. I also repeatedly irritated the glands with a needle, and seratehed and pricked the blarles, but neither the blade nor the tentaeles beeame at all infleeted. We may therefore eonelude that they are incapable of movement.

On the Power of Absorption possessed by the Glands.It has already been indirectly shown that the glands on pedieels absorb animal matter; and this is further shown by their changed eolour, and by the aggregation of their eontents, after they have been left in contact with nitrogenons substanees or liquirls. The following observations apply both to the glands supported on 
pedieels and to the minute sessile ones. Before a gland has been in any way stimulated, the exterior eells commonly contain only limpid purple fluid; the more central ones ineluding mulberry-like masses of purple granular matter. A leaf was placed in a little solution of one part of carbonate of ammonia to 146 of water ( 3 grs. to 1 oz.), and the glands were instantly darkened and very soon became black; this change being due to the strongly marked aggregation of their contents, more especially of the inner cells. Another leaf was plaeed in a solution of the same strength of nitrate of ammonia, and the glands were slightly darkened in $25 \mathrm{~m}$., more so in $50 \mathrm{~m}$., and after $1 \mathrm{hr} .30 \mathrm{~m}$. were of so dark a red as to appear almost black. Other leaves were placed in a weak infusion of raw meat and in human saliva, and the glands were much darkened in $25 \mathrm{~m}$., and after $40 \mathrm{~m}$. were so dark as almost to deserve to be called black. Even immersion for a whole day in distilled water occasionally induees some aggregation within the glands, so that they become of a darker tint. In all these cases the glands are affeeted in exactly the same manner as those of Drosera. Milk, however, which acts so energetically on Drosera, seems rather less effective on Drosophyllum, for the glands were only slightly darkened by an immersion of $1 \mathrm{hr}$. $20 \mathrm{~m}$., but became decidedly darker after 3 hrs. Leaves which had been left for $7 \mathrm{hrs}$. in an infusion of raw meat or in saliva were placed in the solution of carbonate of ammonia, and the glands now became greenish; whereas, if they lad been first placed in the carbonate, they would have become black. In this latter ease, the ammonia probably combines with the acid of the secretion, and therefore does not act on the colouring matter; but when the glands are first subjected to an orgunic 
fluid, either the aeid is consumed in the work of digestion or the eell-walls are rendered more permeable, so that the undecomposed carbonate enters and aets on the eolouring matter. If a partiele of the dry carbonate is plaeed on a gland, the purple eolour is quickly diseharged, owing probably to an exeess of the salt. The gland, moreover, is killed.

Turning now to the aetion of organie substances, the glands on whieh bits of raw meat were plaeed became dark-eoloured; and in 18 hrs. their contents were conspieuously aggregated. Several glands with bits of albumen and fibrin were darkened in between 2 hrs. and 3 hrs.; but in one case the purple eolour was completely discharged. Some glands which had eaught flies were eompared with others elose by; and though they did not differ much in colour, there was a marked differenee in their state of aggregation. In some few instances, however, there was no sueh difference, and this appeared to be due to the insects having been eaught long ago, so that the glands had reeovered their pristine state. In one ease, a group of the sessile colourless glands, to which a small fly adhered, presented a peculiar appearanee; for they had beeome purple, owing to purple granular matter eoating the eell-walls. I may here mention as a eaution that, soon after some of my plants arrived in the spring from Portugal, the glands were not plainly aeted on by lits of meat, or inseets, or a solution of ammonia-a cireumstance for which I cannot account.

Digestion of Solid Animal Matter. - Whilst I was trying to place on two of the taller glands little enbes of albumen, these slipped down, and, besmeared with secretion, were left resting on some of the small sessilc grlands. After 24 hrs. one of these cubes was found 
eompletely liquefied, but with a few white streaks still visible; the other was much rounded, but not quite dissolved. Two other eubes were left on tall glands for 2 hrs. $45 \mathrm{~m}$., by which time all the secretion was absorbed; but they were not pereeptibly aeted on, though no doubt some slight amount of animal matter had been absorbed from them. They were then plaeed on the small sessile glands, which being thus stimulated seereted eopiously in the course of 7 hrs. One of these eubes was mueh liquefied within this short time; and both were completely liquefied after 21 hrs. $15 \mathrm{~m}$.; the little liquid masses, however, still showing some white streaks. These streaks disappeared after an additional period of 6 hrs. $30 \mathrm{~m}$.; and by next morning (i.e. 48 hrs. from the time when the eubes were first plaeed on the glands) the liquefied matter was wholly absorbed. A eube of albumen was left on another tall gland, which first absorbed the seeretion and after $24 \mathrm{hrs}$. poured forth a fresh supply. This eube, now surrounded by seeretion, was left on the gland for an additional 24 hrs., but was very little, if at all, aeted on. We may, therefore, eonelude, either that the seeretion from the tall glands has little power of digestion, though strongly aeid, or that the amount poured forth from a single gland is insuffieient to dissolve a partiele of albumen whieh within the same time would have been dissolved by the seeretion from several of the small sessile glands. Owing to the death of my last plant, I was unable to aseertain which of these alternatives is the true one.

Four minute shreds of pure fibrin were plaeed, each resting on one, two, or three of the taller glands. In the eourse of 2 hrs. $30 \mathrm{~m}$. the seeretion was all absorbed, and the shreds were left almost dry. They 
were then pushed on to the sessile glands. One shrerl, after 2 hrs. $30 \mathrm{~m}$., seemed quite dissolved, but this may have been a mistake. A second, when examined after $17 \mathrm{hrs} .25 \mathrm{~m}$., was liquefied, but the liquid as seen under the microseope still eontained floating granules of fibrin. The other two shreds were eompletely liquefied after $21 \mathrm{hr}$. $30 \mathrm{~m}$.; but in one of the drops a very few granules could still be deteeted. These, however, were dissolved after an additional interval of 6 hrs. $30 \mathrm{~m}$.; and the surface of the leaf for some distance all round was eovered with limpid fluid. It thus appears that Drosophyllum digests albumen and fibrin rather more quiekly than Drosera ean; and this may perhaps be attributed to the aeid, together probably with some small amount of the ferment, being present in the seeretion, before the glands have been stimulated ; so that digestion begins at once.

Conchuling Remarks.-The linear leaves of Drosophyllum differ but slightly from those of certain speeies of Drosera; the chief differenees being, firstly, the presence of minute, almost sessile, glands, which, like those of Dionæa, do not secrete until they are excited by the absorption of nitrogenous matter. But glands of this kind are present on the leaves of Drosera binata, and appear to be represented by the papilla on the leaves of Drosera rotundifotia. Seeondly, the presenee of tentaeles on the baeks of the leaves; but we have seen that a few tentacles, irregularly plaeed and tending towards abortion, are retained on the baeks of the leaves of Drosera binata. 'There are greater differenees in funetion between the two genera. The most important one is that the tentacles of Drosophyllum have no power of movement; this loss being partially replaced by the drops of viseid 
seeretion being readily withdrawn from the glands; so that, when an inseet eomes into eontaet with a drop, it is able to erawl away, but soon touehes other drops, and then, smothered by the seeretion, sinks down on the sessile glands and dies. Another differenee is, that the seeretion from the tall glands, before they have been in any way excited, is strongly aeid, and perhaps eontains a small quantity of the proper ferment. Again, these glands do not seerete more eopiously from being exeited by the absorption of nitrogenous. matter ; on the eontrary, they then absorb their own seeretion with extraordinary quiekness. In a. short time they begin to seerete again. All these eircunstanees are probably eonneeted with the faet that inseets do not eommonly adhere to the glands with which they first eome into eontret, though this does sometimes oeeur; and that it is ehiefly the seeretion from the sessile glands whieh dissolves animal matter out of their bodies.

\section{RORIDULA.}

Roridula dentata.-This plant, a native of the western parts of the Cape of Good Hope, was sent to me in a dried state from Kew. It has an almost woody stem and branehes, and apparently grows to a height of some feet. The leaves are linear, with their summits mueh attenuated. Their upper and lower surfaees are eoneave, with a ridge in the middle, and both are eovered with tentaeles, whieh differ greatly in length; some being very long, espeeially those on the tips of the leaves, and some rery short. The glands also differ mueh in size and are somewhat elongated. They are supported on multicellular pedieels.

This plant, therefore, agrees in sereral respects with 
Drosophyllum, but differs in the following points. I could detect no sessile glands; nor would these have been of any use, as the upper surface of the leaves is thickly clothed with pointed, unicellular hairs directed upwards. The pedicels of the tentacles do not include spiral vessels; nor are there any spiral cells within the glands. The leaves often arise in tufts and are pinnatifid, the divisions projecting at right angles to the main linear blade. These lateral divisions are often very short and bear only a single terminal tentacle, with one or two short ones on the sides. No distinct line of demarcation can be drawn between the pedicels of the long terminal tentacles and the much attennated summits of the leares. We may, indeed, arbitrarily fix on the point to which the spiral vessels proceeding from the blade extend; but there is no other distinction.

It was evident from the many particles of dirt sticking to the glands that they secrete much viscid matter. A large number of insects of many kinds also adhered to the leaves. I could nowhere discover any signs of the tentacles having been inflected over the captured insects; and this probably would have been seen even in the dried specimens, had they possessed the power of movement. Hence, in this negative character, Roridula resembles its northern representative, Drosophyllum.

\section{Bybiss.}

Byblis gigantea (Western Australia). - A dried specimen, about 18 inches in height, with a strong stem, was sent me from Kew. 'lhe leaves are some inches in length, linear, slightly flattened, with a small projecting rib on the lower surface. They are covered on all sides by glands of two kinds 
--sessile ones arranged in rows, and others supported on moderately long pedicels. Towards the narrow summits of the leaves the pedicels are longer than elsewhere, and here equal the diameter of the leaf. The glands are purplish, much flattened, and formed of a single layer of Jadiating cells, which in the larger glands are from forty to fifty in number. The pedicels consist of single elongated cells, with colourless, extremely delicate walls, marked with the finest intersecting spiral lines. Whether these lines are the result of contraction from the drying of the walls, I do not know, but the whole pedicel was often spirally rolled up. These glandular hairs are far more simple in structure than the so-called tentacles of the preceding genera, and they do not differ essentially from those borne by innumerable other plants. The flower-peduncles bear similar glands. The most singular character about the leaves is that the apex is enlarged into a little knob, covered with glands, and about a third broadẹ than the adjoining part of the attenuated leaf. In two places dead flies adhered to the glands. As no instance is known of unicellular structures having any power of movement,* Byblis, no doubt, catches insects solely by the aid of its viscid secretion. These probably sink down besmeared with the secretion and rest on the small sessile glands, which, if we may judge by the analogy of Drosophyllum, then pour fourth their secretion and afterwards absorb the digested matter.

Supplementary Observations on the Power of Absorption by the Glandular Hairs of other Plants.-A few observations on this subject may be here conveniently introduced. $\Lambda$ s the glands of many, probably of all,

* Sachs, 'Traité do Bot.' 3rd edit. 1874, p. 1026. 
the species of Droseracere absorb various fluids or at lcast allow them readily to enter, ${ }^{*}$ it secmed desirable to ascertain how far the glands of other plants which are not specially adapted for capturing insects, had the same power. Plants wcre chosen for trial at hazard, with the exception of two specics of saxifrage, which were selected from belonging to a family allied to the Droseracer. Nost of the experiments were made by immersing the glands either in an infusion of raw meat or morc commonly in a solution of carbonate of ammonia, as this latter substanceracts so powerfully and rapidly on protoplasm. It secmed also particularly desirable to ascertain whether ammonia was absorbed, as a small amount is contained in rainwater. With the Droseracer the secretion of a viscid fluid by the glands does not prevent their absorbing; so that the glands of othcr plants might excrete supcrfluous matter, or secrete an odoriferous fluid as a protection against the attacks of insects, or for any other purpose, and yet have the power of absorbing. I regret that in the following cases I did not try whether the secretion could digest or render solublc animal substances, but such experiments would have been difficult on account of the small size of the glands and the small amount of sccretion. We shall see in the next chapter that the secretion from the glandular hairs of Pinguicula certainly dissolves animal matter.

Sraxifraga umbrosa. - The flower-peduncles and petioles of the leaves are clothed with short hairs, bearing pink-coloured glands, formed of several polygonal cells, with thcir pedicels divided by partitions into distinct cells, which are generally colourless, but somctimes pink. The glands secretc a yellowish viscid fluid, by

* 'The distinetion between truo absorption and mere permeation, or imbibition, is by no means elenrly understood: seo Miiller's 'Physiology,' Lng. translat. 1838, vol. i. p. 280. 
whieh minute Diptera are sometimes, though not often, eaught.* The eells of the glands eontain bright pink fluid, elarged with granules or with globular masses of pinkish pulpy matter. This matter must be protoplesm, for it is seen to unclergo slow bnt ineessant ehanges of form if a gland be plaeed in a drop of water and examined. Similar movements were observed after glands had been immersed in water for 1, 3, 5, 18, and 27 hrs. Even after this latter period the glands retained their bright pink eolour; and the protoplasm within their eells did not appear to have beeome more aggregated. The eontinnally ehanging forms of the little masses of protoplasm are not due to the absorption of water, as they were seen in glands kept dry.

A flower-stem, still attaehed to a plant, was bent (May 29) so as to remain immersed for 23 hrs. $30 \mathrm{~m}$. in a strong infusion of raw meat. The eolour of the eontents of the glands was slightly ehanged, being now of a duller and more purple tint than before. The eontents also appeared more aggregated, for the spaees between the little masses of protoplasm were wider; but this latter result did not follow in some other and similar experiments. The masses seemed to ehange their forms more rapidly than did those in water; so that the eells had a different appearanee every four or five minutes. Elongated masses beeame in the eourse of one or two minutes spherieal; and spherieal ones drew themselves ont and united with others. Minute masses rapidly inereased in size, and three distinet ones were seen to unite. The movements were, in short, exaetly like those deseribed in the ease of Drosern. The eells of the pedieels were not affeeted by the infusion; nor were they in the following experiment.

Another flower-stem was plaeed in the same mauner and for the same length of time in a solution of one part of nitrate of ammonia to 146 of water (or 3 grs, to $1 \mathrm{oz}$. ), and the glands were diseoloured in exaetly the same manner as by the infusion of raw meat.

Another flower-stem was immersed, as before, in a solution of one part of earbonate of ammonia to 109 of water. The glands, after 1 hr. $30 \mathrm{~m}$., were not diseoloured, but after 3 hrs. $45 \mathrm{~m}$. most of them had beeome dull pmrple, some of them blaekish-

* In the ense of Saxifraga tridartylites, Mr. Druee says ("1'hurmaeentienl Journal,' May 1\&75) that he examined some dorms of plunts, and in almost every in- staneo remnants of inscets adliered to the leares. So it is. as I hear from a friend, with this plant in Ireland. 
green, a few being still unaffeeted. The little masses of protoplasm within the eells were seen in movement. T'he eells of the pedieels were unaltered. The experiment was repeated, and a fresh flower-stem was left for 23 hrs. in the solution, and now a great cffeet was produced; all the glands were mueh blackened, and the previously transparent fluid in the cells of the pedieels, even down to their bases, eontained spherical masses of gramular mattor. By comparing many different hairs, it was evident that the glands first absorb the earbonate, and that the effect thus produced travels down the hairs from eell to ccll. The first ehange which could be observed is a eloudy appearanee in the fluid, clue to the formation of very fine granules, which afterwards aggregate into larger masses. Altogether, in the darkening of the glands, and in the proeess of aggregation travelling domn the cells of the pedicels, there is the closest resemblanee to what takes plaee when a tentrele of Drosera is immersed in a weak solution of the same salt. The glands, however, absorb very much more slowly than those of Drosera. Besides the glandular hairs, there are star-shaped organs which do not appear to secrete, and whieh were not in the least affeeted by the above solutions.

Although in the ease of uninjured flower-stems and leaves the earbonate seems to be absorbed only by the glands, yet it enters a eut surface mueh more quiekly than a gland. Strips of the rind of a flower-stem were torn off, and the eells of the pediecls were seen to eontain only colourless transparent fluid; those of the glands including as usual some granular matter. These strips were then immersed in the same solution as before (one part of the earbonate to 109 of water), and in a few minutes granular matter appeared in the lower eells of all the pedicels. The action invariably eommeneed (for I tried the experiment repeatedly) in the lowest eclls, and therefore elose to the torn surfaec, and then gradually travelled up the hairs until it reached the glands, in a reversed direetion to what oecurs in uninjured specimens. The glands then became discoloured, and the previously eontained gramular matter was aggregated into larger masses. Two short bits of a flower-stem were also left for 2 hrs. $40 \mathrm{~m}$. in a weaker solution of one part of the earbonate to 218 of water; and in both speeimens the pedicels of the hairs ncar the eut ouds now contained mueli granular matter; and the glands were eompletely discolonred.

Lastly, bits of meat were plaeed on some, glands; these were examined after 23 lırs., as were others, whiel had apparently not long before eaught minute flies; but they did not present any 
difference from the glands of other hairs. Pcrhaps there may not have been time cnough for absorption. I think so as some glands, on which dead flies had cridently long lain, were of a pale dirty purple colour or even almost colourless, and the granular matter within them presented an unusual and somewhat peculiar appearance. That these glands had absorbed animal matter from the flies, probably by exosmose into the viscid secretion, we may infer, not only from their changed colour, but because, when placed in a solution of carbonate of ammonia, some of the cells in their pedicels become fillerd with granular matter; whereas the cells of other hairs, which had not caught flies, after being treated with the same solution for the same length of time, contained only a small quantity of granular matter. But more evidence is necessary before we fully admit that the glands of this saxifrage can absorb, even with ample time allowed, animal matter from the minute insects which they occasionally and accidentally capture.

Suxifraga rotuudifolia (?).- The hairs on the flower-stems of this specics are longer than those just described, and bear pale brown glands. Many were examined, and the cells of the pedicels were quite transparent. A bent stem was immersed for $30 \mathrm{~m}$. in a solution of one part of carbonate of ammonia to 109 of water, and two or three of the uppermost cells in the pcdiccls now contained granular or aggregated matter; the glands having become of a bright yellowish-green. The glands of this species therefore absorb the carbonate much more quickly than do those of Saxifraga umbrnsa, and the upper cells of the pedicels are likewisc affected much more quickly. Pieces of the stem were cut off and immersed in the same solution; and now the process of aggregation travelled up the hairs in a reversed direction; the cells close to the cut surfaces being first affected.

Primula sinensis.-The flower-stems, the upper and lower surfaces of the leaves and their footstalls, are all clothed with a multitude of longer and shorter hairs. The pedicels of the longer hairs are divided by transverse partitions into eight or nine cclls. The enlarged terminal cell is globular, forming a gland which secretes a variable amount of thick, slightly viscid, not acid, brownish-yellow matter.

A piece of a young flowc1-stem was first immersed in distilled water for 2 hrs. $30 \mathrm{~m}$., and the glandular hairs wcrc not at all affected. Another picce, bearing twenty-fire short and nine long hairs, was carcfully examined. The glands of the latter contained no solid or semi-solid matter; and those of only two 
of the twenty-five short hairs eontained some globules. This pieee was then immersed for 2 hrs. in a solution of one part of carbonate of ammonia to 109 of water, and now the glands of the twenty-five shorter hairs, with two or three exceptions, eontained either one large or from two to five smaller spherical masses of semi-solid matter. Three of the glands of the nine long hairs likewise included similar masses. In a few hairs there were also globules in the cells immediately beneath the glands. Looking to all thirty-four hairs, there eould be no doubt that the glands had absorbed some of the earbonate. Another pieee was left for only $1 \mathrm{hr}$. in the same solution, and aggregated matter appeared in all the glands. My son Franeis examined some glands of the longer hairs, whieh eontained little masses of matter, before they wcre immersed in any solution; and these masses slowly ehanged their forms, so that no doubt they consisted of protoplasm. He then irrigated these hairs for $1 \mathrm{hr}$. $15 \mathrm{~m}$., whilst under the mieroseope, with a solution of one part of the earbonate to 218 of water ; the glands were not pereeptibly affeeted, nor eould this have been expceted, as their contents were already aggregated. But in the eells of the pedicels numerous, almost colourless, spheres of matter appeared, whieh ehanged their forms and slowly coaleseed; the appcaranee of the cells being thus totally ehanged at sueeessive intervals of time.

The glands on a young flower-stem, after having been left for 2 hrs. $45 \mathrm{~m}$. in a strong solution of one part of the earbonate to 109 of water, contained an abundance of aggregated masses, but whether generated by the action of the salt, I do not know. This pieee was again plaeed in the solution, so that it was immersed altogether for 6 hrs. $15 \mathrm{~m}$., and now there was a great change ; for almost all the spherieal masses within the gland-eells had disappeared, being replaeed by granular matter of a darker biown. The experiment was thriee repeated with nearly the same result. On one oeeasion the pieee was left immersed for $8 \mathrm{hrs} .30 \mathrm{~m}$., and though almost all the spherical masses were ehanged into the brown granular matter, a few still remained. If the spherieal masses of aggregated matter had been originally produeed merely by some ehemieal. or physical action, it seems strange that a somewhat louger immersion in the same solution should so eompletely alter their charaeter. But as tho masses whieh slowly and spontaneously changed theil forms must lave consisted of living protoplasm, thero is nothing surprising in its being injured or killed, and its appearanee wholly ehanged by long immersion in so strong a solution of the earbonate as that 
employed. A solution of this strength paralyscs all movement in Drosera, but does not kill the protoplasm; a still stronger solution prevents the protoplasm from aggregating into the ordinary full-sized globular masses, and these, though they do not disintegrate, become granular and opaque. In nearly the same manner, too hot water and certrin solutions (for instance, of the salts of soda and potash) cause at first an imperfcct kind of aggregation in the cells of Drosera; the little masses aftcrwards breaking up into granular or pulpy brown matter. All the foregoing cxperiments wcre madc on flowerstems, but a piece of a leaf was immerscd for $30 \mathrm{~m}$. in a strong solution of the carbonate (one part to 109 of water), and little globular masses of matter appcared in all the glands, which before contrined only limpid fluid.

I made also several experiments on the aetion of the vapour of the carbonate on the glands; but will give only a few cases. The cut end of the footstalk of a young leaf was protented with sealing-wax, and was then placed undcr a small bell-glass, with a large pinch of the carbonate. Aftcr $10 \mathrm{~m}$, the glands showed a considcrable degrce of aggrcgation, and the protoplasm lining the cells of the pediccls was a little separated from the walls. Another leaf was left for $50 \mathrm{~m}$. with thc same result, excepting that the hairs became throughout their whole length of a brownish colour. In a third leaf, which was exposed for $1 \mathrm{hr}$. $50 \mathrm{~m}$., there was much aggregated matter in the glands; and some of the masses showed signs of breaking up into brown granular matter, This leaf was again plaeed in the rapour, so that it was cxposed altogether for 5 hrs. $30 \mathrm{~m}$; and nor, though I examined a large number of glands, aggregated masscs were found in only two or three; in all the othcrs, the masses, which before had been globular, werc eonverted into brown, opaque, granular matter. We this sce that cxposure to the vapour for a considerable time produces the same effects as long immersion in a strong solution. In both cases there could hardly be a doubt that the salt had been absorbed ehiefly or exclusivcly by the glands.

On anothcr oecasion bits of damp fibrin, drops of a weak infusion of raw meat and of water, wcre left for 24 hrs, on some lcaves; the hairs were then examined, but to my surprise differed in no respect from others whieh liad not becn touched by these fluids. Most of the cclls, however, included hyaline, motionless little spheres, which did not sccm to consist of protoplasm, but, I supposc, of somo balsam or essential oil.

P'elargonium zoncle (rar, edged witl white).-Tire lenves 
are elothed with numerous multicellular hairs; some simply pointed; others bearing glandular heads, and differing mueh in length. The glands on a piee of lcaf were examined and found to eontain only limpid fluid; most of the water was removed from beneath the eovering glass, and a minute drop of one part of carbonate of ammonia to 146 of water was added; so that an extremely small dose was given. After an interval of only $3 \mathrm{~m}$. there were signs of aggregation within the glands of the shorter hairs; and after $5 \mathrm{~m}$. many small globules of a pale brown tint appeared in all of them; similar globules, but larger, being found in the large glands of the longer hair's. After the speeimen had been left for $1 \mathrm{hr}$. in the solution, many of the smaller globules had ehanged their positions; and two or three vaeuoles or small spheres (for I know not whieh they were) of a rather darker tint appeared within some of the larger globules. Little globules could now be seen in some of the uppermost eells of the pediecls, and the protoplasmie lining was shightly separated from the walls of the lower eclls. After $2 \mathrm{hrs}, 30 \mathrm{~m}$. from the time of first immersion, the large globules within the glands of the longer hairs were eonverted into masses of darker brown granular matter. Henee from what we have seen with Primula sinensis, there ean be little doubt that these masses originally eonsisted of living protoplasm.

A drop of a weak infusion of raw meat was plaeed on a leaf', and after 2 hrs. $30 \mathrm{~m}$. many spheres eould be seen within the glands. These spheres, when looked at again after $30 \mathrm{~m}$, had slightly ehanged their positions and forms, and one had separated into two; but the ehanges were not quite like those whieh the protoplasm of Drosera undergoes. These hairs, moreover, had not been examined before immersion, and there were similar spheres in some glands which had not been tonehed by the infusion.

Erica tetralix. - A few long glandular hairs projeet from the margins of the upper surfaces of the leaves. The pedieels are formed of several rows of eells, and support rather large globular heads, seereting viseid matter, by whieh minute inseets are oeeasionally, though rarely, eaught. Some leaves were left for 23 hrs, in a weak infusion of raw meat and in water, and the hairs were then eompared, but they differed very little or not at all. In both eases the eontents of the eells seemed rather more granular than they were beforo; but the granules did not exhibit any movement. Other leaves were left for $23 \mathrm{hrs}$. in a solution of one part of earbonate of ammonia to 218 of water, and lere again the granular matter appeared to have inereased 
ill amount; but one such mass retained exactly the same form as before after an interval of $5 \mathrm{hr}$., so that it could hardly have consisted of living protoplasm. These glands scem to have vel'y little or no power of absorption, certainly much less than those of the forcgoing plants.

Mirabilis longiflora.-The stems and both surfaces of the lcaves bear viscid hairs. Young plants, from 12 to 18 inches in height in my greenhousc, caught so many minute Diptera, Colcoptcra, and larve, that they wcre quite dusted with them. The hairs are short, of unequal lengths, formed of a single row of cells, surmounted by an enlarged ccll which secretes viscid inatter. These terminal cells or glands contain granules and often globules of granular matter. Within a gland which had caught a small insect, one such mass was observed to undergo incessant changes of form, with the occasional appearance of vacuoles. But $I$ do not believe that this protoplasm had becn generated by mattcr absorbed from the dead insect; for, on comparing scveral glands which had and had not caught insects, not a shade of difference could be perccived between them, and they all contained fine granular matter. A piece of leaf was immerscd for 24 hrs. in a solution of one part of carbonate of ammonia to 218 of water, but the hairs seemed rery little affected by it, excepting that perhaps the glands were rendered lather morc opaque. In the leaf itself, however, the grains of chlorophyll near the cut surfaces had run together, or become aggregatcd. Nor wcre the glands on another leaf, after an immersion for 24 hrs, in an infusion of raw meat, in the least affected; but the protoplasm lining the cells of the pedicels had slrunk greatly from the walls. This latter effect may have been due to exosmose, as the infusion was strong. We may, therefore, conclude that the glands of this plant either have no power of absorption or that the protoplasm which they contain is not acted on by a solution of carbonate of ammonia (and this seems scarccly credible) or by an infusion of mcat.

Nicotiana tabacum.-This plant is covered with innumerable hairs of uncqual lengths, which catch many minute insects. The pedicels of the hairs are divided by transverse partitions, and the sccreting glands are formed of many cells, contrining grcenish mattcr with little globules of some substance. Lenves were left in an infusion of raw meat and in water for 26 hrs., but presented no differencc. Some of these same leaves werc then left for above 2 hrs. in a solution of carbonate of ammonia, but no effect was produced. I legrct that other experiments were not tried with morc care, as M. Schloesing 
has shown * that tobacco plants supplied with the vapour of carbonate of ammonia yield on analysis a greater amount of nitrogen than other plants not thus treated; and, from what we have seen, it is probable that some of the vapour may be absorbed by the glandular hair's.

\section{Summary of the Observations on Glandular Hairs.-} From the foregoing observations, few as thcy are, we see that the glands of two spccics of Saxifraga, of a Primula and Pelargonium, have the power of rapid absorption; whercas the glands of an Erica, Mirabilis, and Nicotiana, either have no such power, or the contents of the cells are not affected by the fluids employed, namely a solution of carbonate of ammonia and an infusion of raw mcat. As the glands of the Mirabilis contain protoplasm, which did not become aggregated from exposure to the fluids just named, though the contents of the cells in the blade of the leaf were greatly affected by carbonate of ammonia, we may infer that they cannot absorb. We may further infcr that the innumerable insects caught by this plant are of no more service to it than are those which adhere to the deciduous and sticky scales of the leaf-buds of the horse-chestnut.

The most interesting casc for us is that of the two specics of Saxifraga, as this genus is distantly allied to Drosera. Their glands absorb matter from an infusion of raw meat, from solutions of the nitrate and carbonate of ammonia, and apparently from dccayed insects. This was shown by the changed dull purple colour of the protoplasm within the cells of the glands, by its statc of aggregation, and apparently by its more rapid spontancous movements.

* 'Comptes renclus,' Juno 15, 1874. A good abstract of this paper is given in the 'Gardener's Chronicle,' July 11, 1874. 
The aggregating process spreads from the glands down the pedicels of the hairs; and wc may assume that any matter which is absorbed ultimately reaches the tissues of the plant. On the other hand, the process travels up the hairs whencver a surface is cut and exposed to a solution of the carbonate of ammonia.

The glands on the flower-stalks and leaves of Primula sinensis quickly absorb a solution of the carbonate of ammonia, and the protoplasm which they contain becomes aggregated. The process was seen in some cases to travel from the glands into the upper cells of the pedicels. Exposure for $10 \mathrm{~m}$. to the vapour of this salt likewise induecd aggregation. When leaves werc left from 6 hrs. to 7 hrs. in a strong solution, or were long exposed to the vapour, the little masses of protoplasm became disintegrated, brown, and granular, and were apparently killed. An infusion of raw meat produced no effect on the glands.

The limpid contents of the glands of Pelargonium zonale became cloudy and granular in from $3 \mathrm{~m}$. to $5 \mathrm{~m}$. when they were immersed in a wcak solution of the carbonate of ammonia; and in the course of $1 \mathrm{hr}$. granules appearcd in the upper cells of the pediccls. As the aggrcgated masses slowly changed their forms, and as they suffered disintegration when left for a considerable time in a strong solution, there can be little doubt that they consisted of protoplasm. It is doubtful whether an infusion of raw meat produced any effect.

The glandular hairs of ordinary plants have generally been 'considered by physiologists to serve only as secreting or excreting organs, but we now know that they have the powcr, at least in some cases, of absorbing both a solution and the vapour of ammonia. As rainwatcr contains a small percentage of ammonia, and the atmosphere a minute quantity of the carbonate, this 
power can hardly fail to be beneficial. Nor can the benefit be quite so insignificant as it might at first be thought, for a moderately fine plant of Primula sinensis bears the astonishing number of above two millions and a half of glandular hairs, ${ }^{*}$ all of which are able to absorb ammonia brought to them by the rain. It is moreover probable that the glands of some of the above named plants obtain animal matter from the insects which are occasionally entangled by the viscid secretion.

\section{Conchuding Remaris on the Droseraced.}

The six known genera composing this family have now been described in relation to our present subject, as far as my means have permitted. They all capture insects. This is effected by Drosophyllum, Roridula, and Byblis, solely by the viscid fluid secreted from their glands; by Drosera, through the same means, together with the movements of the tentacles; by Dionxa and Aldrovanda, through the closing of the blades of the leaf. In these two last genera rapicl

* My son Francis eounted the hairs on " $t$ spaee measured by means of a mierometer, and found that there wero 35,336 on a square inch of tho upper surfiee of a leaf, and 30,035 on the lower surfaee; that is, in about the proportion of 100 on the upper to 85 on the lower surtieo. On a square ineh of both surfiees there wero 6.5,371 hairs. A moderately fino plant bearing twelvo leaves (the larger ones being a little more than 2 inelies in diameter) was now sclected, and the arca of all the leaves, torgether with their foot-stalks (the flewer-stems not being included, was found by a planimeter to be $39 \cdot 285$ square inches; se that the area of beth surfaees was $78 \cdot 57$ squaro inehes. Thus the plant (exeluding the flower-stems) must have borme the astonishing number of $2,568,099$ glandular hairs. Tho hairs wero eounted late in tho autumn, and by the following spring (May) the leaves of some other plants of the same lot were found to be frem one-third to onefourth broader and longer than they were before; so that no doubt the glondular hairs had inerensed in number, and prehably now muel execeled three millions. 
movement makes up for the loss of viseid secretion. In every ease it is some part of the leaf whieh moves. In Aldrovanda it appears to be the basal parts alone which eontraet and earry with them the broad, thin margins of the lobes. In Dionæa the whole lobe, with the exeeption of the marginal prolongations or spikes, curves inwards, though the ehief seat of movement is near the midrib. In Drosera the ehief seat is in the lower part of the tentaeles, which, homologieally, may be eonsidered as prolongations of the leaf; but the whole blade often curls inwards, eonverting the leaf into a temporary stomaeh.

There ean hardly be a doubt that all the plants belonging to these six genera have the power of dissolving animal matter by the aid of their seeretion, 'vhich eontains an aeid, together with a ferment almost identieal in nature with pepsin; and that they afterwards absorb the matter thus digested. This is certainly the ease with Drosera, Drosophyllum, and Dionæa; almost eertainly with Aldrovanda; and, from analogy, very probable with Roridula and Byblis. We can thus understand how it is that the three firstnamed genera are provided with sueh small roots, and that Alcrovanda is quite rootless; about the roots of the two other genera nothing is known. It is, no doubt, a surprising faet that a whole group of plants (and, as we shall presently see, some other plants not allied to the Droseraeex) should subsist partly by digesting animal matter, and partly by deeomposing carbonic aeid, instead of exelusively by this latter means, together with the absorption of matter from the soil by the aid of roots. We have, howerer, an equally anomalous ease in the animal lingdom; the rhizoeephalous crustreeans do not feed like other animals by their mouths, for they are destitute of an 
alimentary eanal; but they live by absorbing through root-like proeesses the juices of the animals on which they are parasitic.*

Of the six genera, Drosera has been ineomparably the most suceessful in the battle for life; and a large part of its sueeess may be attributed to its manner of catehing inseets. It is a dominant form, for it is believed to include about 100 species, $\uparrow$ which range in the Old World from the Aretie regions to Southern India, to the Cape of Good Hope, Madagasear, and Australia; and in the New World from Canada to Tierra del Fuggo. In this respeet it presents a marked eontrast with the five other genera, which appear to be failing groups. Dionæa includes only a single species, which is eonfined to one distriet in Carolina. The three varieties or closely allied speeies of Aldrovanda, like so many water-plants, have a wide range from Central Europe to Bengal and Australia. Drosophyllum ineludes only one species, limited to Portugal and Moroeeo. Roridula and Byblis each have (as I

* Fritz Müller, 'Facts for Darwin,' Eng. trans. 1869, p. 139. 'The rhizoceplialous crustaccans aro allied to the cirripedes. It is hardly possible to imargine a greater difference than that between an animal with prehonsile limbs, a wellconstrueterl mouth and alimentary canal, and ono destitute of all these organs aud feeding by absorption through brauching rootlike processes. If one rure cirriporle, the Anelasma squalirolr, liml become extirict, it woulel have been very diffieult to conjecturo how so cnormous a change could have been gralually effecterl. But, as Fritz Miiller remarks, we have in Anolasma an animal in an almost exactly intermediatc condition, for it has root-like processes cmbedded in tho skin of the shark on which it is parasitic, and its prehensile cirri and mouth (as deseribed in my monograph on the Leparlide, 'Ray Soc.' 1851 , p. 169) are in a most fecble and almost rudimentary condition. Dr. R. Kossmann has given a very interesting dischssion on this subject in his 'Snctoria and Lcparliclio,' 1873. Sco also, Dr. Dohrn, "Der Ursprung dor Wirbeltliero,' 1875, p. 77.

† Bentham and Honker, 'Generu Plantarum.' Anstulia is the metropolis of the genus, forty-one species having been described from this eountry, as Prol. Oliver informs ine. 
hear from Prof. Oliver) two species; the former confined to the western parts of the Cape of Good Hope, and the latter to Australia. It is a strange fact that Dionse, which is one of the most beautifully adapted plants in the regetable liugdom, should apparently be on the high-road to extinetion. This is all the more strange as the organs of Dionæa are more highly differentiated than those of Drosera; its filaments serve exelusively as organs of touch, the lobes for eapturing inseets, and the glands, when excited, for secretion as well as for absorption; whereas with Drosera the glands serve all these purposes, and secrete without being exeited.

By comparing the structure of the leaves, their degree of complication, and their rudimentary parts in the six genera, we are led to infer that their common parent form partook of the charaeters of Drosophyllum, Roridula, and Byblis. The leaves of this ancient form were almost eertainly linear, perhaps divided, and bore on their upper and lower surfaees glands which had the power of secreting and absorbing. Some of these glands were mounted on pedicels, and others were almost sessile; the latter secreting only when stimulated by the absorption of nitrogenous matter. In Byblis the glands consist of a single layer of cells, supported on a unicellular pedieel; in Roridula they have a more complex structure, and are supported on pedicels formed of several rows of cells; in Drosophyllum they further include spiral eells, and the pediecls include a bundle of spiral vessels. But in these three genera these organs do not possess any powcr of morement, and there is no reason to donbt that they are of the nature of hairs or triehomes. Althongh in innumerable instances foliar organs more when cxeited, no case is linown of a trichome having snch 
power.* We are thus led to inquire how the so-ealled tentacles of Drosera, whieh are manifestly of the same general nature as the glandular hairs of the above three genera, eould have aequired the power of moving. Many botanists maintain that these tentaeles consist of prolongations of the leaf, because they inelude vaseular tissue, but this can no longer be eonsidered as a trustworthy distinction. $\dagger$ The possession of the power of movement on exeitement would have been safer evidenee. But when we eonsider the vast number of the tentaeles on both surfaces of the leaves of Drosophyllum, and on the upper surfaee of the leaves of Drosera, it seems searcely possible that each tentaele could have aboriginally existed as a prolongation of the leaf. Roridula, perhaps, shows us how we may reeoneile these diffieulties with respect to the homologieal nature of the tentaeles. The lateral divisions of the leaves of this plant terminate in long tentacles; and these include spiral vessels whieh extend for only a short distanee up them, with no line of demareation between what is plainly the prolongation of the leaf and the pedieel of a glandular hair. Therefore there would be nothing anomalous or unusual in the basal parts of these tentacles, whieh eorrespond with the marginal ones of Drosera, aequiring the power of movement; and we know that in Drosera it is only the lower part whieh becomes infleeted. But in order to understand how in this latter genus not only the marginal but all the inner tentaeles have beeome eapable of movement, we must further assume, either that through the prineiple of correlated development this

* Sachs, 'Traité de Botanique,' 3rd edit. 1874, p. 1026 .

+ Dr. Warming, 'Sur la Différenec entre les 'Trichomes,' Copes- hague, 1873, p. 6. 'Extrnit des Videnskabeligo Meddelelser de la Soc. d'Hist. nat. cle Copenliague,' Nos. 10-12, 1872. 
powcr was transferred to the basal parts of the hairs, or that the surfaee of the leaf has been prolonged upwards at numerous points, so as to unite with the hairs, thus forming the bases of the inner tentacles.

The above named three gencra, namely Drosophyllum, Roridula, and Byblis, which appear to have retained a primordial condition, still bear glandular hairs on both surfaces of their leaves; but those on the lower surfaee have since disappeared in the more highly developed genera, with the partial exception of one species, Drosera binata. The small sessile glands have also disappearcd in some of the genera, bcing replaced in Roridula by hairs, and in most speeies of Drosera by absorbent papilla. Drosera binata, with its linear and bifurcating leaves, is in an intermediate eondition. It still bears some sessile glands on both surfaces of the leaves, and on the lower surface a fow irregularly placed tentacles, which are incapable of movement. A further slight change would convert the linear leaves of this latter species into the oblong leaves of Drosera anglica, and these might easily pass into orbieular ones with footstalks, like those of Drosera rotundifolia. The footstalks of this latter species bear multicellular hairs, which we hare good reason to believe represent aborted tentacles.

The parent form of Dionea and Aldrovanda seems to have been closely allied to Droscra, and to have had rounded leaves, supported on distiuct footstalks, and furnished with tentacles all round the circumference, with other tentacles and sessile glands on the upper surface. I think so because the marginal spikes of Dionæa apparently represent the extreme marginal tentacles of Drosera, the six (sometimes eight) sensitive filaments on the upper surface, as well as the more numerous ones in Aldrovanda, representing the central 
tentacles of Drosera, with their glands aborted, but their sensitiveness retained. Under this point of view we should bear in mind that the summits of the tentaeles of Drosera, elose beneath the glands, are sensitive.

The three most remarkable eharacters possessed by the several members of the Droseracer consist in the leares of some having the power of movement when exeited, in their glands secreting a fluid whieh digests animal matter, and in their absorption of the digested matter. Can any light be thrown on the steps by whieh these remarkable powers were gradually aequired?

As the walls of the cells are neeessarily permeable to fluids, in order to allow the glands to seerete, it is not surprising that they should readily allow fluids to pass inwards; and this inward passage would deserve to be ealled an aet of absorption, if the fluids eombined with the eontents of the glands. Judging from the evidenee above given, the seereting glands of many other plants ean absorb salts of ammonia, of which they must reeeive small quantities from the rain. This is the case with two speeies of Saxifraga, and the glands of one of them apparently absorb matter from captured inseets, and certainly from an infusion of raw meat. There is, therefore, nothing anomalous in the Droserneex having aequired the power of absorption in a much more highly developed degree.

It is a far more remarkable problem how the members of this family, and Pinguicula, and, as Dr. Hooker has recently shown, Nepenthes, eould all have aequired the power of secreting a fluid which dissolves or digests animal matter. The six genera of the Droseracese have probably inherited this power from a eommon progenitor, but this cannot apply to 
Pinguicula or Nepenthes, for these plants are not at all closely related to the Droseracex. But the difficulty is not nearly so great as it at first appears. Firstly, the juices of many plants contain an acid, and, apparently, any acid serves for digestion. Secondly, as Dr. Hooker has remarked in relation to the present subject in his address at Belfast (1874), and as Sachs repeatedly insists, ${ }^{*}$ the embryos of some plants secrete a fluid which dissolves albuminous substances out of the endosperm; although the endosperm is not actually united with, only in contact with, the embryo. All plants, moreover, have the power of dissolving albuminous or proteid substances, such as protoplasm, chlorophyll, gluten, aleurone, and of carrying them from one part to other parts of their tissues. This must be effected by a solvent, probably consisting of a ferment together with an acid. $\dagger$ Now, in the case of plants which are able to absorb already soluble matter from captured insects, though not capable of true digestion, the solvent just referred to, which must be occasionally present in the glands, would be apt to exude from the glands together with the viscid secretion, inasmuch as endosmose is accompanied by exosmose. If such exudation did ever occur, the solvent would act on the animal matter contained within the captured insects, and this would be an act of true digestion. As it cannot be doubted that this process would be of high service to plants

* 'Traitć de Botanique,' 3rd edit. 1874, p. 844. Sce also for following ficts pp. 64, 76, 828, 831.

+ Since this sentence was writton, I have rescived a paper by Gorup-Besanez ('Berichte del' Deutschen Chem. Gescllschatt,
Berlin, 1874, p. 1478), who, with the nid of Dr. H. Will, has aotually unde the discovery that the scuds of the retch contrin a ferment, which, when extrieted by glyccrinc, dissolves albuminous substances, such as fibriu, and converts them into truo peptones. 
growing in very poor soil, it would tend to be perfeeted through natural seleetion. Thereforc, any ordinary plant having viseid glands, which oeeasionally eanght inseets, might thus be converted under favourable cirelimstanees into a species capable of true digestion. It eeases, therefore, to be any great mystery how several genera of plants, in no way elosely related together, hare independently aequired this same power.

As there exist several plants the glands of which cannot, as far as is known, digest animal matter, yet can absorb salts of ammonia and animal fluids, it is probable that this latter power forms the first stage towards that of digestion. It might, however, happen, under eertain eonditions, that a plant, after having aequired the power of digestion, should degencrate into one capable only of absorbing animal matter in solution, or in a state of decay, or the final products of decay, namely the salts of ammonia. It would appear that this has aetually oecurred to a partial cxtent with the leaves of Aldrovanda; the outer parts of which possess absorbent organs, but no glands fitted for the seeretion of any digestive fluid, these being eonfined to the inner parts.

Little light ean be thrown on the gradual nequirement of the third remarkable character possessed by the more highly developed genera of the Droseraeex, namely the power of movement when exeited. It should, however, be borne in mind that leaves and their homologucs, as well as flower-peduncles, have gained this power, in innumerable instanees, independently of inheritance from any common parent form; for instance, in tendril-bearcrs and leaf-climbers (i. e. plants with their leaves, petioles and flower-peduneles, \&e., modified for prehension) belonging to a large 
number of the most widely distinct orders,--in the leaves of the many plants whieh go to sleep at night, or move when shaken,- -and in the irritable stamens and pistils of not a few species. We may therefore infer that the power of movement ean be by some means readily aequired. Sueh movements imply irritability or sensitiveness, but, as Cohn has remarked,* the tissues of the plants thus endowed do not differ in any uniform manner from those of ordinary plants; it is therefore probable that all leaves are to a slight degree irritable. Even if an insect alights on a leaf, a slight moleeular ehange is probably transmitted to some distanee aeross its tissue, with the sole differenee that no pereeptible effeet is produeed. We have some evidenee in favour of this belief, for we know that a single touch on the glands of Drosera does not exeite infleetion; yet it must produce some effeet, for if the glands have been immersed in a solntion of camphor, inflection follows within a shorter time than would have followed from the effeets of eamphor alone. So again with Dionæa, the blades in their ordinary state may be roughly touehed without their elosing; yet some effeet must be thus eansed and transmitted aeross the whole leaf, for if the glands have reeently absorbed animal matter, even a delieate toueh causes them to close instantly. On the whole we may eonelude that the aequirement of a high degree of sensitiveness and of the power of movement by eertain genera of the Droseraeex presents no greater diffieulty than that presented by the similar but feebler powers of a multitude of other plants.

* Sce the abstract of his memoir on the contractile tissues of plants, in the 'Annals and
Mag. of Nat. Hist.' 3rd series, vol. xi. p. 188. 
The specialised naturc of the sensitiveness possessed by Drosera and Dionæa, and by certain other plants, well deserves attention. A gland of Drosera may be forcibly hit once, twice, or even thrice, without any effect being produced, whilst the continued pressure of an extrcmely minute particle excites movement. On the other hand, a particle many times heavier may be gently laid on onc of the filaments of Dionæa with no effect; but if touched only once by the slow movement of a delicate hair, the lobes close; and this difference in the nature of the sensitiveness of these two plants stands in manifest adaptation to their manner of capturing insects. So does the fact, that when the central glands of Drosera absorb nitrogenous matter, they transmit a motor impulse to the exterior tentacles much more quickly than when they are mechanically irritated; whilst with Dionæa the absorption of nitrogeneous matter causes the lobes to press together with extreme slowness, whilst a touch excites rapid movement. Somewhat analogous cases may be observed, as I have shown in another work, with the tendrils of rarious plants; some being most excited by contact with fine fibres, others by contact with bristles, others with a flat or a creviced surface. The sensitive organs of Drosera and Dionæa are also specialised, so as not to be uselessly affected by the weight or impact of drops of rain, or by blasts of air. This may be accounted for by supposing that these plants and their progenitors have grown accustomed to the repeated action of rain and wind, so that no molecular change is thus induced; whilst they have been rendered more sensitive by means of natural selection to the rarer impact or pressure of solic bodies. Although the absorption by the glands of Drosera of various fluids excites move- 
ment, there is a great difference in the action of allied fluids; for instance, between certain vegetable acids, and between eitrate and phosphate of ammonia. The specialised nature and perfection of the sensitiveness in these two plants is all the more astonishing as no one supposes that they possess nerves; and by testing Drosera with several substances which act porverfully on the nervous system of animals, it does not appear that they include any diffused matter analogous to nerve-tissue.

Although the cells of Drosera and Dionza are quite as sensitive to eertain stimulants as are the tissues which surround the terminations of the nerves in the higher animals, yet these plants are inferior even to animals low down in the seale, in not being affected except by stimulants in eontact with their sensitive parts. They would, however, probably be affected by radiant heat; for warm water excites energetic movement. When a gland of Drosera, or one of the filaments of Dionza, is excited, the motor impulse radiates in all directions, and is not, as in the case of animals, directed towards special points or organs. 'This holds good even in the case of Drosera when some exciting substance has been plaeed at two points on the disc, and when the tentacles all round are inflected with marvellous precision towards the two points. The rate at which the motor impulse is transmitted, though rapid in Dionaa, is mueh slower than in most or all animals. This fact, as well as that of the motor impulse not being specially directed to eertain points, are both no doubt due to the absence of nerves. Nevertheless we perhaps see the prefigurement of the formation of nerves in animals in the transmission of the motor impulse being so much more rapid down the eonfined space within the tentacles of Drosern than 
elsewhere, and somewhat more rapid in a longitudinal than in a transverse direction across the disc. These plants exhibit still more plainly their inferiority to animals in the absenec of any reflex action, except in so far as the glands of Droscra, when cxcitcd from a distance, send back some influence which causes the contents of the cells to become aggregated down to the bases of the tentacles. But the greatest iuferiority of all is the absence of a central organ, able to reccive impressions from all points, to transmit their effects in any definite direction, to store them up and reproduce them. 


\section{CHAPTER XVI.}

\section{Pinguiglla.}

Pinguicula vulgaris - Strueture of leaves - Number of insects and other objeets eaught-Movement of the margins of the leares Uses of this movement - Seeretion, digestion, and absorption Action of tho seeretion on various animal and regetable substances - The effects of substances not eontaining soluble nitrogenons matter on the glands - Pinguicula grandifiora - Pinguicula lusitanica, eatches inseets-Movement of the leaves, secretion and digestion.

Pinguicula vulgaris. - This plant grows in moist places, generally on mountains. It bears on an average eight, rather thick, oblong, light green leaves, having searcely any footstalk. A full-sized leaf is about $1 \frac{1}{2}$ inch in length and $\frac{3}{4}$ inch in breadth. The young eentral leaves are deeply coneave, and project upwards; the older ones towards the outsicle are flat or convex, and lie close to the ground, forming a rosette from 3 to 4 inches in diameter. The margins of the leaves are incurved. Their upper surfaces are thickly covered with two sets of glandular hairs, differing in the size of the glands and in the length of their pedicels. The larger glands have a cireular outline as seen from above, and are of moderate thickness; they are divided by radiating partitions into sixteen cells, containing light-green, homogeneous fluid. They are supported on elongated, unicellular pedieels (containing a nucleus with a nueleolus) which rest on slight prominences. The small glands differ only in being formed of about half the number of cells, contrining much paler fluid, and supported on much shorter pedieels. Near the midrib, towards the base of the leaf, the 
pedicels are multicellular, are longer than elsewhere, and bear smaller glands. All the glands secrete a colourless fluid, which is so viscid that I have seen a fine thread drawn out to a length of 18 inches; but the fluid in this case was secreted by a gland which had been excited. The edge of the leaf is translucent, and does not bear any glands; and here the spiral vessels, proceeding from the midrib, terminate in cells marked by a spiral line, somewhat like those within the glands of Drosera.

The roots are short. Three plants were dug up in North Wales on June 20, and carefully washed; each bore five or six unbranched roots, the longest of which was only 1.2 of an inch. Two rather young plants were examined on September 28; these had a greater number of roots, namely eight and eighteen, all under 1 inch in length, and very little branched.

I was led to investigate the habits of this plant by being told by Mr. W. Marshall that on the mountains of Cumberland many insects adhere to the leaves.

A friend scrt me on June 23 thirty-nine leaves from North Wales, which were selected owing to objeets of some kind adlering to them. Of these leaves, thirty-two had caught 142 inscets, or on an average 44 per leaf, minute fragments of insects not being included. Besides the inscets, small leaves belonging to four different linds of plants, those of Erica tetralix being much the commonest, and three minute seedling plants, blown by the wind, adhered to nineteen of the leaves. One had caught as many as ten leaves of the Erica. Seeds or fruits, commonly of Carex and one of Juneus, besides bits of moss and other rubbish, likewise adhered to six of the thirty-nine leaves. The same friend, on June 27, colleeted nine plants bearing seventy-four leaves, and all of these, with the execption of thrce young leaves, had cought insoets; thirty inscets were counted on one leaf, cighteen on a sceond, and sixteen on a third. Another friend examined on August 22 some plants in Donegal, Ireland, and found insects on 70 out of 157 leaves; fiftecn of 
these leaves were sent me, cach having caught on an average $2 \cdot 4$ insects. To nine of them, lcaves (mostly of lirica tetialix) adhered; but they had becn specially selected on this latter account. I may add that early in August my son found leaves of this same Erica and the fruits of a Carex on the learcs of a Pinguicula in Switzerland, probably Pinguicula alpina; some insects, but no great number, also adhercd to the leaves of this plant, whieh had much bettcr developed roots than those of Pinguirula vulgaris. In Cumberland, Mr. Marshall, on Scptember 3, earefully examined for mc ten plants bearing eighty leaves; and on sixtythree of thesc (i.e. on 79 per cent.) he found inseets, 143 in number; so that eaeh lcaf had on an average 227 insects. A few days latcr he sent ime some plants with sixtecn sceds ol fruits adhcring to fourteen lcaves. There was a seed on three leaves on the same plant. The sixteen seeds bclonged to nine different kinds, which could not be recognised, cxcepting one of Ranunculus, and several belonging to three or four distinct species of Carex. It appears that fewer insects are eaught late in the year than earlier; thus in Cumberland from twenty to twenty-four inseets were obscrved in the middle of July on several lenves, whereas in the beginning of September the average number was only $2 \cdot 27$. Most of the insects, in all the foregoing cases, were Diptcra, but with many minute Hymenoptera, including some ants, a few small Colcoptera, larvæ, spiders, and even small moths.

We thus sce that numerous insects and other objects are caught by the viscid leaves; but wc have no right to infer from this fact that the habit is beneficial to the plant, any more than in the bcfore given case of the Mirabilis, or of the horse-chestnnt. But it will presently be seen that dead insects and other nitrogenous bodies excite the glands to increased secretion; and that the secretion then becomes acid and has the power of digesting animal substances, such as albumen, fibrin, \&c. Moreover, the dissolved nitrogenous matter is absorbed by the glands, as shown by their limpid contents being aggregated into slowly moring granular masses of protoplasm. The same results follow when insects arc naturally captured, and as the plant lives in poor soil and has small roots, there can be 110 
doubt that it profits by its power of digesting and absorbing matter from the prey which it habitually captures in such large numbers. It will, however, be convenient first to describe the movements of the leaves.

Movements of the Leaves. - That such thick, large leaves as those of Pinguicula vulgaris should have the power of curving inwards when excited has never even been suspecterl. It is necessary to select for experiment leares with their glands secreting freely, and which have been prevented from capturing many insects; as old leaves, at least those growing in a state of nature, have their margins already curled so much invards that they exhibit little power of movement, or move very slowly. I will first give in detail the more important experiments which were tried, and then make some concluding remarks.

Experiment 1.-A young and almost upright leaf was seleeted, with its two lateral edges equally and very slightly ineurved. A row of small flies was plaeed along one margin. When looked at next day, after 15 hrs., this margin, but not the other, was found folded inwards, like the helix of the human ear, to the breadth of $\frac{1}{10}$ of an ineh, so as to lie partly over the row of flies (fig. 15). The glands on which the flies rested, as well as those on the orerlapping margin which had been brought into eontaet with the flies, were all scereting: eopiously.

Lixperiment 2. $-\Lambda$ row of flies was plaeed on one margin of a rather old leaf, whieh lay flat on the ground; and in this ease the margin, after the samo interval as before, namely 15 hrs., had only just begun to curl inwards; but so mueh secretion had been poured forth that the spoonshaped tip of the leaf was filled with it.

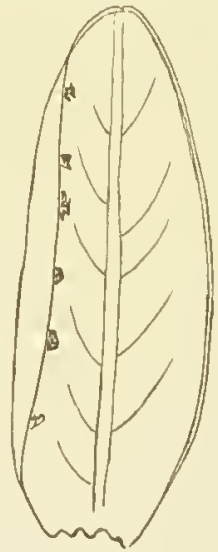

Fig. 15.

('inguicula vulgaris.)

Outline of lear with left margin inflected over is row of small flies.

Experimene 3.-Fragments of a largo fly were placed close to the apex of a vigorous leaf, as woll as aloug half one margiw. 
Aftcr 4 hrs. $20 \mathrm{~m}$. there was deeided incurvation, whieh increascd a little during the aftcrnoon, but was in the same state' on the following morning. Near the apex both margins were inwardly curved. I have never scch a case of the apcx itself being in the least curved towards the base of the lcaf. After 48 hrs. (always reckoning from the time when the flics were plaeed on the leaf) the margin had everywhere begun to unfold.

Experiment 4.-A large fragment of a fly was placed on a leaf, in a mcdial line, a little bencath the apex. Both lateral margins were perecptibly incurved in 3 hrs, and after 4 hrs. $20 \mathrm{~m}$. to such a degree that the fragment was clasped by both margins. Aftcr 24 hrs. the two infolded edges near the apcx (for the lomer part of the leaf was not at all affectcd) were measured and found to be 11 of an inch $(2.794 \mathrm{~mm}$.) apart. The fly was now removed, and a strcam of watcr poured over the leaf so as to wash the surface; and after 24 hrs. the margins were 25 of an ineh $(6.349 \mathrm{~mm}$.) apart, so that they werc largely unfolded. After an additional 24 hrs. they werc complctely unfolded. Another fly was now put on the same spot to sce whethcr this leaf, on which the first fly had been left 24 hrs., would move again; aftcr 10 hrs. therc was a traee of ineurvation, but this did not inerease during the next 24 hrs. A bit of mcat was also placed on the margin of a leaf, which four days previously had bccome strongly incurved over a fragment of a fly and had aftermards re-expanded; but the mcat did not causc cren a trace of incurvation. On the contriry, the margin became somewhat rcflexed, as if injured, and so rcmained for the three following days, as long as it was obser'red.

Experiment 5.-A large fragment of a fly was placed halfwny betwcen the apcx and base of a leaf and halfway bctween the midrib and one margin. A short spacc of this margin, opposite the fly, showed a trace of incurvation after 3 hrs., and this bccame strongly pronounced in 7 lirs. After 24 hrs. the infolded edge was only 16 of an inch $(4.064 \mathrm{~mm}$.) from the midrib. The margin now began to unfold, though the fly was left on the leaf; so that by the ncxt morning (i.e. 48 hrs. from the time when the fly was first put on) the infolded edge had almost eompletely rceovered its original position, being now 3 of an inch $(7.62 \mathrm{~mm}$.), instead of 16 of an inch, from the midrib. A traee of flexurc was, howevcr, still visible.

Laperiment 6.-A young and conearc leaf was sclected with its margins slightly and naturally ineurved. Two rather large, oblong, rcetangular pieecs of roast meat werc placed with their. ends touching the infolded edge, and 46 of an inch ( $11.68 \mathrm{~mm}$.) 
apart from onc another. After 24 hr's. the margin was greatly and equally incurved (see fig. 16) throughout this space, and for a length of 12 or 13 of an inch ( 3.018 or $3.302 \mathrm{~mm}$.) above and below each bit; so that the margin had becn affected over $\Omega$ greater length betwcen the two bits, owing to their conjoint action, than beyond them. The bits of meat were too large to be elasped by the margin, but they were tilted up, one of them so as to stand almost vertically. After 48 hrs. the margin was almost untolded, and the bits had sunk down. When again examined after two days, the margin was quite unfolded, with the exception of the naturally inflected edge; and one of the bits of meat, the end of which had at first tonched the edge, was now 067 of an ineh $(1.69 \mathrm{~mm}$.) distant from it; so that this bit liad becn pushed thus far across the blade of the leaf.

Experiment 7.-A bit of meat was placed close to the incurverl edge of a rather young leaf, and after it had re-cxpanded, the bit was left lying 11 of an inch $(2.794 \mathrm{~mm}$.) from the cdge. The distance from the edge to the midrib of the fully expanded leaf was 35 of an ineh $(8.89 \mathrm{~mm}$.); so that the bit had bcen pushed inwards and across nearly one-third of its semi-diametcr.

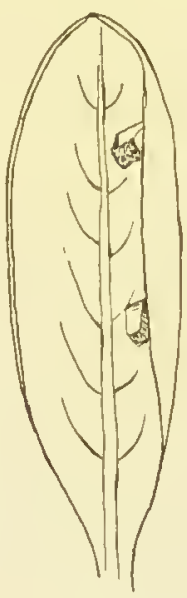

F1G 16.

(Pinguicula vulgaris.)

Outline of leaf, with right margin inflected against two Equare bits of meat.

Experiment S. - Cubes of sponge, soaked in a strong infusion of raw meat, were placed in elose eontact with the incurved edges of two lcaves, - an older and younger onc. The distance from the edges to the midribs was earefully measured. After $1 \mathrm{hr} .17 \mathrm{~m}$. there appeared to be a trace of incurvation. After 2 his. $17 \mathrm{~m}$. both leaves. were plainly infleeted; the distance between the edges and midribs being now only half what it was at first. 'The ineurvation increased slightly during the next $4 \frac{1}{2}$ hrs.s., but remained nearly the same for the next 17 hrs. $30 \mathrm{~m}$. In 35 lirs. from the time when the sponges were placed on the leares, the margins were a little unfolded-to a greater degree in the younger than in the older leaf. The latter was not quite unfolded until the third dry, and now hoth bits of sponge wcre left at the distance of 1 of an ineh $(2.54 \mathrm{~mm}$,) from the edges; or about a quarter of the distance betwecn tlue edge and midrib. A third bit of sponge adhered to the erlge, and, as the margin unfolded, was dragged backwards, into its original position. 
Experiment 9.-A ehain of fibres of roast meat, as thin as bristles and moistened with saliva, were placed down one whole side, elose to the narrow, naturally incurved edge of a leaf. In 3 hrs. this side was greatly ineurred along its whole length, and after 8 hrs. formed a cylinder, about $\frac{1}{2} \frac{1}{0}$ of an inch $(1 \cdot 27$ $\mathrm{mm}$.) in diameter, quite concealing the meat. This eylinder remained elosed for 32 hrs., but after 48 hr's. was half unfolded, and in $72 \mathrm{hrs}$. was as open as the opposite margin where no meat had been placed. As the thin fibres of meat were eompletely overlapped by the margin, they were not pushed at all inwards, across the blade.

Experiment 10.-Six cabbage seeds, soaked for a night in water, were plaeed in a row close to the narrow incurved edge of a leaf. We shall hereafter see that these seeds yield soluble matter to the glands. In 2 hrs. $25 \mathrm{~m}$. the margin was decidedly inflected; in 4 hrs. it extended over the seeds for about half their breadth, and in 7 hrs. over three-fourths of their breadth, forming a cylinder not quite closed along the inner side, and about .7 of an inch $(1.778 \mathrm{~mm}$.) in diameter. After 24 hrs. the inflection had not increased, perhaps had decreased. The glands which had been brought into eontact with the upper surfaees of the seeds were now secreting freely. In 36 hrs. from the time when the seeds were put on the leaf the margin had greatly, and after 48 hrs. had completely, re-expanded. As the seeds were no longer held by the inflected margin, and as the seeretion was beginning to fail, they rolled some way down the marginal channel.

Experiment 11. - Fragments of glass were placed on the margins of two fine young leaves. After 2 hrs. $30 \mathrm{~m}$. the margin of one eertainly became slightly ineurved; but the inflection never inereased, and disappeared in $16 \mathrm{hrs} .30 \mathrm{~m}$. from the time when the fragments were first applied. With the second leaf there was a trace of incurvation in 2 hrs. $15 \mathrm{~m}$., whieh beeame decided in $4 \mathrm{hrs}$. $30 \mathrm{~m}$., and still more strongly pronounced in 7 hrs., but after 19 hrs. $30 \mathrm{~m}$. lhad plainly decreased. The fragments excited at most a slight and doubtful inerease of the secretion; and in two other trials, no increase conld be perecived. Bits of coal-cinders, placed on a leaf, produced no effect, either owing to their lightness or to the leaf being torpid.

Experiment 12.-We will now turn to fluids. A row of drops of a strong infusion of law ment were plaeed along the margins of two leaves; squares of sponge soaked in the same infusion being plaeed on the opposito margins. My object was to ascer- 
tain whether a fluid would act as cnergetically as a substance yielding the same solublo mattcr to the glands. No distinct differcneo was perceptible; ccrtainly none in the degrec of incurvation; but the incurvation round the bits of sponge lasted rather longer, as might perhaps have been cxpected from the sponge remaining damp and supplying nitrogenous matter for a longer time. The margins, with the drops, became plainly incurved in $2 \mathrm{hrs} .17 \mathrm{~m}$. The incurvation subscquently increased somewhat, but after $2 \pm$ hrs. had grcatly dccreased.

Expreriment 13.-Drops of the same strong infusion of raw meat were placed along the midrib of a young and rather deeply concare lcaf. The distance across the broadest part of the leaf, between the naturally incurved edges, was 55 of an inch $(13.97$ $\mathrm{mm}$.). In 3 hrs. $27 \mathrm{~m}$. this distance was a trace less; in 6 hrs. $27 \mathrm{~m}$. it was cxactly 45 of an inch $(11.43 \mathrm{~mm}$.), and had therefore decreascd by 1 of an inch ( $2.54 \mathrm{~mm}$.). Aftcr only $10 \mathrm{hrs} .37 \mathrm{~m}$. the margin began to re-cxpand, for the distance from edge to edge was now a trace wider, and after 24 hrs. $20 \mathrm{~m}$. was as great, within a hair's breadth, as when the drops were first placed on the leaf. From this experiment we learn that the motor impulsc can be transmitted to a distance of 22 of an inch $(5.588 \mathrm{~mm}$.) in a transverse direction from the midrib to both margins; but it would be safer to say ' 2 'of an inch (5.08 mm.), as the drops spread a little beyond the midrib. The incurvation thus caused lasted for an unusually short time.

Experimerit 14.-Three drops of a solution of one part of carbonate of aminonia to 218 of water (2 grs. to $1 \mathrm{oz}$.) were placed on the margin of a leaf. These cxcited so much sccretion that in $1 \mathrm{~h} .22 \mathrm{~m}$. all thrce drops ran together; but althongh the leaf was observed for $24 \mathrm{hrs}$, , therc was no trace of inflection. We know that a rather strong solution of this salt, though it does not injure the leares of Droscra, paralyses their power of movement, and I have no doubt, from the following casc, that this holds good with Pinguicula.

Experiment 15.-A row of drops of a solution of one part of carbonate of ammonia to 875 of water ( $1 \mathrm{gr}$. to $2 \mathrm{oz}$.) was placed on the margin of a leaf. In 1 hr. there was apparently some slight incurvation, and this was well marked in $3 \mathrm{hrs} .30 \mathrm{~m}$. After 24 hrs. the margin was almost completely re-cxpanded.

Experiment 16. - A row of large drops of a solution of one part of phosphate of ammonia to 4375 of water ( $1 \mathrm{gr}$. to $10 \mathrm{oz}$.) was placed along the margin of a leaf. No effect was produced, and after 8 hrs. fresh drops woro added along the same margin without the least effect. We know that a solution of this 
strength aets powerfully on Drosera, and.it is just possible that the solution was too strong. I regret that I did not try a weaker solution.

Experiment 17.-As the pressure from hits of glass causes incurvation, I seratehed the margins of two leaves for some minutes with a blunt needle, but no effeet was produeed. The surface of a leaf beneath a drop of a strong infusion of raw meat was also rubbed for 10 . $\mathrm{m}$. with the end of a hristle, so as to imitate the struggles of a enptured inseet; but this part of the margin did not bend sooner than the other parts with undisturbed drops of the infusion.

$W_{c}$ learn from the foregoing experiments that the margins of the leaves curl inwards when excited by the mere pressure of objects not yielding any soluble matter, by objects yielding such matter, and by some fluids-namcly an infusion of raw meat and a weak solution of carbonate of ammonia. A stronger solution of two grains of this salt to an ounce of water, though exciting copious secretion, paralyses the leaf. Drops of water and of a solution of sugar or gum did not cause any movement. Scratching the surface of the leaf for some minutes produced no effect. Therefore, as far as we at present know, only two causes-namely slight continued pressure and the absorption of nitrogenous matter-excite movement. It is only the margins of the leaf which bend, for the apex nerer curves towards the base. The pedicels of the glandular hairs have no power of movement. I observed on several occasions that the surface of the leaf became slightly concave where bits of meat or large flies had long lain, but this may have been due to injury from over-stimulation.

The shortest time in which plainly marked morement was observed was 2 hrs. $17 \mathrm{~m}$., and this occurred when either nitrogenous substances or fluids were placed on the leaves; but I bclicve that in some cases 
there was a trace of movement in $1 \mathrm{hr}$. or $1 \mathrm{hr} .30 \mathrm{~m}$. The pressurc from fragments of glass excites movement almost as quickly as the absorption of nitrogenous matter, but the degrec of incurvation thus caused is much. lcss. After a leaf has become well incurved and has again expanded, it will not soon answer to a fresh stimulus. The margin was affected longitudinally, upwards or downwards, for a distance of - 13 of an inch ( $3.302 \mathrm{~mm}$.) from an excited point, but for a distance of 46 of an inch between two excited points, and transversely for a distance of '2 of an inch (5.08 mm.). The motor impulse is not accompanied, as in the case of Drosera, by any influence causing increased secretion; for when a single gland was strongly stimulated and secreted copiously, the surrounding glands were not in the least affected. The incurvation of the margin is independent of increased sccretion, for fragments of glass cause little or no secretion, and yet excite movement; whereas a strong solution of carbonate of ammonia quickly excites copious secretion, but no movement.

One of the most curious facts with respect to the morement of the leaves is the short time during which they remain incurved, although the exciting object is left on them. In the majority of cases there was wellmarked re-expansion within $24 \mathrm{hrs}$. from the time when even large pieces of meat, \&c., were placed on the leaves, and in all cases within $48 \mathrm{hrs}$. In one instance the margin of a leaf remained for 32 liss. closely inflecterl romd thin fibres of meat; in another instance, when a bit of sponge, soaked in a strong infusion of raw meat, had been applied to a leaf, the margin began to unfold in 35 hrs. Fragments of glass keep the margin incurved for a shorter time than to nitrogenous bodies; for in the former case there was 
completc re-expansion in 16 hrs. $30 \mathrm{~m}$. Nitrogenous fluids act for a shortcr time than nitrogenous substances; thus, when drops of an infusion of raw meat were placed on the miclrib of a leaf, the incurved margins began to unfold in only $10 \mathrm{hrs} .37 \mathrm{~m}$., and this was the quickest act of re-expansion observed by me; but it may have been partly due to the distance of the margins from the midrib where the drops lay.

We are naturally led to inquire what is the use of this movement which lasts for so short a time? If very small objects, such as fibres of meat, or moderately small objects, such as little flies or cabbage-seeds, are placed close to the margin, they are either completely or partially embraced by it. The glands of the overlapping margin are thus brought into contact with such objects and pour forth their secretion, afterwards absorbing the digested matter. But as the incurvation lasts for so short a time, any such benefit can be of only slight importance, yet perhaps greater than at first appears. The plant lives in humid districts, and the insects which adhere to all parts of the leaf are washed by every heavy shower of rain into the narrow channel formed by the naturally incurver edges. For instance, my friend in North Wales placed sereral insects on some leaves, and two days afterwards (there having been heary rain in the interval) found some of them quite washed away, and many others safely tncked under the now closely inflected margins, the glands of which all round the inscets were no doubt secreting. We can thus, also, understand how it is that so many insects, and fragments of insects, are generally found lying within the incurved margins of the leaves.

The incurvation of the margin, due to the presence of an exciting object, must be serviceable in another 
and probably more important way. We have seen that when large bits of meat, or of sponge soaked in the juice of meat, were plaeed on a leaf, the margin was not able to embraee them, but, as it beeame ineurved, pushed them very slowly towards the middle of the leaf, to a distanee from the outside of fully $\cdot 1$ of an ineh $(2.54 \mathrm{~mm}$.), that is, aeross between one-third and one-fourth of the spaee between the edge and midrib. Any objeet, sueh as a moderately sizerl inseet, would thus be brought slowly into eontact with a far larger number of glands, indueing mueh more seeretion and absorption, than would otherwise have been the ease. That this would be highly servieeable to the plant, we may infer from the faet that Drosera has aequired highly developed powers of movement, merely for the sake of bringing all its glands into eontret with eaptured inseets. So again, after a leaf of Dionæa has eaught an insert, the slow pressing together of the two lobes serves merely to bring the glands on both sides into eontaet with it, eausing also the seeretion eharged with animal matter to spread by eapillary attraetion over the whole surfaee. In the ease of Pinguieula, as soon as an inseet has been pushed for some little distanee towards the midrib, immediate re-expansion would be benefieial, as the margins eould not capture fresh prey until they were unfolderl. The serviee rendered by this pushing action, as well as that from the marginal glands being brought into eontaet for a short time with the upper surfaees of minute eaptured insects, may perhaps aeeount for the peeuliar movements of the leaves; otherwise, we must look at these movements as a remnant of a more highly developed power formerly possessed by the progenitors of the genus.

In the four British speeies, and, as I hear from 
Prof. Dyer, in most or all the speeies of the genus, the edges of the leaves are in some degree naturally and permanently ineurved. 'This ineurvation serves, as already shown, to prevent inseets from being washed away by the rain; but it likewise serves for another end. When a number of glands have been powerfully excited by bits of meat, insects, or any other stimulus, the secretion often triekles down the leaf, and is eaught by the ineurved edges, instead of rolling off and being lost. As it runs down the ehannel, fresh glands are able to absorb the animal matter held in solution. Moreover, the seeretion often eollects in little pools within the ehannel, or in the spoon-like tips of the leaves; and I aseertained that bits of albumen, fibrin, and gluten, are here dissolved more quiekly and eompletely than on the surfaee of the leaf, where the seeretion eannot aeeumulate; and so it inould be with naturally eaught inseets. The secretion was repeatedly seen thus to eolleet on the leaves of plants proteeted from the rain; and with exposed plants there would be still greater need of some provision to prevent, as far as possible, the seeretion, with its dissolved animal matter, being wholly lost.

It has already been remarked that plants growing in a state of nature have the margins of their leaves mueh more strongly ineurved than those grown in pots and prevented from eatehing many inseets. We have seen that inseets washed down by the rain from all parts of the leaf often lodge within the margins, whieh are thus exeited to eurl farther inwards; and we may suspeet that this action, many times repented during the life of the plant, leads to their permanent and well-marked ineurvation. I regret that this riew did not occur to me in time to test its truth.

It may here be added, though not immediately 
Chap. XTt. SECRETION, Absorption, DiGestion. 381

bearing on our subject, that when a plant is pulled up, the leaves immediately eurl downwards so as almost to eonceal the roots, - a fact which has been noticed by many persons. I suppose that this is due to the same tendeney whieh causes the outer and older leaves to lie flat on the ground. It further appears that the flower-stalks are to a certain extent irritable, for Dr. Johnson states that they "bend backwards if rudely handled." *

Secretion, Absorption, and Digestion.-I will first gire my observations and experiments, and then a summary of the results.

\section{The Effects of Objects containing Soluble Nitrogenous Matler.}

(1) Flies were placed on many leaves, and excited the glands to secrete copiously; the secretion always becoming acid, though not so before. After a time these insects were rendered so tender that their limbs and bodies could be separated by a mere touch, owing no doubt to the digestion and disintegration of their muscles. The glands in contact with a small fly eontinued to secrete for four days, and then became almost dry. A narrow strip of this leaf was cut off. and the glands of the longer and shorter hairs, which had lain in contact for the four days with the fly, and those which had not touched it, were compared under the microscope and presented a wonderful contrast. Those which had been in contact were filled with brownish graunlar matter, the others with homogeneous fluid. There could therefore be no doubt that the former had absorbed matter from the fly.

(2) Small bits of roust meat, placed on a leaf, always cansed much acid secretion in the course of a few hours-in one case within $40 \mathrm{~m}$. When thin fibres of meat were laid along the margin of a leaf which stood almost npright, the secretion ran down to the ground. Angular bits of meat, placed in little pools of the secretion near the margin, were in the eourse of

* 'English Botany' by Sir J. E. Smith; with coloured figures by J. Sowcrlyy ; edit. of 1832 , tal, $24,25,26$. 
two or threo days mueh redueed in size, rounded, rendered more or less eolourless and transparent, and so mueh softened that they fell to pieees on the slightest toueh. In only one instanee was a very minute partiele eompletely dissolved, and this oceurred within $48 \mathrm{hrs}$. When only a small amount of seeretion was exeited, this was generally absorbed in from 24 hrs. to $48 \mathrm{hrs}$; the glands being left dry. But when the supply of seeretion was eopious, round either a single rather large bit of meat, or round several small bits, the glands did not become dry until six or seven days had elipsed. The most rapid ease of absorption observed by me was when a small drop of an infusion of raw meat was plaeed on a leaf, for the glands here beenme almost dry in 3 hrs. $20 \mathrm{~m}$. Glands exeited by small partieles of meat, and which have quiekly absorbed their own seeretion, begin to secrete again in the eourse of seven or eight days from the time when the meat was given them.

(3) Three minute eubes of tough cartiluye from the leg-bone of a sheep were laid on a leaf. After 10 hrs. $30 \mathrm{~m}$. some aeid seeretion was exeited, but the eartilage apperred little or not at all affeeted. After 24 hrs, the eubes were rounded and mueh redueed in size; after $32 \mathrm{hrs}$. they were softened to the eentre, and one was quite liquefied; after 35 hrs. mere traees of solid eartilage were left; and after 48 hrs. a traee eould still be seen through a lens in only one of the three. After 82 hrs. not only were all three eubes eompletely liquefied, but all the seeretion was absorbed and the glands left dry.

(4) Small eubes of albumen were plreed on a leaf; in 8 hrs. feebly aeid seeretion extended to a distanee of nerrly $\frac{\lambda}{10}$ of an ineh round them, and the angles of one eube were rounded. After 24 hrs. the angles of all the eubes were rounded, and they were rendered throughout very tender; after 30 hr's, the seeretion began to deerease, and after 48 lurs. the glands were left dry; but very minute bits of albumen were still left undissolved.

(5) Smaller eubes of albumen (about $\frac{3}{50}$ or $\frac{1}{60}$ of an ineh, $\cdot 508$ or $\cdot 428 \mathrm{~mm}$.) were plaeed on four glands; after 18 lirs. one eube was eompletely dissolved, the others being mueh reduced in size, softened, and transparent. After 24 lirs. two of the eubes were eompletely dissolved, and already the seeretion on these glands was almost wholly absorbed. After 42 lirs. the two other eubes were eompletely dissolved. T'hese four glands began to seerete again after eight or nime days.

(6) Two large eubes of albumen (fully $\frac{1}{2 v}$ of an ineh, $1.27 \mathrm{~mm}$.) were plreed, one near tho midrib and the other nor the margin 
of a leaf; in 6 hrs. there was much secretion, wlich aftor 48 hrs. aceumulated in a little pool round the cube near the margin. This cube was much morc dissolved than that on the blade of the leaf; so that after three days it was greatly reduced in size, with all the angles rounded, but it was too large to be wholly dissolved. The secretion was partially absorbed aftcr four days. The eube on the blade was mueh less redueed, and the glands on which it rested began to dry after only two days.

(7) Fibrin excites less secretion than does meat or albumen. Several trials were made, but I will give only three of them. Two minute shreds were placed on some glands, and in 3 hrs. $45 \mathrm{~m}$. their seeretion was plainly inercased. The smaller shred of the two was completely liquefied in 6 hrs. $15 \mathrm{~m}$., and the other in 24 hrs. ; but even after $48 \mathrm{hrs}$. a few granules of fibrin could still be seen through a lens floating in both drops of secretion. After 56 lirs. $30 \mathrm{~m}$. these granules were completely dissolved. A third shred was placed in a little pool of secretion, witlin the margin of a leat where a seed had been lying, and this was completely dissolved in the course of 15 hrs. $30 \mathrm{~m}$.

(S) Five very small bits of gluten were placed on a leaf, and they cxeited so much secretion that one of the bits glided down into the marginal furrow. After a day all five bits seemed mueh reduced in size, but none wore wholly dissolved. On the third day I pushed two of them, which had begun to dry, on to fresh glands. On the fourtli day undissolved traces of three ont of the five bits could still be detected, the other two having quitc disappeared; but I am doubtful whether they had really beon completely dissolved. Two fresh bits were now placed, one near the middle and the othor near the margin of another leaf; both excited an extriordinary amount of secretion; that near the margin had a little pool formed round it, and was much more reduced in size than that on the blade, but after four days was not complctely dissolved. Gluten, therefore, exeites the glands greatly, but is dissolved with much difficulty, exactly as in the case of Drosera. I regret that I did not try this substance after laving becn immersed in weak hydrochloric acid, as it would then probably have been quiekly dissolved.

(9) A small square thin piece of pure gelutine, moistened with watcr, was placed on a leaf, and excited very little secretion in 5 hrs. $30 \mathrm{~m}$., but later in the day a greater amount. After 24 his. the whole squaro was completoly liquefied; and this mould not have occurred had it beon left in water. The liquid was acid.

(10) Small particles of chomically prepared casein excited 
aeid seeretion, but were not quite dissolved after two days; and the glands then began to dry. Nor eould their eomplete dissolution have been expeeted from what we have seen with Drosera.

(11) Minute drops of skimmed milk were plaeed on a leaf, and these eaused the glands to seerete freely. After $3 \mathrm{hrs}$. the millk was found eurdled, and after 23 hrs. the eurds were dissolved. On plaeing the now elear drops under the mieroseope, nothing eould be deteeted exeept some oil-globules. The secretion, therefore, dissolves fresh easein.

(12) Two fragments of a leaf were immersed for $17 \mathrm{hrs}$, ench in a draehm of a solution of curbonate of ammonia, of two strengths, namely of one part to 437 and 218 of water. The glands of the longer and shorter hairs were then examined, and their eontents found aggregated into granular matter of a brownish-green eolour. These granular masses were seen by iny son slowly to ehange their forms, and no doubt consisted of protoplasm. The aggregation was more strongly pronouneed, and the movements of the protoplasm more rapid, within the glands subjeeted to the stronger solution than in the other's. The experiment was repeated with the same result; and on this oceasion I observed that the protoplasm had shrunk a little from the walls of the single elongated eells forming the pedieels. In order to observe the proeess of aggregation, a marrow strip of leaf was laid edgeways under the mieroseope, and the glands were seen to be quite transparent; a little of the stronger solution (viz. one part to 218 of water) was now added under the covering glass; after an hour or two the glands eontained very fine granular matter, whieh slowly beeame eoarsely granular and slightly opaque; but even after 5 hrs. not as yet of a brownish tiut. By this time a few rather large, transparent, globular masses appeared within the upper ends of the pedieels, and the protoplasm lining their walls had shrunk a little. It is thus evident that the glands of Pinguieula absorb earbonate of ammoria; but they do not absorb it, or are not aeted on by it, nearly so quickly as those of Drosera.

(13) Little masses of the orange-eoloured pollen of the eommon pea, placed on several leaves, exeited the glands to secrete freely. Even a very few grains whieh aeeidentally fell on a single gland eaused the drop strrounding it to inerease so mueh in size, in 23 hrs., as to be manifestly larger than the drops on the adjoining glands. Grains subjected to the secretion fur 48 hrs. did not emit their tubes; they were quite discoloured, and seemed to contrin less matter than before; that 
which was left being of a dirty colour, including globules of oil. They thus differed in apperrance from other grains kept in water for the same length of time. The glands in eontact witl the pollen-grains had evidently absorbed matter from them; for they had lost their natural pale-green tint, and contained aggregated globular masses of protoplașm.

(14) square lits of the leaves of spinach, cabbage, and a saxifrage, and the entire leaves of Erica tetralix, all exeited the glands to inereased secretion. The spinacl was the most effeetive, for it eaused the seeretion evidently to inerease in $1 \mathrm{hr}$. $40 \mathrm{~m}$., and ultimately to run some way down the leaf; but the glands soon began to dry, viz. after 35 hrs. The leaves of Ervicu tetralix began to aet in 7 hrs. $30 \mathrm{~m}$., but never caused mueh secretion; nor did the bits of leaf of the saxifrage, thougl in this case the glands continued to seerete for seven days. Some leares of Pinguicula were sent me from North Wales, to which leaves of Ericu tetrulix and of an unknown plant adhered; and the glands in contact with them had their eontents plainly aggregated, as if they had been in contact with insects; whilst the other glands on the same leaves contained only elear homogeneous fluid.

(15) Seeds.-A considerable number of seeds or fruits seleeted by hazard, some fresh and some a year old, some soaked for a short time in water and some not soaked, were tried. The ten following kinds, namely eabbage, radish, Anemone nemorosú, Rumex acetosu, Carex syluatica, mustard, turnip, cress, licununculus ucris, and Avena pubescens, all excited much secretion, which was in several cases tested and found always acid. The five first-named seeds excited the glands more than the others. The secretion was seldom copious until abont 24 hrs. had elapsed, no doubt owing to the coats of the seeds not being easily permeable. Nevertheless, cabbage seeds exeited some secretion in 4 hr's. $30 \mathrm{~m}$.; and this increascd so mueh in $18 \mathrm{hrs}$. as to run down the lenves. The seeds or properly the fruits of Carex are much oftener found adhering to leaves in a state of nature than those of any other genus; and the fruits of carex sylvatica excited so much secretion that in 15 hr's, it ran into the incurved edges; but the glands eeased to secrete after 40 hrs. On the othor hand, the glands on which the secks of the Rumex and Avena rested continued to secrete for nine days.

The nine following kinds of seeds excited only a slight amount of secretion, namely celery, parsnip, caraway, limum grundiflorum, Cassia, I'rifulium pannonicum, Plantago, onion, 
and Bromus. Minst of these seeds did not excite any secretion until $48 \mathrm{hrs}$. had elapsed, and in the ease of the Trifolium only onc seed aeted, and this not until the third day. Although the seeds of the Plantago excited very little secretion, the glands continued to secrete for six days. Lastly, the five following kinds excited no secretion, though left on the leaves for two or three days, namely lettuce, Erica tetratix, Atriplex hortensis, Phaluris canariensis, and wheat. Ncrertheless, when the seeds of the lettuee, wheat, and Atriplex were split open and applicd to leaves, secretion was excited in considerable quantity in $10 \mathrm{hrs}$, and I believe that some was excited in six hour's. In the case of the Atriplex the secretion ran down to the margin, and after 24 hrs. I speak of it in my notes "as immense in quantity and aeid." The split seeds also of the Trifolium and celery aeted powerfully and quickly, though the whole seeds caused, as we have seen, very little secretion, and only after a long interval of time. A sliee of the common per, which however was not tried whole, caused secretion in 2 hrs. From these faets we may conclude that the great difference in the degree and rate at which various kinds of sceds excite secretion, is chiefly or wholly due to the different permeability of their coats.

Some thin slices of the eommon pen, which had been previously soaked for $1 \mathrm{hr}$. in water, were placed on a leaf, and quiekly excited mueh acid seeretion. After $24 \mathrm{hrs}$. these slices were eompared under a high power with others left in water for the same time; the latter contained so many fine grannles of legumin that the slide was rendered muddy; whereas the slices which had been subjected to the secretion wore much eleaner and more transparent, the granules of legumin apparently having been dissolved. A cabbage seed whieh had lain for two days on a leaf and had excited much ncid secretion, was cut into slices, and these were compared with those of a seed whieh had been left for the same time in water. Those suljeeted to the secretion were of a paler eolour; their eoats presenting the greatest differences, for they were of a pale dirty tint instead of chestnut-brown. The glands on which the cabbage seeds had rested, as well as those bathed by the surrounding secretion, differed sreatly in appearanee from the other glands on the same leat, for they all contained brownish granular matter, proving that they had absorbed matter from the secds.

That the secrotion aets on the seeds was also shown ly some of them being killed, or by the seedlings being injured. Fourteen eabbage seeds were left for three days on leaves and exuited 
nuch secretion; they were then placed on damp sand under conditions known to be favourable for germination. Tince never germinated, and this was a far larger proportiou of deaths than occurred with seeds of the same lot, which had not been subjected to the secretion, but were otherwise treated in the same manner. Of the eleven seedlings raised, three had the edges of their cotyledons slightly browned, as if scorched; and the cotyledons of one grew into a curious indented shape. Two mustard seeds germinated; but their cotyledons were marked with brown patches and their radicles deformed. Of two radish seeds, neither germinated; whereas of many seeds of the same lot not subjected to the secretion, all, excepting one, germinated. Of the two Rumex seeds, one died and the other germinated; but its radicle was hrown and soon withered. Both seeds of the Avena germinated, one grew well, the other had its radiele brown and withered. Of six seeds of the Erica none germinated, and when cut open after liaving been left for five months on damp sand, one alone seemed alive. Twenty-two seeds of various kinds were found adhering to the leares of plants growing in a state of nature; and of these, though kept for five months on damp sand, none germinated, some being then evidently dead.

\section{The Effects of Objects not containing Soluble Nitrogenous Matter.}

(16) It has already been shown that bits of glass, placed on leaves, excite little or no secretion. 'The small amount which lay beneath the fragments was tested and found not acid. A bit of wood excited no secretion; nor did the several kinds of seerds of which the coats are not permeable to the secretion, and which, therefore, acted like inorganic bodies. Cubes of fat, left for two days on a leaf, produced no effect.

(17) A particle of white sugar, placed on a leaf, formed in $1 \mathrm{hr} .10 \mathrm{~m}$. a large drop of fluid, whieh in the course of 2 additional hours ran down into the naturally inflected margin. This fluid was not in the least acid, and began to dry up, or more probably was absorbed, in jurs. $30 \mathrm{~m}$. 'L'he experiment was repeated; particles being placed on a leaf, and others of the same size on a slip of glass in a moistened state; both being covered by a bell-glass. This was done to see whether the inereased amount of fluid on the loaves could be due to mere deliquescence; but this was proved not to be tho case. The particle on the leaf caused so nuch secretion that in tho eourso of 4 hrs. it ran down across two-thirds of the lcaf. After 8 lirs. the leaf, which was concave, was actually filled with very viscid 
fluid; and it partieularly deserves noticc that this, as on the former oceasion, was not in the least acid. This grcat amount of secrction may be attributed to exosmose. The glands which had been covered for $24 \mathrm{hrs}$. by this fluid did not differ, when examined under the microscope, from others on the same leaf, which had not come into contact with it. This is an interesting fact in eontrast with the invariably aggregated condition of glands which have becn bathed by the secretion, when holding animal matter in solution,

(18) Two particles of gurn arabic were plaeed on a leaf, and they certainly caused in $1 \mathrm{hr}, 20 \mathrm{~m}$, a slight increase of secretion. This continued to increase for the next $5 \mathrm{hrs}$, that is for as long a time as the lcaf was observed.

(19) Six small particles of dry starch of commeree were placed on a leaf, and one of these caused some secretion in $1 \mathrm{hr} .15 \mathrm{~m}$., and the others in from 8 hrs. to 9 hrs. The glands which had thus been excitcd to sccrete soon became dry, and did not begin to secretc again until the sixth day. A larger bit of starch was then placed on a lcaf, and no secretion was excited in 5 hrs. $30 \mathrm{~m}$; ; but after $8 \mathrm{hrs}$. there was a eonsiderable supply, which increascd so much in $24 \mathrm{hrs}$. as to run down the leaf to the distanee of $\frac{3}{4}$ of an inch. This secretion, though so abundant, was not in the least acid. As it was so eopiously excited, and as secds not rarely adhere to the leaves of naturally growing plants, it occurred to me that the glands might pcrhaps have the power of seereting a ferment, like ptyaline, capable of dissolving starch; so I carefully obscrved the above six small partieles during several days, but they did not seem in the least reduced in bulk. A particle was also lcft for two days in a little pool of secretion, which had run down from a pieee of spinach leaf; but although the partiele was so minute no diminution was perceptible. We may thercfore conclude that the secretion eannot dissolve starch. The increase caused by this substance may, I presume, be attributed to exosmose. But I am surprised that starch acted so quickly and porrerfully as it did, though in a less degree than sugar. Colloids are known to possess some slight powcr of dialysis; and on placing the leaves of a Primula in watcr, and others in syrup and diffinsed starch, those in the starch became flaeeid, but to a lcss dcgrce and at a much slower rate than the leaves in the syrup; those in water remaining all the time crisp.

From the foregoing experiments and observations we 
see that objects not containing soluble matter have little or no power of exciting the glands to sccrete. Non-nitrogenous fluids, if dense, cause the glands to pour forth a large supply of viscid fluid, but this is not in the least acid. On the other hand, the secretion from glands excited by contact with nitrogcnous solids or liquids is invariably acid, and is so copious that it often runs down the leaves and collects within the naturally incurved margins. The secretion in this statc has the power of quickly dissolving, that is of digesting, the muscles of insects, meat, cartilage, albumen, fibrin, gelatine, and casein as it exists in the curds of milk. The glands are strongly cxcited by chemically prepared cascin and gluten; but these substances (the latter not having been soaked in weak hydrochloric acid) are only partially dissolved, as was likewise the case with Drosera. The secretion, when containing animal matter in solution, whether clerived from solids or from liquids, such as an infusion of raw meat, milk, or a weak solution of carbonate of ammonia, is quickly absorbed; and the glands, which were before limpid and of a greenish colour, become brownish and contain masses of aggregated granular matter. This matter, from its spontancous movements, no doubt consists of protoplasm. No such effect is produced by the action of non-nitrogcnous fluids. After the glands have been excited to secrete frecly, they ccase for a time to secrete, but begin again in the course of a few days.

Gilands in contact with pollen, the leaves of other plants, and various kinds of sceds, pour forth much acid secretion, and afterwards absorb matter probably of an albuminous nature from them. Nor can the benefit thus derived be insignificant, for a considerabl. 
amount of pollen must be blown from the many wind-fertilised eariees, grasses, \&e., growing where Pinguieula lives, on to the leaves thiekly eovered with viseid glands and forming large rosettes. Even a few grains of pollen on a single gland eauses it to seerete eopiously. We have also seen how frequently the small leaves of Erica tetralix and of other plants, as well as various kinds of seeds and fruits, espeeially of Carex, adhere to the leaves. One leaf of the Pinguieula had eaught ten of the little leaves of the Eriea; and three leaves on the same plant had eaeh eaught a seed. Seeds subjeeted to the aetion of the seeretion are sometimes killed, or the seedlings injured. We may, therefore, eonelude that Pinguicula vulgaris, with its small roots, is not only supported to a large extent by the extraordinary number of inseets whieh it habitually eaptures, but likewise draws some nourishment from the pollen, leaves, and seeds of other plants which often adhere to its leaves. It is therefore partly a regetable as well as an animal feeder.

\section{Pinguidula grandiflora.}

This speeies is so elosely allied to the last that it is ranked by Dr. Hooker as a sub-speeies. It differs ehiefly in the larger size of its leaves, and in the glandular hairs near the basal part of the midrib being longer. But it likewise differs in eonstitution; I hear from Mr. Ralfs, who was so liind as to send me plants from Cornwall, that it grows in rather different sites; and Dr. Moore, of the Glasuerin Botanie Gardens, informs me that it is mueh more manageable under eulture, growing freely and flowering amnually; whilst Pinguicula vulgaris has to be renewed every year. Mr. Ralfs found numerous 
inseets and fragments of inseets adhering to almost all the leaves. 'These eonsisted chiefly of Diptera, with some Hymenoptera, Homoptera, Coleoptera, and a moth. On one leaf there were nine dead insects, besides a few still alive. He also observed a few fruits of Carex pulicaris, as well as the seeds of this same Pinguieula, adhering to the leaves. I tried only two experiments with this speeies; firstly, a fly was plaeed near the margin of a leaf, and after 16 hrs. this was found well infleeted. Seeondly, several small flies were plaeed in a row along one margin of another leaf, and by the next morning this whole margin was eurled inwards, exaetly as in the ease of Pinguicala vulgaris.

\section{Pinguicula lusitanica.}

This speeies, of whieh living specimens were sent me by Mr. Ralfs from Cornwall, is very distinct from the two foregoing ones. The leaves are rather smaller, much more transparent, and are marked with purple branehing veins. The margins of the leaves are mueh more involuted; those of the older ones extending over a third of the spaee between the midrib and the outside. As in the two other species, the glandular hairs eonsist of longer and shorter ones, and have the same structure; but the glands differ in being purple, and in often eontaining granular matter before they have been excited. In the lower part of the leaf, almost half the spaee on each side between the midrib and margin is destitute of glands; these being replaeed by long, rather stiff, multieellular hairs, which intercross over the midrib. These hairs perhaps serve to prevent insects from settling on this part of the leaf, where there are no viscid glands by which they eould be canght; lunt it is hardly probable that they were developed for this purpose. The spirnt vessels pro- 
ceeding from the midrib terminate at the extreme margin of the leaf in spiral eells; but these are not so well developed as in the two preeeding speeies. The flower-peduncles, sepals, and petals, are studded with glandular hairs, like those on the leaves.

The leaves eateh many small inseets, which are found chiefly beneath the involuted margins, probably washed there by the rain. 'The eolour of the glands (m) which insects have long lain is ehanged, being wither brownish or pale purple, with their contents coarsely granular; so that they evidently absorb inatter from their prey. Leaves of the Erica tetralix, flowers of a Galium, seales of grasses, \&e. likewise adhered to some of the leaves. Several of the experiments whieh were tried on Pinguicula vulgaris were repeated on Pinguicula lusitanica, and these will now be given.

(1) A moderately sized and angular bit of culbumen was plaetd on one side of a leaf, halfway between the midrib and the naturally involuted margin. In 2 hrs. $15 \mathrm{~m}$. the glands poured forth mueh seeretion, and this side beenume more infolded than the opposite one. The infleetion inereased, and in $3 \mathrm{hrs} .30 \mathrm{~m}$. extended up almost to the apex. After 24 hrs. the margin was rolled into a eylinder, the outer surface of whieh touched the blade of the leaf and reaehed to within the $\frac{1}{20}$ of an inch of the midrib. After 48 hrs. it began to unfold, and in 72 hrs. was eompletely unfolded. 'The eube was rounded and greatly redueed in size; the remainder being in a semi-liquefied state.

(2) A moderately sized bit of allumen was placed near the apex of a leaf, under the naturally ineurved margin. In 2 hrs. $30 \mathrm{~m}$. mueh seeretion was exeited, and next morning the margin on this side was more ineurved than the opposite one, but not to so great a degree as in tho last ease. The margin unfolled at the same rate as before. A large proportion of the albumen was dissolved, a remnant being still left.

(3) Large bits of albumen were laid in a row on the midribs of two leaves, but produeed in tho eour'se of 24 his. no effeet; 
nor could this have been expeeted, for even had glands existed here, the long bristles would have prevented the albumen from eoming in eontaet with them. On both leaves the bits were now pushed elose to one margin, and in 3 hrs. $30 \mathrm{~m}$. this beeame so greatly infleeted that the outer surface tonehed the blade; the opposite margin not boing in the least affeeted. After three days the margins of both leaves with the albumen were still as mueh infleeted as ever, and the glands were still secreting eopiously. With Pinguicula vulyuris I have never seen infleetion lasting so long.

(4) Two cubbige seeds, after being soaked for an hour in water, were plaeed near the margin of a leaf, and eaused in 3 hrs. $20 \mathrm{~m}$. inereased seeretion and incurvation. After 24 hrs. the leaf was partially unfolded, but the glands were still seereting freely. These began to dry in 48 hrs., and after 72 hrs. were almost dry. The two seeds were then placed on damp sand under favourable eonditions for growth; but they never germinated, and after a time were found rotten. They had no doubt been killed by the seeretion.

(5) Small bits of a spinach leaf caused in $1 \mathrm{hr} .20 \mathrm{~m}$. increased seeretion; and after 3 hrs. $20 \mathrm{~m}$. plain ineurvation of the margin. The margin was well inflected after 9 hrs. $15 \mathrm{~m}$., but after 24 hrs. was almost fully re-expanded. The glands in eontaet with the spinach beeame dry in $72 \mathrm{hrs}$. Bits of albumen had been placed the day before on the opposite margin of this same leaf, as well as on that of a leaf with eabbage sceds, and these margins remained elosely infleeted for $72 \mathrm{hrs}$., showing how much more enduring is the effect of albumen than of spinaeh leaves or eabbage seeds.

(6) A row of small frayments of glass was laid along one margin of a leaf; no effeet was produeed in 2 hrs. $10 \mathrm{~m}$., but after 3 hrs. $25 \mathrm{~m}$. there seemed to be a trace of infleetion, and this was distinet, though not strongly marked, after 6 hrs. The grlands in contaet with the fragments now scereted more freely than before; so that they appear to be more easily exeited by the pressurc of inorganie oljeets than are the glands of $P$ inyuiculu vulyuris. The above slight infleetion of the margin had not inereased after $24 \mathrm{hrs}$, and the glands were now beginning to dry. The surface of a leaf, near the midrib and towards the base, was rubbed and serateled for some time, but no movement ensucd, 'L'he long lairs which are situated hero were treated in the same manner, with no effect. This latter trial was made beeause I thought that the hairs might perhaps le sensitive to a toueh, like the filaments of Dionwa. 
(7) The flower-pedumcles, sepals and petals, bear glands in general appearance like those on the leaves. A piece of a flower-peduncle was therefore left for $1 \mathrm{hr}$. in a solution of one part of carbonate of ammonia to 437 of water, and this caused the glands to change from bright pink to a dull purple colour; but their contents exhibited no distinct aggregation. After $8 \mathrm{hrs} .30 \mathrm{~m}$. they beeame colourless. Two minute eubes of albumen were plaeed on the glands of a flowerpeduncle, and another cube on the glands of a sepal; but they were not excited to increased secretion, and the albumen after two days was not in the least softened. Henee these glands apparently differ greatly in function from those on the leaves.

From the foregoing observations on Pinguicula lusitanica we see that the naturally mueh ineurved margins of the leaves are exeited to eurve still farther inwards by eontaet with organie and inorganie bodies; that albumen, eabbage seeds, bits of spinaeh leaves, and fragments of glass, eause the glands to seerete more freely; - that albumen is dissolved by the seeretion, and eabbage seeds lilled by it;-and lastly that matter is absorbed by the glands from the inseets whieh are eaught in large numbers by the viscid seeretion. The glands on the flower-peduneles seem to have no sueh power. This speeies differs from Pinguicala vulgaris and grandiflora in the margins of the leaves, when exeited by organie bodies, being infleeted to a greater degree, and in the infleetion lasting for a longer time. The glands, also, seem to be more easily exeited to inereased seeretion by bodies not yielding soluble nitrogenous matter. In other respeets, as far: as my observations serve, all three speeies agree in their funetional powers. 


\section{CHAPTER XVII.}

\section{UTRICLI,ARIA.}

Utricularia neglecta-Structure of the bladder-The uses of the several parts - Number of imprisoned animals - Manner of capture The bladders cannot digest animal matter, but absorb the products of its decay - Experiments on the absorption of certain fluids by the quadrifid processcs - Absorption by the glands-Summary of the observation on absorption - Development of the bladders Utricularia vulgaris - Utricularia minor - Utricularia clandestina.

I was led to investigate the habits and structure of the species of this genus partly from their belonging to the same natural family as Pinguicula, but more especially by MIr. Holland's statement, that "water insects are often found imprisoned in the bladders," which he suspects "are destined for the plant to feed on." * The plants which I first received as Utricularia vulgaris from the New Forest in Hampshire and from Cornwall, and which I have chiefly worked on, have been determined by Dr. Hooker to be a very rare British species, the Utricularia neglecta of Lehm. $\dagger$ I subsequently received the true Utricularia vulgaris from Yorkshire. Since drawing up the following description from my own observations and those of my son, Francis Darwin, an important memoir by Prof. Cohn

* 'The 'Quart. Magr. of the High Wycombe Nat. Hist. Soc.' July 1868, p. 5. Delpino ("Ult. Osservaz. sulla Dicogania,' \&c. 1868-1869, p. 16) also quotes Crouan as having found (1858) crustaceans within the bladders of Utricularia vulgaris. f I am much indebted to the Rev. H. M. Wilkinson, of Bistern, for laving sent me several fine lots of this species from the New Forest. Mr. Kalfs was also so kind as to send me living plants of the same species from near Penzance in Cornwall. 
on Utricularia vulgaris has appeared; * and it has been no small satisfaction to me to find that my aeeount agrees almost eompletely with that of this distinguished observer. I will publish my deseription as it stood before reading that by Prof. Cohn, arlding oceasionally some statements on his authority.

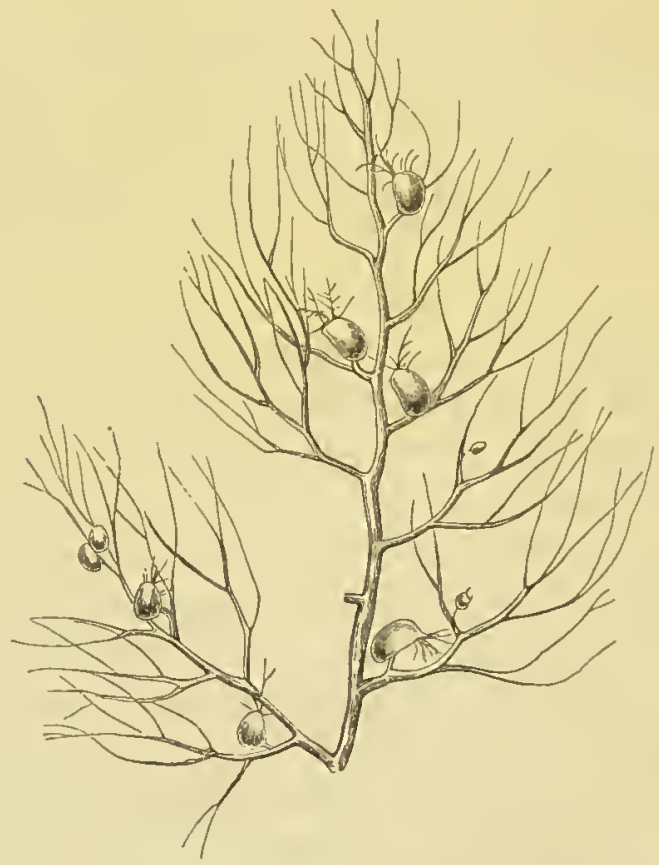

Fig. 1\%.

(Ctricularia neglecta.)

Branch with the divided lenves bearing bladders; about $t$ wice enlarged.

Utricularia neglecta.-The general appenranee of a branch (about twice enlarged), with the pimnatifid leares bearing bladders, is represented in the above sketeh (fig. 17). The leaves eontinually bifurcate, so that a full-grown one terminates in from twenty to thirty

* 'Beitrige zur Biologie der P'lanzen, ' drittes IIeft, 1875. 
points. Each point is tipped by a short, straight bristle; and slight notches on the sides of the leaves bear similar bristles. On both surfaces there are many small papille, crowned with two hemispherical cells in close contact. The plants float near the surface of the water, and are quite destitute of roots, even during the earliest period of growth.* 'They commonly inhabit, as more than one observer' has remarked to me, remarkably foul ditches.

The bladders offer the chief point of interest. There are often two or three on the same divided leaf, generally near the base; though I have seen a single one growing from the stem. They are supported on short footstalks. When fully grown, they are nearly $\frac{1}{10}$ of an inch $(2.54 \mathrm{~mm}$.) in length. They are translucent, of a green colour, and the walls are formed of two layers of cells. The exterior cells are polygonal and rather large; but at many of the points where the angles meet, there are smaller rounded cells. These latter support short conical projections, surmounted by two hemispherical cells in such close apposition that they appear united; but they often separate a little when immersed in certain fluids. The papilla thus formed are exactly like those on the surfaces of the leaves. Those on the same bladder vary much in size; and there are a few, especially on very young bladders, which have an elliptical instead of a circular outline. The two terminal cells are transparent, but must hold much matter in solution, judging from the quantity congulated by prolongerl immersion in alcohol or ether.

* I infer that this is the ease from $n$ drawing of $n$ secdling given by Ur. Warming in his paper, "Bidrag til Kiundslkaben om Lentibulnriacea," fron the "Videnskabelige Meddelelser," Coponlungen, 1874, Nos. 3-7, Pl.
33-58. 
The bladders are filled with water. They generally, but by no means always, contain bubbles of air. According to the quantity of the contained water and air, they vary much in thickness, but are always somewhat compressed. At an early stage of growth, the flat or ventral surfacc faces the axis or stem; but the footstalks must have some power of movement; for in plants kept in my greenhouse the ventral surface was generally turned either straight or obliquely downwards. The Rev. H. MI. Wilkinson examined

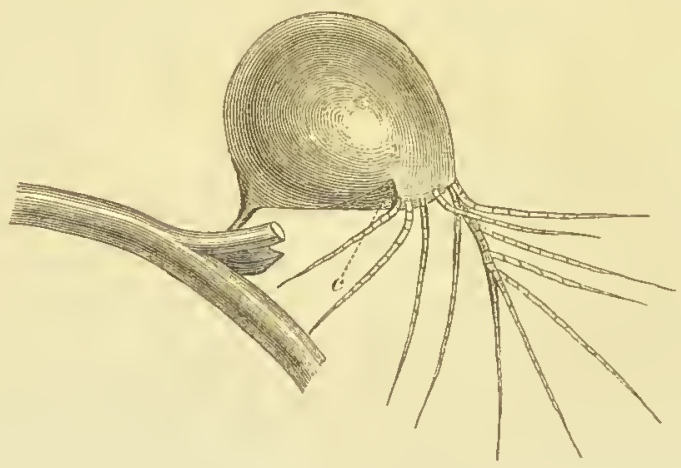

FIG. 18,

(Ctricularia neglecta.)

Blatiler; much enlarged. c, collar indistinctly seen through the walls.

plants for me in a state of nature, and found this commonly to be the case, but the younger bladders often had their valves turned upwards.

The general appearance of a bladder viewed laterally, with the appendages on the near side alone represented, is shown in the accompanying figure (fig. 18). The lower side, where the footstalk arises, is nearly straight, and I have called it the ventral surface. The other or dorsal surface is convcx, and terminates in two long prolongations, formed of screral rows of rells, containing chlorophyll, and bearing, chicfly on 
the outside, six or seven long, pointed, inultieellular bristles. These prolongations of the bladder may be conveniently ealled the antennx, for the whole bladder (see fig. 17) euriously resembles an entomostraean erustiteean, the short footstalk representing the tail. In fig. 1S, the near antenna alone is shown. Beneath the two antenne the end of the bladder is slightly trumeated, and here is situated the most important part of the whole strueture, namely the entranee and valve. On eaeh side of the entranee from three to rarely seven long, multieellular bristles projeet out-

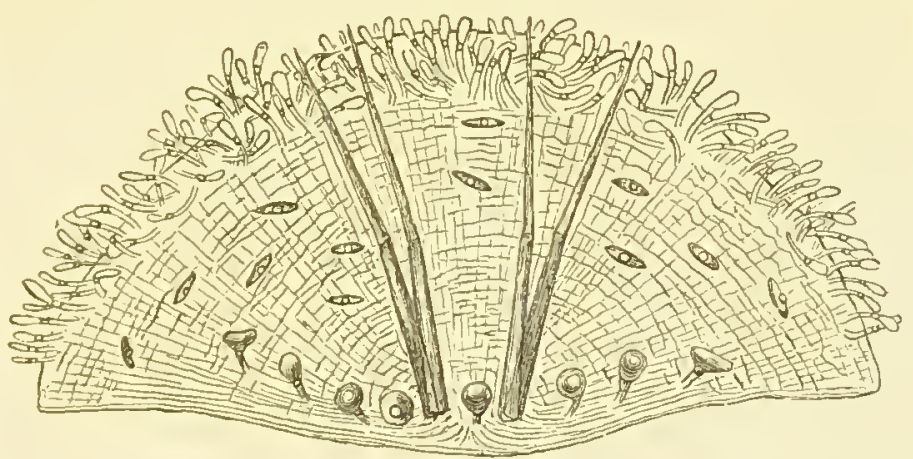

FIG. 19.

(litricularia negtecta.)

Valve of bladder; greatly enlarged.

wards; but only those (four in number) on the near side are shown in the drawing. These bristles, together with those borne by the antennx, form a sort of hollow eone surrounding the entranee.

The valve slopes into the eavity of the bladder, or upwards in fig. 1S. It is attaehed on all sides to the bladder, exeepting by its posterior margin, or the lower one in fig. 19, whieh is free, and forms one side of the slit-like orifice leading into the blarlder. 'This margin is sharp, thin, and smooth, and rests on the edge of a rim or eollar, whieh dips deeply into the 
bladder, as shown in the longitudinal section (fig. 20) of the collar and valve; it is also shown at $c$, in fig. 18 . The edge of the valve can thus open only inwards. As both the valve and collar dip into the bladder, a hollow or depression is here formed, at the base of which lies the slit-like orifice.

The valve is colourless, highly transparent, flexible and elastic. It is convex in a transverse direction, but has been drawn (fig. 19) in a flattened state, by which its apparent breadth is increased. It is formed,

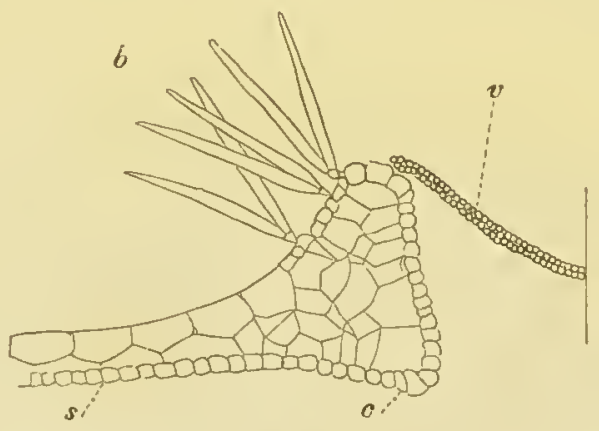

FIG. 20.

(Ttricularia neglecta.)

Longitudinal vertical section through the ventral portion of a bladder; showing valve and collar. $v$, valve; the whole projection above $c$ forms the collar; $b$, bifid processes; $s$, ventral surfacc of bladder.

according to Cohn, of two layers of small cells, which are continuous with the two layers of larger cells forming the walls of the bladder, of which it is evidently a prolongation. Two pairs of transparent pointed bristles, about as long as the ralve itself, arise from near the free posterior margin (fig. 18), and point obliquely outwards in the direction of the antenne. There are also on the surface of the valve numerous glands, as I will call them; for they have the power of absorption, though I loubt whether they ever secrete. They consist of three kinds, which 
to a eertain extent graduate in to one another. 'Those situated round the anterior margin of the valve (upper margin in fig. 19) are very numerous and erowded together; they eonsist of an oblong head on a long pedicel. The pedieel itself is formed of an elongated eell, surmounted by a short one. The glands towards the free posterior margin are mueh larger, few in number, and almost spherical, having short footstalks ; the head is formed by the confluenee of two eells, the lower one answering to the short upper cell of the pedieel of the oblong glands. The glands of the third kind have transversely elongated heads, and are seated on very short footstalks; so that they stand parallel and close to the surfaee of the valve; they may be ealled the two-armed glands. The cells forming all these glands contain a nueleus, and are lined by a thin layer of more or less granular protoplasm, the primordial utriele of Mohl. They are filled with fluid, which must hold much matter in solution, judging from the quantity eoagulated after they have been long immersed in aleohol or ether. 'The depression in whieh the valve lies is also lined with innumerable glands; those at the sides having oblong heads and elongated pedieels, exactly like the glands on the adjoining parts of the valve.

The collar (called the peristome by Cohn) is evidently formed, like the valve, by an iuward projection of the walls of the bladder. The eells eomposing the outer surfice, or that facing the valve, have rather' thick walls, are of a brownish colour, minute, very numerous, and elongated ; the lower ones being divided into two by vertical partitions. The whole presents a complox and elegant appearanee. The eells forming' the inner surface are continuous with those over the whole inncr surface of the bladder. The spaee be- 
tween the inncr and outer surface consists of coarsc cellular tissue (fig. 20). The inner side is thickly covcred with delicate bific processes, hcreafter to be described. The collar is thus made thick; and it is rigid, so that it retains the samc outline whether the bladder contains little or much air and water. This is of great importance, as otherwise the thin and flexible valve would be liable to be distorted, and in this case would not act properly.

Altogether the entrance into the bladder, formed by the transparent valve, with its four obliquely projccting bristles, its numerous diversely shaped glands, surrounded by the collar, bearing glands on the inside and bristles on the outside, together with the bristles borne by the antenna, presents an extraordinarily complex appenrance when viewed under the microscope.

We will now consider the internal structure of the bladder. The whole inner surface, with the exception of the valve, is seen under a moderately high porrer to be covered with a serried mass of processes (fig. 21). Each of these eonsists of four divergent arms; whence their name of quadrifid processes. They arise from small angular eells, at the junctions of the angles of the larger eells which form the interior of the bladder. The middle part of the upper surface of these small cclls projects a little, and then contracts into a very short and narrow footstalk which bears the four arms (fig. 22). Of these, two are long, but oftcn of not quite equal length, and project obliquely inwards and towards the posterior end of the bladder. The tro others are much shorter, and project at a smaller angle, that is, are more ncarly horizontal, and are directed towards the anterior end of tlic bladder. 'These arms arc only moderately sharp; they arc composed of ex- 
tremely thin transparent membrane, so that they ean be bent or doubled in any direetion without being broken. They are lined with a delicate layer of protoplasm, as is likewise the short eonieal projeetion from which they arise. Eaeh arm generally (but not invariably) eontains a minute, faintly brown partiele, either rounded or more eommonly elongated, whieh exhibits ineessant Brownian movements. These par-

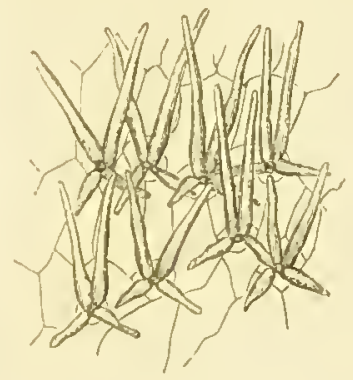

Fic. 21.

(Ctricularia neglecta.)

Small portion of inside of blaclder, much enlarged, showing quadrifid processes.

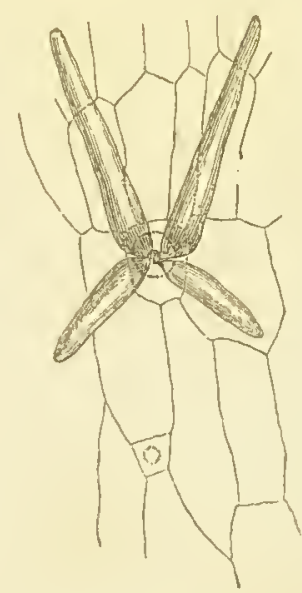

F'IG. 22.

(Ctricularia neglecta.)

One of the quadrifid processes greatly entarged.

tieles slowly ehange their positions, and travel from one end to the other of the arms, but are eommonly found near their bases. They are present in the quadrifids of young bladders, when only about a third of their full size. They do not resemble ordinary nuclei, but I believe that they are nuclei in a modified eonrlition, for when absent, I eould oecasionally just distinguish in their plaees a delicate halo of matter, including a darker spot. Moreover, the quadrifids of Utricularia montence contain rather larger and much 
more regularly spherical, but otherwise similar, particles, which closely resemble the nuclei in the cells forming the walls of the bladders. In the present case there were sometimes two, three, or even more, nearly similar particles within a single arm; but, as we shall hereafter see, the presence of more than one seemed always to be connected with the absorption of decayed matter.

The inner side of the collar (see the previous fig. 20) is covered with several crowded rows of processes, differing in no important respect from the quadrifids, except in bearing only two arms instead of four; they are, however, rather narrower and more delicate. I shall call them the bifids. They project into the bladder, and are directed towards its posterior end. The quadrifid and bifid processes no doubt are homologous with the papillie on the outside of the bladder and of the leaves; and we shall see that they are developed from closely similar papillie.

The Uses of the several Parts.- After the above long but necessary description of the parts, we will turn to their uses. The bladders have been supposed by some authors to serve as floats; but branches which bore no bladders, and others from which they had been removed, floated perfectly, owing to the air in the intercellular spaces. Bladders containing dead and captured animals usually include bubbles of air, but these cannot have been generated solely by the process of decay, as I have often seen air in young; clean, and empty bladders; and some old bladders with much decaying matter had no bubbles.

The real use of the bladder's is to capture small aquatic animals, and this they do on a large scale. In the first lot of plants, which I received from the New Forest early in July, a large proportion of the fully 
grown bladders eontained prey; in a second lot, receiver in the beginuing of Angust, most of the bladders were empty, but plants had becn sclceterl whieh had grown in unusually pure water. In the first lot, my son examined seventcen bladders, including prey of some kind, and eight of these eontained entomostraean erustaeeans, three larve of inseets, one being still alive, and six remnants of animals so mueh deenyed that thcir nature could not be distinguished. I picked out five bladders whieh seemed very full, and found in them four, five, eight, and ten crustaceans, and in the fifth a single much elongated larva. In five other bladders, selectcd from eontaining remains, but not appearing vcry full, thcre were one, two, four, two, and five erustaceans. A plant of Utricularia vulgaris, whieh had becn liept in almost pure watcr, was plaecd by Cohn one evening into watcr swarming with erustaeeans, and by the next morning most of the bladders eontained thesc animals entrapped and swimming round and round their prisons. They remained alive for several days; but at last perished, asphyxiated, as I suppose, by the oxygen in the water having been all consumed. Freshwater worms were also found by Cohn in some bladders. In all cases the bladders with dccayed remains swarmed with living Algæ of many kinds, Iufusoria, and other low organisms, which evidently lived as intruders.

Animals enter the bladders by bending inwards the posterior free edge of the valve, which from being highly elastic shuts again instantly. As the edge is extremely thin, and fits elosely against the edge of the collar, both projecting into the bladder (see section, fig. 20), it would evirlently be very difficult for any animal to get out when once imprisoned, and appurently they never do escape. 'To show low elosely the edge 
fits, I may mention that my son found a Daphnia which had inserted one of its antennæ into the slit, and it was thus held fast during a whole day. On three or four occasions I have seen long narrow larvæ, both dead and alive, wedged between the eorner of the valve and eollar, with half their bodies within the bladder and half out.

As I felt much, difficulty in understanding how such minute and weak animals, as are often captured, could force their way into the bladders, I tried many expcriments to ascertain how this was effeeted. The free margin of the valve bends so easily that no resistance is felt when a needle or thin bristle is inserted. A thin human hair, fixed to a handle, and cut off so as to projeet barely $\frac{1}{4}$ of an inch, entercd with some diffieulty; a longer piece yielded instead of entering. On threc occasions minute particles of blue glass (so as to be easily distinguished) were placed on valves whilst under water; and on trying gently to move them with a needle, they disappeared so suddenly that, not seeing what had happened, I thought that I had flirted them off; but on examining the bladders, they were found safely enelosed. The same thing occurred to my son, who placed little cubes of green box-wood (about $\frac{1}{60}$ of an inch, 423 $\mathrm{mm}$.) on some valves; and thriee in the act of placing them on, or whilst gently moving them to another spot, the valve suddenly opened and they were engulfed. He then plaeed similar bits of wood on other ralves, and moved them about for some time, but they did not enter. Again, particles of blue glass were placed by me on threo valves, and extremely minute shavings of lead on two other valves; after 1 or 2 lirs. none had entered, but in from 2 to 5 hrs. all five were enclosed. One of the particles of glass was a 
long splinter, of which one end rested obliquely on the valve, and after a few hours it was found fixed, half within the bladder and half projecting out, with the edge of the valve fitting closely all round, oxcept at onc angle, where a small open space was left. It was so firmly fixed, like the above mentioned larvæ, that the bladder was torn from the branch and shaken, and yet the splinter did not fall out. My son also placed little cubes (about $\frac{1}{65}$ of an inch, $\cdot 391 \mathrm{~mm}$.) of green box-wood, which wore just heavy enough to sink in water, on three valves. These were examined after 19 hrs. $30 \mathrm{~m}$., and were still lying on the valves; but after 22 hrs. $30 \mathrm{~m}$. one was found cnclosed. I may here mention that I found in a bladder on a naturally growing plant a grain of sand, and in another bladder three grains; these must have fallen by some accident on the valves, and then cntercel like the particles of glass.

The slow bending of the valve from the weight of particles of glass and even of box-wood, though largely supported by the water, is, I suppose, analogous to the slow bending of colloid substances. For instance, particles of glass were placed on various points of narrow strips of moistened gelatine, and thesc yiclded and became bent with extreme slownoss. It is much more difficult to understand how gently moving a particle from one part of a valve to another causes it suddenly to open. To ascertain whether the valves were endowed with irritability, the surfaces of several wore scratched with a needle or brushed with a fino camcl-hair brush, so as to imitate the crawling movement of small crustaceans, but the valve clid not open. Some bladders, before being brushed, wore left for a time in water at temperatures between $80^{\circ}$ and $130^{\circ} \mathrm{F} \cdot\left(26^{\circ} \cdot 6-54^{\circ} .4\right.$ Cont.), as, judging from a wide- 
spread analogy, this would have rendered them more sensitive to irritation, or would by itself have excited movement; but no effeet was produced. We may, therefore, eonelude that animals enter merely by foreing their way through the slit-like orifiee; their heads serving as a wedge. But I am surprised that sueh small and weak ereatures as are often eaptured (for instanee, the nauplius of a erustacean, and a tardigrade) should be strong enough to aet in this manner, seeing that it was diffieult to push in one end of a bit of a hair $\frac{1}{4}$ of an ineh in length. Nevertheless, it is eertain that weak and small ereatures do enter, and Mrs. Treat, of New Jersey, has been more suecessful than any other observer, and has often witnessed in the case of Utricularia clandestina the whole process.* She saw a tardigrade slowly walking round a bladder, as if reconnoitring; at last it crawled into the depression where the valve lies, and then easily entered. She also witnessed the entrapment of various minute erustaceans. Cypris "was "quite wary, but nevertheless was often eaught. "Coming to the entranee of a bladder, it would some" times pause a moment, and then dash array; at "other times it would eome elose up, and even ven"ture part of the way into the entrance and baek out "as if afraid. Another, more heedless, would open " the door and walk in; but it was no sooner in than "it manifested alarm, drew in its feet and antennæ, and closed its shell." Larvie, apparently of guats, when "feeding near the entrance, are pretty certain " to run their heads into the net, whenee there is no "retreat. A large larva is sometimes three or four " lours in being swallowed, the proeess bringing to

" 'New York Tribune,' reprinted in the 'Garl. Chron.' 1s75, ए. 303. 
" mind what I have wituessed when a small snake "makes a large frog its victim." But as the valve does not appear to be in the least irritable, the slow swallowing proeess must be the effect of the onward movement of the larva.

It is difficult to conjecture what ean attract so many ereatures, animal- and regetable-feeding crustaccans, worms, tardigrades, and various larva, to enter the bladders. Mrs. Treat says that the larvæ just referred to are vegetable-feeders, and seem to have a special liking for the long bristles round the valve, but this taste will not account for the entrance of amimalfeeding crustaceans. Perhaps small aquatie animals habitually try to enter every small crevice, like that between the valve and collar, in search of food or proteetion. It is not probable that the remarkable transparency of the valve is an aceidental eircumstanee, and the spot of light thus formed may serve as a guide. The long bristles round the entrance apparently serve for the same purpose. I believe that this is the ease, becanse the bladders of some epiphytic and marsh species of Utricularia whieh live embedded either in entangled vegetation or in mud, have no bristles round the entrance, and these under such conditions would be of no serviee as a guide. Nevertheless, with these epiphytic and marsh speeies, two pairs of bristles project from the surface of the valve, as in the aquatic speeies; and their use probably is to prevent too large animals from trying to forec an entrance into the bladder, thus rupturing the urifice.

As under fuvourable circumstances most of the blarllers suceecl in securing prey, in one case as many as ten crustaceans; - as the valve is so woll fitterl to 
allow animals to enter and to prevent their escape;-and as the inside of the bladder presents so singular a structure, clothed with innumcrable quadrifid and bifid processes, it is impossible to doubt that the plant has been specially adapted for sceuring prey. From the analogy of Pinguicula, belonging to the same family, I naturally expected that the bladders would have digested their prey; but this is not the case, and therc are no glands fitted for secreting the proper fluid. Neverthcless, in order to test their power of digestion, minute fragments of roast meat, three small cubcs of albumen, and threc of cartilage, werc pushed through the orifice into the bladders of vigorous plants. They wcre left from onc day to three days and a half within, and the bladders were then cut open; but none of the above substances cxhibited the least signs of digestion or dissolution; the angles of the cubes being as sharp as ever. These obscrvations werc made subsequently to those on Droscra, Dionaa, Drosophyllum, and Pinguicula; so that I was familiar with the appearance of these substances when undergoing the early and final stages of digestion. We may therefore eonchude that Utricularia cannot digest the animals which it habitually captures.

In most of the bladders the captured animals are so mueh decayed that they form a pale brown, pulpy mass, with their chitinous coats so tender that they fall to pieces with the greatcst case. The black pigment of the eye-spots is preserved better than anything clse. Limbs, jaws, \&e. are often fonmd quite detached; and this I suppose is the result of the rain struggles of the later captured animals. I have sometimes felt surprised at the small proportion of imprisoned animals in a fresh state compared with those utterly deeayed. Mrs. Treat states with respect 
to the larvo above referred to, that "msually in less "than two days after" a large one was eaptured the fluid " eontents of the bladders began to assume a clondy " or muddy appearanee, and often beeame so dense "that the outline of the animal was lost to view." 'This statement raises the suspieion that the bladders seerete some ferment hastening the process of deeay. There is no inherent improbability in this supposition, eonsidering that meat soaked for ten minutes in water mingled with the milky juiee of the papaw beeomes quite tender and soon passes, as Browne remarks in his 'Natmral History of Jamaiea,' into a state of putridity.

Whether or not the deeay of the imprisoned animals is in any way hastened, it is eertain that matter is absorbed from them by the quadrifid and bifid proeesses. The extremely delieate nature of the membrane of whieh these proeesses are formed, and the large surfaee whieh they expose, owing to their number crowded over the whole interior of the bladder, are eircumstanees all favouring the proeess of absorption. Many perfeetly elean bladders whieh had never eaught any prey were opened, and nothing eould be distinguisherl with a No. 8 objeet-glass of Hartnaek within the delieate, struetureless protoplasmie lining of the arms, excepting in each a single yellowish particle or modified nueleus. Sometimes two or even three sueh partieles were present; lont in this ease traees of decaying matter conld generally be deteeted. On the other hand, in bladders eontaining either one large or several small deeayed animals, the proeesses presented a widely different appearance. Six such bladders were earefully examined; one eontained an elongated, eoiledup larva; another a single large entomostracan erustaecan, and the others from two to five smaller ones, all 
in a deeayed state. In these six bladrlers, a large number of the quadrifid processes eontainerl transparent, often yellowish, more or less eonfluent, spherical or irregularly shaped, masses of matter. Some of the proeesses, however, eontained only fine granular matter, the partieles of whieh were so small that they could not be defined elearly with No. $\delta$ of Hartnnek. The delieate layer of protoplasm lining their walls was in some eases a little shrunk. On three oecasions the above small masses of matter were observed and sketehed at short intervals of time; and they eertainty changed their positions relatively to eaeh other and to the walls of the arms. Separate masses sometimes beeame confluent, and then again divided. A single little mass would send out a projeetion, whieh after a time separated itself. Henee there eould be no doubt that these masses eonsisted of protoplasm. Bearing in mind that many elean bladders were examined with equal eare, and that these presented no sueh appearance, we may eonfidently believe that the protoplasm in the above eases had been generated by the absorption of nitrogenous matter from the deeaying animals. In two or three other bladders, which at first appeared quite elean, on eareful seareh a few proeesses were found, with their outsides elogged with a little brown matter, showing that some minute animal had been eaptured and had deeayed, and the arms here ineluded a very few more or less spherieal and aggregated masses; the proeesses in other parts of the bladders being empty and transparent. On the other hand, it must be stated that in three bladders eontaining dead erustaceans, the proeesses were likewise empty. This fact may be aeeounted for by the animals not haring been sufficiently deeayed, or by time enough not having been allowed for the generation of proto- 
plasm, or by its subsequent absorption and transference to other parts of the plant. It will hereafter be seen that in three or fom other speeies of Utrieularia the quadrifid proeesses in eontaet with deeaying animals likewise contained aggregated masses of protoplasm.

On the Absorption of certain Fluids by the Quadrifid and Bifid Processes.-These experiments were tried to aseertain whether eertain fluids, whieh seemed adapted for the purpose, would produee the same effeets on the proeesses as the absorption of deeayed animal matter. Sueh experiments are, however, troublesome; for it is not suffieient merely to plaee a braneh in the fluid, as the valve shuts so elosely that the fluid apparently does not enter soon, if at all. Even when bristles were pushed into the orifiees, they were in several eases wrapped so elosely round by the thin flexible edge of the valve that the fluid was apparently exeluded; so that the experiments tried in this manner are doubtful and not worth giving. The best plan would have been to puncture the bladders, but I did not think of this till too late, exeepting in a few cases. In all sueh trials, however, it cannot be aseertained positively that the bladder, though translueent, does not eontain some minute animal in the last stage of deeay. Therefore most of my experiments were made by eutting bladder's longitudinally into two ; the quadrifids were examined with No. S of Hartnaek, then irrigated, whilst under the eovering glass, with a few drops of the fluid under trial, kept in a damp chamber, and re-examined after stated intervals of time with the same power as before.

Fowr bladders wore first tried as a eontrol experiment, in the mannor just described, in a solution of one part of gum arabic to 218 of water, and two bladders in a solution of one part of sugar to 437 of water; and in neither case was any 
change pereeptible in the quadrifids or bifids after 21 hrs. Four bladder's were then treated in the same manner with a solution of one part of nitrate of ammonia to 437 of water, and re-examined after $21 \mathrm{hrs}$. In two of these the quadrifids now appeared full of very finely granular matter, and their protoplasmie lining or primordial utriele was a little shrunk. In the third bladder, the quadrifids ineluded distinetly visible granules, and the primordial utriele was a little shrunk after only 8 hrs. In the fourth bladder the primordial utriele in most of the proeesses was here and there thiekened into little, irregular, yellowish speeks; and from the gradations whieh eould be traeed in this and other eases, these specks appear to give rise to the larger free granules eontained within some of the processes. Other bladders, whieh, as far as eould be judged, had never eaught any prey, were punetured and left in the same solution for $17 \mathrm{hr}$ s.; and their quadrifids now eontained rery fine granular matter.

A bladdel was biseeted, examined, and irrigated with a solution of one part of earbonate of ammonia to 437 of water. After 8 hrs. $30 \mathrm{~m}$. the quadrifids eontained a good many granules, and the primordial utriele was somewhat shrunk; after 23 hrs. the quadrifids and bifids eontained many spheres of hyaline matter, and in one arm twenty-four sueh spheres of moderate size were eounted. Two biseeted bladders, whieh had been previously left for 21 hrs. in the solution of gum (one part to 218 of water) without being affeeted, were irrigated with the solution of earbonate of ammonia; and both had their quadrifids modified in nearly the same manner as just deseribed,-one after only $9 \mathrm{hrs}$, and the other after $24 \mathrm{hrs}$. Two blaclders whieh appeared never to have eaught any prey were punetured and plreed in the solution; the quadrifids of one were examined after 17 hrss, and found slightly opaque; the quadrifids of the other, examined after 45 hrs., had their primordial utrieles more or less shrunk with thiekened yellowish speeks, like those due to the action of nitrate of ammonia. Several uninjured bladder's were left in tho same solution, as well as in a weaker solution of one part to 1750 of water, or $1 \mathrm{gr}$. to $4 \mathrm{oz}$; and after two days the quadrifids were more or less opaque, with their eontents finely granular; but whether tho solution had entered by the orifiee, or had been absorbed from the ontside, I know not.

Two biseeted bladder's were irrigated with a solution of one part of urea to 218 of water; but when this solution was employed, I forgot that it had bcen kopt for some days in a warm room, and had therefore probably generated ammonia; anyhow 
the quadrifids were affected aftcr 21 hrs. as if a solution of carbonate of ammonia had becn used; for the primordial utriclc was thickened in specks, which sccmed to graduate into separate granules. Thuree bisected bladder's werc also irrigated with a fresh solution of urca of the same strength; their quadrifids after 21 hrs. were much less affected than in the former case; nevertheless, the primordial utricle in some of the arms was a little shrunk, and in others was divided into two almost symmetrical sacks.

Three bisccted bladders, aftcr being examined, were irrigated with a putrid and very offensive infusion of raw moat. After $23 \mathrm{hrs}$. the quadrificls and bifids in all threc spccimens abounded with minute, hyaline, sphcrical masses; and some of their primordial utricles were a little shrunk. Threc bisected bladder's were also irrigated with a fresh infusion of raw meat; and to my surprise the quadrifids in one of them appeared, after $2.3 \mathrm{hrs}$, finely granular, with their primordial utricles somewhat shrunk and marked with thickened yellowish spccks; so that they had been acted on in the same manner as by the putrid infusion or by the salts of ammonia. In the second bladder some of the quadrificls werc similarly acted on, though to a very slight degree; whilst the third bladdor was not at all affected.

From these experiments it is clear that the quadrifid and bifid processes have the power of absorbing earbonate and nitrate of ammonia, and matter of some kind from a putrid infusion of meat. Salts of ammonia were seleeted for trial, as they are known to be rapidly generated by the decay of animal matter in the presenee of air and water, and would therefore be generated within the bladders eontaining eaptured prey. The effeet produeed on the proeesses by these salts and by a putrid infusion of raw meat differs from that produced by the decay of the naturally eaptured animals only in the aggregated masses of protoplasm being in the latter case of larger size; but it is probable that the fine grimules and small hyaline spheres produced by the solutions would coalesce into larger masses, with time enough allowed. 
We have secn with Drosera that the first effect of a wcak solution of carbonate of ammonia on the celleontents is the production of the finest granules, which afterwards aggregate into larger, more or less rounded, masses; and that the granules in the layer of protoplasm which flows round the walls ultimately eoalesee with these masses. Changes of this nature are, however, far more rapid in Drosera than in Utricularia. Sinee the bladders have no power of digesting albumen, eartilage, or roast meat, I was surprised that matter was absorbed, at least in one ease, from a fresh infusion of raw meat. I was also surprised, from what we shall presently see with respeet to the glands round the orifice, that a fresh solution of urea produced only a moderate effect on the quadrifids.

As the quadrifids are developed from papillæ whieh at first elosely resemble those on the outside of the bladders and on the surfaees of the leaves, I may here statc that the two hemispherical eells with which these latter papillie are erowned, and whieh in their natural state are perfeetly transparent, likewise absorb earbonate and nitrate of ammonia ; for, after an immersion of $23 \mathrm{hrs}$. in solutions of one part of both these salts to 437 of water, their primordial utrieles were a little shrunk and of a pale brown tint, and sometimes finely granular. The same result followed from the immersion of a whole braneh for nearly three days in a solution of one part of the earbonate to 1750 of water. The grains of chlorophyll, also, in the eells of the leaves on this branch bceamc in many places aggregated into little green masses, which werc often connected together by the finest threads.

On the Absorption of certain Fluids by the Glands on the Valve and Collar.- -The glands round the orifiees of blatders which are still young, or which have been 
long kept in moderately pure water, are colourless; and their primordial utrieles are only slightly or hardly at all granular. But in the greater number of plants in a state of nature-and we must remember that they generally grow in vory foul water - and with plants kept in an aquarium in foul water, most of the glands were of a pale brownish tint; their primordial utricles were more or less shrunk, sometimes ruptured, with their eontents often eoarsely granular or aggregated into little masses. That this state of the glands is due to their having absorbed matter from the surrounding water, I eannot doubt; for, as we shall immediately see, nearly the same results follow from their immersion for a few hours in various solutions. Nor is it probable that this absorption is useless, seeing that it is almost universal with plants growing in a state of nature, excepting when the water is remarkably pure.

The pedieels of the glands whieh are situated close to the slit-like orifice, both those on the valve and on the collar, are short; whereas the pedieels of the more distant glands are mueh elongated and projeet inwards. The glands are thus well placed so to be washed by any fluid coming out of the bladder through the orifice. The valve fits so closely, judging from the result of immersing uninjured bladders in varions solutions, that it is doubtful whether any putrid fluid habitually passes outwards. But we must remember that a bladder generally eaptures several animals; and that each time a fresh animal enters, a puff of foul water must pass out and bathe the glands. Moreover, I have repeatedly found that, by gently pressing bladders which containerl air, minute bubbles were driven rut through the orifice; and if a bladder is laid on

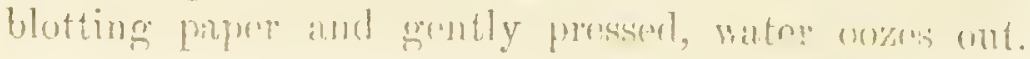


In this latter ease, as soon as the pressure is relaxed, air is drawn in, and the bladder recovers its proper form. If it is now placed under water and again gently pressed, minute bubbles issue from the orifice and nowhere else, showing that the walls of the bladder have not been ruptured. I mention this bécause Cohn quotes a statement by 'Treviranus, that air cannot be forced out of a bladder without rupturing it. We may therefore eonclude that whenever air is secreted within a bladder already full of water, some water will be slowly driven out through the orifice. Hence I ean hardly doubt that the numerous glands eromded round the orifiee are adapted to absorb matter from the putrid water, which will occasionally escape from bladders ineluding deeayed animals.

In order to test this eonelusion, I experimented with various solutions on the glands. As in the ease of the quadrifids, salts of ammonia were tried, sinee these are generated by the final deeay of animal matter under water. Unfortunately the glands eannot be earefully eramined whilst attached to the bladders in their entire state. Their summits, therefore, ineluding the valve, eollar, and antennæ, were slieed off, and the condition of the glands observed; they were then irrigated, whilst beneath a eovering glass, with the solutions, and after a time re-examinad with the same power as before, namely No. 8 of Hartnaek. The following experiments were thus made.

As a eontrol experiment solutions of one part of white sugar and of one part of gum to 218 of water were first used, to see whether these produced any ehange in the glands. It was also neeessary to observe whether the glands were affeeted by the summits of the bladders having been cut off. The summits of four were thus tried; one being cramined after 2 hrs. $30 \mathrm{~m}$., and the other three after $23 \mathrm{hrs}$; ; but there was no marked ehange in the glands of any of them.

Two summits bearing quite eolourless glands were irrigated with a solution of earbonate of ammonia of the same strength (viz. one part to 218 of water), and in $5 \mathrm{~m}$. the primordial utrieles of most of the glands were somewhat eontraeted; they were also thiekened in speeks or patehes, and had assumed a palo 
brown tint. When looked at again after $1 \mathrm{hr} .30 \mathrm{~m}$., most of them presented a somewhat differeut appearance. A third specimen was treated with a weaker solution of one part of the carbonate to 437 of water, and after $1 \mathrm{hr}$, the glands wcre pale brown and contained numcrous granules.

Four summits were irrigated with a solution of one part of nitrate of ammonia to 437 of water. One was cxamined after $15 \mathrm{~m}$, and the glands seemed affected; after $1 \mathrm{hr} .10 \mathrm{~m}$. therc was a greater change, and the primordial utricles in most of them were sumewhat shrunk, and included many granules. In the second specimen, the primordial utricles were considerably shrunk and brownish after 2 hrs. Similar effects were observed in the two other specimens, but these were not examined until 21 hrs. had elapsed. The nuclei of many of the glands apparently had increased in size. Five bladders on a branch, which had been kept for a long time in moderately pure water, were cut off and examined, and their glands found very little modified. The remainder of this branch was placed in the solution of the nitrate, and after 21 lirs. two bladders were examined, and all their glands were brownish, with their primordial utricles somewhat shrunk and finely granular.

The summit of another bladder, the glands of which were in a beautifully clear condition, was irrigated with a few drops of a mixed solution of nitrate and phosphate of ammonia, cach of one part to 437 of water. After 2 hrs. some few of the glands were brownish. After 8 hrs. almost all the oblong glands were brown and much more opaque than they were before; their primordial utricles wero somewhat shrunk and contained a little aggregated granular matter. The spherical glands were still white, but their utricles were broken up into three or four small hyaline spheres, with an irregularly contracted mass in the middle of the basal part. These smaller spheres changed their forms in the course of a few hours, and some of them disappeared. By the next morning, after 23 hrs. $30 \mathrm{~m}$, they had all disappcared, and the glands wore brown; their utricles now formed a glo ular shrunken mass in the middle. 'l'he utricles of the oblong glands had shrunk very little, but their contents were somewhat aggregated. Lastly, the summit of a bladder which had been previously irrigated for 21 hrs. with a solution of one part of sugar to 218 of water without being affected, was treated with the above mixed solution; and after 8 hrs. $30 \mathrm{~m}$. all the glands became brown, with their primordial utricles slightly shrunk.

Four summits were irrigated witl a putrid infusion of raw 
meat. No change in the glands was observable for some hours, but after 24 hrs. most of them had become brownish, and more opaque and granular than they were before. In these speeimens, as in those irrigated with the salts of ammonia, the nuclei seemed to have increased both in size and solidity, but they were not measured. Five summits were also irrigated with a fresh infusion of raw meat; three of these were not at all affected in $24 \mathrm{hrs}$., but the glands of the other two liad perhaps become more granular. One of the speeimens which was not affeeted was then irrigated with the mixed solution of the nitrate and phosphate of ammonia, and after only $25 \mathrm{~m}$. the glands contained from four or five to a dozen granules. After six additional hours their primordial utrieles were greatly shrunk.

The summit of a bladder was examined, and all the glands found colourless, with their primordial utricles not at all shrunk; yet many of the oblong glands contained granules just resolvable with No. 8 of Hartnack. It was then irrigated with a few drops of a solution of one part of urea to 218 of water. After $2 \mathrm{hrs} .25 \mathrm{~m}$. the spherical glands were still colourless; whilst the oblong and two-armed ones were of a brownish tint, and their primordial utricles much shrunk, some eontaining distinetly visible granules. After $9 \mathrm{hrs}$. some of the spherical glands were brownish, and the oblong glands were still more changed, but they contained fewer separate granules; their nuclei, on the other hand, appeared larger, as if they had absorbed the granules. After 23 hrs. all the glands rere brown, their primordial utricles greatly shrunk, and in many eases ruptured.

A bladder was now experimented on, whieh was already somewhat affected by the surrounding water; for the spherieal glands, though eolourless, had their primordial utrieles slightly shrunk; and the oblong glands were brownish, with their utricles much, but irregularly, shrunk. The summit was treated with the solution of urea, but was little affeeted by it in 9 hrs.; nevertheless, after 23 hrs. the spherical glands were brown, with their utrieles more shrunk; several of the other glands were still browner, with their utrieles eontraeted into irregular little masscs.

Two other summits, with their glands eolourless and their utricles not shrunk, were treated witl the same solution of urea. After 5 hrs. many of the glands presented a shade of brown, with their utricles slightly shruml. After 20 hrs. $40 \mathrm{~m}$. some few of them were quite bromn, and eontaincd 
irregularly aggregated masses; others werc still colourless, though their utricles were shrunk; but the greatcr number wcre not much affected. This was a good instance of how unequally the glands on the same bladder are sometimes affected, as likewise often occurs with plants growing in foul water. T'wo other summits were treated with a solution which had been kept during scveral days in a warm room, and their glands were not at all affected when cxamined after 21 hr's.

A weaker solution of one part of urea to 437 of water was next tried on six sumuits, all carefully cxamined before being irrigated. The first was re-examined after 8 hrs. $30 \mathrm{~m}$., and the glands, including the spherical oncs, were brown; many of the oblong glands having their primordial utricles much shrunk and including granules. The sccond summit, before being irrigated, had been somewhat affceted by the surrounding water, for the spherical glands were not quite uniform in appearance; and a few of the oblong ones wcre brown, with their utricles shrunk. Of the oblong glands, those which were bcfore colourlcss, became brown in 3 hrs. $12 \mathrm{~m}$. after irrigation, with their utricles slightly shrunk. 'l'he spherical glands did not become brown, but their contents seemed changed in appearancc, and after 23 hrs. still more changed and granular. Most of the oblong glands were now dark brown, but their utricles were not greatly shrunk. The four other spccimens werc examined after 3 hrs. $30 \mathrm{~m}$., after 4 hrs., and 9 hrs.; a brief account of their condition will be sufficient. The sphcrical glands were not brown, but some of them werc finely gramular. Many of the oblong glands were brown; and these, as well as other's which still remained colourless, had their utricles more or less shrunk, some of them including small aggregated masses of matter.

Summary of the Observations on Absorption.-From the facts now given there. ean be no doubt that the variously shaped glands on the valve and round the eollar have the power of absorbing matter from weak solutions of eertain salts of ammonia and urea, and from a putrid infusion of raw meat. Prof. Cohn believes that they secrete slimy matter; but I was not able to pereeive any trace of such aetion, exeepting that, after immersion in alcohol, extremely fine lines could sometimes be seen radiating from their 
surfaces. The glands are variously affected by absorption; they often beeome of a brown colour; sometimes they contain very fine granules, or moderatcly sized grains, or irregularly aggregated little masses; sometimes the nuclei appear to have increased in size; the primordial utricles are generally more or lcss shrunk and sometimes ruptured. Exactly the same changes may be observed in the glands of plants growing and flourishing in foul water. The sphcrical glands are generally affected rather differently from the oblong and two-armed ones. The former do not so commonly become brown, and are acted on more slowly. We may therefore infer that they differ somewhat in their natural functions.

It is remarkable how unequally the glands on the bladders on the same branch, and even the glands of the same kind on the same bladder, are affected by the foul water in which the plants have grown, and by the solutions which were employed. In the former case I presume that this is due either to little eurrents bringing matter to some glands and not to others, or to unknown differcnces in their constitution. When the glands on the same bladder are differently affected by a solution, we may sispect that some of them had previously absorbed a small amount of matter from the water. However this may be, we have seen that the glands on the same leaf of Drosera are sometimes very uncqually affected, morc especially when exposed to certain vapours.

If glands which have already become brown, with their primordial utricles shrunk, are irrigated with one of the effective solutions, they are not acted on, or only slightly and slowly. If, however, a gland contains merely a few coarse gramules, this does not prevent a solution from acting. I have nerer seen 
any appearance making it probable that glands whieh have been strongly affeeted by absorbing matter of any kind are capable of reeovering their pristine, eolourless, and homogeneous condition, and of regaining the power of absorbing.

From the natmre of the solntions whieh were tried, I presume that nitrogen is absorbed by the glands; but the modified, brownish, more or less shrunk, and aggregated eontents of the oblong glands were never seen by me or by my son to undergo those spontaneous ehanges of form eharaeteristic of protoplasm. On the other hand, the eontents of the larger spherieal glands often separated into small hyaline globules or irregularly shaped masses, which ehanged their forms very slowly and ultimately eoalesced, forming a eentral shrunken mass. Whatever may be the nature of the eontents of the several kinds of glands, after they have been acted on by foul water or by one of the nitrogenous solutions, it is probable that the matter thus generated is of serviee to the plant, and is ultimately transferred to other parts.

The glands apparently absorb more quickly than do the quadrifid and bifid proeesses; and on the view above maintained, namely that they absorb matter from putrid water oeeasionally emitted from the bladders, they ought to act more quickly than the processes; as these latter remain in permanent eontact with eaptured and deeaying animals.

Finally, the conelusion to which we are led by the foregoing experiments and observations is that the bladders have no power of digesting animal matter, though it appears that the quadrificls are somewhat affeeted by a fresh infusion of raw meat. It is ecrtain that the processes within the bladders, and the glands outside, absorb matter from salts of 
ammonia, from a putrid infusion of raw meat, and from urea. The glands apparently are acted on more strongly by a solution of urea, and less strongly by an infusion of raw mcat, than are the proccsses. The case of urea is particularly interesting, because we have seen that it produces no effect on Droscra, the leaves of whieh are adapted to digest fresh animal matter. But the most important fact of all is, that in the present and following species the quadrifid and bifid processes of bladdcrs containing decayed animals generally include little masses of spontaneously moving protoplasm; whilst such masses are never seen in perfectly clean bladders.

Development of the Bladders.-My son and I spent much time over this subject with small success. Our observations apply to the present species and to Utricularia vulgaris, but were made chiefly on the latter, as the bladders are twice as large as those of Utricularia neglecta. In the early part of autumn the stems terminate in largc buds, which fall off and lie dormant during the winter at the bottom. The young leaves forming these buds bear bladders in various stages of early development. When the bladders of Utricularia vulgaris are about $\frac{1}{100}$ inch $(.254 \mathrm{~mm}$.) in diameter (or $\frac{1}{200}$ in the case of Utricularia neglecta), they are cireular in outline, with a narrow, almost closed, transverse orifice, leading into a hollow filled with water; but the bladders are hollow when mueh under $\frac{1}{100}$ of an ineh in diameter. The orifices face inwards or towards the axis of the plant. At this early age the bladders are flattened in the plane in which the orifice lies, and therefore at right angles to that of the mature bladders. They are eovered cxteriorly with papilla of different sizes, many of whieh have au elliptical outline. A bundle of vessels, formed of 
simple elongated eells, runs up the short footstalk, and divides at the base of the bladder. One branch extends up the middle of the dorsal surface, and the other up the middle of the ventral surfnee. In full-grown bladdcrs the ventral bundle divides elose beneath the collar, and the two branehes run on each. side to near where the corners of the valve unite with the collar; but these branches eould not be seen in very young bladders.

The accompanying figure (fig. 23) shows a seetion, which happened to be strietly medial, through the footstalk and between the nascent antennæ of a bladder of Utricularia vulgaris, $\frac{1}{100}$ ineh in diameter. The specimen was soft, and the young valve became separated from the collar to a greater degree than is natural, and is thus represented. We here clearly see that the valve and eollar are infolded prolongations of the walls of the bladder. Even at this early age, glands eould be deteeted on the valve. The state of the quadrifid proeesses will presently be deseriber. The antennæ at this

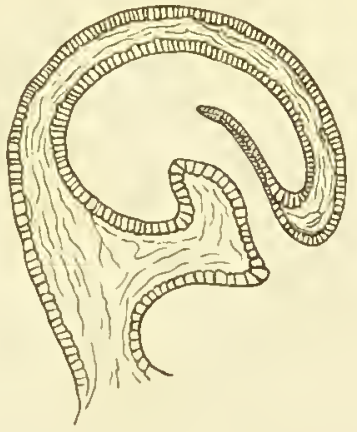

FIG, 23.

(Ctricularia vulgaris.)

Longitudinal section through a young bladder, yo of an inch in length, with the orifice too willely open.

period consist of minute cellular projeetions (not shown in the above figure, as they do not lie in the medial plane), which soon bear incipient bristles. In five instanees the young antenna were not of quite equal length; and this faet is intelligible if $I$ am right in believing that they represent two divisions of the leaf, rising from the end of the bladder; for, with the true leavcs, whilst very young, the divisions are never, as far as I have seen, strictly oplposite; they 
must therefore be developed onc after the other, and so it would be with the two antennæ.

At a much earlier age, when the half formed bladders are only $\frac{1}{300}$ ineh $(.0846 \mathrm{~mm}$.) in diameter or a little more, they present a totally different appearance. One is represented on the left side of the aceompanying drawing (fig. 24). The young leaves

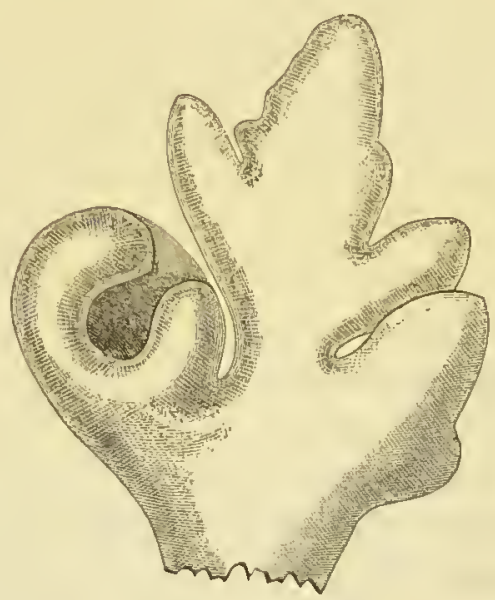

Fig. 24.

(Utricularia vulgaris.)

Young leaf from $a$ winter bud, showing on the left side a bladader in its enrliest stage of development.

at this age have broad flattcned segments, with their future divisions represented by prominences, one of which is shown on the right side. Now, in a large number of specimens examined by my son, the young bladders appeared as if formed by the oblique folding over of the apex and of one margin with a prominence, against the opposite margin. The circular hollow between the infolded apex and infolded prominence apparently eontracts into the narrow orifice, wherein the valve and collar will be developed; the bladder itself being formed by the confluence of the opposed 
margins of the rest of the leaf. But strong objeetions may be meed against this view, for we must in this ease suppose that the valve and eollar are developed asymmetrieally from the sides of the apex and prominenee. Moreover, the bundles of vasenlar tissue have to be formed in lines quite irrespeetive of the original form of the leaf. Until gradations ean be shown to exist between this the earliest state and a young yet perfeet bladder, the ease must be left doubtful.

As the quadrifid and bifid proeesses offer one of the greatest peeuliarities in the genus, I earefully observed their development in Utricularia neglecta. In bladders about $\frac{1}{100}$ of an ineh in diameter, the inner surfaee is studded with papilla, rising from small eells at the junetions of the larger ones. These papillre eonsist of a delieate eonieal protubcranee, whieh narrows into a very short footstalk, surmounted by two minute eells. They thus oeeupy the same relative position, and elosely resemble, exeept in being smaller and rather more prominent, the papilla on the outside of the bladders, and on the surfaees of the leaves. The two terminal eells of the papilla first beeome mueh elongated in a line parallel to the inner surfaee of the bladder. Next, eaeh is divided by a longitudinal partition. Soon the two half-eells thus formed separate from one another; and we now have four cells or an ineipient quadrifid proeess. As there is not space for the two new eells to inercase in breadth in their original plane, the one slides partly under the other. 'Their manner of growth now ehanges, and their outer sides, instead of their apiees, continue to grow. 'The two lower eclls, whieh have slid partly beneath the two upper ones, form the longer and more upright pair of proeesses; whilst the two upper cells form the shorter 
and more họrizontal pair; the four together forming a perfect quadrifid. A trace of the primary division between the two cells on the summits of the papillix can still be seen between the bases of the longer processes. The development of the quadrifids is very liable to be arrested. I have seen a bladder $\frac{1}{3} \frac{1}{0}$ of an inch in length including only primordial papillæ; and another bladder, about half its full size, with the quadrifids in an early stage of development.

As far as I could make out, the bifid processes are developed in the same manner as the quadrifids, excepting that the two primary terminal cells never become divided, and only increase in length. The glands on the valve and collar appear at so early an age that I could not trace their development; but we may reasonably suspect that they are developed from papillæ like those on the outside of the bladder, but with their terminal cells not divided into two. The two segments forming the pedicels of the glands probably answer to the conical protuberance and short footstalk of the quadrifid and bifid processes. I am strengthened in the belief that the glands are developed from papillæ like those on the outside of the bladders, from the fact that in Utricularia amethystina the glands extend along the whole rentral surface of the bladder close to the footstalk.

\section{UTRICULARIA VULGARIS.}

Living plants from Yorkshire were sent me by Dr. Hooker. This species differs from the last in the stems and lenves being thieker or eoarser; their divisions form a more acute angle with one another; the notches on the leares hear three or four short bristles instead of one; and the bladders are twice as large, or about $\frac{1}{5}$ of an ineh $(5.08 \mathrm{~mm}$.) in diameter. In all essential respeets the bladders resemble those of Vtriculariv neglecta, but the sides of the peristome are perhaps a little more 
prominent, and always bear, as far as I have secn, seven or cight long multicellular bristles. There are eleven long bristles on each antenna, the terminal pair boing included. Five bladders, containing prey of some kind, wcre examined. The first included fire Cypris, a large copepod and a Diaptomus; the sccond, four Cypris; the third, a single rather large crustacean; the fourth, six crustaccans; and the fifth, ten. My son examined the quadrifid proccsses in a bladder containing the remains of two crustaceans, and found some of them full of spherical or irregularly shaped masscs of matter, which were observed to move and to coalcsce. Thesc masses therefore con. sisted of protoplasm.

\section{UTRICULARIA MINOR.}

This rare species was scnt me in a living state from Cheshire, through the kindness of Mr. John Pricc. The lcaves and bladders are much smaller than those of Citricularia neglecta. The leaves bear fewer and shortcr bristles, and the bladders are more globular. The antcnnæ, instead of projecting in front of the bladders, arc curled under the valve, and are armed with twelve or fourteen extremely long multicellular bristles, generally arranged in pairs. These, with scven or eight long bristles on both sides of the peristome, form a sort of net over the valve, which would tend to prevent all animals, exccpting very small ones, entering the bladder. The valve and collar have the same esscntial structure as in the two previous species; but the glands are not

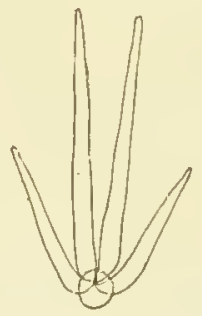

FIG. 25.

(Utricularia minor.)

Quadrifid process; greatly eularged. quite so numerons; the oblong ones are rather morc clongated, whilst the two-armed oncs arc rather less elongated. The four bristles which project obliquely from the lower cdge of the valve are short. Their shortness, compared with those on the valves of the forcgoing specics, is intelligible if my view is conect that they serve to prevent too large animals forcing an entrance through the valve, thus injuring it; for the valve is already protected to a certain cxtent by the incurved antenne, together with the lateral bristles. The bifid processes are like those in the previous species; but the quadrifids differ in the four ar'ms (fig. 25) 
being direeted to the same side; the two longer ones being central, and the two shorter ones on the outside.

The plants were collceted in the middle of July; and the eontents of five bladders, which from their opacity seemed full of prey, were examined. The first contained no less than twenty-four minutc fresh-water erustaceans, most of them eonsisting of empty shells, or including only a few drops of red oily matter; the seeond containcd twenty; the third, fifteen; the fourth, ten, some of them being rather larger than usual; and the ffth, whieh seemed stuffed quite full, contained only seven, but five of these were of untsually large size. The prey, therefore, judging from these five bladders, consists exclusively of fresh-water crustaeeans, most of which appeared to be distinet species from those found in the bladders of the two former species. In one bladder the quadrifids in contact with a decaying mass eontained numerous spheres of granular matter, whieh slowly ehanged their forms and positions.

\section{UTRICULARIA CLANDESTINA.}

This North American speeies, which is aquatie like the three foregoing ones, has been described by Mrs. Treat, of New Jersey, whose excellent obscrvations have already been largely quoted. I have not as yet seen any full deseription by her of the strueture of the bladder, but it appears to be lined with quadrifid proeesses. A vast number of captured animals were found within the bladders; some being erustreeans, but the greater number delieate, elongatcd larvæ, I suppose of Culicidæ. On some stems, "fully nine out of every ten bladders contained thcse larvæ or their remains." The larvæ "showed signs of life from twenty-four to thirty-six hours after being imprisoned," and then perished. 


\section{CHAPTER XVIII.}

\section{Utricolaria (continued).}

Utricularic montana-Description of the bladders on the subterranean rhizomes - Prey captured by the bladders of plants under eulture and in a state of natmre - Absorption by the quadrifid processes aud glands-Tubers serving as reservoirs for watcrVarious other species of Utricularia - Polypompholyx - Genlisea, different naturc of the trap for capturing prey-Diversified methods by which plants are nourished.

Utricularia montana.-This speeies inhabits the tropical parts of South Ameriea, and is said to be epiphytie; but, judging from the state of the roots (rhizomes) of some dried speeimens from the herbarium at Kew, it likewise lives in earth, probably in ereviees of rocks. In English hothouses it is grown in peaty soil. Lady Dorothy Nevill was so kind as to give me a fine plant, and I reeeived another from Dr. Hooker. The leaves are entire, instead of being mueh divided, as in the foregoing aquatie speeies. They are elongated, about $1_{\frac{1}{2}}$ inch in breadth, and furnished with a dis-

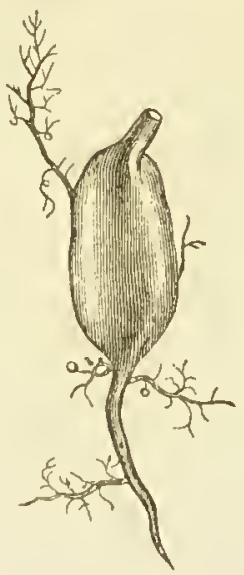

FIG. 26.

(Utricularia montana.)

Rhizome swollen into a tuber; the branches bearing ininute blalders; of natural size. tinet footstalk. The plant produees numerous eolourless rhizomes, as thin as threads, which bear minute bladders, and occasionally swell into tubers, as will 
hereafter be described. These rhizomes appear exactly like roots, but occasionally throw up green shoots. They penetrate the earth sometimes to the depth of more than 2 inches; but when the plant grows as an epiphyte, they must creep amidst the mosses, roots, decayed bark, \&c., with which the trees of these countries are thickly covered.

As the bladders are attached to the rhizomes, they are necessarily subterranean. They are produced in extraordinary numbers. One of my plants, though young, must have borne several hundreds; for a single branch out of an entangled mass had thirty-two, and another branch, about 2 inches in length (but with its end and one side branch broken off), had seventy-three bladders.* The bladders are compressed and rounded, with the ventral surface, or that between the summit of the long delicate footstalk and valve, extremely short (fig. 27). They are colourless and almost as transparent as glass, so that they appear smaller than they really are, the largest being under the $\frac{1}{20}$ of an inch $(1.27 \mathrm{~mm}$.) in its longer diameter. They are formed of rather large angular cells, at the junctions of which oblong papilla project, corresponding with those on the surfaces of the bladders of the previous species. Similar papillæe abound on the rhizomes, and even on the entire leaves, but they are rather broader on the latter. Vessels, marked with parallel bars instead of by a spiral line, run up the footstalls, and

* Prof. Oliver has figured a plant of Utrieularia Jamesoniana ('Proc. Tinn. Soe.' vol. iv. p. 169) having entire leaves and rhizomes, like those of our present species; lut the margins of the terminal halves of somo of the leaves are converted into bladders. 'This fact elearly indieates that the bladders on the rhizomes of the present and following speeies are modified segrments of tho lenf; and they are thus brought into accordance with the bladders attuched to the divided and floating lenves of the aquatic species. 
just enter the bases of the bladders; but they do not bifureate and extend up the dorsal and ventral surfaees, as in the previous species.

The antennæ are of moderate length, and taper to a fine point; they differ eonspiouously from those before described, in not being armed with bristles. Their bases are so abruptly curved that their tips generally rest one on eaeh side of the middle of the bladder, but

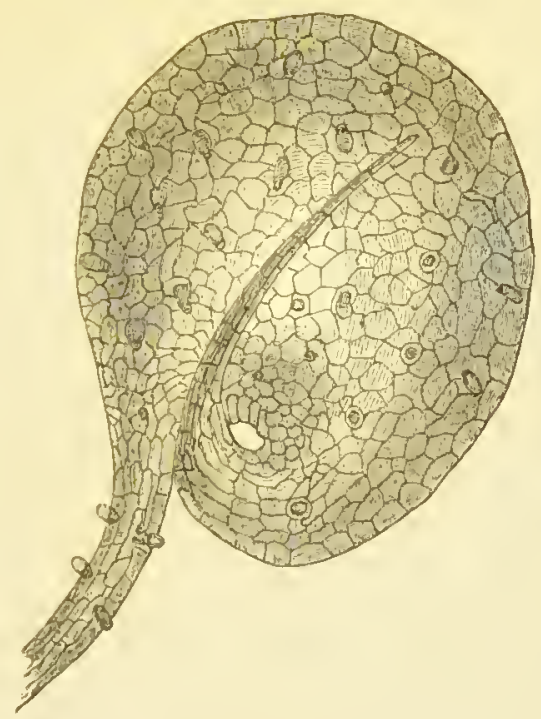

Fis. 27.

(Ĺtricularia montana.)

Bladder; alsout 27 times enlarged.

sometimes near the margin. Their curverl bases thus form a roof over the eavity in which the valve lies; but there is always left on each side a little cireular passage into the cavity, as may be seen in the drawing, as well as a narrow passage between the bases of the two antenne. As the blarlders are subterranean, had it not been for the roof, the eavity in whieh the valve lies would have been liable to be bloeked up with earth 
and rubbish; so that the curvature of the antemne is a serviceable character. There are no bristles on the outside of the collar or peristome, as in the forcgoing species.

The valve is small and steeply inclined, with its free posterior edge abutting against a semicircular, deeply flepending collar. It is moderately transparent, and bears two pairs of short stiff bristles, in the same position as in the other species. The presence of these four bristles, in contrast with the absence of those on the antenme and collar, indicates that they are of functional importance, namely, as I believe, to prevent too large animals forcing an entrance through the valve. The many glands of diverse shapes attached to the valve and round the collar in the previous species are here absent, with the exception of about a dozen of the two-armed or transversely elongated kind, which are seated near the borders of the ralre, and are mounted on very short footstalks. These glands are only the $\frac{3}{7000}$ of an inch $(.019 \mathrm{~mm}$.) in length; thongh so small, they act as absorbents. The collar is thick, stiff, and almost semi-circular; it is formed of the same peculiar brownish tissue as in the former species.

The bladders are filled with water, and sometimes include bubbles of air. They bear internally rather short, thick, quadrifid processes arranged in approximately concentric rows. The two pairs of arms of which they are formed differ only a little in length, and stand in a peculiar position (fig. 28); the two longer ones forming one line, and the two shorter ones another parallel line. Each arm includes a small spherical mass of brownish matter, which, when crushed, breaks into angular pieces. I have no donbt that these spheres are uuclei, for closely similar ones 
are present in the eells forming the walls of the bladders. Bifid processes, having rather short oval arms, arise in the usual position on the inner side of the eollar.

These bladders, therefore, resemble in all essential respects the larger ones of the foregoing speeies. They differ ehiefly in the absenee of the numerous glaurls on the valve and round the eollar, a fer minute ones of one kind alone being present on the valve. They differ more conspienously in the absence of the lowg bristles on the antennæe and on the outside of the eollar. The presence of these bristles in the previously mentioned species probably relates to the eapture of aquatie animals.

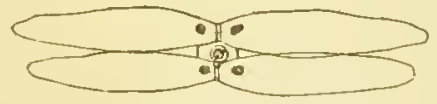

FIG. 28.

(tricularia montana.)

One of the quadrifid processes; much enlarged.

It seemed to me an interesting question whether the minute bladders of Ltricularia montana served, as in the previous speeies, to eapture animals living in the earth, or in the dense vegetation eovering the trees on whieh this species is epiphytie; for in this ease we should have a new sub-class of carnivorous plants, namely, subterranean feeders. Many bladders, therefore, were examined, with the following results:-

(1) A small bladder, less than $\frac{x}{30}$ of an inch ( $847 \mathrm{~mm}$.) in diametor, contained a minute mass of brown, much docayed mattor; and in this, a tarsus with four or five joints, tcrminating in a double hook, was elearly distinguished under the miorosoopo. I suspect that it was a remnant of one of the Thysanoura. The quadrifids in contact with this docayod rommant contained oither small massos of translucont, yellowish mattor, gonorally more 
or less globular, or fine granules. In distant parts of the same bladder, the proeesses were transparent and quite empty, with the exception of their solid nuelei. My son made at short intervals of time sketches of one of the above aggregated masses, and found that they continually and completely changed their forms; sometimes separating from one another and agrin conleseing. Evidently protoplasm had been generated by the absorption of some element from the deenying animal matter.

(2) Another bladder included a still smaller speek of decayed brown matter, and the adjoining quadrifids contained aggregated matter, exactly as in the last ense.

(3) A third bladder ineluded a larger organism, whieh was so mueh deeayed that I eould only make out that it was spinose or hairy. The quadrifids in this ease were not mueh affeeted, exeepting that the nuclei in the several arms differed much in size; some of them containing two masses having a similar appearanee.

(4) A fourth bladder contrined an artieulate organism, for I distinetly saw the remnant of a limb, terminating in a hook. The quadrifids were not examined.

(5) A fifth ineluded much decryed matter apparently of some animal, but with no reeognisable features. The quadrifids in contact eontrined numerous spheres of protoplasm.

(6) Some fer bladders on the plant whieh I reeeived from Kew were examined; and in one, there was a worm-shaped animal very little deeayed, with a distinct remnant of a similar one greatly deenyed. Several of the arms of the proeesses in eontaet with these remains eontained two spherical masses, like the single solid nucleus whieh is properly found in eaeh arm. In another bladder there was a minute grain of quartz, reminding me of two similar eases with Utricularia neglectr.

As it appeared probable that this plant would capture a greater number of animals in its native country than under culture, I obtained permission to remove small portions of the rhizomes from dried specimens in the herbarium at Kew. I did not at first find out that it was advisable to soak the rhizomes for two or three days, and that it was neeessary to open the hlarders and spread out their eontents on glass; as from their state of deeay and from having been dried and pressed, their nature eould not otherwise be well distinguished. Several bladders on a plant which had grown in blaek earth in New Granada were first examined; and four of these included remnants of animals. The first contained a hairy Acrirus, so mueh decayed that nothing was left except its transparent coat; 
also a yellow chitinous liead of some animal with an internal fork, to whieh the osophagus was suspended, but I eould sce no mandibles; also the double hook of the tarsus of some animal; also an elongated greatly deeayed animal; and lastly, a curious flask-shaped organism, having the walls formed of rounded eells. Professor Claus has looked at this latter organism, and thinks that it is the shell of a rhizopod, probably one of the Arcellidio. In this bladder, as well as in several others, there were some unieellular Algæe, and one multieellular Alga, whieh no doubt had lived as intruders.

A seeond bladder eontained an Aearns mueh less deeayed than the former one, with its eight legs preserved; as well as remnants of several other articulate animals. A third bladder eontained the end of the abdomen with the two hinder limbs of an Aearus, as I believe. A fourth eontained remnants of a distinetly artieulated bristly animal, and of several other organisms, as well as much dark brown organie matter, the nature of whicls conld not be made out.

Some bladders from a plant, whieh had lived as an epiphyte in Trinilad, in the West Indies, were „next examined, but not so eurefully as the others; nor had they been soaked long enough. Four of them eontrined much brown, translucent, granular matter, apparently organie, but with no distinguishable parts. The quadrifids in two were brownish, with their contents granular; and it was evident that they had absorbed matter. In a fifth bladder there was a flask-shaped organism, like that above mentioned. A sixth contained a very long, mueh deeayed, worm-shaped animal. Lastly, a seventh bladder contained an organism, but of what nature eould not be distinguished.

Only one experiment was tried on the quadrifid processes and glands with referenee to their power of absorption. A bladder was punetured and left for 24 hrs. in a solution of one part of urea to 437 of water, and the quadrifid and bifid processes were found much affected. In some arms there was only a single symmetrieal globular mass, larger than the proper nucleus, and consisting of yellowish matter, generally translucent but sometimes granular; in others there were two masses of different sizes, one large and the 
other small; and in others there were irregularly shaped globules; so that it appeared as if the limpid contents of the proeesses, owing to the absorption of matter from the solution, had beeome aggregated sometimes round the nueleus, and sometimes into separate masses; and that these then tended to coalesee. The primordial utriele or protoplasm lining the proeesses was also thickened here and there into irregular and variously shaped speeks of yellowish translueent matter, as oeeurred in the ease of Utricularia neglecta. under similar treatment. These speeks apparently did not ehange their forms.

The minute tro-armed glands on the ralve were also affeeted by the solution; for they now eontained several, sometimes as many as six or eight, almost spherieal masses of translucent matter, tinged with yellow, whieh slowly ehanged their forms and positions. Sueh masses were never observed in these glands in their ordinary state. We may therefore infer that they serve for absorption. Whenever a little water is expelled from a bladder eontaining animal remains (by the means formerly speeified, more especially by the generation of bubbles of air), it will fill the eavity in whieh the valve lies; and thus the glands will be able to utilise deeayed matter which otherwise would have been wasted.

Finally, as numerous minute animals are enptured by this plant in its native eountry and when eultivated, there ean be no doubt that the bladders, though so small, are far from being in a rudimentary condition; on the eontrary, they are highly effieient traps. Nor ean there be any doubt that matter is absorbed from the decayed prey by the quadrifid and bifid proeesses, and that protoplasm is thus generated. What tempts animals of such diverse kinds to enter 
the cavity beneath the bowed antemnx, and then force their way through the little slit-like orifice between the valve and collar into the bladders filled with water, I camnot conjecture.

Tubers.-Whese organs, one of which is represented in a previous figure (fig. 26) of the natural size, deserve a few remarks. Twenty were found on the rhizomes of a single plant, but they cannot be strictly counted; for, besides the twenty, there were all possible gradations between a short length of a rhizome just perceptibly swollen and one so much swollen that it might be doubtfully called a tuber. When well developed, they are oval and symmetrical, more so than appears in the figure. The largest which I saw was 1 inch $(25.4 \mathrm{~mm}$.) in length and 45 inch $(11.43 \mathrm{~mm}$.) in breadth. They commonly lie near the surface, but some are buried at the depth of 2 inches. The buried ones are dirty white, but thosc partly exposed to the light become greenish from the development, of chlorophyll in their superficial cells. They terminate in a rhizome, but this sometimes decays and drops off. They do not contain any air, and they sink in water; their surfaces are covered with the usual papillx. The bundle of vessels which. runs up each rhizome, as soon as it enters the tuber, separates into three distinct bundles, which remite at the opposite end. A rather thick slice of a tuber is almost as transparent as glass, and is seen to consist of large angular cells, full of water and not containing starch or any other solid matter. Some slices were left in alcohol for several days, but only a few extremely minute granules of matter were precipitated on the walls of the cells; and these were much smaller and fewer than those precipitated on the cell-walls of the rhizomes and bladders. We may therefore con- 
elude that the tubers do not serve as reservoirs for food, but for water during the dry season to whieh the plant is probably exposed. The many little bladders filled with water would aid towards the same end.

To test the eorreetness of this view, a small plant, growing in light peaty earth in a pot (only $4 \frac{1}{2}$ by $4 \frac{1}{2}$ inehes outside measure) was eopiously watered, and then kept without a drop of water in the hothouse. Two of the upper tubers were beforehand uncovered and measured, and then loosely eovered up again. In a fortnight's time the earth in the pot appeared extremely dry; but not until the thirty-fifth day were the leaves in the least affeeted; they then beeame slightly reflexed, though still soft and green. This plant, which bore only ten tubers, would no doubt have resisted the drought for even a longer time, had I not previously removed three of the tubers and eut off several long rhizomes. When, on the thirty-fifth day, the earth in the pot was turned out, it appeared as dry as the dust on a road. All the tubers had their surfaees mueh wrinkled, instead of being smooth and tense. They had all shrunk, but I cannot say aceurately how mueh; for as they were at first symmetrieally oval, I measured only their length and thielness; but they eontracted in a transverse line mueh more in one direction than in another, so as to become greatly flattened. One of the two tubers which had been measured was now three-fourths of its original length, and two-thirds of its original thickness in the direction in whieh it had been measured, but in another direction only one-third of its former thiekness. 'The other tuber was one-fourth shorter, oneeighth less thiek in the direetion in whieh it had been measured, and only half as thick in another direction.

A slice was cut from one of these shrivelled tubers 
and examined. The eells still contained mueh water and no air, but they were more rounded or less angular than before, and their walls not nearly so straight; it was therefore clear that the cells had contracted. The tubers, as long as they remain alive, have a strong attraetion for water; the shrivelled one, from which a sliee had been eut, was left in water for 22 hrs. $30 \mathrm{~m}$., and its surfaee beeame as smooth and tense as it originally was. On the other hand, a shrivelled tuber, which by some aceident had been separated from its rhizome, and whieh appeared dead, did not swell in the least, though left for several days in water.

With many kinds of plants, tubers, bulbs, \&e. no doubt serve in part as reservoirs for water, but I know of no ease, besides the present one, of sueh organs having been developed solely for this purpose. Prof. Oliver informs me that two or three other speeies of Utricnlaria are provided with these appendages; and the group containing them has in eonsequenee reeeived the name of orchidioides. All the other speeies of Utricularia, as well as of eertain closely related genera, are either aquatic or marsh plants; therefore, on the principle of nearly allied plants generally having a similar eonstitution, a never failing supply of water would probably be of great importanee to our present speeies. We ean thus understand the meaning of the development of its tubers, and of their number on the same plant, amounting in one instance to at least twenty.

Utricularia nelumbirolia, amethystina, GriFFITHII, CIERULEA, ORBICULATA, MUL'TICAULIS.

As I wisher to aseertain whether the bladders on the rhizomes of other speeies of Utricularia, and of the 
specics of ccrtain closely allied gcnera, had the same essential structure as those of Utricularia montana, and whether they captured prey, I asked Prof. Oliver to send me fragments from the herbarium at Kow. He lindly selected some of the most distinct forms, having entire leaves, and believed to inhabit marshy ground or water. My son, Francis Darwin, examined them, and has given me the following observations; but it should be borne in mind that it is extremely difficult to makc out the structure of such minute and delicate objects after they have been dried and pressed.*

Utricularia nelumbifolia (Organ Mountains, Brazil).The habitat of this species is remarkable. According to its discoverer, Mr. Gardner, $\dagger$ it is aquatic, but " is only to be found growing in the water which collects in the bottom of the leaves of a large Tillandsia, that inhabits abundantly an arid rocky part of the mountain, at an elevation of about 5000 feet above the level of the sea. Besides the ordinary method by seed, it propagates itself by runners, which it throws out from the base of the flower-stem; this rumner is always found directing itsclf towards the nearest Tillandsin, when it inserts its point into the water and gires origin to a new plant, which in its turn sends out another shoot. In this manner I have scen not less than six plants united." The bladder's resemble those of Utricularia montana in all essential respects, even to the presence of a fow minute two-armed glands on the valve. Within onc bladder there was the remnant of the abdomen of some larva or crnstacean of large size,

* Prof. Oliver has given (' Proc. Linn. Soe.' vol. iv. p. 169) figures of the bladders of two South Ameriean speeies, namely, Utrieularia Jamesoniana and peltata; but he does not nppear to have paid partienlar attention to these organs.

+ "Travels in the Interior of Brazil, 1536-11,' p. 527. 
having a brush of long sharp bristles at the apes. Other bladders included fragments of articulate animals, and many of them contained broken pieces of a curious organism, the nature of which was not recognised by anyone to whom it was shown.

Utricularia amethystina (Guiana).-This species has small entire leaves, and is apparently a marsh plant; but it must grow in places where crustaceans exist, for there were two small species within one of the bladders. The bladders are nearly of the same shape as those of Utricularia montana, and are covered outside with the usual papillæ; but they differ remarkably in the antenne being reduced to two short points, united by a membrane hollowed out in the middle. This membrane is covered with innumerable oblong glands supported on long footstalks; most of which are arranged in two rows converging towards the valve. Some, however, are seated on the margins of the membrane; and the short ventral surface of the bladder, between the petiole and valve, is thickly covered with glands. Most of the heads had fallen off, and the footstalks alone remained; so that the ventral surface and the orifice, when viewed under a weak power, appeared as if clothed with fine bristles. The valve is narrow, and bears a fer almost sessile glands. The collar against which the edge shuts is yellowish, and presents the usual structure. From the large number of glands on the ventral surface and round the orifice, it is probable that this species lives in very foul water, from which it absorlos matter, as well as from its captured and decaying prey.

Utricularia griffithii (Malay and Borneo). - The bladders are trunsparent and minute; one which was measured being only $\frac{2 \mathrm{~B}}{100}$ of an inch $(711 \mathrm{~mm}$.) in diameter. The antenne are of moderate length, and 
projeet straight forward; they are united for a short spaee at their bases by a membrane; and they bear a moderate number of bristles or hairs, not simple as heretofore, but surmounted by glands. The bladders also differ remarkably from those of the previous speeies, as within there are no quadrific, only bifid, proeesses. In one bladder there was a minute aquatie larva; in another the remains of some artieulate animal; and in most of them grains of sand.

Utricularia cærulea (India). - The bladders resemble those of the last speeies, both in the general charaeter of the antennæe and in the proeesses within being exelusively bifid. They eontained remnants of entomostraean erustaeeans.

Utricularia orbiculata (India).-The orbicular leares and the stems bearing the bladders apparently float in water. The bladders do not differ much from those of the two last speeies. The antennæ, which are united for a short distanee at their bases, bear on their outer surfaees and summits numerous, long, multieellular hairs, surmounted by glands. The proeesses within the bladders are quadrifid, with the four diverging arms of equal length. The prey whieh they had eaptured eonsisted of entomostraean erustaeeans.

Utricularia multicaulis (Sikkim, India, 7000 to 11,000 feet). - The bladders, attaehed to rhizomes, are remarkable from the strueture of the antennæ. These are broad, flattened, and of large size; they bear on their margins multieellular hairs, surmounted by glands. Their bases are united into a single, rather narrow pedieel, and they thus appear like at great digitate expansion at one end of the bladder. Internally the quadrifid proeesses have divergent arms of equal length. The bladder's eontained remnants of articulate animals. 


\section{Polypompholyx.}

This genus, whieh is eonfined to Western Australia, is eharaeterised by having a "quadripartite calyx." In other respects, as Prof. Oliver remarks," "it is quite a Utrieularia."

Polypompholyx multifida.-The bladdlers are attaehed in whorls round the summits of stiff stallss. The two antennæ are represented by a minute membranous fork, the basal part of whieh forms a sort of hood over the orifice. This hood expands into two wings on eaeh side of the bladder. A third wing or erest appears to be formed by the extension of the dorsal surfaee of the petiole; but the strueture of these three wings could not be elearly made out, owing to the state of the speeimens. The inner surfaee of the hood is lined with long simple hairs, eontaining aggregated matter, like that within the quadrifid proeesses of the previously deseribed speeies when in eontact with deeayed animals. These hairs appear therefore to serve as absorbents. A valve was seen, but its strueture eould not be determined. On the eollar round the valve there are in the plaee of glands numerous one-eelled papillæ, having very short footstalks. The quadrifid proeesses have divergent arms of equal length. Remains of entomostraean crustaeeans were found within the bladrders.

Polypompholyx tenella.-The bladders are smaller than those of the last speeies, but have the same general strueture. They were full of débris, apparently organic, but no remains of artieulate animals eould be distinguished.

* 'Proc. Linn. Soc.' vol. iv. p. 171. 


\section{Genlisea.}

This remarkable genus is technically distinguished from Utricularia, as I hear from Prof. Oliver, by having a five-partitc calyx. Species are found in sevcral parts of the world, and are said to be "herbee annuæ paludosæ."

Gentisea ornata (Brazil). - This spccics has been described and figured by Dr. Warming,* who states that it bears two kinds of leaves, called by him spathulate and utriculiferous. The latter include cavities; and as thesc differ much from the bladders of the foregoing specics, it will be convenicnt to speak of them as utricles. The accompanying figure (fig. 29) of one of the utriculiferous leaves, about thrice enlarged, will illustrate the following description by my son, which agrecs in all esscntial points with that given by Dr. Warming. The utriclc $(b)$ is formed by a slight enlargement of the narrow blade of the lcaf. A hollow neck $(n)$, no less than fiftecn times as long as the utricle itself, forms a passage from the transverse slit-like orifice $(o)$ into the cavity of the utricle. A utricle which measured $\frac{1}{36}$ of an inch $(.705 \mathrm{~mm}$.$) in its longer diameter had a neck \frac{15}{36}$ $\left(10.583 \mathrm{~mm}\right.$.) in length, and $\frac{\mathrm{l}}{100}$ of an inch $(.254 \mathrm{~mm}$.) in brcadth. On cach side of the orifice there is a long spiral arm or tubc $(a)$; the structure of which will be best understood by the following illustration. Take a narrow ribbon and wind it spirally round a thir cylinder, so that the edges come into contact along its whole length; then pinch up the two edges so as to form a little crest, which will of course wind spirally

* "Bidrag til Kundskaben om Lentibulnuiacex," Copenhagen, 187. 
round the eylinder like a thread round a serew. If the cylinder is now removed, we shall have a tube like one of the spiral arms. The two projecting edges are not aetually united, and a needle ean be pushed in easily between them. They are indeed in many plaees a little separated, forming narrow entranees into the tube; but this may be the result of the drying of the speeimens. The lamina of whieh the tube is formed seems to be a lateral prolongation of the lip of the orifiee; and the spiral line between the two projecting edges is eontinuous with the eorner of the orifiee. If a fine bristle is pushed down one of the arms, it passes into the top of the hollow neek. Whether the arms are open or elosed at their extremities could not be determined, as all the specimens were broken; nor does it appear that Dr. Warming ascertained this point.

So mueh for the external structure. Internally the

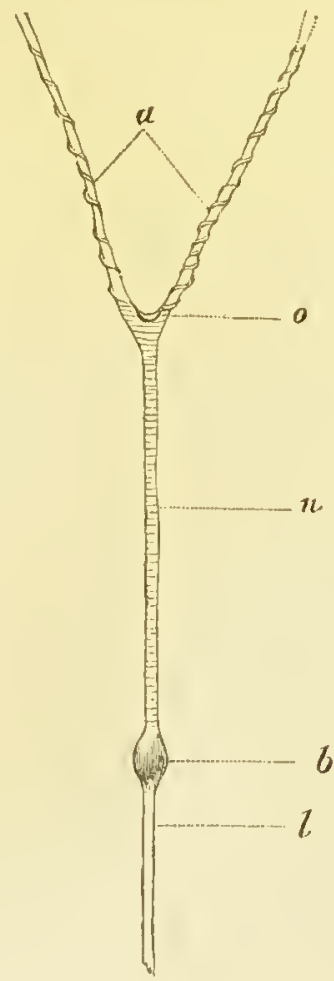

F'IG. 29.

(Gentisea ornata.)

Utriculiferous leaf; enlarged about three times.

7. Upper part of lamina of leaf.

6 Utricle or blatder.

$n$ Nrck of utricle.

o Oriflce.

a Spirally wound arms, with theil. ends broken oft.

lower part of the utricle is eovered with spherical papillie, formed of four eells (sometimes eight according to Dr. Warming), which evidently answer to the quadrifid processes within the bladders of Utrieularia. 
These papillæ extend a little way up the dorsal and ventral surfaces of the utricle; and a few, according to Warming, may be found in the upper part. This upper region is covered by many transverse rows, one above the other, of short, closely approximate hairs, pointing downwards. These hairs have broad bases, and their tips are formed

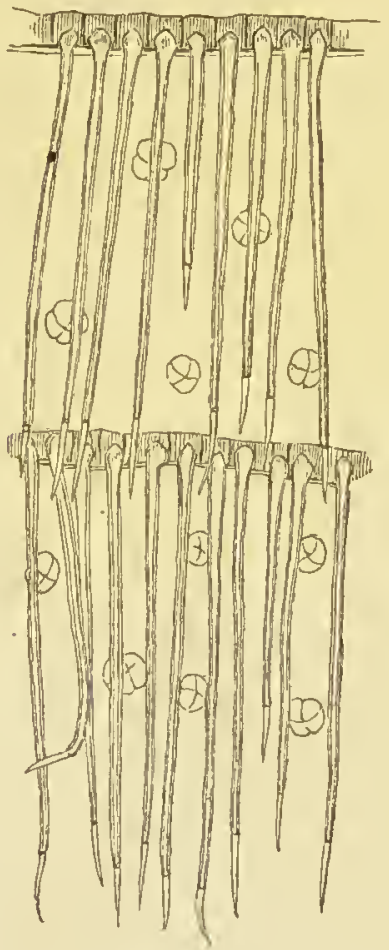

Fig. 30.

(Genlisen ornata.)

Purtion of inside of neck leading into the utricle, greatly enlarged, showing the downward pointed bristles, and small quadrifid cells or processes. by a separate cell. They are absent in the lower part of the utricle where the papillæ abound. The neck is likewise lined throughout its whole length with transverse rows of long, thin, transparent hairs, having broad bulbous (fig. 30) bases, with similarly constructed sharp points. They arise from little projecting ridges, formed of rectangular epidermic cells. The hairs vary a little in length, but their points generally extend down to the row next below; so that if the neck is split open and laid flat, the inner surface resembles a paper of pins,the hairs representing the pins, and the little transverse ridges representing the folds of paper through which the pins are thrust. These rows of hairs are indicated in the previous figure (29) by numerous transverse lines crossing the neck. The inside of the neck is 
also studded with papillæ; those in the lower part are spherical and formed of four cells, as in the lower part of the utricle; those in the upper part are formed of two cells, which are much elongated downwairds beneath their points of attachment. These two-celled papillæ apparently correspond with the bifid process in the upper part of the bladders of Utricularia. The narrow trinsverse orifice ( 0 , fig. 29) is situated between the bases of the two spiral arms. No valve could be detected here, nor was any such structure seen by Dr. Warming. The lips of the orifice are armed with many short, thick, sharply pointed, somewhat incurved hairs or teeth.

The two projecting edges of the spirally wound lamina, forming the arms, are provided with short incurved hairs or teeth, exactly like those on the lips. These project inwards at right angles to the spiral line of junction between the two edges. The inner surface of the lamina supports two-celled, elongated papilla, resembling those in the upper part of the neck, but differing slightly from them, according to Warming, in their footstalks being formed by prolongations of large epidermic cells; whereas the papillæe within the neck rest on small cells sunk amidst the larger ones. These spiral arms form a conspicuous difference between the present genus and Utricularia.

Lastly, there is a bundle of spiral vessels which, running up the lower part of the linear leaf, divides close beneath the utricle. One branch extends up the dorsal and the other up the ventral side of both the utricle and neck. Of these two branches, one enters one spiral arm, and the other branch the other arm.

The utricles contained much débris or dirty matter, which seemed organic, though no distinct organisms 
could be recognised. It is, indeed, scareely possible that any objeet could enter the small orifice and pass down the long narrow neck, except a living creature. Within the neeks, however, of some specimens, a worm with retracted horny jaws, the abdomen of some articulate animal, and specks of dirt, probably the remmants of other minute creatures, were found. Many of the papille within both the utricles and neeks were discoloured, as if they had absorbed matter.

From this deseription it is sufficiently obvious how Genlisea secures its prey. Small animals entering. the narrow orifice--but what induces them to enter is not known any more than in the case of Utriculariawould find their egress rendered difficult by the sharp incurved hairs on the lips, and as soon as they passed some way down the neek, it would be scareely possible for them to return, owing to the many transverse rows of long, straight, downward pointing hairs, together with the riclges from which these project. Such creatures would, therefore, perish either within the neck or utricle; and the quadrifid and bifid papilla would absorb matter from their decayed remains. The transverse rows of hairs are so numerous that they seem superfluous merely for the sake of preventing the escape of prey, and as they are thin and delicate, they probably serve as additional absorbents, in the same manner as the flexible bristles on the infolded margins of the leaves of Aldroranda. The spiral arms no doubt aet as aceessory traps. Until fresh leares are examined, it cannot be told whether the line of junction of the spirally wound lamina is a little open along its whole course, or only in parts, but a small creature which forced its way into the tube at any point, would be prevented from escaping by the incurved hairs, and would find an open path down 
the tube into the neek, and so into the utriele. If the ereature perished within the spiral arms, its deeaying remains would be absorbed and utilised by the bifid papillx. We thus see that animals are eaptured by Genlisea, not by means of an elastie valve, as with the foregoing speeies, but by a eontrivanee resembling an eel-trap, though more eomplex.

Gentisea africana (South Afriea).-Fragments of the utrieuliferous leaves of this speeies exhibited the same strueture as those of Genlisea ornata. A nearly perfeet Aearus was found within the utriele or neek of one leaf, but in whieh of the two was not reeorded.

Gentisea aurea (Brazil).-A fragment of the neek of a utriele was lined with transverse rows of hairs, and was furnished with elongated papilla, exaetly like those within the neek of Genlisec ornata. It is probable, therefore, that the whole utriele is similarly eonstrueted.

Gentisea filiformis (Bahia, Brazil).-Many leaves were examined and none were found provided with utrieles, whereas sueh leaves were found without diffieulty in the three previous speeies. On the other hand, the rhizomes bear bladders resembling in essential eharaeter those on the rhizomes of Utrieularia. These bladders are transparent, and very snall, viz. only $\frac{1}{\text { Tog }}$ of an inch (.254 mm.) in length. The antenna are not united at their bases, and apparently bear some long hairs. On the outside of the bladders there are only a few papilla, and internally very few quadrifid proeesses. These latter, however, are of unusually large size, relatively to the bladder, with the four divergent arms of equal length. No prey eould be seen within these minute bladdcrs. As the rhizomes of this speeies were furnished with bladders, those of Genlisea africana, ornata, and amrea were carefully 
examined, but none could be found. What are we to infer from these faets? Did the three species just named, like their close allies, the several species of Utricularia, aboriginally possess bladders on their rhizomes, whieh they afterwards lost, acquiring in their place utriculiferous leaves? In support of this view it may be urged that the bladders of Gentisea filiformis appear from their small size and from the fewness of their quadrifid processes to be tending towards abortion; but why has not this speeies acquired utriculiferous leaves, like its eongeners?

Conclusion.--It has now been shown that many species of Utricularia and of two elosely allied genera, inhabiting the most distant parts of the worldEurope, Afriea, India, the Malay Arehipelago, Australia, North and South Ameriea-are admirably adapted for capturing by two methods small aquatic or terrestrial animals, and that they absorb the produets of their deeay.

Ordinary plants of the higher classes proeure the requisite inorganic elements from the soil by means of their roots, and absorb carbonie aeid from the atmosphere by means of their leaves and stems. But we have seen in a previous part of this work that there is a class of plants which digest and afterwards absorb animal matter, namely, all the Droseraeex, Pinguicula, and, as cliscovered by Dr. Hooker, Nepenthes, and to this elass other species will almost certainly soon be added. These plants ean dissolve matter out of eertain vegetable substanees, such as pollen, seeds, and bits of leaves. No doubt their glands likewise absorb the salts of ammonia brought to them by the rain. It has also been shown that some other plants can absorb ammonia by 
their glandular hairs; and these will profit by that brought to them by the rain. There is a seeond elass of plants whieh, as we have just seen, eannot digest, but absorb the products of the deeay of the animals which they eapture, namely, Utricularia and its elose allies; and from the excellent observations of Dr. Melliehamp and Dr. Canby, there ean seareely be a doubt that Sarracenia and Darlingtonia may be added to this elass, though the fact ean hardly be considered as yet fully proved. There is a third elass of plants which feed, as is now generally admitted, on the produets of the deeay of vegetable matter, sueh as the bird's-nest orehis (Neottia), \&c. Lastly, there is the well-known fourth elass of parasites (sueh as the mistletoe), which are nomished by the juiees of living plants. Most, however, of the plants belonging to these four elasses obtain part of their carbon, like ordinary speeies, from the atmosphere. Sueh are the diversified means, as far as at present known, by which higher plants gain their subsistenee. 



\section{N DEX.}

ABSOLPTION.

\section{A.}

Absoription by Dionæa, 295

- by Drosera, 17

by Drosophyllum, 337

liy Pinguicula, 381

by glandular hairs, 344

421

by glands of Utricularia, 416 ,

by quadrifids of Utrieularia, 413,421

by Utricularia montana, 437

Acid. niture of, in digcstive secretion of Drosera, 88

- present in digestive tluid of various species of Drosern, Dionar, Drosopliyllum, and Pinguicula, 278, 301, 339, 381

Acids, various, action of, on Dlosern, $18 \mathrm{~S}$

of the acctie series replaeing liydrochlorie in digestion, 89

_- arsenious and chromie, aetion on Droseril, 185

—, diluted, inducing negative osmose, 197

Adiler's poison, aetion on Drosera, 206

Argregation of protoplasm in Droscra, 38

_ in Drosera induced hy sults of aınmonia, 43

_- catused by small doses of carbonate of ammonia, 145

— of protoplasm in Drosera, a reflex ation, 242

Drosern, 278

speeics of

—— in Dionaa, 290, 300

\section{AMMONIA.}

Aggregation of protoplasm in Drosophyllum, 337, 339

- in Pinguicula, 370, 389

$429,430,436$

Albumen, digested by Drosera, 92

--, liquid, action on Drosera, 79

Alcohol, diluted, action of, on Drosela, 78,216

Aldrovanda vesiculosa, 321

- absorption and digestion by, 325

- , varieties of, 329

Alga, aggregation in fronds of, 65

Alkalies, arrest digestive process in Drosera, 94

Aluminium, salts of, action oll Drosera, 184

Ammonia, amount of, in rain water, 172

- , carbonate, aetion on heated lcaves of Droseri, 69

$\longrightarrow,-$, smallness of doses causing aggregation in Drosera, 145

- - , its action on Droserir, 141

- - , vapour of, absorbed by glands of Drosern, 142

$\longrightarrow,-$, smullness of doses causing inflection in Drosern, 145, $16 \mathrm{~S}$

- phosphate, smallness of doses causing inflection in Droser:, $153,16 \mathrm{~S}$

,-- , size of particles affecting Drosera, 173

—, nitrate, smallness of doses causing inflection in Drosera, 148, 168

$\longrightarrow$, salts of, aetion on Droscra, 136; 


\section{AMMONIA.}

Anmonia, salts of, their action affected by previous immersion in water and various solntions, 213

$\longrightarrow$, - iuduce aggregntion in Droscin, 43

_- various salts of, causing inflection in Drosern. 166

Antimony, turtrate, action on Droscin, 185

Areolar tissuo, its digestion by Dro:cra, 102

Ar:enious acid, action on Drosera, 185

Atropine, action on Drosera, 204

B.

Barium, salts of, action on Droscra, 183

Bases of salts, preponderant action of, on Drosela, $186^{\circ}$

Basis, fibrous, of bone, its digestion by Droscra, 108

Belladonna, extract of, action on Drosera. 84

Bennett, Mr. A. W., on Droscra, 2

- coats of pollen-grains nut digested by insects, 117

Binz, on action of quinine on white blood-corpuscles, 201

-, on puisonous action of quinine on low organisms, 202

Bone, its digestion by Drosera, 105

Brunton, Lauder, on digestion of gelatine, 111

\section{5}

- on tlie digestion of urca, 124 ,$- \quad-$ of cliloropliyll, 126

Byblis, 343

\section{C.}

Cabbagc, decoction of, action on Droserit, 83

Cudmiun chloride, action on Drosela, 183

Casium, chlorido of, action on Drosera, 181

\section{CURTIS.}

Calcium, sults of, action on Drosera, 182

Camphor, action on Drosera, 209

Cunby, Dr., on Dionsea, 301, 310, 313

$\longrightarrow$, on Drosern filiformis, 281

Caraway, oil of, action on Drosera, 211

Carbonic acid, action on Drosera, 221 59

Cartilage, its digestion by Drosera, 103

Casein, its digcstion by Drosera, 114

Cellulose, not digested by Drosera, 125

Chalk, precipitated, causing inflection of Drosela, 32

Cheese, its digestion by Drosera, 116

Chitinc, not digested by Drosera, 124

Chloloform, effects of, on Drosera, 217

- - - on Dionxa, 304

Chlorophyll, graius of, in living plants, digested by Droscra, 126

- pure, not digested by Diosera, 125

Chondrin, its digestion by Drosera, 112

Chromic acid, action on Drosera, 185

Cloves, oil of, action on Drosern, 212

Cobnlt chloride, action on Drosera, 186

Cobra poison, action on Drosera, 206

Colm, Prof., on Aldrovandn, 321

- on contractile tissues in plants, 364

- on movements of stamens of Compositse, 256

- on Utricularia. 395

Colchicine, action on Droscra, $20 t$

Copper chloride, action on Drosera, 1 s 5

Crystallin, its digestion by Drosera, 120

Curare, action on Drosern, $20 \pm$

Curtis, Dr., on Dionea, 301 
DALWIN.

D.

Darwin, Francis, on the effect of an induced galvanic current on Droseri, 37

- , on the digestion of grains of ehlorophyll, 126

- , on Utricularia, $\mathbf{4 4 2}$

Delpino, on Aldrovanda, 321

- , on Utricularia, 395

Dentine, its digestion by Drosera, 106

Digestion of various substances by Dionæa, 301

- by Drosern, 85
- by Drosophyllum, 339
- by Pingnicula, 381
- origin of power of, 361

Digitaline, action on Drosera, 203

Dionæa muscipula, small size of roots, 286

- , structure of leaves, 287

- sensitiveness of filaments, 289

- , absorption by, 295

-, secretion by, 295

-

_- effects on, of chloroform, 304

- , manner of capturing insects, 305

313

Dive-expansion of lobcs, 318

Dircetion of inflected tentacles of Droscra, 213

Dohrn, Dr., on rhizocephalous crustaceans, 357

Dunders, Prof., small amount of atropine affecting the iris of the dog, 172

Dragonfly canght by Droscla, 2

Droscra anglica, 278

_- binata, vel dichotoma, 281

capensis, 279

filiformis, 281

heterophylla, 284

- intermedin, 279

Droscra rotundifolin, structure of leaves, 4

- efficets on, of nitrogenous fluids, 76
FIBROOS.

Drosera rotundifolia, effects of heat on, $60^{\circ}$

-

231

$23 !$

- , general summary, 262

spathulata, 280

Droseraceæ, concluding remarlks on, 355

_- their sensitiveness compared with that of animals, 366

Drosophyllum, structurc of leaves, 333

-

—, absorption by, 337

- , digestion by, 339

\section{E.}

Enamel, its digestion by Drosera, 106

Erica tetralix, glandular hairs of, 351

Etber, effects of, on Drosern, 219

$\longrightarrow$, - on Dionrea, $30 t$

Euphorbia, process of aggregation in roots of, 63

Exosmose from baeks of leaves of Drosera, 231

F.

Fat not digested by Drosera, 126

Fayrer, Dr., on the naturo of cobra poison, 206

- , on the action of cobra poison on animal protoplasm, 208

_- , n cobra poison paralysing nerve centres, 224

Ferment, nnture of, in secretion of Drosern, 94, 97

Fibrin, its digestion by Drosera, 100

Fibro-cnitilnge, its digestion by Drosern, 104

Fibro-clastic tissuc, not digested by Diosera, 122

Fiblous basis of bone, its digestion by Droscra, 108 


\section{FLUIDS.}

Fluids, nitrogenons, effeets of, on Drosera, 76

Fouruier, on acids eausing movements in stamens of Bcrberis, 196 Frankland, Prof, on nature of acid in seeretion of Drosera, 88

G.

Galvanism, eurrent of, causing infleetion of Drosera, 37

- effects of, on Dionren, $31 \mathrm{~s}$

Gardner, Mr., on Utricularia nelumbifolia, 442

Gelatine, impure, aetion on Drosera, S0

\section{0}

Genlisea afrieana, 451

filiformis, 451

Genlisea ornata, strmeture of, 446

-450 manner of eapturing prey,

Glandular hairs, absorption by, 344

\section{- summary on, 353}

Globulin, its digestion by Drosera, 120

Gluten, its digestion by Drosera, 117

Glyeerine, inducing aggregation in Drosera, 52

, action on Drosera, 212

Gold chloride, aetion on Drosera, 184

Gorup-Besauez on the plesence of a solvent in seeds of the veteh, 362

Grass, deeoetion of, action on Drosera, 84

Gray, Asa, on the Droserneer, 2

Groenland, on Drosera, 1, 5

Gum, action of, on Drosern, 77

Gun-eotton, not digested by Drosera, 125

H.

Hrematin, its digestion by Drosera, 121

Hairs, glandular, absorption by, 344

$\longrightarrow,-$, summary on, 353

\section{LEA VES.}

Heat, indueing aggregation in Drosera, 53

- efficet of, on Drosera, 66

- - - - on Dinnæa, 294, 319

Heekel, on state of stamens of Berberis after excitement, 43

Hofmeister, on pressure arresting movements of protoplasm, 61

Holland, Mr., on Utricularia, 395

Hooker, Dr., on earnivorous plants, 2 _- on power of digestion by $\mathrm{Ne}-$ penthes, 97

_ history of observations on Dionæa, 286

Hydroeyanie aeid, effects of, on Dionæe, 305

Hyoseyamus, action on Drosera, \$4, 206

\section{I.}

Iron chloride, aetion on Drosera, 185

Isinglass, solution of, aetion on Drosera, 80

J.

Johnson, Dr., on movement of flowerstems of Pinguieula, 381

B.

Klein, Dr., on mieroseopie eharacter of half digested bone, 106

- , on state of half digested fibroeartilago, 104

, on size of mieroeocei, 173

Knight, Mr., on feeding Dionren, 301

liossmann, Dr., on rbizoeephaluus erustaeeans, 357

L.

Lend eliloride, atiou on Drosera, 184

Lenves of Droscra, bueks of, not seusitive, 231 


\section{LEGUMN.}

Legumin, its digestion by Drosera, 116

Lemna, aggregation in leaves of, 64 Lime, carbonate of, precipitated, eausing inflection of Droser"u, 32

- phospliate of, its action on Drosera, 109

Lithium, salts of, aetion on Drosera, 181

II.

Magnesium, salts of, action on Drosera, 182

Manganese ehloride, action on Drosera, 185

Marshall, Mr. W., on Pinguicula, 369

Means of movement in Dionrea, 313 - in Drosern, 254

Meat, infusion of, eausing aggregation in Drosera, 51

$\longrightarrow$ - $\longrightarrow$, action on Drosera, 79

—, its digestion by Drosera, 98

Mercury perchloride, action on Drosera, 183

Milk, inducing aggregation in Drosera, 51

—, aetion on Drosera, 79

__ its digestion by Drosera, 113

Mirabilis longiflora, glandular hairs of, 352

Moggridge, 'Trahernc, on aeids injuring seeds, 128

Moore, Dr., on Pinguicula, 390

Morphia acetatc, action on Drosern, 205

Motor impulse in Drosera, 234, 258

- in Dionrea, 313

Movement, origin of power of, 363

Moventents of leaves of Pingnieula, 371

__ of tentaeles of Drosera, means of, 254

- of Dionren, means of, 313

Mucin, not digested by Diosern, 122

Mueus, action on Drosera, 80

Miiller, Fritz, on rhizocephalous cristaceans, 357
PINGUICULA.

N.

Nepenthes, its power of digestion, 97

Nickel ehloride, netion on Drosera, 186

Nicotiana tabacum, glandular hairs of, 352

Nicotine, action on Drosera, 203

Nitric ether, action on Droser'a, 220

Nitschkc, Dr., refercnees to his papers on Dioscra, 1

- on sensitivencss of baeks of lcaves of Dirosera, 231

- , on direction of infleeted tentacles in Diosera, 244

$\longrightarrow$, on Aldrovinda, 322

Nourishment, various mcans of, by plants, 452

Nuttall, Dr., on re-expansion of Dionæa, 318

o.

Odour of pepsin, emitted from leaves of Drosera, s8

Oil, olive, action of, on Drosera, 78 , 126

Oliver, Prof., on Utricularia, 432, $441-446$

\section{P.}

Papaw, juiee of, hastening putrefnetion, 411

Particles, minute size of, causing inflection in Droscra, 27, 32

Pcas, decoction of, action on Drosera, 82

Pelnrgonium zonalc, glanitular hairs of, 350

Pepsin, odour of. emitted from Drosera lenves, $8 S$

—, not digested by Drosera, 123

- its secretion by animals $e x-$ ciled only after absorption, 129

Peptogenes, 129

Pinguicula grancliflorn, 390

— lusitaniea, 391 
PINGUICLLA.

Pinguicula vulgaris, structure of leaves and roots, 368

-369 number of insects caught by,

-

- , sccretion and absolption by, 381

- digestion by, 381

seeds, 390

Platinum chloride, action on Drosera, 186

Poisou of cobra and adder, their. actiou on Drosera, 206

Pollen, ils digestiou by Drosera, 117

Polypompholyx, structure of, 445

Potassium, salts of, iuducing aggregation in Drosera, 50

$\longrightarrow,-$, action ou Droscra, 179

- phosphate, not decomposed by Droscra, 180, 187

Price, Mr. Jolın, on Utricularia, 429

Primula sinensis, glaudular hairs of, $3 \pm 8$ 355 , number of glandular hairs of,

Protoplasm, aggregation of, in Drosera, 38

- , - in Drosera, caused by small doses of carbonate of ammovia, 145

- , in Drosera, a reflex action, 242

- - aggregated, ree-dissolution of, 53

—, aggregation of, in various species of Droscra, $27 \mathrm{~S}$

——, in Dionea, 290, 300

$\longrightarrow$, in Drosophyllum, 337, 339

- , - in Pinguicula, 370, 389

$429,430,436$

Q.

Quinine, salts of, action on Drosera, 201

\section{SAXIFRAGA.}

R.

Rain-water, amount of ammonia in, 172

Ralfs, Mr , on Pinguicula, 390

Ransom, Dr., action of poisons on the yolk of eggs, 225

Re-expansion of headless tentacles of Drosern, 229

- of teutacles of Drosera, 260

- of Dionra, 318

Roots of Drosera, 18

- of Drosera, process of aggregation in, 63

_ _ of Drosern, absorb carbonate of ammonia, $1 \pm 1$

_ of Dioura, 286

— of Urosophyllum, 332

— of Pinguicula, 369

Roridula, $3 \pm 2$

Rubidium chloride, action on Drosera, 181

S.

Sachs, Prof., effects of heat on protoplasm, 66, 70

$\longrightarrow$, on the dissolution of proteid compounds in the tissues of plants, 362

Saliva, artion ou Drosera, 80

Salts and acids, various, effects of, on subsequent action of ammonia, 214

Sanderson, Burdon, on coagulation of albumen from hent. 74

cluloric in digestion, 89

- , on the digestion of fibrons basis of boue, 108

$\longrightarrow$ - - of gluten, 118

$\longrightarrow$ - of globulin, 120

- — of chlorophyll, 126

, on difterent eflect of sollium and potassium on animals. 187

__ on clectric currents in Dionæa, 318

Suxifraga umbrosa, glandular hairs of, 315 


\section{SCl11FF.}

Schiff, on hydrochlorie acid dissolviug coagulated albumen, $86^{\circ}$

albumen, 93

, on changes in meat during digestion, 99

114

116

- - - of mucus, 123

- , on peptogenes, 129

Schloesing, on absorption of nitrogen by Nicotianu, 352

Scott, Mr., on Drosera, 1

Secretion of Drosera, general aeeount of, 13

15

eitement, 86

$9 \pm, 97$

- by Dionæa, 295

by Drosuphyllum, 335

by Pinguicula, 381

Seeds, living; acted on by Drosera, 127

385,390

acted on by Pinguicula,

Sensitivencss, localisation of, in

Drosera, 229

- of Dionæa, 289

___ of Pinguicula, 371

Silver nitrate, action on Drosera, 181

Sodium, salts of, nction on Drosera, 176

Drosera, 50 inducing aggregation in

Sondera heterophyllı, 284

Sorby, Mr., on coluuring malter of

Drosera, 5

Spcetroscopc, its power compared with that of Drosera, 170

Starch, action of, on Drosera, 78, 126

Stcin, on Aldrovanda, 321

Strontium, salts of, action on Drosera, 183
TURPENTINE.

Strychuine, salts of, action on Drosern, 199

Sugar, solution of, action of, on Diosera, 78

,$--\ldots$, indueing aggregation in

Diosera, 51

Sulphuric ether, action on Drosera, 219

- - - on Dionae, 304

Syntonin, its action on Drosera, 102

T.

Tait, Mr., on Drosophyllum, 332

Taylor, Alfred, on the detection of minute doses of poisons, 170

Tea, infusion of, action on Drosera, 78

Tentacles of Diosera, move when glands cut of, 36, 229

- inflection, direction of, 243

_- means of movenuent, 254

- re-expansion of, 260

Theine, action on Drosera, $20 t$

Tin chloride, action on Drosera, 185

Tissue, areolar, its digestion by Drosera, 102

__ fibro-elastic, not digested by Drosera, 122

Tissues through which impulse is transmitted in Drosera, 247

- in Dionrea, 313

Touches repeatcd, enusing inflection in Drosera, 34

Trinsinission of motor impulse in Drosera, $23 t$

- in Dionæa, 313

Traubc, Dr., on artifieiul cells, 216

Treat, Mrs., on Droscra filiformis, 281

- , on Dinnxa, 311

$\ldots$, on Utricularia, 408, 430

'Trécul, on Dinscra, 1,5

'I'ubcrs of Utricularia montana, 439

'Tur'pentine, action on Drosor'a, 212 


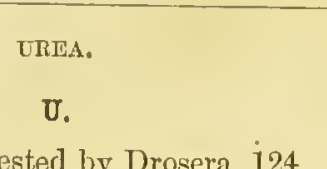

Urea, not digested by Drosera, 124

Urine, action on Droser'a, 79

Utricularia clandestina, 430

minor, 429

Utricularia montana, structure of bladder's, 431

- - animals caught by, 435

-., absorptiou by, 437

- - , tulbers of, serving as reservoirs, 439

Utricularia neglecta, structure of bladdel's, 397

- animals caught by, 405

-.., absorption by, 413

-, summary on absorption, 421

-... development of bladders, 424

Utricularia, various species of, 441

Utricularia vulgaris, 428

\section{V.}

Veratrine, action on Drosera, 204

Vessels in leaves of Drosera, 247 of Dionxa, 314

Vogel, on effects of camphor on plints, 209

\section{ZINC. \\ W.}

Warming, Dr., on Drosera, 2, 6

$\longrightarrow$, on roots of Utricularia, 397

$\longrightarrow$, on trichomes, 359

-, on Genlisea, 446

, on parenchymatous cellș in tentacles of Drosera, 252

Water, drops of, not causing inflection in Drosela, 35

-, its power in causing aggregation in Drosera, 52

_ in Drosera, 139

- and various solutions, effects of, on subsequent action of ammonia, 213

Wilkinson, Rev., on Utricularia, 398

\section{Z.}

Ziegler, his statements with respect to Drosera, 23

- experiments by cutting ressels of Drosera, 249

Zinc chloride, action on Drosera, $18 \pm$ 





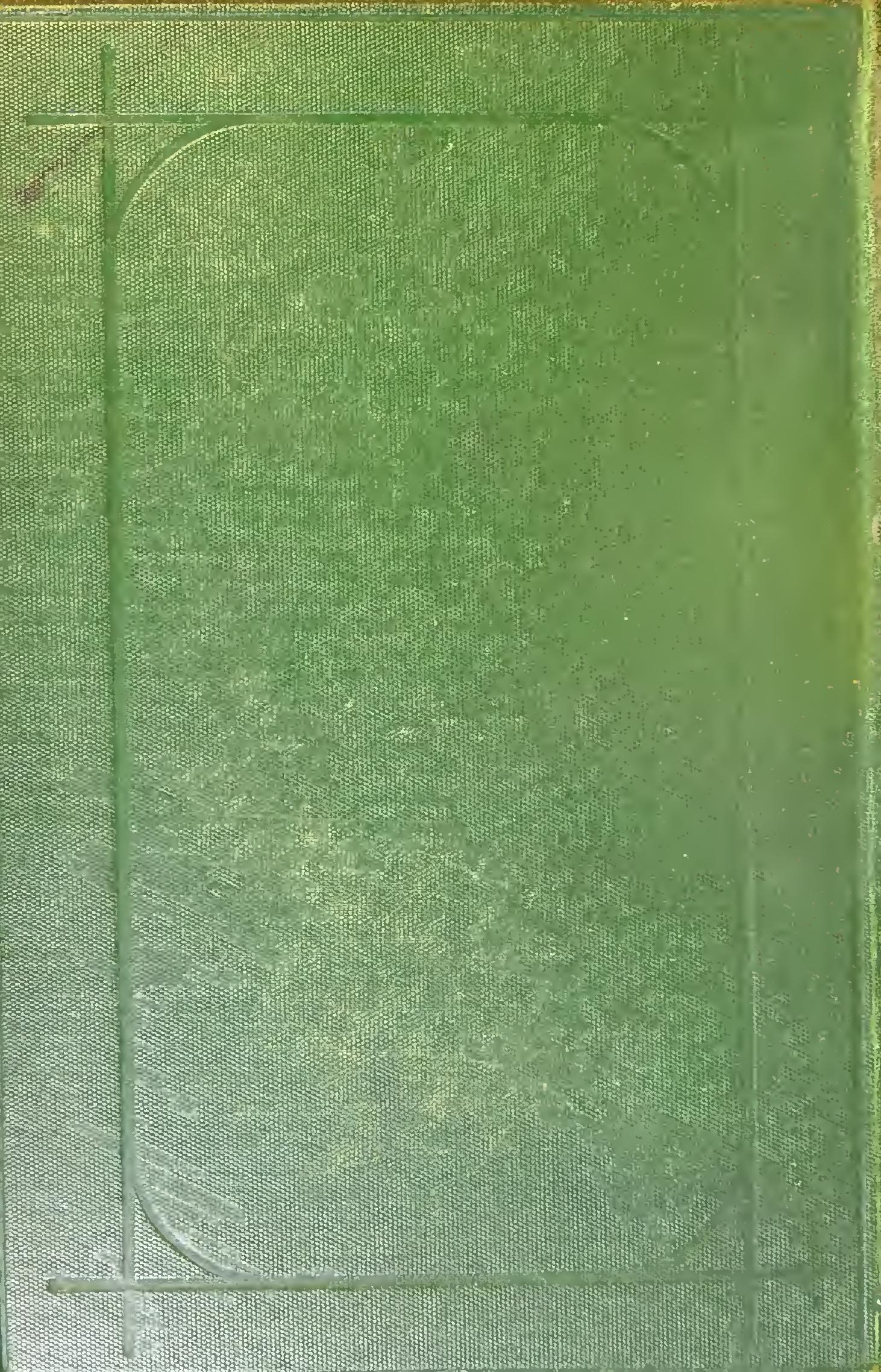





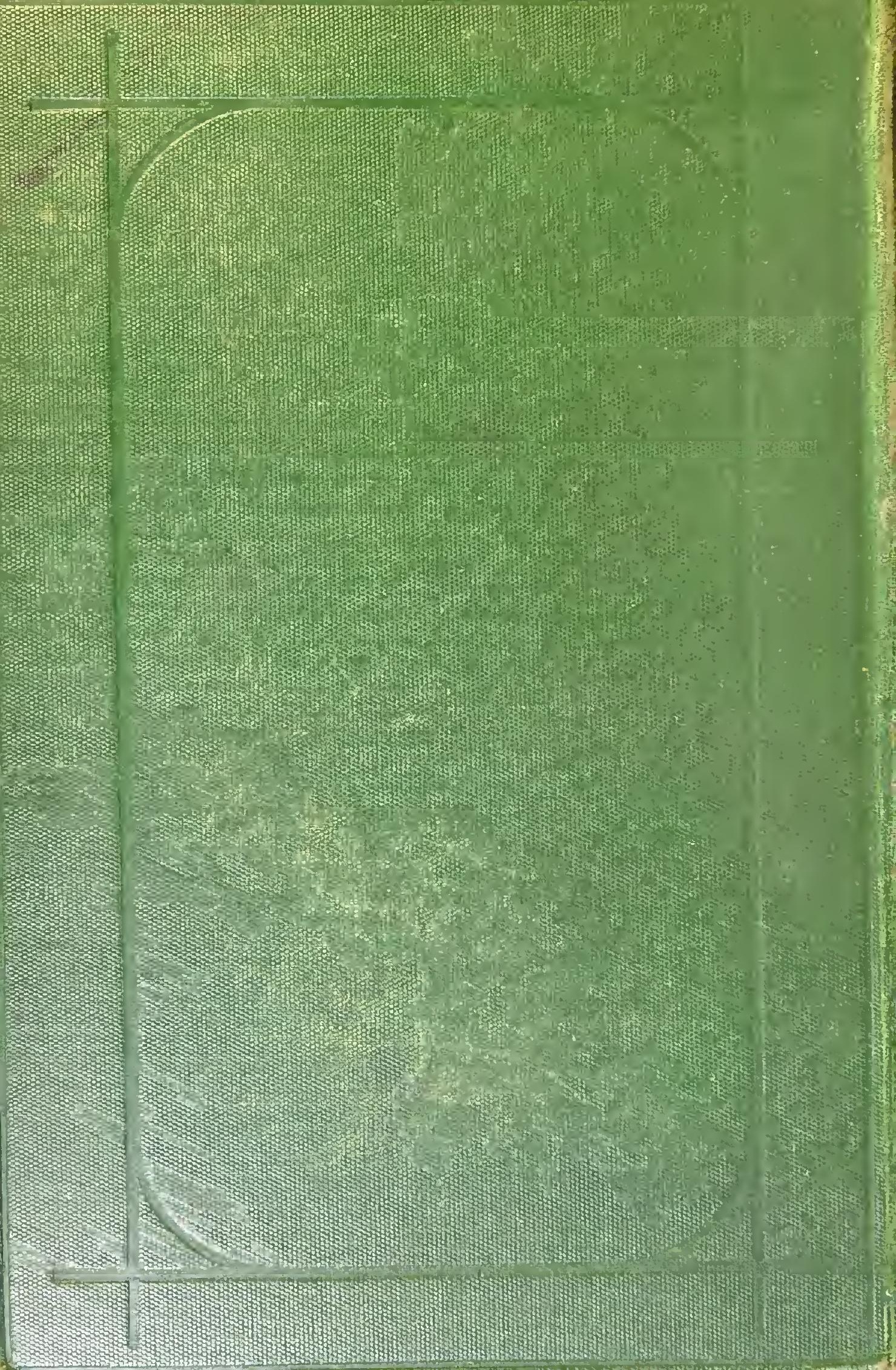

